


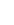


. 


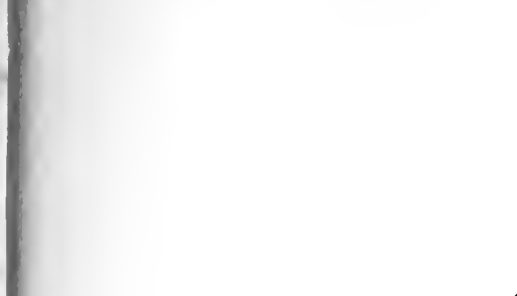
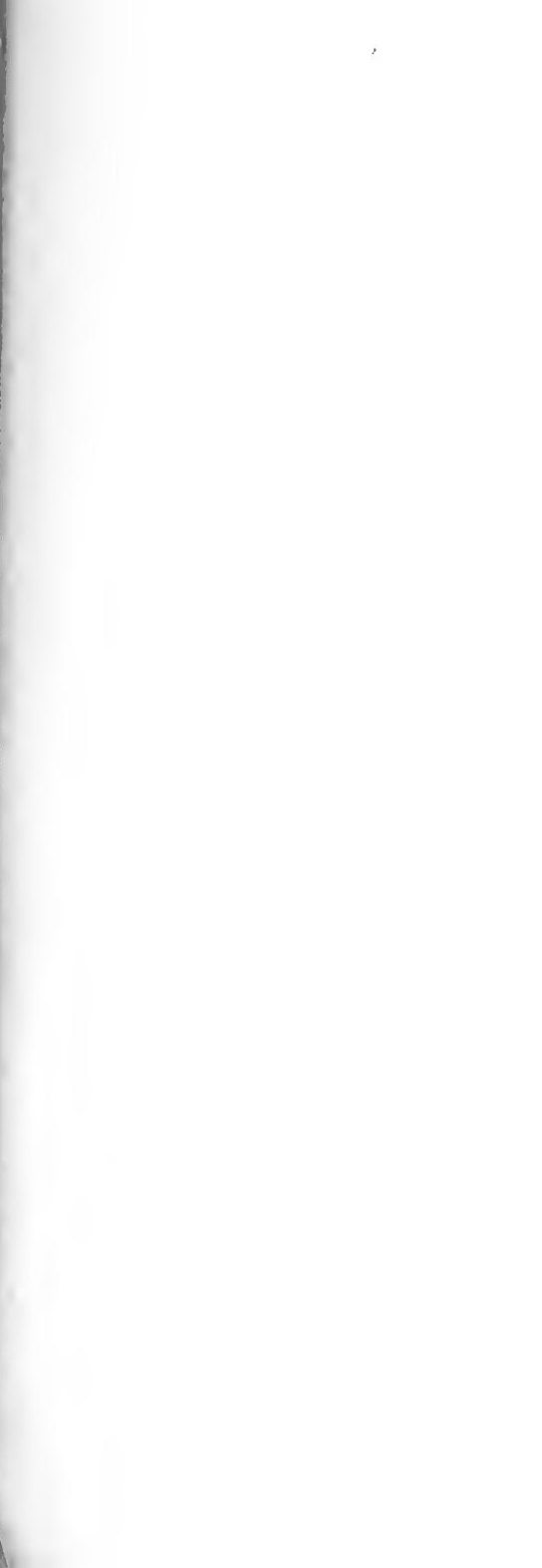
(1)

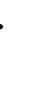


Digitized by the Internet Archive in 2007 with funding from

Microsoft Corporation 
-

, 


\section{THE ENGLAND AND HOLLAND OF THE PILGRIMS}


$$
4
$$ 


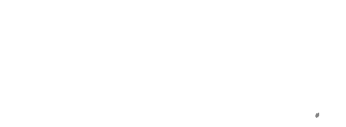




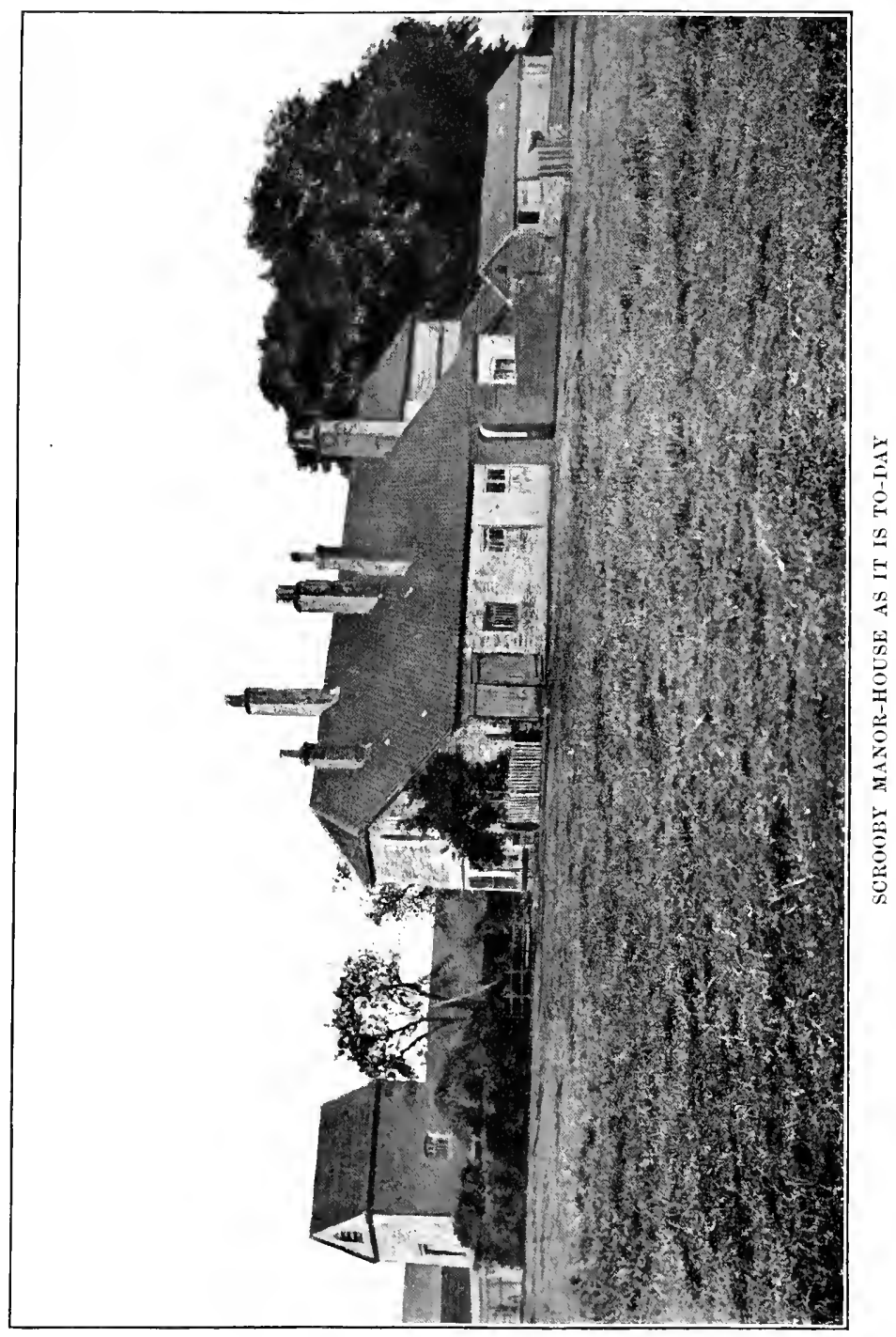




\section{THE ENGLAND AND HOLLAND OF THE PILGRIMS}

BY THE LATE

HENRY MARTYN DEXTER, D. D., LL. D.

AND HIS SON

MORTON DEXTER
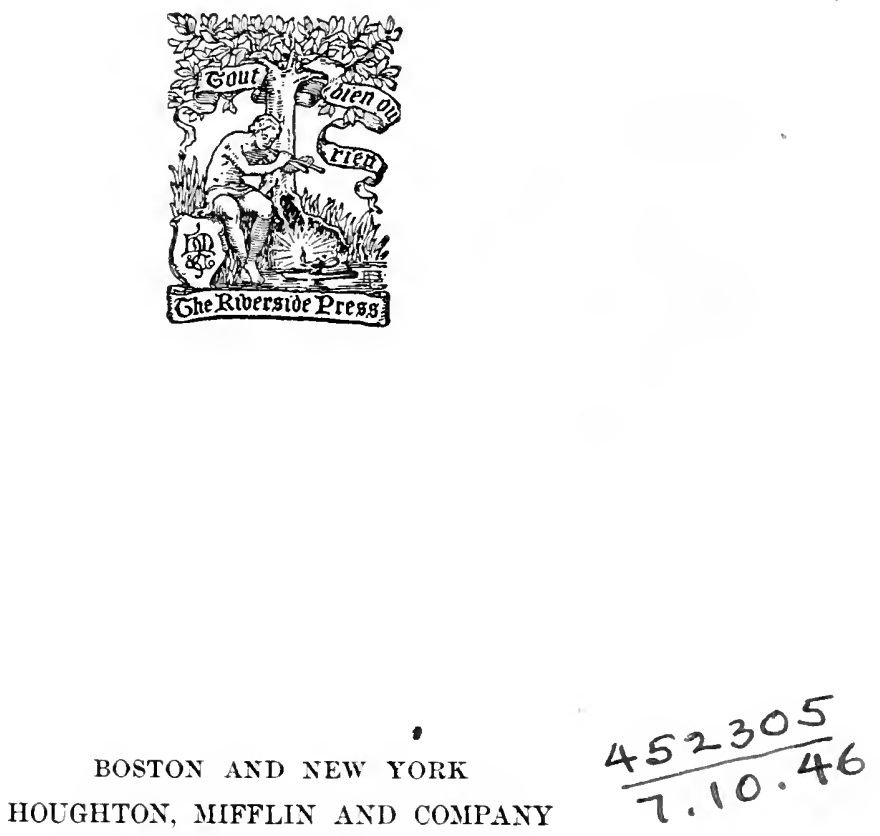

Che Atiuergioe Arcsis, Cambrioge 
COPYRIGHT IGOS BI MORTON DEXTER

ALL RIGHTS RESERVED

Published Octobcr 1005 


\section{PREFACE}

Most of the contents of this work were collected by my father, the late Dr. Henry M. Dexter. To this task he devoted much of his time for many years. Of Pilgrim descent and born almost within sight of Plymouth Rock, he desired to give to the world a more complete record than any which had been written of the religious and ecclesiastical movement in England that made the Pilgrims what they were, and of their emigration to Holland and their life there before they came to America. But he died in 1890 , leaving his chosen task unaccomplished.

In his first rough draft he had written five long chapters which appear in these pages as the first five books - and a part of the sixth. But they were hardly more than rudely shaped masses of crude material, as he had not reached that work of revision which no one else was more competent than he to perform. By his will the manuscript passed at his death into the hands of Prof. Franklin B. Dexter, Litt. D., of Yale University, and myself. Professor Dexter completed the author's last chapter, or book, and I have rewritten and edited the whole, adding considerable material obtained by my own researches.

Had Dr. Dexter lived to finish it, the work undoubtedly would have been published some years ago. But, much although I have desired to hasten its appearance, I have felt that he would have preferred delay on my part to any neglect of careful study. Until 1901 the duties of an exacting profession forbade me to give it more than my spare time. Since then it has absorbed my attention. In addition to the use of his own unique collection of the special literature of the subject, now in the Yale University Library, and besides exhausting the resources of American libraries, Dr. Dexter made several visits to Europe in order to consult original sources of information in England and Holland, and I have pursued the same course. 
It is gratifying to know that, although the completion of the work has been delayed so long, the number of people who are specially interested in the Pilgrims has been increasing rapidly, so that such a study may expect a wider welcome than it could have received earlier. That it could not have, up to its actual issue, the advantage of Dr. Dexter's probably unrivalled knowledge of the subject is greatly to be regretted. But so far as concerns his conscientious effort to perform lis undertaking thoroughly, I have endeavored to supply his place. That no errors have escaped correction is too much to be hoped, but I trust that they may not prove numerous or grave.

Some of these pages necessarily discuss matters dealt with more or less fully by Dr. Dexter in his earlier work, "The Congregationalism of the Last Three Hundred Years, as Seen in its Literature;" e. g., the careers of Robert Browne and John Robinson and the history of the Ancient Church in Amsterdam. But they are treated here independently, although with few essential changes of opinion.

In citing from ancient publications I generally have retained the ancient spelling, partly because of its quaintness, and partly because I believe that Dr. Dexter would have used it. But in some instances, although earlier editions have been consulted, I have had to depend at last upon modernized editions of the works cited, and in these cases I have followed their spelling for the sake of quoting exactly. In a few instances quotations from different editions of the same work have seemed necessary, and now and then the same name is spelled differently. In one instance (p. 381) an extended abstract is set in smaller type, in order to save space, but all the other extracts are intended to be exact. For the same reason, also, the notes often have been grouped. Dates are set down in the Old Style when they relate to England, - which retained its use until 1752, - and in the New Style when they relate to Holland, - which abandoned the Old Style in 1583. But whenever clearness has 
seemed to require it, especially in connection with the months of January, February and March, a date has been stated in both the Old and the New Styles.

It only remains to acknowledge gratefully the assistance which has been rendered me. First, and chiefly, my thanks are due to Professor Dexter, who not only, at considerable cost of time and labor, completed the original narrative from the point at which Dr. Dexter unexpectedly laid down his pen, but also has read portions of my own manuscript and has aided me throughout from time to time in various ways. Mr. George Ernest Bowman, editor of "The Mayflower Descendant," Rev. W. H. Cobb, D. D., the Librarian of the Congregational Library in Boston, and Miss M. E. Stone and Miss E. E. White, his assistants, and Mr. O. A. Bierstadt and others of the Boston Public Library, also have given me valuable help.

The painstaking coöperation of Mr. G. F. Barwick, B. A., and his subordinates in the Reading Room of the British Museum Library, in London, and of the officials of the Manuscript Room in the same institution, and of the Public Record Office, has been appreciated heartily ; as well as the courtesy of S. Wayland Kershaw, M. A., in charge of the Archbishop of Canterbury's Library at Lambeth Palace, Canon John . Watson, Librarian at York Minster, and the officials of the Bodleian Library, at Oxford, and of Trinity College Library, at Cambridge. I also am indebted to the courtesy of the Syndic of the University Press, Cambridge, for permission to use the plan of Peterhouse (p. 266), taken from Willis and Clark's "Arch. Hist. of Cambridge."

To Dr. J. C. van Overvoorde, the learned Archivist of the city of Leyden, and to his assistants, Messrs. W. J. J. C. Byleveld and W. C. van Rijn, as well as to Messrs. F. de Stoppelaer and A. E. des Tombes, I also am much indebted. And to no one else in Leyden do I owe more than to my friend, L. G. Le Poole, Esq.

Morton Dexter.

Boston, Mass., August 29, 1905. 



\title{
CONTENTS
}

\author{
BOOK I \\ The England of our Fathers
}

Chap. I. The Country and the People ... . . . . . . . 3

Population, Classes, 3. Homes, 9. Roads, Travel, 11. Dress, 12. Food, Drink, 14. Amusements, 15. Festivals, 16. Crops, Manufactures, 17, 18. Guilds, 18. Marine affairs, 19. Army, 21.

Chap. II. Education and Literature . . . . . . . . . 22

Illiteracy, 22. Schools, 24. General literature, 28. Separatist literature, 29.

Chap. III. The Shadows in the Picture . . . . . . . . . 31

Unhygienic conditions, 31. Remedies, 32. Epidemics, 33. Surgery, 34. Superstitions, 35. Witcheraft, 36. Callousuess, 42. Coarseness, 47.

\section{BOOK II}

\section{The Protestantism of our Fathers}

Chap. I. The Beginning of the English Reformation . - . 5

Mediæval Church, 53. Awakening, 54. Colet, 56. Hen. VIII. and his break with Rome, 57.

Chap. II. Progress and Retrogression

Ed. VI. and reform, 69. England at Ed.'s death, 80. Mary's reign and results, 83.

Chap. III. The Issues and how They were Met. . . . .

Perplexities of Eliz., 88. Reaction against Popery, 90. Mild reform, 92. Advice from Continent, 95. Conformity, 96. Eliz.'s attitude, 97. Comments on Reformers, 99. Bishops' side of case, 100. Reformers' side, 101. Pressure on Reformers, 105, 109. Burning of Anabapts., 107.

Chap. IV. The Literature of the Conflict

Separatists' difficulties in publishing, 112. Manifesto of Dissenters, 114. Suggestions from Continent, 118. Popular appeals, 119. True aim of Reformers, 122. Prominent Reformers, 124. Appeals to authorities, 126. Cartwright and Whitgift, 128. Civil rulers and Church, 139. More severities, 140. 
Chap. V. More Battles of the Books. . . . . . . . 141

Charges against State Church, 141. Eccles. independence not sought, 143. Renewed popular appeals, 144. Renewed appeals to authorities, 151 . Details of new eccles. govt., 153. Discussion, 155.

Chap. VI. Some Special Features of the Struggle . . . 165

Extreme views, 165. Oath ex officio, 169. Bancroft's eriticisms, 170. Attack upon Hooker, 173. Family of Love, 177. Marprelate Controv., 179. Summary, 184.

Chap. Vil. The Earliest Experiments in Practical Churci REFORM . . . . . . . . . . . . . . . . . . 188

London and Norwich, 188, 203. R. Browne, 189. Brownism, 193198, 202, 211. Fate of Church, 199. Barrowe and Greenwood, 199. Summary, 210.

\section{BOOK III}

The Birthplace of the Pilgrim Church

Chap. I. ScroogY . . . . . . . . . . . . . . . . 215

Early hist., 215. Princess Marg.'s visit, 218. Woìsey's, 223. Manor-house about 1558, 225. Hen. VIII.'s visit, 228. Partial dismantling, 229. Brewster lease, 231. Eliz.'s attempt to bny, 233. Manor-house in 1582, 236. Jas. I.'s attempt to buy, 238. Pilg. church organized, 1606, 239. Further dismantling, 240. Owner and tenants, 241. Mod. house and estate, 246.

\section{BOOK IV}

The Pilgrims themselves and how the Conflict developed them

Chap. I. William Brewster and English University Life. . 253

Family, 253. Peterhouse, 256. Fellow-students, 259. The college, 264, 265. The university, 264, 271.

Chap. II. Glimpses of Public Service . . . . . . . . . . . 282

Brewster's stay at Cambridge, 283. Entry into Davison's service, 286. Position, 286. In Low Countries, 290.

Chap. III. The Fall of Brewster's Patron . . . . . . . 299

Mary, Q. of Seots, 299. Davison's relation to her fate, 310. His imprisonment, 313. Value to Brewster of service under him, 318.

Chap. IV. Brewster at Scrooby Manor . . . . . . . 320

Postmaster and bailiff, 320. Family, 326. Progress towards Separatism, 327.

Chap. V. More Controversy about the True Church . . 330 Activity of Papists, 330. Rural England, 332. Millenary Petition, 334. Hamp. Ct. Conf., 339. 
Chap. Vi. The Controversy Contrnued . . . . . . . . . 352

Discussion prolonged, 352. More severities, 354. Deprivation of ministers, 357. Sunday observance, 371. Revised Bible, 375.

Chap. Vil. Other Pilgrms and the Exodus . . . . . . . 377

Clyfton, 377. Smyth, 378. Departure to Amst., 386. Pilg, chureh, 386. Bradford, 387. Ninor members, 391. Robinson, 393. Life at Corpus Christi, 393. Becomes Separatist, 400. Persecutions, 401. Attempts to escape, 403 .

\section{BOOK V}

\section{The Pilgrims in Amsterdam}

Chap. I. Amsterdam as the Pilgrims found It .

Hist. and characteristics, 411. Oppression by Chas. V., 416. By Phil. II., 417. Revolt and reform, 418. Relig. toleration, 419.

Chap. II. Earlier English Separatists 421

F. Johnson and his ch., 421. Ainsworth, 423. Troubles of church, 425.

Chap. III. The Further History of the Ancient Church . . 431

Eng. exiles - statistics, 431. Confess. of Faith and efforts for recognition, 433. Other Eng. churches in Amst., 442. Prosperity of Anc. Church, 445. Smyth's peculiarities, 446.

Chap. IV. The Pilgrims in the City . . . . . . . . . . 449

Robinson's eccles. labors, 451. Smyth's new views and se-baptism, 453. Disruption of his ch., 460. Arminian Controv., 461. Johnson's drift towards Presbyterianism, 464. Pilg. application for leave to settle in Leyd., 467. Dutch-Spanish truce, 468.

\section{BOOK VI}

\section{The Pilgrims in Leyden}

Chap. I. The City and its History. . . . . . . . . . . 473

Characteristics, 473. Govt., 476. Siege, 478. University, 482. Armin. Controv., 484. Leicester insurrect., 485.

Chap. II. Leyden University and its Great Men . . . . . 487

Homes and employments of Pilgs., 487. Notable features of city, 491. Univ. and faculty, 493.

Chap. III. The Pilgrims' First Year in Leyden - 1609 • . . 500

Early researches, 500. Public records, 502. Personal details, 505.

Form of marriage, 507. Citizen's oath, 509. Armin. Controv., 510.

Chap. IV. The Succeeding Years - 1610 . . . . . . . . . 514

Personal details, 514. Robinson's literary characteristics, 517. 
Division amoug Eng. at Amst., 520. Armin. Controv., 524. Utrecht revolt, 526. Jülich campaign, 526.

Chap. V. The Succeeding Years - 1611-1612

Pilg. headquarters secured, 529. Personal details, 533, 540. Controv. over Vorstius, 535. More troubles at Amst., 536. Order of worship, 541.

Chap. VI. The Succeeding Years - 1613-1616 .

Personal details, 548, 552, 555, 559. Armin. Controv., 551. Robinson's progress toward liberalism, 553. Discussion with Ames, 557. Debate with Episcopius, 560. Clyfton's death, 561.

Chap. VII. The Succeeding Years - 1617-1619 . . . . . . 564

Personal details, 564, 571, 576. Decision to leave Holland, 566.

Negotiations about emigration, 568, 573, 579. Armin. Controv., 570, 574. Synod of Dort, 575. Pilg. printers suppressed, 578.

Chap. Vili. The Year of the Departure - 1620 . . . . 583

Personal details, 583. Hudson scheme, 583. Agreement with Weston, 584. Hindrances in getting away, 585. Departure from Holland, 586. From England, 589.

Chap. IX. Concluding Words . . . . . . . . . . . 591

Robinson's remaining years, 591. His growth in liberalism, 592.

\section{APPENDIX}

The Pilgrim Company in Leyden . . . . . . . . . . . . 601

Other English People in Leyden . . . . . . . . . . . . . 641

Citizenship List . . . . . . . . . . . . . . . . . .648

English Sources of the Pilgrim Emigration . . . . . . . . . . 649

Plymouth Colonists from Leyden . . . . . . . . . . . 650

\section{INDEXES}

Index of Publieations . . . . . . . . . . . . . .655

General Index . . . . . . . . . . . . . . . . . . . 663 


\section{LIST OF ILLUSTRATIONS}

PAGE

Scrooby Manor-House as It IS TO-Day . . Frontispiece

The Pilgrim Region . . . . . . . . . . . . 215

West Side of Manor-House $\quad$. $\quad . \quad$. . . . . . . 246

St. Helex's Church, Austerfield . . . . . . . 388

The Se-Baptism • . . . . . . . . . 456

Pesyns-hof, on the site of Robinson's House . . . $\quad 532$

Robinson Tablet on the Pieterskerk . . . . . . 592 


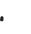

. 


\section{BOOK I}

THE ENGLAND OF OUR FATHERS 
I considered the dayes of olde, and the yeeres of ancient time. - Ps. lxxvii : 5.

The fact cannot be too often reasserted that human beings are chiefly what their forefathers have made them, and that the difference between any one generation and the next preceding is barely perceptible. It is only in the long course of ages that the advance of civilization is marked, only a comparison of one age with another which can tell us in what direction we are progressing. - L. O. PIKE, Crime in England, ii : 81.

It is a commonplace, but one which cannot be too often repeated, that we must interpret an ancient writer by himself and by his own age, and not by modern notions. We must not add on to him our mysteries and moralities, or translate his confused modes of thought into our more distinct ones (more distinct at least to us). Neither must we measure him by our standards of right and wrong. His range of view may be limited, but we cannot safely enlarge it. - B. Jowetr, Introd. to Thucyd. xv. 


\title{
THE ENGLAND AND HOLLAND OF THE PILGRIMS
}

\author{
CHAPTER I \\ THE COUNTRY AND THE PEOPLE
}

IT is impossible to do justice to the earlier colonists of New England without gaining some conception of that Old England out of which they came. Its traditions, habits and methods became prime factors of their great endeavor here, even while reaction from intolerable oppression of the conscience was the crowning cause of their self-exile hither. The New Plymouth of 1620 must find much of its best interpretation in that old life which, sadly, yet with a great hope, the Mayflower was leaving behind the hazy hills of Cornwall as she drew away from them westward on her eventful voyage. And this the more because the tendency of the present always is to judge old times mistakenly by the standards and circumstances of to-day. Some study of the condition of the mother country, therefore, is imperative.

We may take, for convenience, an even period for our starting-point. On March 25, 1601, which to the English nation was the birthday of the seventeenth century, Queen Elizabeth, then nearing sixty-eight, was in the fifth month of the forty-third year of her reign. At this date England appears to have contained $4,000,000^{1}$ of people, or a little more. Of these perhaps 225,000 lived in London and Westminster and their suburbs. There were some twenty-five other cities, twelve or fifteen of which, especially York, Bristol, Norwich, Lincoln and Salisbury, were of considerable size. In comparison with the present dis-

1 Knight, Hist. Eng. iii : 267. Sir Fred. Eden, State of Poor, i: 92. Pike, Hist. Crime in Eng. ii : 293. Motley, Un. Neths. iv: 119. 
tribution of population, the northern counties, especially Lancashire and Cumberland, were thinly peopled; and, in general, those portions of the realm best adapted to husbandry were settled most fully.

Many causes long had hindered the kingdom from any such growth as has marked its later history. Chief among these were the enormous death-rate, due to wretched sanitary conditions, the terrible devastations of epidemics and the steady waste of life in war. Moreover, statesmen then deprecated, and even actively hindered, the growth of population. ${ }^{1}$ Indeed, repeated enactments had been aimed to check it.

The dissolution of monasteries in the sixteenth century, by throwing thousands of monks or nuns upon the necessity of secular self-support, had added perceptibly to the multitude seeking labor or asking to be housed somehow in towns. And, while increasing numbers gravitated towards London, the old-time jealousy on the part of the nobles of the rapid advance of the burghers in wealth and power lay at the root of their hostility to the enlargement of the metropolis. This fact, of what then was regarded as wise public policy, also explains the palpably low estimate of the value of a human life, and how the State, seemingly without suspicion of injuring itself, could submit to the most appalling losses, and, even for the most trivial causes, could imprison, banish, hang, behead or burn its able-bodied eitizens, sometimes by dozens and scores at once.

The kingdom was divided into fifty-three shires, or counties, of which thirteen were in Wales. Over each presided a lordlieutenant, beneath whom was a sheriff, having an under-sheriff and bailiffs with high and petty constables. In each were held quarter sessions, with jury trials and petty sessions for the hearing of minor causes.

This English people was divided horizontally into four ranks, gentlemen, citizens, yeomen and laborers. The first included the Sovereign; the Prince of Wales, the king's eldest son ; dukes

1 Harrison (Descrip. Eng. [Furnivall's ed. 1877] 306) cites the judgment of some that "We haue alreadie too great store of people in England; and that youth by marrieng too soone doo nothing. profit the countrie, but fill it full of beggars [to the hurt and vtter vodooing (they saie) of the commonwealth]." State Papers, Domestic Proclamation Bk. 41. 
- although at this date there happened to be none; marquises; earls and viscounts.? Besides whom there were forty-three lords or barons ; two archbishops and twenty-two bishops. These ninety-two in right of birth or position constituted the House of Lords. Below them were simple knights and esquires, bearing coats of arms, easily to be had for money by those of good education who could live without manual labor, with lawyers, physicians and the clergy.

Originally the rank of Esquire was military, but the name had come to be applied to those regarded as gentlemen by birth, without being noblemen, like the younger sons of peers, the elder sons of knights and the chief representatives of ancient families. Such gentlemen as had no special title of nobility, and were not entitled to be called "Esquire," were addressed and spoken of as "Master," or "Mr."

The second rank of citizens, or burgesses, were the freemen of cities and boroughs, competent to vote for members of, and to sit in, the lower house of Parliament; with conspicuously successful merchants. This class was numerous, and in the fifteenth century it had gained great influence, much of which it had lost during the interval.

The same was true of the yeomen, - in the third rank, - freeborn men, who from their own land had an annual income of not less than six pounds, perhaps $\$ 150$ of our present money. Most of them were thriving farmers. Now and then they climbed to places vacated by decayed gentlefolk, and educated their sons. They usually fought on foot, but their bravery made them a chief dependence of the king. They were addressed by their Christian names, and were spoken of as "Goodman" this or that. In legal instruments they were described by their class title, as "John Smith, yeoman."

In the fourth, and lowest, rank were lumped some petty merchants having no free land, copyholders, ${ }^{2}$ all artificers, poor husbandmen and day-laborers; and, lower down, the rabble rout of the non-industrious and the criminal. This class, whether

1 There were respectively one, twenty and two.

2 A copyholder was so named because he held his land by grant from the lord of the manor, his evidence of title being his copy of entries on the court rolls. 
better or worse, producers or non-producers, had neither authority nor voice in the commonwealth. Yet, in default of suitable yeomen, the superior handicraftsmen sometimes were put upon inquests, made church-wardens, sidesmen or ale-cunners, and, now and then, headboroughs, tithing-men ${ }^{1}$ or constables.

$\mathrm{He}$ who recalls with what imperfect success even the nineteenth century has been able to deal with the relations of Church and State to the "lower," or the "dangerous," classes, cannot be surprised that 300 years ago in England there should have been not only very many in straitened circumstances, but also many others absolutely destitute, if not utterly abandoned. There were, so to speak, the normal poor: the widows and orphans; the constitutionally feeble, the blind, lame or palsied, victims of accident or sufferers from chronic distempers; the worn out with age, hardship or excess; the idiotic; and those who have no "faculty," and live only to be cheated, to lose and to waste.

Add to these other multitudes who had brought home from the wars an inveterate reluctance, if not an actual inability, for manual, labor $;^{2}$ households emerging decimated and penniless from those terrible tidal waves of epidemic disease, ${ }^{3}$ which for dreary months arrested the ordinary goings-on of society; and thousands born in abject penury, to whose utmost endeavor no avenue of honest labor gave welcome. Add also the shameless spawn of the lowest, born under a hedge, seldom roofed when not in prison, lisping in "pedlar's French," 4 and habitual beggars, ever on the watch to steal. Of this last and worst class, who habitually haunted wild lands and such localities as the

1 Sidesmen were assistants to church-wardens. Ale-cunners were officers appointed to inspect bread, ale and beer. Headboroughs were officials subordinate to constables. Tithing-men were men appointed for every hundred families to determine lesser causes between villages or individuals.

2 R. Hitcheock, Pollitique Plot (1580), 27.

3 The plague had appeared in London eight times between 1592 and 1665, killing from 12,000 to 68,000 persons each time. Iu 1485, 1507, 1517 and 1528 an entirely distinct distemper, known as the "sweating sickness," caused swift and frightful mortality in the kingdom. Enc. Brit. Graunt, Observations on Bills of Mortality (5th ed.), 46-54.

4 "A speach compact thirty years since, of English, and a great number of od words of their owne deuising." Harrison, 218. Thomas Harman in his Caveat for Cursetors (repr. 1871) gives examples. 
Peak of Derbyshire, it was estimated that there were more than 10,000 in the kingdom. ${ }^{1}$

Nor were these various classes of the needy and wretched mainly congregated, as now, in or near the great towns. For example, not far from the date under consideration, a careful "survaie" was made of the little town of Sheffield." It showed that on January 2, 1615, there was a total population of 2207 persons. Of these 725 were "begging poore," unable to live without charity. There were 100 householders, able to do something for the relief of their needy townspeople; yet they were but poor working folk, not more than ten of whom had grounds of their own that would keep a cow. There were, further, 160 householders who could do little or nothing for others; who usually by the hardest labor made both ends meet, but who by " the storme of one fortnight's sickness would be driven to beggary." More than half the population - 1222 - were children or servants of these 260 householders, of whom "the greatest parte are such as live of small wages, and are constrained to work sore to provide them necessaries."

This is a sombre picture. But there is no reason to doubt its fairness. The condition of things was due partly to the waste and woe of civil war and partly to the concentration of power in the hands of the Crown at the cost of the comparative independence and vigor of the towns. Sir Frederic Eden ${ }^{3}$ also ascribes the development of the poor, as a distinct class needing support, largely to the beginnings of the growth of commerce and manufactures. The growth of woollen manufactures raised the value of wool, which had become one of the foremost articles of English production and export. The higher price of wool stimulated sheep farming on a large scale. That could be managed only by consolidating petty holdings into large tracts. This deprived many, who knew how to do nothing but work on the land, of that opportunity, and the manner in which it often was done, by fraud or force, ${ }^{4}$ left them bitter as well as destitute. One shepherd could take the place of a dozen men with plough, hoe and scythe, and sometimes the major part of the

I Harrison, 217, 218.

3 i : 57.
2 J. Hunter, Hallamshire (ed. Gatty), 148.

4 Moryson, Itin. iii : 147. 
dozen joined the tramps. So long as the nation was made up almost wholly of land-owners and servile land-workers, the latter in extremity conld depend npon the former. But as villeinage, the current name for English servitude, declined, those who were thrown out of dependence on masterhood for sustenance, and who could not, or would not, pass up into the higher plane of self-reliance, were left to starvation or beggary.

Thus there came to be in the land a permanent host of " broken men." A justice in Somersetshire, in 1596, declared that in that county, during that twelvemonth, forty persons had been executed for various felonies, thirty-five burned in the hand and thirty-seven whipped; and that, of 183 who had been discharged, all were wicked and desperate but mostly too cunning to be convicted. He added that other shires were in as ill a case or worse, enough able-bodied vagabonds being abroad, infesting every county and sometimes massing themselves to spoil the inhabitants, " if they were reduced to good subjection, to give the greatest enemy her majesty hath a strong battle."

Perhaps the earliest symptom of thought for their relief appears in the remark of Blackstone that, by the common law, the indigent are to be "sustained by parsons, rectors of the church, and the parishioners." 2 The monasteries, at first numerous, naturally were resorted to by the needy, who received largely of their bounty. Yet, as Hallam ${ }^{3}$ suggests, they caused the same sort of misery which they relieved. As early as 1376 Parliament began to study the subject, and in 1388 the germs of what afterwards became "parochial settlement" appeared in a statute. And, after many generations of experiment, all these devices almost insensibly passed, in 1601, into that famous Act, which, borrowing from former legislation the appointment of overseers of the poor, compulsory assessments, the setting at work of all able adults, the relief of the impotent and the apprenticing of pauper children, added some new provisions, and so established what remained substantially the English law as to pauperism down to modern days.

1 Letter of Ed. Hext. to Lord Treas. Strype, Annals (ed. 1824), iv : 404-412, 40. Harrison, 231.

2 Comms. (ed. 1807) i : 359, and Introd. sect. iii.

3 Const. Hist. Eng, i : 80. 
Moreover, in the beginning of the reform of husbandry, much labor, thrown off through the absorption of small farms, was regained by the adoption of a more thorough tillage. Middlemen, able to help themselves by employing others, gradually grew up. The quickening of manufactures - which had been begun in the fifteenth century, with some rude machinery - commerce and the fisheries began to put a new face upon the national welfare, and the last quarter of the sixteenth century saw the foreshadowing of an era for poor people beyond anything which any poor-law could promote. ${ }^{1}$

Outside of the towns the land largely was unenclosed. ${ }^{2}$ At intervals of from two to four miles would be a parish church, with a few cottages, and not far away the manor-house of the squire, who perhaps owned most of the land within sight. His dwelling ordinarily would be of two stories, the upper often overhanging the lower, built of brick or stone; or it might be framed of strong timbers with studs from four to nine inches apart filled in with stones and clay, coated with whitewashed plaster and roofed with tiles or slates. A few years only had elapsed since even the costliest dwellings had depended for windows upon lattice-work pieced out with horn or oiled paper. Glass, although imported for churches and palaces, hardly had become common.

The rooms of the mansion often would be lofty and spacious, and would have the walls hung with tapestry, or wainscoted with native oak. The domestic offices and farm buildings would be near but not under the same roof; excepting sometimes in the north, where necessity urged most shelter from least material. The better residences of country gentlemen included a large hall and a chapel. The yeoman's home had several rooms, and was roofed with reeds. The cottages of laborers usually were of clay walls upon a timber frame, thatched with straw, windowed with one or two lattices, and seldom including more than two rooms.

Harrison says that old men in his village " noted three things to be maruellouslie altred in England within their sound remem-

1 J. R. Green, Hist. Eng. People, ii : 384-390.

2 Rye, Eng. as Seen by Foreigners, 31. See also road-maps in Owen's Britannia Depicta (1764). 
brance." One was the number of chimneys, in their youth there having been not more than two or three in most country towns, smoke escaping through the "louver." I The second was sleeping accommodations. Instead of lying, at best, upon a flock-bed stuffed with coarse wool, with a sack of chaff for a bolster, the farmer had feather-beds, sheets and pillows, which latter formerly had been accounted luxuries for women in childbed. The third was table furniture. Where the fathers had eaten with wooden platters and spoons, their sons would have a fair garnish of pewter on the cupboard, with a full dozen of spoons. Excepting in bedrooms, the floors, even of palaces, were strewn with rushes.

Most dwellings had gardens, although scarcely yet had people learned how useful are vegetables in supplying wholesome nourishment cheaply. Harrison enumerates melons, pumpkins, gourds, ${ }^{2}$ cucumbers, radishes, skirrets, ${ }^{3}$ parsnips, carrots, cabbages, navews, ${ }^{4}$ turnips and all kinds of salad herbs. Potatoes, brought to England in Raleigh's vessels a quarter of a century before, had not become generally known. The gardens of the nobility were beautiful, and the taste for rare plants had begun to show itself among some who had but little land. Harrison declares that his own home lot, containing only some three hundred square feet, which he tilled himself, contained nearly that number of "simples," not one of which was common. Orchards yielded apples, pears, plums, walnuts and filberts, and gentlemen's grounds often abounded further in cherries, apricots, peaches, grapes, almonds and figs.

Probably not above a quarter of the land was cultivated, ${ }^{5}$ the remainder being woods, moors, fens, commons and parks or warrens. Of the forty counties in England but fifteen were destitute of forests, some of which, like Sherwood and Dean, were of great extent. Moors and mosses occupied immense tracts. The fens of Lincolnshire were famous resorts of wild fowl. Already some plans had been made for the reclamation of boggy

1 "A turret, lantern, or any apparatus on the roof of a building for the escape of smoke." - Halliwell.

2 Nearly what are called squashes in America.

8 The skirwort, resembling the parsnip. See Evelyn, Acetaria, 65.

4 Navets, either French turnips or rape-seed.

5 G. W. Thornbury, Shakspere's England, ii : 237. 
tracts, which soon came to trial on a larger scale. ${ }^{1}$ Common lands abounded. There were comparatively few fences, ploughed fields being separated by balks of earth. Where arable land had been turned into pasture there were enclosures, excepting when hundreds of acres were grazed by flocks guarded by a shepherd with his dog. In every shire, moreover, were numerous parks and warrens. The Crown alone had nearly two hundred of the former, which supplied venison to the royal tables. Every noble, and almost every man of wealth, also, had his park, and sometimes it was miles in eircuit. ${ }^{2}$ The number of rabbitwarrens was almost beyond computation.

The highways afforded passage and offered safety in degrees differing with locality, most, on leaving thickly settled territory, degenerating quickly into mere cart or bridle paths. Even the Roman roads, originally marvels of excellence, had not been kept up. In many regions the ordinary routes had become so defective as to almost interdict inland traffic. ${ }^{3}$ Morasses had to be floundered through and rocks and rough places evaded or overcome. When the path reached a river - unless the stream had been bridged by private or ecclesiastical benevolence - one had to ford it, or to creep across upon a single timber, with a handrail at the side, leading his wading or swimming beast. When Mary, Queen of Scots, was removed from Bolton Castle to Ripon, ${ }^{4}$ in 1569 , the party were from early morning until late in the evening in making the sixteen miles. Queen Elizabeth died on the morning of Thursday, March 24-April 3, 1602-3, at three o'clock, but the news, carried at top speed by an eager courier, did not reach York, then counted as 196 miles from London, until daybreak on the following Sunday. ${ }^{5}$

Near London the roads were said by Fynes Moryson, in 1617 , to be "sandy and very faire, and continually kept so by labor of hands." Coaches were used upon them but seldom,

1 S. $P$. Dom. exx vii : 143 , etc.

2 Moryson, iii : 148.

${ }^{3}$ Goods cost fifteen pence a ton per mile for transportation (Goadby, 10). A penny then was equal to about ten cents, in our modern money, and a shilling to about $\$ 1.25$.

4 Leader, Mary, Queen of Scots, in Captivity, 27.

5 Drake, Eboracum, 130. And Drake reckoned it only 150 miles. 
while their cost was great, and none were on hire, even in London, before 1630. Most Englishmen who could afford it rode their own horses. Yet along the chief thoroughfares posthouses had been established about every ten miles, where horses could be hired. Carriers also let horses from town to town, on condition that the traveller stay at the inns where the carriers lodged. Between London and the chief towns such carriers made regular trips with long covered carts. But as these cumbrous vehicles started betimes and made but tardy arrival, few made use of them. Luggage was carried upon packhorses or in twowheeled carts, drawn sometimes by five or six horses harnessed tandem. When the Court broke up in one place to migrate to another, there would then be several hundred of these carts, although before long the number was much reduced.

Fynes Moryson declared in 1617, that "the World affoords not such Innes as England hath." 1 The humblest village contained some little thatched house, belike with an ivy bush as a sign, whose lowliness found easy pardon from the tired and hungry wayfarer; while on frequented thoroughfares huge hostelries stood ready to welcome either the solitary horseman or the cavalcade of some bishop or noble. However highwaymen might plot with servants at the inns, for the spoiling of travellers whose luggage promised sufficient reward, ${ }^{2}$ there always was safety as well as comfort within. A man might not command his own household more freely than he might, with Jack Falstaff, take his ease in his inn.

Much apparel ${ }^{3}$ of the time would seem to our modern eyes exaggerated, if not preposterous. Queen Elizabeth liked magnificence in those about her, so that whoever wished to secure her favor adorned himself and cultivated grandeur in his retimue. The Earl of Hereford once met her at Elvethan with 3000 men with black and yellow feathers and mostly wearing gold chains. At one of her visits to Suffolk she was attended by 200 bachelors in white velvet, with as many burghers in black velvet with gold chains, and 1800 mounted serving-men in livery. A fashionable lady in 1601 had her hair - occasionally

1 iii : 151.

2 Harrison, iii : 107, 108.

s See hints and descriptions in Thornbury, Goadby, Fairholt and Drake. 
her own, but more often false or dyed - "curled, frisled and crisped," piled up into some striking fashion, often with jewelled. wreaths of gold or silver. Her neck was encircled by an immense ruff or collar from one to two feet in diameter and stiffened by starch, backed by forks and wires. ${ }^{1}$ Her gown was of some thick quilted brocade, with a bodice whose point descended well below the knees, and its skirt was puffed out all around by an enormous farthingale, or whaleboned petticoat. All was lifted to an unnatural height by "chopines," or shoes with excessive cork heels, and topped off by a velvet hat with a crown gored like a balloon, and a curved brim.

The men indulged in starched ruffs, but of comparatively moderate dimensions. They wore shirts of linen, sometimes embroidered extravagantly. Jerkin, doublet, girdle, hose, nether stocks and rose-tied shoes, with a rich short cloak, worn mainly on one shoulder, composed a costume surmounted by a steeplecrowned hat of velvet, taffeta (watered silk) or beaver, ornamented with a feather. These garments, as compared with ours, were diversified in quality and gay in colors. Jerkin, doublet and hose might be, in substance, of velvet, silk, satin, camlet, grogram or taffeta; and of any color. Moreover, they often were slashed, jagged, pinched and laced with gold and silver. One absurd fashion for men's leg wear was the "bombasted," or " beer-barrel," breeches. These were so stuffed and padded ${ }^{2}$ that the wearer resembled Jack Falstaff's "forked radish." Lawyers and the clergy were restricted to a graver costume, of which a long robe was the chief characteristic. Physicians usually were habited in a velvet cap and a doctor's gown. From the girdle hung on one side a purse and a dagger, and on the other a long rapier. Most men, including the clergy, wore a short dagger. The unsettled state of society made it only reasonable to equip one's self for self-protection.

The humbler classes were clad in russet, or in Lincoln or

1 Supportasses. Stubbes, Anat. of Abuses, D. 8.

2 Bulwer (Pedigree of Eng. Gallant. 548) says that a man took out of his breeches a pair of sheets, two tablecloths, ten napkins, four shirts, a brush, glass and comb, with nightcaps; and Strutt (ed. 1842, ii : 144, n.) says that a special gallery was erected around the inside of the Parliament House for the accommodation of members who wore this protuberant attire. 
Kendal green $;^{1}$ sometimes in canvas, fustian or leather. Apprentices wore round woollen caps; the yeomen, homespun russet in summer and frieze in winter; the rustic, some coarse gray cloth, with a featherless hat or a cap. A blue suit, with a silver badge on the left sleeve, was the uniform of serving-men, excepting that the menials of bishops were clad in yellow. The wives and daughters of farmers made their kirtles, or loose gowns, of some light homespun stuff, with linen aprons. Upon the head they often had a linen coif under a high felt hat. Men wore the hair, beard and mustache moderately long, and beards had distinctive characters.

A revolution quite as great also has taken place in respect to the table. The very idea of the modern breakfast was mainly unfamiliar to the English nind.2 Excepting for farm laborers, who took their pottage, more or less heartened by meat, by the light of the molming star, the very young and the infirm or aged, but two meals a day were usual: dinner, at from half-past ten to eleven in the forenoon in the country, and an hour later in London, and supper at five or six in the afternoon. Both tea and coffee still were to be unknown for more than a generation. ${ }^{3}$ The poor ate rye or barley bread, those better off manchets of white wheat flour. Bacon, souse, brawn, powdered (salted) beef or mutton, and barrelled (pickled) herrings, or other fish, were the mainstay of the table in winter. Brewis ${ }^{4}$ was eaten largely. Meat pies, or pasties, especially of venison, and florentines ${ }^{5}$ were much regarded. Such pasties also were filled with herrings, pilchards, eels and the like. Concluding courses consisted of eakes and sweetmeats. Common people ate with wooden or latteen ${ }^{6}$ spoons from wooden trenchers. All fed

1 Kendal and Lincoln were famous for the manufacture of green cloths for foresters.

${ }^{2}$ Harrison, i : 102. Moryson, iii : 150.

3 Tea is said to have been sold in England on rare occasions as early as 1635, at what now would be from $\$ 175$ to $\$ 270$ a pound, and chiefly to princes or noblemen. Coffee was brought into England first by Mr. N. Canopus, a Cretan, who made it his common beverage at Balliol College, Oxford, in 1641; and the first coffee-house in England was kept by a Jew, named Jacobs, in Oxford, in 1650. Haydn, Dict. of Dates.
4 Bread soaked in pot-liquor.
5 A meat pie having no bottom crust.

${ }^{6}$ Iron plated with tin. 
themselves, as their fathers had, with the knife, aided by the fingers - giving much use to the napkin - as it still was years before forks ${ }^{1}$ were introduced from Italy. In the hall, at the long dining-table, the retainers and domestics sat with the family, but below the salt. ${ }^{2}$ Beer, spiced ale or wine was the common drink, and a "morning-draught," with which radishes frequently were taken, often served as breakfast. ${ }^{3}$ Little wine was made in England, but Harrison speaks of fifty-six kinds of imported French or German clarets or white wines, and of thirty Italian, Greek or Spanish stronger brands. Tobacco had made its way into the kingdom, it is understood, in 1586, with some of Raleigh's Virginia colonists, ${ }^{4}$ whom Drake carried home. The fashion was to draw the smoke from the pipe into the mouth and eject it through the nostrils. ${ }^{5}$ This was called "drinking tobacco." Snuff-taking also became popular before long. ${ }^{6}$

The date under consideration was before the advent of newspapers and magazines, ${ }^{7}$ and books were few and costly. Consequently people resorted to games and kindred methods of passing their leisure hours. Within doors they indulged in riddles, jests and merry tales, and often in cards, dice, draughts, shuttle-cock and shove-groat, or shovel-board, and, in the more cultivated circles, in chess. Then there were dancing and, ont of doors, wrestling, quarter-staff, pitching the bar, tilting at the

1 Thos. Coryat, Crudities, 90. Moryson, iii : 114. Ben Jonson, Devil is an Ass, Act v. sc. 3. Court and Country (ed. Roxburgh, 1868), 201. But see also Toun Life in 15th Cent. ii : 74, $\mathrm{n}$.

2 A large salt-cellar was placed about in the middle of the long table, and the seats above were assigned to guests of distinction, and those below to dependants.

3 J. C. Jeaffreson (Book About the Table, i : 219) says : -

"The 'morning-draught' at the inn was, in fact, the ordinary breakfast of the majority of Englishmen. ... Unless they bear this fact in mind, readers of old biographies are apt to attribute tavern-hannting propensities to sober and disereet gentlemen."

4 This agrees with King James's statement (Counterblast, Works, 215) better than the more usual account.

5 Hentzner, Itin. (1598) 43.

6 Deeker, Gull's Horn-Boøk, Proem and chap. v.

7 Pamphlets of news began to appear soon after the coming in of the serenteenth century. Burton, Anat. of Melancholy, 1614. The first proper newspaper in English appeared in 1622, the first literary periodical in 1680. Enc. Brit. 
ring, football, hurling, ${ }^{1}$ running at quintaine, ${ }^{2}$ barley-break, ${ }^{3}$ and shooting at butts, with fishing, hawking and hunting. Wandering companies of minstrels and harpers were common, and rude plays were acted before the public. Archery was required by royal order, with bow of yew, ash or elm, three fingers thick and seven feet long, and with arrows of ash, from two and a half to four feet in length, and heavy or light for long or short distances. In London there were lounging in Paul's Walk, ${ }^{4}$ bull and bear baiting, masques and the theatre.

There also were numerous special ceremonies and gambols at specific seasons and days — such as Christmas, New Year's, May Day, Twelfth Day, Plough Monday, ${ }^{5}$ Shrove Tide, ${ }^{6}$ Easter, Whitsuntide, Candlemas Day, Martinmas, All Hallow's Eve, and Sheep-shearing, with Church-ale, ${ }^{7}$ Leet-ale, Lamb-ale, Brideale, Clerk-ale and others. Annual fairs also were held, during which ordinary business was suspended, sometimes by law. Not unnaturally all of these appropriated valuable time, while many lielped to cause a grave corruption of manners. How the Puritans regarded some of these occasions is shown by their utterances. Thus Philip Stubbes in 1583 said of Christmas :-

Who is ignorant that more mischiefe is [at] that time committed than in all the yeere besides? what masking and mumming! whereby robberie, whordome, murther and what not is committed! what dicing \& carding, what eating and drinking, what banqueting and feasting is than [then] vsed more than in all the yeere besydes! to the great dishonor of God, and impouerishing of the realme.

1 A small ball was to be carried "by force or slight to the place assigned." Carew, Cornwall, i : 197.

${ }^{2}$ A bar was balanced on a pivot with a broad board at one end and a bag of sand at the other. The play was to hit the board when riding by and escape the bag as it was thrown around suddenly.

${ }^{3}$ Played by six persons coupled by lot, on a ground with three compartments, the middle one being named "hell." The middle couple, who could not break hands, had to catch the others, who were allowed to do so, the eaught taking the place of the catchers.

4 'The middle aisle of St. Paul's Cathedral, then the fashionable resort from 3 to 6 P. M.

5 The first Monday after Epiphany.

6 The time between Ash Wednesday and the preceding Saturday evening.

7 An annual ale-drinking pienic for the benefit of the Church. 
And he lays equally heavy charges ${ }^{1}$ against the maying customs of that time in describing the bringing home of the May-pole. Christopher Fetherstone also said, in 1582: "The abuses whiche are comitted in your may-gaymes are infinite," 2 and went considerably into details, and Henry Barrowe in 1590 condemned this whole range of excess with equal severity. ${ }^{3}$

Farming was the great industry of the English people. Michaelmas Day, September 29, in a sense began the agricultural new year, when rye was sown, land drained, hempseed beaten out, wheat threshed, the year's crop of wool sold, strawberries, barberries and gooseberries planted, rushes gathered for thatch or floor, and cider and perry made. In October winter wheat was sown and children kept watch against hungry crows. November saw the fat pigs killed, barley threshed, souse pickled, beef salted, peas and beans seeded down and the garden made ready for planting-time. In December good farmers gathered wood for their fires, cleaned and repaired farm-tools, and guarded tender plants from frosts, until the Christmas holidays set them all to eating, drinking and frolicking. In January and February gardens were planted, oats sown, calves weaned or killed and the hopyard weeded. March saw the hops set and the fields rolled. In April the hops were poled and the dairy was expected to turn out a crop of cheese. May was weeding-time and bees were swarmed. In June were sheep-shearing and the beginning of the hay-curing, completed in July. In August came wheat and barley harvest. At Bartholomew-tide (August 24) was held Stourbridge Fair, when butter and cheese were marketed. Hoppicking followed. And so the year went round.

The rent of land had risen from one shilling and fourpence, or one and eightpence, in the early part of the sixteenth century, to perhaps six shillings an acre. The wheat crop was the best, but averaged not over fifteen to twenty bushels an acre. ${ }^{4}$ This was perhaps five-eighths of a ton, while barley often yielded a ton and oats a ton and a quarter. But the value of wheat had gone up faster than the rent of the land, being now sometimes

1 Anat. 174, 149.

2 Dial. against light, lewde and lascivious dancing, sig. D. 7.

3 Brief Discoverie, 81.

4 Thornbury, ii : 243. 
forty shillings, instead of six. Little grain was exported. The great staple for foreign trade was English wool, marketed at Bristol, Exeter, Lincoln, London, Newcastle, Winchester and York, whence it was carried by the Merchants of the Staple to Antwerp, Bruges or Calais, or sold more miscellaneously by the Merchant Adventurers. Besides the London livery companies there were three great trading corporations - that of New Trades, that of Tripoli Merchants, and that of East Land Merchants, just formed, which grew into the East India Company.

The thirteenth and fourteenth centuries had witnessed the rise of the guilds. These were associations of craftsmen, each aiming to secure the protection and monopoly of its own trade in its own town. This form of organization passed through many varieties of experience, but often it became identified with the corporation of the town, and exerted political power. Some of these ancient guilds still survive, and, although in the seventeenth century their powers had become modified, the guild continued to have much to do with the direction of trade of all sorts.

The fall of Calais, in 1558, with other causes, had led to new attention to manufactures at home. Flemings were invited into Yorkshire to work up the English wool. Coventry had become famous for its " true blue" woollens, as had other towns for their green cloths. Manchester had just begun to attract attention to its " coatings," or cottons. Norwich and Sandwich had received a considerable inmigration of makers of baize, serges, bombazines and beaver hats. In London the Flemings made felt hats, at Bow they dyed, at Wandsworth they wrought in brass, at Fulham and Mortlake they fabricated arras and tapestry. French and Belgian immigrants also had set up lacemaking at Cranfield in Bedfordshire, and at various towns in Devon. As yet there were no factories, all such labor being in the family, and no man being allowed by statute to have more than two looms. Yarmouth learned from Dutch incomers how to cure herrings. Lead and tin were smelted in Cornwall, and the roofs of English churches and some mansions, and of many buildings in France, were covered with the products. Coal mining was in its infancy, yet considerable coal was dug in Durham, Northumberland, South Wales and elsewhere. 


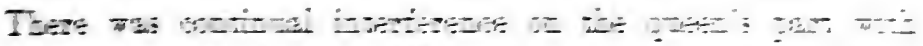

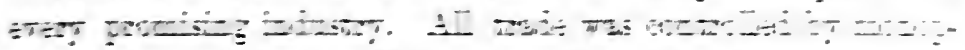
oly

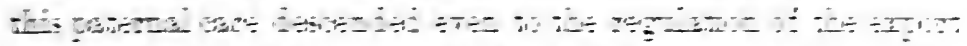
of Daid is

I

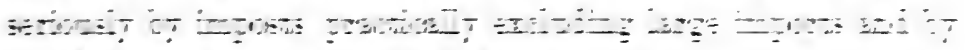

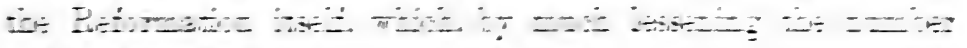

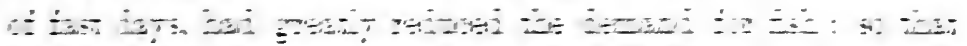
20

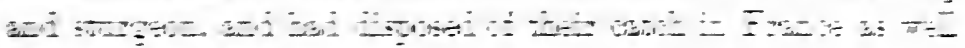
a

I

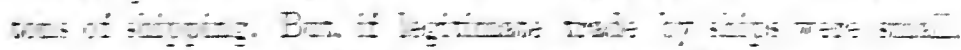
a

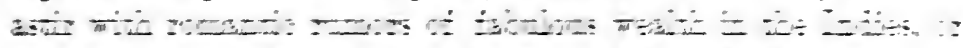

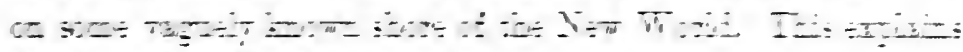

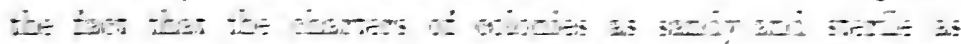

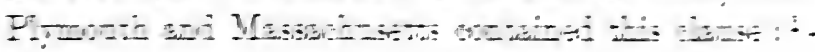

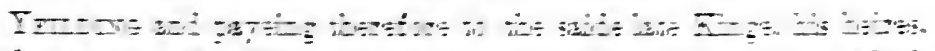
琏

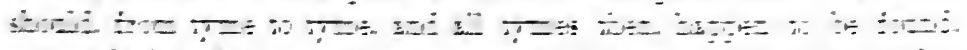

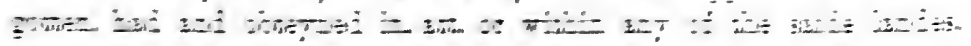
ㄱ:-

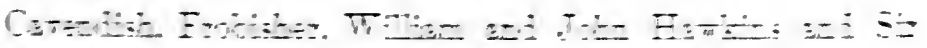
W

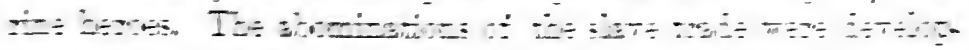

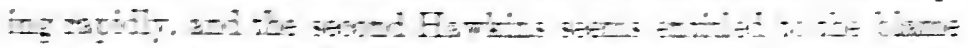
o

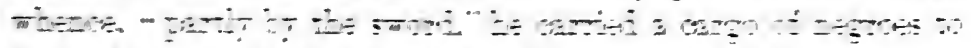
6.

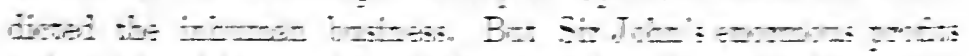

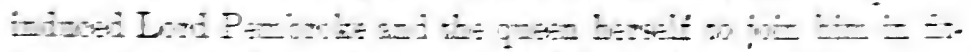
动 
on the African coast, and got rid of them for gold in the Spanish colonies, netting the "owners" sixty per cent on their shares. In 1577 Drake made the first English voyage around the world, returning, late in 1580 , laden with twenty tons of silver and gold bullion, with emeralds, pearls and miscellaneous spoils of Spanish ships and general piracies. The queen knighted him and gave him $£ 10,000$.

At this time most ships were small. Sir Humphrey Gilbert's Squirrel was of only ten tons, ${ }^{1}$ and of Drake's five vessels the largest was of only 100 tons, while their united tonnage was less than 300 , and their crews all together mustered only 166 men. A few vessels ranged from 400 to 900 tons, and one of 1500 tons had been built as early as 1512.2 Harrison gives the names of twenty-four warships and three galleys at the beginning of the seventeenth century. He further estimates that 135 vessels, including goods-ships, exceeded 100 tons apiece, and that 656 were between 40 and 100 tons. They were navigated as well as was possible to the rude science of the period. But although the compass is said to have been in use as early as about 1424 , nothing like the $\log ^{3}$ was known, and the clumsy astrolabe and cross-staff were relied on for guiding the voyage and determining the latitudes and longitudes. ${ }^{4}$ It is more remarkable that mariners found their way to port at all than that they often, perhaps always, blundered in so doing; and the more that no account then had been taken of the dip of the horizon, refraction or parallax, and that the tables of the zodiacal ephemeris were recalculated only about once in thirty years.

Such ships would strike a modern eye as wide for their length, blunt-bowed and excessively clumsy, because built up at stem and stern, often with several stories, or decks, and especially by having an almost mountainous poop. These lofty cabins were called castles. That at the poop, highest above the great cabin,

1 Goadby, 48.

2 Enc. Brit. Charnock, Hist. Marine Arch. (ed. 1801) ii : 58, 176, 178. Cruden's Gravesend (131), eited by Mrs. Green, Town Life, i : 84, n.

${ }^{3}$ Purchas dates the nse of the $\log$ in 1607 . Enc. Brit. Mrs. Green, Town Life, i : 107.

${ }^{4}$ Rev. E. F. Slafter, D. D., N. E. Hist. \& Geneal. Register, xxxvi : $145 . \quad J o h n$ Davis, Seaman's Secrets. Voyages andWorks (ed. 1880), x: 270. 
was called the Round House. Usually there were a foremast, a mainmast, and a small mizzenmast, at or near the taffrail, and carrying a spanker. There would be a topsail upon the mainmast and possibly another upon the foremast, and one or more jibs, or sprit-sails, between the latter and the bowsprit. But the chief dependence was upon the fore and mainsails, which were square and of good size.

At this time there was no standing army in England. 1 But most men were liable to serve in the militia, and were drilled systematically from one to six times a year. Armor liad become lighter than formerly. Infantry were mostly pikemen, billmen or musketeers. But the practical value of their weapons was much impaired by rudeness of construction. Cavalry were armored lancers, fighting with pike, sword and dagge (pistol); cuirassiers, wearing a cuirass over the leather jerkin ; or arquebusiers, additionally equipped with the arquebus. The larger pieces of ordnance, the robinet, falconet, falcon, minion, sacre, demi-culverin, culverin, demi-canon, canon, $\mathrm{E}$ canon and basilisk, varied in weight from about 200 pounds up to 9000 , in bore from an inch and a quarter to eight inches and three quarters, and in charge from a pound or two of powder and the same weight of ball up to sixty pounds of powder and also of ball.

1 Enc. Brit. ii : 569. 


\section{CHAPTER II}

\section{EDUCATION AND LITERATURE}

UP to the seventeenth century most of the common people had been illiterate. A volume of the Lansdowne Manuscripts ${ }^{1}$ contains the original petition of the church-wardens and others of St. Clement's in London, apparently dated April 7, 1589, with forty-eight signers, of whom seven made their marks; and also a memorial signed, on November 7, by thirty-six of the parish of St. Michael's in St. Albans, touching Mr. Dyke, their rector, of whom twenty-nine made their marks. Such illiteracy, however, probably was more true of the Establishment than of Dissenters; for the Reformation had tended to bring about a different state of affairs. Every parent thus spiritually moved would desire to be able to study the Bible himself, and, according to his ability, ${ }^{2}$ he would instruct his children. In some places, also, rudimentary schools were kept in the Parvise, ${ }^{3}$ or little room over the church porch. Sometimes a weaver or a tailor ${ }^{4}$ would have scholars around him while at work.

A peculiar fact may be recalled here - that of the privilege of

$161: 39,23$.

2 As late as 1670, Governor Berkeley, of Virginia, in reply to the question, What course is taken about instructing the people, said: "The same conrse that is taken in England out of towns ; every man, according to his ability, instructing his children." - Amer. Jour. of Educa. March, 1856, 300.

${ }^{3}$ T. Staveley, Hist. Churches in Eng. 159. Evelyn, Diary, i: 4.

4 Coote's English Schoolmaster (1597), v.: "Such men and women of trade as Taylers, Weavers, Shop-Keepers, Seamsters, and such others," sometimes undertook "the charge of teaching others;" and were not expected to be much in advance of their pupils. On the other hand, Mrs. J. R. Green (Town Life, ii : 15) claims that in the fifteenth century "apparently reading and writing were everywhere common among the people," and quotes Rogers's Agric. and Prices (iv: 502) to the effect that "in the royal accounts, the principal artizans in each craft audit ... the accounts ... and sign every page." Probably the general decline of prosperity after the fifteenth century was accompanied by a decline of attention to popular education. 
the clergy. Christian princes early granted two privileges to the Church : the exemption of consecrated places from the sweep of criminal arrest, or the right of sanctuary; and the freedom of the persons of the priesthood from process before the secular courts, or the benefit of clergy. By the former, whatever robber, murderer, or worse, could outrun the officers of justice and grasp the ring on the church door, ${ }^{1}$ crying " Peto pacem Dei et Ecclesiae," was temporarily beyond arrest, with possibilities of permanent escape. By the latter, when any priest or other "religious person" was summoned before a civil judge, his clerical tonsure and habit secured his immediate delivery to his Ordinary, or superior church official, to be dealt with by him; usually with surprising mildness. ${ }^{2}$

This had its origin in the rudest times, and grew into a legal process, and it became custom, and law, to accept the ability to read as sufficient proof that the reader really belonged to the clerical class; and it became common for a rascal who could read, and so could demonstrate his "clergy" out of a book, to lead a life of crime, and even of violence, and evade punishment. So grave did these abuses become that, in 1488-89, a law was passed to insure that no layman should have the benefit of his clergy more than once, enforced by the expedient of branding upon the brawn of his left thumb the letter $M$ if he were a murderer, and the letter $\mathrm{T}$ for any other felony. Surgery, however, soon learned to neutralize this scar, and it became needful sometimes for a jury to decide whether a given accused party already had been cleared and branded.

In 1536-37 and 1540-41, Statutes of Henry VIII. slightly modified this condition of affairs, but an act of 1547 granted benefit of clergy, without branding, to every peer of the realm guilty of any crime clergyable to commoners, or of housebreaking, highway-robbery, horse-stealing, or robbing churches, even though unable to read! In 1576 , it was enacted further that, after clergy and branding, the party, instead of being

1 Rogeri de Hovenden Annalium, pars postr. 542, Harl. MS. 4292, shows that between 1478 and 1538 from 400 to 500 scoundrels were shielded thus by taking "sanctuary" in the single church of St. John at Beverley, Yorks. See Evelyn, ii : 264, and Pike, ii : 254.

2 Pike, i : 104, 116, 207, 300, 449, 482. Blackstone, Comms. iv, ch. 28. 
turned over to his Ordinary, "be enlarged and delivered out of prison," power being reserved to the justices to imprison for not more than a year, when expedient. With modifications in 1717,1719 and 1779 , this extraordinary provision continued to be law until 1827. That this singular proof of general illiteracy had full force as evidence in 1601, is shown by a Latin record, lately discovered in the Clerkenwell Sessions House in London. It is the original indictment, ${ }^{1}$ in October, 1598, on which "rare" Ben Jonson was tried for the murder, in a duel, of Gabriel Spencer, at Shoreditch on September 22, previous. Jonson did not deny the crime, but pleaded his clergy.

It seems surprising, at first, in view of this widespread ignorance, ${ }^{2}$ that there should have been so many endowed "free grammar" schools. A history of such institutions, published in 1818 by a distinguished antiquary, ${ }^{3}$ mentions 475 such schools then existing or known to have existed. For twenty no date could be assigned, which argues an age beyond the tradition of men then living. But, of 252 traceable to a period before 1600 , 112 had been founded before 1450 ; eighty-three between 1550 and 1575 , and thirty-seven others before 1600 .

Had most of these schools corresponded, as some did, to those now known by the same name, so far as concerns free tuition, the mass of the people hardly could have failed of great enlightenment. But many such schools speedily fell into temporary decay, if they did not die. ${ }^{4}$ Secondly, they were "free" 5 only in the sense of being open without charge, or at small charge, to

1 Mid. Co. Recs. i : xxxviii.

2 Ibid. ii : 282-285. As late as 1662, the famous Samuel Pepys, who had been at school in Huntingdon and afterwards at St. Paul's School in London until he was seventeen, and subsequently was an M. A. at Magdalen, Cambridge, and who had been some years in the public service, says (Diary, $\ddot{\mathrm{ii}}: 4$ ) :-

"By \& by comes Mr. Cooper, . . of whom I intend to learn mathematiques. ... After an houre's being with him at arithmetique (my first attempt being to learn the multiplication-table) ; then we parted till tomorrow."

${ }^{3}$ Nicholas Carlyle, Concise Description of Endowed Grammar-Schools in Eng. and Wales. See also Harrison, 83.

4 Docs. Relating to Univ. and Colleges of Camb. iii : 153.

5 The Latin phrase employed, Libera Schola, rarely, in classical, post-classical or mediæval Latin, meant a school whose teaching was gratuitous, but almost always one free in the sense of being exempt from certain jurisdictions, taxes, etc. 
boys selected by the vicar or some one else of place or wealth, who meant to send them to college, and to the children of certain families or in certain localities designated by the founder. ${ }^{1}$ Thirdly, the great majority of them were so feebly mastered as to be of small use, even to their select pupils. Roger Ascham says $:^{2}$ -

I remember, when I was yong, in the North they went to the gramer schole litle children : they came from thence great lubbers, alwayes learning, and litle profiting; learning without booke everything, vnderstandyng with in the booke litle or nothing. Their whole knowledge by learning without the booke was tied onely to their tongue and lips, and neuer ascēded vp to the braine and head, and therfore was sone spitte out of the mouth againe.

John Brinsley, who, in 1601 and for many years after, was master of the school at Ashby-de-la-Zouch, which dated back to $\mathbf{1 5 6 7}$, published several works from which the quality of instruction and the methods of management may be inferred. ${ }^{3} \mathrm{He}$ says that children entered these "free" schools at about seven or eight years. School began at six A. M., the usher being there to enforce order. The master came at seven. There was a quarter-hour's intermission at nine, and the forenoon session ended at eleven. Afternoon school began at one, and, with a short recess at three, was closed at half-past five by the reading of " a peece of a Chapter," the singing of "two staues of a Psalme," and prayer. Charles Hoole, who was master of a free school in Rotherham and later taught in London, also published several schoolbooks which had great repute.

But it is Edmund Coote who describes that training which is more than probable for most of those who came to New England. It would be a cluster of ten or a dozen younglings grouped around some clerk or dame in the Parvise, or some weaver at his loom or tailor in his little workshop. The hornbook provides the alphabet. Then Coote's own " English Schoolmaster" takes them on. Its first pages are columned with $a b, c b$, $i b, b a b e b, b i b o b$, etc., ending in a lesson for reading, which

1 Staunton, 423, 67. H. C. M. Lyte, Hist. Eton. Coll. 3, 19, 483. Carlyle, i : xxvii.

2 Ascham, Scholemaster (ed. 1864), 170.

8 Ludus Literarius, or the Grammar School (1612), 296-298, 259. 
illustrates the solicitude for good morals and religion, even in primary manuals : ${ }^{1}$ -

Boy, go thy way to the top of the hill, and get me home the bay nag, fill him well, and see he be fat, and I will rid me of him, for he will be but clull as his dam ; if a man bid well for him, I will tell him of it [his dulness]; if not, I do but rob him: and so God will vex me, and may let me go to hell, if I get but a jaw-bone of him ill.

Eight such chapters, each increasingly difficult, complete the first book. The second book has six chapters; treating of words of one syllable, the number of syllables in a word, etc.; of observations needful to perfect a scholar, and how scholars shall appose (question) one another. There follow a short catechism, with sundry observations and prayers, Scripture selections and a few Psalms in metre. There are added some words on Arithmetic and a brief chronology, the whole concluding with a vocabulary explaining words oftener met, with than understood. These glances into the quality of primary education, even in the glorious age of Elizabeth, indicate that Brinsley spoke truth, and of many of the "free," or grammar, schools, as well as of the lesser ones, when, in 1622, he thus voiced the lamentations of many parents ${ }^{2}$ -

My sonne hath bene vnder you six or seven yeares, and yet is not able so much as to reade English well; much lesse to construe or vnderstand a peece of Latin, or to write true Latin, or to speake in Latin in any tolerable sort, . . Another shall complaine: my sonne comes on nener a whit in his writing. Besides that his hand is such, that it can hardly be read; he also writes so false English, that he is neither fit for trade, nor any employment wherein to vse his pen.

A boy taking the course in a grammar school should have been fitted for Cambridge or Oxford at fourteen or fifteen, the earliest usual age of admission. ${ }^{3}$ As we shall examine later the studies and methods of university life, only a general glance at

I The English Schoolmaster, 3, 11.

2 A Consolation for our Grammar Schooles, etc., 43.

${ }^{3}$ Christ. Wordsworth (Social Life at Eng. Univs. in 18th Cent. 94) regards the occasional cases of persons who entered at ten as those of precocious exceptions, and looks upon fifteen or sixteen as the usual age; the latter (689) having significance becanse such scholars then would be eligible for holy orders after their seven years at the university. 
them is given here. The system of study was largely, and even vitally, different from what it afterward became. By the Elizabethan statutes Mathematics - in place of the earlier grammar - Logic and Rhetoric were the three studies of the four years which preceded the bachelor's degree. These were the "Trivium." Then, with a continuance of the former, followed the "Quadrivium," ${ }^{1}$ Philosophy, Astronomy, Perspective and Greek, filling" the three years before proceeding master of arts.

Although these statutes remained in force, the strictness of their application had declined. Arithmetic, and whatever physical science was comprehended under Astronomy and Perspective, if not Greek - of which the same was true a little later were studied before, as well as after, bachelorhood, 2 but were not compulsory. And, although the statute continued to recognize only Aristotle and Cicero as text-books in logic, as early as 1584 an edition of the "Dialecticae Libri Duo" of that Peter Ramus, who in 1563 had defended in the College of Navarre the then astounding proposition that all the precepts of Aristotle are founded upon fiction, had been printed in Cambridge, and the Ramistic logic soon had large acceptance there. Theology also received much attention. Furthermore, although the official theory of study required all instruction to be taken either in the colleges, from their tutors, or in the halls of the university, from its professors or lecturers, so that nine whole terms of actual work in residence had to precede admission to the master's degree, exceptional circumstances had modified the rule, which, seven years later, virtually was rescinded. Thus a considerable and undesirable change had been effected. Such an education as this would train a young man to be familiar with the classics and with theology and the art of reasoning, and fit him to speak and write Latin fairly well, but it had serious drawbacks. A few years of foreign travel, especially in Italy, gave the finishing touch to the education of a young nobleman, although Ascham, when asked his opinion by Sir Richard Sackville, frankly doubted its value. ${ }^{3}$

1 Wordsworth, Schol. Acad. 82.

2 Mullinger, University of Cambridge, ii : 404. Masson, Milton, i : 226.

3 Schol. 71. 
It is diffienlt to crowd to-day's conceptions of English literature back into the narrow horizon of 1601. It long ago became the fashion to speak of Elizabeth's reign, especially in respect to authorship, as "the golden age of merrie England," and more than ninety-five per cent of that reign already was gone by. Yet, when one seans closely the books that there were for the people who could read, the showing is neither large nor brilliant. As Ilallam says : ${ }^{1}$ -

It is in consequence of the reputation for learning acquired by some men distinguisher in eivil life, such as Smith, Sadler, Ralegh, and even by ladies, among whom the queen ${ }^{2}$ herself, and the accomplished daughters of Sir Antony Cooke, ${ }^{3}$ Lady Cecil ${ }^{4}$ and Lady Russell, are particularly to be mentioned, that the general character of her reign has been, in this point of view, considerably overrated.

Roger Ascham's repeated and familiar glorification of that remarkable girl, Lady Jane Grey, ${ }^{5}$ has siggested an exaggerated conception of the feminine, and, indeed, of the usual, culture of that time. When Elizabeth came to the throne, few clergymen of her Establishment knew Greek, while the majority could not even read into English the Latin of their publie prayers $;^{6}$ and that this was true of the most learned men in the parishes compels a very low estimate of the general eulture. But when the exiles who had fled from Bloody Mary to the Continent eame back under the new reign, they brought a better state of things. And after 1580 the aspect of learning throughout the kingdom brightenerl, until the succeeding decade saw the beginning of that mighty movement of mind which suddenly exalted the nation to an illustrious standing in good letters.

\section{Lit. IIist. Eur. i : 520. 2 Aschan, Schol. 180. Works, i : 191.}

3 lfe had five danghters, esteemed the most learned women of the time, viz.; Mildred, mother of the Earl of Salisbury ; Anne, mother of Lord Bacon; Margaret Rowlett, Elizabeth Russell and Catharine Killigrew.

4 schol. 228.

5 She was now fifteen. Ibid. i: 227 .

${ }^{6}$ Ifallam (Const. Ilist. Eng. i : 198, n.) eites a census of the clergy of the Archdeaconry of Middlesex in 156:\%. Of 114 clergymen, only three were good Latin and Greek scholars, twelve were fair scholars, nine knew Latin alone, thirty-one conld read Latin tolerably well, forty-two read it very badly, and seventeen could make nothing of it. He adds: "If this were the case in London, what can have been true in more remote parts!" 
It would be very impressive as an object-lesson for some one, rich in the literature of our tongue in all departments in each century since it has had existence, to put aside temporarily such volumes as hardly could have been in the average English library, in the spring of 1601 , and to note what would remain. Probably we should be surprised by the number of those commonly accounted Elizabethan writers whom our time-limit would exclude. As in prose we should just miss Bacon, Sir Thomas Browne, Burton, Thomas Fuller, Milton, most of Raleigh, Jeremy Taylor and Izaak Walton, so in poetry we should have to lay aside the great galaxy of Milton, Herbert, Vaughan, Henry More, Quarles, Drummond of Hawthornden, Suckling, three Beaumonts, three Fletchers, John Davies of Hereford, Wither, Shirley, most of Drayton, Donne, Carew, Lord Brooke, William Browne, Dekker, Middleton, Cartwright, Bishop Corbet, Randolph, Massinger, George Sandys, Ben Jonson and most of Shakespeare himself. Of the barely twenty-one or two poets who fairly may claim places before the date of our survey, fourteen fall not only within the last quarter of the time, but actually within its concluding nine years.

In history, travel, theology and religion, medicine, music, education, navigation, husbandry, etc., there would be left from four or five to fifteen or twenty volumes apiece, but the really conspicuous works in each could be numbered upon the fingers of one hand. And in general prose literature there were only seven or eight men whose writings have made their names familiar now. From two hundred to three hundred books might be named which had come into being by 1601 . But probably no library included all, and few libraries contained half of them. Indeed, many existed only in manuscript and never became popular, if at all, until printed in modern days.

Another class of books, indeed, had place in some houses, but not openly, the literature of the Separatists. Often written in fragments and in prison, and sent secretly, sheet by sheet, to be printed by some Dutchman, the resultant tracts being smuggled back into England, it was a matter of life and death merely to shelter them. Even the Scriptures themselves in English then were so costly, as well as so liable to involve the reader in peril, 
that probably only a few families had them. Copies were kept chained in the churches for public use. ${ }^{1}$

The condition of general intelligence in 1601 is even more difficult for us to make real to ourselves, for in almost every particular the data of our daily life have received substantial revision since then.

It is enough to note that in 1601 it was from a few years to three centuries before logarithms, the velocity of light, the laws of motion and gravitation, galvanism, the circulation of the blood, vaccination, life-insurance, the thermometer, the steamengine, gas, photography, cheap postage, the telegraph and telephone, etc., were discovered or invented. It was hardly the same world as ours.

1 See Antiquary, November, 1890, 209, for notices of chained books at present. 


\section{CHAPTER III}

\section{THE SHADOWS IN THE PICTURE}

WE are not to snppose that, because of their ignorance of all this as yet undiscovered science and art, the people of that day were conscions of a great lack waiting to be supplied. Within a century there had been a noticeable decline in material prosperity, accompanied by, and in some part the cause of, a decline of popular intelligence. The growing democratic tendency of the fifteenth century had been suppressed, and power had been concentrated in the Crown. ${ }^{1-}$ With the resulting partial loss of the sense of personal responsibility for the public welfare had come some loss of stimulus to personal intellectual growth. In some things the average Englishman of 1601 was not much in advance of his ancestors of the fifteenth century. The popular mind was crowded with crude, false and pernicious notions. It was at the mercy of honest delusion and, too often, of impudent empiricism. The condition of things may be indicated by an examination of two subjects having vital relation to the civilization of that time.

Several causes peculiarly exposed people to dangerous distempers. They had but the most general notions of hygiene. Indeed, they had almost no understanding of the need of pure air, pure water and personal cleanliness. ${ }^{2}$ Andrew Boorde, ${ }^{3}$ a

1 "Municipal independence was struck down at the very roots, and the free growth of earlier days arrested by an iron discipline invented at Westminster and enforced by a selected company of Townhall officials, whose authority was felt to be ultimately supported by the majesty of the king himself. . . . Under the new conditions the individual life of the borough ceased to have the same significance as of old." - Mrs. Green, Town Life, ii : 445, 448.

2 Erasmus, Epis. cccexxxii, App.:-

"The floors [of houses] are generally strewed with elay, and that covered with rushes which are now and then renewed, but not so as to disturb the foundation, which sometimes remains for twenty years nursing a collection of spittle, vomits, excrements of dogs and human beings, spilt beer and fishes bones, and other filth."

${ }^{8}$ Authorities for these statements are Boorde's Breuyary of Health (1547); 
fanous physician of the sixteenth century, advised people to wipe their faces daily with a scarlet cloth, and to wash them but once a week. Onyx was imagined to strengthen the heart, and ruby to protect from the plague and resist poison. Diamond also preserved from poison, yet, if taken inwardly, would be deadly. Tumors were to be reduced by being stroked with a dead man's land. Pills from the powdered skull of a hanged man, water drunk from that of his victim, powdered mummy, scorpion oil, dried entrails and equally loathsome doses were thought useful. Chips from a gallows kept off the ague. The words Abraxas and Abracadabra were much worn as a talisman to cure the ague. Pepys records this charm as efficacious for a burn :--

There came three Angells ont of the East;

The one brought fire, the other brought frost -

Out fire ; in frost.

In the name of the Father, and Son, and Holy Ghost. AMEN

and gives another for a hemorrhage.

The great remedy for a severe flow of blood was scarcely less preposterous, viz.: "Cleave a hen in two, and lay her hot upon the wound, and it will staunch." 1 This was thought equally good for other troubles. When the Prince of Wales was ill, in 1612, the royal physicians attended, with the famous $\mathrm{Dr}$. William Butler of Cambridge. A cock was cloven and applied to the soles of the feet, but in vain. Afterwards Drs. Palmer and Gifford were called in and discordium administered, but the prince died.

On the other hand, blood-letting was a constant resort for health, and even that was mixed up with astrology. ${ }^{2}$ It was declared to be very dangerous to "lette bloud in anie member, with any chirurgical instrument eyther" when the moon is in Tauro, Gemini, Leo, Virgo, Capricorn, the last half of Libra or first of Scorpio; or when the sun, moon or lord of the horo-

Francis Bacon's Historia Vitae et Mortis (1623) ; Sharpe's London Magazine (1863), Article, "Medicine of our Forefathers;" J. M. Richards's Chronology of Medicine (1880) ; Pepys's and Evelyn's Diaries; Goadby's England of Shakespeare, and The Roll of the Royal College of Physicians of London (1818).

1 Bacon was no wiser than this. Hist. Vitae et Mortis (ed. 1863), vol. x: 138, 137.

2 R. Harvey, Astrol. Discourse, 75, 79. 
scope is in the sign which rules the member to be blooded, etc. There were unlucky days in every month, which usually were noted in almanaes, and particularly set down in Latin verses in ancient calendars.

Sometimes as many as forty remedies were compounded into a single prescription, so that if one did not cure, another might. Sir Walter Raleigh in the Tower of London invented a Great Cordial which long was famous, a conglomeration of pearl, musk, hartshorn, bezoar, mint, borage, gentian, mace, red rose, aloes, sugar, sassafras, spirits of wine and a score or two more ingredients. ${ }^{1}$ Charles II. would take nothing else. In 1675 Lord Berkeley having a fit of apoplexy at Whitehall, several famous doctors finally recovered him " to some sense, by applying hot firepans and spirit of amber to his head; . . . almost a miraculous restoration." 2

The essential unreasonableness of the public mind on this subject is revealed also by its attitude toward that condition of the constitution now known as scrofula; which usually may be mitigated slowly and sometimes overcome eventually, but which cannot be instantly cured. Our fathers called it "king's evil," and fancied that it could be healed by the sovereign's tonch. Between 1661 and 1715 the English prayer-books contained a form of service for use on such occasions. ${ }^{3}$ It is said that Charles II. averaged 4000 such "cures" a year, and that as late as March 30, 1712, two hundred persons were "touched" by Queen Anne.

Aside from ordinary diseases, three dire disorders ever and anon invaded the panic-stricken and nearly helpless homes of the people, due, beyond doubt, to the general filthiness. In 1617 Moryson said of England, "In great Cities it is forbidden to kill Kytes or Ravens, because they denoure the filth of the streetes." These three terrors were the plague, or pest, the sweating sickness, and the smallpox. The plague was an eruptive, contagious fever, accompanied by glandular swellings, which sometimes carried off its victims in a few hours, and which, in the worst stricken localities, has been known to result fatally in

W. H. Dixon, Her Majesty's Tower, i : 181.

2 Evelyn, ii : 102.

${ }^{3}$ W. H. Frere, New Hist. of Book of Com. Prayer (ed. 1901), 253. 
over ninety per cent of all cases. Down to its last appearance in England, in 1665 when nearly 70,000 died in London out of a population of 460,000 - of whom two thirds were supposed to have fled from the contagion - it is said to have appeared on the average at least once in a generation, while in a few congenial localities it perhaps lay dormant always.

The sweating sickness was even more terrible. It was known first in England in 1485, and afterwards in 1507, 1517 and 1528, and its last appearance was in 1551. It often attacked the superior classes, as well as the poor. It is supposed to have been akin to what now is known as miliary fever, and its distinguishing feature was a chill followed by an exhausting sweat. It seldom lasted longer than a single day, and sometimes eaused death in two hours. In 1517 many distinguished people died of it. In some cases half the population of a town perished.

The smallpox has been so robbed of its terrors by vaccination as to make it hard to understand how serious it was in former times. Its malignance used to be aggravated by the remedies. Not until 1666 was it understood that measles and scarlet fever liffer from it, and that free ventilation and a cooling regimen furnish it the best treatment. Next to the other two diseases, this used to be most destructive, being dreaded especially also as sparing no exposed person, ${ }^{1}$ and as exceptionally loathsome and disfiguring. The average condition of the public health may be inferred from the fact that in Sheffield, which then contained 2207 people, there had been between 1590 and 1601 an annual average, neglecting fractions, of 46 marriages, 136 baptisms, ${ }^{2}$ and 132 deaths. ${ }^{3}$ This gives an average annual death-rate of sixty in the thousand, as against twenty-two and a half for the whole of England from 1840 to $1874,{ }^{4}$ which is rather above than below the ordinary average now in healthy localities.

A slight hurt then was dangerous, and surgical operations were very apt to prove fatal. Says Pepys, even two generations later, on October 19, 1663 :

1 Haydn, Dict. of Dates (ed. 1883), 628. Evelyn, i: 239, 341 ; ii : 212, 333.

2 That is, probably, 126 births.

3 Hunter, Hallamshire, 21.

4 Haydn, 562. 
The famous Ned Mullins, by a slight fall, broke his leg at the ancle, which festered; and he had his leg cut off on Saturday, but so ill done, notwithstanding all the great chyrurgeons about the towne at the doing of it, that they fear he will not live with it;

adding, on October 23 :-

Mr. Holliard, . . tells me that Mullins is dead of his leg cut off the other day.

As to the supernatural, also, we have passed so far from the attitude of our fathers that to appreciate it is almost impossible. ${ }^{1}$ In the childhood of the race the conception of a spiritual in. dweller, whose withdrawal causes death, easily suggested the theory that to some other, some ghost life should be attributed all abnormal developments, especially all whose symptoms involved any appearance of conflict. Thus the contortions of hysteria, epilepsy and insanity were ascribed to some hostile spirit, and it naturally followed that the road to prevention and cure lay in the direction of forefending, or ending, such incarnations. Hence arose exorcists and medicine-men, with their incantations.

This kind of belief in departed spirits easily augmented itself by kindred convictions regarding good, and, especially, evil angels, until a whole science of demonology, sorcery and witchcraft took shape. Christianity, of course, found it in full force, and to some extent even among the Hebrews. The Old Testament forbade all magical arts. The chosen people were commanded to avoid enchanters, inquirers by familiar spirits, consulters of the dead and diviners; and, as necessary to defend the Israelites from the abominations of the Canaanites, to put wizards and enchantresses to death. When Christ came, He conformed to the common speech - because his use of exact terms would have been incomprehensible - and confined himself to such practical treatment as was possible and benignant, trusting to the increasing influence of truth to lift men to higher

1 In this résumé are used articles in the Enc. Brit.; C. W. Upham's Lectures on Witchcraft (1831), and Hist. Witchcraft and Salem Village (1867); the third rol. of H. C. Lea's Hist. of Inquisition; Scot's Discovery of Witcheraft (1584) ; J. Webster's Displaying of Supposed Witchcraft (1677); and King James's Daemonologie (1597). 
levels of intelligence. The early centuries of the Church, however, did not favor rapid advance in this direction, and the new Christianity and the old paganism kept step together for a long time. What now would be treated as hysteria, epilepsy or lumacy, was supposed to be "possession" by the devil.

Gradually a distinct doctrine of witcheraft formed itself. Its first principle was that Satan is in incessant warfare with the Church, and works through the fallen angels, and especially through human beings whom he has won to himself. These, it was conceived, sold their souls to him formally and agreed to help him. In return they were to be endowed by him with extra-natural power, enabling them to read men's thoughts, to leave their bodies and return to them, to fly through the air, to transform themselves into the shapes of animals, and to call up the spirits of the dead. The special weight of all charges against them lay in the supposed fact that they not only had freely sacrificed their souls, but also were striving to tempt men to revolt against Christ's beneficent reign. It was held further' that Satan sealed the compact by a touch which calloused the skin and left a permanent " witch-mark," and that the fountain of tears was dried up. Witches oftenest were old women, "wizard" being the term for a man thus "possessed." The distinguishing feature of "the new witchcraft" of the Middle Ages was the notion of the worship of Satan in the Sabbat, an assembly held at night. It was given out that wizards and witches sailed to this through the air, astride of a broomstick, a goat or a dog. And it was believed that the most infernal rites were celebrated and the foulest license allowed.

Since the Church - which included the educated and wellto-do people - soberly believed all this, of course the masses lived in terror of these pests. Learned writers proved, to the general affright, that witches caused abortion, rendered men impotent and women barren, dried up a nursing mother's milk, killed and ate infants, entered houses at night and slew sleeping children by a touch, killed unbaptized children when they could, raised tempests, hailstones, and plagues of locusts and caterpillars, caused mortal sicknesses, and blasted men with lightning. 
Here a citation from Mr. Lea's learned work ${ }^{1}$ is in order :-

To understand the credulity which accepted these marvels as the most portentous and dreadful of realities, it must be borne in mind that they . . . were facts substantiated by evidence irrefragable according to the system of jurisprudence. . . . The criminal whom endless repetition of torment had reduced to stolid despair naturally sought to make his confession square with the requirements of his judge; the confession once made he was doomed, and knew that retraction, in place of saving him, would only bring a renewal and prolongation of his sufferings. He therefore adhered to his confession. . . . In many cases, moreover, torture and prolonged imprisonment in the foulest of dungeons doubtless produced partial derangement, leading to belief that he had committed the acts so persistently imputed to him. In either case, desire to obtain the last sacrament, which was essential to salvation, and which was only administered to contrite and repentant sinners, would induce him to maintain to the last the truth of his confession. No proof more unquestionable than this could be had of any of the events of life, and belief in the figments of witchcraft was therefore unhesitating. To doubt, moreover, if not heresy, was cause for vehement suspicion. The Church lent its overpowering authority to enforce belief on the souls of men. The malignant powers of the witch were repeatedly set forth in the bulls of successive popes for the implicit credence of the faithful.

Such being the convictions of the Romanism of the fifteenth century, there was nothing in the dawning Protestantism of the sixteenth to change at once the popular beliefs. Those who undertook the herculean task of modifying public opinion as to any matters of faith songht to excite as little antagonism as possible. Moreover, the natural influence of Protestantism, in throwing men back upon the Bible self-interpreted for the grounds of belief - even while sowing seeds which would ripen into a rational faith that must uproot witcheraft — at first would be to strengthen the existing conviction of its reality and baleful power. In commenting on the passage, "Thou shalt not suffer a witch to live," Calvin says: " "Since such illusions carry with them a wicked renunciation of God, no wonder that He would have them punished with death."

I iii : 502. For an official selection of Papal Bulls on this subject, see Corpus Juris Canonici. Greg. XIII. Lib. Sept. Decretal, v. tit. 12.

2 Exod. xxii : 18. Harm. of Pent. ii : 90. Inst. I. xiv : 18. 
The tenacity of this delusion, even in the Protestant mind, is shown by two facts. In 1665, Sir Matthew Hale, Lord Chief Justice of England, one of the most devout and humane of his generation, charged a jury at Bury St. Edmunds ${ }^{1}$ thus : -

That there are such creatures as witches, I make no doubt at all; for first, the Scriptures have affirmed so much; secondly, the wisdom of all nations hath provided laws against such persons.

The verdict was "guilty," and the accused died protesting their innocence.

Exactly one hundred years later, Blackstone said in his "Commentaries" 2 - and he spoke within eight years of the emptying into the dock at Boston of the tea from British ships -

To deny the possibility, nay, actual existence, of witeheraft and sorcery, is at once flatly to contradict the revealed word of God . . . and the thing itself is a truth to which every nation in the world hath in its turn borne testimony. . . . The civil law punishes with death not only the sorcerers themselves, but also those who consult them. . . . And our own laws, both before and since the conquest, have been equally penal; ranking this crime in the same class with heresy, and condemning both to the flames. The President Montesquieu ranks ${ }^{3}$ them also both together, but with a very different view : Laying it down as an important maxim, that we ought to be very circumspect in the prosecution of magic and heresy; because the most unexceptionable conduct, the purest morals, and the constant practice of every duty in life, are not a sufficient security against the suspicion of erimes like these. And indeed the ridiculous stories that are generally told, and the many impostures and delusions that have been discovered in all ages, are enough to demolish all faith in such a dubious crime; if the contrary evidence were not also extremely strong. Wherefore it seems to be the most eligible way to conclude, with an ingenious writer ${ }^{4}$ of our own, that in general there has been such a thing as witcheraft; though one cannot give credit to any particular modern instance of it.

It is true that there had been a few utterances on the other side. In 1392 Walter Brute ${ }^{5}$ declared the Popish exorcisms abominable and absurd. In, or about, 1577, John Wierus, physician to the Duke of Cleves, maintained ${ }^{6}$ that persons accused

1 Campbell, Lives of the Chief Justices (ed. 1849), i: 565. 2 Ed. 1790, iv: 60.

3 Spir. of Laws, Bk. 12, c. 5 .

4 Addison, Spectator, No. 117.

5 Story of Walter Brute. John Foxe, Acts and Monuments, ed. 1844.

${ }^{6}$ De Prestigiis Demonum et Incantationibus. 
of witcheraft were unbalanced and deserved pity. Seven or eight years later came out in London the courageous " Discovery of Witchcraft," by Reginald Scot, whose object was to stop the cruel persecutions for witcheraft by proving that there was no solid foundation for the infamous superstructure of popular belief. He insisted that the tales were fables; that witches, who were declared able to squeeze through keyholes, to become animals, to fly, and the like, never escaped thus from prison; that the hypothesis was against all just views of God, and that the Bible rightly interpreted gave no countenance to the doctrine. But he was more than a century in advance of his age, and King James, in 1597, tried to demolish him in the preface to his own "Daemonologie," and at least was able to have Scot's book burned.

There was a revival of interest in this subject during the seventeenth century. In 1600 Thomas Ady ${ }^{\mathrm{l}}$ had publicly disfavored the extreme views then common, as had Tobias Tandlerus $^{2}$ six years later, and six treatises, ${ }^{3}$ reaffirming substantially the old views, were printed within twenty-five years; while at least fourteen more ${ }^{4}$ appeared before the close of the century

1 Treatise concerning Witches and Witchcraft, $4^{\circ}, 1600$.

2 De Fascino et Incantatione, Dissertationes Physicae-Medicae, 1606.

${ }^{3}$ G. Giffard, Dialogue concerning Witches and Witcherafts, $4^{\circ}, 1603$. W. Perkins, Discourse of the damned Art of Witchcraft, etc., $8^{\circ}, 1608$. J. Cotta, The Triall of Witchcraft, shewing the True and Right Methode of the Discouery, $4^{\circ}, 1616$. A. Roberts, A Treatise of Witchcraft, etc., $4^{\circ}, 1616$. T. Cooper, The Mystery of Witcheraft, etc., $12^{\circ}, 1617$. R. Bernard, $A$ Guide to Grand Iury men, etc., 24ㄴ, 1627.

${ }^{4}$ J. Gavle, Select Cases of Conscience, concerning Witches and Witchcraft, $8^{\circ}$, 1646. Steame, Confirmation and Discovery of Witchcraft, $4^{\circ}, 164 \mathrm{~S}$. T. Ady, Perfect Discovery of Witches, etc., $4^{\circ}, 1601$. J. Glanvil, A Blow at Modern Sadducism In Some, or Philosophical Considerations about Witchcraft, etc., $4^{\circ}, 1666$. M. Casaubon, Of Credulity and Incredulity against the Sadducism of the Times in denying Spirits, Witches, etc., $8^{\circ}, 1668$. A Pleasant Treatise of Witches. Their Inps, and Meetings, ete. By a pen near the Covent of Eluthery, 1673. J. Brinley, $A$ Discovery of the Impostures of Witches and Astrologers, $8^{\circ}, 1680$. J. Brinley, $A$ Discourse of the Impostures Practised in Judicial Astrology, $8^{\circ}, 1680$. The second part of the foregoing. J. Glanvil, Sadducismus Triumphatus, or Full and Plain Evidence Concerning Witches and Apparitions, $8^{\circ}$, 1681. R. Bovet, Pandaemonium, etc., $8^{\circ}, 1684$. G. Sinclair, Satan's Invisible World discovered, etc., $12^{\circ}, 1685 . A$ Discourse Proving by Scripture \& Reason And the Best Authors, Ancient and Modern, that there Are Witches, etc., 1686. I. Mather, Cases of Conscience concerning Witchcraft, $4^{\circ}, 1691$. Sir M. Hale, Collection of Modern Relations of Matter of Fact, concerning Witches, $4^{\circ}, 1695$. 
on the same side, with two ${ }^{1}$ in the main defending the doctrines of Scot. We will glance at two of these.

The "Guide to Grand Iury men," in reference to witch trials, was written, two years after Robinson's death, by Richard Bernard, himself a Puritan, with whom Robinson had a controversy upon church polity, but with whom in other essentials he was at one. The object is to prove that although there may be both self-deceived and counterfeit witches, nevertheless, there are witches who make an express league with Satan; and to declare how bewitchment may be known and how witches are to be detected. He believes in the "witch's mark," favors the teartest, and after enumerating various ways of inducing the suspect to confess, he advocates torture, or "a shew thereof at least," and the death of those convicted.

The "Discourse of the damned Art of Witcheraft" was preached as sermons at St. Andrew's, in Cambridge, by William Perkins, and was published after his death, in 1602. No man stood higher with the godly people of England than he. There is reason to think that he was the spiritual teacher of Robinson, and Robinson certainly had a great regard for his opinions. There can be no doubt that his views upon this subject were those in which our fathers were indoctrinated. Perkins teaches that witcheraft is an actual thing, which for wise reasons God permits; that there is a league between Satan and the witch; that witcheraft includes divination, necromancy and juggling; that there are good and bad witches; that "of the two the more horrible and detestable Monster is the good Witch," and that all witches should be put to death. His meaning as to these "good witches" perhaps comes out also in another treatise, "A Resolution to the Countrey-man, proouing it vtterly vnlawfull to buie or use our yearely Prognostications," in which he condemns the folly and wickedness of casting nativities, telling fortunes, predicting floods or droughts, and prophesying life or death. And this reminds us again that the public mind still was

${ }^{1} \mathrm{~J}$. Wagstaffe, Question of Witchcraft Debated . . . against their opinion that affirm Witches, $8^{\circ}, 1671$. J. Webster, Displaying of Supposed Witcheraft . . that there is a corporeal League made betwixt the Devil and the Witch, etc., utterly disproved, fol. 1677. 
ruled by superstitions in regard to the influence of the planets, stars aud moon upon human fortunes.

A pertinent illustration is found in a little volume by Richard Harvey, in 1583, in which with utmost sincerity he declares that the "malice of the vnlucky planet Saturne, hath by his mischieuous importunitie ouercome and vanquished the good, wholsome \& sweete nature of the benevolous and favourable planet Iupiter." This will cause floods, cold weather, envy, debate, quarrelling, going to law, persecution, poverty, sterility, barrenness, fire, shipwrecks, pestilence, and many other mournful things. And he adds that certain direful consequences of a small eclipse of the sun in the previous June remained to be experienced, which he particularizes thus : ${ }^{1}$ -

The whole yeare, to speake more vniversally, is like to proue but a bad yeare for al maner of cattel, but especially and principally for sheepe. Pease \& Beanes, I suppose, will be plentiful and good cheape : but wheate, by my coniectures, will be searce \& very deare. Barlie shall be indifferent, but yet of the two, rather deare than cheape. We are like to haue good store of Honie, \& sufficient plentie of Oyle. Butter and Cheese shal be some what deare: we are not to looke for anie store or aboundaunce of fruite : a dearth of victualles is muche to be feared: grieuous losses by shipwracke: sundrie danımages by fire: manie shamefull whoredomes, thefts, robberies, spoiles, oppressions, treacheries, and mutinies greatly to be dreaded : perillous factions, seditions, tumultes, insurrections \& uprores, togither with hote preparance [preparation] for warre to be looked for, especially in $\mathrm{y}^{\mathrm{e}}$ Northeast countries. Many infirmities and diseases, shal generally raigne, both amongst men, women, \& children, proceeding of unnatural moistnesse, \& distemperate heat, as by ye event wil more sensibly appeare. The death of some mightie, and renowmed Magistrate by al Astrological coniectures is to ensue: and finally, a sore mortalitie is very like to inuade manye places, as well somewhat neare hande, as farther off.

The community was not wise enough to treat this as nonsense, and the book threw the whole kingdom into consternation. Even the Privy Council censured the author, especially because of the foretold death of "some mightie, and renowmed Magistrate," supposed to mean Queen Elizabeth.

1 An Astrological discourse vpon the great and notable Coniunction of the tvvo Superiour Planets, SATURNE \& IVPITER, which shall happen the 28 day of April, 1583, 14,74 . 
Public thinking was saturated with infatuations and misjudgments, and nothing seemed too incredible for sober acceptance. It was not long since Ricobaldi gravely had asserted, that an Italian woman had had forty-two children before her fortieth year $;^{1}$ and the "Osnaburg Chronicle" had declared that one mother had 300 sons at a birth, ${ }^{2}$ and that a man, named Nicolanus Piscis, because of maternal malediction, lived in the sea, unable to exist out of water.

With all this superstition there was a hardness of feeling which looked without emotion upon human suffering, and tolerated social conditions now abhorrent. Some favorite amusements of the people were cruel. There was a "Master of the King's games of bears, bulls, and mastiff dogs," 3 and one wrote in 1575 as follows : ${ }^{4}$

It waz a sport very pleazannt of theez beastz; to see the bear with hiz pink nyez [eyes] leering after hiz enmies approch, the nimblness and wayt of ye dog too take hiz auantage, and the fors and experiense of the bear agayn to avoyd the assauts : . . if he wear taken onez, then what shyft with byting, with clawyng, with roring, tossing and tumbling, he woold woork to wynde hymself from them; and when he waz lose, to shake hiz earz twyse or thryse wyth the blud and the slauer about his fiznamy [physiognomy] waz a matter of a goodly releef.

\section{In 1598 Paul Hentzner also said :}

There is still another place, built in the form of a theatre, which serves for the baiting of Bulls and Bears, they are fastened behind, and then worried by great English bull-dogs. . . . To this entertainment there often follows that of whipping a blinded Bear.

All this continued far into the seventeenth century. The ducking-stool, also, and the scold's bridle, often were cruelly used upon the imnocent and helpless, as well as upon those who perhaps had earned them fairly.

1 Fort. Med. Econ. during Mid. Ages, 362-363.

${ }^{2}$ Evelyn, September 1, 1641, describes seeing at Leyden both a monument to a Countess of Holland who had 365 children at one birth, and also the basins in which they were baptized! So Howells (Famil. Letters (ed. 1754),9), and Pepys, May $19-29,1660$.

3 Rye, 215.

4 Robert Laneham, Letter from Kenilworth Castle (ed. 1821), 25.

542. 
This hardness of the general heart was manifested especially in the treatment of prisoners. If a man struck another in the king's court so as to draw blood, his right hand was chopped off and the stump seared with a hot iron. ${ }^{1}$ The stocks and the pillory were designed at once to disgrace a culprit and to tempt the brutality of the multitude. Sometimes, when one was pilloried, his ears were nailed to the post and he was left to tear himself away. ${ }^{2}$ The rabble were expected to pay their respects to such captives by pelting them with stones and garbage. There also was a place of detention hard by the stocks, apparently open to public view and called the "cage," in which persons arrested for slight offences were kept. A generation later, in 1631, at Salisbury, a prisoner about to be condemned to transportation for felony, threw a stone at the judge, which broke the wainscoting; whereupon his right hand was cut off, and he was hung upon an extemporized gallows in the presence of the court. ${ }^{3}$ Hanging usually was done by driving the prisoner in a cart under the gallows, and driving on the cart, leaving him to dangle; or by making him ascend a ladder, which then was knocked away.

Treason - and many things then were accounted as treason which long since have been transferred to a lower grade of guilt and penalty - was punished with awful severity, as appears from the sentence of the Earl of Carlisle:-

The award of the Court is that for your treason you be drawn, and hanged, and beheaded; that your heart, and bowels, and entrails, whence came your traitorous thoughts, be torn out, and burnt to ashes, and that the ashes be scattered to the winds; that your body be cut into four quarters, and that one of them be hanged upon the Tower

1 Stowe, Annals, 581.

2 See case of 'Timothy Penredd, Pike, ii : 82, 83, 85, 616. The last person to be pilloried in England is thought to have been Robert James Bossy, sentenced for perjury to transportation for seven years, and to stand one hour in the pillory at the Old Bailey, which he did, June 24, 1834. - Old and New London, ii : 471.

3 The account shows the odd, semi-French lingo then in use :-

"Richardson, C. J. de C. Banc. al. Assizes at Salisbury in summer, 1681, fuit assault per prisoner la condemne pur felony; que puis son condemnation, ject un brickbat a le dit Justice, qui narrowly mist; et pur ceo immediately fuit indictment drawn per Roy [Attor. ${ }^{y}$ Gen $^{1}$ ] envers le prisoner, et son dexter manus ampute and fix at gibbet, sur que luy meme immediatement hange in presence de Court."

- Treby, C.J., Notes to Oyer's Reports, fol. ed. 188, b. 
of Carlisle, another upon the Tower of Newcastle, a third upon the Bridge of York, and the fourth at Shrewsbury; and that your head be set upon London bridge.

Those convicted of robbery were hung in chains and left to the weather. Perhaps the worst punishment of all was the peine forte et dure, which, about 1400, succeded the prison forte et dure, which had been confinement in a narrow cell and absolute starvation. The terms of the infliction of this penalty - to which those were sentenced who refused to plead to their indictments, and so could not be convicted, and preserved their lands for their heirs - were these $:^{1}-$

That you be taken back to the prison whence you came, to a low dungeon into which no light ean enter ; that you be laid on your back on the bare floor, with a cloth round your loins, but elsewhere naked; that there be set upon your body a weight of iron as great as you can bear-and greater; that you have no sustenance, save, on the first day, three morsels of the coarsest bread, on the second day three draughts of stagnant water from the pool nearest to the prison door, on the third day again three morsels of bread as before, and such bread and such water alternately from day to day until you die.

Gradually it became customary to place a sharp piece of timber beneath the back of the sufferer to hasten death. In 1658 a portion of the mass of iron and stone laid upon one Strangeways was placed angle-wise over his heart. This proving insufficient to crush out his life, the attendants added the weight of their own bodies. ${ }^{2}$

Other methods of torture also were tolerated, and apparently approved. There was the room in the Tower, "Little Ease," where standing erect and lying at length alike were impossible. There was the "Dungeon among the Rats." There were the thumb-screw, the whip-cord drawn tighter and tighter around the thumbs; the rack, and "Skevington's Daughter," invented by a lientenant of that name. The last two were complementary to each other; the former straining the joints and ligaments apart, the latter forcing the legs back to the thighs, the thighs to the stomach, and drawing the whole body together by iron bands, until the blood was forced out of the tips of the fingers,

1 Pike, i : 226, 387.

2 Harleian Miscellany, iv : 1-11. 
the toes, the nostrils and the mouth, and the ribs and breastbone were erushed in.

The strange insensibility of even the educated classes to injustice and cruelty is shown strikingly by two cases almost a generation later. In 1621 one Floyd, a gentleman imprisoned in the Fleet, spoke slightingly of the Elector Palatine and his wife. Just then the comment excited popular displeasure, especially as Floyd was a Romanist. The House of Commons took up the matter and the king interfered to protect Floyd, which did him no good, as the king was suspected of leaning towards Popery. Floyd actually was sentenced ${ }^{1}$ - and this took place within six months after the sailing of the Mayflower — to be degraded from his gentility and held infamous, and incompetent to testify in a court; to ride from the Fleet to Cheapside on horseback with no saddle and with his face to the horse's tail, which he was to hold in his hand; there to stand two hours in the pillory and to be branded with the letter $\mathrm{K}$; four days later to ride in the same manner from the Fleet to Westminster, and there stand two hours in the pillory with words on a paper on his hat setting forth his crime; to be whipped at the eart's tail from the Fleet to Westminster Hall; to pay a fine of $£ 5000$; and to remain in Newgate a prisoner for life. On Prince Charles's urgency the whipping was omitted, but the poor man seems to have undergone the remainder of his sentence!

Roman Catholics frequently were objects of public vengeance, but less, generally, for their religion than for their constant plots against the government. ${ }^{2}$ In 1580 it was declared to be treason for any one to leave the Established Church and become a Romanist.

In 1628 a Scotch divine, Alexander Leighton, published in Holland "An Appeal to the Parliament, or Sion's Plea against the Prelacie," in which he assailed the Church of England. Nothing, however, went beyond what long had been common in the invective of such literature, and quite as common in the writings of the bishops and their apologists as in those of their

1 Hallam, Const. Hist. Eng. 1: 361.

2 The Venetian ambassador in London, 1608-11, M. A. Correr, in his Relation d'Angleterre, traus. by Rye, 228. 
antagonists; nothing which now would subject its author to anything severer than criticism of his taste and emphasis. But in 1630 the Star Chamber took it up and Leighton was condemned ${ }^{1}$ unanimously to degradation from his ministry, to imprisonment for life, to the enormous fine of $£ 10,000$, to be whipped and set in the pillory at Westminster in presence of the Court, to have one of his ear's cut off and his nose slit, to be branded in the face with the letters S S (Stirrer of Sedition), to be imprisoned in the Fleet, to be whipped and pilloried again on a market-day in Cheapside at some convenient later time, and to have the other ear cut off.

We lack some of those helps for discovering the intimate quality of these years which are supplied for a generation or two later by the diaries of Pepys and Evelyn. But it is safe to take their testimony as throwing light also upon the earlier period, because there is no evidence that in their days the English were less civilized than formerly. The time of Charles II., indeed, exceeded any previous period in its shameless debatchery. Yet the general tone of English society, as these diarists knew it, was essentially the same as in the earlier years of the century. Says Evelyn, on January 30, 1660:

This day ( $O$ the stupendous and inscrutable judgments of God!) were the carcases of those arch-rebels, Cromwell, Bradshawe (the judge who condemned his Majesty) and Ireton (son-in-law to the Usurper), dragged out of their superb tombs in Westminster among the Kings, to Tyburn, and hanged on the gallows there from nine in the morning till six at night, and then buried under that fatal and ignominious monument in a deep pit; thousands of people who had seen them in all their pride being spectators.

And again, on October 17, 1660, he adds : -

I saw not their execution [Scot, Scroop, Cook and Jones], but met their quarters, mangled, and cut, and reeking, as they were brought from the gallows in baskets on the hurdle.

And Pepys says, October 21, 1660:-

I met George Vines, who carried me up to the top of his turret, where there is Cooke's head set up for a traytor, and Harrison's set up on the other side of Westminster Hall. Here I could see them plainly.

${ }^{1}$ Rushworth, Hist. Coll. ii : 55-57. 
That this want of sensitiveness exhibited itself in other directions is obvious. Pepys says, January 1, 1660, that his cousin, Anthony Fenner, was "so civil" as to come and eat oysters, neat's tongues and anchovies with him, and make himself "pretty merry with wine of all sorts, and Northdowne ale," although that cousin's only child had died that morning. He also narrates, A pril 4, 1662, how the corpse of a drowned man floated up and down the Thames in the face of London four days, no one taking the trouble to bury him; how Bishop Braybrooke's body, after it fell down from its tomb during the great fire, lay a long time in Convocation House Yard " to be handled and derided;" and how the poor remains of Katharine of Valois were - February, 1668 - exposed to the mocking homage of passers-by at Westminster.

Personal habits often were worse than careless. King James never washed his hands. ${ }^{1}$ Pepys declares that his own wife spent the "Lord's Day," November 22, 1668, in " making herself clean, after four or five weeks being in continued dirt;" and mentions her bathing in hot water as unlikely to be repeated sufficiently; and more than once speaks of scrubbing his own face with a pumice-stone as " a very easy, speedy, and cleanly" practice. He declares that he was driven indoors by the carelessness of Sir William Penn, his neighbor, with his slops. It was not unusual for the persons of gentlemen and ladies to be troubled with vermin. Pepys narrates how once, upon a journey, at an inn near Salisbury Plain, a peddler was dispossessed of his room, Pepys and his wife occupying the bed, and their two maids a trundle-bed in the same apartment, and how they discovered that the beds were "good but lousy." Mrs. Pepys found it needful in this respect to cleanse assiduously the person of a new maid; he himself bought a periwig that was full of " nits;" and, ealling once on the Russian Embassy, he found its nembers busily hunting the same pests.

The freedom with which sacred things often were treated is

1 James Balfour, Annales of Scotland, ii : 108. Pepys (iii : 267) declares that: "The fine Mrs. Middleton [a famous beauty and the daughter of Sir R. Needham] is noted for carrying about her body a continued sour base smell, that is very offensive, especially if she be a little hot."

As to Charles II's personal disagreeableness, see Evelyn, ii : 207. 
illustrated by the fact that after a dinner at Lambeth, the palace of the Archbishop of Canterbury, " one Cornet Bolton ... did pray and preach like a Presbyter Scot, with all the possible imitation in grimaces and voice." Pepys says, "It made us all burst;" but adds his wonder that the Bishop (Sheldon) should have countenanced such a scene by his presence, although he did " have the room door shut."

Excess in drinking was common among those accounted the best people. Pepys himself and his guests caroused until they were " mighty merry, smutting" one another with eandle-grease and soot, till most of us were like devils," and the women "put on periwigs." A young parson "got himself drunk before dinner." A clerk of the council came to Pepys's house so intoxicated that Pepys had to defend the ladies from his mandlin approaches. Sir William Penn not infrequently was in such a state as to make it useless to do business with him. A Government Commissioner was " as drunk as a dogg, but could stand, and talke, and laugh." Pepys's surgeon became so inebriated that he "did talk nothing but Latin, and langh," so that "it was very good sport to see a sober man in such a humour, though he was not drunk to scandal"! Two members of Parliament were so tipsy in their places that they "did both speak for half an hour together, and could not be either laughed, or pulled, or bid to sit down and hold their peace." When Pepys made his great speech in the Commons, it was impossible to get the vote because his speech " being so long, many had gone out to dinner and came in again half drunk; " and the same frank narrator mentions more than one instance when noblemen became so crazy with wine as to strip themselves nearly or quite naked and run amuck through the streets.

This suggests that great grossness of manners then was exhibited even in respectable circles. Friends paid their respects to the bridegroom and the bride after they had retired upon the wedding-night; and ladies, while still in bed, or while dressing, received their male friends. Pepys once called on Mrs. Turner, the wife of a serjeant-at-law, and was admitted to her bedroom where she was robing herself. She "took occasion" to show him her leg, which he declares the finest he ever saw, "and she 
not a little proud of it." Fashionable ladies wore masks to the theatre, so that they might listen to the vulgarity of many plays without the trouble of blushing. ${ }^{1}$

In 1601 the Established Church, of course, ruled religious matters with a high hand. Whitgift was nearing the end of his primacy at Canterbury, Matthew Hutton was Archbishop of York, and Richard Bancroft, soon to succeed Whitgift, was Bishop of London. Many rectors were university graduates, and some were men of learning and piety. But others were different, and multitudes of the small and remote parishes either were without clergy or were served by unfit men. The service for Sunday and for baptisms, marriages and burials remained essentially what it had been since the Reformation. In the country marriages often were put off till late. In the city and among the higher classes they sometimes were solemnized at a preposterously early age. ${ }^{2}$ A public betrothal preceded the marriage.

The "passing bell" 3 still was tolled, as in the old unreformed days, nor had that ceremony altogether become divested of the Romish superstition that it repelled evil spirits. After a death the friends assembled for the "liche-wake," 4 which, once having the purpose of tenderly watching the body until its burial, under Romish influence had degenerated into an occasion of drunkenness and scandal, from which it had not recovered itself wholly. At the funeral service the body was met by the priest at the churchyard gate, and he led the procession into the church, where the prescribed ritual was performed, succeeded by the burial with its anthems, prayers and collect.

It is not to be inferred that England was given over wholly to rudeness, ignorance, superstition, and even vice. There were many earnest men and women, and doubtless among all classes,

1 Evelyn, ii : 270.

2 Evelyn, ii : 77, 135, speaks of the marriage of the only daughter of Lord Arlington at five years, and of her remarriage at twelve years. Goadby (68) says, "Children of twelve were married in solemn state."

$32 H e n$. IV, I : 1. Pepys refers to this sixty-five years later (iii : 203, 206). Jeremy Taylor, who died in 1667 , gave forms of prayer to be used during the tolling of the passing bell, in which it was petitioned that the spirits of darkness might be driven far from the couch of the dying sinner. Drake, i : 233.

rom lich, a dead body, and wake, a watching. 
of upright life, fine character, and ennobling influence. There was much sturdy integrity at the core of the nation's heart, however diseased the body social and politic might be. There had been before, and there was to be again, conscientious, determined effort towards a nobler life, alike personal and national. But, nevertheless, it was a time of mental and moral darkness.

To such changes from this old order of things as already had begun to be wrought by Nonconformity and Separation, allusion will be made more particularly hereafter. 


\section{BOOK II}

THE PROTESTANTISM OF OUR FATHERS 
The toleration of firee speech and free thought is too essen. tially modern an idea, and is as yet too imperfectly reduced to practice, for us to waste surprise on its non-existence in past ages. - H. C. LEA, Chapters from Religious Hist. of Spain, 15.

So absolute, indeed, was the authority of the crown that the precious spark of liberty had been kindled, and was preserved, by the Puritans alone; and it was to this sect . . that the English owe the whole freedom of their constitution. - HuME, Hist. of Eng. ch. 40.

Puritanism, which began in impulses of liberty, and which, through all its history, has been so associated with the assertion of political independence and the rights of conscience, has yet always been intolerant of dogmatic differences. In the seventeenth century it manifested this intolerance in an extreme degree. - Tulloch, Rat. Theol. and Christ. Phil. i : 63.

If in some things they were too rigid, they are rather to be pitied, considering their times and sufferings, than to be blasted with reproach to posterity. - BRADFord, Dial. in Young's Chrons. 440. 


\section{CHAPTER I}

\section{THE BEGINNING OF THE ENGLISH REFORMATION}

GrEat and critical voyages seldom find fair winds. One must veer and tack. The sailor rarely seems to be sailing whither he is bound, his progress being won through a series of courses which, as related to his desired haven, seem inapt.

It therefore has fallen out sometimes that what in the Divine purpose was merely a long subordinate reach, necessary to carry the advancing keel clear of some imminent obstruction, has been mistaken for, and persisted in as if it were, the normal direction of the voyage. Thus not merely has the intended point of going about been overshot, but sometimes the ship has been cast away where a better instructed seamanship would have escaped, or has been sent off upon a false errand to the ends of the earth. Such mistakes of judgment explain some of the saddest passages of history. Rome did not go about with the Reformation. She fails to see that, in thus exalting a temporary course into the permanent direction of the voyage, she has fatally mistaken the sailing directions of the Word.

The true relation to the great problems of human destiny of any epoch, procedure or people, must be ascertained essentially through the determination of its real place in and its genuine influence upon such successive alternations of advance. The " dark ages" touched their gloomiest point near the middle of the fourteenth century. As a factor in human development the mediæval Church had a threefold function. It subjugated, and in some measure exalted, rude peoples to a Christianity which offered at least a yoke and a name. It forestalled the absorption of religious organisms in the State. And, in its monastic retreats, it collected and conserved somewhat of the ancient learning. Then its ambition overleaped itself and its fall began. Undertak- 
ing to reduce all divine revelation to the formulas of its specific dogmas, and to compress within its ritual all expression of spiritnal life, it assumed also to depose sovereigns and to exact secular tribute from all nations, and resorted to exactions as illegitimate as they were intolerable, culminating in a traffic in indulgences which degenerated into demoralization and disgrace. All was emphasized by the lurking terrors of the Inquisition. ${ }^{1}$ Thus it had convinced the conscience of the world that halfway measures no longer were possible, and that repudiation remained the only available reform.

About these days, as by some common impulse, a tendency towards a simpler, purer, and more vigorous spiritual life began to appear. Wyclif at Oxford, Huss in Prague, John of Wesel, John Wessel of Groningen, at Florence Savonarola, in Mechlin John von Goch, and elsewhere others, moved by simultaneous stress of inward conviction, began to appeal from the Papacy and its Decretals to Christ and his Word. This was the time, too, when the bonds of the scholastic philosophy burst asunder, a new spirit began to electrify the thinking nations, and new forces combined for the delivery of the world.

In 1453 Christendom was dismayed by the fall of Constantinople. It did not yet appreciate that, as one result, Greek scholars of eminence ${ }^{2}$ were to revive the study of classical literature in Italy and all over Europe, and, particularly, to offer to minds just then eager for such learning the inestimable treasure of Gospels, Acts and Epistles in their long practically unknown originals. ${ }^{3}$

Thus that which many had supposed the death-knell of Chris-

1 See indulgences and the Inquisition, discussed in H. C. Lea's Hist. of Inquis. i : $41-56$, etc.

2 Cosmo de Medici appointed Argyropulos Greek professor at Florence. Chalcondyles taught Greek at Milan. John Andrew Lascaris settled in Padua. In 1513 he persuaded Leo X. to found the Greek College in Rome, of which he became principal as well as superintendent of the Greek press. Constantine Lascaris taught Greek and rhetoric at Naples. Both he and Chalcondyles published Greek grammars. But the knowledge of Greek in Italy dates back, no doubt, to the arrival there in 1396 of Emanuel Chrysolaras, whose Erotemata was the first Greek grammar in Europe ; and John Aurispa in 1423 had carried into Italy a considerable collection of the Greek classics.

3 The Latin of the Vulgate was the orthodox language, and Greek was a pagan and heretical tongue. Seebohm, Oxford Reformers, 6 . 
tendom proved to be the matin-bell ringing in its revival and renovation. Moreover, almost at the same time John Gutenberg was at once introducing to the world a new art of immeasurable value and bequeathing some of the most splendid specimens of that art to the admiring future. ${ }^{1}$ Printing once thus made practical, culture began to be diffused among the people; and the sceptre of a purely positional influence passed from the hand of the hierarchy forever.

The discovery of America in 1492 by Columbus and the doubling of the Cape of Good Hope by Vasco de Gama five years later not only revealed a new world, but also strained towards rupture the narrowness of former conceptions of spiritual things, and intimated that of old charts of dogma as well as of the old maps of continents and oceans, the divine voice might be heard saying, "Behold, I make all things new!" The rapid increase of commerce contributed to the same result.

With the sixteenth century, and under the novel social conditions thus suggested, modern Church History begins. To outline, even briefly, the general course of the great Reformation would be outside of the purpose of this narrative; which limits itself, as its chief object, to determining the relation of the Pilgrims to that ethical and ecclesiastical past which was behind them, and of which they were the logical and the theological outgrowth. To do this, it is mainly needful to note the progress of religious thought in England and the Low Countries.

The Reformation in our Fatherland was to be extremely gradual, was to assume its own type and, excepting as it passed into Nonconformity, was to be arrested in mid-development. Those devout Englishmen who looked towards it for spiritual benefit were to gain no direct power to help it on; and were to be only too happy if they could serve it by suffering for it,

1 The earliest book known to have been printed with movable metal type formerly was styled the Mazarin Bible (because a copy was discovered in Cardinal Mazarin's library), but now is called the Gutenberg Bible. It was printed 1450-55. It is in two volumes, measuring $15 \frac{3}{4} \mathrm{in}$. by $11 \frac{1}{2} \mathrm{in}$., is without title-page, signatures or pagination, and the initials and rubrics are in MS. throughont. There are 641 leaves printed in double columns, with 42 lines to a column. At the sale of the Perkins Library, June 6,1873 , a copy on vellum brought $£ 3400$ and one on paper $£ 2690$. In 1847 the Lenox Library copy cost about $\$ 2500$, but a copy has been sold since for nearly $\$ 20,000$. - Recollections of Jas. Lenox, 31 . 
while gaining from it indirectly a little help to their souls. On the other hand, those in power, by whom its public measures were to be shaped, cared mainly for the freedom which was wrested thereby from the secular tyranny of Rome. So far from seeking or accepting ethical or dogmatic advances or advantages from it, they appeared anxious for nothing else so much as, the Papal supremacy being abolished, to preserve all things as they were.

Spiritually the English soil was well-nigh without culture. Wyclif, indeed, a century and a half before Luther, had anticipated Protestantism, and even Puritanism; had given the Scriptures to his countrymen in manuscript ${ }^{1}$ in their own tongue; and had gained an influence so enduring that, when the throne and the nobles tried to exterminate his teachings, the effort in large measure failed. Beyond doubt, the principles of Lollardy secretly survived, preparing some men to welcome and assimilate the truths of the new German agitation.

There also had been at Oxford, much later, a beginning of reform before the Reformation. In 1496 John Colet delivered a course of lectures on the Epistle to the Romans. Their subject was unusual. It was common to lecture on Duns Scotus or Peter Lombard. But Colet drew out the meaning of the Bible in the most plain and natural manner, instead of following the misleading fashion of the day, which undertook to find in Scripture four senses - the literal, tropological, allegorical and anagogical - of which the last three almost extinguished the first.

His lectures, which in substance survive to our time, are as refreshing in their terse simplicity as if from the pen of a devout exegete of to-day. And their delivery at Oxford has been regarded justly as the first overt act in a new order of spiritual things. ${ }^{2}$ Fifteen years later, when Dean of St. Panl's, he preached before Convocation a sermon which, when it is remembered that it antedates Luther's first great public move by at least six years, becomes remarkable indeed. Some of its opening sentences prove this :-

1 First printed in a scholarly manuer by Rev. Josiah Forshall and Sir Frederic Madden at Oxford in 1850 in four vols.

2 Seebohm, 20. 
We wish, that once remembring your Name and Profession, ye would mind the Reformation of Ecclesiastical Affairs: for assure your selves there never was more need of it, the state of the Church did never more desire your Endeavours. The Spouse of Christ (whom ye would should be without spot or wrinkle) is made deform'd and illfavour'd. ... Wherefore I come hither to day (Fathers) to warn you, that in this your Council ye bestow your whole thoughts upon the Reformation of the Chureh.

Then, taking Romans xii : 2 as his text, he dwells upon that conformity which it forbids, and upon that reformation which it enjoins. He is terribly severe upon pride of life, concupiscence, covetousness and engrossing secularities. Then he implores the clergy to rehearse their canons, renew their vows and reform their lives, and says, ${ }^{1}$ " Wherefore if ye will have the Lay-People to live after your Wish and Will, first live you your selves after the Will of God."

Dean Colet died eight years after this, and before Luther's movement had become a practical issue in England. Very likely, had he lived, he would have been more repelled from many things which Luther said and did than won by what was common to them. While he lived, however, he was the centre of a little circle of kindred spirits. Chief of these were Erasmus and Thomas More. The "Enchiridion" of Erasmus, as Seebohm aptly says, ${ }^{2}$ reëchoed the very key-note of Colet's faith. His "Praise of Folly," with its stinging lash for the monks, was written in More's house. His "Novum Instrumentum " was inspired by the same purpose which had animated Colet's Oxford lectures. And More's "Utopia," published within a twelvemonth, faithfully applied to public affairs the stimulus and the sarcasm of the contrast between an ideal commonwealth and the king. doms of the time. In the desire for a great spiritual advance these three famous men were at one, however they differed otherwise. And in heartening Erasmus to those herculean labors which produced the New Testament in its original with brief comment, and his edition of Jerome, both Colet and More deserved the gratitude of the world.

Henry VIII. came to the throne, April 21, 1509, a well-

1 Erasmus, Life of Colet (trans. in Phenix, 1708), ii : 1-12.

293. 
favored, muscular, hearty, gallant, intelligent, and, for his time, well-trained youth of eighteen. The common people liked him because he looked their ideal of a king; scholars, because in more than royal measure he, too, was a scholar; and statesmen, because he developed a large capacity for public activities, and had ambitions for England. But for the next twenty years the dignitaries of the Church perhaps liked him best of all, because he was "very religious." 1 Educated by ecclesiastics, at thirty he published a treatise ${ }^{2}$ against the "damnable and pestiferous errours and heresies broached by Martin Luther," which so gratified Pope Leo X that he commanded all Christians in speaking or writing of Henry to add after the word "king" the title, "Defender of the Faith." Soon after this, however, circumstances put an entirely new face upon affairs.

The common notion, until recently, has been that, after ten or twelve years, the king tired of a wife whom he had married for prudential reasons, in his extreme youth; whom, as his brother's widow, he could marry only by special dispensation from Rome; whose uncongeniality was exaggerated by the fact that, five years older than he, she was more than twice that much his elder in temperament and constitution; and that, having fallen in love with one of her ladies, he trumped up a charge of illegality against his marriage as the pretext for a divorce. Other considerations, however, should be recalled.

Katharine of Aragon, youngest child of Ferdinand and Isabella of Spain, came to England in 1501, aged nearly sixteen, to marry Arthur, Prince of Wales, and the wedding took place in November, he being about ten months her junior. In the next April he died suddenly. Her dowry was to be 200,000 ducats, but only half had been paid. The king of England wanted the remainder, and disliked to return the portion already received. The king of Spain also desired influential friends. So they agreed that the original arrangement should remain essen-

1 According to the standards of that time. The Venetian ambassador reported (Despatches, ii : 312 ) : -

"His Majesty hears three masses daily when he hunts, and sometimes five on other days: he hears the office every day in the Queen's chamber, that is to say vespers and compline [i. e. the 9 P. M. service]."

2 Assertio Septem Sacramentorum aduersus Martin Lutherü. MDXXI. 
tially unchanged; that the Infanta should reside in England, and in time should wed a second Prince of Wales, who was not quite eleven at his elder brother's death. To obviate ecclesiastical objection, ${ }^{1}$ a bull was procured from Pope Julius II., licensing such a marriage, and betrothal took place on June 25, 1504, the intended bridegroom being not yet thirteen. However, probably to leave opportunity for any more promising alliance, Henry, acting of course upon his scheming father's prompting, on the evening before he became fifteen protested before witnesses that, not having reached the age of consent when the betrothal had taken place, he disclaimed and renounced it.

Thus matters rested. Katharine, upon whom or upon any of whose Spanish friends it may be doubted whether this prudent protest ever were served, lived on in England ; the paid portion of her dowry unreturned, and the political status undisturbed either by open repudiation of the proposed marriage, which would have enraged Spain, or by its consummation, which would have angered France.

When Henry came to the throne, this whole question came up for settlement. In the judgment of the Council the political horizon remained essentially unaltered, and the Spanish alliance still was preferred, on the whole, to one with France or the house of Burgundy. The protest therefore was ignored. It was assumed that the bull of 1503, supplemented by Katharine's claim that her first marriage never had been consummated, met all objections, and on June 3, 1509, the marriage was celebrated.

For ten or fifteen years the union seemed happy. But in 1520, after several still-births and the speedy death of two infant princes, the Princess Mary, born February 18-28, 1516-17, and infirm from infancy, remained the sole offspring. The queen's health also seemed to preclude the hope of better things to come. In these circumstances, the king recalled the old Mosaic statute, ${ }^{2}$ which denounced sterility upon such a union as his, and, with the habits of thought of that age, he honestly may have feared that its threatened blight was resting upon his household. Could

1 Warham, Archbishop of Canterbury, opposed it, and many others disfarored it. Burnet, Hist. of Ref. of Ch. of Eng. i: 35.

2 Levit. xx : 21. 
the Pope nullify a divine ordinance? If not, he had not been married legally to his queen, and the Princess Mary, feeble at best, had no legitimate claim to the throne.

England never had had a queen reigning in her own right, and, occurring so soon after the conflicts between the houses of York and Lancaster, this possibility awakened anxiety. Many besides the king felt that the birth of a prince, hopeless excepting from some new alliance, would justify almost anything needed to secure it. But Katharine was the near relative of Charles V., and harshness towards her would imperil relations with him. While, should the Pope revoke his predecessor's dispensation licensing the marriage, thus making it void from the beginning, he would impair, awkwardly if not perilously, the very substance of all Papal claim to spiritual rectitude and supreme authority.

Apparently, as far back as 1524, a practical separation had begun between the king and queen. ${ }^{1}$ By the summer of 1527 it became a matter of conversation, having been made the subject of secret negotiations earlier at Rome. The Pope at first was rather favorably lisposed, appreciating that, should the lack of a male heir to the British throne cause civil war, it might injure the Church. But he wanted delay because of the delicacy of his relations with the emperor. Henry grew impatient. He sent embassy after embassy to Rome. Distinct threats that, were the desired separation not obtained in one way, it would be in another, were not withheld. And early in 1527 a collusive suit was entered secretly before Wolsey, Archbishop of York, and Cardinal and Papal Legate, summoning Henry to answer for cohabiting with his brother's widow. But proceedings finally were dropped.

When, in 1528, Clement VII. was in refuge at Orvieto, he so far yielded to Wolsey, who was terror-stricken lest the Church should suffer, as reluctantly to commission a Legatine Court to try the case in England; and he empowered Cardinal Campeggio, with Wolsey, to constitute it. No doubt there was an accompanying understanding that some private arrangement

1 Brewer, cexxv. But from what the king told Campeggio, in October, 1528 (Ibid. ccecx), possibly the date was 1526. Sir Thomas Boleyn's (Viscount Rocheford's) deposition (Ibid. iv : iii (5774)) would make it 1527. 
should be effected first, if possible. Campeggio could do nothing with the king, and turned to Katharine, hoping that she would retire voluntarily to conventual life. But she was as immovable as Henry. She indignantly refused to concubinize herself and illegitimate her daughter.

- The Legatine Court therefore had to do its best. On May 31, 1529, it was opened in the Great Hall of Blackfriars, London. It dawdled on, Katharine merely protesting and making a touching appeal to the king for justice, ${ }^{1}$ until, on July 22, by order from Rome, proceedings suddenly were adjourned until October. Angry excitement followed. Charles, Duke of Suffolk, gave a great slap on the table and blurted out: "Now, by the mass! do I see that the old-said saw is true, that never was Legate or Cardinal did good in England:" 2 The matter then was postponed until Christmas and transferred to Rome.

For the first time it began to look as if Henry VIII. could not have his own way. He became convinced that the Pope did not intend to come to his relief. He had studied the literature of the subject until he was as familiar with it as the best of the canonists, and had become positive that Pope Julius II. had exceeded his power in authorizing the marriage, and that no marriage really had taken place. Therefore there was no legal successor to the crown. With one exception, ${ }^{3}$ all the bishops in England confirmed this view. Moreover, he already had been keeping his chosen second wife for nearly two years in magnificent state at Greenwich and elsewhere, too near to himself for Katharine's peace, his own honor or the public conscience.

It might be expected, then, that he would insist on having his way, and it is clear that, upon the last postponement of his case, he began to plan how to sever his kingdom from the spiritual jurisdiction of Rome. Certain German principalities and kingdoms of the north already had moved in a somewhat similar direction. A change of agencies followed, Wolsey who had failed ignominiously in all these negotiations - was

1 Brewer, cecclxxii.

2 Ibid. ceccxeviii.

3 "Only the Bishop of Rochester [Fisher] refused to set his hand to it." Burnet, i: 38 . 
disgraced, and in little more than a year was dead. Parliament was summoned, after an interval of seven years, and, no doubt by royal instigation, the Commons petitioned the king, as " the only Head, Sovereign, Lord and Protector of both parties, spiritual and temporal," against the spiritual courts and the abuses committed by the clergy, and several acts were passed for their reform. Subsequently, under the same fearful pressure of the praemunire ${ }^{1}$ which had crushed Wolsey, the two Convocations $^{2}$ of Canterbury and York, which by law were held to share the fallen cardinal's guilt, were compelled to acknowledge Henry VIII. as "the Protector and Supreme Head of the Church and Clergy of England," the demand being softened only by the vague clause, "in so far as is permitted by the law of Christ." The queen took alarm, and, on her supplication, two briefs of inhibition were issued by the Pope - who, however, could get them posted no nearer than Flanders - threatening the king with the greater excommunication and the putting his kingdom under interdict.

About this time Thomas Cranmer suggested the manufacture of a public sentiment which should offset the Pope's action. It was an admitted feature of the Romanist system that a question affecting the extent of the Papal powers must be decided by a General Council, which perhaps could be demanded by common consent of Christendom. It was determined, therefore, to appeal to the universities and learned men throughout Europe as to whether the dispensation of Pope Julius had been legitimately within his power.

As the result, the advice of the universities of Paris, Orleans, Angers, Bourges, Toulouse, Bologna, Padua, Cambridge and Oxford, as well as that of above a hundred learned doctors, soon was laid before Parliament, all denying the validity of the dispensation. This gave the king a legal pretext for appeal-

1 Dealing with the offence of asserting the supremacy of a foreign power, like the Pope, over the realm. It involved the loss of civil rights, forfeiture of lands, goods and chattels, and imprisonment during the royal pleasure. Enc. Brit. xix : 653.

${ }^{2}$ A kind of ecclesiastical parliament, composed of an upper house, of bishops, and a lower house, of deans, archdeacons and representatives of the ordinary clergy, within the jurisdiction of each archbishop. It meets, summoned by special writ, whenever Parliament meets, and adjourns when Parliament goes out. 
ing to a General Council. The Lords also joined with such of the Commons as remained in London after the prorogation of Parliament in addressing the Pope, imploring him to confirm so just and general a judgment. In June, 1531, two months after Parliament had been prorogued, the queen once more was appealed to to withdraw her recourse to Rome and consent to arbitration within the kingdom. And once more she prondly refused.

The next month she was secluded at Ampthill. Parliament reassembled. All statutes giving Rome power in England were abrogated. The annates ${ }^{1}$ were made payable to the Crown. Peter's pence ${ }^{2}$ were abolished. It was made a penal offence to ask any dispensation from Rome. The archbishops, or any two bishops, were empowered to consecrate new bishops. The king was styled "Supreme Head in Earth of the Church of England immediately under God." The power of visitation of the Church to correct abuses was lodged in him. Sequestration, already begun, which, by suppressing the monasteries, would yield immense funds and enable the king to give great gifts to his favorites, was made further possible. Yet it was made clear that no dogmatic reform was desired, existing statutes against " heretics" being confirmed, and the body of William Tracy, of Todington, Gloucestershire, being dug up and burned, after a post-mortem trial and condemnation before Convocation, because he had left nothing to any priest to pray for his soul. ${ }^{3}$

In view of all this, the Pope trembled in fear of losing England, yet could not believe Henry so intensely in earnest that some arrangement could not be contrived. So he held out vague hopes of accommodation, until he precipitated the catastrophe. The king at last determined to take his case into his own hands. In great privacy, on November 14, 1532, he was married to Anne Boleyn. Possibly he scrupled less to take this course because the Pope himself at one time had intimated that perhaps a Papal dispensation could be had authorizing him to have two

1 A year's income payable to the Pope, on the death of a bishop, abbot or parish priest, by his successor.

2 An annual gift of a penny by every Roman Catholic to the Pope.

${ }^{3}$ Strype, Annals, i (2): 198. 
wives at once! ${ }^{1}$ In springtime it became obvious that by early autumn the new wife would become a mother, and therefore that all measures needed to legitimate her offspring must be taken speedily. On May 10, 1533, Cranmer, the new Archbishop of Canterbury, with the Bishops of London, Lincoln, Winchester, and Bath and Wells, opened a court at Dunstable, and eited Katharine before it. She refused to recognize its authority. The court denounced her for contumacy, and went on and, on May 23 , it decreed the marriage invalid and the parties separated, and Katharine was notified formally that she no longer was queen, but simply, as the widow of her first husband, Prificess Dowager of Wales. On May 31 , with a pageant exceeding in gorgeousness anything before known in England, Anne Boleyn passed from the Tower to Westminster, where she slept. The next morning in the Hall she was crowned and anointed queen by archiepiscopal hands scarcely washed from the ink-stains of the Dunstable divorce.

Tidings of this made a stir in Italy. The emperor joined in negotiations. The king was eited to Rome. He refused to go. He still intended to be a good Catholic. But he seems to have persuaded limself that he had lived illegally with Katharine. On June 29, he appealed from the Pope to the next General Council. ${ }^{3}$ The Pope was angered. His first. impulse was to excommunicate, but the threatened penalties were suspended until September.

The king, however, began to look about him for aid in withstanding Rome, and to take steps towards an alliance of all ${ }^{4}$ who were renouncing her supremacy. Under this menace negotiations were reopened by the Pope. Progress was made towards a court, to sit at Cambray, to condemn the original marriage and devise relief for Henry within the Papal Church. Once and again the date of final censure was postponed, and apparently the delay of a courier precipitated a result which otherwise

1 Gregory Casalis to the king, September 18, 1530. Herbert, 330.

2 Herbert, 377.

${ }^{3}$ As the root of the matter was whether the Pope can dispense with a law of Scripture, he himself conld not decide thereon impartially.

4 'The kings of Poland and Hungary, the dukes of Saxony, Bavaria and Brandenburg, the landgrave of Hesse, etc. S. P. Hen. VIII, v: Pref. ii-iv. 
would have been different. ${ }^{1}$ At last, in March, 1534, Henry was excommunicated, and was declared to have forfeited the allegiance of his subjects.

This action was met bravely. Even before it was reported, Convocation declared that the Bishop of Rome had no more power in England than any other bishop, and his name was erased from the mass-book. Papal authority was abolished by the Act of Supremacy. A fresh oath of allegiance was enacted. The coronation oath was reconstructed. All affairs were readjusted. Final appeals were ordered to be made to the king in chancery instead of to Rome. The smaller monasteries were suppressed, and the harbors and coasts were fortified.

It looked for a time as if some elements of this extraordinary reconstruction might make for Protestantism. It had been from direct appeal to Scripture that the first marriage had been invalidated. In the same line had been the king's license for the distribution of the Scriptures in the vernacular, with the order to place a copy in every church. No donbt some little beginning of doctrinal reformation crept in among the people thus. Indeed, Henry was not indifferent to the religious changes on the Continent. In 1535 he sent envoys to Saxony to confer with certain of the most influential Lutheran reformers. Discussions were held, at some of which not only Pontanus and Burckhardt, but also Luther and Melancthon, were present, in hope of some concord of faith and unity of action. But all came to little or nothing because of English reluctance to accept portions of the Augsburg Confession.

Still further, in 1538 a German embassy ${ }^{2}$ visited London, representing John Frederick, Elector of Saxony, and Philip, Landgrave of Hesse, to promote, politically, a league against the Pope, and, doctrinally, some common Confession of Faith.

1 The Pope had assented to terms never made fully public which Henry approved. To hear from England, sentence was deferred until Mareh 23. Something delayed the courier. The Spanish party prevailed and sentence was made public against the king, affirming the validity of his marriage with Katharine. Two days later the courier arrived with the king's assent to the proposition of the Pope. An all-night session of the cardinals was held to eonsider the situation, but the result was nothing.

2 Strype, Eccles. Mem. i (i) : 348 ; i (i) : 507 (ii) : 386 ; Cranmer, ccxxxvii. Hardwick, Hist. of Arts. of Relig. 56. 
But England was not ready for so much Protestantism. And the king could not concede the equality of these German princes with himself, or consent to any scheme in which England did not lead. So these legates returned home. But they deposited in Cranmer's mind forces which subsequently aided strongly to shape the Protestantism already vaguely existing there. ${ }^{1}$

Convocation set forth, in July, 1536, by the king's command, Ten Articles of Religion, the first five of which were taken from the Augsburg Confession. The Scriptures, with the Apostles', Nicene and Athanasian Creeds, were declared the standard of truth. Three sacraments only, baptism, penance and the Lord's Supper, were mentioned, much in Luther's sense. But, with regard to images, honoring and praying to saints, purgatory, vestments, candles, palms and the like, no important change appeared. ${ }^{2}$ Yet reliance upon the elergy to explain these modifications and the rightfulness of the abrogation of the Pope's authority was the only way of reaching the masses, and this exaltation of preaching helped forward reform. So, too, the requirement that children be taught the Lord's Prayer, the Creed and the Commandments in English ${ }^{3}$ laid a foundation for church service in the vernacular in the next reign.

But the majority of the nation, especially in the less enlightened regions, still was set on the ancient beliefs; the suppression of the cloisters was unpopular; and an insurrection arose in the north. So the king took sharp measures to prove that he was a good Catholic still. He required the usual church ceremonies to be observed to the last genuflexion. He prohibited the marriage of priests. He established a censorship of the press and insisted upon vigorous dealings with Dissenters.

His church supremacy also was confirmed by a new act; the greater abbeys were suppressed, partly that the upper classes might be propitiated with their lands; and, in 1539, the sanguinary statute of the Six Articles ${ }^{4}$ was enacted, which in sev-

1 Lives of Abps. of Cant. VII : 2S, 30.

2 See Articles in full. Burnet, i (3) : 215-216.

3 Injunctions given by 'Authority of the King's Highness to the Clergy of this Realm, Art. 5. This was the king's first act of pure ecclesiastical supremacy. Burnet, i (3) : 161.

4 But Hook says (vii : 267): "The king only desired through this statute - 
eral particulars receded towards Popery. It sanctioned transubstantiation, reëstablished confession, private masses and vows of chastity, and forbade the marriage of priests and the giving of the cup to the laity, all under heavy penalties. The only leaning toward reform was that procedure had to be "upon presentments, and by a jury;" although this did not save those of whom it was thought expedient to make examples. Still, among the prelates there were some, notably Cranmer, Archbishop of Canterbury, who sympathized vitally with their Protestant friends on the Continent, and the Bible was printed in English and ordered to be set publicly in churches.

There is literally nothing pleasant in the last days of Henry VIII. Physical excesses rendered him so corpulent and diseased in his fifty-sixth year that he had to be wheeled about, and he was so ill-tempered that he was a burden to his friends. The succession to the throne, which had been with him the urgent motive through the most startling vicissitudes of his extraordinary career, was left, after all, to hang upon the lives of a prince, still a mere lad and giving small promise of vigorous life; and two princesses, respectively twenty-nine and thirteen years old, each of whom had been declared illegitimate.

The king himself, first "Supreme Head, in Earth, of the Chureh of England," died substantially an unreformed Roman Catholic. In his will 1 " in the name of God, and of the Glorious and Blessed Virgin our Lady St. Mary, and of all the Holy Company of Heaven," he desired the prayers of the Virgin, and all that Holy Company, and he ordered that "daily masses ... be said perpetually while the world shall endure" for the repose of his soul, and that 1000 marks be given "to move the poor people that shall have our alms to pray heartily unto God for remission of our offences and the wealth of our soul."

As to the spiritual future of the kingdom, it clearly was his purpose to perpetuate that compromise between the old religion and the new which he had established in England, by which Romanist doctrine should be maintained essentially, while Papal

hung in terrorem over the heads of the Reformers - to compel silence for a time, with a view to further reform in due season."

1 Froude, iv: $479-485$. 
control was rejected. And, not trusting any one person, he provided in his will that during the long minority of his son, a Privy Comncil should supervise affairs. As its members he named three Reformers, three adherents of the old faith, and ten others representing intervening shades of opinion. In the main the dying king left the nation still adhering to the faith and the forms of Romanism. But, to carry his point against the Pope, he had been forced to resort to some arguments which were essentially and fruitfully Protestant, and to tolerate some ecclesiastical as well as secular officials largely leavened by the spreading reform.

The religious history of this reign has been dwelt upon with so much of detail in order to show how really insignificant was the actual progress of England, under the influence of the man to whom her rupture with Rome was due, towards either doctrinal or practical reform. 


\section{CHAPTER II}

\section{PROGRESS AND RETROGRESSION}

EDwaRD VI. came to the throne, January 28-February 7, 1546-47, when a lad of nine. He was intelligent and, indeed, precocions, conscientious, obstinate, ${ }^{1}$ evidently impressed by his responsibilities and anxious to discharge them well. Yet, necessarily, he was mainly dependent upon the guidance of his counsellors. Henry had sought to secure that these should be friendly to the lad and to each other, but should represent different opinions, so that, at least until the young king's majority, matters might go on much as in the past. But Cranmer, much further advanced in Protestantism than his old master probably knew, with the Earl of Hertford, the king's uncle, proved to be the determining forces in the Council. And Hertford - made Duke of Somerset, Protector of the Realm and Governor of the King's person - whose chief idea seems to have been to play the king pro tempore, also was committed strongly against Rome.

It is further obvious from the speech and conduct of the young monarch, and especially from his "Discourse about the Reformation of many Abuses," 2 that personally he was earnestly in favor of the new movement in religion. Here was one mighty force likely to be efficient. On the other hand, in addition to the multitudes of remaining Romanists, thousands remembered that the late king's will left his daughter by his Spanish wife who, should she come to the throne, might be expected to carry England back to the Pope - next in succession to the throne, and governed themselves accordingly.

${ }^{1}$ Hook says (vii : 285) : "The young king, whose precocious talents were accompanied by the self-sufficiency and obstinacy by which the Tudor race was, for good or evil, distinguished."

2 In full in Burnet, ii (2): 69. 
Moreover, Henry VIII. had died heavily in debt. Although he had begun his reign with a large sum in hand, ${ }^{1}$ his extravagance, with that of the State, had driven England into two grave financial errors. She had borrowed money at Antwerp at usurious rates, and she had begun to debase her own coin. These blunders had serious influence upon her subsequent religious development.

The reformers lost no time. The coronation oath was amended. Cranmer in his address to the youthful monarch repudiated all dependence upon the Bishop of Rome; reminded Edward of the boy-king of Israel, Josiah; and suggested that, as in Josiah's case, it might become his dnty to suppress idolatry. A popular movement began. The officials of St. Martin's, in Ironmonger Lane, London, cleansed it of crucifix, images and pictures of saints; and, although compelled to restore them, were justified by the primate and imitated by others. ${ }^{2}$ At Canterbury a crucifix was melted into coin. Nearly forty injunctions were sent out in the king's name, and the clergy were required to have the same "observed and kept of all persons." ${ }^{3}$ The tendency of all this must have been to dislodge remaining Romanism, and to substitute Protestantism. A translation of the "Paraphrases of Erasmus" on the Gospels and the Acts also was directed to be studied by the clergy and to be set up in churches with the great Bible, so as to be accessible by everybody.

A royal visitation followed. The conntry was divided into six circnits, and representatives of the Crown were sent through them to inquire how far old superstitions were giving way. A Book of Homilies, ${ }^{4}$ or sermons in English, was prepared, to supply the defects of a ministry largely incompetent to make sermons, and still more so to make sound ones. Preachers, among whom were Hugh Latimer, and, later, John Knox, diligently instructed those whom they could reach. When Parliament met in November the obnoxious Six-Articles Bill and the old stat-

1 "No less than $£ 1,800,000$." Ibid. i (1): 2.

2 Ibid. ii (1): 9.

3 A. Sparrow, Collection of Articles, Injunctions, Canons, etc. (ed. 1675), 11, 6.

4 Certayne Sermons or Homilies appoynted by the Kynges Maiestie to be declared and redde in Churches, etc., 4to, 1547. 
utes against the Lollards were repealed. A new Order for the Communion, in English, was set forth, whose vital terms of administration were these ${ }^{1}$ -

When he [the Priest] doth deliver the Sacrament of the body of Christ, he shall say to every one these words following:

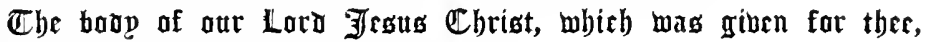
preserbe thy bady unto eberlasting life.

And the Priest delivering the Sacrament of the blood, and giving every one to drink once and no more, shall say:

The bland af our Lard Jestes Christ, which was shed far thee, pre ortbe thy soul unto rberlasting life.

By the second assembling of this Parliament, in November, 1548, Cranmer was ready with his draft of a Prayer-Book in English, ${ }^{2}$ intended to supersede the ancient Rome-saturated Latin service.

In the preface of this volume it is said :-

Here you have an ordre for praier (as touchyng the readyng of holy scripture) ... a greate deale more profitable and commodious, then that whiche of late was used. It is more profitable, because here are left out many thynges whereof some be vntrue, some vncertein, some vain and supersticious: and is ordeyned nothyng to be read, but the very pure worde of God, the holy scriptures, or that whiche is euidently grounded vpon the same: and that in suche a language \& ordre, as is most easy \& plain for the vnderstandyng, . . . It is also more comodious, bothe for the shortnes thereof, \& for the plaines of the ordre, \& for that the rules be fewe \& easy. . . .

And where heretofore, there hath been great diuersitie in saying and synging in churches within this realme: some folowyng Salsbury vse $^{8}$ some Herford vse, some the vse of Bangor, some of Yorke, \&

1 The Order of the Communion, etc. (5), in Sparrow. At once translated into Latin by Miles Coverdale and sent by him to Calvin (Original Letters, 1537-58, Parker Soc. xix), in the expectation that he would approve and print it, as he could more easily than the translator. But Calvin does not seem to have done this.

2 The booke of the common praier and administracion of the sacramentes, and other rites and ceremonies of the Churche: after the vse of the Churche of England, 1549, fol. iv.

3 A term applied to the ritual as arranged by authority and practised in any diocese. Before this date the service, with a general resemblance, had varied in minor particulars in the five dioceses named. See F. Procter, Hist. Bk. Com. Prayer, 4. 
some of Lincolne: Now from heceforth, all the whole realme shall have but one vse.

This, commonly called the First Book of Edward VI., had been prepared with wide consultation, from which Lutherans, Calvinists and Zwinglians had not been excluded. Of its thirteen compilers all but one had been educated at Cambridge. Founded on the Salisbury ritual, ${ }^{1}$ from whose missal and breviary chiefly it was rendered into English, it was largely indebted to a German work ${ }^{2}$ diawn up five years before for Hermann, Prince Archbishop of Cologne, to suggest to his subjects a Scriptural form of doctrine and worship. That work had been done by Melancthon and Bucer, their model being a form composed fifteen years before for the use of Brandenburg and $\mathrm{Nu}$ remberg by Luther. Traces of the influence of two other manuals have been thought to exist in this Prayer-Book: one, the reformed breviary of Cardinal Quignon ; ${ }^{3}$ the other, the ServiceBook ${ }^{4}$ of the church at Glastonbury, which is believed to have suggested the Introductory Sentences and the Exhortation, Confession and Absolution, with the Ten Commandments and their Responses. ${ }^{5}$ Thus a considerable consent of leading Protestant minds was wrought quietly into this manual, although it is difficult to trace anything directly back to Calvin, whose General Service-Book also probably was in hand.

The new Prayer-Book was sanctioned by Convocation, but there was sharp debate in Parliament, and some bishops opposed it to the end. ${ }^{6}$ It shows unavoidable traces of the temporary and compromised condition of affairs. It uniformly styles the officiant the "priest." The Communion table still is the "altar." The name of the Virgin is mentioned specially in the praise

${ }^{1}$ Hook, vii : 252.

2 Simplex Judicium de Reformatione Ecclesiarum Electoratus Coloniensis, 1543, A Latin rendering (Simplex ac pia Deliberatio, 1545) was issued; and in 1547 an English version: A Simple and religious Consultation of us Herman, ete. This was revised and printed again the next year. Both are in the British Museum.

${ }^{3}$ Breviarium Romanum, ex sacra potissimum Scriptura, etc., 15ł3. Hook, viii : 269.

${ }^{4}$ Liturgia Sacra, seu Ritus Ministerii in ecclesia peregrinorum profugorum propter Evangelium Christi Argentinae, etc., 1551.

5 Procter, $45-46$.

${ }^{6}$ King Edward's Journal. Burnet, iii : Coll, of Records: 6. Traheron to Bullinger, Orig. Letters, Parker Soc. clii. Ranke, i : 175. 
offered for the saints. The sign of the cross is preseribed in marriage, confirmation, anointing the sick, and the consecration of the water of baptism, and twice each in the baptismal and communion services. The trine immersion, the form of exoreism, the anointing and the chrism are retained in baptism, and the water of the font must be changed and reconsecrated at least once a month, for which service an extended form is provided. Prayer is offered for the dead. The Communion service is neutral as to the Real Presence.

An Act of Uniformity made the use of this liturgy, which began with Whit-Sunday, June 9, 1549, imperative. On the whole, the new Prayer-Book was well received, largely, no doubt, because so much of it was old. Many Romanists liked it as containing the primitive elements of true worship. Most Reformers favored it because they so much had their own way in it. But some Papists termed it "a parliamentary religion," and some Protestant extremists thought it tinged with Lutheranism. It was translated into Latin. ${ }^{1}$

Events moved on rapidly. To disfavor to the last degree any possible return to the old mass-books, an Order in Council, afterwards confirmed and extended by act of Parliament, required that they be called in, defaced and destroyed. Hooper in his Lent Sermons before the Court ${ }^{2}$ pleaded, since no Christian sacrifice now requires an altar, that the magistrates remove "all the monuments and tokens of idolatry and superstition," and a movement in that direction began. Multitudes also were led to scruple the priests' robes as remnants of Popery, ${ }^{3}$ especially the scarlet vestments of the bishops.

When, in 1550, Hooper was named Bishop of Gloncester, the matter gained prominence by lis reluctance to accept the office on that account. He declined to receive the tonsure or to wear a mitre, or any robe excepting his university gown of black. Controversy ran high. Bucer at Cambridge and Peter Martyr at Oxford preferred simplicity, but questioned whether, when weightier

1 By Alex. Alesins - known also as Ales and Alane - whom Cranmer employed so that Bucer and Martyr, who could not read English, might give him their views upon it. Dict. Nat. Biog. i : 257.

2 Fourth Sermon upon Ionas. Early Writings of Hooper, Parker Soc. 488.

3 Bullinger on Prayer-Book, Parker Soc. 2 Zurich, 357. 
matters should have been adjusted, the vestments and ceremonies might not be managed more easily. ${ }^{1}$ Hooper inclined towards a more serious view. To him the oath "in the name of God, the saints and the gospels" was impious and the surplice the very badge of Antichrist. He was forbidden to preach and sent to the Fleet. Cool reflection brought him round to the position of his Continental friends. The king cancelled the objectionable portion of the oath, and Hooper agreed to wear the obnoxious garments when preaching before the king, if he might disuse them afterwards.

Such discussions stimulated Protestantism until it became obvious that the Prayer-Book had not gone far enough. The king himself wanted more changes. ${ }^{2}$ Accordingly, a committee of divines under Crammer undertook its revision in the antumn of 1550. Parliament met, January 23-February 2, 1551-52, and in April the revised Prayer-Book was adopted, but was not to be used until All Saints' Day, November 1. The many changes made uniformly were in the interest of Protestantism, so far as they were doctrinal. The name of the Virgin Mary and the sign of the cross were omitted. Exorcism, anointing and the trine immersion were stricken from the baptismal service. Prayers for the dead disappeared. In the rubric concerning the robing of the clergy it was ordered that neither alb, vestment nor cope be put on. An archbishop or bishop was to wear a rochet, priests and deacons the surplice only. The most important change concerned the Lord's Supper. A believer in the substantial corporeal presence of Christ in the bread and wine might have accepted the Prayer-Book of 1549 with a good conscience, but this of 1552 represented our Lord as present only as He always is present to the prayers of his disciples. In place of "The body of our Lord Jesus Christ, which was given for thee, preserve thy body unto everlasting life," etc., the new book reads : -

Take and eat this, in remembrance that Christ died for thee, and feed on him in thy heart by faith, with thanksgiving.

1 Strype, Eccl. Mems. ii (2) : 456, and Cran. i : 304. Epis. Tigurin, eclxiii, exxiv. Foxe, Acts and Mons. (ed. 1584) iii : 120.

2 Martyr to Bucer, January 20, 1551. Strype, Cran. ii : 899. 
And the minister that delivereth the cup, shall say:

Drink this in remembrance that Christ's blood was shed for thee, and be thankful.

An odd fact only lately has become known. This revised liturgy not only had been printed, but was bound and ready for distribution. It required the consecrated bread to be delivered to the people " kneeling." Joln Knox was in London that year and was a royal chaplain, and a contemporary letter ${ }^{1}$ intimates that it was he who preached before the king and the Council in October, iuveighing against kneeling at the Lord's Supper. There is some probability, also, that he protested before the Privy Council against this rubric. ${ }^{2}$ All ended in a statement ${ }^{3}$ to be pasted into the already completed books : -

Lest yet the same kneelynge myght be thought or taken otherwyse, we dooe declare that it is not mente thereby, that any adoracion is doone, or ought to bee doone, eyther vnto the Sacramentall bread or wyne there bodelye receiued, or vnto any reall and essencial presence there beyng of Chrystes naturall fleshe and bloude. For as concernyng the Sacramentall bread and wyne, they remayne styll in theyr verye naturall substaunces, and therefore may not bee adored. . . . And as concernynge the naturall bodye and bloud of our Saviour Christ, they are in heaven and not here. ... .

Thus, at the last moment and in a manner clearly open to criticism, this additional heavy weight in favor of Protestantism was thrown into the scale. ${ }^{4}$

Coincidently there were prepared Articles of Faith, authoritatively intended "for the auoiding of contronersie in opinions, \& the establishment of a godlie Concorde." It already has been stated that, as early as 1536 , ten Articles had been ordained by royal anthority to "stablyshe Christen quietnes and unitie among us." They were a compromise and never were wholly satisfactory; while the heightened conservatism of the subse-

1 Epis. Tig. celxxiii.

2 P. Lorimer, John Knox and Ch. of Eng. 110.

3 Two Liturgies, Parker Soc. 279, 283.

4 In some copies this was pasted in, having been printed on a slip for that purpose. Sometimes an extra leaf was intercalated, interrupting the regular paging. And some copies were issued without it, or with it so ill attached that it was lost in the course of time. Liturgies of Ed. VI. Parker Soc. $2 \$ 3$. 
quent reactionary Six Articles, of 1539 , only made their unfitness more distressing. Moreover, by some the Reformers were suspected, if not accused, of heresy, a disrepute which they determined to neutralize by an authentic statement of belief. Furthermore, the new outspring of thought which the Reformation was favoring was producing over all the Reformed countries a crop of wild vagaries which needed criticism. Accordingly in 1551 Cranmer was directed to recast the old Articles to meet existing needs. He long had desired greatly, and the more since the Romanist gathering at Trent," that a "Godly Synod," representing all the Reformed churches, might enrich that age, if not also succeeding ages, with some strong and sage deliverance, not merely propounding the genuine essence of Orthodoxy, but also illustrating the wisest forms of its expression. He was the more anxious that this should be international because there was a dearth of scholars, fitted for such work, at home. ${ }^{2}$

He had written on the subject to Melancthon several times, and addressed him again early in 1552 , saying ${ }^{3}$ that the king promised his own royal assistance and a secure and quiet place of assembly in England for such a Synod. He also had written to Calvin and Bullinger.

In the time of Henry VIII., Cranmer at Nuremberg had made the accuaintance of Andreas Osiander, an eminent scholar and critic, whose niece he married, and who, as an un-Lutheranized Reformer, strongly won his sympathy. Through him he came to know others. He learned to think highly of the Swiss theologians. ${ }^{4}$ It pleased him greatly when, in Edward's time, some of them visited Cambridge and Oxford. His hospitality to them was unbounded. Such men as Valerandus Pollanus, the pastor of the Walloon Church, then sheltered in Glastonbury; the converted Jew, John Emanuel Tremellius, for a time Hebrew professor at Cambridge; his gifted associate, Anthony Rodolph Chevallier, a personal friend of Calvin; and the Spanish Francis

1 In session, with long interruptions, from Dec. 13, 15்5, to Dec. 4, 1563.

2 Prin. Cunningham, Reformers and Theol. of Reformation, 190. Mullinger, ii : 102.

${ }^{3}$ Parker Soc. celxxxv, cexcviii; Epis. Tig. cecxxxvii.

* Mullinger, ii : 108. 
Encinas - often known as Dryander - who for a short time tanght Greek in the same university and translated the New Testament into his vernacular, were Craumer's casual guests.

But he also welcomed for periods of weeks or months others of similar qualities and fame. Among them were John a Lasco, the Polish nobleman, who was superintendent of the Dutch congregation in Austin Friars, London ; John Uitenhovius, from Ghent, another officer of that same church; Martin Bucer, the famous Alsatian; Peter Martyr, the Florentine, Regins professor of theology at Oxford; Paulus Fagius, the German; Peter Alexander, a French refugee, who under Cranmer's roof compiled a new volume of "Sentences," to correct misrepresentations of patristic teaching as to doctrines at issue; Matthew Negelinus, afterwards a minister at Strasburg; and Beruard Ochinus, an erudite Italian, the author of effective clialogues against the Pope's primacy.

Add to these, most of whom were on the ground, still others with whom correspondence was maintained freely - Calvin and Melaucthon, with Wolfgang Musculus and Henry Bullinger of Zurich, a powerful upholder of the Zwinglian doctrines, who presumably exerted a stronger influence over this phase of the Reformation in England than any other foreigner ${ }^{1}$ - and it is plain that, although no formal synod met, the new Confession did not lack the aid of Continental experts.

The body of doctrine, which took the shape of the Forty-two Articles, was mnch more exclusive and repressive than inclusive and upbuilding. The recent and novel freedom of popular thought had started many peculiar opinions, but only special study can develop the surprising facts adequately. All things considered, it would have been unreasonable not to expect that intense but narrow minds, long and unjustly repressed and now turned loose to interpret Scripture for themselves, with little knowledge and no experience, would grow giddy and think that they ought to believe, preach and practise many things contrary to the ancient ways. Nor can it be clenied that even their worst excesses were likely to be only corollaries illegitimately drawn from postulates common to them and to the most discreet

1 Cunningham, 190. 
Reformers ; with whom they joined in asserting the supremacy of the Bible, the sacred independence of the individual judgment and conscience, and the supreme importance of personal faith.

Beginning with the preaching tours of Thomas Minzer in 1521, and growing through imagined divine revelations into a strange mixture of socialistic and spiritual truth and error; reaching its height in the "Peasants' War" of 1525 ; and reappearing ten years later in the Münster insurrections and excesses $;{ }^{1}$ what, from a single distinctive tenet, it became common to call Anabaptism soon grew to be regarded as the synonym of whatever was fanatical, corrupt and corrupting. This hydra-headed public nuisance, with some forth-puttings of Socinus, Servetus, Schwenkfeld and the Gospellers, with the Arians, Marcionists, Libertines, Danists, etc., alarmed Cranmer and his associates. They felt that they must set forth on behalf of the Church of England with authority that it held no sympathy with any such hallucinations and heterodoxies; and that, if it repudiated ancient Papal errors, it no less denied the foolish and fatal fancies of the enthusiasts.

Accordingly, the Forty-two Articles fall into four classes. The first consists of distinct assertions of truth ; the second of distinctions between the Church of England and Romanism; the third of affirmations condemning tenets known by the general name, Anabaptism; the fourth of such as controverted both these and other systems believed perilous.

Of the first class there are four: the seventh, setting forth the verity of the Apostles', the Nicene and the Athanasian Creeds ; the thirty-second, affirming that excommunicate persons are to be avoided; the thirty-fourth, asserting the spiritual value of the Book of Homilies; and the thirty-fifth, endorsing the latest Book of Common Prayer.

Of the second class there are nine: the twelfth, against some Schoolmen, and denying the sufficiency of works before justification; the thirteenth, of the impossibility of works of supererogation ; the twentieth, of the Church, denying the infallibility and supremacy of Rome; the twenty-first, limiting the author-

1 Lambertns Hortensius, Tumultuum Anabaptistarum, 1548, passim. Hardwick, Hist. Arts. Relig. S6-93. 
ity of the Church to the warranty of the Bible; the twentysecond, that General Councils are convocable only by the civil power, have erred and enjoy no extra-Seriptural prerogatives; the twenty-third, that the doctrine of Purgatory is unscriptural; the twenty-fifth, that divine worship should be intelligible to the people; the thirtieth, that Christ's oblation on the cross needs no supplementing by the mass; and the thirty-first, sanctioning the marriage of the clergy.

Of the third class there are twenty : the first, treating of the divine unity and trinity; the second, of the very manhood of Christ; the third, of his descent into Harles; the fourth, of his resurrection; the sixth, of the abiding value of the Old Testament; the ninth, that man has no free will without grace; the tenth, of grace as aiding, yet never forcing, the will; the fifteenth, of sin after baptism ; the sixteenth, of blasphemy against the Holy Spirit; the eighteenth, declaring that sincerity and sect-fealty will not save; the nimeteenth, that men are bound to keep the moral law; the twenty-fourth, that no man should minister unless regularly called; the twenty-seventh, that the personal unfitness of the minister does not destroy a sacrament; the thirty-third, that church tradition should not yield unduly to private judgment; the thirty-seventh, that Christians should not hold their property in common; the thirty-eighth, that a Christian may take a civil oath; the thirty-ninth, that the resurrection is not past; the fortieth, that souls neither die nor sleep with their bodies; the forty-first, that the millenarian second coming of Christ to earth to reign is a fable; and the forty-second, that belief in universal restoration is dangerous.

Of the fourth class there are nine: the fifth, asserting that Holy Scripture contains all things necessary to Salvation, aimed at the Romanists and some Illuninati; the eighth, as to Original Sin, repudiating Anabaptist disbelief and the Romanist theory of its entire eradication by baptism; the eleventh, that justification is "by only faith in Jesus Christ," not by works ; the fourteenth, that Christ alone is sinless, against the doctrine of the Immaculate Conception, and all Perfectionists ; the seventeenth, treating of Predestination and Election, condemning certain crude and extreme views; the twenty-sixth, of the Sac- 
raments ; the twenty-eighth, of Baptism, against both Romanists and Anabaptists ; the twenty-ninth, of the Lord's Supper, making more of it than the Zwinglians and less than the Transubstantiationists; and the thirty-sixth, of civil magistrates, condemning the Papal secular supremacy and the Anabaptist denial of all magistracy and of the lawfulness of war.?

Clearly, most of these Articles are not tenets, calmly and symmetrically crystallized by their own suggestive law, and, disregarding external facts, from the Bible. They are controversial propositions, arraying the affirmations and condemnations of that Word against current phases of belief. Some important doctrines are mentioned only indirectly. Some are not named at all. And large attention is given to topics umimportant in such a summary of faith. The question whether these Articles are Calvinistic or Arminian ${ }^{2}$ relates to them more properly in their revised and condensed form of 1562, under Elizabeth.

A new Act of Uniformity accompanied the second PrayerBook. Scarcely, however, had the nation fairly been brought to face compliance with its demands, when the king, never robust, died, on July 6, 1553. And with him dropped the keystone of the arch of the English Reformation in its secondary form. More than a month later, the wasted remains of this remarkable boy, not yet sixteen, were entombed in Westminster Abbey. ${ }^{3}$

What was the actual condition of the land when Edward closed his youthful eyes upon it? Hasty generalization might have in-

1 Hardwick, 90, 100-106.

2 As it was eight years before Arminius was born when these Articles were adopted, and as Episcopins, who methodized the system, was not born until Elizabeth had been on the throne a quarter of a century, Arminianism, as such, is unlikely to be found therein. And since Cranmer and his chief helpers themselves were moderate Melancthonian Calvinists (Cunningham, 190), it is equally unlikely that anything radically anti-Calvinistic can be detected in them.

${ }^{3}$ Stanley, Mems. West. Abbey, 149, 150. In 1869 researches among the Abbey tombs, in discovering the original leaden inscribed plate, revealed the unrecorded fact that, unique among the rulers of the land, Edward's epitaph declared that on earth, under Christ, he had been Defender of the Faith, and of the Church of England, France and Ireland the Supreme Head. To this, as Dean Stanley says, "as with a pathetic and singular earnestness" was added the exact time of his decease: "he departed this life at eight o'clock in the evening of $6 \mathrm{July}, 1553$, in the seventh year of his reign, and the sixteenth of his age." 
terpreted all this process of legislation, this statement of doctrine and these symbols of faith into the conclusion that England was far advanced towards a prosperous Protestantism. But a cahmer study would have dispelled the illusion. All was not gold that glittered. Nor did all glitter. There has been a widespread tendency to believe that the English people under Edward VI. in its majority had learned to love Protestantism, and that it was due mainly to the fanatical bigotry of his successor that the nation went back so quickly, to the Papacy. But this misrepresents the truth. Undoubtedly Mary was an intense bigot, but other influences than hers made England what it was during her doleful reign.

With the exception of Bonner, Bishop of London, Gardiner of Winchester, Heath of Worcester, Tunstall of Durham, and a few others, most of the eminent clergy had committed themselves to the new views. Yet the real sympathies of most country rectors and curates seem to have inclined the other way. Underneath the thin Protestant seeming was the solid substance of Popery. ${ }^{1}$ Many were too ignorant even to read a homily ${ }^{2}$

1 Hooper described the condition of things in 1549 to Bullinger in this sombre way : -

"The public celebration of the Lord's Supper is very far from the order and institution of our Lord. Although it is administered in both kinds, yet in some places the Supper is celebrated three times a day. Where they used heretofore to celebrate in the morning the mass of the apostles, they now have the communion of the apostles; where they had the mass of the blessed Virgin, they now have the communion which they call the communion of the Virgin; where they had the principal, or high mass, they now have, as they eall it, the high communion. They still retain their vestments and the candles before the altars; in the churches they always chant the hours and other hymns relating to the Lord's Supper, but in our own language, yet most carefully observe the same tone and manner of chanting to which they were heretofore accustomed in the papacy." - Epis. Tig. xxxv.

2 Thomas Lever, in his sermon before the king on the third Sunday in Lent, 1550 , boldly said : -

"Yes, forsoth he [the common parish priest] ministreth Gods sacramentes, he sayeth his seruyce, and he readeth the homilies, as you $f_{y}$ ne flatring courtiers, which speake by imaginacion, tearme it: But the rude lobbes of the countrey, which be to symple to paynte a lye, speake foule and truly as they fynde it and saje : He ministreth Gods sacraments, he slubbers vp his service, and he can not reade the humbles [homilies]. Yet is there some that can reade very well: but how many of those be not either supersticious papystes, orels carnall gospellers, whiche by their euyll example of lyuyng and worse doctrine, do farre more harme then they do good by their fayr reading and saying of servyce." - Arber's reprint, 65 . 
fairly. Many parishes were without pretence of a ministry. In some a sermon hardly had been heard since the Black Preaching Friars had been suppressed fifteen years before. Many church edifices were tumbling under the weather, and young fellows stabled their horses and practised pigeon-shooting in St. Paul's. The breaking up of the monasteries and other ecclesiastical endowments had destroyed, or suspended, most charitable institutions. Hospitals, almshouses, and even schools thus were swept at least temporarily out of sight.

Of the fact that the king was a child advantage had been taken by the Privy Council and the government, and especially by the Lord Protector; and public injustice in the service of private ambition and avarice had been committed and tolerated, until the country was indignant; and until, although they were the king's uncles, both the Duke of Somerset and his brother, Lord High Admiral Seymour, who admitted frauds in the coinage to the amount of $£ 100,000$, had been beheaded with the royal assent. Some of the best of the nobility had retired to their estates and kept aloof from public affairs.

Throughout this reign all the business of the kingdom was in a bad way and growing worse. Public life was shamelessly corrupt, private life alarmingly impure. Among the higher classes luxury and waste were general, and fraud all but universal. Because of the false policy of the regency and of rapacious swindling by some members of the government, the currency had so depreciated that the rates of exchange had almost checked foreign commerce. The Antwerp money-brokers, who had driven a sufficiently hard bargain with Henry VIII., had made terms with Edward so exorbitant that only the impossibility of paying the money prevented a rebellion. Huge bales of goods lay upon the quays of Continental cities, unsold "through the naughtiness of the making." Thousands of laborers were driven to choose between starvation, stealing and beggary. Prices had gone up so that a cow, formerly sold for six shillings and eight pence, could not be bought under forty shillings, and for wheat that could have been had earlier for six shillings and eight pence thirty shillings were demanded. The stench-laden, sickness-smitten, vermin-haunted jails were crowded. The land 
swarmed with vagabonds. Justice was paralyzed. Law availed nothing. ${ }^{1}$

Comparatively little of all this though he could see, or seeing understand, Edward VI. evidently had been distressed by the condition of things. The discourse left in his own handwriting, and truly remarkable for his years, "About the Reformation of Many Abuses," suggests both his keen sense of the evil and his sagacious ideas as to its reform. Bishop Hooper, in a letter to Bullinger at about the middle of this reign, testifies sadly as to the general state of religious matters : ${ }^{2}-$

How dangerously our England is affected by heresies of this kind [Anabaptism, etc.], God only knows ; . . . There are some who deny that man is endued with a soul different from that of a beast, and subject to decay. ... There are such libertines and wretches who are daring enough in their conventicles not only to deny that Christ is the Messiah and Saviour of the world, but also to call that blessed seed a mischievous fellow and deceiver of the world. On the other hand, a great portion of the kingdom so adheres to the popish faction, as altogether to set at nought God and the lawful authority of the magistrates; so that I am greatly afraid of a rebellion and civil discord. . . . The state of our country is indeed most deplorable.

The Pope all along had sought to aggravate the dissatisfaction of the suppressed Romanism of the English realm by secret emissaries and other means, and to persuade men that all existing discomforts and dangers were due to England's desertion of her ancient faith. Moreover, many Englishmen, whose general sympathies at first were with the new theology, had been alienated by an apparently excessive consideration paid to the Continental element of the Reformation. All had been made worse by the endeavor of Edward, acting upon the prompting of the Duke of Northumberland, to change by his will the succession to the throne - a project which ended in speedy imprisonment and eventual death for the Lady Jane Grey and the conspirators who had used her as their reluctant tool.

When Mary came to the throne, July 19, 1553, thirteen days after Edward's death, his body still was unburied; and she

I See Froude's fifth vol., especially pp. 114, 121, 154-155, 257, 259, 265, 324, 327, $403,415$.

2 June 25, 1549. Epis. Tig. xxxiii. 
announced her intention of inaugurating her reign by a requiem and dirge for him with a mass for the repose of his soul. But finally she compromised by having the mass sung in her presence in the Tower coincidently with his burial at Westminster. Soon, however, mass, with matins and vespers, was said in Latin at St. Paul's before the restored high altar and by the side of the crucifix replaced in the rood-loft, while the Real Presence was defended from the pulpit.

The foreign preachers soon felt the change. Peter Martyr was imprisoned six weeks in his house at Oxford. It was only when he himself pushed up to London and pleaded that the late king had invited him into England, and had expressly refused him leave to depart, a year before, that, about September 19, he obtained a safe-conduct ${ }^{1}$ and left at once.

Finding a considerable popular welcome for the new, which was the old, religion, and being reasonably certain that the majority of the nation was on her side, the queen delivered a succession of staggering blows against reform. She forbade the marriage of the clergy, and those who were married had to separate from their wives. More than eight hundred fled to the Continent, among whom were five bishops, five deans, five archdeacons and more than fifty doctors of divinity. Many hundreds of noblemen, merchants, tradesmen, artificers and others, also became refugees. The next Parliament, by 350 votes to 80 , restored the mass and reduced the clergy to celibacy.

Anxious about the succession, the queen soon married that bitter Romanist, Philip of Spain. Bonner, once more Bishop of Iondon, sent through his diocese Articles of Visitation, that neither scrap nor vestige of Protestantism might remain therein. The monks came out of their retreats. And by November 29, 1554, with but two nays in a House of Commons of $360 \mathrm{mem}$ bers, England formally had resumed the yoke of the Pope. In January the Statute of Reconciliation repealed sixteen specific laws, and, from a strictly ecclesiastical point of view, swept away the entire anti-Papal legislation of the two previous reigns.

1 Epis. Tig. clxxxii, cexxxvii. Hardwick (218) speaks of a proclamation issued to these foreign preachers "to avoid the realme" within twenty-four days, on pain of imprisonment and forfeiture, but no such proclamation appears in Cardwell's Documentary Annals. 
Even the old bloody Lollard statutes of Henry IV. and Henry V. were revived. Only as to the succession of the Princess Elizabeth to the throne, and the refusal to restore church property which had been alienated into lay hands, did Parliament remain unyielding. The reason of action in the former case perhaps lay in reluctance to disturb adjustments which Henry VIII. deliberately had made; in the latter in the palpable fact that 40,000 families, ${ }^{1}$ which had benefited by those wholesale confiscations, did not mean to be disturbed.

Had Mary used her good fortune with moderation, ruled discreetly and persecuted no man, she might have consolidated the nation again as an integral, and fairly submissive, part of the dominions of the Pope. But she was unfortunate in her nature and unhappy in her circumstances. The finances fell into confusion again and a forced loan exasperated the citizens. Her confident expectations of bearing an heir to the throne ended in humiliating disappointment. Her husband went back to Spain and proved false. Even those who once had liked her learned to loathe her. Her nature became abnormal and diseased. Ailments latent in her constitution made malignant disclosure. She grew moody, wretched, almost insane. Her conscience was morbid. She fancied that her troubles were distinctly God's frowns. And, seeking the cause of such divine indignation, she could reach no other conclusion than that she had been too tender of Protestantism. So she admonished her bishops to heighten their zeal against heretics. Noailles, the friendly envoy of the King of France, wrote to his master $\mathbf{~}^{2}-$

She is in a continual fury because she can neither enjoy the presence of her husband nor the affection of her subjects; and is actually in momentary dread lest she may be assassinated by her own attendants.

Swollen and haggard with disease, this wretched queen would sit upon the floor for whole days, brooding upon her misery, while public affairs were left to the legate of the Pope and a few bigoted Papists. The persecution of Nonconformists grew more savagely cruel. Not only were some of the noblest men in England, such as Hooper, Cranmer, Latimer and Ridley, burned

\footnotetext{
1 Ranke, i : 214.
}

2 May 7, 1556, Ambassades, v. 
at the stake, but even the dead bodies of Bucer and Fagius were disinterred and solemnly tried for heresy; and, being undefended, their coffins were chained to a stake in the marketplace, Bibles, primers and Prayer-Books were heaped around them, and the books and the poor remains of bodies were reduced to one common ash-heap. The corpse of Catharine Cathie, Peter Martyr's wife, buried in the cathedral at Oxford before Mary came to the throne, also was exhumed and cast into a cesspool ${ }^{1}$ because she had been a nun before her marriage.

What those endured who merely suffered long imprisonment is shown by a letter in which the Bishop of Gloucester describes his experience during eighteen months in the Fleet: ${ }^{2}$ -

$\mathrm{He}$ [the warden] obtained to put me in to the wards, where I continued a long time, having nothing appointed to me for my bed but a little pad of straw, a rotten covering, with a tick and a few feathers therein, the chamber being vile and stinking, until by God's means good people sent me bedding to lie in. On the one side of which prison is the sink and filth of all the house, and on the other side the town ditch; so that the stench of the house hath infected me with sundry diseases. During which time I liave been sick; and the doors, bars, hasps and chains being all closed and made fast upon me, I have mourned, called, and cried for help. But the warden, when he hath known me many times ready to die, and when the poor men of the wards have called to help me, hath commanded the doors to be kept fast, and charged that none of his men should come at me, saying, "Let him alone ; it were a good riddance of him." And among many other times he did thus the 18th of October, 1553, as many can witness. . . And sithence that time I have paid him as the best gentleman doth in his house: yet hath he used me worse and more vilely than the veriest slave that ever came to the hall-commons.

The high-water mark of this frenzied hatred towards all who were not Papists is indicated by a proclamation ${ }^{3}$ five months before Mary's death by which comforting, speaking to, touching or even approaching heretics on their way to execution was made punishable by death! When, having reigned a little more than five years, this miserable woman died, she had been the direct or indirect cause of the death of at least 300 poor sufferers.

1 Froude, vi : $435-436$

${ }^{2}$ Hooper, Later Writings, Parker Soc. 620.

${ }^{3}$ Froude, vi : 480. 
The later years of her reign were made endurable only by the eertainty that its end must come soon. It was better to await the natural aecession of Elizabeth than to submit to the sure ills of a revolution. Yet the future showed little of light. War, famine and plague had devastated the people, and the finances were nearly exhausted.

The Pope's legate, Cardinal Pole, died the night after the queen, and thirteen bishops also died a little before or after her. As to religion, however, notwithstanding all reaction from the abominations of her reign and the smart of renewed subjugation to Papal oppression, probably a large majority of the people, if they had not relished the rule of the Pope or alliance with Spain, still did prefer the old religion to the new. A writer deelares that "the Catholics were in the majority in every county in England, exeept Middlesex and Kent," I while, as late as 1585, Edward Rishton asserts that the majority of the nobility, the country gentlemen and the farmers were unmistakably Catholie; and that not a eounty, exeepting those near London and the Court, and seareely any towns but those on the sea-coast had aecepted Protestantism. ${ }^{2}$

1 Dom. Mss. Eliz. 1.

2 De Orig. ac Prog. Schism. Angl. 1585, 159 verso. Strype (An. iii. (1) 601) cites Creichton, a Scotch Jesuit, to the same effect. 


\section{CHAPTER III}

\section{THE ISSUES AND HOW THEY WERE MET}

Elizabeth, who, just under twenty-five, now came to the throne, was the clild of Anne Boleyn. She had inherited her mother's mild Protestantism. She seems, however, to have conformed quietly during Mary's reign, excepting that she forbade Oglethorpe, Bishop of Carlisle, to elevate the host in her presence. She was crowned with all the mediæval rites. Her first Council of State included reformed and unreformed members; the former superior in influence, the latter in numbers. She personally favored the splendor of the Romish ritual more than the Presbyterian simplicity. She was prejudiced against certain of the Marian exiles because of the books which Knox and Goodman had published at Geneva against the rule of women, and asserting the right, under stress of conscience, of disobedience to magistrates. ${ }^{1}$

These were aimed at Mary, the first queen to rule by herself and in her own right over England, and the question of right fairly was open in her case. But their logic pointed at the younger sister ${ }^{2}$ also, who could be made only a good exception to a bad rule. Not without some grounds, then, these zealous reasoners became conscious of "her graces displeasur." Nor is it strange that Elizabeth's distrust extended itself to the Genevan reformers as a body. Calvin complained to Cecil that she declined to accept a copy of one of his books. Knox she would not permit even to pass through England.

Indeed, all personal tastes aside, the young queen was en-

1 First Blast of the Trvmpet against the Monstrous regiment of women (155s), 1. How Superior Powers ought to be obeyd of their subiects : and wherein they may lawfully by God's Worde be disobeyed and resisted (1558), 166.

2 Knox, S. P. Scot. i : 65. 
vironed with perplexities, ${ }^{1}$ especially in the religious condition of the realm. To move towards the Papacy meant to go counter to her own major convictions and her past with all its best associations, discreetest advisers and most constant friends, to be false to her father's memory, and to aceept the stigma of bastardy. To move in the other direction meant not only to face the hidden dangers of a Papal hate, but also to encourage that majority of her subjects which had clung to the ancient faith, to disaffect that large number of her Court and the gentry, jurists and scholars of the kingdom, who, alienated from Rome, still disfavored Geneva and Zurich; and to summon to her most intimate support men with whom she had almost nothing in common, and whom she was determined never, excepting in small part, to follow. Her first need clearly was to gain time to look about her, to consider men as much as measures, and to estimate carefully as well what could not as what could be done.

When the news of Mary's death reached the Continent, the exiles there began to hasten home; some having large expectations of an uplifting of the banner of Protestantism, possibly of Lutheranism or even of Calvinism, over the new Court. The tidings do not appear to have been confirmed in Strasburg until December 19.2 On December 20-30 Sir Thomas Wroth, Sir Anthony Cooke and others started from Strasburg for London, and Edwin Sandys, Robert Horne and numbers more followed as soon as possible. Meanwhile, those, like Matthew Parker, William Bill, Edmond Guest, William Alley and William May, who had been secluded in England, came forth, until there was at hand a considerable number of men whose learning and piety demanded respect, and many of whom gained distinction from their association alike with the late noble army of martyrs, such

1 A document of the time tersely describes this :-

"The Qneen poor; the realm exhausted; the nobility poor and decayed; good captains and soldiers wanting; the people out of order; justice not executed; all things dear; excesses in meat, diet and apparel; division among ourselves; war with France; the French king bestriding the realm, having one foot in Calais and the other in Scotland; steadfast enemies, but no steadfast friends." - S. P. Dom. Address to Council.

2 Zurich Letters, Eliz. II. 
as Cranmer, Ridley and Latimer, and with the great fathers of the Srviss and German reformation.

But this company was not always agreed, excepting in their general hostility to Rome. Some, like John Foxe, Laurence Humphrey and Thomas Sampson, hardly would admit that any opinion other than theirs could be honestly Protestant. To them even every remnant of the vestments of Rome was "a defiled robe of Antichrist." Others, like James Pilkington and Robert Horne, regarded such matters, as Martyr and Bullinger had advised, as non-essentials, to be tolerated temporarily. Thomas Young, John Scory and others, who had been sheltered in Wesel — and those were said to number one hundred-were content with Edward's Prayer-Book, having used no other. ${ }^{1}$ No doubt, however, all these exiles brought home an ineradicable repugnance towards the attire and the eeremonies which had been used by their persecutors, and yearned for the simplicity of their Continental friends.

On the Sunday after the queen's accession Dr. William Bill, afterwards Dean of Westminster, preached at Paul's Cross a quieting sermon. But he was followed there, a week later, by Christopherson, Bishop of Chichester, a "notorious Papist," who had been active in the burning of the bodies of Bncer and Fagius, and who exhorted the people vehemently against the "new doctrine;" for which the queen imprisoned lim. A rush was made for the many empty pulpits by the few who could preach, which threatened confusion. In London a mob tore down the crosses and threw the priests into the kennels. After four Sundays more, on December 27,1558 , the queen by proclamation ${ }^{2}$ forbade all preaching or teaching "other than to the Gospells and Epistles, commonly called the Gospel and Epistle of the day, and to the Ten Commaundments in the vulgar tongue, without exposition or addition," in order to prevent " unfruteful dispute" and "occasion to break common quiet" — this " until consultation may be had by parlament, by her majesty, and her three estates of this realme."

Parliament met, on January 23-February 2, 1558-59, the

1 Strype, Eccles. Mems. iii (1) : 233. Soames, Eliz. Relig. Hist. 20.

2 Cardwell, Doc. An. i: 20 S. 
queen having been crowned eight days before. Meanwhile, a select body of divines - Barker, Bill and May, who had remained in England during Mary's reign, and who had not become familiar, like those who had lived on the Continent, with the idea of church reconstruction through reversion to the Scriptures alone; Cox and Whitehead, who had been at Frankfort; with Grindal, who had been there and at Strasburg, and Pilkington, who had stayed at Basel - had been holding sessions with Sir Thomas Smith, in Canon Row, Westminster, to revise the second Prayer-Book of Edward VI. for parliamentary action. ${ }^{1}$ In the House of Lords the Romish party had great advantage because, as no new Protestant bishop could be consecrated until Parliament had modified the oaths recognizing the Pope, the Romish prelates had their own way, and the more that there happened to be no lay peer capable of arguing with them. ${ }^{2}$

Convocatiou was sitting beside Parliament, having been opened with High Mass. Yet by April, throngh act of Parliament after a great debate, England once more was severed from Rome. The Crown again was made supreme " in all catses Ecclesiastical as well as civil," although the title, Supreme Head, for the sovereign was waived. ${ }^{3}$ The statutes of Henry IV. and Henry V. against heresy, with Mary's act reviving them, were abolished and the monasteries were again dissolved.

On April 18, the revised Prayer-Book was proposed in the House of Commons for restoration. Those who had adopted the Genevan ideas protested that it exalted "fooleries" to consequence and sacrificed truth to expediency, and the Romanists of course fought against it. But the Act of Uniformity, with a fine of a shilling for every Sunday's absence, passed its three readings in three successive days, and, substantially, the liturgy which Cranmer chiefly had framed came again into force. The principal changes made heightened the ceremonial by prescribing that the ornaments of the churches and ministers shonld be as in the second year of Edward VI. $;{ }^{4}$ modified the commun-

1 Strype, Life Sir Thos. Smith, 56.

2 Zur. Lets. Eliz. IV.

${ }^{3}$ Sandys to Parker: "Mr. Lever wisely put such a seruple in the Qneen's head that she would not take the title of supreme head." - Corresp. of Parker, xlix.

${ }^{4}$ Stats. I Eliz. i. cap. 2 : sect. xxv. 
ion offices so that it might be possible for Romanist, Lutheran, Calvinist and Zwinglian each to insist that the sense was his; and omitted that declaration on kneeling which had been added in 1552 .

Before the year was out this policy of compromise had been pursued by the elevation to the Primacy of Matthew Parker, a mild conservative, whose opposition to Rome was largely because the Papacy had departed from primitive Christianity as expounded by the Fathers. The result, as it seemed to one of the godly ministers of Zurich, was that: ${ }^{1}$ -

Perceiving that popery can neither honestly be defended nor entirely retained [they] adopt those artifices by which they invent a form of religion of a mixed, uncertain, and doubtful character, and obtrude the same upon the churches under the pretext of evangelical reformation, from which the return to papistical superstition and idolmadness is afterwards most easy. . . We have now experienced in Germany for some years, to the great detriment of the churches, the extent of influence possessed by men of this character ; forasmuch as their counsels appear to the carnal judgment to be full of moderation, and especially adapted to the promotion of concord: and it is likely that the common enemy of our salvation will also find suitable instruments among yourselves, by the aid of which he will endeavor to retain the seeds of popery; which must be firmly resisted.

The very mild form of the Reformation in England at this time may be indicated. Upon Elizabeth's accession almost the whole clergy was Romanist, but out of 9400 priests apparently less than 200 resigned, ${ }^{2}$ although, of course, the extreme Romanists now took their turn abroad. ${ }^{3}$ The inevitable inference is that several thousand ministers outwardly accepted the situation, evading the oath of supremacy when possible, absenting themselves, shutting up their churches, and perpetually laboring, at least in secret, against the cause which their vows bound them to uphold.

Like priest, like people. Comparatively few of the laity, however bigoted Romanists, felt obliged, during the first five

1 Gualter to Masters, Zur. Lets. Eliz. V.

2 Marsden, Early Puritans, 100.

3 Dodd, ii : S. Rishton in his continnation of Sander's Anglican Schism (26) says that some 300 of all conditions went abroad at once, largely to Belgium. 
years of Elizabeth's reign, to absent themselves from the churches with their modified service. But for the bishops neutrality was impossible. They began with defiance of the queen, vaguely hoping to be sustained somehow, by Romanist influence from without or by a revolution. ${ }^{1}$ But when confronted with the distinct alternative of taking the oath or losing their sees, only one yielded, Kitchin, of Llandaff - the same who four years before had sent poor Rawlins White, the fisherman of Cardiff, to the stake for heresy. ${ }^{2}$ The bishoprics previously empty, or vacated thus, were filled by Grindal, Pilkington, Horne, Davies, Mexick, Berkeley, Cheney, Barlow, Cox, Alley, Scory, Bentham, Bellingham, Parkhurst, Scambler, Guest, Jewel, Sandys, Best, Downham, and Young; of which twenty-one, thirteen had passed most of Mary's reign in Germany or Switzerland, and eight had contrived to stay in England. Downham had been Elizabeth's chaplain. Cheney, then a rector, had conformed. Bentham and Scambler had managed somehow to preach to Protestants in London. The Pope did not neglect some counteraction. But his nuncio could approach no nearer than Calais.

Soon after Parker's nomination to the Primacy, on July 19, the queen, as spiritual head of the Church, issued a warrant ${ }^{3}$ creating Parker and Grindal, with seventeen associates, a High Commission, six of whom were to be a quorum, to enforce the Act of Uniformity. This was the first warrant for such a court, and the beginning of an instrument of oppression ${ }^{4}$ which always could be used against even the most mild-mannered Dissenter.

Doctrinally, further than as involved in the changes referred to already in the Prayer-Book, it was purposed to wait for a more convenient season. While the Forty-two Articles of Edward were held in abeyance, recourse was had to a brief independent formula of eleven clauses, approved by the archbishops and bishops. It acknowledges for the priest, and requires from

1 Froude, vii : 90-93.

2 Foxe, Acts and Mons. iii : 180.

${ }^{8}$ Queen's Warrant for Court of High Commission in Causes Ecclesiastical, sects. v, ix. Cardwell, Doc. An. i : 255-263.

4 Lingard, the Romanist historian of England, says : "Whoever will compare the powers given to this tribunal with those of the Inquisition which Philip the Second endeavored to establish in the Low Conntries, will find that the chief difference between the two courts consisted in their names." - Ed. 1827 , viii : 60 , n. 
the people, belief in the Trinity, the sufficiency of Scripture and the three Creeds. It declares that the true teaching of the Word authenticates the Church, and that a church so authenticated can institute, change or abolish ceremonies; that only a ministry lawfully called is valid; that the queen is supreme in Church as in State; and that the Pope's power has been lawfully repudiated. It asserts that the Prayer-Book is agreeable to the Scriptures; that exorcism, oil, salt, spittle and holy water have been disused reasonably; that private masses and the notion that they release from Purgatory are most ungodly; that the faithful have right to commumion in both kinds; and that images, relics, feigned miracles, pilgrimages, candles, beads, etc., lie under malediction of Scripture.

When, in 1562-63, the Forty-two Articles of Edward came to revision and readoption in Convocation, four were added, seven subtracted and seventeen modified, leaving thirty-nine. ${ }^{1}$ All these changes appear to have been dictated by the desire to discard such as were becoming obsolete, to insert references to newer spiritual vagaries, and to clear up misrepresentations, steer a middle course between extremists, and maintain in essentials that general policy which the government was pursuing in other respects. $^{2}$ No immediate action of Parliament endorsed and legalized these Articles in their new form, so that for several years they remained merely in moral force.

Late in 1564, at the queen's command, Archbishop Parker with the Bishops of London, Ely, Rochester, Winchester and Lincoln, sent out certain Advertisements, ${ }^{3}$ which contained four classes of articles to promote unity in doctrine and practice. These were remarkable chiefly in that they annulled all existing licenses to preach, forbade unlicensed preaching, required the minister to wear " a comely surples with sleeves," every celebrant of the communion a cope, and all communicants to receive kneeling; and ordained that all "ecclesiasticall persons" wear long

1 The 10th, 16th, 19th, 39th, 40th, 41st and $42 \mathrm{~d}$ articles were omitted. The 5th, 12 th, 29 th and 30 th were added.

2 Hardwick notes the odd fact that no small part of the fresh matter inserted was borrowed from the Confession of Wurtemberg, "a Lutheran Document, itself in turn an echo of the Augsburg Confession," 125-147.

${ }^{8}$ Cardwell, Doc, An. i: 321-331. 
gowns and caps ordinarily and "hattes but in their journeinge ;" winding up with a list of eight pledges of obedience required of all ecclesiastics. This deliverance revealed the queen's purpose to crush Nonconformity by the mere exercise of royal prerogative, and to compel scruplers as to "rags of Rome" to wear them or become mere laymen. She proposed this of her own authority, yet she meant to make the bishops bear the responsibility. ${ }^{1}$

Very earnest were the appeals for advice sent by some tenderconscienced ones to their Continental friends. Not more than two to five years earlier some of these very bishops had had scruples upon some of these very points. Even now they insisted that they conformed simply to keep the high places of the Church from the Romanists. ${ }^{2}$ That such men so soon should turn so sharp a corner was discouraging. The difficulty scarcely was relieved by the advice which came back from Switzerland and Germany, advice not always self-consistent. Martyr at first said, on July 15, 1559 :

Truly, if we hated superstitions from the heart, we should endeavor by all means that their very vestiges should be rooted out.

Later, on November 4, he declared :-

Though I have always been opposed to the use of ornaments of this kind, yet as I perceived the present danger of your being deprived of the office of preaching, and that ... as altars and images have been removed, so this resemblance of the mass may also be taken away, provided you and others who may obtain bishopricks will direct all your endeavours to that object (which would make less progress, should another succeed in your place, who not only might be indifferent about putting away those relics, but would rather defend, cherish and maintain them ;) therefore was I the slower in advising you rather to refuse a bishoprick, than to consent to the use of the garments.

1 Mitchell (47 and 11.) says: "The peremptory mandate requiring them to give this subscription issued from the sovereign herself ; but it was carried out, if with reluctance yet with submission, by several of the prelates, and especially by Parker, Archbishop of Canterbury. I have no doubt... that the queen wished and urged him to proceed, just as she encouraged Aylmer's action against Cartwright, but that (as in that case) she wished him to take the onus on himself."

2 Horne to Gualter: "We complied with this injunction, lest our enemies should take possession of the places deserted by ourselves." - Zur. Lets. LXIV. 
And on February 1-11, 1560, he wrote: ${ }^{1}$ -

You may therefore use these habits either in preaching, or in the administration of the Lord's Supper, provided however you persist in speaking and teaching against the use of them.

Bullinger wrote to a conformist : -

I approve of the zeal of those persons who would have the church purged from all the dregs of popery ... On the other hand, I also commend your prudence, who do not think that churches are to be forsaken because of the vestments [of the clergy].

The new departure was followed up resolutely. On March 26, the London clergy were summoned to Lambeth, and in presence of Archbishop Parker, Grindal, Bishop of London, and others of the Ecclesiastical Commission, the bishop's chancellor pointed to Robert Cole, of St. Mary-le-Bow, who was habited in a square cap, a scholar's gown, and tippet, and said : ${ }^{2}$ -

The Council's pleasure is, that strictly ye keep the unity of apparel like to this man, ... as you see him ... and in the church a linen surplice : and inviolably observe the rubric of the Book of Common Prayer, and the Queen's Majesty's Injunctions: and the Book of Convocation [i. e. the Thirty-nine Articles].

Ye that will presently subscribe, write volo; ye that will not subscribe write nolo.

Be brief: make no words!

The roll of ehurches then was called, and of the ninety-eight clergy present sixty-one submitted. Thirty-seven refused, among whom "were the best." 3 Those refusing were suspended and notified that, unless they yielded within three months, they would be deprived. A few conformed, some entered secular callings and some landed in prison. When Parliament met, the Commons, December 5, 1566, sent up to the Lords a bill making subscription to the Thirty-nine Articles the condition of holding a benefice in the Church. De Feria, the Spanish ambassador and really the representative of the Pope, besonght the queen

1 Zur. Lets. XLIII, XII, XIV, XVII, I: App. II.

2 Strype, Grindal, 144.

${ }^{3}$ So Parker said. Yet he added: "As for the most part of these recusants, I would wish them out of the ministry, as mere ignorant and vain heads." - Corresp. ccrii, ccix. 
to defeat the measure; and she consented, nor was it until 1571 that these Articles really became law. ${ }^{1}$

No wonder that this royal action, added to the galling yoke of the Advertisements, hastened a crisis. Hope deferred died altogether out of many breasts. Elizabeth had been queen more than eight years and had had time to show what she really was. $^{2}$ At the beginning of her reign those whose views had sent them into voluntary exile during Mary's time had believed her piety genuine. According to Holinshed ${ }^{3}$ she certainly offered a good prayer before she started for her coronation. Sandys, on the eve of leaving Strasburg for London, wrote to Bullinger:-

The queen has changed almost all her counsellors, and has taken good Christians into her service in the room of papists; and there is great hope of her promoting the gospel, and advancing the kingdom of Christ to the utmost of her power.

On her coronation day Gualter, in a letter from Zurich, expressed the strongest confidence in her piety and her purpose to purify the Church. He also wrote to Lord Russell that her "piety had been already proclaimed through the whole world;" and to Richard Masters, her physician, eulogizing her as a " most godly Queen." In February following, Sir Anthony Cooke wrote to Martyr, "the zeal of the queen is very great."

By March 20-30, however, John Jewel, soon to be Bishop of Salisbury, wrote to Martyr: -

Though she openly favors our cause, yet is wonderfully afraid of allowing any innovations : this is owing partly to her own friends, by whose advice everything is carried on, and partly to the influence of Count Feria, a Spaniard, and Philip's ambassador.

Less than a month later he complained to the same friend:-

If the queen herself would but banish it [the mass] from her private chapel, the whole thing might easily be got rid of. . . . She has, however, so regulated this mass of hers (which she has hitherto retained only from the circumstances of the times) that although many things

1 Froude, viii : $336-341 ; \mathrm{x}: 194$.

2 Dodd (ii : 30 ) gives fairly the Romanist idea of her. They thought her Catholic leanings were "in a strain altogether human and unevangelical."

3 Chrons. 1180. 
are done therein, which are scarcely to be endured, it may yet be heard without any great danger.

By the middle of November he wrote again to the same: ${ }^{1}$ -

That little silver cross, of ill-omened origin, still maintains its place in the queen's chapel. Wretched me! this thing will soon be drawn into a precedent. There was at one time some hope of its being removed ; . . . But as far as I can perceive, it is now a hopeless case.

These hints suggest the truth. In the beginning Elizabeth had very little, if any, deep sympathy with godliness, while every day evolved some opposing influence. Great cares of State pressed heavily. For a long period it seemed to be her civil strength to sit still in all matters of religion. Not without some reason did she apparently suppose that a conformity, which at first might have to be compulsory, gradually would become a matter of course, and finally would be accepted as natural and proper. She also undertook negotiations with Spain and France, which she was unwilling to imperil for religion. Moreover, her statesmen and her Parliament constantly begged her to marry, and her suitors, - Philip of Spain, the Duke of Holstein, the Archduke of Austria, the King of Sweden, a Saxon prince, the Earl of Leicester, the Earl of Arundel, the Duke of Anjou, Sir William Pickering and the Earl of Arran - would be on and off almost at the same time, all of which diverted her attention. Furthermore, her nature seems to have repelled her from sympathy with spiritual religion. Waiving all questions as to her relations with her favorites, she plainly was self-willed, haughty and sometimes insolent, often profane, liable to ungovernable rage, parsimonious, and not seldom cruel, unjust and hypocritical; while her conceit, vanity and love of show were sometimes preposterous. These are not "the fruits of the Spirit," and no character which steadily grows in the direction which they indicate can have much sympathy with the temper or aims of such men as Sampson, Humphrey and the others, who were striving to bring England back to "the simplicitie that is in Christ."

Add to all this her urgent preference for the showiness of the old way, which restored crucifix, candles, etc., to her chapel, ${ }^{2}$

1 Zur. Lets. I, ii ; II, iii, iv, $\nabla$, vi ; I, i, , vi, xxiv.

2 Ibid. I, liii, lvij. 
and it is not strange that the reformers should have concluded that, if she were not in heart a Romanist, she was at least so hostile to Protestantism that she could be expected to do nothing in its aid, but rather to oppose it. As if on purpose to annoy the Protestants, she had revived the fooleries of the carnival. And surely, occurrences ${ }^{1}$ like one almost contemporaneous with the issue of the Advertisements, must have confirmed their belief. On Ash Wednesday, she took De Silva, then Spanish ambassador, to St. Paul's to hear Dean Nowell. The Dean's subject soon led to some reference to images, which " he handled roughly." "Leave that alone!" commanded Elizabeth from her seat of state. But the Dean, not understanding her, went on. Whereupon she screamed, "To your text! Mr. Deane; to your text; leave that; we have heard enough of that; to your subject!" The amazed and insulted speaker reddened, stammered and sat down, while the queen sailed away with her Papal friend.

Of course some then, like many since, belittled the conscientiousness of those who were aggrieved by these tendencies, and minimized their scruples as if worthless. The Primate contemptuously called them "silly recusants." 2 Bishop Jewel wrote: "That matter [of the surplice and ceremonies] still somewhat disturbs weak minds." Bishop Sandys remarked to Bullinger : "There is some little dispute about using or not using the popish habits;" and Bishop Grindal wrote $:^{3}$ "It is scarcely credible how much this controversy about things of no importance has disturbed our churches, and still, in great measure, continues to do. Many of the more learned clergy' seemed to be on the point of forsaking their ministry."

Later English church writers also have failed to do justice to these men. Fuller ${ }^{4}$ stigmatizes them as "fierce (not to say furious) sticklers against church-discipline." Collier ${ }^{5}$ calls their opinions "ill-supported scruples" and " misapplication of zeal" and the "indiscretions of zealots." Heylyn ${ }^{6}$ uses such terms as " peevish frowardness," " unlawful and disorderly conventicles" and "zealous and conceited of their own dear Sanctity." Hook ${ }^{7}$

1 De Silva to Phil. Simancas MSS. March 12 ; cited by Froude, viii : 139.

2 Parker, Corresp. ccix.

${ }^{4}$ Ch. IIist. Britain, iv: 330.

${ }^{6}$ Hist. Presbs. 259, 264.

${ }^{3}$ Zur. Lets. I, Ixvii, lxvi, Ixxiii.

5 Eccles. Hist. Great Britain, vi : 394-395.

7 Lives Abps. Cant. vi : 152. 
styles them "men of theory." Lathbury ${ }^{1}$ insists that the differences were simply " factious disputes concerning trifles." Perry ${ }^{2}$ accuses them of a "bitter and litigious spirit," and of " convulsing, worrying and distracting the young Church ... on the miserable questions of Church vestments, or the insignificant matter of the use of the cross in Baptism." So generally fairminded a man as Soames ${ }^{3}$ eriticises the original grounds of separation as "trivial and illiberal." Marsden ${ }^{4}$ also characterizes the Separatists as showing " a spirit violent and discontented, a "zeal for discord." Curteis ${ }^{5}$ argues that " a narrow and unstatesmanlike bigotry" led them " to erect some mere trifling matters of ecclesiastical ceremony and arrangement - which no human being desired to elevate into anything more than symbols of good order, and proofs of canonical obedience - into matters of morbid scruple and obstinate antipathy." And Hardwick ${ }^{6}$ laments that

sereral of the most able scholars and most energetic preachers, - men whose hearts were overflowing with affection for their parishes, whose name is still revered among the worthies of their generation, and whose writings still inform and edify the Church - were victims of these petty scruples, and must therefore be in part responsible not only for the agitations of that age, but also for the mightier tempests which eventually broke upon their country, levelling alike the altar and the throne.

No judgment can be scrupulously fair which does not give to each side the benefit of its own contemporaneous statements. This testimony from the bishops we have in the letter of Grindal and Horne to Bullinger and Gualter, ${ }^{7}$ February 6-16, 1567:

The sum of our controversy is this. We hold that the ministers of the Church of England may adopt without impiety the distinction of habits now prescribed by public authority, both in the administration of divine worship, and for common use ; especially when it is proposed to them as a matter of indifference, and when the use of the

1 Hist. Prayer-Book, 42.

3 Eliz. Relig. Hist. $2 \mathrm{~S}$.

2 Hist. Ch. of Eng. from death of Eliz. 16.

4 Hist. Early Puritans, 52.

5 Dissent in Relation to Ch. of Eng. 54. He cites Parker to Burghley (Parker Corresp. ccclxix) : -

"Does your lortship think that I care either for cap, tippet, surplice or waferbread, or any such? But for the laws so established I esteem them.'

${ }^{6}$ Hist. Christ. Ch. during the Ref. 232. i Zur. Lets. I, Ixxv. 
habits is enjoined only for the sake of order and due obedience to the laws. And all feeling of superstitious worship, and of the necessity [of these habits] as far as making it a matter of conscience, may be removed, rejected and utterly condemned, both by the terms of the laws themselves, and the diligent preaching of purer doctrine. They [the objecting minister's] contend on the other hand, that these habits are not on any account now to be reckoned among things indifferent, but that they are impions, papistical and idolatrous; and therefore that all pious persons ought rather with one consent to retire from the ministry, than to serve the church with these rags of popery, as they call them ; even though we have the most entire liberty of preaching the most pure doctrine, and likewise of exposing, laying open, and condemning, by means of sound instruction, errors and abuses of every kind, whether as to ceremonies, or doctrine, or the sacraments, or moral duties. . . . If we were to acquiesce in the inconsiderate advice of our brethren, and all unite our strength illegally to attack the habits by law established, to destroy and abolish them altogether, or else all lay down our offices at once; verily we should have a papistical, or at least, a Lutherano-papistical ministry or none at all. But honored brethren in Christ. we call Almighty God to witness, that this discussion has not been occasioned by any fault of ours, nor is it owing to us that vestments of this kind have not been altogether done away with: so far from it that we most solemnly make oath that we have hitherto labored with all earnestness, fidelity, and diligence, to effect what our brethren require, and what we ourselves wish. ${ }^{1}$

A little later we find Parker and Sandys making a serious charge against their opponents : ${ }^{2}$ -

The church is sore assaulted; but not so much of open enemies, who can less hurt, as of pretensed favourers and false brethren, who under the colour of reformation seek the ruin and subversion both of learning and religion. Neither do they only cut down the ecclesiastical state, but also give a great push at the civil policy. Their colour is sincerity, under the countenance of simplicity, but in very truth they are ambitious spirits and can abide no superiority.

On the other side we have several contemporary statements, drawn up by the dissentients for their friends on the Continent, extracts from which present the difficulty as they saw it. Coverdale, Humphrey and Sampson, in July, 1566, wrote to Farell, Viret, Beza and others thus :-

1 Strype $(A n . I(1)$ : 264) bears testimony to this.

2 To a Brother Eccles. Commissioner. Parker, Corresp. cccxxxi. 
It is now settled and determined, that an unleavened cake must be used in place of common bread; - that the communion must be received by the people on their bended knees; - that out of doors must be worn the square cap, bands, a long gown and tippet; while the white surplice and cope are to be retained in divine service. And those who refuse to comply with these requirements, are deprived of their estates, dignities, and every ecclesiastical office. . . . We think that it must be assumed in this question, that the Jewish, Turkish, Christian, and Popish religions have each their own peculiar sacraments and signs; and that external profession ought to be the test and badge of any one's doctrine; and that we are to seek our pattern not out of the cisterns and puddles of our enemies, but from the fountain of the scriptures, and of the churches of God; so as not to be connected by any similarity of rites with those from whose religion we are altogether abhorrent. . . . Nor indeed can we regard these things as altogether indifferent, when compnlsion is made use of, and when too they are branded with the mark of superstition; . . . Nor is there any oceasion in the church of Christ ... that sacred garments should be worn now-a-days in the christian temple, or that a dress not common, but distinct and peculiar, shonld be prescribed for ordinary use. But we think with Celestine, that the clergy should be distinguished from the people by their doctrine, not their garments; their conversation, not their dress; their purity of mind, not their adornment of person; ... We considered it more for the good of the church to stand fast in our liberty with an accession of godly men on our side, than to depart from the opinion we have taken up and the custom we have received, to the scandal of many and the downfall of purer doctrine. . . . The question, we confess, is nice, and difficult, whether it is better to yield to circumstances, or to depart ; to admit the relics of the Amorites, or to desert our post. Either alternative is harsh, grievous, and productive of mischief both to ourselves and the ehurch.

About the same time Humphrey and Sampson wrote to Bullinger : ${ }^{1}$

We make no vexations opposition; we always avoid any bitterness of contention; we are ready to enter into an amicable conference; we do not voluntarily leave [our churches] to the wolves; but constrained and driven from our places, we depart with unwillingness and regret. We leave our brethren and the bishops to stand or fall to their own master; and we look most submissively, but in vain, for the like forbearance towards ourselves. . . Far be it from us either to sow 
schisms in the church by a vexatious contest, or by a hostile opposition to our brethren to do an injury to ourselves :... to charge with impiety things which are in their nature indifferent: far be it from us either to make our own feelings the pretense of abuse, or under the name of conscience to conceal a fondness for dispute. These dregs, and this leaven of popery are, believe us, the source of the whole controversy : we desire it to be taken away and buried in eternal oblivion, that no traces of antichristian superstition may remain. . . . That your reverence may understand that the controversy is of no light or trifling character, but of great importance, and that we are not merely disputing about a cap or a surplice, we send you some straws and chips of the popish religion.

They mention, among other things required which are against their conscience: the use of the sign of the cross in baptism; the requirement of surplice and cope and kneeling and using unleavened bread at the Lord's Supper; popish habits - rochet, square cap, tippet and long gown - obligatory upon the ministry; the absence of church discipline; the denial of the sanction of law to the marriage of the clergy; the retention of the popish manner of betrothal; the open sale of dispensations by the bishops $;^{1}$ and the prohibition of ministers from preaching, or even expounding, the Scriptures without a bishop's fresh certificate and an absolute promise to conform.

When the uncertainty in the Protestant mind of the kingdom as to Elizabeth's spiritual affinities and the influences under which she placed herself are remembered, it is not surprising that a statement of difficulties, thirteen months later, to Bullinger and Gualter by George Withers and John Barthelot, culminated thus : ${ }^{2}$

Moreover, there is power given by act of parliament to the queen, ${ }^{8}$ and the archbishop, to introduce whatever ceremonies they please into every church in the kingdom.

1 Strspe (Grindal, 542) mentions the prices of various privileges. A license to marry without banns cost $10 \mathrm{~s}$. One to eat flesh on forbidden days, 40s.; with 3s. 4 d. to the clerk, 6 s. Sd. to the archbishop, 3s. $4 \mathrm{~d}$. to the commissary, and as much to the registrar. A commendam - the right to do the duty and have the revenue of a parish pending the appointment of a rector - cost $£ 16$, with $£ 8$ to the queen, 35 s. 6 d. to the lord chancellor, $13 \mathrm{~s} .9$ d. to the clerk, $£ 3$. 11s. 1 d. to the archbishop, $17 \mathrm{~s} .9 \mathrm{~d}$. to the commissars, and the same to the registrar.

2 Zur. Lets. II, lviii.

${ }^{3}$ Parker, Corresp. CCLXXX: iii. See also xciv. 
Certainly the questions at issue involved more, and more vital, matters than mere vestments or trifles of any sort.

Particulars have been dwelt upon thus because their consideration seems needful to a fair understanding of the course which many of the most conscientious members of the Church of England felt bound to take. Whether right or wrong in their judgment - and there is room for honest difference of opinion about it - those men most sincerely believed the very substance of religion to be so involved that the only way in which they could work the works of Him who sent them, or deliver their souls, was to oppose unflinchingly the religious influences then dominant in the nation, and to endeavor, by the sheer force of intellectual and moral conviction and by personal example, to purify and evangelize them.

In time their Continental friends also appreciated the gravity of the situation. As early as 1555, Calvin had written to Knox and Whittingham : ${ }^{1}$ -

In the liturgie of Fnglande [in Edward's time] I see that there were manye tollerable foolishe thinges . . . there was not that puritie whiche was to be desired. Theis vices, though they coulde not at the firste daie be amended, yet seinge there was no manifeste impetie [impiety] they were for a season to be tollerated... If godlie Religion had flourished till this daie in Englande, there ought to have bin a thinge better corrected, and manie thinges cleane taken awaie. . . . I cannot tell what they meane whiche so greatly delite in the leavinges off Popishe dregges.

And Beza, who had shared the impression disseminated, that the controversy was wholly ill-advised, and about trivial matters, changed his mind and wrote to Bullinger: ${ }^{2}-$

I thought the difficulty was only about the matter of the habits; that some blemishes were left behind, which the Bishops were perhaps too tardy in removing, or, as is everywhere wont to be the case in practice, they were unable to obtain what they most desire. But if the case is as $I$ hear it to be (and indeed these things can scarcely be invented,) where did such a Babylon ever exist?

It was inevitable, that, as those who felt alike and acted together in regard to these things began to attract public atten-

1 Epis. Anglis Francford (ed. 1667), 98.

${ }^{2}$ Zur. Lets. II, lx. 
tion, they should receive some popular desigmation. About 1565 Parker styled them "these precise men," and by the end of 1570 he referred to them as "the precisians," which name soon passed into that - a natural synonym - of "Puritans." When, in 1571, Field and Wilcox published their "Admonition to the Parliament," they complained in its preface ${ }^{1}$ that the bishops and their friends --

slaunderously charge poore men (whom they have male poore) with grievous faults, calling them Puritans, worse tha the Donatists.

To which Whitgift replied :-

This name Puritane is very aptely given to these men, not bicause they be pure no more than were the Heretikes called Cathari, ${ }^{2}$ but bicause they think them selues to be mundiores caeteris, more pure than other's, as Cathari clid, and seperate them selues from all other Churches and congregations as spotted and defyled. Bicause also they suppose the Church which they haue deuised to be without all impuritie.

These Puritans found their dearest convictions ridiculed, as well as what seemed to them their righteous requests disallowed. A net of enactments, of which some lacked all qualities of just human law, as all lacked the higher qualities of divine law, was closing about them, designed to drive them into absolute conformity. It was only natural, therefore, that they should contend earnestly for their liberty of faith and of spiritual life. Reference has been made to the proclamation forbidding preaching (1558), the Injunctions (1559), the Act of Uniformity accompanying the Prayer-Book (1559), the Court of High Commission (1559), the Advertisements (1563), and the Eleven (1559) and the Thirty-nine Articles (1563-71). These were but the beginnings of sorrows. As the sturdy English nature resisted such tyrannies, the queen grew more sternly determined to enforce them, and measure after measure was adopted in the vain endeavor.

Thus, on September 22, 1560, a proclamation was made for the banishment within twenty days of such "Auabaptists and such lyke, from sundrye partes beyonde the seas" as refused

1 Reprinted by Whitgift in his Answere to a Certein Libel intituled "An Admonition to the Parliament" (1572), 10, 18.

2 A sect, originally of Eastern Europe and distinguished for asceticism. 
to be reconciled. In 1563 an Admonition forbade expounding without license, or the least alteration of the prescribed divine service. In 1564 an Advertisement required the solemn pledge of every person admitted to any ecclesiastical office to absolute uniformity. And when remonstrance and argument began to get to press on the Continent and to work cautiously into circulation in England, a royal letter, of January 24-February 3, 1564-65, denounced them as "seditious and slanderous books," and commanded search for them in the custom-houses, and all persons even suspected of complicity with their circulation to be punished. Articles of Enquiry were also set iorth by Parker in 1567, one clause of which was meant to detect any minister favoring Nonconformity. And, on May 24, 1568, an Order of Enquiry was issued against strangers from beyond sea, "Anabaptistes, and such other sectaris," and ordering their prompt trial.

Just here it is suggestive to note a royal proclamation on April 26, 1569, directing the maintenance of order while certain licensed games were played on Sundays, to wit :-

the shotinge with the standerd, the shotinge with the brode arrowe, the shotinge at the twelve skore prick, the shotinge at the Turke, the leppinge for men, the runninge for men, the wrastlinge, the throwinge of the sledge, and the pytchinge of the barre, with all suche other games as have at any time heretofore, or now be lycensed, used or played.

On November 6, 1569, the Council desired of the Archbishop of Canterbury the names of all "recusants" openly "forbearing to resort to their parish churches." Soon after, and apparently in response to this monition, a visitation was ordered of all territory under his jurisdiction. This demanded particularly whether any "privily use or frequent any kinde of divine service, or common prayer, other than is set forth by the lawes of this realme," and the mention of any "that keepe any secret conventicles, preachings, lectures, or readings contrary to the lawes," or any "suspected of heresy, or that maintain any erronious opinions." Parliament, which had not met for five years, was summoned on April 2, 1571, and legalized the Thirty-nine Articles, and again, in May, 1572, when strenuous measures, provoked by the Pope's excommunication of the queen, were enacted against the Papists. 
On Angust 13, 1571, the queen again addressed the Primate, "straitly" charging the reform of Nonconformity. In the same year the Archbishop of York sent out injunctions, among many other things requiring "all above fourteen years of age to receive in their own churches the communion three times at the least in the year." On October 20, 1573, the queen, regretting that Nonconformity grew worse rather than better, sternly ordered prelates, justices of assizes, and "Oyer and Terminer," and mayors, and others holding authority, to execute the Act of Uniformity. This was reënforced, on November 7, by a letter from the Privy Council to the Primate, intimating that existing disorders were due largely to his dissembling, and warning him, should not matters speedily be rectified.

On July 15, 1575, almost two months after the death of Parker had vacated the Primacy, the determined sovereign commissioned ${ }^{1}$ Sir Nicholas Bacon, Lord Keeper of the Great Seal, to legalize the burning in Smithfield of John Peeters and Henry Turwert, ${ }^{2}$ two obstinate Flemish Anabaptists. The warrant seems to have been executed on July 22.3 A nearly contemporaneous publication ${ }^{4}$ in Dutch and in rude verse purports to outline their case as it appeared to them, and seems to be confirmed by the account of them in the great classic Dutch record ${ }^{5}$ of such sufferers. A few passages are quoted in the hope that the most literal rendering will brighten rather than obscure the simple story:-

\footnotetext{
Listen, from Holland bloody

Some went forth

In order to follow God's Word.

Being persecuted, and so it being hard to live,
}

1 Cardwell, i : 292, 319, 330, 332, 340, 342, 346, 351, 354, 359, 360, 368, 371-385, $357,392-393$.

2 Otherwise known as Henry Snel.

${ }^{3}$ Stow and Holinshed, s. d.

4 Een Nieu Liedeken gemarckt van twee Frienden opgheoffert tot Lonnen in Enghelant, An. 15\%5. Op die wüss "Babel is nu ghevallen" (1579, 24mo), pp. 332. (A new song composed by two friends sacrificed in London, Eng., in the year 15\%5. To the tune "Babel now is fallen.")

5 Het Bloedig Tooneel. of Martelaers Spiegel der Doops-Gesinde of Weereloose Christenen (1685), 697-699. (The Bloody Stage, or Martyr's Example of the Baptist Sect or Harmless Christians.) 
'They shipped themselves, for

They thought without difficulties

They conld stay in England.

When they were established

In London within the town

They would not omit

To hear God's simple word.

The Congregation pure came together,

It was on an Easter day. ${ }^{1}$

We were without suspicion of danger

There were we watched

As you will hereafter understand.

In the blessed prayer

We were occupied,

The constable fiery

He then burst in

He spake very boldly, in words very hard,

"Who is the preacher?"

He called us - listen well

He called us "devils :"

Very cruelly he spake to us in hard words,

- To us in harsh words -

He wrote down our names

And remained hard in heart.

We spake well - kindly - to him

But he in no way minished his wrath.

He has driven us before him

As sheep to the slanghtering-place

Taken us together into prison

Five-and-twenty altogether.

It then describes how they were labored with, how some weakened and "fell through the great pressure," and how others were bound "very tightly to a cart," and with a whip were driven to a ship to be carried away.

They spoke without anger

As they were cruelly beaten

"This is for Christ's sake."

Two of them were condemned to the flames.

Next Sunday was taken to them

The news that within three days

They would be burned.

Then they said: "Do you wish it put off?"

Hènry answered courageously :

"If it must be as you say

Let it be as quick as possible:

1 April 3 in 1575. 
Rather death than life."

Henry said openly :

"We shall be free, at least, then

of the horrible vermin."

Friday now soon came on

Then they went - it must be told -

To Smithfield to die.

John said : "I am not ashamed

Of this way - understand

Many prophets of veneration

Have gone such a way."

An English preacher

Spake to them mockingly

Publicly before the people :

"They do not believe in God:"

John then replied before woman and man:

"We believe with all our hearts

In God the Heavenly Father

And in Christ His Son."

When they were bound to the stake

"Recant and be pardoned," was said.

John spake firmly: "You bave tried

To bring us to your side

And now since yon could not,

You set about to kill us."

But he spake to stakes and pillars.

Even if we were - mark it well

Ourselves the tares

We should grow up till harvest-time :

Such is the decision of Christ.

Articles of Enquiry and Visitation were issued again under Grindal, the new Archbishop of Canterbury, in 1576, aimed to suppress conventicles and secret worship of every sort. Another order in the same year from him forbade laymen and deprived ministers to speak publicly on religion; and in the next year a royal charge threatened to make examples of such bishops as should fail to imprison all who attended " mnlawful assemblies ;" and specially directed Whitgift, then Bishop of Worcester, "that all such prophecies be forborne." On January 17-27, 1579, the Privy Comneil required the Primate to compel all preachers to administer the sacraments according to law, and to send "intractables" before it. On June 18, 1580, it complained $^{1}$ to the archbishop once more of so many absentees

1 Cardwell, Doc. An. i : 397-421, 424, 434, 440, 448. 
from church, and required him to correct them at once according to the direction of the High Commission. On January 16-26, 1580-81, the Parliament of 1572 once more passed acts $^{1}$ - having in mind Papists, it is true, more than Protestants - fining an absentee from the parish church $£ 20$ a month, and classing among felonies the publication of anything printed or written to the defamation of the queen; it being made clear that all criticism of her religious intolerance would be construed as such defamation.

On May 28, 1581, the Council, moved especially by the recent Jesuit invasion, insisted again that the Primate execute the law without remissness. Energetic, if not savage, Whitgift succeeded the comparatively mild Grindal as Archbishop of Canterbury on September 23, 1583, and on October 19 he issued an order to every priest in his jurisdiction to warn all Noneonformists at once; and, if they persisted, to follow them up even to excommunication, and, if necessary, arrest.

It is recorded ${ }^{2}$ that "the state of the Church," notwithstanding all this perpetual shoring up by enactments and penalties, was "now but in a tottering condition, both from the Papists on the one hand, and the disaffected Protestants on the other." Nevertheless, apparently without doubting its efficacy, the queen persisted in the old course, having now a primate after her own heart. And the new archbishop within a month sent out those remarkable, and indeed epochal, Articles, ${ }^{3}$ which not only once more drew the sword against the Puritans, but even threw away the scabbard. All private catechising, family teaching and religious service shared by non-members of the household were prohibited. No man could preach who did not "four times a year, at the least, say service, and minister the sacraments, according to the book of common prayer;" who did not wear the preseribed apparel; who was not by English law in orders a provision aimed at Whittingham, Travers, and perhaps Cartwright and others, who had received Presbyterian ordination on the Continent; who would not affirm the queen's supremacy over the Church, and the agreeableness in every part to the

1 Stats. 23 Eliz. cap. 1.

2 Strype, Whitgift, i: 228.

${ }^{3}$ Cardwell, Doc. An. i: 457, 461, 466. 
Word of God of the entire Prayer-Book and the Thirty-nine Articles; or who had not a bishop's license.

This terrific stringency was followed, in 1585 , and again in 1588, by Articles aimed to detect and punish all non-conforming or conventicle-using ministers and others. On February 13 $23,1588-89$, the queeu again fulminated a proclamation against schismatical books and writings. And in September, 1591, the archbishop ${ }^{1}$ admonished the bishops to look after and correct neglects in the confirmation of children who " can say the catechisme." On February 19-29, 1593, a new parliament was summoned. This condemned persistent Nonconformists even to banishment and death. The Romanist leanings of the queen found expression in this Act in the astonishing proviso, "that no Popish Recusant shall be compelled or bound to abjure, by virtue of this Act." The following year, on August 26, we find the Privy Council complaining to the Primate of the non-efficiency of the late statute in the cases of "sundry men's wives dwellinge within the dioces of Cant[erbury]., that refuse to come to the church; and that sundrie persons do entertayne, keepe, and releive servants, and others that be recusants." They "earnestlie require" his lordship to look to this and enclose a schedule of " notes and directions." And, once more, on December 27, 1596, we have Whitgift addressing the Bishop of London as to popular neglects. A great "dearth and scarcitye" prevailed. A closer observance of fasts must be had, and public prayers, according to the Book of Common Prayer, be "on all Wednesdaies and Frydaies hereafter devoutly used." A monthly return of "the names of disobedient delinquents " also must be made.

1 Articles to be Enquired upon in the visitation of the Diocese of Chichester, ii : 22, and Articles to be Enquired of within the Diocese of Sarum, ii : 33, 39, 12. 


\section{CHAPTER IV}

\section{THE LITERATURE OF THE CONFLICT}

ThrovgH more than thirty-six years we have followed the resolute policy and endeavor of the State to repress that liberty of thought and conseience which these Puritans claimed as a right, and as the condition of all true spiritual life. That policy and endeavor had crept steadily on from comparatively petty questions as to caps and surplices, until they had covered the entire feld of religions conviction and conduct. And all this took place - or seemed to do so - in the interest of Rome within a professedly Protestant church.

Of course, to men who valued eternity more than time, and truth more than peace, but one path offered itself - a path along which the noble army of martyrs always has walked. As Englishmen, at once loyal and devout, they conld not but endeavor, first to maintain a clear conscience, and then to adjust it to existing civil conditions by conformity, wherever possible, and by submission to all suffering involved in nonconformity. And they never failed to appeal to the reason and conscience of queen, privy comncil, parliament, and nation in the effort to persuade them to a better mind.

Their sole avenne of approach to the public was by means of such broadsides, pamphlets and volumes as they could produce. The public printing-offices were closed to them, so that all such work had to be done by dangerous stealth in England or done abroad. Foreign workmen - at Amsterdam, Leyden, Dort, Frankfort, Zurich, Geneva, or elsewhere - sure to blunder in a language imperfectly, if at all, understood, and whose "proofs" seldom conld have the author's supervision ; or migratory typesetters, working in enforced obscurity at home, necessarily were their resort. And so Argus-eyed were the officials that the 
results of their painful toil never were out of danger while being smuggled across the German Ocean or passed from hand to hand in England. Yet so assiduously did these men, often in close imprisonment, ${ }^{1}$ use these imperfect means of reaching the public, that more than 100 of their works, including a few solid quartos, can be named, most of which survive to our time in a few sporadic copies. Some of these laborious issues, which appear to have had most to do with the Genesis and Exodus of English Nonconformity and American Congregationalism, ${ }^{2}$ it will be well to consider.

Probably as early as 1553 , and before the close of the first year of Mary's reign, we hear a warning note, evidently from some refugee in Geneva or Strasburg, appealing to Englishmen not to surrender any of the favorable results accomplished under young Edward. The writer says: ${ }^{3}$ -

Is it not an abhomination of desolation standinge in the chief cytie of Englande, to se a franked fat Boore sittinge at euery sermon preached at Pauls Crosse, and the same not to be found ones in the yere in the same pulpit, feadinge the flocke comitted to his spirituall charge? Is it not abhomination of Desolation standinge in the holy place, to se the holy Scriptures in our native English tonge written vpon enerie wall in the Churches, now to be by comaundmente blotted out, and in the stede thereof erected kerved ymages of wood and of stone, by Gods owne sentence accursed, and al they that make the same?

In the third year of Mary one John Churchson writes. ${ }^{4}$ Confessing himself "a pigmey," he nevertheless makes bold to discuss a subject, for failure to understand which "the pitilesse slaughter of no small number of soules" is going on. He exhibits average ability and some patristic learning. He is moved especially by the fact that "of late tyme, many dyverse scismes, sectes and heresies haue sprong vp in the churche of our sauiour Jesus Chryst," and he replies to those whom he stigmatizes as

1 Depositions in Egerton Papers, Camden Soc. 1840, 171-175.

2 This term, as here used, of course inclades Unitarians, Baptists, etc.

3 A short Description of Axtichrist veto the Nobilitie of Exglande, etc., fol. 26.

4 A brefe Treatyse declaryng what and where the churche is, that it is knowen, and whereby it is tryed and knowen, $1556 \mathrm{iv}$ : iii : $11,33,46,49,53,63,81,125$. 
" donatystes." That must be the true church which is universal, "sensyble, visible, manyfest, and knowen;" not "vnder a busshell or stryke, ${ }^{1}$ but vpon the candylstycke." It is not strange that in this church should be "many bad, so well as good." Here he reasons thus :-

Good and euil be in the church but amonge heretykes be onely euyll, \&c. We graunte in the Churche of catholykes to be good and bad, but as corne \& chaffe . . . For as good corne suffereth no detriment ne damage by myxture of the chaffe, but is rather conserued $\&$ preserued good therewyth, lykewise the good people receiveth no corruption, contagion, nor infection in the substaunce of their religion, by the societie of the euyll. . . .

He declares that "the infallyble tokens," distinguishing the "catholyke churche," are " universalitie, antiquitie and vnitie." Having proved this to his own content, he adds :-

You may euidently vnderstand vnitie to be a sure token of the Catholyke Churche, from the which those fragementes, that be dyuided and broken, doo publyshe and thrust fourth dyssonante, pugnaunt and contrariant Doctryne, by the vyolente perswasyon, and instructio of $y^{\mathbf{e}}$ proud spyryte of error.

It has been mentioned that in 1566, the London clergy suddenly were called upon to subscribe to the Act of Uniformity, and that thirty-seven of the ninety-eight present refused and suffered accordingly. Out of the following agitation several publications arose, among which two or three were the earliest examples of the so-called " Puritan literature." The first place belongs to the manifesto of the dissentients. ${ }^{2}$ Its object is to give some reasons for their course. Their fundamental principle is that all things should be done to edify, i. e., upbuild. It is their business to build up, not pull down, the Church. But to wear the required vestments would be to grieve simple Chris-

1 An old measure, containing sometimes one bushel, and sometimes four.

2 A briefe discourse against the outwarde apparrell and Ministring garmentes of the popishe Church, 16mo. This has the inside running title, The unfolding of the popish attire. It also is called $A$ Declaration of the doings of those ministers of Gods worde and Sacraments, in the Citie of London, which haue refused to weare the outwarde apparrell, and Ministring garmentes of the Popes church, 4, 8, 9, 18-18, 20, 41. Abel (Zur. Lets. ii : xlix) says: "As soon as the authorities heard of it, the book was prohibited, the printers cast into prison, and the copies destroyed." 
tians and encourage obstinate Papists. Their general position is stated thus : -

If the Prince shall take in hande to commaunde vs to doe anye of those things whiche God hath not commaunded, in such sorte that we maye not leaue them vndone, vnlesse we wil thereby runue into the penaltie of the law (whe we shal see that in doing thereof, we can not edifie but destroye) we must then refuse to doe the thyng comaunded by the Prince, and humbly submit our selues to suffer the penaltie, but in any case not consent to enfringe the Christian libertye, wich is to vse things indifferent to edification and not to destruction.

Then they justify their position. They cite Jerome, the clergy of Ravenna's famous averment: " discernendi a plebe, vel ceteris sumus, doctrina, non veste: conversatione, non habitu: mentis puritate, non vultu," Bucer, Martyr, Ridley and Jewel. And this is their solemn and plaintive ending:-

Our goodes, our bodyes, and our lyues, we do with al humble submission yelde into $\mathrm{y}^{\mathrm{e}}$ hands of gods officers vpon earth : but our conscience we keepe vnspotted in the sight of him that shall iudge al men. Desiring no thing, but that it may be free for us by doctrine to teach $\mathrm{y}^{\mathbf{e}}$ flocke of Christ, whereof we have taken charge : and when we haue so taught them, to goe before them, in doing that which we have tauglit according to the truth of gods holy worde.

This was replied to at once in a neat black-letter quarto ${ }^{1}$ from the press of Richard Jugge, the queen's printer. The book is courteous for those days and merely replies to the main points of their argument; ending by quoting Bucer and Martyr. Its argumentative quality is seen in the answer to the dissentients' plea for keeping conscience undefiled :-

This your petition in some thynges touchyng the worshyp of God, myght haue his place: But in these matters (which you call indifferent) what is it that shoulde defyle you? the thynge it selfe, or your weake opinion of it? The thing it selfe doth not pollute you : For (as S. Paule sayth) to the pure, all thynges are pure. And agayne: Nothyng is common or vncleane of it selfe. Nowe as concernyng your weaknes (thankes be to God) that which the same S. Paule reporteth of the Corinthes, may be verified of you: We all have knowledge.

${ }^{1}$ A briefe examination for the tyme, of a certaine declaration, lately put in print in the name and defence of certaine Ministers in London, refusyng to weare the apparell prescribed by the lawes and orders of the Realme, 4to, 54-84, 50,6. 
And: We are sure that an Idoll is nothyng in the worlde, and that there is none other God but one. It were to be wyshed (and would to God there were no examples now of it) that none of them which pretende herein a straytness of conscience, dyd strayne a Gnat, and swallowe a Camell.

The best thing in the book is an appended Latin prayer, which is Englished thus : -

The Churche, O Christ, thy spouse, opprest with worldly spight,

Thy ioyfull peace doth erave, by thee to her behight:

A wake sweete Lorde awake, and styll this raging sea,

That thine elect be saude, whiche ouce were gevne to thee.

One insinuation occurs against the quality of these protestants :-

They be but a very fewe in them selues, other then such as have ben eyther vnlearnedly brought $\mathrm{vp}$, most in prophane occupations, or suche as be puffed vp in an arrogancie of them selues, ... The aduersaries of true religion can winne no great rejoyce at these mens onersightes, as beying but a very fewe, and counted in deede none of the sincere and learned protestauntes, howsoeuer for a tyme they seemed to be amongest vs.

It was not long before a rejoinder ${ }^{1}$ appeared. This included, and, sentence by sentence, replied to the "Brief Examination." As to the taunt of the scant numbers and social insignificance of the dissentients, it said : -

It is well known that not onelie a few vnlerned brought vp in prophane occupations, as yow vncharitable and slaūderushe report: but a gret nomber of wise, godlie, and lernid men, such as haue bene and are the eldest prearchers in England neuar stayned with any recantacion, or subscription, brought upp in all kind of lerning, both of artes and toungs, such as have the name not onelie at home but also in forraine nations, to be in the nomber of the best lerned in the realm, agree with us, in this cause, and of them partly have wee lernid this indgment. . . . To be called from an occupation to the mynisterie of the church, is no more reproch nowe, to men mete for that function, than it was to Petar, Paule, and the rest of the apostoles. If they ${ }^{2}$

1 An Ansuce for the tyme to the examination put in print, without the authour's name, pretending to mayntayne the apparrell prescribed against the declaration of the mynisters of London. M.D.LXVI. $16 \mathrm{mo}, 13,16,38,26,28,33,57,76,20,18,17$.

2 Dissenting ministers charged with unfitness because they came from "occupations." 
were unmete than [then] the Bishopes are to be blamed for admitting them and most of all for retayning, and daylie multiplying others, whom nothing ells but a capp and a Surples do make comendable.

In the great dearth of Christian labor in the kingdom, those who sincerely desire the progress of religion, it is urged, ought to welcome all fairly competent workmen. As to the vestments, the authors say, "wee deni not but that they are reteynid of a good intent, but we see that an euill end doth follow of the restoring of the." Upon the main question of authority and its application it is declared: -

The Ceremonies and apparell tend not to edification, but destruction, for that no man by them is directed to Christ, and the sinceritie of the Gospell, neyther yet prouoked to amendment of lyfe, but to Antichrist, and the remembraunce of poperie. . . . When we graunt them to be indifferent, wee speke of the substans, matter and creature, we graunt not, that they are indifferent, in everie kind of vse. . . As they are monumentes of idolatrie, and stombling blockes to the weke, they are no to be receined, though all the Princis in the world command them. . . . In dede we confesse the magistrat ought to set forth Ecclesiasticall lawes, but vnelie out of gods word, ffor neyther the magistrat nor the church, hath any poure but to edifie. . . It is trew all edification, order, and decencie and authoritie of magistrates haue groundes in the Scripture: but your apparrell hath not anie aedification, decēcie or order, nor lawfull authoritie, for wee haue no power but to edifie. Therefore it hath no grownd in the Scripture.

Very rigorous and effective is the protest made against suspending everything upon the question of vestments:-

But now experience teacheth, that an asse, a dissembling papiste, a dronkard, a Swerer, a Gamester, so he receaue your apparell, may haue the honor of retaining lis liuing, but qui optime praesunt they that rule neuer so well, and are comendable in all poinctes, that S. Paule requirith in a perfecte good minister, for onlye refusinge the apparell are thruste out, as men vnworthy of any honor dewe to a minister of Christe.

The foree of the letters of Bucer and Martyr is parried by the suggestion that "what so euar seemed to them tollerable for a tyme, is not to be inforced as a perpetuall lawe." And the substance of the Nonconformist position is declared thus in the Address to the Christian Reader :- 
Wee thanke god, that he hath gyven vs grace, rather to sustayne such reproche at your handes, and what so euar else lawes and magistrates shall lay $\mathrm{vp} \overline{\mathrm{o}} \mathrm{vs}$, then to peruert the synceritie of the gospel, by mynglyng of it with the leuen of Antichrist.

Not unnaturally those who were distressed at home looked abroad for sympathy and counsel. Humphrey and Sampson each wrote to Bullinger, desiring his testimony. The gist of their inquiries lies in three points: whether the prescribing of habits borrowed from abolished Judaism, or from idolaters or heretics, be lawful; whether the sovereign may prescribe them to the Church when they do not tend to edification; and whether a pastor of unblemished life and doctrine may be deposed rightfully for not using them.

Bullinger replied to both letters by one for himself and Gualter. On the whole they advised conformity :-

I also exhort you all . . . that every one of you should duly consider with himself, whether he will not more edify the church of Christ by regarding the use of habits for the sake of order and decency, as a matter of indifference, and which hitherto has tended somewhat to the harmony and advantage of the Church; than by leaving the church, on account of the vestiarian controversy, to be occupied hereafter, if not by evident wolves, at least by ill-qualified and evil ministers.

Contrary to the expectation of those addressed, Bullinger immediately sent a copy of this letter to Bishops Horne, Grindal and Parkhurst; and they, contrary to the expectation of Bullinger and Gualter, at once printed the same. The Swiss pastors promptly objected, and wrote to Coverdale, Humphrey and Sampson, complaining of this "improper use" of their communication, and protesting in advance against the possibility that men in, or out of, Convocation, should distort their words as "if we seemed now to approve and desire the restoration of things that every pious person, who is acquainted with our writings, has long known us to disapprove of." They wrote further to the Earl of Bedford, ${ }^{1}$ praying him -

not to refuse your patronage to these godly brethren, who, notwithstanding they may have erred in some respects, are yet deserving of

1 Zur. Lets. I : lxviii, lxix; App. iii, iv, v; ii : liv; i: App. vi; ii : lv. 
pardon, as it is plain that they have been actuated by a fervent zeal for godliness, and that their sole object is to have the church purified from all the dregs of popery.

The same year saw several other tractates discussing the general subjects involved, ${ }^{1}$ one of which was understood to proceed from the Primate ${ }^{2}$ and others of the Ecclesiastical Commission. This brought out one or two on the other side to counteract its influence. One ${ }^{3}$ of these, made up of extracts from Bullinger's works, contained the following effective paragraph:

It is not meete yt any King or Magistrate shuld think that he hath any authority geven him to make new lawes of the worshipping of God, or of the misteries or sacramentes. . . . The Scripture, which is the word of God, doth plenteously ynough set out \& declare all thinges whatsoeuer perteyne vnto trew religiō, eve the Lord forbiddeth to put anything to his word, or take anything frōit. Therefore $y^{e}$ Magistrate can make no new lawes for the worshipping of God.

The only immediate result was that the queen ordered the Archbishop of Canterbury to enforce the laws as they stood. Clearly nothing was to be hoped for directly from her or from the hierarchy. The only course left open was to appeal to the general judgment.

Anthony Gilby, an M. A. of Christ's College, Cambridge, in 1535, who had spent Mary's reign at Frankfort and Geneva, had been made vicar of Ashby-de-la-Zouch by the Earl of Huntingdon, and remained such until he resigned in 1583 in favor of his son-in-law. Apparently he took the field first in a pamplilet ${ }^{4}$ designed to cheer the troubled. Later, in May, 1566, he issued a popular appeal. ${ }^{5}$ There are two speakers: Miles

1 Whether it be mortall sinne to transgresse civil lawes, which be the commaundementes of Civill Magistrates, etc., 1566, 8vo.

2 Strype, An. i (2) : 174.

8 The mynd and exposition of that excellente learned man Martyn Bucer uppon these wordes of S. Mathew: Woo be to the worlde bycause of offences, etc., 1566, 8vo; and The iudgement of the Reuerend Father Master Henry Bullinger, Pastor of the church of Zurich, in certeyne matters of religion, otc., 1566, 16mo, Sig. C. iii, verso.

4 To my louynge brethren that is troublyd about the popishe apparrell, two short and comfortable Epistels, 1566, 8vo.

5 A Pleasavnt Dialogve Betweene a Souldior of Barwicke, and an English Chaplaine. Wherein are largely handled $\&$ laide open, such reasons as are brought in for maintenaunce of popishe Traditions in our Eng. Church, 16mo, B. verso, 2, 3 verso, 4 verso; C. 2 ; D. 6 verso; K. ; L. 5,6 ; M. 2. 
Monopodios, a clever, one-legged soldier of Berwick, and Sir ${ }^{1}$ Bernarde Blynkarde, a former fellow-soldier, who lacks a finger and an eye and has scant learning and few brains, but who somehow has become a parson with a plurality of benefices, besides being the private chaplain of a nobleman. Sir Bernarde is so transformed by the regulation garments that Miles for a time cloubts his identity, and then inquires :-

What was the cause that thou haste bin in so many chaunges of Apparell this forenoone, nowe blacke, nowe white, now in silk and golde, and nowe at the length in this swonping blacke gowne, and this sarcenet flaunting tippet, wearing mōe hornes also vpon thy heade than ener did thy father, unlesse he were a man of the same order: I pray thee, of good fellowship tell me how thou art come to this chaunge, since thou leftest our companie: for surelie I haue gotten nothing by my long seruice but stripes and woundes, and nowe I must needes leaue of [f] this trade, because I. want my legges, and ashamed I am to begge.

Sir Bernarde candidly confesses that Miles is the better taught of the two, but having himself entered "within the holy orders of Priesthood," he insists on being treated with due respect; and, when begged to explain how all has come about, he says :- -

Why man: thou knowest not what a state this is, for though hee [the ar'chbishop] finde vs nener so very dolts, yet can he and the other Bishops by the laying on of their handes, giue rs the holy Ghost: for so sayde they to me and my fellowes, Holde, take the holy Ghost: so that I am no more of the lewde laitie, but of the holy spiritualitie, and I have gotten a good Benefice or twaine, and am called maister Parson, and may spend with the best man in our towne, and doe keepe company with Gentlemen of the countrey, in hauking, hunting, dicing, carding, and take my pleasure all the day long: so that I do come to the church sometime in the morning, and reade a little whiles dinner bee made readie.

Miles presses for particulars, how he may come to the like, and Sir Bernarde replies :-

I will tell thee all for old fellowships sake, and I will helpe thee to auowe some [to an advowson] for money: and that is the surest way.

1 As most ministers had taken their first degree, it became usual to call them Dominus, or Sir. 
But if thou haue no money, then must thou fawne vppon some Gentleman, that either hath some impropriations, on other Benefices in his hande, or else by other meanes, to seeke some little gaine by it, or hath some in his gifte. Get his letters to the Bishop, and thou needest not to doubt of orders.

He adds, however, that if his old comrade happens to be infected with the modern strict notions, he would better abandon them, and warns him :-

There are verie few that can agree to the Geneuians fashion, to haue nothing in the church but naked walls, and a poore fellow in a bare gowne, telling a long tale, and brauling and chiding with all his auditorie. Nay my Lorde my M[etropolitan]. will none of that. As for my Lorde, ${ }^{1}$ I hearde him say, that he could neuer go, to any of these Geneuians Sermons, that hee came quiet home, but that there ,was euer somewhat, that pricked his conscience, hee thought alway that they made their whole Sermon against him. But in the hearing of Mattius, euensong \& pricksong ${ }^{2}$ at Paules, or in my reading of my seruice in his chapell, he sayth, he feeleth no such thing, for he is neuer touched, but goeth merilie to his dinner.

Miles gets the better of his acquaintance; who admits that he "cannot reason with Scriptures," though he thinks people "starke fooles, that wil loose so good liuings, for a cappe of two shillinges, or a Surples that shall cost them nothing." Miles now and then interjects a solemn warning, such as: "Beware least it be not more easie at the day of iudgmet to the Sodomits, then to the English mock-gospellers;" and not without some effect, as Sir Bernarde says: "Me thinke I smell a ratte in this geare. All is not golde that glittereth." Sir Bernarde later asks whether, in the dearth of educated men, cobb]ers and tailors should be called upon, so that every parish may have an incumbent, to which Miles replies:-

Yea a great deale better were it so to doe than to place popishe Priestes, the denourers of Christes Lambes. For theyr priest crafte, was the wickedest occupation that euer was in the worlde, and the most craftie.

1 The nobleman whose chaplain he was.

2 An ancient name for ornate plain-song. The vellum leaves were marked with an instrument called a pricket, so as to enable the stave of four lines to be drawn thereupon. - Lee, Glossary. 
The "Dialogue" is accompanied by an enumeration of "An hundred pointes of Poperie, yet remayning, which deforme the Englishe reformation," and which are "nothinge but a packe of poperie, and a pudle of corruption."

In 1570 Dr. Percival Wyburne - a graduate of St. John's College, Cambridge, who in Mary's time had fled to Geneva, and who, on returning, became a canon of Norwich and Westminster, and later vicar of St. Sepulchre's, London, and had been deprived for refusing subscription - published a rejoinder to the attacks upon the Nonconformists. ${ }^{1} \mathrm{He}$ points out that trials always have caused some weak Christians to fall. He then speaks freely of the bishops. They are "blinded with estimation of them selues, with desire to please those who are in high authoritie, and with carefull carking, as well to keepe that which they haue, as also greedily to gather more to it." They "pretende one thing and doe plainlie the contrarie." $\mathrm{He}$ also testifies as to some of the ordinary clergy :-

I knowe double beneficed men that doe nothing els but eate, drinke, sleepe, play at dice, cardes, tables [backgammon], bowles, a read seruice in the church; but these infect not their flockes with false doctrine, for they teach nothing at all.

And he ends thus:-

Let vs wey therefore where the fault is, and who are the cause of this schisme. First of all such Bishops as fled in Queene Maries time, or els taried here vnder the crosse, had cast of, renounced, and forsaken all this trumperie, for the which the peace is nowe disturbed, and afterwarde for their promotion sake, put them on agayne: yet no man seuered him selfe from them, but liued and laboured in louing consent, till such time as they, not regarding the peace of Gods Church, did thrust vs their brethren fro them: They therefore regard not the peace but are the authours of this disturbance.

Here we strike the initial and germinant idea of that " $\mathrm{Re}$ formation within the Reformation" which is known as Puritanism. The fact cannot be understood too distinctly, stated too clearly or remembered too faithfully, that the old notion

1 A comfortable epistle written (as it is thought) by Maister $D[r$.$] . W[yborne],$ Doctour of Diuinitie in his owne defence, and [that of ] the brethren that suffer depriuation for the popish ceremonies urged by the Bishops. - Repr. in A Parte of a Register, 1-12. 
that the Puritans undertook to supplant the church government of England through bishops by the Presbyterian system, elaborated at Geneva, simply, or mainly, for the sake of a change of polity, is an untruth which wrongs them, while misconceiving and belittling history. Doubtless, some of the Marian exiles had brought back a liking for Calvin's system, and, other things being equal, might have preferred it at home. But it is difficult to find evidence that any one of them revolted from the government of bishops, or the discipline of the Church, until driven to it by the aggressions of the government; or for any other purpose than to resist the refluent wave of popery and preserve the imperilled essence of godliness.

They insisted that they did not wish to sow schisms, to charge with impiety things indifferent, or to conceal a disputatious spirit under the name of conscience; and that all for which they asked was toleration in obeying their own consciences, without compelling others to agree with them. And the uniform advice of their Continental friends, even of Calvin, favored their continuance, if in conscience they could, with the old Church. Had the queen and her counsellors shown moderation and conciliation, to say nothing about sympathy with the evangelical purpose of the Puritans, and granted the little that was asked; and, as Coverdale and his fellows said," permitted that " in the dissimilarity of rites they may preserve the sweetest harmony of spirit and brotherly love," the whole current of English ecclesiastical history, and, indeed, of American, might have followed a different channel.

Here, then, in a nutshell we have the origin of the movement. A few devout men, trained by persecution and exile to believe in the unrighteousness of the Papacy, came home to find the Established Church only partially weaned from Rome, practically tolerant of worldly living, and meagrely using, when not altogether misusing, the ordained means of grace. They found it hedging up, and finally forbidding, all encleavors for reform ; until they were forced to believe that, unless through a revolutionary change, which should sweep the ground bare of all that

1 Zur. Lets. I, lxxi; II, l, xvii ; I, App., ii, vi ; II, lvii, lxi, lxxv, xcvi, xciv, civ, $\mathbf{x v}, 1$. 
was and so make room for the growth of that which ought to be, the effort for a better state of things was hopeless. So, in last resort, braving the misconceptions of many old friends, with the contempt and even bitter hostility of multitudes of often sincere, but misled and sometimes savage disciples, facing deprivation, destitution and imprisonment should they escape Tyburn or St. Thomas Watering, these heroic men took their lives in their hands and deliberately undertook to reform "Reformed" England.

To their minds the first essential was to discredit before the popular intelligence the existing unscriptural hierarchy, with the corrupt system of which it was the fruit and crown. The second was to suggest in its place something more scriptural, more congenial to a devout piety, more just to the rights of men and less burdensome to the public treasury.

Naturally, those who were like-minded as to this held conference. Among them was Anthony Gilby, already named, who must have been about sixty. Another was Thomas Sampson, perhaps fifty-three, edncated at Pembroke Hall, Cambridge, ${ }^{1}$ trained in the common law in the Inner Temple, London, ordained by Ridley, an exile at Strasburg, and resident at Geneva long enough to become attached to its system. In 1560 he had refused the bishopric of Norwich and had been installed canon of Durham, and later Dean of Christ Chureh, Oxford, where, after the Act of Uniformity had silenced the Papists, he, with Laurence Humphrey and Andrew Kingsmill, were the only persons who could preach. But he had been ejected and imprisoned because he would not conform, and now had just been appointed Prebendary of St. Pancras in the church of St. Paul and theological lecturer at Whittington College, London. Another was Thomas Lever, about fifty, who had been educated at St. John's, Cambridge; had preached repeatedly before Edward VI. and his court, and at Paul's Cross, sermons which have come down to our time for their bold eloquence; who took refuge in Zurich and Geneva, and finally became minister of the English congregation at Aarau. On his return he was re-

1 See Brook, Lives of Puritans; Ath. Cant.; Strype, etc. Brook says that Sampson was educated at Oxford. 
puted to have influenced Queen Elizabeth to decline her father's title, Head of the Church. Subsequently he-became archdeacon of Coventry and canon of Durham, was deprived for nonconformity, but retained the mastership of Sherburn Hospital, and contimued to preach without wearing the habits.

Another was Laurence Humphrey, still under forty-five, who had studied at both Cambridge and Oxford; who spent Mary's reign in Switzerland; who came back to be appointed, in 1560 , Regins professor of divinity at Oxford, and the next year president of Magdalen College and afterwards Dean of Gloucester and of Winchester. Another was Nicholas Standen, who had studied at Cambridge and been rector of St. Margaret's in East Cheap, London, but had been deprived. Others were John Field and Thomas Wilcox, graduates of Oxford; one in charge of St. Mary's, Aldermary, and the other of Allhallow's, Honey Lane, London, both of whom had refused the habits and so lost place.

These details prove that the leaders of the new reform were not men of no learning or reputation, dissatisfied because of personal ill-success, and favoring something new in the hope of private advantage. So far as this world was concerned, they had everything to lose and nothing to gain by their course.

For some time they counselled together in private in London, and, as their numbers grew, they left their congregations and assembled for worship " in priuate houses, in woods, \& fields." 1 Their gatherings were contemptuously termed conventicles, but they preferred the name, Conferences. ${ }^{2}$ In time a considerable number of able young ministers, who afterwards left shining records of usefulness, joined the company - such as William Bonham; Nicholas Crane, of Cambridge; William Charke, of Peterhouse, Cambridge, who in 1572 was ejected from the university for maintaining the parity of the ministry; Walter Travers, of Trinity, Cambridge, who lived in Switzerland long enough to agree with its learned divines, was ordained at Antwerp by a Presbytery, became Cartwright's assistant there, came

1 R. Bancroft, Davngerovs Positions and Proceedings, etc., 1503, 4to, 65, wrongly numbered 41 (bis).

2 Soames, 188. Cartwright, Second Replie of T. C. agaynst Maister Doctor Whitgiftes Second answer touching the churche Discipline, 1575, xxxviii. 
back to be lecturer at the Temple Church while Richard Hooker was its Master, and became a prominent author in favor of the new discipline, but who, because of persecution, took refuge in the provostship of Trinity College, Dublin, and at last returned to die in England; Richard Gardiner, also of Cambridge, and Stephen Egerton, of both universities and preacher at Blackfriars, London. Among them then also were Thomas Barbar, fellow of St. John's, Cambridge, preacher to crowded congregations at St. Mary-le-Bow in London, and suspended for refusing the oath ex officio, who afterwards turned against his comrades; and Thomas Edmunds, who, after some years of fidelity to the new views, at last took the oath. ${ }^{1}$

There had been no parliament since 1566. But the national treasury was low, and no resource remained to the queen but to summon another. It was called for April 2, 1571. The little band of associate Puritans drew up, mainly by the hands of Field and Wilcox, two brief communications to its members, to urge them towards further religious reform. ${ }^{2}$ How far these were supplied to those addressed does not appear; but they do not seem to have been made public until after the session, ${ }^{3}$ for Whitgift complained ${ }^{4}$ of the neglect. Fuller, who wrongly attributes the twin tracts to Cartwright, says that the title gave some offence. But the writers were in solemn earnest, and the word selected had a force which, no doubt, both commended it to their choice and won the favor of serious men to whom it was addressed.

1 Brook, i : 174, 362, 429; ii : 113, 236, 289,314; iii : 512, 515. Ath. Cant. ii : 39, 236. Strype, Whitgift, 264, App. 274, 277. Baneroft, Davng. Posits. 67, 89, 121, 123-124.

2 An Admonition to the Parliament, 1571, 16mo, and A Seconde Admonition to the Parliament, by T. Cartwright, 1572, 12mo. It has been usual, if not universal, to speak of these as one, yet clearly there were two. The first comprised but twelve pages, duly concluded with "Finis." The second covered nineteen, also ending formally. When republished together, almost immediately, they were introduced thus (1):-

"Two treatises yee haue heare ensuing (beloved in Christ)."

And the next year, when Cartwright wrote what was styled A Seconde Admonition, he said (2): -

"There were two little Treatises lately sette forth, both tending to one ende . . . and ... they beare one name, that is, An admonition to the parliament."

3 May 29.

4 Defense of the Aunswere to the Admonition, 34. 
This "Admonition" states squarely in its prelude the proposition which it proceeds to argue :-

In a few words to saye what we meane. Either must we have a right ministerye of God \& a right gouernment of his churche, according to the scriptures set vp (bothe whiche we lacke), or else there can be no right religion, nor yet for contempt thereof can Goddes plagues be from vs any while deferred.

And it is declared : -

We in England are so far off, from hauing a church rightly reformed, according to the prescripte of Gods worde, that as yet we are scarse come to the outward face of the same.

The first tract aims to set forth "a true platforme of a Churche reformed," by way of emphasizing "the great vnlikenes betwixt it \& this our english churche." Pure preaching, sincere sacraments and a faithful discipline are the three outward marks of a true Christian church. Specific criticism of the State Church is made in regard to each of these.

Then, say they :-

If you will restore the church to his ancient offycers, this you must do. In stead of an Archbishop or Lord bishop, you must make equalitie of ministers. In steade of Chauncelors, Archdeacons, Offycialles, Commissaries, Proctors, Summoners, churchwardens, and such like, You have to plat in euery congregation a lawfull and godly seigniorie. ... And to these three ioyntly, that is, the ministers, Seniors and deacons, is the whole regiment of the churche to be committed.

Some discussion follows as to methods of discipline, after which occurs this deliverance on a vital point : -

Not that we meane to take away the authoritie of the civill Magistrate and chefe gouernoure ... but that ... the Prince'may be better obeyed, the realme more florishe in godlinesse, and the Lord himself more sincerely \& purely according to his revealed will serued, then heeretofore he hath bene, or yet at this present is.

This first part ends by direct appeal to Parliament to amend " these horrible abuses ;" assures its members that, in so doing, God will deliver and defend them, and asks, "is a reformation good for France : and can it be euill for Englande : is discipline meete for Scotlande: and is it unprofytable for this realme." 
The second part details twenty-one Popish abuses which still remain in the reformed Prayer-Book, and mentions objections to the apparel and other matters, appealing again to Parliament " to reform Gods church according to your duties and callynges." As for themselves, the authors declare : ${ }^{1}$ -

If this can not be obtayned, we will by God's grace addresse our selues to defend his truthe by suffring, and willingly lay our heads to the blocke, and thys shall be oure peace, to have quiet consciences with our God.

Letters from Beza and Gualter are appended to support the views advanced by the anthority of their great names; ${ }^{2}$ and the final page is filled out this : -

\author{
England repent, Bishops relent \\ returne while you haue space, \\ Time is at hand, by truth to stand, \\ if you hane any grace. \\ Ioyne now in one, that Christ alone, \\ by scepter of his word: \\ May heare the stroke : least you pronoke \\ his heauy hand and sword.
}

The authors of this bold appeal soon experienced the "suffring" which they had foreseen. The government regarded the "Admonition" as " a seditious libel," and, mable to stop its circulation, it being soon reprinted several times, imprisoned Field and Wilcox. On September 3 they appealed to Lord Treasurer Burghley, acknowledging that their book demanded the reformation of abuses, but in order that religion, being freed from Popish superstition, might be restored by Parliament with the queen's approbation. They besought his kind interference, but they were indicted under the statute of uniformity and sent back into Newgate. Here they became a rallying point for many, and before long a new champion took the field.

This was the famous Thomas Cartwright, not yet turned of forty. A graduate of St. John's, Cambridge, and a fellow of Trinity, he had become a popular preacher and Lady Margaret

1 Admon. to Parl. 2, 4, 3, 4, 11, 13, 13-14, 16-30, 31-34, 33, 34.

2 Gualter wrote to Cox (Zur. Lets. Eliz. I : App. vii.) that it distressed him that his letter had been published, that he had been beguiled into writing as he did by false accusations, and would make it right soon by a public testimony. 
professor of divinity, had been deprived and banished the university, and had retreated to Antwerp and Middleberg, where he had been chaplain to the English merchants. But he went back just then and joined the little Puritan company, and surely did valiant work in their behalf. The archbishop saw the inexpediency of leaving the "Admonition" unanswered, and selected John Whitgift, a fellow of Peterhouse, Cambridge, and Cartwright's predecessor as Lady Margaret professor, who as vice-chancellor had banished Cartwright, to reply. In a few months he published his book. ${ }^{1}$ He begins by wholesale depreciation of that which he, nevertheless, takes pains to answer carefully.

He then stigmatizes the logic of the treatise, as so weak as hardly to need to be met by argument. He goes on, however, to the extent of 268 quarto pages - enlarged in the second issue of the following year to 332 , although the little book to which he is replying is only a $16 \mathrm{mo}$ of fifty-eight pages - to take it up, sentence by sentence, in order to neutralize its force. Nor does he forget to append letters from Gualter and Bullinger, "upon better information" revoking those of Beza and Gualter which had come out with the "Admonition."

The character of this "Answere" may be inferred sufficiently from what has been said, and from its concluding sentence:-

When you saye, that you stryue for true Religion and gouernemente of the Churche, \&c. You saye, that yon dooe that, whyche is to bee wyshed you shoulde doo: But youre doings tende to the defacing of true Religion, and ouerthrowe of the righte gouernement of the Churehe, and although you be not the head of Antichrist, yet are you his taile: For the tayle of the beast (as learned me say) be false prophets, hypocrits, such as stirre vp schismes and factions among true Christians, and by pretence of zeale, by cloked and couloured meanes, seeke to drawe into the Church Antichrist backeward, as Cacus ${ }^{2}$ did the oxen into his denne.

Cartwright seems to have been quick to issue another pam-

1 An Answere to a certen Libel intituled, An adnonition to the Parliament. By Iohn VVhitgifte, D. of Diuinitie, 1572, 4to, vii, viii, ix, x, 260.

2 A fabled giant on Mt. Aventinus, who stole the oxen of Geryon from Hercules, concealing the theft by dragging them backwards into his cave, so that their tracks seemed to point outwards. 
phlet, "A Seconde Admonition to the Parliament." Like the first it was brief, having but eighty-four small pages. It is nothing new, he says, to see the divine admonitions rejected by those who should be first to heed and defend them. After eiting plenty of proofs of this assertion from Scripture, he censures the severity with which Field and Wilcox were being treated; and insists boldly that in the day of judgment it will be easier for Sodom and Gomorrha, than for a parliament which turns a deaf ear to such "Admonitions." As for this present " Admonition," as the previous ones had been so short as to have explained not so much how as what to reform, his purpose is to show how to do these things, so far, at least, that they "may have sufficient lyght to proceede by." The present condition cannot be endured :-

I say that we are so skarce come to the outwarde face of a Churche rightly reformed, that although some truth be taught by some preachers, yet no preacher may withoute greate danger of the lawes, vtter all truthe comprised in the booke of God. It is so circumseribed \& wrapt within the compasse of suche statutes, suche penalties, suche iniunetions, suche advertisements, suche articles, suche canons, suche sober eaueats and suche manifolde pamphlets that in manner it doth but peepe out from behinde the screene. The lawes of the lande, the booke of common prayer, the Queenes Iniunctions, the Commissioners aduertisements, the Bishops late Canons, Lindwoodes Prouincials, euery bishops Articles in his dioeesse, my Lord of Canterburie's sober eaueats in lis licenses to preachers, and hys highe Courte of prerogative, or graue fatherly faculties, these together, or the worste of them (as some of them be too badde) may not be broken or offended against, but with more daunger then to offende against the Bible. To these subscribing, and subseribing againe, and the third subscribing, are required, for these Preachers and others are endited, are fined, are prisoned, are excommunicated, are banished, and haue worse things threatned them : and the Bible, that muste haue no further seope, then by these it is assigned. Is this to professe God his worde: is this a reformation:

He repuliates Anabaptism and contempt of magistracy, but claims that, if law be offended by truth, the law should be reformed and not the holders of the truth punished. He declares it wicked to attribute to a prayer-book authority due to God's book alone; and that indictment and imprisonment for such a 
cause are "cruell persecution." He insists that all in which the Church of England differs from the Reformed churches of the Continent is in that it is not "directed by the course of the Scriptures." So that, instead of being "singular," those who plead for further reform desire "to drawe by one line with the primitiue church, and the churches best reformed at thys day." Provision should be made for a preaching ministry, by drawing upon the funds of the bishops and the cathedrals, if necessary. Each parish onght to have a pastor and teacher.

The bestowal of the titles of Bachelor's and Doctors of Divinity "by frendship, or corrupt bribery" is condemned. The pomp and apparelling of the hierarchy, and its cruel treatment of Nonconformists, are censured heavily. And, with sharp criticism of the existing way, the platform of a true church is outlined, with its officers and their manner of election, its service, its consistory and its powers of discipline. "Tell the church" is "tel that consistorie of the Iewes and the scriptures that directe their gouernement." Allusion is made to the then not clearly thought out Presbyterian idea of "a more generall Synode, and councell of the whole land . . . to whose determination they shall stande, excepte there be a more general Synode of all [Reformed] churches." 1

Early, it seems, in 1573, Cartwright followed this pamphlet with a black-letter quarto, ${ }^{2}$ refuting Whitgift's reply to the "Admonition," his authorship being avowed by the initials T. C. He begins with a graceful expression of regret that he must oppose those who as to so many things are friends. But there is no good reason why a polity employed in the Apostles' times should be stigmatized as "new," or condemned as "strange" when now full-grown across the Channel. Least of all should that be accused of disorder

whose whole worke is to provyde that nothing be done out of place, out of time, or otherwise, then the condytion of euery mans calling will beare : which putteth the people in subiection vnder their gouernoures, the gouernoures in degree, and order one vnder an other, as the

1 Second Admonition, 16mo, 1, 3-5, 6, 8, 9, 10, 12, 15, 16, 25, 31, 44-54.

$2 A$ Replye to an Ansvvere made of $M$. Doctor VVhitgifte, agaynste the Admonition to the Parliament, by T. C. 4to, 1, 2, 61 . 
Elder, vnderneath the Pastor, and the Deacon, vnderneath the Elder, whych teacheth, that a Particuler church, shall gine place vnto a Prouinciall synode, where many churches are, and the Prouincial to a Nationall, and likewyse that, vnto the Generall, if any be, and all vnto Christe, and his worde.

Nor can such a system be condemned justly, as -

An enemy to magistrates, and the common wealth. . . . It helped and vpholded the common wealths, whych were gonerned by tyrantes, and can it hinder those, whych are gouerned by godly princes? . . . If it be asked of the obedience due vnto the prince, and vito the magistrate, it answeareth that all obedience in the Lord, is to be rendred: and if it come to passe, that any other be asked, it so refuseth, that it disobayeth not, in preferring obedience to the great God, before that whych is to be given to mortall man. It so resisteth, that it submitteth the body, and goodes of those that professe it, to abide that whych God will haue them suffer in that case. And if it be shewed, that this is necessary for the church, it cannot be, but profitable for the common wealth. . . . And vndonbtedly, seeing that the church \& common wealth ... belike vnto Hypocrates twinnes, whych were sicke togither, and well togither, laughed togither, and weeped togither, and alwayes like affected: it can not be, but that the breaches of the common wealth haue proceeded from the hurtes of the church, and the wants of the one, from the lackes of the other. Neyther is it to be hoped for $y^{t}$ the common wealth shall flourishe, rntill the church be reformed.

Two principles underlie this entire argument: the all-sufficiency of Scripture in its revelations of the primitive Church to furnish the model of all church govermment, and the absolute inadmissibility of any Papal defilement of such a model. The grasp and rigor of the reasoning are indicated by this passage :

Is it a like[ly] thyng that he whych did not only appointe the temple and the tabernacle, but the ornamentes of them, woulde not onely neglecte the ornamentes of the churche, but also that, wythout the whych (as we are borne in hand) it canne not long stande? Shall we thincke that he whych remembred the barres there, hath forgotten the pillers heere? or he that there remembred the pinnes, did heere forgette the master-builders? howe he should there remember the besomes, and heere forget Archbishoppes, if anye had bene needefull? 
No wonder that to the hierarchy such strong sense appeared dangerous. Accordingly a proclamation ${ }^{1}$ was issued, on $J$ une 11 , 1573 , denouncing the "Admonitions" and the authors as divisive. All persons were strictly charged to keep the preseribed order, and all who had any copies of the books to deliver them up within twenty days or go to prison. On the day after the expiry of these twenty days the Bishop of London wrote to Lord Burghley : ${ }^{2}-$

Althoughe the date of the late proclamation for bringinge in of the admonition to the parliament, and other sediciouse bokes is alredy expired, yet the whole Citie of London, where no doubt is greate plentie, hath not brought one to my hande and I can hardely think yat your Lordships of hir Maiesties privey Counsell haue receyued many.

At our distance of more than 300 years, it is difficult to recover and properly group even the main publications which had influence in this struggle, a difficulty immensely increased by the fact that those of the Puritans were so hunted by the officials that their surreptitious production only introduced them to a most precarious life. This comes out graphically upon one title-page, which, instead of an imprint at the bottom of the page, bears these lines :-

The Prynter to the Reader.

Thys worke is frnished, thankes be to God,

And he only wil keepe is from the searchers rod.

And though master Day and Toy ${ }^{3}$ watch \& warde,

We hope the liuing God is our sanegarde.

Let them seeke, loke, and doe now what they can,

It is but inuentions and pollicies of man.

But you wil marnel where it was fynished,

And you shal know (perchance) when domes day is.

Imprinted we know where, and whan,

Iudge you the place and [if] you can.

This book ${ }^{4}$ is a little black-letter of sixteen pages, whose object is to answer objections to the "Admonition."

A volume ${ }^{5}$ of nearly 200 pages soon appeared, apparently

1 Grenville Coll. of Procs. 150.

2 Lansd. MSS. xvii : 37.

${ }^{3}$ Officials bidden to suppress unlicensed printing.

4 Certaine Articles collected and taken ( $a$ s it is thought) by the Byshops out of a litle boke entituled An Admonition to the parliament, wyth an Answere to the same, etc., $15 \% 2,16 \mathrm{mo}, 15$.

5 A Defense of the Ecclesiasticall Regiment in Englande defaced by T. C. in his Replie agaynst D. VVhitgifte, 1574, 12mo, 11, 192, 122-132. 
anonymous, which makes heroic endeavor to answer the criticisms of the established order. It tries to show that the State Church already is very nearly what it should be, and the book is well seasoned with contempt for those whom it answers. In its eighth section, on the Presbytery, it offers perhaps its best contribution as to the real merits of the question, some of its suggestions being fair and weighty, e. g.: -

Now, if this be true that euery congregation had their seniors [elders], it is not like[ly] that Antioch, where Christiās first tooke their name, was rnprouided of so necessarie an office. But whereas mention is made of Prophets and Doctours, Act. 13, there is not a worde of Seniors : therefore it is not like that any such were there, and besides the questions of religion whiche fell out at Antioche, beeing decicled at Jerusalem, argueth no suche domesticall and neighborly iurisdiction. S. Paule repeating al the offices and functions of the Churche. Ephe. 4. speaketh not a worde of seniors, which maketh me doubt of their authoritie: for, otherwise I am sure the Apostle would haue alowed them a bench, though one of the meanest \& basest in the cōpany.

Whitgift took the field once more, late in 1574 , in a great black-letter folio. ${ }^{1}$ In the preface he insists that Cartwright's whole argument rests upon two "rotten pillers:" viz., that the Church in Apostolic times must be our model, and that we may not lawfully retain anything abused under the Pope. These he tries to knock away by proving that much is "left to the discretion and libertie of the Church." He seeks to demonstrate his own superior scholarship, by prefacing his plea with a list of twenty-one "dlangerous pointes of cloctrine," and another of fifty-one "vntruthes, and falsified authorities," all of which, he alleges, may be found in Cartwright's " Replye " to his former book. To his credit be it said, however, that he reprints that "Replye" paragraph by paragraph as he answers it; and, when needful, he even cites the original "Admonition," and also his own "Answere" to that which preceded the last " Replye," with which he now is dealing. But he is not always temperate in language; e.g., he declares that those who hold the new views not

1 The Defence of the Aunswere to the Admonition, against the Replie of T. C. by John Whitgifte, D. D. 1574, fol. iv, v, viii, ix, 256, 696, 697 . 
only refuse to go to church but also "spitte in our faces, reuile vs in the streates and shewe such like villanie vnto vs, and that onely bicause of our apparell."

As to one point, that in any event the civil magistrate should enforce church regulations, both parties were essentially at one. Cartwright had said : ${ }^{1}$ -

As for the making of the orders \& cerimonyes of the church, they doe (where there is a constituted and ordered church) pertayne vnto the mynisters of the church, and to the ecelesiastycall gouernoures, and that as they meddle not with the making of cyvill lawes and lawes for the common wealth: so the cyvill magistrate hath not to ordayne ceremonies pertayning to the churche. But if those to whome that doth appertayne, make any orders not meete, the magistrate may and ought to hynder them, and dryue them to better, for so much as the ciuill magistrate hath thys charge to see that nothing be done agaynst the glory of God in hys dominion.

Whitgift did not fail to point out the weak spot in this, for he replied :-

What if they [the ecclesiastical governors] saye they [their orders which the secular magistrate says are "not meete"] be meete, \& wil stand to it, as you do now in this fonde [foolish] platforme? will they not crye out vpon the magistrate, \& saye that he is a persecutour, a maynteiner of an vnlawful authoritie, \& of that which is against the glory of God, if he withstande the ?

But as to the main issue under this head, Whitgift only finds fault with Cartwright for not going far enough, and for resting in the same place which the Papists occupy.

Certain Church of England writers have represented that Cartwright confessed himself worsted and undertook no further discussion. ${ }^{2}$ On the contrary, during the next year he published a thick quarto ${ }^{3}$ in reply to Whitgift, followed within two years by another. The type of the former suggests that probably it came from the Zurich press, which at about the same time was printing the "Brieff discours off the troubles begonne at Franckford in Germany, Anno Domini 1554." The reasons of

\footnotetext{
1 Replye to Ans. 192.
}

2 Fuller, iv : 383 ; Heylyn, 275 ; Collier, vi : 509.

8 The second replie of Thomas Cartwright: agaynst Maister Doctor Whitgiftes second Answer, touching the Churche discipline. M.D.LXXV. 4to, xxvi, xi, 395, $667,668,666$. 
the delay in preparing the volume are stated to have been his poor health and his exile. Perhaps the weightiest considerations which Cartwright urges herein in reply to Whitgift are as follows. He gives this thrust at the reading ministers who lacked wit to make sermons : -

Where sermons are applied to the present eircumstance, whiche by chaunge off times, budding off new vices, rising of errors, \&c. vary almost every day: this kinde of interpretation (as that which is stareke and annimmed [benumbed] ean not poursue them. for when the preacher with his sermon, is able according to the manifold windinges, and turninges of sinne, to winde, and turne in with yt, to thend [that] he may stricke it: the homilies are not able to turne, neither off the right hand, nor off the left, but to what quarter soever the enemies are retyred, yt must keepe the traine wherin it was set off the maker.

He insists upon these two axioms: "The Scripture is a perfect rule off all actions, which can fall into mās life ;" and "the . churche gouernement, is one off the three markes off the Church: ... yt is safely taken, from the Apostels times: and daūgeronsly from the first 500. yeares after them." And his chief point, he sets forth thus in closing :-

Thus we are (by the grace off god) come, to an ende off this treatise, wherin let the reader indge, whether yt hathe bene proued that the offices off archbishops and archdeacons be rnlawfull, that they came not into the church 300. yeares after the ascension off our Sa. Christe: that there names are likewise vnlawfull by the worde, forbidde by auncient councels, not to be founde in any auncient writing before 400 . yeares approched. Further whether that enery congregation, owght to hane a bishop: that one onely may haue two or moe; that they owght all to haue like titles and autoritie. Sauing that in their meetings for orders sake one by consent of the rest gonerneth that action, in suche sorte as is declared . . . Finally, whether that euen the elder Bishops when they were declined from the synceritie off god's ordinance, and the archbishops and archdeacons which he never ordained : were much more tollerable then ours: as those whose autority was without comparison les, and pompe none at all.

Two years later Cartwright, ${ }^{1}$ still in exile, put to press the

1 It has been thought - and as to this Dr. Dexter learned that he had been misled in his Bibliography of 1880 - that Cartwright was the author of a small 
remainder ${ }^{1}$ of his second reply to Whitgift. In the former part he had eritically followed Whitgift's volume down to its diseussion of civil offices in ecclesiastical persons. In this second part he argues that it is unlawful for a minister of Christ to bear civil office; that church goverument by an eldership in every congregation is perpetual; that cathedral churches should be turned into colleges, or put to some good use; that exconmunication does not belong to the bishop alone; that the deacon's office is eleemosynary; and that baptism by private persons, especially women, is unlawful and void, etc. Upon one point he alvances a little beyond where he and his party so far had stood. As to authority, as between Church and State, he says: "As wel in the decision of the doctrine, as in the chois of the variable ceremonies of the church, the principal autority belogeth vuto the ministery."

For a short time no attempt seems to have been made to set forth in any systematic form the new polity which, in general, had been advocated in the "Admonition" and in Cartwright's books. But now and then the wide discontent thrust itself into notice. A fair sample of these exhibitions of feeling is this paragraph, dated $1574:^{2}$

O you Pastours, you Preachers, you Guides of the people, \& you pillers of the churches, $\mathrm{O}$ you maisters of this worke, \& surueyors as it were, of this building, doeth then the kingdome of heauen stande in eating and drinking? Can the Temple of God be sustained with Pluralities and Tot quots, ${ }^{3}$ with Deanries and Prebendes, with office and honour? hath not Christ ordained you as Lanternes of light, as salt of the earth, and ministers of Salvation? Is it not sayde you are Gods labourers, Gods worckemen, and the builders of Gods Temple? Howe happes it (then) that you bee builders of your own stoare, and

16mo, entitled An Examination of M. Dr. VVhitgiftes censures. Conteined in two Tables, set before his book intituled the defence of the Answere to the admonition against the Replye of T. C. 1575. But Cartwright said in the introduction to the Second Replye (xxx) that he had just seen this Examination, after he had ended that Replye; and that for the truth's sake he was glad to see it, and heartily thanked its author. This of course proves that lie did not write it.

1 The rest of the second replie of Thomas Carturight : agaynst Master Doctor V'vhitgifts Second ansuer, touching the Church discipline. M.D.LXXVII. 4to, ii : 1-31, 32-71, 73-76, 77-98, 79-115, 116-143, 170, 265.

2 E. Hake, A Tovchstone for this time present, etc., 1574, 8vo.

3 Exactions of annates already paid. 
not builders of Gods churche? Maintayners of your owne wealth, \& not sustainers of gods temple? feeders of your selues \& not of your flocke?

In 1574 Walter Travers - who had taken his degree in Divinity at Cambridge, had been connected with the beginnings of Puritanism in England, and had found refuge in Antwerp, where he subsequently, in 1578, was ordained by a Dutch synod - wrote a book, ${ }^{1}$ printed at Rochelle. Its object is to set forth the necessity of ecclesiastical discipline, with the facts that it can be made certain from the Scriptures and must follow them closely; and then to expound the functions of the Scriptural office-bearers, and the corresponding duties of the body of the Church towards them. It has a preface by some one else, said to be Cartwright. ${ }^{2}$

In the same year Cartwright, if, indeed, he did not translate it, superintended the issue from a Continental press of the same work in a black-letter English version. ${ }^{3}$ The preface is that of the other. The book itself is considerably extended - although with care not to modify the sense - particularly by the addition of two pages ${ }^{4}$ of direct address to the queen. The book asserts as fundamental that every human society must have some certain manner of government and discipline, and that for the church " let ... all thinges be exacted as nere as maie be vnto the worde off God." 5 It divides ecclesiastical discipline into ecclesiastical functions, and the duty of the remainder of the faithful.

1 Ecclesiasticae Disciplinae et Anglicanae Ecclesiae ab illa aberrationis, plena, è verbo Dei, \& dilucida explicatio, M.D.LXXIIII, 16mo.

2 Brook, Cartwright, 243.

${ }^{3}$ A full and plaine declaration of Ecclesiasticall Discipline out off the word off God, and off the declininge off the churche off England from the same, M.D.LXXIIII, 4to. Several times reprinted. The issues of Geneva $(1580,16 \mathrm{mo})$ and of Leyden (Wm. Brewster, 1617, 4to), with the original Latin and the earliest English editions, are in Dr. Dexter's collection.

4 Pages 188, 189. Also there appears to have been prefixed - there is no trace of anything resembling it in the Latin original - an elaborate analysis, or " a table or short view off all Ecclesiasticall Discipline ordained by the word of God," covering both sides of two large folding leaves. Probably owing to its size, and to the ease with which such prefixed or appended leaves suffer damage, it is now seldom seen. Brewster alone - in his Leyden issue of 1617 - reprinted it, making five and a half quarto pages.

5 Full and plain declar. 17, 1-17, 44, 57, 39, 89-109, 110-117, 118-125, 128-132, $161,177,178,185,187$. 
There are two sorts of ecclesiastical ordinary officials, the bishops and the deacons. No man may be appointed to any ecclesiastical office "but he that is called to a certen churche wherto exercise it." A minister must be maintained by the Church, but modestly. A plain black gown is most suitable as his apparel. The "consystory or councell of the churche" is declared to consist of pastors, doctors and elders. To it the keys of heaven are entrusted. It is declared an "Aristocratie, that is, that gouernment and state wherin a fewe off the best do beare the rule." The subject of Synods is touched upon lightly, probably not yet having been thought out. Every estate, including the magistracy, is declared subject to discipline; and then the weak point of the movement reveals itself in the remission of the whole essential work of the Church back to the world to gain its efficiency :-

But the Magistrates have this proper and peculier to them selves abone the rest off the faithfull. To set in order and establishe the state off the churche by ther authoritie and to preserue and mainteine it according to godds will being once established. Not that they should rule the Ecclesiasticall matters by their anthoritie, for this belongeth vnto Christ alone and to hym he hath committed this charge, but ... they ought to prouide, and see that the seruice off God be established as he hathe appointed, and administred by suche as ought to administre the same, and afterwardes preserued in the same simplicitie and sinceritie vndefiled.

A few years of comparative quiet followed the first clamor of this disciplinarian controversy. Yet this quiet had its uneasinesses for faithful men, an example being the case of Richard Gawton. ${ }^{1}$ He was charged before the bishop with having confuted the bishop's chaplain. He acknowledged that he had confuted some false doctrine of the chaplain. Then he was accused of repudiating lawful ecclesiastical authority, which he denied. A sharp discussion followed on the propriety of the name and style of "Lord Bishop:" and the bishop suspended the intrepid preacher, who commented on the act thus:-

1 The Troubles of Mr. Richard Gawton, of late preacher at Noruich, about Anno. 15\%6, 20 Aug. 396, 399. Reprinted, 1590, in 1 Parte of a Register, 393-400. Strype, $A n$. ii (2): 59. 
I perceine now that as was lately affirmed, if one had ... the diuinitie of S. Paul, if he were heere and woulde not weare the surplesse, you would put him out. Briefly answered [the Registrar or some official] they would doe so. And the Bishop vpheld it, saying: if S. Paul were here hee would were [wear] a fooles coate rather then bee put to silence. I answered, hee should then be contrarie to his owne doctrine, for if hee had rather neuer eat flesh, then hee would offend his weake brother, he would also be as scrupulous to goe against those rules the Holy Ghost had set downe by him.

The barbarism of the government towards those who differed from it as to any vital matters was mabated. Matthew Hammond, ${ }^{1}$ a plough-wright of Hetherset, Norfolk, was burned to death at Norwich on May 20, 1579, having the week before lost his ears, for denying the divinity of Christ and abusing the queen and council. And, on November 3, Jolm Stubbe, a gentleman and scholar of Trinity College, Cambridge, and a lawyer of Lincoln's Inn, London, had his right hand chopped off by the public executioner for a pamphlet against the threatened marriage of the queen with the Romanist and profligate Francis of Valois, afterwards Duke of Anjou. Before he fainted, he had time to wave his hat with his left hand and shout, "God save the Queen!" and he lived, after a merciless imprisonment in the Tower, to be employed by Lord Burghley in the refutation of Cardinal Allen, ${ }^{2}$ to distinguish himself in the Irish wars, and finally to be buried in the sea-sand of France with military honors.

1 Soames, 234.

2 Then, as usually after his misfortune, he added Scaevus (left-handed) to his signature. 


\section{CHAPTER V}

\section{MORE BATTLES OF THE BOOKS}

LATE, it seems, in 1583 or early in 1584 began another battle of the books about church affairs. It was opened by William Stoughton, a professor of the civil law, in a volume ${ }^{1}$ intended to prove by existing statutes that a learned ministry was commanded by law, that pluralities were prohibited, that excommunication by one alone was unauthorized, that an ecelesiastical person could exercise no civil authority, that it was unlawful to ordain a minister without a specific charge, that the manner of archbishops', bishop's', and archdeacons' visitations was unwarranted, and that fees for Letters of Orders were forbidden. After condemning the incompetent clergy, he refers to the prevalent injustice and favoritism, and says : ${ }^{2}$ -

May a Byshop depriue an honest poore man from his benefice, dispossesse a faythfull man of his Ministerie, stoppe the mouth of the Lordes watchmen, and imprison a paynefull [conscientious] teacher in the Clinke, in case hee weare not a Surplesse, in case he marrie not with a Ring, in case he crosse not in Baptisme, or in case hee subscribe not to euerie newe Article inuented by his Ordinarie? And may not the same Bishop remone a man that hath openly played the hypocrite, publikely falsified his word. . . . If a Puritane (as they call him) making conscience not to offende his God in any small thing, for his conscience sake bee worthie to be whipped-and excommunicated ; is a Foolitane, making no conseience to offend his God in all thinges not worthy once to be summoned?

The first and second of Stoughton's contentions soon were replied ${ }^{3}$ to by Richard Cosin, LL. D., Dean of Arches and

${ }^{2}$ An Abstract of Certain Acts of Parliament: of certaine her Maiesties Iniunctions: of certain Canons, Constitutions and Synodalles prouinciall: established and in force, for the peaceable gouernment of the Church, etc., 1584, 4 to.

290.

${ }^{3}$ An Answer to the Two first and principall Treatises of a certeine factious libell, put foorth latelie, without name of Author or Printer, and without approbation by authoritie vnder the title of "An Abstract," etc., 1584, 4to, 1, 33, 170. 
Vicar-general of the Province of Canterbury; who, although a civilian, had been granted ecclesiastical jurisdiction. $\mathrm{He}$ begins with a sweeping characterization :-

It seemeth to mee that the principall scope of the authour of this booke was, couertlie to bring the gouernours and gouernement ecclesiasticall of this church of England into contempt, hatred and obloquie, speciallie with preiudicate and vnwarie readers of it; as though the said gonernours were either grossely ignorant, or wilfull breakers of lawes, canons, \&c. in force, touched in this booke.

This is not without some warrant. But the reader may decide that he sometimes uses strong language not only in response to that of Stoughton, but also because of the difficulty of effective reply to the uncomfortably telling arguments of the "Abstract." Perhaps his strongest position is that.

there are not set downe in particular by Scripture, or by necessarie collection to be gathered, all circumstances of policie, gouernement, discipline and ceremonies necessarie and vniformlie to be vsed in enerie seuerall church: and that the christian magistrats and gonernors are not in the said former points, whereof something is touched in scripture, of necessitie tied to that precise forme that is there set downe, but to the generall doctrine concerning them; to wit, that all be done to edifieing, orderlie, comelie, and such like.

And perhaps the weakest is the insinuation against the " $\mathrm{Ab}$ stract" that, if its charge that the existing ministry is largely unlearned be true, danger to property interests will arise, due to the possible invalidity of marriages and baptisms.

Dudley Fenner - who had left Peterhouse at Cambridge before graduating to take the ministry of Cranbrook, Kent, and, dissatisfied with the State Church, had gone to Antwerp and Middleberg to be chaplain to the English merchants - speedily replied to Dr. Cosin in a modest, yet effective, little $16 \mathrm{mo},{ }^{1}$ in which he considers objections made to the new discipline and argues strenuously for the eldership. It will illustrate how far the Puritans of those days were from favoring any really popu-

1 A Counter-poyson, Modestly Written for the time, to make aunswer to the obiections and reproches, wherewith the aunswerer to the Abstract would disgrace the holy Discipline of Christ, London, 1584. When reprinted in 1590 by Waldegrave (Parte of Reg. 412-505), Fenner's name was prefixed as author, he having died in 1587. Ibid. 387 . 
lar church government to note how Fenmer parries one of Cosin's statements. Cosin had said : ${ }^{1}$ -

He saith, that All the faithfull of the land have an interest in choise and allowance of their pastors. So that by this reckoning, men, women, and children (for all the faithfull be interessed) shall have voices in election of their minister; and if one dissent, all must be dashed, if we follow that rule.

Which Fenner answers thus: ${ }^{2}$

Hee is not ashamed in steede of encountring with the trueth, to frame himselfe an vnknowne aduersarie, that is, in steed of onerthrowing the consent of people in Church-elections, to make warre against a meere populer Election, not gouerned with fore-direction of the Elders, which hath no ground in the scriptures, and was neuer maintained (as himselfe confesseth) but by Anabaptists.

To the objection that the new discipline would destroy the queen's rightful authority over the Church, Fenner replies that those for whom he pleads are far from advocating, or even conceiving, the idea of any proper church-independency of the State. Soon after - probably ${ }^{3}$ at the bidding of his ecelesiastical superiors - Dr. John Copeot, then a fellow of Trinity, and later Master of Corpus Christi College, Cambridge, preached at Paul's Cross a defence ${ }^{4}$ of the existing constitution of the Church against Fenner's assault. Besides arguing squarely against the Eldership, he accuses the Puritans of denouncing the Church of England as " no Church but after a sort," because "it lacketh Discipline." This was denied ${ }^{5}$ as soon as the manuscript sermon could be obtained :--

Our wordes, our preaching and writinges have alwayes witnessed that we holde the Churche for a true Churche of Christ, from which no member may separate him selfe: although he must disallowe the

1 Ans. to Abstract, 99, 206.

2 Counter-poyson, 24, 28.

8 Strype, $A$ n. iii (1) : 344.

4 A Sermon preached at Powles Crosse in 1584, wherein answeare is made unto the autor of the 'Counter-poyson,' touching the sense of the 17th verse of the fifte chapter of the first to Timothye, etc. Lambeth Ms. ccelxxiv: 115. An extract - the sermon seems never to have been printed in full - is in A Parte of a Reg. 507-508.

${ }^{5} \boldsymbol{A}$ defence of the reasons of the 'Counter-poyson' for the maintenance of the Eldershippe, against an answere made to them by Doctor Copequot, etc., 1586, 16mo, 9, 31. Usually attributed to Fenner (Ath. Cant. ii : 73), but the introduction implies that some one else wrote it. $\mathrm{He}$ distinguishes himself from Fenner, and hopes that Fenner "will take it in good part." 
wantes in her. Wee haue alwayes when subscription was vrged, bin readie to subscribe to the Article of her Maiesties authoritie, and to the substance of doctrine, in as large a manner as the statut in that behalfe required. ... Wee have by writinge defended the cause of the Churche and our Prince, as much as they, that we say no more. . . . Haue we not by perswasions continued many in the bosome of the Church? Yea whe through weaknes, because of many abuses they would have departed? Hane wee sought redresse by any other meanes thā by hīble supplication towards our Superiours according to duetie?

An argument of great force follows in proof that the Ellership, having confessedly had existence once in the Church, is perpetnal.

The movers in this reform comprehended that their best hope of success lay in influencing those masses of the people intelligent enough to comprehend and have an interest in the subject, yet not high enough socially to feel conclusively the adverse influences of the Court and the hierarchy. One method wisely adopted was that of an appeal through the popular form of the dialogue. Gilby's effort of the sort nearly twenty years before has been referred to. Three similar endeavors now were made, in 1584,1588 and 1589. The first ${ }^{1}$ was anonymous and was printed openly in London. There are four speakers: Orthodoxos, a divine who argues for Puritanism; Philodoxos, a lawyer, leaning towards candor, yet no convert to the new way; Philochrematos, a bishop's chaplain, who champions the Establishment; and Philodonos, an inn-holder, full of the prejudices of his class. In the preface the writer draws a sad picture of the neglected condition of the Church.

Philodonos begins by the stereotyped complaint that " there be so manie new-fangled Preachers," who "keep small hospitalitie themselues, and not content with that, they preach and crie out against it in other men," so that inn-keepers make but "slender provision." He well remembers "when a dozen or sixteene Gentlemen and wealthie yeomen haue met together, and made merrie foure or fiue daies, or a weeke, at cards or Bowls, as the time did serve. Nowe all good fellowship is laide aside, the worlde is waxen stark nought." Orthodoxos speaks of the real condition of multitudes of pulpits in England

1 A Dialogue concerning the strife of our Churche: ete., 1584, 16mo, 71, 95, 100. 
at that time with a severity justifiable only because of its tremendous truth :-

Are there not a rablement of vngodlye \& vnlearned mé appointed to be guides ouer the flock of Christ? Is there not lesse account made of the soules of gods people, then men make of their hogs? Are there not in sundry places poore sely creatures which were Popish priests, that a man shall hardly find any so simple in all their parish, such as coulde hardlye liue : as seruing men, bankrupts \& vnthriftes, have they not knocked at the gate and bin let in? Tailers, sadlers, shomakers, and other handy crafts men that could scarce read english before, are they not consecrated, and become masters in Israel? A multitude of such as are idle, and cannot indure to take any pains, but lone to play at bowls, cards \& tables a great part of $y^{\mathbf{e}}$ week, and to be at the alehouse drinking among good fellowes, have founde the ministery $\mathrm{y}^{\mathrm{e}}$ fittest place to serne their turne. For their chiefe worke is vpon the Sunday to read an Homely, and then he hath preached as wel as he that studied hardest all the weeke. Are there not drunkards, adulterers, and men spotted with manye foule vices in this holy function.

And, to the plea that, although many of the clergy be "blinde guids" yet the people do well enough, because "they depende upon the bishops and Archdeaeons, which can see better than the Puritans," Orthodoxos replies:-

Noe, no, they can see that they shal be kept in blindnesse, as they are, but what ean they doe vnto those whome they nener saw nor knew? doth there goe such vertne ont of a Byshoppe or an Archdeacon, that it can spreade itselfe oner all the Conntry, enen to sane their soules, that neyther heare nor see them? shall the blinde bee ledde by those that neuer come nigh them, or by those that are presente and take them by $\mathrm{y}^{\mathrm{e}}$ hand? for shame, holde youre peace.

As to the aetual spiritual needs of the people, he adds:-

There be thousandes which bee men and women growen, which if a man aske them howe they shall be saued they can not tell. As for wickednesse, in pride, enuie, hatred, \& al sinns yt can be named almost, it doth oner flowe, \& yet you are not ashamed to say, are they not christians? do they not call vpon God at their ende?

The second dialogue, ${ }^{1}$ soon burned by the authorities, ${ }^{2}$ which

1 The State of the Church of Englande, laide open in a conference betweene Diotrephes a Byshopp, Tertullus a Papiste. Demetrius an Tsurer, Pandochus an Inne-keeper, and Paule a preacher of the worde of God [by Joln Udall], 15s8, 16mo (Arber's ed.), 6,31 .

2 Demonstr. of Disc. viii. 
beyond doubt was by John Udall, who soon after printed the first brief systematic manual of the new way of discipline, is shorter and abler. There are five speakers. Diotrephes, the bishop, and Tertullus, the Papist, meet Demetrius, the usurer, and Paul, the preacher, in the house and presence of Pandochus, the inn-keeper. As before, the host begins, and by finding fault.

Our towne standeth on vitelling, because it is a thorowfare, and he [the Puritan rector] preacheth against good fellowship (which hee calleth drunkennesse) and against playing at cardes and tables, wherein, if he might have his wil, I and my neighbors might go on begging within one twelue-moneths, and he hath so preuailed, that I take not so much by foure pounds in a weeke, as I was woont to doe: yea I have had ten shillings of one man in a weeke for drincke onelie, that will nowe scarce spend three.

In general this dialogue resembles the other, but the Conclusion ventures a definite suggestion touching a petition to the queen.

The third dialogue, ${ }^{1}$ anonymous, has four speakers: Puritan, Papist, Jack-of-both-sides, and Idol Minister. It is intensely severe upon the Establishment. Says Puritan :-

Wel, he [the bishop] stands in the state of damnation as you [Idollminister ] doe, and thus much I say vnto you and to all ministers, and to him, and all vsurping Archbishops and Lord Bishops: leane your vnlawful callings into which you haue intruded your selues, and with speed repent, and humble your selues before the Majestie of God, confessing your horrible and greenous sinnes with Peters teares, in that you are the cause, yea and also the verye murtherers of so manye soules, as perish in your charges.

The same method also was adopted by others of different judgment. Two instances should be noted, in 1582 and 1589. The tone of each, however, suggests that it came, not from a violent Churchman, but from somebody in sympathy with the effort to deepen and enrich its piety, yet no Separatist. The former, ${ }^{2}$ indeed, was an early production of one who started

I A Dialogue vvherin is plainly laide open the tyrannicall dealing of L. Bishops against Gods children : with certaine points of doctrine, etc., 1589, 12mo, 10.

2 A Briefe discourse of certaine points of the religion which is among the commo sort of Christians, which may be termed the Countrie Diuinitie, etc., 15\$2, 16mo, v, 1 verso, 17 verso, 22 verso, $18,23,76$. In the same year he published, in another direction, A Dialogue betweene A Papist and a Protestant, applied to the capacitie of the unlearned, $16 \mathrm{mo}$. 
with the Puritans but became an antagonist of the Separatists, George Gifford, minister of Maldon, Essex, educated at Hart Hall, Oxford. In its Epistle Dedicatory, to the Earl of Warwick, it strongly confirms the complaints by the Puritans of the deplorable condition of ecclesiastical affairs :-

Our church therefore \& common wealth, being the Lords husbandrie, is ouergrowne with weedes \& almost laid waste . . Among which [causes of this condition] the want of a sincere ministerie of the woorde is the greatest through absence of which, there is a flood of ignorance and darknes, onerflowing the most part of the land: the feare of God is banished from the greatest parte: the woonderfull heapes and piles of sinne, which should bee washed and cleansed away by the word, do vudoubtedly with one voice cry alowd in the ears of the Lord, for vengeance vpon the whole realme:

To convince of their danger " indifferent" men, who want to enjoy the world and little mind what coat of religion they wear, is the design. The characters are Zelotes, a mild Puritan, and Atheos, one of the class referred to. Atheos goes to church and likes the parson. When asked why, he replies :-

Hee is as gentle a person as euer I see: a verye good fellowe, hee will not sticke when good Fellowes and honest men meete together too spende his groat at the Alehouse.

When asked if this parson is able to teach the people, Atheos answers:-

I knowe not what teaching yee woulde have; hee doeth reade the seruice, as well as anye of them all, and I thinke there is as good edifying in those prayers and Homilies, as in anye that the Preacher canne make.

Zelotes reminds him that a boy of ten years old can do all this, and wants to know if the parson "reprooue naughtinesse," to which Atheos answers :-

Yes, that hee doeth, for if there bee anye that doe not agree, hee will seeke for too make them friendes: for hee will gette them too playe a game or two at Bowles or Cardes, and too dryuke together at the Alehouse: I think it a Godlye waye, to make Charitie.

The faithfulness with which those still unmoved within the Establishment are dealt with appears thus :- 
Zelot. This is a common thing among all the packe of ye, if there be any man which hath a care to know God, and seeketh after his worde, \& will not cōmit those beastly sins which ouerflow in all places, then you which cannot abide to haue Gods word set foorth, deuise a number of lies and slaunders against them, calling them Puritanes, rascals, and many such like. On the contrary part, let a man be a common drunkarde, a Dicer, an ignorāt beast, which hath no knowledge of God, a wretched worldling, or any kinde of such person : he is an honest man.

The truth as to the relation of good men to the law also is set forth well : -

Zelot. Hee whiche doeth disobeye the Prince, doeth disobey GoD vnto his damnation, where the prince setteth foorth and mainteyneth Gods worde. But if there be a prince whiche maketh lawes against the lawes of God, wee must obey Gon rather then men.

The point of view of the author as to Puritanism is explained thus :-

Atheos. Naye you that are precise Puritans doe find faulte where there is none: you condemne men for euery trifle.

Whereas ye are but men, and hane your infirmities as well as other : yet yee woulde make your selues as holye as Angels.

Zelotes. I abhorre the errour of the Catharistes or Puritans, I confesse that I am loden with corruptions: if that be your meaning, to charge mee with that opinion, which is wicked and diuelishe. But if yee take the name Puritane for one which hath more care to obey God, then the common sort, and therefore laboureth to keepe him selfe pure and vnspotted of the worlde (as Saint James speaketh) then looke to it, that yee be not founde among those which reuile not men but God. If ye meane by precise men, those which are so scrupulous, as to make sinne where there is none, as your wordes doe playnely showe, then doe I vtterly renounce that name.

The second dialogue ${ }^{1}$ is anonymous and also has two speakers: Sophronius, a zealous churchman, and Arizelus, a weaker and more impetuous brother, who, having failed to find edification in the husks of the parson of his parish, Master Timotheus, has been attracted by the sermons of Master Eulalus, the earnest rector of a neighboring village. Of course Sophronius gets the

1 Sophronistes: A Dialogue perswading the people to reuerence and attend the ordinance of God, in the Ministrie of their owne pastors, 1589, 4to, 16, $6 \mathrm{~s}$. 
better of the argument and persuades his friend to attend the parish church. The kernel of the argument lies chiefly in this paragraph :-

Sophronius. God is not onely the author of the Ministery, but also the addresser and disposer of the seueral labors of his seruants. And therefore what iniurie is done vnto the ordinance of God by the Minister that refuseth to teach those vito whom he is particularly sent: the same iniurie is done vito his prouidence, by those of the people that refuse to be taught by him whom the Lord hath expressely sent vnto them, and vnto whose ministery he hath subiected them.

The claim that ability to teach is essential to a minister is parried thus :-

It [this ability] hath in deede more affinitie than other parts that should be in him. Yet, . . I take it not to be simply essentiall, as that without which he is no minister.

Something also was done by printing sermons. One was issued six years after its delivery - and in at least three subsequent editions, one printed by William Brewster at Leyden a discourse ${ }^{1}$ at Paul's Cross, October 26,1578 , by Dr. Laurence Chaderton. He was a great light of Cambridge, and Master of Emannel College, and when in advanced years - he lived to be over 102 - he resigned his lectureship at St. Clement's forty clergymen begged him to reconsider, declaring that they owed their conversion to him. His allusions to the bishops and the clergy are quite as severe as any others. On another point because, although he had marked Puritan sympathies, he stood high in public esteem, was one of the translators of the "Anthorized "version of the Bible, and always was noted for moderation - his testimony may be taken safely as conclusive. He says :-

1 A fruitful sermon vpon the 3.4.5.6.\%.\&.8. verses of the 12. Chapiter of the Epistle of $S$. Paule to the Romanes, etc., 1584, 16mo, 3:, table opp. 1, 62, 42. Not usually recognized as by Chaderton, and his latest biograplyy (Dict. Nat. Biog. ix: 430) ignores it. But Brook (ii : 446) says that he preached at Panl's Cross and that his discourse was printed; and Ainsworth (Counter-poyson, 206), Fairlambe (Recantation, 19, 27), Francis Johnson (Certayne Reasons, 6), and John Robinson (Relig. Communion, ii : 81 ) refer to, or eite from, it and call it Chaderton's. Also C. Bowman (Harl. Ms. 7042, iii) deposed that "he was drawn to his present course by a book of a sermon upon the 12. of Romans, made by Master Chatterton." Clearly Chaderton's contemporaries believed him its author. 
If it bee demaunded why there is in the Lande such grosse ignoraunce of God? the aunswere is at hande, wee wante Doctoures and teachers. Whence come such swarmes of Atheistes, Idolaters, Papists, erronions and hereticall sectaries, of the Family of Loue and such like? there are no doctors to teach, nor pastors to exhort. How commeth it to passe that in a Christian church, professing newnesse of life, and the doctrine of regeneration, there shoulde bee such a huge masse of old and stinkinge workes, of coniuring, witcheraft, sorcery, charming, blaspheming the holy name of GoD, swearing and forswearing, prophaning of the Lordes Sabbothes, disobedience to superiours, contempt of inferioures: murther, Manslaughter, robberies, adulterye, Fornication, couenant-breakers, falsewitnesse-bearing, liars with all other kindes of vniversall dealing one with another? Is not the cause euident? wee lacke Elders and Gouernours of euerye congregation to admonish, correct, suspende and excommunicate such noysome, luurtfull, \& monstruous beastes, out of the house of GoD, without respect of persons.

In general this sermon is an earnest, effective plea against the Church of England as it was, and in favor of essential Presbyterianism. It argues that the six verses of its text contain a perpetual law, tonching the government of Christ's Church; under certain officer's, to wit: "Pastours, Doctours, Elders, Deacons, and Widowes;" and it condemns the Church of England for lacking these, and, on the other hand, for having such "as namely the callings of Archby[shops]., Bysh[ops]., Deans, Archdeacons, Deacons, Chancellers, Commissaries Officials," etc.

To this discourse Thomas Rogers, rector of Horninger, ${ }^{1}$ replied in 1590 . He became well known later by his standard Exposition of the Thirty-nine Articles. $\mathrm{He}^{2}$ tries to refute the "Fruitful Sermon," but ends evasively, apparently meaning to show that, even if the positions argued against be mainly true, they do not justify the conclusions drawn. After citing what he esteems adverse opinions from Calvin, Bullinger and Beza, he says :-

Yee see the Iudgment of theis men also against the determination of our Auctor, and that in ordering our Church we are not so much

1 Now Horningsheath, Bury Sṭ. Edmunds.

2 A Sermon vpon the 6. \% and S. Verses of the 12. Chapter of S. Paul's Epistle vnto the Romanes, ete., 1590,4 to, 61 . 
to respect what 'Th' apostles did, as to what ende; the best reformed Churches in this matter of Gouerment do differ; none have the same discipline; neither is it meete theie should; theie all content themselves with a gonerment which is tolerable, and not contrarie to Gods word; ours is commendable (God be praised) we maie be content.

Direct appeal to the queen and the highest court of legislation also was not neglected. When Parliament assembled, late in 1585 , a $16 \mathrm{mo}$ pamphlet was circulated privately among its members, ${ }^{1}$ one also being addressed to the queen. The latter, about half as large as its fellow, alleging ${ }^{2}$ that " the greatest part of the people of the land, are altogether blinde and ignorant of true religion," and that in congregations of one or two thousand souls not over four or five persons can "giue an account of their faith in any tollerable manner," beseeches "the establishing of a learned ministerie, whereby wee may all knowe the Lordes good will and pleasure." It proceeds :-

We pray your highnes ... that... you woulde not sende vs to the Bishops of this lande, or commit this charge of establishing of an holy ministerie vnto their fidelitie. For if they shoulde solemnely promise your Maiestie, and that with an oth, that they woulde haue speciall care of this matter, yet wee could not bee induced to beleeue that they would performe it, either could wee conceive any comfort by such words. Because that by the space of this nine and twentie yeares, their vnfaithfulnes hath manifestly appeared, in that they hauing power, haue not prouided for vs themselues, no not so muche as lawe requireth, neither at any time sought means either in Conrt or Connsell, that euer wee coulde learne, to satisfie our hungrie soules with bread.

The other, ${ }^{3}$ and more labored, pamphlet, addressed to the Parliament, has one effective feature, the graphic portrayal of the result of any attempt at conversation on personal religion with the great majority of the people. Speaking of the common sort of rectors, it says :-

I The humble petition of the Communaltie to their most renowned and gracious Souereigne the Lady Elizabeth, etc., 1585, $16 \mathrm{mo.}$

2 The citations are from the reprint of $1588,5,26,40$.

3 A Lamentable Complaint of The Commonalty, By Way of Sipplication to the High Covrt Of Parliament For A Learned Ministery, 1585, 16mo, 21, 10, 12, 24, $28,59,64$. In the second edition this is a dialogue, as in the later reprint in $A$ Parte of a Register. The later edition is cited (1588), 27. Parte of Reg. 212. 
So we pray you to trie these men, their congregations, which in some places are more then two thousand soules, and see their work: moue but these small questions to trie their knowledge and you shall haue the like answeres for the most part.

Question. Honest man, are you not a sinner?

Ans. Yea, the best of vs all are sinners. . . .

Quest. But how shall you bee saued from your sinnes, tell me that? Ans. By my good workes, and by my good deedes I hope: and some better learned will say, God is mercifull.

Quest. Through whom is God mercifull unto you :

Ans. I cannot tell that, for I am not learned.

Quest. Then I will tell you, God is mercifull through Christ. But what was Christ?

Ans. A man, 1 trowe.

Quest. And was he no more?

Ans. Yes, he was more.

Quest. What more?

Ans. I tolde you that I am not learned to answer such deep questions, for I was neuer asked the like before.

Quest. Are you not certainely perswaded that you shall go to heaven?

Ans. No, for you cannot be certaine of that your self, but I hope well, and meane as well as the best of you Scripture men.

Its great appeal is for a ministry godly and able to teach. The "simple people" are content that their parson "spare to speake . . . in the Latine, Greeke, \& Hebrew tongues " which they understand not; they desire not ministers "whome the Lorde hath not sent, and sanctified to the work of the ministery;" and they need more than "quarterly sermons;" as to which it says : -

Yea, our children will as soone learne the Latin tongue by going to schoole 4 . houres in a yeere, as we that be children in vnderstanding the scripture, shall attaine to a true knowledge and reformation of life fit for a Christian man, by hearing 4 . sermons yeerely.

And they plead further :-

If euery one of you [members of Parliament] . . . should deuise many strong lawes for the preseruation of her majesties person (whom the Lord blesse for euer) the peace and prosperitie of this land ; and the subversion of our enemies the Papists and Iesuites, \& passe ouer this law for a learned ministery ... those good lawes would be as 
weake and fraile to bind fast the head strong papists and Iesuites, as were the 7. greene withs neuer dried, and the new ropes nener occupied able to bind mighty SAMson.

The spirit with which such appeals, manifestly saturated though they were with devont sincerity, were received by the bishops and their friends, is obvious from the nearly contemporaneous criticism of this one by Dean Sutcliffe, of Exeter. He speaks of it incidentally thus : ${ }^{1}$

A discourse in the opinion of wise men very preiudiciall both to her Maiesties authoritie and Lawes, and also to the peace of Gods church, and propagation of the Gospell, and certes very offensive for diffaming of diuers honest men and loyall Subiects, and that before the Princes presence, which was not therein respected'; and, to cease to speake much of a discourse so little worth, very rnsufficient and euilfeatured, beeing stuffed with many weake and false allegations, and much frivolous and idle talke as it were of a dyscrasied braine.

In elaborating the details of the proposed new church government, good progress was made, especially when the many difficulties are considered. William Fulke, D. D., after study in the common law as well as theology, and various services at bome and abroad, had been elected Master of Pembroke Hall, Cambridge, in 1578 . In 1584 he sent out, without his name, a little $16 \mathrm{mo},{ }^{2}$ whose unpretending issue was like the touch which discharges a Krupp gun, the preliminary to a tremendous explosion, since it brought on the famous Martin Mar-Prelate controversy. In this he simplifies and reaffirms several essential principles of Travers's "Declaration" of ten years before, in his "Praeface to the Christian Reader," strongly urging her Majesty and the Council "to appoynt on both sides the best learned, most Godly \& moderate men to debate all differences of vvaight." In the body of the work he declares pastors, doctors, governors, and deacons the only "offices instituted of God" for the Church. To the objection that, in the existing condition of learning, it would be impossible to provide all churches with a teaching ininistry, he replies :- -

1 An Answere unto a certaine calumnious letter, etc., 1594, 4to. To the Reader, viii.

${ }^{2}$ A Briefe and Plaine Declaration. concerning the Desires of all those faithfull Ministers that haue and do seeke for, the Discipline and Reformation of the Church of Englande, etc., 1584, 16mo, 7, 37, 40, 119, 125, 138, 141, 145. 
It is a thing necessarily required at our hands by God almighty, and therefore we must object no impossibilitie, especially whe our owne negligence is the cause of all the difficultie, or, if you will so call it, impossibilitie. We confesse it will be harde at the first, but we must doe our endenour, and commit the successe vnto God, and there is no doubt but in time it will grow to an happy ende. . . .

Synods, he explains, have "authority to decree concerning ceremoniall orders of the Church: Whereof some may be generall to al congregations, some particular to certaine Churches." When a pastorate is to be filled, the Elders "ought to enquire . . . wher they may finde a man meete to supplie his roome, and therein to desire aide of the Synode." Such a man ought to be accepted by the congregation, unless reasonable objection can be made. This " is the right election and ordaining of Pastors, grounded vppon the worde of God, and practised by the primative Church, two hundred yeeres after Christ."

The difficult problem of the inter-relation of the civil and ecclesiastical authorities is made as clear as the partially selfcontradictory theory then held would admit:-

It is the chiefest poynt of their [civil rulers] dutie, to hane especiall regarde that God may be glorified in their dominion, and therefore they onght to make cinill lawes to binde the people vnto the confession of true faith, and the right administring and receining of the sacramentes, and to all ecclesiastical orders. ... If any shall offende against the laws, whether he be preacher or hearer, beside the ecclesiasticall censure, which he shoulde not escape, he is also to be punished in bodye by the ciuill magistrate. . . .

Four years later John Udall sent forth, anonymously and from a secret press, a condensed, systematized, and, one might say, scientific treatise ${ }^{\mathbf{1}}$ in exposition of the new consistorial discipline. He begins by an unwisely harsh address "To the Supposed Gonernours of the Church of England, the Archbishops, lord Bishops, Archdeacons and the rest of that order," saying :-

Will you still continue in your damnable, and most diuelishe course? . . . You are the cause of all the ignorance, Atheisme, schismes,

1 A Demonstration of the trueth of that Discipline which Christ hath prescribed in his worde for the gouernement of his Church, in all times and places, vntill the Ende of the Worlde, etc., 1588 (?), 16mo. Printed again in 1590, ad cal. to Parte of Reg. Svo, 1, 2, 4, 5, 8, 85, 74-76. 
treasons, poperie and vngodlines, that is to be founde in this lande, etc.

The chief purpose of the treatise is to prove that the charge commonly made against the "new discipline," that its advocates were seeking to set up something " not warranterl by the Worde, not heard of in the Church of God, vntill within this few yeares, nor tollerable in any Christian Common-weal," is false. He reduces the whole subject to definite propositions, usually extracted from the "Admonitions to Parliament," or some treatise of Cartwright or Fenner, and defends them, often by citations from the Fathers or later Church writers. All is summed up as follows:-

'Therefore, vpon these grounds of Scriptures, Fathers, Coũcels, Emperours, Lawes, Histories, newe Writers and cleare light of reason, I conclude, that ( $a$ ) Christ hath prescribed vito vs an exacte, and perfect platforme of gouerninge his Church at all times, and in all places: which is this, $(b)$ that there ought to be no ministers of the worde, but Pastours \& Teachers, whiche are to be $(c)$ called by the people, and $(d)$ ordained by the Eldership, are $(e)$ of equall authoritie in their senerall congregations, must $(f)$ with all faythfull diligence imploye them selues, in the ministerie of the worde and Sacramentes, $(g)$ that there are to bee in every Congregation, certaine Elders, whose office is to ouersee the behauiour of the people, and assist their pastour, in the gouernement of the Church : also $(h)$ Deacons, who are to be imployed only in receyuing, and bestowing the liberalitie and goods of the Church, to the reliefe of the poore, and other necessarie vses: Lastlie, (i) that there must be in every Congregation an Eldership of Pastour, Teacher, (if they can have any) and Elders, who are in common, to see that the Church be well gouerned, not only in maintayning the profession and practize of the worde in generall, $(k)$ but also in admonishing, reprehending, or $(l)$ separating from the Lordes Supper, them that walke offensiuely, and $(m)$ lastlie in excommunicating them, that by no other meanes can be reclaimed. So that all and euery gouernement, contrary [to] or besides this, whether in parte or in whole, swarueth fro that order, which Christ hath set downe in his worde and therefore is vnlawfull.

It will show at what points the proposed changes tonched the public interest and welfare, to cite from the fourteenth chapter the chief objections urged against this Presbyterian plan, with Udall's replies. 
1. Obiection. By this euery parishe shal followe their Seniors, ${ }^{1}$ and then there wilbe so many Elderships, so many diuers fashions, seeing one may not medle with another.

Answere. The gouernement desired is vniforme for euerie Church, and admitteth no change, no not in outwarde ceremonies, without a Synode of the choyce men of seuerall Elderships.

2. Obiection. If they being all meane men, chuse an Earle, he may not refuse, but be at their becke and commaundment.

Answere. No man that is chosen is compelled to an office against his will, but he that despiseth to consult with others in Gods matters, becanse they bee poore, reprocheth God that made them. Prou. 17. 5 .

3. Obiection. It ouerburdeneth the parrishe, to prouide for thie nourishment of so many Church-officers.

Answere. It is not necessarie that they should prouide for any moe of them, sauinge those that are exercised in the ministerie of the worde, vnlesse any of the rest may neede the liberalitie of the Church.

4. Obiection. It bringeth in a newe popedome and tyramnie into the Chureh.

Answere. It is blasphemie to tearme the gouernement of Christe so, because we refuse the tyranny of the pope, shall we therfore doe what we list, and not yeelde obedience to the scepter of Christ.

5. Obiection. It is a kind of Donatisme ${ }^{2}$ to chalenge such authoritie ouer Princes.

Answere. And it is flatterie to suffer princes to doe what they liste : this is the obiection of Gualter, who is a professed enemie to discipline.

6. Obiection. It taketh away princes authoritie in causes Ecclesiasticall.

Answere. No more then it did from Dauid in his time, nor so much as the $\mathrm{Bb}$. [Bishops] do nowe, for the prince requireth but this, to see the church well ordered, which the Eldership alloweth and craveth.

7. Obiection. It transformeth the state of the common wealth, into a meere popularitie, and will alter the gouernement thereof.

Answere. It neither transformeth nor altereth any thing in it, for let it be shewed what damage would come by this discipline to any Magistracie, from the Princes throne, to the office of the headborow.

8. Obiection. It wil breede contention and partialitie in iudgement.

1 The session of Elders in that parish.

2 The Donatists were a powerful sect in the beginning of the 4th century in North Africa. It held sometling like the modern theory of the Church's independence of the State, and the spiritual dependence of rulers, like private persons, upon the Church. 
Answere. Where can be greater contention then the Bb. maintaine for their kingdome, or greater partialitie then in them, to their kinsfolkes, seruantes, Sycophants, \&c.

9. Obiection. It will bee contemmed, and so good order neglected.

Answere. None euer deserued more contempt, then the BB. and their officers doe, for all their pompe : but God whose ordinance it is will procure sufficient awe vnto it. marke howe these obiections stand together, in the 4. it was tyramie, and here it is too contemptible. These be contrary.

10. Obiection. All alterations be dangerous.

Answere. Nener (where we change from the obedience of Antichrist, to the seruice of the liuinge God) was it euer daungerons to amende things amisse, by that course whiche is described of God: etc.

The reputed author of a volume which told so many disagreeable truths could not eseape penalty. Udall was examined by the Court of High Commission, January 13-23, 1589-90, charged with being the writer of the "Dialogne" and the "Demonstration." He refused to answer and was imprisoned, and, at the assizes at Croydon, was tried, July 24, 1590, for "wieked, seandalous and seditions libel." He refused again to deny under oath his authorship and was found guilty, but judgment was deferred. Placed at bar in the next February, he was sentenced to death. Influential friends, however, saved his life, and there was some prospect of his being sent to Syria or Guinea for the Turkey merehants. But that failed, and he died in the Marshalsea at about the end of 1592 . His memory might have been honored more had he boldly avowed responsibility for what he had done in eonseience.

Fulke's last little book produced a eommotion beyond anything to be expected. John Bridges, Dean of Salisbury, afterwards Bishop of Oxford, replied to it, first in a sermon at Paul's Cross, and then - it took him more than two years - in a quarto ${ }^{1}$ of more than 1400 pages. Part of this deals with arguments by Calvin, Beza and other's, but the main stress is put upon the "Briefe and Plaine Declaration." Fulke's book weighs four ounces and a quarter. Bridges's reply weighs four pounds and a quarter. The latter, indeed, reprints the former. But an

1 A Defence of the Government established in the Church of Englande for Ecclesias. tical matters, etc., 1587 , 4 to, iii. 
undeniable prolixity pervades the dean's replication. The work is learned but dull, and made little impression.

Ponderously ineffective although this book was, to leave it unanswered never would have done. Dudley Fenner, almost immediately after its appearance, wrote a brief reply, ${ }^{1}$ confining himself to the first fifty-three pages, in which the dean seeks to pulverize the preface of Fulke's little book. Fenner's intention clearly was to answer Bridges's in "seuerall Treatises." 2 His early death prevented this. But apparently he left another manuscript, ${ }^{3}$ printed the next year by the same secret press, which valiantly defends the new discipline. The first is interesting for its citations refuting the dean's denial ${ }^{4}$ that the bishops reviled their opponents. ${ }^{5}$ Fenner cites instances. One bishop, he declares, insulted some godly ministers by sneering ${ }^{6}$ at them: "You are boyes, princokes [pert youths], \&c. and will you teache all others?" In Cambridge another bishop told them that, if he had a boy who reasoned as they did, he would "britche" him. To another he said, "You are a foole, and can saye nothing, holde your peace, let another speake;" and of another: "He was a dolt!" Junius and Tremellius were called "Drunken Germanes. . . . It was pitie that euer they were borne;" and a bishop hurried a minister out of his episcopal presence with the rude command: "Haue him avay, let him goe home and skoolde with his wife!" and, looking "stedfastlie" npon another, said: "Thou boye, beardlesse boye, yesterday birde, newe out of the shell." And when another minister had pleaded "Let vs rather vndergoe anie punishement, then so bee iudged of," the bishop responded: "Vuder-goe goose, vncler-goe foole, as you are phantasticall in your opinions,

${ }^{1}$ A Defence of the godlie Ministers, against D. Bridges slaunders contayned in his ansvvere to the Preface before the Discourse of Ecclesiasticall gouernement, with a Declaration of the Bishops proceeding against them, etc., 1587, 4to. Part of this (4t-51) was reprinted in A Parte of a Reg. (387-393).

2 Defence. Pref.

3 A Defence of the Ecclesiastical Discipline ordayned of Gol to be $v$ sed in his Church. Against a Replie of Maister Bridges, to a briefe and plain Declaration of it, which was printed $A \bar{n} .1584$, ete., 158s, 4 to.

4 Briefe and Plaine Declar. iv.

5 Def. of Eccles. Discip. 11.

${ }^{6}$ Def. of God. Mins. 42-45. 
so are you in your wordes. Where diddest thou ener reade vndergoe?" 1

A passage in the second volume, issued in 1588, illustrates the earnestness of these Dissenters. Replying to Bridges's claim of great good done by the Church, it is said : ${ }^{2}$ -

If there were a commission graunted, to examine what hath bin done by these officers, and their Courtes, for these nine and twentie yeares, what good they have done, and on th'other part what insufficient Ministers they haue made, what godly learned Ministers they have put to silence, and deprined of their benefices, and other places of ministerie; what ceremonies \& subscriptions they hane vrged: what constitutions and articles they haue set out, and sworne men to present, what conuocations and scenes they haue kept, what faculties and dispensations they haue graunted and taken, what censures, suspensions, \& excommunications, they hane set forth, howe manie, of what sorte, and for what causes, they haue cast into prisons, howe long, and in what prisons and order they haue kept them there, what oppressions and extortions have bin committed, what couering and cloakinge of fowle and shamefull matters, with a number of such like. I doubt not, but all men, that indifferentlie considered these things, would be constrayred to say: It is the mercie of the Lorde that wee are not consumed.

John Penry also took part in the controversy, not merely by several pamphlets ${ }^{3}$ in 1587 and 1588 - for the first of which he suffered a month's imprisonment - urging upon the queen and Parliament and the people of Wales that some better order be taken for the preaching of the gospel there $;^{4}$ but still more, in 1589 , by a direct appeal ${ }^{5}$ to Parliament against the injurious

1 "Undergo" was a current word. Milton and Shakespeare use it, the latter seventeen times.

2 Def. of Eccles. Discip. 135.

${ }^{3}$ A Treatise containing the Aequity of an Humble Supplication which is to be exhibited vnto hir Gracious Muiestie, and this High Court of Parliament, in the hehalfe of the country of Wales, etc., 1587, 8vo. An exhortation vnto the gouernours and people of hir Maiesties countrie of Wales, to labour earnestly to haue the preaching of the Gospell planted among them, 1587, Svo. A vieve of some part of such publike wants and disorders as are in the seruice of God, within her Majesties Countrie of Wales, etc., $15 s 8,16 \mathrm{mo}$.

+ A defence of that which hath bin written in the questions of the ignorant ministerie, and the communicating with them, 1588, $16 \mathrm{mo}$.

5 Th' Appellation of Iohn Penri, vnto the High Court of Parliament, from the bad and injurious dealing of th' Archb. of Canterb. $\&$ other his colleagues of the high commission, etc., 15\$9, 8vo, 25. 
dealing of the Archbishop of Canterbury and the High Commission; wherein he utters words which his own judicial murder less than five years later made memorable:-

The spilling of my blood for this cause, though it be a matter to be regarded of you that are in authoritie: yet $I$ thanke the Lorde, it is not the thing that I feare: . . But the discrediting of the truth by my lard vage, is the thing that I regarde, and the spilling of my blood for defending the trueth, and writing against impietie, is it, that I fear me, will make this lande an astonishment to our neighbors round about vs.

Still more mrgently does he plead ${ }^{1}$ in 1590 for genuine reform. He mingles a denunciation which is almost savage with a counsel which is tenderly faithful. Thus, he says of the hierarchy:-

Wil you then come vnto them, and see what they are? Alas, you can behold heere no other sight but a multitude of desperate and forlorne Athiests. . . . You shal finde among this crue, nothing els, but a troup of bloody sonle murtherers, sacriligious church robbers, and suche as haue made them selues fatte with the bloude of mens soules, and the vtter ruine of the Church. The whole endeanour of which cursed generation, ever since the beginning of hir Maiesties raigne, hath tended no otherway, then to make a sure hand to keepe the church in boudage, that being bound in their handes, it shoulde not dare for feare of being murthered to seeke for liberty.

But, exhorting his brethren, he says :-

I beseech you be not ashamed of the chaine of your brethren; mourne with those that lament for the cause of God. VVhen they are imprisoned, think your sehnes to be in bondes. And I do especially and aloue al thinges beseech those that fanor the reformation, to labour more and more in the reforming of themselues, and such as belong vnto them. . . . It night hane bene something tollerable in times past for a sincere professor, to haue an ignorant, an vntaughte, and a vureformed family: but in this cleare light, and in a profession of so great sincerity to continew in these sinnes, is altogether vnbeseeming the gospell of Christ.

1 A Treatise wherein is manifestlie proved, that Reformation and those that sincerely funor the same, are vnjustly charged to be enemies, vnto hir Maiestie, and the state, etc., 1590,4 to, 5, x. Another volume, probably printed at Edinburgh in this year, has been attributed to him (Ath. Cant. ii, 157): An Humble Motion with submissior. vnto the Right Honorable LL. of hir Maiesties Privie Counsell, ete., 1590, 4to. Partly reprinted in $16+1$. It is able, but the internal evidence seems conclusive against Penry's authorship. 
Evilently it was felt that the contention of the reformers, founded upon the miscellaneous character and obvious moral defects of many whom the State Chureh sheltered, had force and needed attention. One effort made to neutralize it was the translation from the French, by Thomas Wilcox, of a "Treatie of the Churche," I by Bertrand de Loque, of Turenne. It argues that the true Church is identified by two marks, the pure preaching of the word and the lawful administration of the saeraments. As to the purity of the Church, it replies to those who insist that regenerate ehurch members should separate themselves from merely formal members : -

Saint Paul considereth the Church not in herselfe, but in Iesus Christe her heade, which shee taketh holde of by faith: ...

Moreover wee might say that Saint Paul speaketh of sanctification or holinesse promised, and which is not yet fully accomplished, as though he called \& saide the Church to bee without spot, not that it is so here belowe on the earth, but because that one day it shall so bee aboue in heauen. And after this sorte Saint Augustine vnderstandeth it. "Iesus Christ" (saith he ${ }^{2}$ ) "cleanseth his Church by the washing of Christians to make it vnto himselfe, without spott or wrinckle, not in this world, but in the world to come."

Several eminent men took part in this controversy on the side of the Establishment. Dr. Robert Some, rector of Girton, and about this time Master of Peterhouse, Cambridge, within two years printed three quartos. ${ }^{3}$ The superciliousness of most Churchmen towards the new disciplinarians finds fresh illustration therein. And, in coneluding, he says: "I have and doe submit my labour to the iudgement of the learned, therefore not of you or your ignorant disciples." Such insolence perhaps had some effect, in leading the multitude who never saw, or never would read, the arguments of the Reformers to despise them, while

1 A Treatie of the Churche conteining a true discourse, to knowe the true Church by, etc., $1581,16 \mathrm{mo}, 15-17,189$.

${ }^{2}$ Lib. de nuptiis Concup. cap. 34.

${ }^{3}$ A Godly Treatise containing and deciding certaine questions, mooued of late in London and other places, touching the Minisierie, Sacraments and Church, etc., 1588, 4to. A Defence of svch points in R. Somes last treatise, as M. Penry hath dealt against, etc., 1588, 4to. A Godly Treatise wherein are examined \& confuted many execrable fancies, giuen out \& holden, partly by Hen. Barrowe and Iohn Greenwood: partly by other of the Anabaptisticall order, 1589, 4 to. 
hardly failing to irritate the reformers themselves to further indignation.

A more important contributor to the discussion on the same side was Matthew Sutcliffe, Dean of Exeter, already mentioned. He directly attacked Udall's " Demonstration of Discipline" in a quarto ${ }^{1}$ which at least has a vigorous title. He exhibits the too common flippant arrogance, and dedicates his volume "to the factious and turbulent T. C. VV. T. I. P., ${ }^{2}$ and to the rest of that anarchical disordered Alphabet which trouble the quiet and peace of the Church of England;" and as he thinks that such "dastards and recreants" should be dealt with by "handie-strokes of Syllogisme," he fills his book with logic chopped fine. His conception of the condition of things in England, if the new discipline were to prevail, is presented thus:-

What may be the funtasie or imaginarie forme of this reformation in matters of Ecclesiasticall gonernment? They themselues skill [know] not: or when you haue supplanted or ouerturned, or turned out those Ecclesiasticall Senators and gouernours which we haue, whence shall the supplie bee of able gouernours? from beyond the seas? that is impossibilitie. From your selues? that is matter of difficultie. From vs againe? that were egregious and ridiculous follie. . . If,$I$ say, your mortall or immortall hatred against the state ecclesiasticall caried you to extinguish this order established in the Church alreadie: blessed God, how would you proceed to the choice of a new Senate Ecclesiasticall and their inuestiture? whiles a man might heare you say of the new Doctor or Pustor, Elder or Deacon, This man hath zeale but no learning, that man learning but no zeale, the other neither zeale nor learning; such a man is factious and full of deadly poison, he a base crafts-man or artisan, another is anaricious, and would carie away our bag. 'T. C. will overtoppe all, or loueth the preheminences as Diotrephes, each man taking exception vnto other. Doe ye not foresee, or rather doe you not see as in a glasse, the image or bodily shape of the imagined state, which you so impetuouslie striue for, and we striue against, and striue will in a good cause vnto the death?...

It will illustrate how this controversy broadened itself to

1 A Remonstrance: or Plaine Detection of Some of the Favlts and Hideovs Sores of Such Sillie Syllogismes and Impertinent Allegations, as ovt of sundrie factious Pamphlets and Rhapsodies, are cobled vp together in a Booke, Entituled "A Demonstration of Discipline: "etc., 1590,4 to, xii, ix.

2 Thomas Cartwright, Walter Travers, and John Penry. 
glance at another volume of this year. Anthony Marten was a member of Trinity Hall, Cambridge, in 1564, but does not appear to have taken any degree. Six years later he was appointed a sewer ${ }^{1}$ of the queen's chamber, and afterwards also royal librarian in Westminster Palace. He sent forth a moderate, candid and Christian treatise, ${ }^{2}$ designed in the main to plead for things as they were. Of the new discipline he says :-

Of the gouernment by an elder ship there is nothing certaine, neither in the Scriptures themselues, nor in any of the auncient histories, or monuments of the Fathers. For the necessitie of the first beginning, before Churches were planted, must not be so neerely exemplified, as the practise of the Apostles afterwarde (when the Church was spread and increased in sundry Prouinces and Kingdomes) must be regarded. For the first kinde by Elders, was but of necessitie, and for a time in some places, till other meanes were founde: But the last, which was done by Bishoppes, was more certaine, and more vniversall, and more like to be perpetuall.

Now therefore since this kinde of gouernment by Bishops, is found to be the verie ordinance of Christ, the practise of the Apostles while they liued, and the constant order of the vniuersall Church, before that Antichrist abused the same, what obiection can there be made against it, ... If they finde that the bishops doe any thing against the comandement of God, or that they execute not those thinges which are committed vnto them, like faithfull and iust stewardes of God, let those thinges bee declared, but let not the iuste gouernement, whose authour is Christe and the Apostles, and whose protector is the lawfull and Godly Magistrate, bee blamed.

In another place, and in the same mild and proper spirit, he refers to a complaint which may have had some justice:-

I doubt not, but that yee your selues, or the most of you, which be learned in the Scriptures, and haue experience of some Churches abroade, were reasonablie well aduised of the ground of your gouernment, before ye published and professed your opinions, yet is not euery one of your partakers and followers so well able to iudge of those things which you shew vnto them: but that by mistaking, or not vnderstanding that which you teach, they are easily carried from one error to another, till at the length they become of no religion at all.

1 Tasters and servers of food at royal feasts.

2 A Reconciliation of all the Pastors and Cleargy of the Church of England, 1590, 8vo, 101 verso, 19. 
Upon a certain class of minds this reasoning, in a temper so unwontedly courteous, must have had considerable influence.

In the last days of the same year Sutcliffe sent to press another treatise ${ }^{1}$ more definitely undertaking to overthrow the new discipline. He goes carefully over the several points involved, in the effort to offer conclusive objections and to establish the new notion of the divine right of episcopacy. His manner may be inferred from this passage :-

The cause of lawes, orders, learning, and reward, commeth also now in question: for if that, which the presbyterie shall deeme to be according to Gods word, must passe for law, what hope of law and order? if the vnlearned husbandman and artificer be iudge and disposer of the rewards of learning, let euery man leaue the Vniuersitie and Schooles, and betake himselfe to the plough, or some good occupation, that he may learne to be an elder rather than a schollar.

He insists that this consistorial discipline must overthrow the queen's supremacy, abate her revenues, threaten the power of Parliament and the liberty of the subject, abridge Magna Charta and impair the common law, hinder the courts of justice, overthrow the ministry by diminishing the rewards of learning, and introduce confusion everywhere. Three times again within five years Sutcliffe printed upon this general subject books ${ }^{2}$ on which, as they introduce no new or important feature, we need not dwell.

1 A Treatise of Ecclesiasticall Discipline: Wherein that confused forme of gouernment, which certeine vnder false pretence, and title of REFormation, and true discipline, do striue to bring into the Church of England, is examined and confuted, 1591, 4to, Epis. ded. 128-186, 166.

${ }^{2}$ An Answere to a certaine Libel Svpplicatorie, or rather Diffamatory, and also to certaine calumnious Articles, and Interrogatories, both printed and scattered in secret corners, to the slaunder of the Ecclesiasticall State, and put forth vnder the name and title of a Petition directed to her Maiestie: ete., 1592, 4to. An Answere vnto a Certaine Calumnious Letter published by M. Iob Throkmorton, and entituled A defence of I. Throkmorton against the slaunders of M. Sitcliffe, etc., 1595, 4to. The examination of M. Tho. Carturights late apologie, etc., 1596, 4 to. 


\section{CHAPTER VI}

\section{SOME SPECIAL FEATURES OF THE STRUGGLE}

Ever since the first cleavage of the English Chirch from Rome, under Henry VIII., of course a contest had been going on between the theologians of the Papacy and the Reformation, to which, with rare exceptions, it has not been pertinent to allude. In 1562 Bishop Jewel had published his "Apologie " 1 in defence of the Church of England, a plea against the Papal exclusion of the Reformers, from the reassembled Council of Trent. In that work "all that was contended for was that Episcopacy was permissible and not against the Scriptures." 2 In it he says : ${ }^{3}$ -

For whereas some use to make so great a vant, that the Pope is Peter's only successor, as though thereby he carried the Holy Ghost in his bosom, and cannot err, this is but a matter of nothing, and a very trifling tale. Gods grace is promised to a good mind, and to one that feareth God, not unto sees and successions.

Whitgift, Cooper and others were of the same mind, and, apparently, this was then the general doctrine of the English Church. But, in or about 1566, Hadrian Saravia, of Spanish extraction, who had taught divinity at Leyden and been pastor of the Walloon church there, became a prebendary of Canterbury, and afterwards a teacher in Jersey and a great friend of the archbishop. He disseminated more extreme views as to the Apostolical Succession, and, in 1590, published a volume ${ }^{4}$ explaining and defending them. Beza replied ${ }^{5}$ and Saravia an-

1 Apologia Ecclesiae Anglicanae, 1562, Svo. Translated by Lord Bacon's mother and published, 1564 , as $A n$ Apologie or answere in defence of the Churche of Englande, etc. Reprinted in Jewel's Works, 1848, iii : 5-112.

2 Perry, i : 19.

3 Jewel, iii : 44.

* De Diversis Ministrorvm Evangelii Gradibus, etc., 1590, 4to. 2. See also 39, 41.

5 Ad Tractationem de Ministrorum Evangelii gradibus, A Saraviae. 
swered ${ }^{1}$ Beza. Richard Bancroft, chaplain to the Lord Chancellor and soon to be Bishop of London and Archbishop of Canterbury, is understood to have imbibed this doctrine privately from Saravia, and it is thought to have colored his famons sermon ${ }^{2}$ at Paul's Cross on Feb. 9-19, 1588-89. He illustrates the cool assurance with which the advocates of the established way treated opponents : -

The doctrine of the church of England is pure and holie : the government thereof, both in respect of hir majestie, and of our Bishops is lawfull and godlie: the booke of common praier containeth nothing in it contrarie to the word of God. . . .

If any one of you now, my brethren, be otherwise affected, the fault is in yourselves: for they remaine (as the nature of truth requireth) to be as they were before: but you through your rashnes in following of everie spirit, are growen to a woonderfull newfanglenes: and are indeed become meere changelings.

About 1593 two labored treatises appeared on this general subject, one of which took its place among the classics of English prose literature. Both championed the Church of England, but they differed in method. One author was Richard Hooker, then about forty, who had proceeded M. A. at Corpus Christi College, Oxford, in 1577, had been made a fellow and pnblic Hebrew lecturer, and later had been rector of Drayton Beanchamp and Master of the Temple, London. At the same time Walter Travers was evening lecturer in this church, and, as he favored the new views, not seldom, "the forenoon Sermon spake Canterbury; and the afternoon Geneva." Led thus to appreciate the need of thorough discussion of so grave a subject, Hooker undertook a treatise upon the vital principles of the questions at issue. In 1591 Whitgift transferred him to Boscombe, near Salisbury, where he elaborated his first four volumes, ${ }^{3}$ published in 1593. He announces his fundamental principle thus : -

1 Defensio Tractationis de diversis Ministrorum Evangelii gradibus ab H. S., etc., 4to.

2 A Sermon preached at Paules Crosse the 9. of Februarie, etc., 1588, 16mo, 89, 102 , ete.

3 The Lawes of Ecclesiasticall Politie, written in defence of the present gouernment established, against the new desired discipline, 1593, fol. (ed. 1807) 362; Bk. iii: sect. 2 ; Pref. 174 . The fifth book came out in 1597 ; the sixth and eighth in 1648 ; 
He which affirmeth speech to be necessary amongst all men throughout the world, doth not thereby import that all men must necessarily speak one kind of Language; even so the necessity of Polity, and Regiment in all Churches may be held without holding any one certaine form to be necessary in them all.

This is a low-church position. It concedes that no "certaine form" of polity is required by Scripture. Furthermore, the whole second book shows that there are other sources of the knowledge of God's will, and that it is sufficient if the superior advantages of Episcopacy can be maintained from them. Incidentally he suggests a difficulty in the practical application of the new discipline which must have proved serions :-

It may justly be feared, whether our Euglish Nobility, when the matter came in trial, would contentedly suffer themselves to be always at the call, and to stand to the sentence of a number of mean persons, assisted with the presence of their poor teacher; a man (as sometimes it happeneth) though better able to speak, yet little or no whit apter to judge, than the rest: from whom, be their dealing never so absurd, (unless it be by way of complaint to a Synod,) no appeal may be made unto any one of higher power, in as much as the order of your Discipline admitteth no standing inequality of Courts, no spiritual Iudge to have any ordinary superiour on earth, but as many Supremacies as there are Parishes and several Congregations.

The other writer was 'Thomas Bilson, also an Oxford student, who, at New College, passed M. A. in 1570 and D. D. in 1580-81. He became a "noted preacher," and was a prebendary of Winchester and warden of the college, subsequently becoming Bishop of Worcester and, later, of Winchester. He was reputed a profounder scholar than Hooker, but he lacked Hooker's genius. He takes the ligh-church side ${ }^{1}$ and argues that bishops are divinely appointed as successors of the Apostles and to hold authority over the Church, so that no true church may lack them. He says :-

all together first in 1662. Doubts exist of the genuineness of the fifth, seventh and eighth books. Probably no reliance should be placed upon any language in them which is not in harmony with that of those published before the author's death in 1600 .

1 The Perpetual Governement of Christes Chvrch, etc., 1593, 4to, 106, 109, 111, $233,3,5,7,14,414$. 
The authoritie of their [the Apostles'] first calling liueth yet in their succession. . . . There must either be no church, or els these must remaine: for without these no church can continne. ... To create ministers by imposing hands, is to gine them, not onely power and leane to preach the word, and dispence the Sacraments; but also the grace of the Holy Ghost to make them able to execute both parts of their function. 'This none can giue, but they that first receined the same. . . .

If the power of the Keies bee given to the Apostles and their successours; then hane laie Elder's (who doe not succeed in the Apostles roumes and functions) nothing to doe with the Apostles keies. . . .

In the beginning having laid down this principle:-

We must not frame what kind of regiment we list, for the ministers of Christes Church, but rather obserue and marke what maner of externall gouernment the Lord hath best liked \& allowed in lis Church enen from the beginning;

he urges that Adam governed the Church 930 years, and that Seth helped him during 500 of them, and continued the service 112 years more. Thus he traces down a patriarchal pontificate from Adam to Moses. Under Moses there were priests above Levites, from which he infers

that the Leuitical discipline vnder Moses doeth cleerely confirme a dituersitie of degrees amongst Pastours and ministers in the Church to be more agreeable to the wisedome of God reuealed in his lawe, then a generall equalitie or paritie.

All ends thus, not withont plausibility :-

Where all are equal, there is as great danger of pride and contention, as where one is supcrionr; yea, the prioritie of one man in euery prouince, as we see confirmed by the practise and experience of the vniversall Church of Christ since the Apostles tines, is sooner resisted and better endured, then the waywardnesse and headinesse of so many Gonernours as you must and would have in your changeable regiment of Presbyters. ${ }^{1}$

I The view which he confutes is given elsewhere (iii) : -

"They have framed a Running regencie, that shall goe round to all the Presbyters of each place by course, and [en]dure for a weeke, or some such space; for the devise is so newe, that they are not yet resolued what time this changeable superioritie shall continue. . . . They pronounce this onely to be Gods institution, and this ouerseer or Bishop to be Apostolike ; all others they reiect as humane." 
The same writer a short time before, by royal command, had written a volume, ${ }^{1}$ which, as a dialogne between Theophilus, a Christian, and Philander, a Jesuit, answered forcibly Dr. William Alleu's "Defence of English Catholiques." 2 But it so nearly demonstrated that in religion subjects need not obey that afterwards it bore undesigned fruit. ${ }^{3}$

In their eagerness against dissenters the Church tribunals for some time had been supplementing the meagre obtainable testimony by requiring those accused to take the oath ex officio mero, ${ }^{4}$ thus confessing or accusing themselves of any criminal matter, no one else having accused them. This was resisted, even to imprisonment, by the more resolute Puritans, who insisted that it was "contrary to the laws of the land, and an inquisition tyrannical." ${ }_{5}$ So believed James Morice, attorney of the Court of Wards, who sent a written argument to the Lord Treasurer, "to shew the iniquity of these proceedings," in which he boldly declares :-

That the exacting of Oathes ex officio, is a great indignitie to the Crowne and Scepter of this Kingdome, and a wrong and injurie to the freedome and libertie of the subjectes thereof. That the same is not necessarie or profitable to the Church and common wealth, but hurtfull to them both, brought in onely by the practize of the Popish cleargie, to the prejudice of the publique peace and tranquillitie of this Realme, and that the same neuer had any good allowaunce by anie lawe, eustome, ordinaunce or statute of this Kingdome, ete.

To this Dr. Cosin soon replied in a small quarto, of which only forty copies seem to have appeared, enlarged in $\mathbf{1 5 9 3}$ to a substantial volume. ${ }^{6}$ It cites Seripture, history, the classics, and especially the Fathers, in proof

1 The Trve Difference betweene Christian Svbiection and vnchristian rebellion, etc., 15S5, 4to, i.

2 A true, sincere and modest Defence of English Catholiques that suffer for their faith both at home and abrode, etc., 1584, 12 mo.

${ }^{8}$ Dict. Nat. Biog. v : 44 . "Whilst this 'True Difference served the Queen's present purpose, it contributed more than any other work to the humiliation and death of Charles I."

4 J. S. Burn, High Commission, 27.

5 Strype, Whitgift, ii : 2S. Fnller, v: 105-115. Morice's book appears to have been A Brief Treatise of Oathes exacted by Ordinaries and Ecclesiasticall Iudges. 1591,4 to, 57.

6 An Apologie for Sindrie Proceedings by Iurisdiction Ecclesiasticall; of late 
that this [ex officio mero] oathe ${ }^{1}$ in a Criminall matter, tendered by one in authoritie, being warranted by the politicke lawes of the Realme, or the Church : ought not to be refused, except there were some direct Prohibition thereof, by the lawe of God.

John Penry again sought to serve the cause in an anonymous review ${ }^{2}$ of Bancroft's Paul's Cross sermon. It was attributed to John Knox. ${ }^{3}$ Besides a general denial and the refutation, one by one, of many points of that discourse, he replies especially to Bancroft's attempt to excite popular feeling against the Puritans as enemies to the queen. Bancroft himself also appealed to the public twice within a short time. One ${ }^{4}$ volume purports to be a candid history of the new discipline and a fair criticism of its points. It concludes with an extended résumé in which this "pragmatical" polity is censured as devised at Geneva, established there by craft, and thence obtruded upon churches elsewhere; as having an original unknown and unwarranted by Scripture; as so lately hatched as to have no certain name; as banishing apostolical bishops, yet having Doctors of its own ; as making princes and noblemen but its inferior officers; as uncertain whether its new-fangled elders are laymen or ecclesiasties ; as very costly ; as condemning in others what it approves in itself ; as disdaining the ancient Fathers and general councils; as pretending to allow of nothing but Seripture, yet depending altogether upon its own friends and synods; as wresting the Seriptures, etc. In the other volume ${ }^{5}$ he seeks to awaken popular times by Some chalenged, and also diuerslie by them impugned, etc. to which is added L. Andrew's Numquid per Ivs dininum Magistratui liceat a Reo Iusiurandum exigere, etc., 1593, 4to, iii : 160.

1 Whoever wishes to understand the full operation of this oath should study it as employed by the Inquisition (Lea, Inquis. i : 413-416, etc.). Those who argued in its favor referred eagerly to the alleged fact that Calvin employed such an oath at Geneva, and they dwelt particularly upon the two cases of Camperell and the widow Balthasar, iii : 159; Collier, vii : 66; Fuller, v : 112.

${ }^{2}$ A briefe discovery of the vntruthes and slanders (against the trve gouernement of the Church of Christ) contained in a Sermon, preached the S. of Februarie 158S, by D. Bancroft, etc., 1590, 4 to.

${ }^{3}$ The title-page of Dr. Dexter's copy bears the sentence, in a handwriting of that period: " $\mathrm{y}^{\mathrm{e}}$ Author supposed to be Mr. Knox of Scotland."

4 A Survay of the Pretended Holy Discipline, etc., 1593, 4to, 461-464.

5 Davngerous Positions and Proceedings, published and practised within this Iland of Brytaine, vnder pretence of Reformation, and for the Preslyteriall Discipline. 1593,4 to, 44, 104, 128, 144-1s4. 
fear and distrust of the Puritans. The last forty pages mainly attempt to fasten odium upon them in connection with the movements of William Hacket, a crazy maltster of Oundle, and his associate fanatics, Edmund Coppinger and Henry Arthington.

Every now and then the old complaint against the inadequacy of the ministry was renewed. Miles Mosse, of Bury St. Edmunds, appealed to Edmund Seambler, Bishop of Norwich, in 1590 through a "diffamatorie Epistle," 1 asserting that " manie Ministers of the word write much, but preach little." To which some Miles Christianus, said to have been Thomas Rogers, of Horninger, conceding much, replied $:^{2}$ -

Were some (whome I could name) in their studies writing, when they are either at the Pondes with their spaniels ducking, or in the Allies with their mates, bowling: I an sure they would thinke them much iniured, that priuely, much more in publike monuments, are disgraced as faultie, which bestow that time profitably in writing for a generall benefite, which others bestow vainly (often times wickedly) for a short and priuate pleasure.

In 1596 Thomas Morton, a fellow of St. John's College, Cambridge, and afterwards successively Bishop of Chester, Lichfield and Coventry, and Durham, dedicated to the queen a double treatise, ${ }^{3}$ in which, with unusual concessions, he still argues against the reformers. He admits that there can be particular churches, and that

the greatest number of a Church rightly established, may thus generally be determined, to wit, that the Church consist of no mōe then can without confusion, or any manifest inconuenience meet together at one time, and in one place, to serue God.

He also admits that ecclesiastical censures, when cleserved, apply to Christian rulers as well as to the people, although the excom-

1 A Short Catechisme, 1590.

2 . Miles Christianus, or a iust Apologie of all necessarie uritings and uriters, etc., 1590,4 to, 19. The substance of Mosse's work is included, in its separate propositions, in this one.

3 Salomon: or a treatise declaring the state of the kingdome of Israel, as it was in the daies of Salomon: Whereunto is annexed another treatise, of the Church: or, more particularly, Of the right Constitution of a church, 1596,4 to, ii : 33,85 ; i: 71 ; ii : $89,111$. 
munication of the prince ought not to be sudden, and, unless publicity be absolutely needful, should be private. He is clear, however, that good people onght to

labour to continue that gonernment which is in force in that place or country where we liue, although we doe perhaps imagine, yea \& perswade our selues that we could finde ont a better forme.

Again, he urges that it is a good man's duty to remain in a very imperfect chmrch, if its imperfections be " not so great, but that notwithstanding them, we have the meanes of saluation \& edification." He also indor'ses fully the magistrate's preëminent charge of the souls of his subjects.

On Dec. 24, 1597, John Howson, a student at Christ Church, Oxford, and afterwards the first bishop of that see, preached at Paul's Cross a powerful sermon ${ }^{1}$ from Matt. xxi : 12,13, vigorously attacking all buying and selling of spiritual promotion as unlawful. He insists, however, that our Saviour's teaching is " not to pull downe Churches for the abuse of them, or the abuse of the Priest ; but reforme the abuse and retaine the good vse." On May 21, at the same place, he completed his treatment of the same text." He ends thus:-

I saye with $S$. Chrysostome upon these words, But you haue made it a denne of thieves. . . . I would to God it conld hane beene [said] only of the Iewes, and not of the Christians ; I would to God it could haue bene applyed to Christians heretofore, and not vnto vs; ... These things are so manifest, that they require neither exposition, nor application ; I would to God they were more obscure, and hidden from vs, and that we did not maintaine these prophanations, by pretences, and long customes, as these Iewes did. Wherefore if we lament ouer them [the Jews], we hane canse to weepe and howle for our selues, who have added as great increase and strength to these sinnes, as time hath added yeares and increase to the world.

About this time two letters were addressed publicly to Mr. Hooker, called out by his work already mentioned. ${ }^{3}$ One was from his old pupil, George Cranmer, who says :-

1 A Sermon preached at Paules Crosse the [2]4. of December, 1597, etc., 1597, 4to, 19.

2 A Sermon preached at Paules Crosse, the 21. of May, 159S, etc., Concluding a former Srrmon, ete., 1598, 4to, 51.

${ }^{3}$ Concerning the New Church Diseipline, etc., 1598, 4to, 2, 24. Reprinted 1642. 
Now of late yeares the heate of men towards the Discipline [Presbyterianism] is greatly decaied: their iudgments begin to sway on the other side : the learned have weighed it and found it light: wise men conceiue some feare, lest it prove not only not the best kinde of gouernment, but the very bane and destruction of all gouermment.

He then names religions evils which the disciplinarian controversy has promoted, and desires Hooker to prepare another treatise correcting certain faults remaining; conchuding finely thus :

The chiefest labour of a Christian should be to know ; of a Minister, to preach Christ crucified: in regard whereof not only worldly things, but even things otherwise precions, even the Discipline it selfe is vile and base: where as now, by the heat of contention, and violence of affection, the zeale of men towards the one hath greatly decayed their love to the other. Hereunto therefore they are to be exhorted, to Preach Christ crucified, the mortification of the flesh, the renewing of the spirit, not those things, which in time of strife seeme precious, but passions being allayed, are vaine and childish.

The other letter ${ }^{1}$ is different. It has been attributed to Cartwright. ${ }^{2}$ Whoever wrote it had keen perceptions and a trenchant pen. After reference to Hooker's amounced intention to inform men of the estate of the Established Church, the author, speaking avowedly for others, proceeds : -

Howbeit sometimes goodlie promises are meere formal, and great offers serue onely to hoodwinke such as meane well. . . . Wee therefore, your louing countrymen, . . hauing so goodlie a champion to offer combat in our defence, were malle verie secure, and by the sweete sounde of your melodions stile, almost cast into a dreaming sleepe: Wee happelie remembring your Preface that there might bee

1 A Christian Letter of certain English Protestants, vnfained fauourers of the present state of Religion, avthorized and professed in ENGLAND; vnto that Reuerend and learned man, Mr. R. Hoo[ker]. requiring resolution in certaine matters of doctrine, etc., 1599, 4to. Reprinted in Hanbury's Hooker, 1830.

2 Wordsworth (Eccles. Biog. 3d ed. iii : 515, n.) says : -

"Somewhere I have seen the 'Christian Letter' attributed to Dr. Andrew Willet, but I cannot at present recall the authority. I remember, however, that, at the time, it seemed to me good."

But the inherent probabilities strongly disfavor Willet, whose great strength was anti-Papal and exegetical ; and who seems to have kept on good terms with the Establishment, which gave him many favors, until his death, in 1621. Covell declares that this work "was not the least cause to procure his [Hooker's] death." 
some other cause, ${ }^{1}$ opened at the length our heauie eyes, and casting some more earnest and intentice [attentive] sight into your manner of fight, it seemed vinto vs that couertlie and vnderhand you did bende all your skill and force against the present state of our English church: and by colour of defending the discipline and gouernement thereof, to make questionable and bring in contempt the doctrine and faith it selfe.

The writer and his sympathizers do not wish to be hard upon " Maister R. Hoo," who may have slipped unadvisedly. He may have been overcarried by his zeal. Doubtless he cannot always mean what he seems to say. So in charity they give him an opportunity to explain himself. ${ }^{2}$

They have selected a few principal things, which trouble many Christians, upon which they ask him to speak further; and then, by the use of the "deadly parallel column" in a rudimentary form, they try to show that at least fifteen of the Thirtynine Articles - viz., 1, 6, 10, 11, 12, 13, 14, 15, 17, 19, 23, 25, 26, 27 and 28 - have been undermined by his "Ecclesiastical Polity." They hope he can explain all this, in which event they will give him "condigne praise ;" but it seems to them needful that he should attempt so much, at the least. Otherwise, they ask, "Shall wee doe you wronge to suspect you as a priuie and subtill enemie to the whole state of the Englishe Church, and that would have men to deeme her Maiestie to haue done ill in abolishing the Romish religion, and banishing the Popes authoritie." Perhaps the unkindest cut is this :-

Our last scruple and demand is this, seeing your bookes bee so long and tedious, in a stile not vsuall. ... And that your Prefaces and discourses before you come to the question are so longe, \& mingled with all kinde of matters and sutes of learning and doctrine : whether your meaning bee to shewe your selfe to bee some rare Demosthenes, or extraordinarie Rabbi, or some great Pythagoras, that enjoyne your scholars or your aduersaries to fiue yeares silence before they can be perfect in your meaning, or able to replye.

1 The reference seems to be to the beginning of Hooker's preface : -

"That posterity may know we haue not loosely through silence permitted things to passe away as in a dream, there shall be for men's information extant thus much concerning the present state of the Church of God, established amongst vs."

2 Christ. Let. 6-33, 48, 49, 45, 46. 
This merciless onslaught was supposed to have hastened Hooker's speedy death; but the pamphlet is almost forgotten although then it was reputed to be "the first publication of the Doctrinal Puritans.-' 1 Three or four years later Dr. William Covell, once fellow of Queen's College, Cambridge, and then vicar of Sittingbourne, Kent, sought, as many thought ineffectually, to make the needed explanations ${ }^{2}$ which Hooker did not live to attempt.

Two general publications in the last decade of the century, upon the same general subject from the opposite side, deserve mention. In 1590, or thereabouts, for the book is undated, Robert Waldegrave, the Puritan printer, reissued in a single volume ${ }^{3}$ forty-two Puritan tracts of the last few years, including several to which, in their original editions, reference already has been made. The other is a small quarto, ${ }^{4}$ lated 1595 - the copy in Dr. Dexter's collection has upon its title-page the autograph of William Brewster - which appears to have been the first publication of the remarkable Francis Johnson. It discusses the ministry of the Church of England and the relation of Christian people towards it. It insists that magistrates are to be obeyed in the Lord, not against the Lord; and that a false ministry should not be heard by God's people, even if it preach some truth. In conclusion, it says :-

It is to be accounted an happy benefit and greatly to be desired, that the Church and people of God may have rest $\bar{a} d$ be suffred to lead a godly life in peace and quyetnes. ... But if this cannot be had

1 Introd. to Hanbury's Hooker, i : x. He styles the pamphlet "very rare," as well as "important."

2 A Iust and Temperate Defence of the Five books of Ecclesiastical Policie written by $\boldsymbol{M}$. Richard Hooker, etc., 1603, 4to. Hanbury calls this "an excessively rare Tract, never reprinted," and himself reprints it in his Hooker (ii : 449-568). He, too, raises the question whether Hooker's reputation does not need further defence than that furnished in this treatise.

3 To this he gave the singularly unsuggestive name, A Parte of a Register, contayninge sundrie memorable matters, written by diuers godly and learned in our time, which stande for, and desire the reformation of our Church, etc., 1590, 8vo.

4 A Treatise of the Ministery of the Church of England. Where in is handled this question, Whether it be [better?] to be separated from or ioyned vnto. Which is discussed in two letters; the one written for it [by A. Hildersham] the other [by $\mathbf{F}$. Johnson] against it, etc., 1595, 4to, 49, 71, 133, 136, 19, 39, 52, 89, 137. 
in peace withont persecution, yet must we not therefore refuse or turne from the way and commaundement of Christ.

In 1599 Philippe de Mornay, a distinguished French Protestant and counsellor to the king, sent out a discussion of the Church, ${ }^{1}$ soon reprinted in English at London, which at least makes some utterances grateful to the Puritans, e. g. : -

A Priest \& a Bishoppe in the Primitive Church were all one, and if they differ now in Titles and in Miters, in the essentiall dignitie they differ nothing at all. ... If the ambition of Bishops, \& the negligence of priests have confounded all these things, and abolished the ancient order of the church, it must not seem strange if we labor to restore it again. ... In a word, the first bishops of the Christian Church were but Priests, and those Priests, Bishops : and the first ministers of the Reformation were Priests, and consequently, Bishops. And these Priests by the institution of the Apostles, had the power of laying on hands, which also our Priests or Ministers hane done, according to the Canons of the Apostles. Therefore, the Ministers that are ordayned by them are well ordained, nor may their calling bee calumniated, or called in question.

During these excited years all religious literature manifested the universal criticism and unrest. How church questions interwove themselves with others is seen in a course of exegetical sermons on the Apocalypse, ${ }^{2}$ by George Gifford, of Maldon, Essex, in which, reaching the ninth verse of the seventh chapter, which speaks of the "great multitude, which no man could number," etc., he tries to confute the Separatists, thus:-

Chiefly looking backe into the idolatrous, darke and bloudie kingdome of Antichrist, a Donatist ${ }^{3}$ will iudge few or none to remaine. But to correct this boldnes, here is shewed that euen in the most miserable times, the Lord did preserue his Church, had his elect in the confused heape, and that in a marueilous great number.

He cannot explain the twenty-fourth verse of the second chap-

I Tractatus De Ecclesia, qvo praecipve quae hoc nostro tempore agitatae fuerunt questiones excutiuntur, $1599,16 \mathrm{mo}, 505,517,518$. A Treatise of the Chvrch, wherein are handled al the principall questions, mooued in our time concerning that matter, 1606,4 to, $377,385,386$.

2 Sermons vpon the whole Booke of the Revelation, 1596, 4to, 148, 80.

${ }^{3}$ Six years before, he had published against the Separatists a specific treatise entitled A Plaine Declaration that our Brownists be full Donatists. 
ter - "But unto you I say, and unto the rest in Thyatira, as many as have not this Doctrine, and, which have not known the depths of Satan, as they speak; I will put upon you none other burden" — without a similar reference :-

Now as Sathan laide the foundation of this his deepe diuinitie in the Apostles times, which he afterward did further builde vp by the Valentinians and others, so in these last times, so soone as euer the light of the gospell brake forth, hee set it on foote againe by the Anabaptists, Lybertines, Familie of Loue, and other such monsters: for they boast of such deepenes of illumined elders, and men deified that looke whatsoeuer they committed, euen the fowlest deeds, yet they simne not.

This passage suggests that the religious struggle in England included one factor, mysterious and elusive, yet of obvious power, which it is easier to recognize than to comprehend, the Familists, or the Fanily of Love, whose originating and animating spirit was one Henry Niclaes ${ }^{1}$ - "H. N." He was born in Munster in 1502. As early as in his ninth year he seemed to himself to see visions sealing his union with God, and to be made entirely one with the will and word of God and inspired to be an expounder of divine love. He soon began labors for holy secrecy. He and his disciples conformed to the established religion whereever they were. His aim was not a new sect but a new spirit within all sects.

He had no sympathy with Luther or the Reformation. $\mathrm{He}$ valued the ceremonies of the Roman Church, but sought to initiate the reign of divine love everywhere. Meantime he amassed wealth as a merchant. About 1561 persecution drove him to England for some years, where he attracted kindred minds, afterwards retreating to Kampen and Cologne. He, or his disciples for him, printed many small tracts, several of which were translated from Low Dutch into English. These are "rarer than white crows," yet they seem easier to be found than understood.

1 The best accounts of him and of the Family of Love are in Robert Barclay's Inner Life of Relig. Socs. of Commonwealth (1876, 25-35), and John Hunt's Relig. Thought in Eng. from Ref. to End of Last Century, 1870, i : 235-237. 
Dr. Dexter owned five of his treatises, ${ }^{1}$ and $\operatorname{six}^{2}$ which, in his day or soon after, were published against his views. It is difficult to grasp the sense, or feel the fascination, of his utterances, or, on the other hand, to discern the cause of the bitter hostility which he awakened. There is a tangled wilderness of words, through which the paths of thought are hard to be discovered. Apparently unconscious that he is verging upon blasphemy, he claims ${ }^{3}$ to be "annoynted with the Holie-gost, in the Oldeage of the holie Vnderstanding of Iesu Christ: godded with God, in the spirit of his Lone: made-heyre with Christ in the heavenlie Goods of the Riches of God," etc. A few sentences may be cited from his great " Revelatio Dei." 4

7. Moreouer, in thissame Reuelation of the great Glorie of God, and in this same liuelie Demonstration or Shewinge of the many and manifolde Thinges, both of that which is in Heauen and also of that which is on Earth, so came-there also vnto mee out of thesame heauenlie Beeinge, Testimony-of-trueth, which distinctlie infourmed mee of the Diuersitie of thinges, and resolned mee also; with cleere vnderstandinge; of the Thinges which I vnderstoode not, \& were shewed vnto mee.

8. But trulye, they are all straunge and incredible Thinges, before the Contemners of the heauenlie Woorkes of God, and before all Vnderstandinges of $\mathrm{y}^{\mathrm{e}}$ Wisdom of the Fleash: But before the godlie

1 The Principall Epistles of $H . N$. which he hath set-foorth through the holy Spirit of Loue, ete., 1574, 1648, $16 \mathrm{mo}$.

Revelatio Dei: the Revelation of God, and his great Propheatie, etc., 1574, $16 \mathrm{mo.}$

The Prophetie of the Spirit of Loue, $16 \mathrm{mo}$.

Evangelium Regni: A Joyful Message of the Kingdom, ete., $16 \mathrm{mo}$.

Terra Pacis: A True Testification of the Spirituall Lande of Peace, etc. 16 mo.

2 A Confutation of monstrous and horrible heresies taught by H. N. and embraced of a number, who call themselues the Familie of Love, by I. Knewstnb, 1579, 8vo.

A Confutation of Certaine Articles deliuered vnto the Family of Loue, etc., by William Wilkinson, 1579, Sro.

An Epistle sent unto two daughters of Warwick by H. N. refuted by Henry Ainsworth, 4 to.

A Description of the Sect called the Familie of Love, with their common Place of residence, ete. by one Mrs. Susanna Snow, 1641, 4to. Repr. in Harl. Misc. iii : 540$5+2$.

Heresiography: or a description of the Hereticks and Sectaries of these latter times, by E. Pagitt, 1645,4 to.

A Survey of the Spirituall Antichrist, opening the secrets of Familisme, by S. Rutherford, 1648, 4 to.

8 Evang. Reg. 3. 
Vnderstandinges, which; vnder the Obedience of the Lone; have a regarde on the Beeing of God and his Almightines, to a great Ioye in their Spirit, and to a great Thankes-geeuing to the lighest God, because that Hee; thesame God; hath manifested his Light, Life, and Wisedom, and the Vnderstandinge of his secreat Woorkes, among the Children of Men, vpon the Eartl.

9. MIoreover, in all this that $I$ sawe and hearde, and that was opened vnto mee, I was forced in my Spirit, to write-it-all, tothende that the secreat heauenlie Woorkes of God, mought be also declared amonge all Loners of the Trueth, and vnderstanded and loned by them, in their Vnderstandinge.

H. N. clearly seems to have claimed to be sent of God as truly as Moses and the prophets, and to have asserted for his writings an authority equal to that of the Bible. So far as any great purpose reveals itself through his glucose style, it is that of exalting the divine love and the duty of love between men. In some respects he anticipated George Fox and in others Swedenborg. There is no evidence that he or his genuine followers were guilty of the immorality freely charged. The name, the Family of Love, assumed by them, favored false inferences, and bad people stood ready to cloak their own misdeeds with a pretence of discipleship. But, so far as such charges ${ }^{1}$ had force, they were true of the counterfeit members only of this remarkable sect. Perhaps the worst thing said about them truly was in the queen's proclamation against them in $1580^{2}$ that they did not recognize the binding force of an oath before a magistrate.

As has been said, Fulke's "Briefe and plaine Declaration" caused a startling commotion. It had the immediate effect of calling out the tremendous treatise of Dean Bridges, already mentioned, and that led to the famous Martin Mar-prelate pamphlet war. Possibly the instigators and author of those excoriating productions were otherwise ready for their experiment of a novel, vigorous, slashing appeal to the shrewd masses of the English people, and of an assault from a fresh quarter upon the State Church. Probably Dean Bridges became the shining mark for arrows long enquivered, awaiting an opportunity of effective discharge. As a target he surely was big and

1 Harl. Misc. iii : 568.

2 Cardwell, i : 451. 
befitting. And the first two Martins - the "Epistle" 1 and the "Epitome" 2 - although little quartos, together less than one fourteenth of the size of the volume into which their missiles were hurled, by their light broadsides wrought a havoc upon it, accompanied by a popular commotion, only to be paralleled by the famons modern attack of the little iron-clad Monitor upon the bulky Merrimac.

The result was to disenchant thousands of the English people of that fictitious, exaggerated reverence for the hierarchy which for generations had incapacitated them to think for themselves; and to convince them that sound common sense vigorously employed might enable an ordinary man, nobody knew who, writing nobody knew where, and printing his surreptitious screeds nobody knew how, not only to argue down doctors of divinity, but to baffle and confound even bishops and archbishops, not to say the Star Chamber and the Privy Council itself. So far as gleanings from every possible source instruct us, there were in all seven genuine Martin Mar-prelate tracts ${ }^{3}$ and eleven which

1 Oh read ouer D. Iohn Bridges, for it is a worthy worke: or an epitome of the fyrste Booke, of that right worshipfull volume, written against the Puritanes, in the defence of the noble cleargie, by as worshipful a prieste, Iohn Bridges, Presbyter, Priest or elder, doctor of Diuillitie, and Deane of Sarum. Wherein the arguments of the puritans are wisely prevented, that when they come to answere M. Doctor, they must needes say some thing that hath bene spoken. Compiled for the behoofe and overthrow of the Parsons, Fyckers, and Currats, that haue lernt their Catechismes, and are past grace; by the reverend and worthie Martin Marprelate gentleman, and dedicated to the Confocationhouse. The Epitome is not yet published, but it shall be when the Bishops are at conuenient leysure to view the same. In the meane time, let them be content with this learned Epistle. Printed oversea, in Europe, within two furlongs of a Bounsing Priest, at the cost and charges of $M$. Marprelate, gentleman, 15S8 [?], 4to. Repr. 1843, 12mo. Also by Arber.

2 Same title as the Epist'e down to "and dedicated." Then it goes on - by a second Epistle to the Terrible Priests. In this Epitome, the foresaide Fickers, \&c. are very insufficiently furnished, with notable inabilitie of most vincible reasons, to answere the cauill of the puritanes. And lest M. Doctor should thinke that no man can urite without sence but his selfe, the senctles titles of the Seueral pages, and the handling of the matter throughout the Epitome, shewe plainely, that beetle-headed ignorance, must not liue and die with him alone. Printed on the other hand of some of the Priests, 1589 [?], 4to. Repr. 1843, 12mo, and by Arber.

3 Two have just been named. The others, briefly, are these :-

Certaine Minerall and Metaphisicall School points, etc. A broadside, 1589.

Hay any worke for Coopcr: or a briefe Pistle, etc., 1589 [?], 4to. Repr. 1642. Also by Arber.

The Protestatyon of Martin Marprelat wherein not withstanding the surprizing of " the printer, he maketh it known vnto the world that he feareth neither proud priest, 
directly replied to them, ${ }^{1}$ with four or five collateral pleas against Martin, ${ }^{2}$ and, no doubt, as many at least in his faror, which last have disappeared.

The chief English expert upon the subject declares this Martin Mar-prelate war to have been " the controversy of the Elizabethan age." 3 At any rate, it is clear to any candid student

Antichristian pope, tiranous prellate nor godlesse catercap, ete., 1589 [?], 12 mo. Repr. by Arber.

Theses Martiniance: That is Certaine demonstrative Conclusions sette downe and collected (as it should seeme) by that famous and renowmed Clarke, the reuerend Martin Marprelate the great, etc., 1589 [?]. Repr. by Arber.

The iust censure and reproofe of Martin Iunior. Wherein the rash and undiscrete headines of the foolish youth is sharply mette with, and the boy hath his lesson tuught him. I warrant you, by his reuerend and elder brother, Martin Senior. sonne and heire vnto the renowmed Wartin Warprelate the Great, ete., 1589 [?], 1:mo.

1 An Admonition to the People of England, etc. T. Cooper, 15s9, 4to, and again 16mo. Also 1847, 12mo.

Antimartinus, sive monitio cuiusdam Londinensis ad adolescentes utriusque; Academice contra personatum, 'juendam rabulam, qui se Anglice Martin Marprelat . . . vocat, ete. A. L. [?], 1589, tto.

A Whip for an Ape: or Martin displaied, 1589 [?], 4to.

Mar-Murtine, 1589 [?], 4to. Repr. in Caesura Literaria, vi : 236, and by Arber.

Marre-Martin, etc., 1589 [?], 4to. Repr. by Arber.

A Countercuffe giuen to Martin Iunior, by the venturesome, hardie, and renouned Pasquill of Englande. T. Nash [?], 1589, 4to. Repr. by Arber.

Pappe with an hatchet, etc., J. Lily [?], 1589 [?], 4to. Repr. 184t, and by Arber.

The Returne of the renowned Caualiero Pasquill of England, ete., 1589, 4to. Repr. br Arber.

An Almond for a Parrat, or Cuthbert Curry-knaues Almes, etc. T. Nash [?], 1589 [?], 4to. Repr. 1S46, $12 \mathrm{mo}$, and by Arber.

Murtins Months minde, that is, $A$ certaine report and true description of the Death and Funeralls, of olde Martin Marre-prelate, ete., 1589, 4to.

Plaine Percevall the Peace-Maker of England. Sweetly indevoring with his blunt persuasions to botch up a Reconciliation between Mar-ton and Mar-tother, ete. R. Harvey [?], 1589 [?], 4to. Repr. 1860, 12mo, and by Arber.

2 Asinus Onustus: The Asse ouerladen. To his Louing and deure Mistress Elizabeth the blessed Queene of England, etc., 1589 [?], 4to. Repr. 164: and 1689 .

A Theologicall Discourse of the Lamb of God, and his enemies. Containing a brief commentary of Christian faith, together with a detection of old and new Barbarisme now called Martinisme. R. Harvey [?], 1590, 4 to.

A Friendly Admonition to Martin Mar-prelate $\$$ his Mates, etc. L. Wright [?], 1590, 4to.

A Myrrour for Martinists, And all other Schismatiques, which in these daungerous daies doe breake the godlie vnitie, and disturbe the Christian peace of the Church, etc. T. Turswell [?], 1590, 4 to

An Advertisement for Pap-hatchet, and Martin Marprelate, ete. G. Harvey, 1592, 4to.

3 W. Maskell, Hist. of Martin Marprelate Controversy in reign of Eliz. 221. 
who makes thorough investigation, that this controversy has been as much underrated in its relation to the movement of the popular thought, as it has been misrepresented in its essential quality. Dr. Dexter has considered elsewhere, ${ }^{1}$ at some length, this portion of the English literature of the period, and has defended it from the condemnation which it almost invariably has received.

As the result of years of research, he was able to find all these tracts, and so to have opportunity to estimate them intelligently. And a most thorongh and conscientions examination convinced him that, so far as the Martinists were concerned, although strong language occurs, with rude and graphic turns of thought, and now and then an inwoven strand of coarse and stinging speech from the current life of common men of that day, nothing brutal or obscene appears. That bitterness now and again tinges the words of Martin, as the official severity towards him increases, is true. But an unselfish, devout and noble purpose inspires and justifies him; and there is a tonic quality in even his sharpest and freest utterances, which cannot be said of most of the counterblasts which the bishops' attorneys issued against him.

Dr. Dexter believed that Henry Barrowe wrote ${ }^{2}$ these genuine Martins, and there is no reasonable doubt that John Penry was their publisher. ${ }^{3}$ Together, presumably, upon this theory, they conceived of the possibility of bringing to bear upon the heavy and lingering labor of church reform that tremendous power which ridicule, satire and sarcasm possess for the dis-

1 Cong. in Lit. 186-202.

2 In his Cong. in Lit. (194-201) Dr. Dexter gave his reasons for this conjecture, largely founded upon the resemblance in style between the Martins and Barrowe's acknowledged works. The discussion which followed only confirmed his opinion that Barrowe was Martin. This confiction was strengthened by his larger acquaintance with Barrowe's manner of thinking and writing, due to his having possessed himself of all of the ten books which, other than the Martins, are attributed to Barrowe's pen. To his mind Barrowe's authorship of the Martins became a moral certainty. But had he lived to read Dr. F. J. Powicke's Henry Barrow, Separatist, etc. (London, J. Clarke \& Co., 1900, S2-85), probably he would have revised, if not abandoned, this conclusion. Dr. Powicke seems to prove that Barrowe cannot have been Martin, although he throws no light upon the question who Martin actually was.

${ }^{3}$ This is proved in Cong. in Lit. 198. 
comfiture of abuses; which Erasmus and Beza not long before had illustrated in Latin, ${ }^{1}$ but which never up to that time seems to have been experimented with in English. Whoever furnished the "copy," "shete by shete," 2 Penry apparently took charge of it, and at Kingston-upon-Thames ; ${ }^{3}$ at Fawsley, in Northamptonshire; at Coventry; in Newton Lane, at Manchester ; or at Woolston, had it printed after their rude fashion, as opportunity could be found or made. When, in the summer of 1589 , the second and last press in this employ was cliscovered, and Penry fled to Scotland, the printing of the Mar-prelate tracts came to an instant and final end. The land was scoured to apprehend Martin, but, if he were Barrowe, he was so safe in the Fleet Prison that they never found him. And, as he and Greenwood, who, as his cell-companion, must have known the facts, and Penry all three were martyred in 1593, the secret of their joint labors in this behalf remained untold.

One thing is clear, that Martin was not instigated by the leading Puritans. The second tract, the "Epitome," which followed the "Epistle" at a sufficient distance of time to observe and record the fact, says : ${ }^{4}$

The Puritans are angrie with me: I meane the puritane preachers. And why? Because I am to open. Becanse I iest.... I did thinke that Martin shoulde not haue beene blamed of the puritans, for telling the truth openly.

Some, like good Richard Greenham, doubted the wisdom of that way of advocating righteousness $;^{5}$ "For (said he) the tendency of this Book is to make sin ridiculous, whereas it ought to be made odious." Others, like Thomas Cartwright, who were anxious to have the whole Church of England become Presbyterian in a quiet, orderly, wholesale manner, took special pains to dissociate ${ }^{6}$ themselves from Martin.

Most of the Establishment were furious at what they deemed

1 The former in Moriae Encomium and several of his Familiarum Colloquiorum Formulae; the latter in Epis. Magistri Benedicti, etc.

2 Egerton Papers, Camden Soc. 1840, 175.

3 Harl. Ms. 7042: 8, 19-25.

4 iii.

5 S. Clarke, Lives Thirty-two Eng. Divines (ed. 1677), 13.

6 Lansd. Ms. lxiv : 20. 
the intolerable impudence of such literature. The more sedate and devout, like Thomas Turswell, calmly referred the whole thing to the devil.1 Doubtless, also, he fairly expressed the judgment of many, that some, who had answered Martin, had gone beyond bounds in doing so.

If now we go back over the ground which we have traversed, and recall the spirit of the many treatises which, between the issue of the "First Admonition to the Parliament " and the close of the century, set forth and urged upon the public mind and conscience church government by eldership, or which opposed this teaching, several things become clear. First, and most distinct, is manifest the dominant motive of the movement, a profound conviction widely felt, that grave spiritual har'm was being done to the cause of morality and religion and to the best welfare of the English nation, not merely by the methods of the Church by law established, but by its very existence as such; and this to that degree that no reasonable expectation remained of any genuine, satisfactory reform, excepting through a radical reconstruction. It must be remembered and emphasized that the fundamental, impelling principle of the Puritans was not dissatisfaction with church government by bishops for its own sake, but the conviction that the hierarchy as it was, and was likely to remain, threatened the very existence of vital godliness. This led them to reinvestigate the Seriptures upon the matter, and that reinvestigation confirmed their conviction.

Evidently the Presbyterianism which many zealous Puritans wished to import from Geneva, as the sufficient remedy for everything wrong in the Church of England, had not yet made itself entirely intelligible and self-consistent, even to its warmest friends. Calvin himself had not even suggested that graded unity of session, presbytery, synod and assembly, which was its final manner of development. Indeed, there is evidence that he donbted whether that form of church government which worked well in Geneva would work well always and everywhere. He himself proposed to Sigismund, king of Poland, a polity combining the Episcopal with the Presbyterian elements. ${ }^{2}$ And in

1 Myrrour for Martinists, iv : 1.

2 P. Henry, Calvin, i : 401. 
his "Institutes," 1 he says that an arrangement which is effectual among a few must not be transferred forthwith to the whole world. His personal aptness for arbitrary power inclined him towards not only a strong but even a hierarchical government. He contimued to be permanent president of the consistory in Geneva, although he thus violated his own rules. Beza declared that Calvin " in effect" was Bishop of Geneva. In 1548, in his letter ${ }^{2}$ to the Protector Somerset, Calvin speaks incidentally of "prelates and curates," "pastors and curates," and "bishops and curates," as if he had no fault to find, either with those terms in their English sense or with the form of polity involving them.

Very late in $1644,{ }^{3}$ seems to have been published a little manual ${ }^{4}$ which, on its title-page, was stated to have been found in Cartwright's study after his death. This has been represented as a reissue ${ }^{5}$ of the English translation of the work of Walter Travers printed on the Continent in 1574 and, as has been seen, the first reduction to definite form of the new way of church discipline. But the treatise of Travers, as issued in Latin, contained 308 pages in $16 \mathrm{mo}$, and as Englished, presumably by Cartwright, 204 pages in quarto. This fact alone should have suggested the impossibility of its reproduction in coarse type in a pamphlet of less than twenty-four small quarto pages. This Directory appears to be the work to which Baneroft refers ${ }^{6}$ as the "Form of Discipline" which, "about the yeare, 1583 . . . is lately come to light." Apparently Bancroft knew it only in Latin. From extracts which he gives from letters written, in 1585, by Field to Travers and by Gellisbrand and Sands to Field, it seems to have been used in embodying those local Classes, which were formed covertly about that time in various localities. Bancroft speaks of a new edition, probably in Eng-

1 Lib. iv. c. vi. sect. S.

2 Jules Bonnet, Lets. of Calvin, ii : 177, 183.

3 Thomason indorsed on the title-page of his copy, as its day of issue, " 14 Feb. 1644-5." Brit. Mus. Lit.

4 A Directory of church Government. Anciently Contended for, and as farre as the Times would suffer, practised by the first Nonconformists in the daies of Queen Elizabeth, etc., 164t, 4 to.

5 Price, Hist. Prot. Nonconformity, i: 363.

6 Davng. Posit. 69, 70-72, 76, 77. 
lish, a copy of which - of course no copies then gained public circulation - no doubt was left by Cartwright, from which this reprint was made. ${ }^{1}$

It begins with a brief declaration of the principles of ehurch Discipline, and a precise statement of the restored "Synodical Discipline " completes it. There are twenty-four " heads," which include the necessity of a calling to the ministry and the manner of entering upon the work, election by the Church, the order of prayer, of preaching, of the catechism, the sacraments, marriage, schools, elders, consistories, censures, etc. There is to be a consistory, or session, in each church, and one minister and one elder are to represent that church session at conferences, which are to meet every six weeks. Delegates from twenty-four conferences - two ministers and two elders from each - form a provincial synod. Every such synod is to send three ministers and three elders to constitute a national synod. Yet all seems tentative, and the fatally weak features reveal themselves in "The Form of the Subscription," with which all concludes :-

This Discipline wee allow as a godly Discipline, and agreeable to the Word of God, (yet so far as wee may be first satisfied in the things hereunder noted) and desire the same so acknowledged by us to be furthered by all lawfull meanes, that by publique authority of the Magistrate, and of our Cluurch it may bee established.

Which thing, if it may bee obtained of Her right Excellent Majesty, and other the Magistrates of this Kingdome, we promise that we will doe nothing against it whereby the publique peace of the Church may be troubled. In the meane time we promise to observe it so far as it may be lawfull for us so to doe, by the publique lawes of this Kingdome, and by the Peace of our Church.

Here, disregarding all minor structural difficulties, are at least four insuperable objections to the fitness of the Presbyterianism thus outlined to furnish at that time an adequate remedy for the spiritual evils needing correction. - First, this Directory waits for the civil power to initiate the desired substitution of

1 In connection with the observance, by the Synod of the Presbyterian Church in England, of the Tercentenary of the establishment of the first Presbytery in England at Wandsworth, in 1572, this Directory was reprinted in facsimile by Prof. Lorimer, of the English Presb. College, with an eight-page introduction. 
Presbyterianism for Episcopacy; an absurdity which it seems incredible that they should not have realized. Secondly, should such a beginning of reform ever prove possible, its failure is inevitable, as it is to be left to be carried on by public authority. Thirdly, the basis proposed for church-membership - baptized children, of the age of fourteen, who confess their faith and submit themselves to the discipline, dependence being placed upon church censures, when needed, to lift up the resultant church-life to the gospel standard - really is indistinguishable in principle from that which it seeks to supplant. Fourthly, if vaguely, yet really, through the proposed national synod, this system so binds all the congregations of its contemplated Church into organic unity, to be enforced by civil constraint from without, that no local assembly can move constitutionally, even towards a better life, until all other portions, or a majority of them, are ready to move with it.

That a mind so sagacious and well-informed as Cartwright's should not merely have felt content in such a scheme, but also have urged it and suffered for it, can be explained only by remembering that environment of inveterate conservatism which made it almost impossible for him to see things as they actually were.

Surely somebody soon must be led of the Lord to see that only by a different road could it be reasonably possible to move towards success. So now it is time to ask whether any better suggestion, with any larger hope, were offered from any other quarter during these laboring years. 


\section{CHAPTER VII}

\section{THE EARLIEST EXPERIMENTS IN PRACTICAL CHURCH REFORM}

IT is not unnatural that the earliest traces of efforts to organize churches of a new and purer sort should be found in London. The hostile watchfulness of the govermment was not much, if at all, more keen there than elsewhere; while it was easier both to find sympathizers with reform, and also to escape notice. In $1567 \mathrm{John}$ Smith and six others were examined before the Lord Mayor and the Bishop of London, and it was testified ${ }^{1}$ that in Queen Mary's days a congregation had met in London, and had used " a booke and order of preaching, ministring of the Sacramentes and Discipline," like those of the English at Geneva. At some time before 1571, certain of these persons united as a church, of which Richard Fytz was pastor and Thomas Rowland deacon. A short declaration, " ${ }^{2}$ "The trewe Markes of Christ's Church," which they set forth, maintained three positions : the free and pure preaching of the Gospel; the simple ministry of the sacraments, after the pattern of Christ; and the church control of the New Testament. These are good Congregational principles, but they scarcely touch actual polity.

In the scanty traces left by these people no proof appears that they differed essentially from Puritans in general, least of all that they had rediscovered the original Congregationalism. ${ }^{3}$

1 Parte of Reg. 25.

2 S. P. Dom. Eliz. xx : 107. Waddington, Hist. Paps. 1 ser. 11-14; Cong. Hist. i: 742-745. J. Brown, Pilg. Faths. of N. Eng. 27.

${ }^{3}$ Dr. Brown $(22-39)$ believes this church to have been Congregational. He also regards it as " a link between the Pilgrim Fathers and the brethren of the earlier generation" that Joln Bolton - who was connected with "the church already established" in Amsterdan, i, e., the "Ancient Church," when the Pilgrims arrived there - had been an elder of Fytz's church. But the Pilgrims did not join the Ancient Church, and there is no mention of Bolton in any of their writings, nor any evidence that they ever had any connection with him. 
Grindal ${ }^{1}$ represents their contention to have been "concerning the habits," and says that they held meetings, administered the sacraments and discipline, and ordained church officers "after their own way." But this is no more than was done by other Puritans. There is no evidence that this particular movement left seerls of influence in the world's soil, which afterwards grew into the Congregationalism of the present. We therefore are left to look ten or twelve years later towards Cambridge and Norwich for the first suggestion which was made a vailable practically of a polity having elements of truth, and so of success, which the Presbyterianism of Calvin and Cartwright lacked.

Robert Browne was born at Tolethorpe, in Rutlandshire, abont 1550, and was a member of Corpus Christi, or Benet, College, Cambridge, in 1570, taking his B. A. there in 1572.2 In 1571 he seems to have been domestic chaplain to the Duke of Norfolls. Then he taught ${ }^{3}$ for about three years. Even then his conviction of his spiritual duty to his pupils was so strong, that he was dismissed. ${ }^{4}$ But he continned to teach privately, and snceessfully, until the plague sent him home. His father was well off and he might have remained at home comfortably.

1 Zur. Lets. LXXXII.

2 The Dict. of Nat. Biog. (vii : 57) suggests that Browne may have entered some other college, and have migrated to Corpus in 1570, which would account for his taking a degree there so soon after matriculation. Perhaps this is favored by the fact that, if he were born in 1550 , or thereabouts, he hardly would have waited until his twentieth year in those days before going to Cambridge.

3 In Dr. Dexter's words : -

"Browne has beell written about more and understood less than most men of his day. Fuller, who claimed some personal knowledge of him, started misstatements about his character and career which most subsequent biographers have copied; while, owing to the zeal with which they were burned, his books have been largely unknown. When I began special study in regard to him, many years since, diligent search in England was rewarded at last by the sight of four of his prineipal treatises, which explain his system. And, in $1875, \mathrm{I}$ discovered, among the anonymous and unassigned quartos in the library of the Archbishop of Canterbury, at Lambeth Palace, a little volume, badly printed and without title-page, printer's name, place or date, passages in which I immediately recognized as having been eited, as from him, by some of lis antagonists. It proved to be - with the aim of explaining his church failure at Middleberg - a substantial autobiography, covering the years during which he was becoming a Separatist and shapiug his system. With the help of this, with letters preserved in the British Museum, his other books, and the parish records of Achurch-cum-Thorpe, it became possible at once to reconceive of and reconstruct both his life and his system."

4 True and Short Declar. 2, 4, 6, 7, 18, 19, 20. 
But his sense of duty led him back to Cambridge, where he put himself under the training of that advanced Puritan, Rev. Richard Greenham, of Dry Drayton. ${ }^{1}$ He soon developed such pulpit power as to be invited, with consent of the mayor and vicechancellor, to preach in Cambridge. This led him to a reëxamination of principles. He decided that it must be the business of the church itself, and not the bishop, to call and receive him. He also debated the whole question thoroughly, not only with his conscience but also with those who took most interest in such matters - he called them "the forwardest." The result was that

he thought it lavvfull first to be tried off the bishops, then also to suffer their power, though it were vnlawfull, iff in aniething it did not hinder the truetl. But to be authorised of them, to be svvorne, toe subscribe, to be ordained \& receaue their licensing, he vtterlie misliked \& kept hiself cleare in those matters.

His brother 2 obtained for him the bishop's seals. But Robert would not pay the fees, and, when his brother paid them, Robert lost one seal and burned another. He also condemned the system openly, and explained that he refused to become connected regularly with the Cambridge parish to which he preached because "he sawe the parishes in such spiritual bondage that whosoever would take charge off them must also come into that bondage with them." After six months of labor he decided that the Lord called him "to a further \& more effectual message," and, although his hearers "gathered him a stipend," he returned it and "gaue them warning of his departure." Never physically strong, in the excitement of these experiences he fell "soare sick." After recovery he reached the conclusion which proved to be the long waited-for pivot on which further reform, and the whole future of free churches, was to turn. This he states thus: -

Therefore he finding the parishes toe much addicted \& pliable to that lamentable state, he iudged that the kingdom off God vvas not

1 Perhaps five miles N. W. from Cambridge.

2 Perhaps named Philip, as he mentions a "Browne" of that name as with him at Cambridge. - Trve and Short Declar. 1. 
to be begun by whole parishes, but rather off the worthiest, vvere they neuer so fevre ...

He considered that if there were not onelie faultes but also open and abominable vickedness in any parish or companie, \& thei would not or could not redresse them, but were held in bondage bie antichristian povver, as vere those parishes in Cambridge by the bishops; then euerie true Christian was to leaue such parishes, \& to seek the Church of God vvhere so euer.

This cut the knot. Thenceforth his quest was to find some place where others thought, or could be brought to think, as he thought. He was in sublime and sorrowful earnest. While he still was in doubt, Robert Harrison, whom he had known at Cambridge, came back from Norwich intending to be ordained by the bishop. Browne dissuaded him, and Harrison soon returned to Norwich. Browne remembered that in Norfolk some were "uerie forward," removed thither and found welcome in Harrison's dwelling. The two young men thought out and classified the new ideas in which, in the main, they were agreed, but at first Harrison could not go so far as Browne.

As revealing the process of the formation of the first substantially Congregational church on record since the days of primitive Christianity, the details are worth noting:-

There was a day appointed, and an order taken ffor redresse off the former abuses and for cleauing to the Lord in greater obedience. So a conenāt vvas made \& ther mutual cōsent vvas geue to hould together. There vvere certain chief pointes proued vnto them by the scriptures, all vvhich being particularlie rehersed vnto them with exhortation, thei agreed vpon them, \& pronoinced their agrement to ech thing particularlie, saiing: to this ve geue our consent.

First therfore thei gaue their consent to ioine them selues to the Lord, in one couenant and felloweshipp to gether \& to keep and seek agrement vnder his lavves and gonernment; and therefore did vtterlie flee and auoide such like disorders \& wickedness as was mencioned before.

Further thei agreed off those vwhich should teach them and vvatch for the saluation of their soules vwhom thei allowed and did chose as able \& meete ffor that charge. For thei had sufficient triall and testimonie thereoff by that which thei hard \& savve by them and had receaued of others. So thei praied for their vvatchfulness and diligence and promised their obedience. 
Likevvise an order vvas agreed on ffor their meetings together, ffor their exercises therein, as for praier, thanckesgiuing, reading of the Scriptures, for exhortation \& edifying, ether by all men vvhich had the guift or by those vvhich had a special charge before others. And for the lavvfulnes off putting forth questions to learne the trueth, as iff anie thing seemed doubtful \& hard, to require some to shewe it more plainlie, or for anie to shewe it himselfe \& to cause the rest to understand it. Further for noting out anie speciall matter of edifing at the meeting, or for talcking seuerally thereo, with some particulars, iff none did require publique andience, or if no vvaightier and more necessarie matter vvere hādled of others.

Againe it was agreed that anie might protest, appeale, complaine, exhort, dispute, reprone \&c. as he had occasion, but yet in dne order, vrhich vvas thē also declared.

Also that all should further the Kingdom off God in themselues, \& especiallie in their charge \& househould, iff thei had anie, or in their freindes \& companions and vwhosoener Vvas Vvorthie.

Furthermore thei particularlie agreed off the manner hovve to Vvatch to disorders, \& reforme abuses, \& for assembling the companie, for teaching priuatlie, and for vvarning and rebukeing both priuatlie \& openlie; for appointing publick humbling in more rare iudgementes, \& publick thankesgening in straunger blessinges ; for gathering \& testifying voices in debating matters and propounding them in the name off the rest that agree; for an order of chosing teachers, guides, \& releeuers when thei want; for separating cleane from vucleane; for receauing anie into the fellowship; for presetting the dailie successe of the church, \& the wantes thereof; for seeking to other churches to haue their helpe, being better reformed, or to bring them to reformation; for taking an order that none contend openlie, nor persecute, nor trouble disorderly, nor bring false doctrine, nor euil cause after once or tvvise warning or rebuke.

Thus all thinges vvere handled, set in order, \& agreed on to the comfort off all, \& soe the matter vvrought \& prospered by the good hand of God.

There is incontrovertible evidence, both from Browne's books and from what ean be recovered surely as to his methods, that his fundamental prineiple was that which lay at the foundation of all genuine Puritanism. He was not, as, with mistaken persistence, he has been charged with having been, a restless, dissatisfied fanatic, looking everywhere for novelty, until, having conceived of democracy as a possible form of church polity, he 
devoted himself to substituting it for that of the State Church. ${ }^{1}$ On the contrary, he receded from things as they were slowly, and only under irresistible compulsion from a supreme conviction, with which, in his thought, polity at first had no connection. That conviction was the same which had prompted Cartwright and all the great Puritan leaders.

He was grieved and overwhelmed by his observation of the too common worldliness of those parish assemblies which were the only chirches of Christ known to the English establishment. In them the Lord's Supper practically belonged to the selfish, the undevout, and even to the actually sensual as truly as to the very elect of God. He could not read the New Testament excepting as bidding all true believers to separate themselves from such. Because the bishops not only tolerated, but justified, this state of things, he insisted that they could not be true ministers of God. And, because the Presbyterian Puritans remained in such a system, and neither undertook nor suggested anything which wonld sever the devout from such unholy alliances forced upon them by the State, he parted company with them. Their continued conformity seemed to him a surrender of their first principles at once inexplicable and indefensible. The more he studied it, the more perilous the situation seemed. Nor was any dawn of hope afforded by appeals to the government. It seemed that, in the nature of things, the magistrate never would attempt any such work. So at last he decided that those who were willing and waiting must go forward, in fealty to God's clear command to his people to separate themselves from the world.

Of gradual growth in his own mind, his completed system, as gathered from his five books ${ }^{2}$ which have survived, involves eleven inter-related principles.

1. It cannot but be the first and supreme duty of every

1 The ninth edition of the Enc. Brit. (iv: 392) represents that it was purels an issue of church government, and not at all one of doctrine, which he raised. The Dict. of Nat. Biog. (vii : 58) also declares his contention to have been for a "new theory of Ecclesiastical polity," and accuses him unfairly of having had little concern to convert a world lying in wickedness.

2 A Treatise of reformation without tarying for anie, and of the uickednesse of those Preachers which will not reforme till the Magistrate commaunde or compell them, etc., 1582, 4to.

A Booke which Sheweth the life and manners of all true Christians, and howe vnlike 
Christian to seek the utmost purity of belief and life. ${ }^{1}$ This he holds in common with all genume Puritans. Beyond this, and because of his interpretation of the relation of this to personal duty, he parts company with them.

2. The Church of England is so corrupt inwardly, and ontwardly so under unscriptural subjection to the State, that, having failed to reform it, the utmost purity of belief and life cannot be attained, excepting by separation ${ }^{2}$ from it. He regards the fact that anything like true chmrch discipline is unknown to the Establishment as one of the strongest conceivable arguments that this cannot be the true church. ${ }^{3}$

3. No reasonable hope of reform for the Church by the civil power remains, and no obligation to wait for prince or magistrate $^{4}$ exists. More than a generation earlier Bishop John Hooper had said in his "Declaration of the Ten Commandments: " 5

As touching the superior powers of the earth, it is not unknown unto all them that hath readen and marked the scripture, that it appertaineth nothing unto their office to make any law to goveru the conscience of their subjects in religion.

But probably Browne never had heard of this utterance. Presumably he supposed himself to be setting forth something quite unsupported by the judgment of any one else when he said : -

The magistrates ... haue no Ecclesiasticall authoritie at all, but onelie as anie other Christians, if so they be Christians. ${ }^{6}$. .

they are vnto Turkes and Papistes and Heathen folke. Also the pointes and partes of all Diuinitie, etc., 1582, 4to.

1 Treatise vpon the 23. of Matthewe, both for an order of studying and handling the Scriptures, and aiso auoyding the Popishe disorders, and vngodly commonion of all false Christians and especiallie of wicked Preachers and hirelings, 1582, 4to.

An Answere to Master Cartwright his Letter for Ioyning with the English Churches, etc., 1583 [?], 4 to.

A Trve and Short Declaration, Both of the Gathering and Ioyning together of certaine Persons: and also of the Lamentable Breach and Diuision which fell amongst them, $158+[?]$, t to.

1 See the whole Trve and Short Declar. In fact this belief underlies all that he wrote.
2 Treat. D3. Matt. 30, 31, 32, 39.
3 Ans, to Cartwright, 84 .
4 Treat. of ref. passim.
6 Treat. of ref. 4.
5 Early Writings, 280. 
If, then, the magistrates will commaunde the Souldiour to be at Minister, or the Preacher to giue ouer his calling, and chaunge it for an other, they ought not to obey him. . . . In all thinges wee must firste looke what is the Lordes will and charge, and then what is the will of man. ${ }^{1}$. . .

4. The Genevan plan offers no trusty assurance of reform. It waits helplessly in the vain hope that the State will take the initiative ; while, at best, it offers nothing beyond a transfer of the parishes, with all their unscriptural and undesirable features, to another system, which easily may be worse than the first, embracing the entire baptized population without regard to personal character. ${ }^{2}$

5. Therefore, since every believer is bound to seek in religion a purity not found, and not in reason to be looked for, in the State Church, all true Christians ought to separate themselves from it into churches from which the irreligious are excluded. ${ }^{3}$

6. Any such separated assemblage of believers, whose members unite by a public covenant with each other and with God thus becomes a genuine, and so far as organization goes, a perfect church. ${ }^{4}$

7. Chureh anthority rests only in the supremacy of Christ over these local companies of believers, making itself manifest and practical through the interpretation by their members of the principles of the Bible and the leadings of divine Providence, nuder the promised guidance of the Holy Spirit.

Contrary to the almost universal assumption of those who have known him, in the nearly entire absence of his writings, chiefly from conjecture and hostile testimony, Browne had no idea of proposing a democracy, although his system necessarily amounts to that. It was meant to be an absolute monarchy. But its king is the invisible Christ. He reigns through visible

1 Booke which Shew. Def. 117 ; Treat. of ref. 5, 7, 12, 10, 11, 14, 15.

2 Treat. 23. Matt. 47; Treat. of ref. 5, 10, 13.

3 Trve and Short Declar. 7 ; Treat. 23 . Matt. 46.

4 This cut another Gordian knot. That age had been so educated to beliere that a true church must show some lineal descent from the Apostles that it was unable to conceive how to form one, excepting by aid of the hierarchy. Browne taught it to cease worrying about making connection with the nnsavory aqueduct purporting to come down from the Christian era, and to dig a well in the sand anywhere, if they wanted pure water. 
vice-regents, every member of his true church being one. Therefore, in the last analysis, his will as to any particular case is ascertainable from them. His voice is to be heard in the testimony of a majority of the voices of the Church, the spiritual democracy thus interpreting his absolute monarchy.

8. According to Scripture the officers of such a church are a pastor, a teacher, one or more elders, one or more relievers or deacons - and one or more widows - or deaconesses. ${ }^{1}$

9. The Lord's Supper is the seal of the union of such a church in one body of which Christ is head, and all members should endeavor to receive it worthily, and should separate from all "vnmeete to receaue."

10. As one great purpose of such a church is to nurture and aid all its members towards spiritual perfection, it should watch them constantly, and lovingly and faithfully amend or stimulate whatever, in the common judgment, needs to be so treated. ${ }^{2}$

11. All such local churehes have a privilege and duty of cooperative fellowship. One in their common Lord and aim, they must be one with each other. The relation is that of equal sisterhood; in no sense of control, in all senses of friendliness and help.

As to this, again, Browne has been misrepresented, even by some of his own household. Most of his books having been destroyed, some early critics, who charged him with originating a rigidly independent way, ${ }^{3}$ possessed and misled the public mind. But the charge, directly in the face of clear proof to the contrary, should not have passed unchallenged until our day. The fact is that he held and taught the fellowship of the churches positively. Provision was made expressly in the constitution of the original church at Norwich for "seeking to other churches to have their help, being better reformed, or to bring them to reformation." And, in his most matured, systematized and careful statement, he teaches that:-

There be Synodes, or the meetings of sundrie churches: which are when the weaker churches seeke helpe of the stronger, for deciding or redressing of matter's. . . .

1 Booke which shew. Defs. 35, 37, 35, 48, 54, 55, 52, 53, 59, 60.

2 Trve and Short Declar. 20. 3 John Cotton, Way of Churches Cleared, 5. 
A Synode is a Ioyning or partaking of the authoritie of manie Churches mette togither in peace, for redress: and deciding of matters, which can not wel be otherwise taken vp.

That he uses the word " authority" here in the sense given it by Congregationalists rather than Presbyterians is clear from what he says in another book. He is justifying himself for not remaining in Cambridge under the bishop, and says : ${ }^{1}$ -

Therefore is the church called the pillar \& ground of trueth. 1 Tim. $3: 15$. \& the voice of the vvhole people, guided bie the elders \& forwardest, is said to be the voice of God. . . . Therefore the meetinges together of manie churches, also of euerie vvhole church, \& of the elders therein, is aboue the Apostle, aboue the Prophet, the Euangelist, the Pastor, the Teacher, and euerie particular Elder. For the ioining and partaking of manie churches together, \& of the authoritie which manie haue, must needes be greater and more vvaightie then the authoritie of anie single person. And this alsoe ment Paul vvhere he saith, 1 Cor. 2: 22. Wee are yours, \& you are Christes, \& Christ is Godes. Soe that the Apostle is inferior to the church, \& the church is inferior to Christ, \& Christ, cōcerning his manhood \& office in the church, is inferior to God.

This system is self-consistent and logical. It is the exact opposite of that of the Papacy and the prelacy. The latter teaches a Christ afar off, reigning through a self-perpetuating hierarchy over a laity whose sole duty is to submit and obey. Browne tanght a Christ equally regnant, yet indwelling and exercising his gracious power through all true believers, who by faith have been lifted into vital union with Him ; who are to choose, ordain over themselves, submit to, and coöperate with, a ministry of instruction aud of service. Brownism - as its enemies called it - thus became that strange anomaly, an absolute monarchy which, interpreted by the philosophy of results, could have developed only into a pure democracy. Those who ask why this system commended itself so swiftly to many should remember that it alone offered instant, effectual remedy for the insufficiency and delay of the Presbyterian plan. Where Providence clearly led the way, it authorized any company of faithful men to unite and thus form a Christian church.

It is true that Browne followed the nomenclature of the New

1 Trve and Short Declar. 20, 2. Also Booke which Shew. Def. 51. 
Testament in naming "Elders" among his church officers, but by his theory they were merely some of the "most forwarde in gifte," duly chosen by the church for oversight and counsel, and redressing things amiss. That is, the original Brownism simply gave the name of elders to what Congregational churches call their Church, or Standing, Committee; which experience has proved to be useful, but which, instead of exercising authority over, and practically supplanting, the church owes its existence and power to the church choice and remains subordinate to the church. In the only extracts which have survived, in the citations of his opponents, from three treatises of Browne's not known to have been preserved in full, ${ }^{1}$ he combats the Presbyterian theory of elders.

Browne also demonstrated the intensely religious spirit which presided over the birth of his system by the vigor of its provisions for personal growth in grace. It threw every member of every church directly upon God and his Word. It bade every one feel that by diligence and prayer he could know of the doctrine. It taught him to regard himself as under a sacred obligation to so conduct himself that it would be natural and congruous for the Great Head of the Church to counsel and act through him. This idea, although faniliar to the Christian consciousness of our day, then was comparatively novel, and must have been stimulating. In fact, this maligned system of this abused man had in it the elements of both a nobler manliness and a richer godliness than any which it was intended to supplant. Browne, however, probably was not moved conclusively, or even especially, by any conviction that he was reproducing the original polity of the Acts of the Apostles. He was striving to make decadent religion live again, and was led chiefly by his Christian common sense as applied to what was in the English Church, but which clearly should not have been there.

His little church at Norwich became fully persuaded, after much trouble and persecution, ${ }^{2}$ that the Lord called them out of England, and they emigrated in a body to Middleberg, in Zealand,

1 Two are in Bancroft's Sermon at Paules Crosse, 76, 96. The third is referred to by Bredwell. Detection, 124.

2 Trve and Shori Declar. 19, 21, 22-24; Booke which Shew. Defs. 53, 115. 
apparently in the autumn of 1581. After about two years of changeful fortunes, the organization was broken up; mainly because many members proved incompetent to meet the high demands of their system. Browne makes it plain that the rock on which they split was their rule enjoining constant mutual criticism. Out of the practice of this grew surmises and contentions, which ended in sharp recriminations, open defiances and final disruption. Browne, with a few followers, got back to Scotland, to England, and, finally, to the Establishment and permanent discredit; relievable only by the probable supposition ${ }^{1}$ that, returning confessedly with shattered health, he never regained entire soundness of either body or mind.

That all of Browne's books, upon which the authorities could lay hold, were destroyed has been mentioned. On June 30 the queen issued a special proclamation ${ }^{2}$ against them. Thus hunted down, they hardly gained much popular circulation or influence. But no doubt a copy here or there, well hidden and at safe hours consulted, sowed its seeds of free thought to bring forth fruit in other minds.

In 1586 - on Nov. 19, apparently just two days ${ }^{3}$ before poor Browne, on his humiliated way back to the Church of England, was elected Master of the grammar-school of St. Olave's, Southwark - Henry Barrowe, already mentioned, well born in Norfolk, a B. A., in 1569-70, of Clare Hall, Cambridge, and a member of Gray's Inn, London, in 1576; who had frequented her Majesty's Court and had led a wild life, but whose mind had been fixed suddenly and convincingly upon religion; was arrested at the Clink Prison, in Southwark. He was visiting John Greenwood, a B. A. of Corpus Christi, Cambridge, in 1580-81, who had been imprisoned for holding a private conventicle. Barrowe probably made this call chiefly as a friend, yet, possibly, in part as a lawyer. But, once in the trap, the door was shut behind him without other warrant than the expressed

1 Cong. in Lit. 116-128.

2 Grenville Coll. fol. 225.

3 Waddington (Hist. Paps. 1 ser. 46; Hidden Ch. 32) names Nov. 21, 1586, as the date of Browne's election, and again (Cong. Hist. i : 23) gives it as Nov. 21, 1589. A writer in Notes \&. Queries, May, 1854 [494], also says 1589. The probabilities faror the earlier date. Barrowe's visit and arrest (Exams. of Henry Barrowe, Iohn Grenewood and Iohn Penrie, 1598, 3) were on Sunday, Nov. 19, 1586. 
wish of the archbishop to have him apprehended as soon as possible.

From this date these two men spent most of their time, usually together, in one or another prison, until, on Apr. 6, 1593 - a little more than two years after Browne had become rector of Achurch-cum-Thorpe ${ }^{1}$ - they were hanged, also together, at Tyburn. ${ }^{2}$ During these less than seven years they wrote much; Barrowe, who obviously was the abler, principally taking the lead. They were encompassed with difficulties, already explained. Yet they managed to increase the Separatist literature of their time greatly, alike in bulk and in merit. More than 1000 pages of their treatises can be counted, with more than 800 of which it seems certain that Barrowe chiefly had to do, and of nearly half of which he appears to have been sole author - without including the more than 275 pages of the Mar-prelate tracts, if Barrowe wrote them.

These two men must have studied Browne's books, ${ }^{3}$ or some of them, and also his fate and that of his church. They must have consented to his fundamental principle, that any local company of Christian believers, joined together and to Christ by mutual covenant, is a true church. But, deterred by the illworking of the experiment in Zealand, they had reacted from Browne's doctrine of the equality of all believers in the control of church affairs, and had turned to the Genevan plan to supply its place. That is, they held, with Browne, to the idea of the local church, self-complete and self-completed by its own action; but felt, with Cartwright, that its management might be entrusted most wisely to elders. In 1589 they contrived to have printed at Dort a "litle thyng of one shete of paper," ${ }^{4}$ which,

1 Peterborough Registers, Sept. 6, 1591.

2 The pathetic story of these two men is told at some length in Cong. in Lit. $205-252$.

${ }^{3}$ No reason to the contrary appears. There is every probability that they studied all such works as came within reach; and as Browne seems (Bancroft. Sermon at Paules Crosse, 76) to have written a treatise, perhaps never printed. "against one Barowe," upbraiding him for his "presbyterie or eldermen," and as no other "Barowe" seems likely to have been addressed thus, the supposition that the two men crossed swords in argument as to the eldership harmonizes all. Clearly Barrowe accepted Browne's view of the church itself.

4 Deposition of Rob. Stokes, Egerton Paps. 175. 
as the earliest quasi Congregational creed ${ }^{1}$ that has come down to us ipsissimis verbis, deserves consideration as to the points which have been raised. It defines a church thus : ${ }^{2}-$

This Church [one eluurch as there is one God, etc.] as it is vniversallie vuderstood, conteyneth in it all the Elect of God that hane bin, are, or shalbe: But being considered more particularlie, as it is seen in this present world, it consisteth of a companie and fellowship of faithful and holie people gathered in the name of Christ Iesus, their only King, Priest, and Prophet, worshipping him aright, being peaceablie and quietlie govemed by his Officers and lawes, keeping the vnitie of faith in the bond of peace \& love vnfained.

In another volume, a year later, they repeat this definition a little more at length. As to the choice of officers, they say :-

Thus hath enerie one of the people interest in the election and ordination of their officers, as also in the administration of their offices, vpon transgression, offence, abuse, \&c., having an especiall care vnto the inviolable order of the Church, is aforesaid.

They add :

The office of the Auncientes [elders] is expressed in their description: Their especiall care must bee, to see the ordinaunces of God truely taught and practized, aswel by the officers in dooing their duetie vprightlie, as to see that the people obey willinglie and readily. It is their duetie to see the Congregation holily and quietly ordered, and no way disturbed, by the contentious ... not taking away the libertie

1 A True Description ovt of the Word of God, of the Visible Church, 15s9, 1, 3, 5. Dr. Dexter adds: "An odd bit of literary listory is connected with this 'litle thyng.' It is excessively rare. I know of copies in Europe only in the British Museum and at Lambeth - each with the date 1589 as finis. But Henoch Clapham (Errour on the Right Hand, 1608, 11) charges that Arthur Billet reprinted this tract at Amsterdam, plaeing at the top of the seventeenth page a paragraph which Barrowe originally had placed after the two paragraphs which there follow it thus essentially softening the tone of the Creed as to excommunication and its effects - yet retaining the old date at the end. I never have seen this referred to elsewhere. As reprinted by Wall (More Work for the Deane, 1681) and by Hanbury (1839, i : 23-34), the order is that which Clapham criticises. But Alison, in his Plaine Confutation of this Creed, printed the year after the Dort original and several years before the Amsterdam alleged reissue, taking it up paragraph by paragraph for answer, gives these three in the order in which Clapham asserts that Barrowe originally wrote them. This looks as if Clapham were correct, and as if Wall and Hanbury had reprinted from the second edition, supposing it to be the first, naturally misled by the false date at the end."

2 A Collection of certain Letters and Conferences, Lately Passed Betvvixt Certaine Preachers \&. Two Prisoners in the Fleet, 1590, 4 to, 67. 
of the least, but vpholding the right of all, wiselie iudging of times and circumstances. They must bee readie assistauntes to the Pastour and Teachers, helping to beare their burden, but not intruding into their office.

In his able and elaborate work, ${ }^{1}$ Barrowe tries hard to harmonize this power of the elders with the perfect liberty of every private member :-

Who can doubt, but that every Christian hath Power and Authority in due time and place (not disturbing Christ's holy order in his Church) publickly to reproue any publick Transgression of any Member of the Church, or of the whole Church; as also to discouer and refute any Error escaped or delivered in publick Doctrine : yet, this (as is said) in due Time and Order, giuing leane and place unto the Elders and Prophets of the said Congregation first.

And, remembering that the average Christian then hardly could be expected to know enough to deal orderly and soberly in high matters, he says again :-

To this I Answer that they are to reprove no more than their assured Knowledge leadeth them unto. If they transgress the limits... then are they for so doing subiect to reproof and censure for abusing their Liberty.

As to Browne's fundamental idea that the godly people must reform the Church without waiting for the magistrate, when it was charged upon him as a part of his teaching, Barrowe replied : ${ }^{2}-$

We are to obey God rather then men, and if anie man be ignorant let him be ignorant still; We are not to stay from doing the Lord's Commaundement vppon the pleasure or offence of anie.

Here we have Browne's contribution to the long and wide controversy, the idea of local churches composed of " the forwardest," and independent of the State. And we have the

1 A Briefe Discoverie of the Fulse Church, etc., 1590, 4to (ed. 1707), 240, 242.

$2 A$ Collection of certaine Sclaunderous Articles gyuen out by the Bisshops against such faithfull Christians as they now vniustly deteyne in their Prisons togeather with the answeare of the saide Prisoners therunto. Also the some of certaine conferences had in the Fleete, according to the Bisshops bloudie Mandate with Tuo Prisoners there, 1590,4 to, 47 . 
Genevan idea of a session of elders, with whom is the power, the church being the supporting body and the eldership the energy within which drives and guides. Individual members have rights, but they must wait for the elders. When it is asked who are to judge whether those members transgress the limits of their knowledge, and become liable to reproof, the answer is, the elders. When it is inquired who is to administer in such a case, the answer again is, the elders. And, if members rebuke the elders, and the question rise who shall decide whether in such rebuke they have exceeded their liberty, the answer, still and always, is, the elders.

In Barrowe's mind this hybrid scheme, substantially involving a Congregational church managed by a Presbyterian session, solved all difficulties. It was Barrowism in distinction from Brownism. The Congregationalism of it broke the deadlock of Cartwright's failure to move towards reform, and the Presbyterianism of it was expected to forefend that anarchy which had ruined poor Browne's experiment. They would reform by companies, queen or no queen, wherever good people enough should be so minded. And in each company the pastor, teacher and "Auncientes" would manage all things discreetly and successfully ; and the "most humble, meek, obedient, faithfull, and loving people, . . . all bound to edifie one another, exhort, reprove, $\&$ comfort one another lovingly," ${ }^{2}$ in sober-minded submissiveness would endorse what the elders had done, and the millennium soon might be expected to dawn !

As early as 1587 or 1588 we find references to secret gatherings of Separatists in or near London, which may have had some connection with these teachings of Barrowe and Greenwood. But they were followed up so closely that their members spent much time in prison. The scattered hints which remain indicate that for three or four years a secret brotherhood existed, which admitted members; which, on one occasion certainly, expelled a member; and at whose instigation and for whose use the "Trve Description" was prepared in 1589 ; but which was not fully officered, and therefore did not enjoy the sacraments, until the early antumn of 1592. Then, according

\section{Trve Descrip. 2.}


to the deposition of Daniel Buck, ${ }^{1}$ of Southwark, Francis Johnson was chosen pastor; John Greenwood, apparently out of prison temporarily, doctor, or teacher; Christopher Bowman and Nicholas Lee, deacons, and Daniel Studley and George Knyveton, elders; showing, as, indeed, seems clear from Greenwood's participation, that this was a Barrowist chureh. Seven infants were baptized and the Lord's Supper was administered, so that the body at last became fully organized according to its principles.

On Apr. 6 Barrowe and Greenwood suffered martyrdom and Johnson was left in charge of the church. Doubtless he and his little company took great comfort, in spite of their limitations, in their initial incarnation of what they believed the true theory of a church. But their time was short. On Dec. 5 following, Johnson was arrested, and, only a little later, the great majority of the other members of the church were surprised at their Sunday worship in the Islington woods, and were hurried to prison. ${ }^{2}$

It was not long, however, before the authorities saw that they had gone too far. The majority of the church soon were set free, clearly in the expectation, if not with the pledge, that they would emigrate. A few left for Holland before the end of 1593 . They tarried a while at Campen and at Naarden, ${ }^{3}$ but at last they settled at Amsterdam. Here, before long, they came under the ministry of Henry Ainsworth, who filled a large place in the history of English Separatism in Holland until his painful death in 1622 or 1623. Francis Johnson and his brother George were detained in prison until the spring of 1597. Possibly this delay was because Francis had offended the authorities, as will be explained hereafter. In the antumn, however, they reached Amsterdam and joined their comrades. The church was

1 Deposition of Wm. Clerke, Harl. Ms. 7042: 110, 116, 117, etc., 14, 18, 399. See also p. 421.

2 Barrowe's Platform, 54, 56. They were " nnbalea [without bail] cōmitted." They had "neyther meate, drinke, fyre, [nor] lodging." Their friends were not allowed access to them. Husbands and wives were separated into different prisons. Some had not a penny about them. All was "contrary to all law, aequitie and conscience."

${ }^{3}$ T. White, Discov. of Brownisme, 15. G. Johnson, Disc. 15. C. Lawne, Prophane Schisme, 27. 
substantially together once more and was fully officered, Johnson resuming his pastorate and Ainsworth becoming teacher. Here the opening of the seventéenth century found them, but in circumstances painfully indigent and otherwise clistressing.

These ten closing years of the sixteenth century, after the printing at Dort of Barrowe's " Briefe Discoverie," gave birth to scarcely any ideas which were new to the great controversy. Robert Harrison, Browne's friend, who nevertheless parted from him at Middleberg and apparently remained there with a fraction of the original Norwich company until his death in, or abont, 1595 , printed a small volume ${ }^{1}$ which Brewster thought worthy of being reprinted at Leyden in 1618. Harrison's purpose was to give comfort and cheer to those remaining in England. He was prompted, in part, by the fact that Browne had just abandoned the enterprise, and he labors to show that the " untoward example of any man," even one "of great credit and estimation," whom "the Lord used also for a speciall instrument unto many things," ought not to "quench our zeale."

$\mathrm{He}$ is strenuous as to the right of every church to establish its own ministry, saying:-

Admit there be onely one church in a nation, and they want a Pastor : must they seek over sea \& land to get a minister ordained by other ministers? But what if there should be but only one apparant to us in the vrorld: shal that church for ever be deprived after they hane once wanted a minister, for defanlt of authority to cal $\&$ ordain another?

But as to the magistracy Harrison is behind Browne, saying : -

The eivill Magistrates may \& ought also to strike vvith their sword, every one which being of the Church, shal openly transgresse against the Lord's commandements.

In 1586 Stephen Bredwell, apparently a London physician of repute, printed an "Aclmonition" " 2 to the new Separatists, fol-

1 A Little Treatise vpon the firste Verse of the 122. Psalm. Stirring up unto carefull desiring \& dutifull labouring for true Church Gouernement, etc., 1583, 16 mo (ed. 1818), 39, 40, 66, 46,79 .

2 A Detection of Edward Glover's Heretical Confection, etc. with an Admonition to the followers of Glover and Browne, 15S6, $16 \mathrm{mo}$. 
lowed, two years later, by a second attack ${ }^{3}$ upon Browne. The opinion has been expressed already that Browne in later life was at least partially insane. This' gains strong support from Bredwell's second book. He assails Browne, largely on the ground of his mental unsoundness, and, as he must have had special knowledge of such matters and talks as if he knows Browne well, his testimony has weight. He speaks of the "tempest " of Browne's "disturbed and stormie affections ;" says that he has been "bitten \& torne" by Browne, "as it were with a mad $\log$;" calls his pen "furious," and speaks of "the inward ruines and downefall of iudgement" in his case. He says, "Browne is sound, his braine is sicke." He adds, "This Trouble-church Browne . . . is (in a heanie, though iust indgement) compassed about with a strong delusion," and, "If he be so mad that he vnderstandeth not practise to be workes, then is he too mad to bee talked withall." His criticism upon one of Browne's positions is, "Whereunto if I shoulde answere hee was madke, I should fanour him much, in moning pitie for him: and if it be not taken so, both friends and enemies, must needes set a harder sentence vppon him." Finally, he declares, "And thus (belike) because Browne is not yet so madde, as that hee will suffer no clothes vpon him, wee shoulde not beleene diuer'se of his great friendes, who say, he is madde, or out of his wittes, whereby they seeke to excuse his dealings."

So far as he reasons against Browne's system, Bredwell condemns it for teaching that "there may bee a true Church of God without the Presbyterie," and insists that no man ought to forsake the Lord's Supper on account of the presence of the unworthy; that the Church of England is no more unsound than divers churches from which no separation is advised; and that discipline is not essential to a church.

In the summer of 1590, Cartwright, then Master of the Hospital at Warwick, wrote to his sister-in-law, to persuade her against Brownism. The original letter, ${ }^{2}$ in the British Museum,

I The Rasing of the Foundations of Brovvnisme, etc., 158s, 4to, 66, xiii, 65, 112, 72, 13,97 , ii.

${ }^{2} A$ Letter against Brownisme : to his sister-in-law, Mrs. Anne Stubbes. IIarl. Ms. 7581,4 . 
shows how the controversy looked to a master-mind thoroughly familiar with the subject, and prepossessed towards Presbyterianism. He boldly controverts the main premise of the Separatists thus :-

As a wief that hath broken her faith is not forthwith out of accompt of a wife, untille, she beinge convinced [convicted] thereof, be for that cause divorced from her husband. So the Church notwithstanding her spiritual adultery, is not unchurched neither ceases to be reputed a church untill such tyme as the Lord, taking away the ministring of the word from her, and the administration of the Sacrament, hath, as it were, by bill of divorce disabled her.

This year, 1590, was fruitful of treatises on church government. Of nearly thirty perhaps half were aimed at the Separatists. One, ${ }^{1}$ by Dr. R. Alison, is a review of the little tract by Barrowe and Greenwood before noted, seeking to neutralize its force. A second is by George Gifford, already mentioned, who seeks to fasten upon the Brownists an odious name ${ }^{2}$ out of the past, while publishing to the world " some of their heresies, and frantike opinions." He also is emphatic in comnecting Barrowe and Greenwood directly with Browne himself, no doubt expressing the common judgment. This was replied to at once by Greenwood, ${ }^{3}$ and in the same year Gifford answered ${ }^{4}$ him. In the next year Barrowe and Greenwood together replied ${ }^{5}$ to Gifford's last. This reply is the small quarto already mentioned as having been burned, excepting two copies, by Francis Johnson before it could be circulated, and reprinted by him at his own expense in 1605. Gifford seems to have obtained a copy, and, although conceding that the book had been "intercepted," thought it worth a short notice. ${ }^{6}$ Only a few points of this discussion need be noted.

1 A Plaine Confutation of a Treatise of Brovvnisme, Published by some of that Faction, Entituled A Description . of the Visible Church, etc., 1590, 4to. See p. 201, n. 1.

${ }^{2}$ A Short Treatise against the Donatists of England, whome we call Brownists, etc., 1590, tto.

${ }^{3}$ An Answer to Geo. Gifford's Pretended Defence of Read Prayers and Devised Leitourgies, etc., 1590, fto.

4 A Plaine Declaration that our Brownists be full Donatists. . . . Also a replie to Master Greenwood touching read prayer, etc., 1590, 4 to.

5 A Plaine Refutation of M. Giffards Booke, etc., 1590, 4to.

${ }^{6}$ A Short Reply vnto the last printed books of Henry Barrow and John Greenwood, the chiefe ringleallers of our Donatists in England, etc., 1591, 4to. 
Barrowe and Greenwood deny any connection with the Brownists, ${ }^{1}$ and define their own position as between the practically popular government of the Brownists and the obviously aristocratic govermment of the Presbyterians, arguing that both the elders and the people have voices in church action. They also vindicate the right, and assert the duty, to form separate churches in needful circumstances, thus :-

The Church in this estate consisting only of private men, ought to erect this ministerie and governement: ells should they also cease and never be had againe vpon the earth : and so should there neuer be any established Church, ministrie, Sacraments etc, agayne in this world.

And, as to waiting for the civil authorities to undertake church reform, they say:-

For this, we alleadged the examples and practize of the Apostles, who then had bene guiltie of the same disobedience \& rebellion, if Princes in this busines had bene to be stayed for, or their restrainte had bene a sufficient let [hindrance]: yea that persecution and the crosse of Christ were vtterly abolished, if the Church and faithfull were not to proceede in their duties, vntill Princes gine leave. We shevved also, that the obedience and practice of Gods vvill was no disobedience or prejudice to the Prince.

In 1596 , while probably the majority - at any rate, the pastor and elders who, by their theory, constituted the most important portion - of the Amsterdam church remained imprisoned in London, there was printed, presumably at Amsterdam, a little quarto, ${ }^{2}$ of twenty-two pages, describing their position with

1 Plaine Ref. 184, 76, 78, 198.

2 A Trve Confession of the Faith and Humble Acknovvledgment of the Alegeance, vwhich veee hir Maiesties Subjects, falsely called Brovvnists, doo hould towards God, and yeild to hir Majestie and all other that are ouer vs in the Lord. Set dovvn in Articles or Positions, for the better \& more easie vnderstanding of those that shall read $y t$ : And published for the cleering of our selues from those vnchristian slanders of heresie, schisme, pryde, obstinacie, disloyaltie, sedicion, \&c. vihich by our aduersaries are in all places given out against $v s, 1596,4$ to, iii, v. Unquestionably the result of much conference between the two separated portions of the church. G. Johnson (Disc. 10) says: "The church for 5. or 6. yeares practised as the Pastor, elders and brethren, being in prison at London, wrote unto them." See also a statement by F. Johnson (Inquirie and Answer of Thos. White, his Discoverie, 61) as to correspondence. Clearly the Confession was the result of such consultation. The documents were sent back and forth by messengers. 
some precision. It begins with a touching preface, referring, with details, to their long and bitter persecution.

Their motives are to testify to " the rufull estate of our poore Contrymen," and to condemn the "barbarous crueltie" of the hierarchy, e. g.: -

24. soules have perished in their prisons, with in the Cittie of London only, (besides other places of the Land) \& that of late yeeres. Manie also have they, by their immanitie [inhmmanity] cansed to blaspheme and forsake the faith of our glorions Lord Iesus Christ, and many mo[re] they terrifie and keep from the same. For all this, yet were not these savage men satisfied, . . . but they procured certeine of vs (after manie yeeres emprisonment) to be indighted, arrayned, condemned and hanged as felons ... Henry Barrow, Iohn Greenwood (and Iohn Penry) whose perticular examinations, araignments and maner of execution, with the circumstances about them, if thou didst truly vnderstand (gentle Reader) it would make thy hart to bleed, considering their vnchristian and vnnaturall usage. About the same tyme they executed also one William Denis, at Thetford in Northfolke, and long before they kylled two men, at Bury, in Suffolk, Coppyn and Elias [Thacker], for the like testimonie. Others they deteyne in their prysons to this day, who look for the like measure at their mereilesse hands, yf God in mercye release them not before.

The essential points of the "Confession" form a summary of doctrinal belief, intended to refute the charge of theological looseness, together with five or six prineiples of polity.

Like the "Trve Description," this "Confession," although somewhat vague as to the eldership, ${ }^{1}$ seems to teach that, although a vote of the whole body is essential to the reception or discipline of members, the real control of church affairs rests with its officers. As to the civil power and their relations with it, they declare frankly:-

It is the Office and duty of Princes and Magestrates, who by the ordinance of God are supreme Governers vuder him over all persons and causes within their Realmes and Dominions, to suppress and root out by their authoritie all false ministeries, voluntarie Religions and counterfeyt vvorship of God. . . . And on the other hand to establish $\&$ mayntein by their lawes every part of Gods word his pure Relligion

1 Probably the difficulty of governing a church in Amsterdam by a body of elders in the London prisons led to a lighter statement of this doctrine than might have been drawn up otherwise, and certainly than their habitual practice implied. 
and true ministerie ... yea to enforce al their Subiects whether Ecclesiastical or civill, to do their dutyes to God and men.

One further point deserves consideration. The twenty-sixth article provides for mutual watchfulness. In general, beyond doubt, this provision is Scriptural and wholesome. But such a theory must be guarded from morbidness in conception and exaggeration in administration. George Johnson's garrulous volume ${ }^{1}$ shows that the mistake of Browne's church was made again when this London-Amsterdam church undertook to administer a similar rule. However helpful towards sanctification habitual mutual criticism might prove to a company of judicious, discriminating believers, it was a perilous resource for these zealously conscientious, rudely cultured, hasty and plain-spoken Separatists.

On the whole this "Confession" takes a highly respectable rank as a clear, compact and Scriptural formula, nor does it lack some felicities of style. Two years later it was translated into Latin. ${ }^{2}$

Our review of the chief religious and ecclesiastical events of the sixteenth century has shown that the origin of Puritanism was both broader and deeper than that mere "scrupling of the vestments" in which so many writers have lodged it. Cartwright, Travers and their co-workers brought home from Continental exile a conception of church government by the eldership which afterwards developed into the full-fledged Presbyterianism of to-day. But they neutralized their own endeavors effectually by waiting for the civil power to initiate that more genuine and thorough reformation, needful to complete what already was begun, by proposing to leave that reformation, when accomplished, under civil control; and by holding to the old, all-embracing, national theory of a church including, by his birthright and baptism, every citizen, of whatsoever character, looking to discipline, if to anything, to raise the general life to the gospel standard. Nor was there struck out from all their multi. plied discussions a spark of real light upon the grave and gloomy difficulties of the situation.

1 A Discourse of some Troubles, etc., 95̃-97, 123-135, v.

2 Confessio Fidei Anglorum Qvorvndam in Belgia Exulantium, 1598, 16mo. 
It has been shown, further, that the first practical suggestion of relief came, in 1580, from Browne, who sought to shape a polity which, by Scripture and common sense, should authorize the action by which any company of spiritually "forward" believers might emancipate itself. Without waiting for the prince, or even for a majority of the people, it might constitute itself by mutual covenant a local church, competent for the regular election and ordination of its own officers and the independent management, under Christ, of its own affairs. And such a church - every member of which, by faithful personal union to Christ, would become a viceroy of the great Head of the Church, a divinely ordained channel through whom the power of Christ would flow to inform decision and to energize action - would be indistinguishable from a democracy to human view. It also has appeared that, by laying upon the membership of such a church a burden of responsibility for each other's personal perfection, Browne brought about an explosion terminating his experiment.

Beyond this it has been seen how Barrowe, laying hold of Browne's seminal idea of the separation of the righteous from the unrighteous; yet seeking to pilot his separated company safely away from the rocks of popular government and the shoals of self-conceit, borrowed from Calvin and Cartwright their session of elders, and conceived the idea of establishing Congregational churches, each of which should elect a board of Presbyterian elders and confide to it the entire control of church affairs.

The close of the sixteenth century, then, found the Church of England in some degree honeycombed by Presbyterianism. There were Puritans in plenty both in and out of its pulpits, who were striving vaguely or urgently for better things. They were seeking in all ready ways to move the Queen, the Court and the State to blow a trumpet of reform by which the bishops should be officially overthrown, and church government by the eldership should take the place of the hierarchy.

Here and there, also - and most of them had much of the experience which Paul describes ${ }^{1}$ as his own :-

12 Cor. xi: 23-27. Gen. vers. ed. 1577. 
In labours more abundant: in stripes aboue measure: in prison more plenteously: in death oft. . . .

In perils of mine own natiō, . . . in perils in the eitie, in perils in the wildernes, in perils in the sea, in perils among false brethren,

In wearines and painfulnes, in watching often, in hunger \& thirst, in fastings often, in colde and in nakednes,

were a few heroic souls unable to rest in mere Puritanism. ${ }^{1}$ In their judgment it halted criminally, and became of no avail, precisely when and where it ought to have gone forward most urgently. Therefore they found no peace until they had pushed on into a Separation which should clear their skirts of guilt, and set an example to an ungodly world and a frigid, half-hearted and hesitant hierarchy - an example of companies of believers covenanted together to reproduce the original polity, and able to work for the Master with a freedom of movement and a beauty and glory of result, such as had not been seen upon earth for more than a thousand years.

So the last day's sun of the year 1600 went down upon a small company of Barrowists, who were struggling against grim and grinding poverty to maintain themselves as a Christian church in Amsterdam; together with a little borly of sympathizers maintaining an associate church life feebly and secretly in London; and possibly a scattered few occasionally meeting together in the safe night-time, or in the shelter of some dense wood, in Norwich, Chattisham or the West of England, or even in Ireland ${ }^{2}$ - rari nantes in gurgite vasto.

1 It may be noted here - in addition to what has been stated about otlers that the oldest Baptist church appears to have been founded in 1611, although there had been little companies of Baptist worshippers here or there for nearly or quite a century previous. Baptist scholars do not agree as to whether immersion was practised by these assemblies or was reintroduced in 1641, or possibly in 1633.

2 G. Johnson speaks (Disc. 205) of wishing to appeal his ease to the church in Norwich, and of a letter to lis brother from "Mr. Hunt the pastor of the Church at Chatsum." F. Johnson says (Inq. and Ans. of Thos. White, 52-53) that White and twelve or thirteen of his company first joined a (Separatist) Chureh "in the West parts of England," and Bredwell speaks (Rasing, iv.) of Separatists in "the West, almost to the nttermost horders thereof." Penry in a letter (Life, 176) urges "Comfort the brethren in the West and North conntries;" and Barrowe's Platform $(49-53)$ has a letter from Separatists in Ireland to a Scotch preacher naned Wood. 


\section{BOOK III}

THE BIRTHPLACE OF THE PILGRIM CHURCH 
Out of the eater came meate, and out of the strong came sweetnesse. — JUDGES xiiii : 14.

A little one shall become as a thousand, and a small one as a strong nation: I the Lord will hasten it in due time. ISAIAH lx : 22 .

The first impression on reaching Scrooby, is that of perfect wonderment how so small a place could possibly have originated the Pilgrim Movement. - E. Arber, Story of Pilg. Faths. 58. 


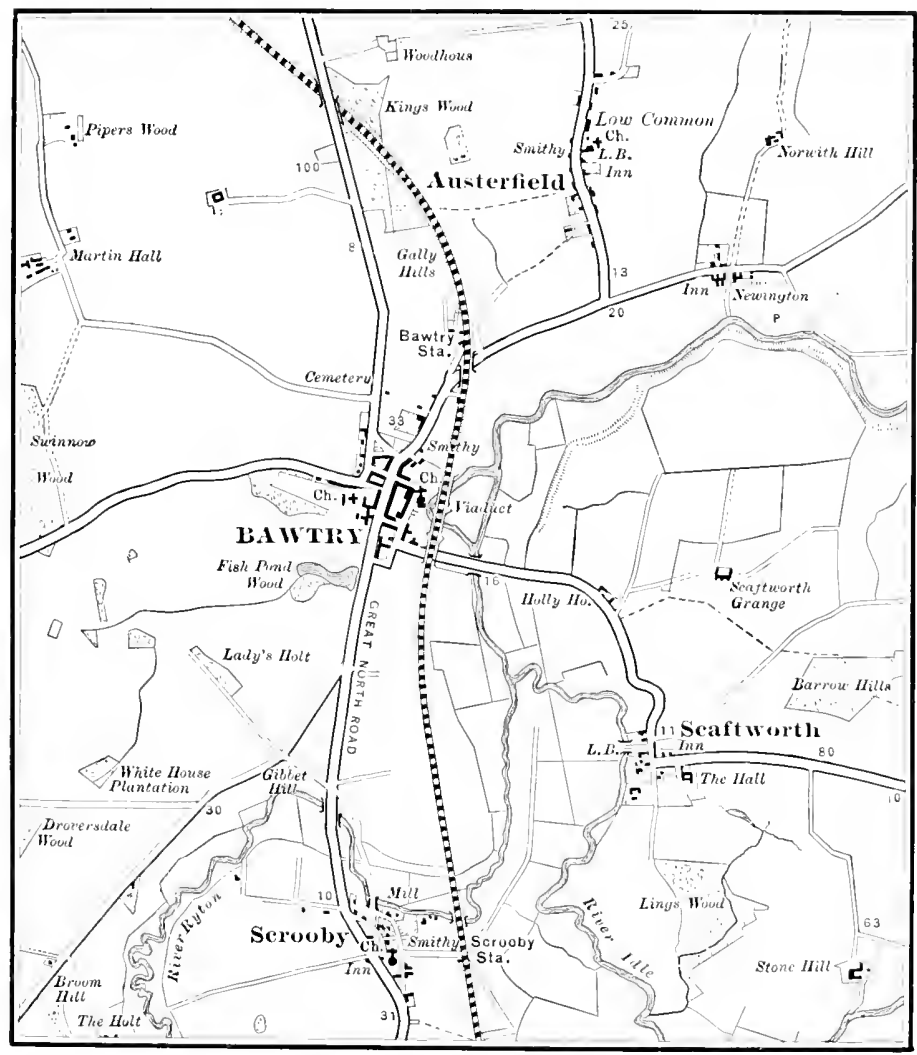

THE PILGRIM REGION 


\section{CHAPTER I}

\section{SCROOBY}

Nottinghamshire thrusts up its northern angle, like a blunt spear-head some fifteen miles in depth, between Yorkshire and Lincolnshire, where they come together below the junction of the Ouse and the Trent to form the Humber. The point of contact of these counties is very nearly in the same latitnde with the southern extremity of the opening through which the Humber pours into the German Ocean, and is about forty-five miles due west from it. A range of hills stretches for about fifty miles almost directly north from Grantham and Lincoln, until it pushes the channel of the Humber northward at West Halton and $W$ interingham. The Trent, with its affluents, drains the basin lying west of these hills and between them and those of Sheffield and the West Riling of York. For twenty-five or thirty miles southwest from the Humber, this basin for the most part is broad and shallow, as if it had been the bottom of a lake. It contains many wide stretches of meadows and fruitful fields, now well drained but in old times swamp lands, the favorite haunts of all manner of wild creatures loving moist places.

The Trent lies well over towards the eastern side of this valley, skirting the western base of the hills. Its sluggish tributaries, the Ille and the Ryton, extend southward and westward ; the former towards Nottingham and Newstead Abbey, the latter enriching itself from the springs of the border of the adjacent shire, and emptying into the Idle about six miles south-southeast of the junction of the three counties. The tongue of fenny land in the midst of encompassing moors, formed by the confluence at an acute angle of gently rolling hills within eyeshot on either side, and once admirably situated for hunting - being within easy ride of the famous old Sherwood Forest of Robin Hood, on 
the soutl, and of Hatfield Chase, on the north, and itself surrounded by the natural haunts of game - lies in the parish of Scrooby, Notts., and eame very early into the possession of the northern archbishop.

At what precise date existing records do not show. Doomsday Book ${ }^{1}$ describes it as one of the properties of the see of York, although no palace seems to have been there then. Almost exactly a century later, however, an official record ${ }^{2}$ implies the use of a residence when his occasions attracted the archbishop to the extreme sonthern portion of his domain. In 1207 King John ordered three tums of Vascon wine and one of Mussac to be conveyed thither ${ }^{3}$ in language possibly signifying not merely his interest in his half-brother, the incumbent of the see, but also some personal expectation of comfort therefrom. And five years later, Aug. 28-30, 1212, he claimed hospitality $^{4}$ there, and signed orders which went thence to distant parts of the kingdom.

During the following century, including the reigus of Henry III. and the first two Edwards, throngh the meagre public records we gain occasional glimpses of what was going on there. Whatever of comfort, or even of rude splendor, then existed evidently was not only kept up well but considerably increased. During the periodical sojournings of the archbishop it became the resort of church and conventual officials, tendering allegiance and desiring recognition, and of civil suitors, asking administration upon the estates of the dead, or other judgments. Its parks were stocked with deer. Grain was laid up there. It

1 The common name of the Liber de Wintonia, a record of a survey of England in the time of William the Conqueror, completed in 1086. It is in two volumes; one a folio [pp. 382 double], and one a quarto [pp. 450 donble]; and is in the Public Record Office, London. It is supposed to be so named because, between different judgments concerning any land, its anthority always has been held to be conclusive. The record is :-

"In SVDTONE, Scrobi, Madressei, I. car. trae VI bov ad ged. etc. [under the head of] Terra Archiep. Ebor. etc.

In Sutton, Scrooby and Mattersey [or Lownd], one earucate [as much as one team can plough in a year, usually 100 acres,] and six ox-gangs to be taxed, ete."

Ed. 1S62, i : vii.

2 Mag. Rot. Pipae for I Rich, I. 1189-90, 9, 10.

3 Close Roll. 9 John, 1207, xxviii Jul. $\quad 4$ Close Roll. 14 John, 1212. 
had a chapel ${ }^{1}$ of its own, although the comely little parish chureh of St. Wilfred - the beantiful gray spire of which remains to this day, probably the only unaltered object within the range of one's vision - stood within 1000 feet. In 1287 an important document ${ }^{2}$ was signed there.

At intervals, although not frequently, during the next 150 years, while a third Edward, a second Richard and the fourth Henry were reigning, this remote place was dignified now and then by the brief stay of some one high in rank. A chamber built there found mention for its importance. Game was hunted and stored. The Bishop of Whitherne ${ }^{3}$ was there. On . Ime 19, 1300, Archbishop Corbridge there gave leave for two Minorites. - Michael de Merton and Reginald de Kington - to confess those of the York Province who were going to fight in Scotland. ${ }^{4}$ On Sunday, Dec. 18, 1300, Robert, abbot of Roche Abbey, professed canonical obedience there. ${ }^{5}$ On July 12, 1306, Archbishop Greenfield wrote from Scrooby to Pope Clement V. that he had obeyed his mandate, and desired the Bishops of Carlisle and Whitherne and the Chancellor and Chamberlain of Scotland to cite the Bishop of Glasgow, but had learned that the last named bishop had been captured, with other rebels, after seizing Cupar Castle; so that they could not serve the citation without the king's leave, which he would not give. ${ }^{6}$

On Sunday, Apr. 13, 1315, the same archbishop wrote from Scrooby to his official at York, directing him to summon all the clergy to a council of war at Doncaster against the Scots. Next day he sent word to John de Mowbray to attend the same council, and named fifty others similarly summoned. And on May 19, 1320, Archbishop Melton wrote from Scrooby to an official at York, ordering him to forbid the tilting and tommament, then arranged to be held near York, on pain of the greater excommu-

1 Dec. 20, 1301, Sir WVm. de Ros, Jr., of Ingmanthorp, did homage to the archbishop in the chapel of Scrooby for the manor of Muskham. Dixon and Raine, Fasti Eboracenses, i : 312, 821, 359, 395, 433.

2 An elaborate instrnment settling old differences between the Vicar of Blyth and some of the neighboring religious people. Raine, Blyth, 59 .

3 He professed obedience, June 20, 1306. Fast. Eb. i: 390, n.

${ }^{4}$ Hist. Paps, and Lets. from North. Registers, 1873, 143.

5 Aveling, Hist. Roche Abbey, 44.

${ }^{6}$ Hist. Paps. 172-175, 245, 246-247, 305. 
nication. Troubles at Blyth, near by, were adjusted there, not for the first time, on Jan. 22, 1346. ${ }^{1}$ On July 26, 1347, the will of Sir John de Warren, eighth Earl of Surrey, was proved there. ${ }^{2}$ On Sept. 6, 1464, the archbishop there commanded Lord William, Bishop of Dromore, his suffragan, to confer benediction upon John Gray, abbot-elect of Roche Abbey ; ${ }^{3}$ and on Dec. 19, 1486, six years before Columbus discovered America, the archbishop there did a like service for Thomas Thurne, abbotelect. Then, in the fragrant summer of the eighteenth year of Henry VII., on June 12, 1503, Margaret, eldest daughter of the monarch, on her way to Scotland to become the second wife of its king, James IV., made stay at Scrooby.

Fortunately for us, John Younge, Somerset Herald, had place in the company in order to record its progress. The princess left Tuxford, some twenty miles nearer London, and "drew hyr Way ryght to sirowsby (a Manayer of the Reverend Father in God my Lord the Archbyshop of Yorke) to her Bedd." 4 There was the Earl of Surrey, Lord Treasurer of England, "varey noblely arayed and all his Trayne," including "many Nobles, Lords, Knights and Squyers," together "with my Lady his Wyffe, accompaned of many Ladys and Gentyllwomen varey noblely arayed." There was the Earl of Kent and the Lords of Strange, Hastings and Willoughby, "varey nobly arayed and accompanyd of theire Folks in Liveray, and on Horses, rychely in Apparayll." There were Sir Davy Owen and Sir Thomas Worteley and their suites. There was Sir Ralph Vernell, "accompayned of my Lady his Wyffe, of many Gentylmen, Gentyllswomen, and others abidyng in Scotland, by the Space folouyng the good Plaisure of the Kyng." There was the " Reverend Father in God my Lord the Bischop of Norwych, well accompanyed and honestly arayed." There, too, was the "Reverend Father in God my Lord the Bishop of Morrey ${ }^{5}$ [Moray], Embassador of the King of Scotts, well and honestly arayed."

Then came "Ladyes mounted upon fayre Pallefrays, many Squyers before them," and then "a Char[iot]" having several

1 Raine, Blyth, 60. 2 "In manerio de Scroby," Pubs. Surtees Soc. 45.

3 Aveling, 60,64. 4 Leland, Collectanea de Rebus Britannicis, iv : 265-300.

5 Andrew Forman, afterwards Archbishop of St. Andrews. 
" Fotemen" with "sixe fayre Horseys leyd," and "others, Gentylls women of the sayd Ladyes, mounted upon Pallefrays well appoynted." There also were "Johannes and his companye, the Menstrells of Musick;" after whom marched officers and sergeants and marshals, gentlemen "ordonned [ordained] to make Space, that more playnly the sayd Quene and her Companey might bee better sene;" the rear of the cavalcade proper being brought up by a great company of retainers. There was, also, the local escort through Nottinghamshire, "Mr. William Perpoynt, Scheriff of Nothynhamshyre, having in his Felloweschip Sir John Marcant, Sir John Duneham, Sir William Beron, Knights, and other Gentylmen and Squyers, accompayned of their Folks well honnestly drest of their Liverays, and horsed, to the Nomber of two hundreth Horsys."

Moreover, there marched in attendance from Tuxford a numerous company of "honest Personnes, next Neybours of the said Place, all on Horseback, honnestly drest, for to se the sayd Quene, wyth many other Personages a Foot in grett nomber; lykewys the next Morning att hyr departyng;" this langnage implying that these last did not spend the night at Scrooby. This would leave to sleep within the precincts of the archiepiscopal manor-house the 300 , who composed what may be termed the through train, together with the 200, of the Nottinghamshire escort, who would give place the next day, at the near line between the shires, to a like troop under Sir William Conyers, the Sheriff of Yorkshire, doubtless with some others.

At this time Thomas Savage was Archbishop of York and in possession of this residence. We do not know why, as the narrative implies, he was not present to do honor to his sovereign's daughter, or who acted as his deputy. But we cannot doubt that amplest preparation had been made for the care of so large and gallant a company. Sherwood Forest and Hatfield Chase donbtless had been hunted and the moors despoiled of their game, as soon as, a few days before, tidings of this burdensome intended honor had arrived ; while the local deer-parks, the fishponds and the dove-cote had made generous contribution. Nor is it unlikely that, as the custom ${ }^{1}$ was, neighbors and friends

1 The Earl of Shrewsbury wrote, Mar. 30, 1603, from Whitehall to Worksop 
from near and far had come to see the great sight, bringing with them "fatt eapons \& hennes, partrydges, or the lyke," to increase the resomrces of the hospitable manor-house, so that not only none should want, but that, as we know happened when the king himself came, much might be left for the poor of the neighborhood. ${ }^{1}$

It is not to be supposed that all these from 400 to 600 people had separate rooms or beds, ${ }^{2}$ or their steeds unshared stabling. The princess and her titled attendants doultless were well accommodated, albeit after what we should regard as a somewhat rude fashion. But most of the company must have bestowed themselves upon the floors of the great hall and other spacions apartments, much as a regiment in bivonac extemporizes quarters for itself, while the horses which overflowed the stables would be picketed in the ample courts or neighboring meadows. But nobody would go to sleep hungry or thirsty. There would be plenty of food of some sort, and, if the Vaseon and the Mussac ran low, there would be abundance of good home-brewed ale to take their place.

After more serious work was over, we safely may imagine Johannes and his "Menstrells of Musick" enlivening the long

that he might entertain the new king [James, proclaimed six days before, who must make his way from Seotland]. So he bade John Harper, "to lett all my good frends in Derbyshire \& Staffordshire know so much, to the end that I may have theire companie against such tyme as his $\mathrm{Ma}^{\text {tie }}$ shall come thither." He promised to let the exact time be known as soon as possible: "but then yt wilbe to late for your horses or anie thinge else to be prepared, unlesse yon prepare them presently upon the receipt hereof." The postscript is significant: "I will not refuse any fatt capons \& hennes, partrydges, or the lyke, yf the Kinge come to mee." The letter bears an endorsement showing that it was circulated among the "good frends," as requested, viz. :-

"I receined this letter from my cousine Harpur, that you gentlemen may see $y t$, \& consider of $\mathrm{yt}^{\prime} \& \mathrm{w}^{\text {th }}$ all I understand by him that $\mathrm{I}^{\mathrm{r}}$. Henry Cavandish answered the noblemen to his eredit, $w^{\text {ch }}$ I am glad of, \& those that love him. -John Curzon." Hunter, Sheffield, 121.

Evidently Curzon, after he had authenticated this letter thus, sent it round to the neighboring gentry; who doubtless were more than glad to take part in such a pageant and to carry ample provision with them.

1 Nichols, Progresses of Jas. I. i : 87.

2 Cavendish sars that 280 beds were reads in Hampton Court Palace in 1527. (E. Law, Hist. Hamp. Ct. Pal.i : 105.) But that palace was many times larger than Scrooby Manor-honse ever was, although the latter sometimes was called a palace. 
twilight with their glees and carols; but, unless we underrate their ability as harmonists or overrate the fondness of the fair Margaret for the melodies of art as compared with those of nature, probably at last she passed with resignation even from the "most excellent soule-ravishing musique," as it died away under the windows of the "great chamber," to the sweeter stillness of the moonlit plain, just modulated by the soft ripple of the Ryton as it washed one side of one of the courts, cnriched now and then by the muffled call of the cuckoo and the indescribably pathetic trill of the nightingale, whose lineal descendants to this day haunt and gladden the spot.

"The XIIIth Day of the said Monneth she departed from the sayd Place, accompanyed as before." Not at dawn, however. For time was given for the reassembling of the dispersed horse and foot companies of neighbors, and for the gathering of the nortlyern sheriff's escort, which probably came down from Doncaster. Presumably Johannes and his men now came to the front, and it was with the blast of trumpets that the "varey noble Trayne" clattered out upon the drawbridge over the moat, turning sharply to the right almost at once by the "mylnes [mills] of Scroby water," which added to the revenues of the see while serving the countryfolk, and so down to the ford, on the other side of which the Yorkshire cavalcade awaited them with loyal shoutings.

The Scrooby palace seems to have reached its best estate soon after this date. It is on record that Archbishop Savage, who was extravagantly fond of hunting, " built much here," until it was ample for the frequent entertainment of " the great number of goodly tall fellows" who habitually attended him. It must be remembered, however, that seven or eight archiepiscopal residences belonged to the see of York, and that the prelate was itinerating ${ }^{1}$ among them almost constantly. Therefore his stay at each residence was apt to be brief; and, instead of furnishing so many edifices elaborately, such dignitaries took with them from place to place not only a retinue of under-servants,

1 Fast. Eb. i : 308. "A bishop, like his sovereign, was rarely more than three days at a time in one place. He was always passing from residence to residence with all the pomp and ceremony of a great feudal baron." 
but all lighter furniture, as well as the richer furnishings of their tables. That most conscientious volume ${ }^{1}$ which begins the history of the northern archbishops in 627, to leave it, to the great loss of scholars, with John de Thoresby in 1373, says :-

Hawks and hounds were frequently his [the archbishop's] companions on his travels, and he would turn aside every now and then from the beaten causeway to flush the heron from its waterpool, or to chase the red deer through the woods. Behind the archbishop there rode a long train of domestics, who carried with them the wardrobe and the plate, and a great part of the furniture of their master. With these each of his manor-houses or castles was equipped, to be stripped again when the visitors deserted it.

Wolsey, next but one in succession to Archbishop Savage, was a constant absentee from his province during the time of his prosperity. We know, however, that in his journeyings he always carried with him a service of plate of very great value. ${ }^{2}$ It belonged to such general conditions that some, at least, of these abiding-places would be, not caravansaries exactly, merely offering bare rooms, to be furnished wholly by the traveller, but skeleton homes, so to speak, perhaps stocked with the more solid articles of household use, yet needing to be refurnished at every recurring period of residence with the lighter and more luxurious equipments.

Moreover, it was necessary that each of these manor-houses should be in charge of some resident agent, to look after the crops, collect rents, make repairs, keep everything in some condition of thrift, and, at however sudden notice, make suitable provision for the periodical visitations of the archbishop. And where the manorial property was large, as at Scrooby, ${ }^{3}$ and many tenants and divers interests required attention, it was inevitable that, for public convenience, some authorized legal representative of the archbishop always should be in residence to afford

1 Fast. Eb. i: 308.

2 S. Giustinian at Court of Henry IIII. ii : 314.

8 "The civil government of the soke or liberty of Soutliwell cum Scrooby, comprehending twenty towuships, is separated from that of the rest of the county of Nottingham. The justices of the peace are appointed by the Archbishop of York, but are under a commission from the crown; they hold quarter-sessions at Southwell and Scrooby." - Cavendish, Wolsey, Wordsworth, Eccles. Biogs. (ed. 1853), 625 and n., $627,628,630$. 
to the rural population such advantage of the absent proprietor's constructive presence as might be had by deputy. That such an officer habitually resided at Scrooby is matter of fair inference. That one actually was on the ground in the sixteentl century will be shown later from documentary evidence.

It is a quieter, not to say a more sombre, picture which we get of Scrooby when, almost a generation afterwards, a ray from written history once more falls upon it. It is later in the year, and the brown ripeness of the harvest time mellows and enriches the landscape. That great but falling statesman, who was taking the archbishopric in his fall, now, driven with averted face from the Court, was on his way to this place of temporary rest. For several days couriers had been arriving with orders, and heavy-laden sumpter-mules and packhorses had been coming in over the drawbrilge, while all the premises had been astir with the bustle of preparation.

Cardinal Wolsey had been at Southwell since about May 1, and desired to push on towards the heart of his ecclesiastical province. It was not until the very last of August, however, that matters altogether suited his movement. There was a large gathering of worshipful gentlemen for his escort. But Wolsey was so anxious to avoid the great hunt which they were planning for him that he stole a march upon them in the gray of a Monday morning, and so paced his mule over the sixteen miles that he reached Newstead Abbey before six o'clock, leaving most of his grand escort in their beds. But "the matter was laughed at, and so merrily jested out, that all was well taken." The next day, Ang. 30, they dined at Rufford Abbey and slept at Blytl Abbey, so that it was on the last day of the last summer month, towards noon, when, without music or maidenly presence, his large cortége drew by the Serlby woods into the great North Road and passed on to Scrooby into the manor-house courts.

The whole of September was spent here. On Sunday it was the habit of the cardinal-archbishop to make an excursion to some neighboring parish church - at Bawtry, Misson, Everton, Mattersey or Harworth - and say or hear mass, causing one of his chaplains to preach to the congregation. After service he would dine at " some honest house in the towne, where should be 
distributed to the people a great almes of meate and drinke; or of money to supply the want of meate, if the nomber of the pore did so excede in necessity." And for the week days his servant 1 draws a genial picture of this wily and worn old diplomat offering himself as a peacemaker for old strifes. Nor will this limning of these fine autumn days here be complete if we do not remember that there were able men in the suite of the cardinal, and that with the diversions of the chase they mingled converse in art and studies in good letters, so that the walls of this rural palace not merely resounded with the strong Saxon of the time, but sometimes echoed a finer flavor of speech in the flowing measures of Petrarch and the statelier, if not profounder, periods of Castiglione. ${ }^{2}$

With the exception of its dry enumeration among the possessions of the see of York in the sworn list, ${ }^{3}$ returned to the king in 1535, of the property of the Church, our next glimpse of this manor-house is in the almost equally arid, but more instructive, mention of the famous antiquary, Leland, who, three years later, paused there on his journey in search of notable objects in that part of the kingdom. He found but two things in the "mene Tounelet of Scroby" to detain his pen. One was the hewnstone parish church, not big, but "very welle buildid," which remains to justify his praise. "The second" 4

was a great Manor Place, standing withyn a Mote, and [be]longging to tharchbishop of York, buildid yn to [two] Courtes, whereof the first is very ample, and al builded of Tymbre, saving the Front of the Haule, that is of Brike, to the wich ascenditur per gradus lapideos. The ynner Courte Building, as far as I markid, was of Tymber Build-

1 Cavendish, who wrote this memoir, was Tolsey's "gentleman usler."

2 Edmond Bonner, afterwards Bishop of London, was Wolsey's Master of my Lord's Faculties and Jurisdictions. In a letter from him, at Scrooby, to Cromwell at this time lie says: -

"And wher ye willing to make me a good Ytalion promised unto me, longe agon, the Triumphes of Petrarcle in the Ytalion tonge. I hartely pray you at this tyme by this beyrer, Mr. Augustine his seruant, to sende me the said Boke with some other at your deuotion; and, especially, if it please you, the boke called Cortigiano in Ytalion."

Ellis, Orig. Lets. 3d. Ser., ii : 17 .

Probably he was studring in view of a possible Italian mission, and within two years he was sent to Rome.

3 Valor Ecclesiasticus, v: 18.

4 Itin. i: 36. 
ing, and was not in cumpace past the 4. parte of the utter [outer] Courte.

These are very dry bones indeed, little better than nothing as the foundation of an imaginary plan. Yet, with such help as may be found elsewhere, they suggest a rude conception of the edifice at that period. In the Chapter-house at York are leases of the property, the first of which dates back to within twenty years of that time, and, interpreting them by Leland's description and amplifying Leland by particulars which they name, some general idea of the premises becomes possible.

First of all, divided, and guarded, from the surrounding territory on its south end and its west side by a moat, and on the north sile, without doubt, by the river Ryton, was a large outer court. Entrance to this was gained over a drawbridge and through a gate-house ${ }^{1}$ on the west side, the gate-house "standing length-wise South and North," and likely to be the dwelling of the keepers, falconers, etc. On its eastern side this outer court had a house 2 "with chambers, rooms, appurtenances, etc., commonly used for the Archbishop's offices, at such times as the Archbishop kept house at Scrooby." The "great chamber" was a building, or in a building, in the northwest corner. The remainder of the east and south sides of this court appears to have been filled by "barns, stables, etc.," apparently including the dove-cote, the grange, or granary, the forge, the kennels, the mews for the hawks, and other outbuildings. That part of the west side between the great chamber and the gate-house seems to have been unoccupied by buildings, and doubtless was protected by a wall or fence inside of the moat.

Most of the north end of this great court, which skirted the river, appears to have been left open for access to the stream. At all events the leases offer no suggestion of any building but the "great chamber" on that side. It seems impossible to harmonize Leland's language, which places the great hall, with its brick front and its stone steps, on the outer court, with the descriptive terms of the leases, unless the hall stood at the northeast corner of that court on the river-bank, forming the northern

1 Lease to James Bryne, Register of Leases, 1543-87, at York, 99-100.

2 Lease to Sam. Sandrs, Dec. 20, 1582, Reg. Leases, York, 327. 
portion of the division between the two courts and having one side, or one end, facing each court. There also was "one house, or building, adjoining to the Hall on the South part," continuing the division between the courts.

He who entered by the gate-house evidently would have had to cross this great outer court obliquely to the left, and to pass between the house arjoining the hall, on his left hand, and the house devoted to chambers, rooms and offices, on his right hand, in order to reach the inner, and lesser, court. According to Leland, this was not more than one fourth the size of the outer court. But Leland qualifies this statement by adding "as far as I markid," as if he were not sure of his estimate. And, as there is evidence that this inner court was bordered by the manor-house, the chapel - probably under the same roof ${ }^{1}$ one or more galleries ${ }^{2}$ from one, or each, of these to the hall, and by the kitchen, the pantry, the bakehouse and the brewhouse; and that there were "other honses, edifices and buildings standing in the Little Court there ;" 3 and that the enclosure also contained an orchard and two or more fishponds; ${ }^{4}$ either it must have been larger than Leland intimates, or the outer court must have been more extensive than we can fairly presume it to have been.

1 This often was the case, as surviving structures prove. And so much of the present farmhouse as presumably was part of the former manor-house indicates that probably it was true in this instance. If the manor-louse, as distinct from the chapel, bordered on the court proper, it must have extended further from the river than the plan indicates, and further than any traces of it in the farmhouse suggest. The point cannot be determined beyond question.

2 Arch. Heath's recorded purpose of pulling down one gallery from the chapel to the hall implies, but does not prove, that there were at least two. The ancient part of the farmhouse indicates that a gallery formerly ran from one building to the other across the front of the modern garden and at the height of one story above the ground floor. There may have been a second gallery, parallel with the first, and at the same height, from building to building, at the back of this open space, as indicated by the dotted lines in the plan. Or, the second gallery may have been under the first, with none on the river-bank. Or, there may bave been a double gallery at the front, and a single, or another double, gallery at the back.

${ }^{3}$ Some, or all, of these minor structures may have stood by themselves, and the language of the Sandys lease rather implies this. But, as the court. with its orchard and ponds, must have been undesirably erowded if it had in it several such independent buildings, it seems more likely that they formed a range enclosing its southeast corner, and the lease does not necessarily forbid this interpretation.

4 Tradition, the custom of the time, local history and the present aspect of the grounds unite to support this statement as to the ponds. 
Possibly the following plan approximates the outlines of the place as accurately as any modern study of the few recorded facts can do so. ${ }^{1}$

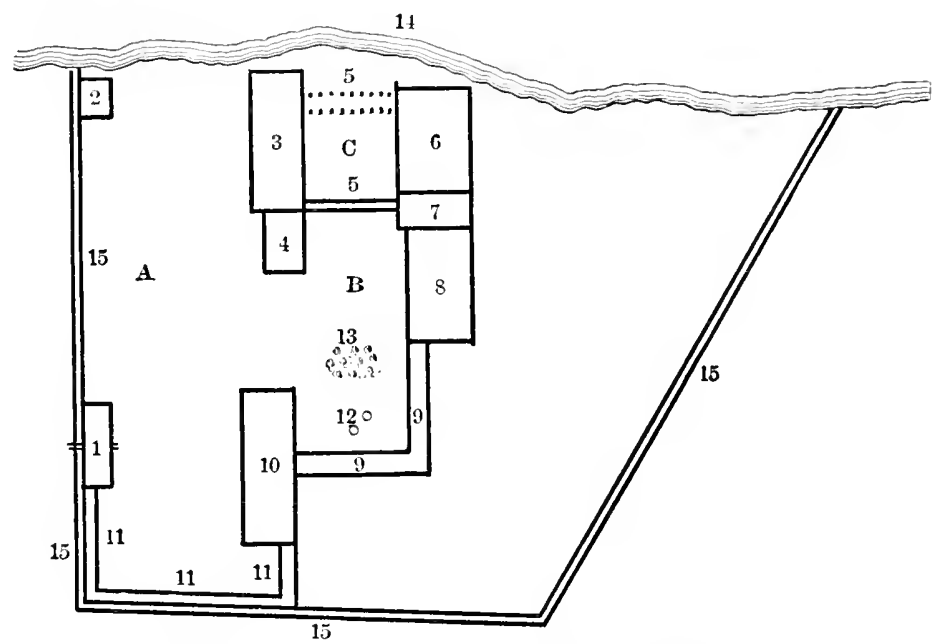
A. Outer, or greater, court.
B. Inner, or lesser, court.
C. Open space, part of lesser court.
1. Gate-house.
2. Great chamber.
3. Great hall.
4. House adjoining hall.
5, 5. Galleries.
6. Manor-house.
7. Chapel.
8. House on east side of orchard.
9 , 9. Kitchen, pantry, bakehouse, brew- house, etc.
10. House of chambers, offices, etc.
11, 11, 11. Barns, stables, sheds, etc.
12. Fishponds.
13. Orchard.
14. River Ryton.
$15,15,15$. Hoat.

It was largely a forest country when this manor-place was erected, so that Leland undoubtedly is right in saying that the most of these structures were of timber. Excepting the hall front and possibly the chapel, if it stood by itself, probably they all were constructed of oaken frames filled in with mortar-work of stones and plaster. This was the fashion of much of the domestic architecture of the early centuries of England, and some fine gabled examples of it remain to the present day.

Such - well placed, substantial, spacious, ${ }^{2}$ comfortable and

1 There are no recorded details of the dimensions of the buildings.

2 Thoroton (Hist. Nottinghamshire, ed. 1797, iii : 479) says : -

"Here [at Scrooby] within memory [i. e. of his first ed., 167i] stood a very fair Palace, a far greater House of receit, and a better Seat for provision than Southwell, and had attending to it the North Soke, consisting of very many Towns thereabouts ; it hath a fair Park belonging to it." 
hospitable, yet plain, and, if in any part comely, probably in no part magnificent; the centre of a widely extended farming region, a good point of departure for hunting parties, and a quiet residence for brief respite from official labor's, or for the performance of imperative duties - was the Scrooby palace in its best estate.

Soon after Leland's visit, apparently ${ }^{1}$ during the same season, a royal stay enlivened the spot for a summex's day and night. Henry VIII. ${ }^{2}$ himself halted there, with a gallant company, in his northern progress. With him were the Dukes of Norfolk and of Suffolk ; Robert, Earl of Sussex, Great Chamberlain of England; Lord John Russell, Great Admiral; Cuthbert Tunstall, Bishop of Durham; Sir Thomas Cheyney, Treasurer of the Household; Sir John Gage, Comptroller of the same; Sir Anthony Browne, Master of the Horse; Sir Anthony Wyngfield, Vice Chamberlain ; Sir Thomas Wriothesley, Secretary; and Sir Richard Riche, Chancellor of the Augmentations; with their attendants. The Court then followed the Sovereign and his ministers, and for the time being was where they were, so that a meeting of the Privy Council was held at Scrooby Manor perhaps in the "great hall," or in the house of offices - on Aug. 17, 1541.

As the result couriers soon were speeding southward, bearing letters to Sir John Baker, Chancellor of the Tenths, and to "Mr. Moyle," signifying to them that

the Kings $\mathrm{Ma}^{\text {te }}$ [Majesty] had assigned them to be cōmissioners at Calais for the $\mathrm{s}^{r}$ vey and odering of etain [certain] things which his $\mathrm{Ma}^{\text {te }}$ would have done there, and therfore requyring them to put themselves in such arredynes [a readiness] as they might upon advertisement of the Kings Ma ${ }^{\text {tes }}$ further pleas ${ }^{r}$ to be gyveu unto them for that purpose repayre thither accordingly.

On the previous day the king and his company had been at Gainsborough, and they proceeded to Hatfield on the day following.

Whether Henry VIII. at this visit became so charmed by the spot as to desire it for his own, there is no evidence. But the

1 Hunter, Colls. 20.

2 Proceedings and Ordinances of Privy Council, Nicolas, vii : 233. 
next record concerning the property seems to be one, a little less than three years later, of its sale by Archbishop Holgate ${ }^{1}$ to the king, a transfer ratified on the same day by the dean and chapter of York. ${ }^{2}$ It is set down in the rent roll, apparently at this time,$^{3}$ as rated at $£ 3214$ s. 8 d. annually. Six or seven year's afterwards it was repurchased from the Crown by Holgate, whom Strype calls "the only wealthy Bishop then in England," for $£ 6307 \mathrm{~s} .8 \mathrm{~d} . ;^{4}$ to be his own and his wife Barbara's during their lives, and "then to [pass to] his successors, Archbishops of York." ${ }_{5}$ Holgate and his wife died soon after, and the manor again became the property of the see.

Nicholas Heath, the next archbishop, appears to have decided that the best interests of all concerned no longer required that it be kept up. It demanded a large outlay for immediate repairs, with a considerable yearly expenditure; and he determined to take down the buildings which were in the worst state, and to make the property a source of income to the see, still retaining a moderate residentiary right therein. Accordingly, on July 4, 1558, he leased Scrooby Manor to James Bryne ${ }^{6}$ for twenty-one years at an annual rate of $£ 2015 \mathrm{~s}$. $10 \mathrm{~d}$. The instrument gave the lessee leave to dispark the park and to dispose of the deer. ${ }^{7}$ It bound him to find food and lodging for the workmen who were to take down certain buildings - the gate [house] of the said manor-place, standing lengthwise south and north; one house or building adjoining the hall on the south part, and the great chamber on the north part and standing upon the west side of the said manor-place; the hall and one gallery leading from the same to the chapel; together with the pantry and the kitchen. All these the archbishop was to pull down and carry away at his pleasure. A further stipulation is that, whenever the archbishop should wish to visit Scrooby,

1 Feb. 6-16, 1544-15, 36 Hen. VIII. Sixty-seven other manors were alienated by Holgate at about the same time, in exchange for adrowsons, which increased his personal wealth at the expense of the see.

${ }^{2}$ Drake, Eboracum, 545-546.

${ }^{3} \mathrm{May}, 1552,6$ Ed. VI. About $\$ 818$ in modern money. The greater purchasing power of money then makes this equivalent in value to a much larger sum.

${ }^{4}$ About \$15,760 in our money. ${ }_{5}^{5}$ Strype, Eccles. Mems. (ed. 1822), ii (2) : T.

6 Reg. Leases, York, 99-100. About \$520.

7 Probably to release its large area for tillage. 
Bryne was to provide lodgings, for a day and a night, for the arehbishop himself, twelve men and fourteen horses.

A comparison of these plans for dismantling with the aceount of the premises already given demonstrates that, even after this partial demolition had been accomplished, the precise date of which is mknown, quite enough of the buildings in their ancient amplitude remained to make the place eonvenient and desirable for the entertainment of even gentle-folk. As all now was under the control of Bryne, who was not only lessee of the property but also receiver and bailiff legally representing the archbishop, ${ }^{1}$ and as all had taken on a commereial drift, probably at about this time it began to be understood that travellers along the great North Road might find aceonmodation in what was left of these eapacious premises. Nameless wayfarers came and went and left no sign. But during the next decade, when rebellion surged up almost to its very doors, we have repeated evidence of the presence here, now and then, as guests, of men who have left their names upon the records of the time.

In the summer of $1560 \mathrm{Sir}$ William Ceeil, Secretary of State, sent to Queen Elizabeth from Scrooby a courier bearing despatches. ${ }^{2}$ Eight summers later, June 2, 1568, Alexander Clark, Provost of Edinburgh, sent word thence to Cecil that Lord Herries and Fleming were offended at being brought to Court, that Fleming was to be sent by the queen to France, and that a suspieious Frenehman in a black cloak was haunting Edinburgh should he not be stayed ? ${ }^{3}$ Not quite eighteen months later, Nov. 30, 1569, Thomas Wentworth wrote from Scrooby to the Marquis of Winchester that the rebels had been lying between York and Tadeaster for a week or more; that a great eompany of soldiers and gentlemen was with the Lord President in York; that Lord Darcy was at Doncaster, and that the country was sorely eharged in making sundry kinds of musters, and organized robberies under that name. And, just a week later, Dec. 7. Admiral Lord Ed. Clynton dated there a dispateh ${ }^{4}$ to

1 Reg. Leases, York, 265.

2 S. P. For. Eliz. Stevenson, 1560-61, 100.

3 S. P. Scot. Eliz. Thorpe, 1509-89, xv : 34.

4 S. P. Dom. Eliz. Lemon, lx: 24. 
the Justices of Hereford, stating that he would send on his men towards Sir George Bowes at Barnard Castle with all diligence; adding that, having been much wearied by marching with their armor on through the heary ways, they were unwilling to trudge thus more than five or six miles a day. Doubtless his troops were around him as he wrote, waking the echoes of the old manor-house and repairing the fatigue of their last march with the best that Bryne could manage for them.

We have no record of what became of Bryne. But abont four and a lalf years before his time would have expired, we find Archbishop Grindal - who had succeeded after the short term by which Thomas Young had followed Heath — leasing the same property, on Jan. 3, 1574, for the same period and with like provisions for his occasional entertainment, to William Marshall for the slightly augmented sum of $£ 212 \mathrm{~s}$. 6 d. a year. Apparently Marshall did not succeed Bryne in his bailiwick as he did in his rental. And here we strike the first link in the chain of circumstances which connects this spot with the early life of the New World.

On Jan. 4, 1575, Archbishop Grindal, just before his translation to Canterbury, granted " "to our trusty and well-beloved

1 The document (Reg. Leases, York, 265) is as follows:-

Omnibus Chri. fidelibus ad quos presentes litera pervenerint Edmundus permissione divina Ebor Archiepüs Anglie primas et Metropolitanus Saltm in domino sempiternā Cum Nicholaus muper Ebor Archiepüs per scriptū suum gerens datam tertio die mensis Ianuarii A nno dño millmo quingenmo. quinquagesimo octavo [1558] ex gratia sua speciali ac ex certa scientia ac mero motu suis tradiderit et conceperit delecto et fideli servienti suo Jacobo Bryne generoso inter alia Officium Receptoris Dominii sive Manerii de Scrobye et totius lib̆tatis ejusdem in Com. Nottinghm. Ac etiā officiü Ballinatus dimii sive Manerii de Scrobye et totius libtatis ejusdem in Com. Nott. predict. habendum gaudendum et percipiendum officia predicta dicto Jacobo Bryne per se vel per sufficientem deputatum suum sive deputates sues sufficientes pro termino vita ejusdem Jacobi. Ac etiā dederit et concesserit prefato Jacobo pro exercioe et occupar predç officii receptoris dominii sive Manerii sui de Scrobye predicta quadraginta solidos bone et legalis monete Anglie p. annū ac pro exerciōe et occupatione officii Ballinatus dñ̄ sive Manerii de Serobye predicta viginti sex solid et octo denarios bone et legalis monete Anglie $p$ anmì habendü et pcipiendum vadia et feod. predicta unacì oubus et $\overline{o l}$ modis aliis vadiis feod. proficuis cömoditatibus regardis emoliment. et preheminentiis quibuscunq. predict. officiis seu eōr. alteri antehec tempora debit. et consuet. prefato Jacobo Bryne, et assignat. suis pro termino vite ipsius Jacobi tam $p$. manus suis proprias. qū p. manus Receptorïs-generalis Archiēpatus Ebor, et successorū quorü pro tempore existentium ad festa Añunciationis bte. Marie Virginis et sancti Michaelis Archi. $p$ equales porcōes annuatim solvend. durā̄ termino vite dicti 


\section{servant William Brewster," the office of "Receiver of our Lordship or Manor of Scrooby, and of all the liberties of the same in the County of Nottingham." 1 Further, Brewster was}

Jacobi prout per predictū scriptū sutm plenius patet. Sciatis $\bar{q} d$ nos per diversis bonis et rationalibus causis et cōsideratoñ nos ad hoc specialiter movend. tradidimus dimisimus et concepimus, ac per presentes pro nobis et successoribus nostris tradimus dimittimus et concedimus dilecto et fideli servienti $\bar{n} r o$ Willmo Brewster predict $\bar{u}$ officiū receptoris dnii sive Manerii ñ̄i de Serobie et totius libtate ejusdem in Com. Nottingham preced. necnon officiü predictü Ballinatus Dominï sive Manerï nïi de Scrobye et totius libtate. ejusdem in Com Nottinghm pred. habendum gaudendum occupand $\bar{u}$ t exercendum officia predicta dicto Willmo Brewster per se vel per sufficientern deputatum suum, sive deputatos suos sufficientes pro termino vite ejusdem Willmi. Dtdimus etiam et concessimus, ac per presentes pro nobis et successoribus $\bar{n}$ is damus et concedimus prefato Willmo Brewster pro exercitione et occupatione predicti officii receptoris daii sive manerii de Scroby predict. quadraginta solidos bone et legalis monete Anglie per annu. Ac pro exercitione et occupatione predicti officii ballinatus dominii sive manerii $\bar{n} i$ de scrobye pred. viginti sex solidos et octo denarios legalis monete Anglie $p$ annū habendum et pcipiendum vadia et feoda predict. unacū ōbus et $\bar{o}$ mod. aliis vadiis feod. proficuis comoditatibus regard. emoliment. et preheminentiis quibuscunq. pred. officiis seu eor $\vec{u}$ alteri anteher tempora debit te consuet. prefato Willmo. et assignat. suis pro termino vite predict. Willm. tam p. manus suas proprias $\overline{q^{m}}$ p. manus receptoris generalis Archiepatus Ebor et successor. suō. pro tempore existeñ ad festa Annunciationis Bate Marie Virginis [25 Mar.] et Sancti Michaelis [29 Sept.] Archie p. equales portiones annuatim solvend. duran. termino vite dicti Willmi, et si contingat predéa seperalia vadia et feoda aut aliquà inde pucella. a retro fore in parte vel in toto post aliquod festum festoru predictor. in quo solvi debeant non soluta. Ad tunc bene liceat et licebit prefato Willmo Brevster et assignat. suis in maneria $\overline{n r}$. de. Askham et Laneh $\bar{m}$ et libtates eorundem in com pred. p. cett. possession dci dmi de Scrobye ac in ōa alia terr. et tenta $\bar{n} r a$, in Askham et Laneh $\bar{m}$ predict. intrare et pro prề. feōd. et vadiis sic a retro existentibus distringere districtiones $q$. sic captos licite aspertare, ab ducere, effugare et penes se retinere, quos $\vec{q}$ de predict. feod. et vadiis unacum arreragiis eorundem siquefuerint sibi fuerit ple-

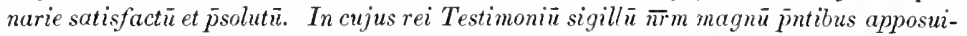

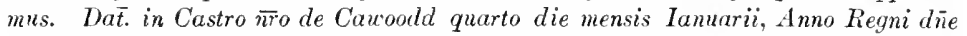
Elizabeth dei grat. Anglie, Francie, et Hibernie Regine fidei defens \&c. decimo octavo $[1575-76]$.

Nos ita $\bar{q}$ Mattheus Hutton sacre theologie professor, decanus ecclie cathedralis et Metropol. beati petri Ebor. et Capitulü ejusdem eccliè omnibus et singlis in büs patentibus $\bar{p}$ tibus annexis content. expressis et specificate habito primitus sup. eisdem in capitulo $\bar{m}$ o tractatu solemni et diligenti qui in hoc casu requiritur cōnséntimus eaq̃ öia et singula quantū ad nos attinet et de jure possumus pro nobis et succes̄s. $\overline{\text { rr }}$ is ratificamus approbamus et confirmamus per presentes Juribus lib̆tatibus ordinationibus Statut. et consuetudinibus $\bar{n} i \mathrm{~s}$ et dicte Ecclie $\bar{n} r e$ in $\bar{o} b u s$ semp. salvis. In cujus rei testimoniū sigillü $\overline{u r} m$ commune $\overline{p u}$ lib. est appensum. Dat. Ebore in domo $\bar{n} r a$ Capitulari

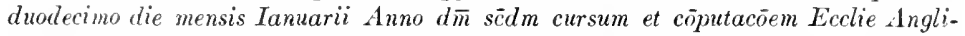
cane millesimo quingentesimo septuagesimo quinto [12 Jan. 1575-70].

1 The State Papers (Dom. Eliz. ccxlvi : 80 ) contain a document, Remembrances touching Southwell and Scroby, of the probable date of 1582, only six or seven years later than Brewster's commission. According to this there were in the ter- 
commissioned to "the office of Bailiff of our Lordship or Manor" of Scrooby and all the liberties of the same in the County of Nottingham, to hold, enjoy, occupy, and exercise the said offices by himself, or his sufficient deputy, or deputies, to the end of his life." He was to have for the first office $£ 2$ a year, and for the second $£ 16$ s. 8 d. Residence in the manor-house is not prescribed but appears to be implied necessarily, so that we may assume that, at, or about, this date, this local, legal representative of the archbishop began to live upon the spot where we find him subsequently as an agent of the government as well. There is evidence " that he already had resided in the neighborhood for some time, inasmuch as, in 1571, one of the same name with William Dawson and Thomas Wentworth — had been assessed in Scrooby parish, he on property of the annual value of $£ 3$.

One of the most abundantly demonstrated characteristics of Elizabeth is her greed. Scarcely anything, gold, jewels or lands, came amiss to her. It therefore need not excite surprise that the next fact in the annals of Scrooby implies that she had cast a longing eye upon this manor, and had hinted that it would be an agreeable addition to her estates. Her letter of suggestion has not survived. But we find Archbishop Sandys writing to her, on Nov. 24, 1582, ${ }^{2}$ and his letter shows that she had gone so far as to send him for signature a lease in due form, conveying the manors of Southwell and Scrooby to the Crown for the period of seventy years, at a rental for Scrooby of $£ 40$ a year.

He had received her communication at Bishopsthorpe six days before, and, mindful that it was most dutiful to answer by word of mouth, had begun a journey to the Court. But, after three days of travel, he had fallen so ill, because of grief, that he was driven to set forth by his pen what he had intended to plead in person. He begs to remind her that he is an old man; that already he has painfully travailed in the gospel for thirty-five years, during which time, as heaven and earth will witness, he

ritory of Scrooby, for which Brewster would be responsible, seventeen towns, and a park " of old time disparked."
1 Hunter, Colls. 19, 57.
2 Le Neve, 58. 
always has walked uprightly, and never has impaired any ecclesiastical living, but always has left the same in better case than he found it. In conscience he must continue the same course.

From this general starting-point of principle he passes to her Majesty's special object. Even to her, he cannot yield that by which he would grieve God, kill his own conscience and dishonor her. She has pledged herself in his presence at Richmond never to impair any bishopric, and has declared that, if any were damaged, it never should be her fault whom God had made as a nurse to the Church. He is sure, therefore, that she has been misinformed. Her original request had been that he would lease to the Crown one manor, naming none; while the instrument forwarded for his signature specifies two great manors, Southwell and Scrooby, with all their appurtenances, being all belonging to the see of York in Nottinghamshire, and estimated to be the third part of the entire property of the province. These manors, he says, "be stately," and, these granted away, the archbishop would be excluded from Nottinghamshire, which is wholly in his diocese; most of which he personally already has visited twice in the way of ordinary jurisdiction ${ }^{1}$ and a third time with the High Commission; and where his habit at such times has been to keep house for four months together.

Furthermore, the rent offered for Scrooby in the queen's proposed lease is but a pitiful $£ 40$ a year, while for 300 years its rent has been $£ 170$, or more. ${ }^{2}$ He also is compelled by law to "repair two fair Houses standing upon these two Manors: whither I resort for my lorging, at such times as I come thither for your Majesty's service," yet this lease would exclude him from both. Again, he is specially restrained from selling or giving away any timber or trees, while this lease grants to whomsoever it might put into possession liberty to cut down and sell all woods, underwoods and trees, which "were an un-

1 He had been translated from London to York Mar. S-18, 1575-76, and so had held his position only about five years.

2 S. P. Eliz. ccxlvi : S0. About $\$ 4250$. See p. 229, n. 3. Probably the apparent discrepancy is to be explained by assuming that the snaller sum was the rental of the manor-honse estate itself only, and the larger one that of the whole property associated with it, including the "towns," etc. 
doinge unto the Contrey yf the $[\mathrm{y}]$ sholde [be] cutt downe." Moreover, there pertain to the two manors in question as many as thirty-two towns, with, it is thought, 1000 tenants. $^{1}$ These, for the most part, are poor copy-holders, who have enjoyed privileges of which the proposed lease might strip them, to their sorrow and the public discontent.

To make a long story short, the archbishop estimates that, with the direct loss in rents (£9100), the probable value of woods that might be cut down, and the increased revenues that might be obtained from tenants - all existing particular leases expiring within twenty years, leaving every one at the mercy of the new holder for a whole half-century after that - and the parks, perquisites of courts and other sources, there probably would result from the arrangement suggested by her Majesty a clear loss to the see of York of $£ 70,000$, at the very least. "Too much, most gracious Sovereign," he goes on to plead, " to pull from a poor Bishopric inferiour to many others in Revenue, but superiour in Charge and Countenance." He cannot consent to it. The Lord forbid! It would be the spoil and ruin of that which in conscience he is bound to help and not to hurt. It would be chronicled by the Papists to the slander of the gospel and to his own perpetual infamy. He assures himself that her Majesty, knowing the facts, cannot press the matter, nor mislike him for his zeal. Rather she must think him unworthy to live, should he consent to so great a wrong. And so he most humbly takes his leave, with zealous protestations of loyalty. We hear no more from the queen in this connection. Probably she saw, if not the injustice of her proposition, at least the impolicy of pressing it in the face of an opponent at once so clear-headed and so determined.

The last mentioned lease of the Scrooby manor-house proper still had more than twelve years to run, when, on Dec. 20, 1582,2 three weeks and five days after the date of the archbishop's letter to the queen, because of Marshall's death or removal, the archbishop made a new indenture of the premises, this time to his

1 If the towns pertaining to Scrooby averaged like the others, the seventeen had a little more than thirty-one tenants apiece, about 535 in all.

2 Reg. Leases, Fork, 327-328. 
oldest son, Samuel, then just turned of his majority. As before, it was for twenty-one years, and at the annual rent of $£ 212$ s. 6 d. As William Brewster, Sr., then had been in residence nearly seven years, as receiver and bailiff, such specification of the premises as was made in this lease assumes peculiar interest as describing its general character and probable appearance at the point where New England history tonches it. This is the more true because a local historian has stated " mistakenly that "the manor-house of Scrooby had gradually and insensibly dwindled down, through lapse of ages, from a large mausion to a moderately-sized farm-house, . . . a plain farm tenement." But, in fact, this lease to Samuel Sandys binds him to repair, maintain and uphold premises as follows: 1. The Manor-house. 2. The Chapel. 3. The Bake-house. 4. The Brew-house. 5. The Gallery. ${ }^{2}$ 6. The house newly repaired standing at the east side of the orehard. 7. All other houses, edifices, buildings, etc., standing in the little court. 8 . The house standing at the east side of the great court, with chambers, rooms, appurtenances, etc., which house had been commonly used for the archbishop's offices. 9. The barns standing on the east and south sides of the great court. 10. The stables, etc., standing on the east and south sides of the same. 11. The park palings, etc.

Here, surely, still remained extensive, if not stately, erections. And here, as can be proved, all things did remain much the same for more than half a century longer, until, as the place became less and less essential to the personal convenience of the archbishop, the buildings at last were neglected and finally did fall into comparative decay. But there is no proof that during the twenty-five years succeeding the date of this lease - at the end of which time the exodus of the surviving Brewsters, with their local friends, to Holland closed the immediate connection of this spot with the history of New England - any change of importance took place in its size, appearance or accommodation.

As it will be more convenient to set forth hereafter the little that is known of the English life of these Brewsters, it is merely

1 Raine, Blyth, 129-130.

2 Unquestionably one still connecting the hall with the chapel, the other, or others, having been pulled down in Bryne's time. 
noted here that at some time in, or, possibly, before, $1588,{ }^{1}$ William Brewster, Sr., the archbishop's legal representative at the manor-house, was appointed to the additional office of postmaster under the Crown. At that time a post-naster was the forwarder of government despatches only, but he aIso was expected to keep an inn for the accommodation of others than government officials who travelled post, and to furnish them with horses for the next stage, which implies an establishment with a number of horses and servants, such as quite naturally might be housed in the old manor-place.

Wre gain, now and then, through some meagre record of the time, a further glimpse of what happened here. On Sept. 11, 1592, Richard Topliffe wrote to the Lord Keeper and begged him, when sending northward to Lord Huntington, to address a note to him at his house in Somerby, and command the post at "Scroby" to forward it." On Sept. 10, 1600, Talbot, Earl of Shrewsbury, wrote to the Archbishop of York : ${ }^{3}$

The next Sprynge, . . . me thynks your Grace may doe exceedyngly well to cum thitler. You may come fyrst to Cawood, thence to Scrowby, and so to Rughford, a peece of an owlde abbay of myne.

In 1603 another royal progress made a pleasant excitement for a day in this rural neighborhood. Elizabeth's long reign was over at last, and King James had succeeded her. Proclaimed in London Mar. 24-Apr. 3, 1602-3, it was several days before he learned that the second crown actually had fallen to him, and he did not leave Edinburgh for London until Apr. 5. He passed the night of Apr. 19 in Doncaster. The next day he rode on to the Earl of Shrewsbury's house at Worksop. On his way thither, at Bawtry - or, more likely, at the forl of the Ryton, ${ }^{4}$ which seems to have marked the boundary between the two counties, -

the High Shiriffe of Yorkshire took his leave of the King; and there Mr. Askoth [Ayscough], the High Shiriffe of Nottinghamshire, received him, being gallantly appointed both with horse and man; and so he conducted his Majestie on till he came within a mile of

1 S. P. Dom. Lemon, 1581-90, ccxxxiii : 48.

2 S. P. Dom. Green, 1591-94, cexliii : 8 .

3 Pubs. Surtees Soc. 1843, 159. * Leland, Itin. i: 35. 
Blyth, where his Highness lighted, and sat down on a banke side to eat and drinke. ${ }^{1}$

The chronicler has not recorded details as minutely as the Somerset Herald did of the progress over nearly the same ground almost exactly a century earlier, but still we have mention of a stately company. There were the king himself ; and with him the Duke of Lenox; the Earls of Argyle, Murray, and Cassilis and Mar ; the French ambassador, and, in general, "multitudes of Lords, Barons, and Gentlemen of Scotland, and some French."

The fact that this cavalcade was heading for Worksop through Blyth must have led them, apparently, to diverge from the great North Road a third of a mile north of the ford, and, leaving Scrooby Manor perhaps a short mile on the left, to skirt the west bank of the winding Ryton through Serlby wood, crossing the river at Blyth. This, with the fact that the archbishop then regarded Scrooby as one of his abodes only in the most occasional way, probably explains why he made the king, so far as we know, no offer of hospitality there. Presumably the Brewster family was not unmindful of so imposing a pageant, and we scarcely can be wrong in assuming William Brewster to have been present as one of the Nottinghamshire escort, and other's of his household to have been in the throng of spectators.

Hardly four months later, on Aug. 18, 1603, we find the new sovereign writing an autograph letter to the Archbishop of York, in which he too attempts to gain the manorial property at Scrooby for the Crown. He says: ${ }^{2}-$

We have observed in $o^{r}[$ our] passage from or realme of Scotland hitherwardes that neere $o^{\text {r }}$ forest of Sherwood in Nottinghamshire we have no howse meet for or abode whensoever in or like passage between $o^{\mathrm{r}}$ two realmes $w^{\text {ch }} o^{\mathrm{r}}$ affaires will oft constrain us unto, We shall have cause to take or pleasure in that forest. And we have been withall informed that neere to the same are two howses and mannors belonging to the see of Yorke called Scroby and Southwell, both very well seated for our convenience in regard as well of the holsomnes of the ayre as of their neernes to that plaice of $o^{r}$ sport which hath caused us to enter into consideration how we might obtain the $s^{\mathrm{d}}$ two howses

I Nichols, Prog. Jas. I. i: 85 .

2 S. P. Dom. Jas. I. iii : No. 27. 
and the lands to them belonging of you without great detriment to the church, and we have found the most expedient way to be by taking the same in exchange from you for other rents of ours to be assigned to you for them.

He adds that his messenger will open his mind more particularly. He offers the prelate as much rent of impropriations or tithes within the latter's diocese, or within the shire of York, as shall "amount at the least to the yearely rent of Scroby and Southwell, with the lands to them belonging," and he will add a confirmation of certain doubtful lands claimed by the church of Southwell. He further urges these three considerations :-

First, we are informed that the s. two houses are exceedingly decayed, so as it is not likely that $\mathrm{y}$ ? selfe or anie successor of yours wilbe willing to be at the charge of repairing them as we intend. Secondly, that nether yourself nor any of your predecessors have used to resyde there, so as they are of little use to you nor shall be to your successors. And thirdly that the mann? of Southwell ${ }^{1}$ hath not been $\mathrm{w}^{\text {th }}$ out question moved to it in the desyer of the late Queen deceased, and before which though we have no purpose to take benefit of, yet is a good inducement to you why you should the rather give us contentment in granting us our desire.

For some reason, either that the king later changed his mind, or that Matthew Hutton took a view of the matter quite in accord with that of Archbishop Sandys earlier, the coveted property remained in the possession of the northern see.

Three years later, as will be described more fully hereafter, the Scrooby manor-house became the birthplace, and, for a short time, the home, of that Separatist Church, which, after its transitional exile in Holland, bore in the Mayflower the seeds of its fresh life to the planting of the New World. The voices of the grave and fatherly Richard Clyfton and the scholarly and broadminded John Robinson were heard within it, preaching, praying and catechizing, making clear, as they understood it, the truth of Scripture long eclipsed by mistaken interpretations and harmful practices, and animating their hearers to a noble zeal.

The story of Scrooby Manor now is mainly told. In 1607

1 Whether the king confused the two manors and attributed here to Southwell what was true of Scrooby, or referred to some facts to which we have no clue, can only be conjectured. 
Brewster resigned his place there under government to seek refuge in Amsterdam and Leyden. It may be possible, from the Lease-books at York, to learn every incumbent of the property through the intervening generations. But it has seemed hardly worth while to investigate the nest so closely after the bird had flown. Two additional facts, however, each of which is believed to be fresh to public knowledge, may be told.

On May 1, 1636, Samuel Harsnet, executor of his father, the late Archbishop of York, petitioned ${ }^{1}$ the king, declaring that his father had held the office but two years and six months, and that the latter's estate was being sued by his successor for dilapidations to the amount of $£ 7000$, of which sum the decay of Ripon and Scrooby houses was rated at $£ 4020$, more than the deceased prelate's whole personal estate. He added that the lands belonging to these houses had been leased out by preceding archbishops, so that only the bare houses, which were in utter decay, remained unleased. No archbishop had lived in either manor-house for forty or fifty years. ${ }^{2}$ He pleaded that these houses, if repaired, would be more burdensome than useful, and that there were three habitable palaces elsewhere. And he asked for a commission to examine the facts, and, if they were found to be as he represented, that the houses might be demolished and all parties freed from further responsibility for them.

This petition was granted, on May 10, 1636, and Sir Hardulf Wasteneys, Sir Arthur Ingram, Sr., Sir Matthew Palmer, Sir Arthur Ingram, Jr., Sir Henry Goodrick, George Stanhope, D. D., Phineas Hodson, D. D., Henry Wickham, D. D., William Mallorpe, Sr., William Francklin, William Stanely, William Sanderson, Hugh Cartwright, Thomas Benson, D. D., Gervase Nevill, clerk, parson of Headon, and Matthew Levett, clerk, and John Favour, clcrk, both prebendaries at York, were appointed to examine and certify as prayed. Then follows the certificate of Sir A. Ingram, Sr., and five others of the commission declaring the averments of the petition to be true, with a minute, dated at Hampton Court, on June 8 of the same year, that the king

1 S. P. Dom. Chas. I. cecxx: No. 64.

2 This would carry the last archiepiscopal use of Scrooby as an occasional residence nearly or quite back to the time of Arch. Sandys and of Brewster's bailiffage. 
is pleased to order that the above-named houses be demolished, provided the Archbishop of York should consent. There follows, also, a letter by Archbishop Neile, of York, to Archbishop Land, dated in Jan., 1636-37, saying that he wishes the old houses demolished, but " so as may be best for his suit of dilapidations." 1 All the probabilities of the case, therefore, seem to settle it that in the summer of 1637 the last demolition took place at Scrooby, enough being spared, and suitably repaired, to shelter the resident farmer, the "plain farm tenement" which is there to this day and which the vicar of Blyth in 1860 seems to have supposed to have been all that was there 300 years ago. ${ }^{2}$

The other fact it is especially gratifying to inake known, because it resenes the memory of Archbishop Sandys from an unpleasant charge by the man who first demonstrated the connection of this neighborhood with the early history of New England, and whose judgment deservedly was ahmost conclusive when he was fully informed. In his "Collections " 3 concerning our Pilgrim Fathers, Rev. Joseph Hunter, long an assistantkeeper of her Majesty's records, accuses Archbishop Sandys of the wrongful perpetual alienation of Scrooby Manor from the see of York, and of nepotism, in having passed this property into the hands of his oldest son, Samuel, in some way requiring " a special justification." In his first edition, in 1849, he refers to this as blemishing a character in many respects worthy of high esteem. But the fact is that the Scrooby Manor, since Holgate bought back the property from the Crown in Edward's time, never has been ont of the possession of the see of York. Leased by a succession of long leases, it always has reverted to the see to be leased again.

He who, by leave of the vicar of Sutton-cum-Lownd, will examine ${ }^{4}$ the parish papers in the church of St. Wilfred at Scrooby will find the "official apportionment of rent charge in lieu of tithes in the Parish of Scrooby," ' dated May 11, 1848, upon

1 S. P. Dom. Chas. I. ccexlv: No. 85.

2 Evidently a portion of this was included in the edifice in the day of its best condition. $323, \mathrm{n}$.

4 This Dr. Dexter did, July 14, 1871.

5 Illustrated by a sworn plan of the parish, made in 1850 by " R. Wightman, Surveyor." The official survey is signed "Geo. Wingrove Cook, Assistant Tithe Commissioner." 
which - numbered from fourteen to eighteen, inclusive- he will discover the territory formerly enclosed within the ancient moat, and will find it stated distinctly that it is owned by the Archbishop of York, and leased to R. Pemberton Milnes, Esq., father of the late Lord Houghton and grandfather of the present Earl of Crewe who is lord of the manor to-day. The Sandys family seems to have continued tenants in possession until the beginning of the eighteenth century, and Francis, grandson of Sir Samuel and great-grandson of the archbishop, and his daughter, Penelope, lie buried in the church. By the marriage of another daughter of Francis, the lease appears to have passed to the Stapletons, of Myton, and thence to the Listers, of Hull, from whom it went into the hands of the eminent family whose tenure still is nnexpired. No shadow of wrong, therefore, ought to rest, as to this, upon the memory of the archbishop.

It only remains to note, as completing, by corroborating, this bit of history which has been narrated, that Thoroton, the great historian of that part of England, writing within forty years of the demolition of the buildings, says : ${ }^{1}$ -

Here [at Scrooby], within memory, stood a very fair Palace, a far greater House of receit, and a better Seat for provision than Southwell, and had attending to it the North Soke, consisting of very many Towns thereabouts; it hath a fair park belonging to it. Archbishop Sandes caused it to be demised 2 to his son Sir Samuel Sandes, since which the House hath been demolished almost to the ground.

The visitor who seeks what now remains of this ancient manor-house will find himself repaid, even by the little which time and change have left to aid him in imagining what it was. If his visit fortunately should fall in May, June or July, he may be sure of a charming excursion, at the least. A rough but sufficiently clear map of the district is on the next page.

He should make his headquarters at Bawtry, ${ }^{3}$ which is conveniently intermediate between the chief places to be sought. Thence let him stroll southward along the main road. A little

1 iii : 439 .

2 "Demise" nsed to mean, and still sometimes means, to transfer property for a term of years. Perhaps Mr. Hunter was misled by this word in Thoroton.

${ }^{3}$ Scrooby has a station near the manor-farm. But only few trains, and those the slowest, stop there. At Bawtry the Crown Inn is the best. 
before he leaves the houses of the village behind him, he will notice the spacious grounds of Bawtry Hall beyond a high wall on his right. These, with their fine trees and dense shrubbery, stretch for a long half-mile to the Serlby road, which diverges on that side. A few minutes' further walk straight on will bring him to where Scrooby toll-bar used to be, until within the memory of living men. On the left, since he reached the open country, have been enclosures running back towards the railway, which here is practically parallel with the highway; some green with pasturage, and enlivened by the animals which they feed; some, very likely, fragrant with new-mown hay; some waving with rapidly ripening grain, often dotted underneath with searlet poppies; some brown with recent tillage, or striped with the delicate green of late crops of beets or tur. nips, just cresting the straight furrows with their springing verdure. The intersecting hedges are brilliant and odorous with hawthorn blossoms, or, later, flecked with privetflowers, elder-blows, wild roses and the sweet-scented buff honeysuckle and

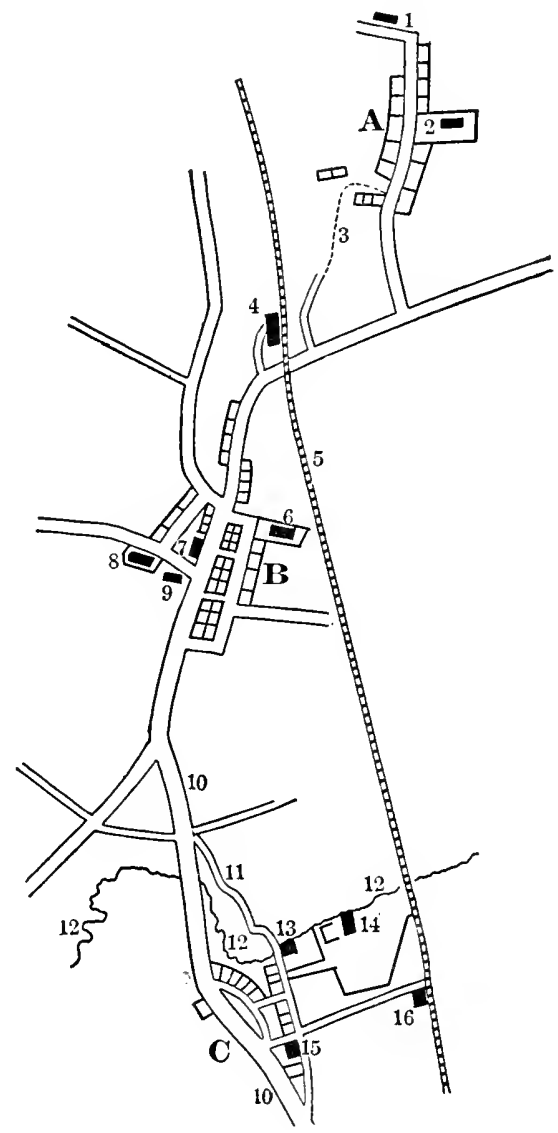

A. Austerfield. 7. Crown Inn.

B. Bawtry.

C. Scrooby.

8. Chapel and hospital of St. Mary Magdalene.

1. Alleged Bradford cot- 9. Bawtry Hall. tage.

2. St. Helen's Church. field.

4. Bawtry station.

5. Great Noroby mill.

road.

6. Bawtry Church.
11. Lane.

12, 12, 12. River Ryton.

15. St. Wilfred's Church.

16. Scrooby station.
$10,10,10,10$. The former

13. Scrooby mill. 
bramble-blooms. Now and then some breath of exceptional sweetness upon the breeze tells of acres to windward blossoming with peas or beans, and musical with the hum of bees.

Passing on by the site of the old bar, where a narrow road comes in from the west, he will see, due south and a little to the left, rather more than half a mile away, over the meadows across the stream which shines immediately below, and partially eclipsed by foliage, the comely gray spire of St. Wilfred's Church, unaltered since the Pilgrims looked upon it before they began their pilgrimage. Some twenty degrees from it towards the left, and east, he will notice several tall Lombardy poplars, with one or two others by themselves more to the east. The cluster of buildings at the right of the latter is what remains to represent the palace whose cellars King Jolm was stocking with Vascon and Mussac almost 700 years ago. A bylane - more than a mere cart-path but less than a road, in part bordered by a hedge, on the left, but mostly open on the right to that uncommon thing in this part of England, a piece of waste land, a prickly little wilderness of gorse, thistles and nettles, studded with occasional brambles and wild-rose bushes - by its look of rural promise beckons away from the broad and dusty highway, which itself before long swerves perceptibly towards the left.

As one walks down this lane, if it be not too far on in the season, the cuckoo almost surely will be heard across the meadows, while many little birds of pleasant song call out of the thickets, or from among the dark boughs of something very like a diminutive group of New England pitch-pines, which stands down the way a little to the east. At fortunate hours one may see here the heaven-seeking lark, mounting high and dropping an ever sweeter song while receding into the far invisible; although one is more likely to be amused by the saucy clamor of blackcoated rooks, scolding each other as they fly. In June, wherever a few trees afford a sufficient canopy, the ground beneath them is blue with the sweet but strong-scented wild hyacinth. In July the quaint bells of the foxglove abound. And in each month the patch of wilderness between the lane and the highway is gay with the vivid contrast of the sombre green of the foliage 
of the gorse with the brilliance of its yellow flowers, and beautiful with the variegated loveliness of just such pansies, growing wild in profusion, as the flower-gardens of New England rejoice in as the fruit of painstaking.

Passing on along the lane over two little bridges - one of which lets off the overflow from the river where a dam has utilized it, while the other sluices a brook, which, by some engineering craft, has been made to underrun the larger stream one skirts a pleasant field on the left, stretching off towards the manor farmhouse, but on the hither side of the water, beyond which, straight ahead but on the further bank of the river, is the mill, in turning which, to grind the village wheat, the lazy Ryton is made to work its passage to the Idle and the sea. Evidences of farm life abound. The meadow is dotted with cows. There are swans and ducks and geese upon the stream. Beyond the mill-bridge the hamlet begins. There may be forty or fifty honses. Most of them are modest cottages, low and long, with dingy brick walls and bright red-tiled roofs. The tiny inn, The Saracen's Head, stands on the main road, fronting the church but with a house or two intervening. The five or six streets are narrow, short and sometimes crooked. But the hedges are richly green, and the little plots in front of the dwellings are comely with flowers, while many windows show pots of blooming geraniums, and the almost universal white muslin curtains give a tidy and tasteful look to even the humblest abode.

Following the lane over the milldam, and keeping always to the left, one soon reaches the entrance to the manor-house grounds. The gate stands between the side of a brick house on the north and a smart, small, modern cottage on the south, and seems to mark, beyond a doubt, the ancient place of entrance, where the drawbridge gave access throngh the gate-house. It is about 370 feet sonth from the river. On its right, skirting the meadow, the old moat may be traced distinctly for 130 feet down that side. Just beyond an elder bush, grown into a tree, it turns towards the east, at an angle of 95 degrees, and takes a nearly straight course for 420 feet, for most of which distance it lately has been deepened again to hold water. Then, at the oblique angle of 122 degrees, it extends in a straight line north- 
easterly for about 475 feet, until it strikes the railway. The Ryton, whose slightly winding course here averages nearly east and west, forms the northern and longest boundary — some 675 feet - of what, if the little cormer shaved off by the railway be included, is an irregular quadrilateral enclosure. It contains between six and seven acres. ${ }^{1}$

Entering at the gate and following the wagon-track, which bends towards the river and the farmbouse on the north - soon parting company with a cart-path ruming off on the left to the farmyard - a little more than 200 feet bring one to a point between two well-grown sycamores. In front, and at a little greater distance to the northeast, is the present farmbouse. A little kitchen and flower garden, perhaps 100 feet square, separates the house from the farm-buildings on the left, the nearest of which rises at its south end into a second story, to form a dove-cote. This building is the cow-house, a portion of whose frame illustrates the ease with which, in this world, some things may be transferred from æsthetic and sacred to humble and secular uses. These two buildings are the only ones upon the premises which directly suggest connection with the manor-house that was; and of these the cow-house, for the most part, like the barns, sheds, etc., obviously is an erection of the last century. The present orchard, on the left as one passes from the entrance to the farmyard, also clearly is of no great age. A rough general plan of the modern estate is shown on the following page.

Turning to face the west, the spire of St. Wilfred's preseuts itself again as a pleasing link between the present and the past. Excepting this and most of the village lanes, the calm river on the north, the distant landscape and the over-arching sky, it is doubtful if anything outside of the enclosure remains as it was in the olden time.

1 The official table is :-

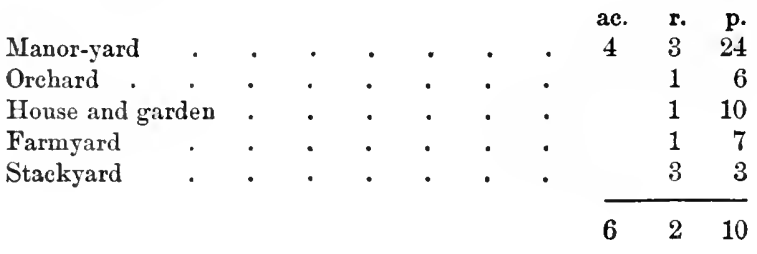




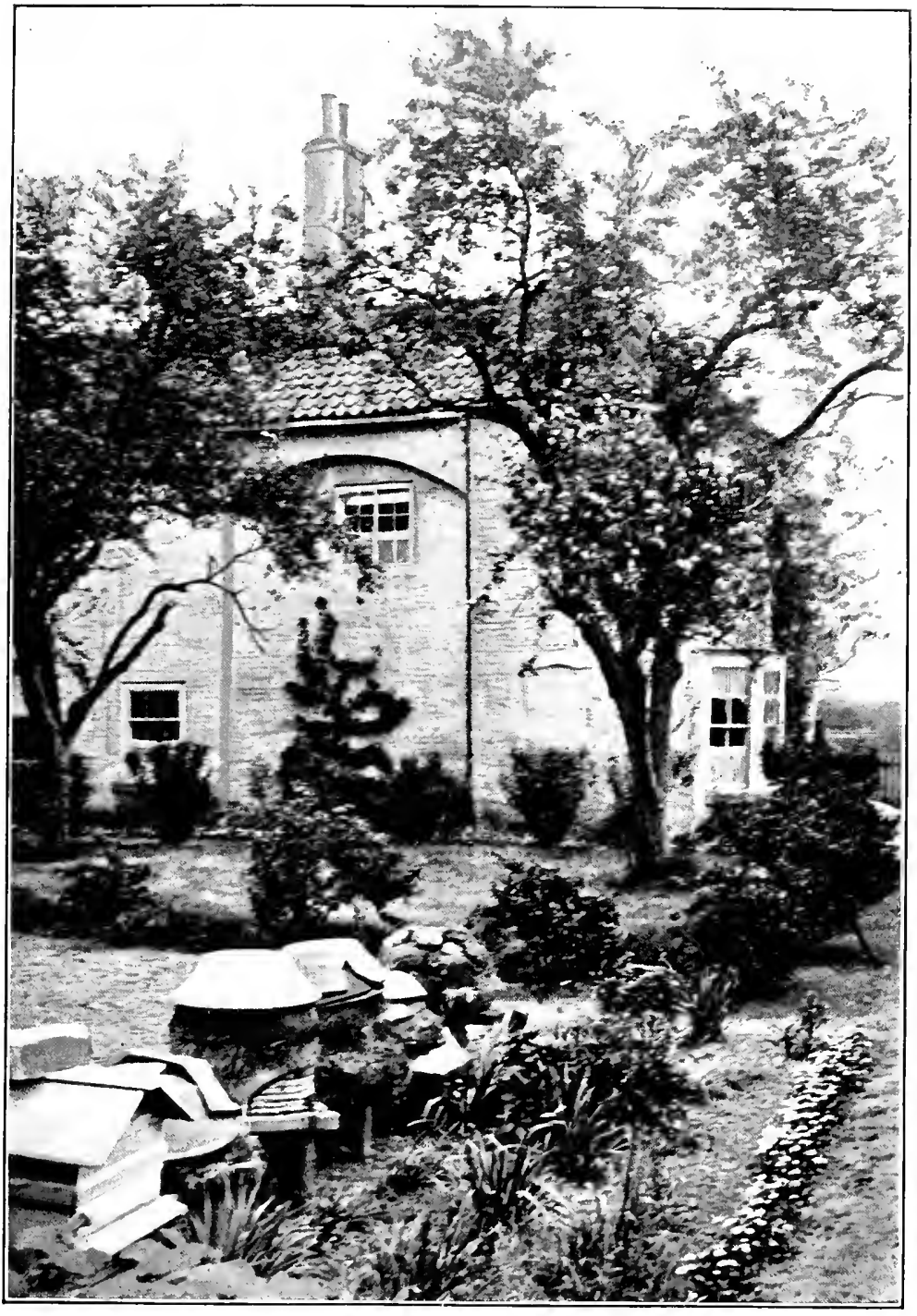

WEST SIDE OF MANOR-HOUSE 
Advancing to ascertain what that is now visible is worthy of examination, it will be found that the southern part of the farmhouse, that which includes the best room, with its bay-window, and the front entry with the stairs, has walls of exceptional

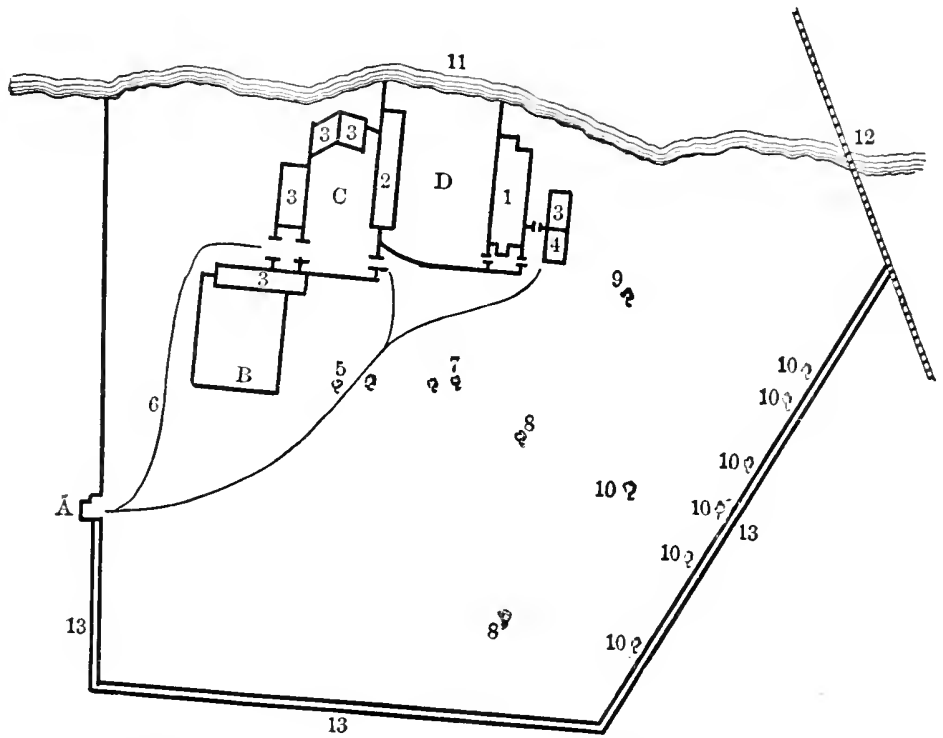
A. Entrance gate.
B. Orchard.
C. Barnyard.
D. Garden.
1. Farmhouse.
2. Cow-house, where beams are.
3, 3, 3, 3, 3. Sheds.
4. Small open enclosure.
5. Sycamores.

6. Cart path.

7. Thorn trees.

8 , 8. Old pear trees.

9. Apple tree.

$10,10,10,10,10,10,10$. Willows.

11. River Ryton.

12. Railway.

$13,13,13$. Ditch where moat was.

thickness, and seems much older than the remainder of the building which has been erected upon and around it. We hardly can go astray in the conclusion that this is a lingering portion of one of the original structures. But precisely what it was, how it was related to the general plan, and what was the primary intent of the large round-headed arch in its western side, one cannot presume to say. Perhaps the most plausible supposition is that it was one end of the old chapel and that the arch had some connection with a gallery.

A window, or door, has been bricked up in the outer wall on 
this west side, halfway from the south side of the arch to the front corner. A small double-arched window at the left of the top of the arch also evidently is very old. As one looks out through this from the head of the staircase inside the thickness of this part of the wall is seen to advantage.

The partition which divides this end of the house lengthwise in the middle also is of considerable thickness, as is evident when one, having ascended the stairs and passed back to the east side of the house, turns to the right into the little end room. Here he can see another arch bricked up, and, within easy reach, in the wall adjoining at a right angle, another small window or niche. The possibility, not to use a stronger term, that this arch was a doorway into the chapel, and the niche a receptacle for holy water, occurs to one at once.

Much of the roof of one division of the cow-house is upheld by oaken timbers, ${ }^{1}$ the shapes of which bear witness that they were wronght for a more honorable place. Not long ago there were four of the larger tie-beams, stretching from wall to wall; ten of that medium size which, in the original framing, connected these tie-beams horizontally; and nearly forty smaller ones, whose function it was, being framed up and down between those last described, to take on the roof-boarding directly. Each of these was wrought into a simple ornamental form - although they hardly can be described as carved - the product of a somewhat rude workmanship, yet sufficiently well executed to have rendered the whole effect pleasing, although scarcely ornate.

The dimensions of these largest beams fix the width of the building which they originally were fitted to cover at abont seventeen feet. Such a roof scarcely can have been that of anything but the great hall or the chapel, and seems hardly wide enough for the former, while of about the natural proportions

1 Dr. Dexter received permission to take away three of these beams, one of which now is in the Congregational Library in Boston. It may be added that he visited the place at least eiglit times, in 1851, 1865, 1871, 1872, 1877, 1881, 1884 and 1887. In 1871 he remained six weeks, and - with the aid of his son who also has visited the spot repeatedly, and as recently as 1902 - by permission of the late Lord Houghtion, then lord of the manor, he made thorough exanination of the premises, including measurements and excavations. 
for the chapel of such an establishment as this manor-house certainly was. It is worth noting here, perhaps, that the church in Misson, in the near neighborhood and apparently of about the same age as this manor-house, has a roof strikingly similar in pitch, form and material to that which these beams evidently upheld. There seems to be little or no doubt that, wherever the chapel was in 1600, and earlier and later, these beams — which, after it had been demolished in 1637, still being tough and hearty, were then, or at some subsequent time, put to their present baser use - helped to roof it in; and, accordingly, that they were over the heads and echoed the voices of Robinson, Clifton, Brewster, Bradford and their associates in the days when the Mayflower church was formed. If the insensate things, when degraded to their present position, only could have taken comfort in the thought that a stable and a manger are sacredly historic in connection with the church of the New Testament!

At different points, as one strolls about the place, the observant eye readily catches other, although less striking, traces of the past. Just by the rear of the poultry-house the segment of a circular rubble foundation crops out of the ground. A section of the stone underpinning of some structure is built into the base of the brick garden wall which is in a line with it near the entrance to the farmyard. Fragments of carved stone-work lie in the rubbish-heaps. ${ }^{1}$ A few inches from the root of the pear tree which lies nearly prone with age, yet still makes annual encleavor to take its place in leaf with the rest of nature, a little south of the centre of the front meadow, one may dig up bricks, scarcely concealed by the turf, still in position as the masons laid them centuries ago. Halfway between this spot and the pair of thorn trees in the direction of the barnyard may yet be discerned with some distinctness a circular mound nearly eighteen feet in diameter, slightly hollowed in the centre, like the crater of an extinct volcano, which, on being opened, proved to be full of bricks, stones and mortar. A similar mound, more perfectly preserved and quite as rich in débris, lies about fifty feet more to the west. ${ }^{2}$ And at various other

1 One of these fragments also is now in the Congregational Library in Boston.

2 These may represent the ancient fishponds, which must have been in about 
places may be found the remains of buildings or of terraced mounds which seem to have had some relation to the ancient days and structures. This is true, especially, in the eastern portion of the estate, where considerable embankments remain.

All this is not much! No: not much - only that, at some times and in some places and with regard to some things, a little is more than much. There is a flavor of the majesty of a mighty past about even these simplicities; bringing back to us that " golden age of merry England" which knew not the day of its visitation, and sullied the splendor of the time of its Spenser and its Shakespeare, its Bacon and its Milton, by threshing multitudes of the most Christian of its people with the rods of its Star Chamber and its High Commission, and by carefully gathering much of the chaff into its garners and savagely driving the heaviest of the grain out of the land and over the sea. ${ }^{1}$

this part of the premises, and which, if it were desired to fill them up, naturally would have had such debris thrown into them.

1 A tablet lately has been placed upon the low wall in front of the bay window of the house, bearing this inscription :-

This tablet erected by the Pilgrim Society of Plymouth, Mass., U.S. A., to mark the site of the ancient manor-house where lived

William Brewster

from 1588 to 1608 , and where he organized the Pilgrim Church, of which he became ruling elder, and with which, in 1608 , he removed to Amsterdam, in 1609 to Leyden, and in 1620 to Plymouth, where he died

April 16, 1644. 


\section{BOOK IV}

THE PILGRIMS THEMSELVES AND HOW THE CONFLICT DEVELOPED THEM 
A patient suffering, when we cannot in conscience obey, is the best obedience. - W. Bradshaw, Treat. of Div. Worship, 44 margin.

It will generally be found that the leaders in enterprises of this kind, though but private men and little known perhaps in their own time, were not of the very obscure, but men of some education, of some energy, and even of some position in the social scale. - Hunter, Founders of New Plymouth, 3.

And being a little raised above the rest in fortune, attainments, and social position, all we read of him seems to be but in the natural course of things, and had there been no Brewster at hand, it is probable that no Separatist Church would have been gathered after Smith and the Gainsborough people had withdrawn. - Ibid. 54.

It was not the mingling of good and bad in the national church, but the fact that, under the episcopal order, the power of self-purification lodged by God with the people was lost, which drove John Robinson into Separation. - Rev. O. S. Davis, PH. D., John Robinson, The Pilgrim Pastor, 115.

Whereupon we (the weakest of all others) have been perswaded to embrace this truth of our Lord Jesus Christ, though in great and manifold affictions, \& to hold out his testimony as we do, though without approbation of our Sovereigne, knowing that as his approbation in such points of God's worship as his word warranteth not, cannot make them lavful; so neyther can his disallowance make unlariful such duties of religion, as the word of God approveth, nor can he give dispensation to any person to forbeare the same. - Robinson, Justif. of Separ. 14. 


\section{CHAPTER I}

\section{WILLIAM BREWSTER AND ENGLISH UNIVERSITY LIFE}

When the seventeenth century came in, on Mar. 25-Apr.4, 1601 , the two persons who were to be the chief leaders of that Pilgrim emigration which was to have so large a part in shaping the fortmes of the New World, were living in England, one in Nottinghamshire and the other in Yorkshire, within three miles of each other. The former, William Brewster, was in middle life. The latter, William Bradford, was entering upon his twelfth year.

It is uncertain where Brewster was born. Even his birthday is undetermined within a twelvemonth. That such uncertainty should exist as to the dates of both the birth and the death ${ }^{1}$ of one so eminent is strange indeed. The nearest approach to exactness in regard to the former is in an affidavit at Leyden, June 25,1609 , in which he declares himself " aged about forty-two years." 2 This indicates that he was born in 1566, making him enter the new century at thirty-five. His father's name was William and his mother's Prudence, and no other child of theirs was living in $1590 .^{3}$ His father appears to have lived in Scrooby when this son was about five, for a William Brewster was assessed to the subsidy of $\mathbf{1 5 7 1}$, in the township of Scrooby-cumRanskill, on goods valued at three pounds. ${ }^{*}$ "Four or five years later, as we have seen already, this William Brewster, Sr., became the Archbishop of York's receiver and bailiff, which evidently inrolved residence in the manor-house.

1 See Dr. Dexter's art. in N. E. Hist. $\&$ Gen. Register, 1864, 18.

2 Getuignis boeck van Leiden, K. fol. 26 , verso.

3 The probate record. of July 24, 1590, mentions only a son, William. Act Book. York, Retford cum Laneham, 1590. See p. 323.

4 Only two others - Thomas Wentworth, of the Earl of Strafford's family, who then lived in the manor-house, and William Dawson - were assessed thus, which, as well as the sum, implies that Brewster was a man of some substance. Hunter, Colls. 19. 
We lack proof of his origin, and the search is especially diffcult because it runs back of existing parish register's. Clearly there was in the neighborhood a family of his name, and of a station making his connection with it not improbable. In 1565, about six years before our first trace, through the subsidy record, of the presence of William Brewster, Sr., at Scrooby, one Henry Brewster became vicar of Sutton-cum-Lownd, about four miles south from Scrooby and forming one parish with it. In 1584, or about six years before the senior William's death, a James Brewster was made master of the Hospital of St. Mary Magdalene in Bawtry, about a mile and a half northwest of the Scrooby manor-house. ${ }^{2}$ In 1590 , the year in which the senior William died at Scrooby, a warrant was issued against James Brewster and two others, for having "profaned and ruinated" the chapel of the hospital. Early in 1596, after William Jr. had been post at Scrooby for at least two years in his own right, James finally was ousted, and two years later, on the death of Henry, he became vicar of Sutton, which took him to Serooby once on each Sunday during the ten remaining years of William's tenancy of the manor-house.

There nust have been at least a considerable acquaintance between these men, and it has been natural to suppose them of one family. Hunter thought the younger William and James to be brothers, but no child excepting William Jr. appears in the settlement of William Sr.'s estate. The new "Dictionary of National Biography" suggests that William may have been the son of Henry or James. But Henry had no children, James was young enough to be William's brother, and William's father had the same name. If other considerations favored it, the striking similarity of their signatures might indicate that William and James were brothers. Hunter supplies these, one being from a fac-simile in Davis's "New England's Memorial" and the other from the Sutton records. Dr. Dexter compared an autograph of William's in his own possession, written when William was much

1 Hunter, Colls. 73, 79, 82, 84, 74, 86.

2 See plan of district, p. 243 . The hospital, now an humble cottage, where one or two poor women are maintained, at least in part, by the endowment, stands just inside the Harworth line but is a part of Bawtry village. 
younger, with the original autographs of James upon the Sutton records, and the resemblance between them is much closer than would be inferred from Hunter's reproductions.

James Brewster copied the entire first volume of the records of his parish, and continued the register down to his own death; and when he inscribed his family name, which occurred often, he wrote it in one way, in accord with the handwriting of the time; while, when he wrote his own name therein, as his signature, which he did four times, he wrote it in another way, with peculiarities precisely resembling characteristics of the well-known signature of William. ${ }^{1}$ But the facts that William Brewster never suggested

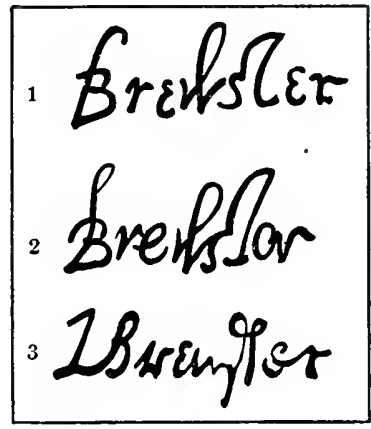
such a relationship; that Bradford, who hardly could have helped knowing the truth, makes no reference to it; and that the settlement of the estate of the senior William implies that William Jr. was the only living child; seem to refute any such supposition. ${ }^{2}$

A single other suggestion occurs. In the State Papers for $1582^{3}$ is a petition from inhabitants of Bury St. Edmunds to the Privy Council, in the case of Mr. Handson and Mr. Gayton, ministers there who had been ejected. This is signed by 174 names. The first five are designated as "gentlemen," and the thirteenth is that of William Brewster. William, the son,

1 As given above, 1 is the signature of James, from the parish records; 2 that of William, from the title-page of a book from his library in Dr. Dexter's possession (now in the Yale University Library) ; and 3 is the name as conmonly written at that time, and as always written in the parish records by James, excepting when he wrote his own signature.

2 A. Steele (Chief of Pilgrims, 3S) infers that Brewster was descended from the Brewsters of Wrentham because an "old copy of the same coat of arms " is said to have been preserved in one branch of the family in this country. But there appear to be several Brewster families in this country, and a coat of arms, unless supported by conclusive proof, is not satisfactory evidence. It deserves record, however, that when Brewster was cited before the High Court of Commission, Dec. 1, 1607, - see p. 401 - he was described officially as "William Bruster of Scrowbie, gen."

"Gen" doubtless is an abbreviation of "generosus" i. e., "well-born."

${ }^{3}$ S. P. Dom. Eliz. CLV. No. 5. 
then was about sixteen, and his father, William, who had been in Scrooby at least eleven years, might have been from forty to forty-five. He, too, might have had a father, William, still living and sixty-five to seventy years old; and a resident of Bury St. Edmunds and the signer of that name to this petition. When his father became receiver and bailiff, William must have been nine or ten years old, and we must think of him then, and for some years afterwards, as living in the manor-house; which still must have been impressive to a boy's mind.

It is a necessary inference from the few data in our possession that this Brewster family was neither socially obscure nor poor. If William Brewster, of Bury St. Edmunds, were his grandfather, possibly the young William spent some years with him and studied at the grammar school there, founded by Edward VI. and having the rights of two scholarships at Cambridge. Or, if at home, he may have prepared for the university under Henry Brewster, the vicar, no doubt quite competent for such instruction. Preparation for Cambridge or Oxford turned largely upon a good knowledge of Latin. ${ }^{1}$ A beginner had to make himself familiar with William Lyly's grammar, first published in 1513 for the scholars of St. Paul's, and so enjoined by Henry VIII. ${ }^{2}$ as to make it "penal for any publicly to teach any other." The writing and speaking of Latin also were subjects of special drill.

On Dec. 3, 1580, William Brewster was matriculated at St. Peter's, ${ }^{3}$ more commonly called Peterhouse, the oldest of the fourteen colleges at that time grouped into the University of Cambridge. Founded on Mar. 31, 1284, by Hugh Balsham, Bishop of Ely, in 1309 it had gained possession of the property of the friars of the order De Poenitentia Jesu. ${ }^{4}$ Originally the support of a master and fourteen perpetual fellows was con-

1 Fitzherbert, Descrip. Oxoniensis Acad. 17. Lyte, Hist. Eton Coll. 150.

${ }^{2}$ Fuller, Ch. Hist. Brit. Bk. v: 19. This regulation, says Masson (Milton, ed. 1859 , i : 48), continued in force through James's reign.

3 Matric. Reg. Cambridge.

4 The second Council of Lyons, in 1274, in favor of the four great orders of friars suppressed all others; including that De Poenitentia, whose property in passing to Peterhouse became the earliest instance of that species of conversion which so largely angmented the resources of the Universities at a later period. Mullinger, i : 229, 231. 
templated. But in Brewster's time there were fellows, who lived from the revenues of the college; ${ }^{1}$ fellow-commoners, who sat at the table and enjoyed the conversation of the fellows; scholars, or students partly supported from the funds of the institution; Bible-clerks, whose duty it was to read the Seriptures alond at meals : pensioners, who paid a pensio, or rent, for lodging in the college ; and sizars, or poor students, who performed menial, or semi-menial, services.

All of these classes may not lave been represented always in the body of students, but most of them were. No returns of the precise years of Brewster's membership of Peterhouse remain. But seven years before there were in residenee the master and fifteen fellows, five Bible-clerks, sixty pensioners, and eight sizars, eighty-nine in all. Forty-eight years later the figures were: the master and seventeen fellows, twenty-one seholars and Bible-clerks, and 101 other students - 140 in all. If this growth were distributed evenly, the number in Brewster's years must nearly, if not quite, have reaehed 100 .

To which class Brewster belonged cannot be determined. Probably he was a pensioner, the elass most natural to the child of a family in confortable but not affluent cireumstances. The cost of living for a pensioner probably was forty to fifty pounds a year, of the current value of money.

Peterhouse had been for twenty-six years under the mastership of Dr. Andrew Perne, then not far from sixty-one. Edueated at St. John's, he was afterwards a fellow of Queen's, before becoming the head of Peterhouse, and was Dean of Ely.2 He had gone through the Reformation and what followed with a supple sagaeity, which, under Henry VIII. and Edward VI. and his two sisters, had saved not only Dr. Perne's head but also his prominenee. He had preached, under Mary, at the exhuming and cremation of the poor remains of Bucer and Fagius, and, under Elizabeth, had taken prominent part in atonement

1 C. Wordsworth, Social Life at Eng. Univs. in 1Sth. Cent. 98, 646, 639, 641 (from Cooper's Annals and Camb. Univ. Cal.), 648, 650. Masson, i: 76-78 (from Add. Mss. 11,720 Brit. Mus. Lib.). Hentzner, Itin. 64. Mullinger, i : 252; ii : 399.

2 Ath. Cunt. ii: 45. This work, Cooper's Annals, Fuller's Worthies, the Egerton Papers, the Enc. Brit. (ninth ed.), and the Dict. of Nat. Biog. supply most of the biographical details. 
to their memory. He was twice Papist and twice Protestant, and five times Vice-chancellor of Cambridge. The wags turned his name into a Latin verb - perno, pernare, pernavi, pernatum - "I rat; I change often ;" 1 and, in 1588, Martin Marprelate referred to him as "Dr. Turneoats" and "the Old Turner." 2

Nevertheless, he had his good qualities. His lack of keen theological convictions was not accompanied by a dulled moral sense, nor was he to be despised as a scholar or a man of affairs. Under Edward he had been one of the six chaplains appointed to go through the kingdom and set forth the reformed doctrines, and in 1563 he shared the work of revising the "Bishops" Bible, the books assigned to him being Ecelesiastes and Canticles. In Angust, 1564, he preached in King's College chapel before the queen a discourse, which so pleased her that she said that "it was the first that ever she heard in Latin, and she thonght she should never hear a better." Archbishop Parker sent his son to Peterhouse to be under Perne's tutelage and influence.

He exhibited genuine public spirit in regard to his college, and provided in his will for a new library building, besides large gifts from his own collection of books and mannseripts $;^{3}$ and Fuller declared that his doctrinal laxness increased his usefulness in one respect: ${ }^{4}$ -

His memory ought most to be honored (saving God's living temples, is better than building deal Colleges) on this account, becanse in the days of Queen Mary he was the screen to keep off the fire of persecu-. tion from the faces and whole bodies of many a poor Protestant; so that by his means no Gremial ${ }^{5}$ of the university was martyred therein.

In situation Peterhonse ${ }^{6}$ then was, as it still is, the southeasternmost college, the first on the left as one enters Cambridge by the Trumpington road. A few steps further on at the right was Pembroke (1347). From this point the street

1 Mullinger, ii : 179-180.

2 Epistle, 16, 39, 43.

8 "Supposed to be the worthiest in all England." Cooper, Annals, ii : 278.

4 Worthies, ii : 464.

5 An intimate friend, or child born in the lap.

6 Mullinger, as most trustworthy, is followed. Masson sometimes gives other dates. 
wound on a half-mile or more to its junction with Bridge Street, having on the east a single college, Corpus Christi, or Benet (1352), with several ehurches - St. Botolph's, St. Mary's, St. Michael's, and All Saints, with St. Sepulcher's opposite to the point of junction - interspersed with shops and dwellings.

On the left eight colleges were abutting, or near: Queen's (1448), 100 yards along Silver Street; Catherine's (1475); King's (1440); Clare Hall (1359), 150 yards down a lane; Trinity Hall (1350), next north of Clare; Gonville and Cains (1348); Trinity (1546), and St. John's (1511). Magdalen (1542) was near Castle Hill, to the northwest. Jesus (1497) was approached through Jesus Lane out of Bridge Street, to the north. And Christ's (1505) was on the west side of the town. It was still four or five years before Emanuel was founded, near' Christ's.

We can identify only a few then resident in these other colleges who became famous in some degree, and whom Brewster must have seen, and may have known. John Udall, matriculated at Christ's two years before, soon had migrated to Trinity, was about taking his B. A. when Brewster reached Cambridge, and must have remained throughout the latter's residence. He was to become author of the "Dialogue" and "Demonstration," already mentioned, and was to die in the Marshalsea. John Greenwood, of about equal standing, was in Corpus Christi, and was to share the martyrdom of Henry Barrowe at Tyburn. George Johnson, brother of Franeis, matrieulated at Christ's when Brewster entered Peterhouse and remained eight years, taking both degrees. He went through banishment and shipwreek to Amsterdam, was excommunieated with his father, and died in prison at Durham in 1605, when nearly done publishing a volume on his family troubles and the Ancient English Church in Amsterdam. Brewster brought a copy of the book to this eountry. ${ }^{1}$

Possibly Thomas Settle, who shared George Johnson's arrest as a Brownist in 1592, still was at Queen's, where he had been matrieulated in 1575 , and whieh he left without a degree. Thomas Brightman was just proeeeding B. A. at Queen's, where

1 Plym. Court Records. Wills, i: 53-59. Inventory of Eng. Books. Item 79. 
he was a stout advocate of the new views of religion. He became rector of Hawnes in Bedfordshire. He was an eminent preacher and scholar. He left, in Latin manuscript, commentaries on the Apocalypse, Daniel and the Canticles, which were printed at Frankfort in 1609, at Heidelberg in 1612, and at Leyden, in English, in 1616 - Brewster leaving a copy in his library - and at London in 1644.

Another was the afterwards famous William Perkins. He took his B. A. at Christ's about the time of Brewster's entrance, and became a fellow about 1582. Beginning soon to preach to the prisoners in Cambridge Castle, he won a pulpit reputation and was chosen lecturer at Great St. Andrew's. His works fill three stout folios, and some made their way into Latin, Welsh, Dutch and even French and Spanish. He could write only with his left hand, the other being lame. This suggested to somebody a Latin couplet which Fuller rendered thus : ${ }^{1}$ -

Though nature thee of thy right hand bereft,

Right well thou writest with the hand that's left.

Both John Robinson ${ }^{2}$ and William Bradford ${ }^{3}$ refer to him with profound respect, and eleven copies of his treatises are in the list of Brewster's library.

About this time, moreover, two men were preachers to the university, whose names survive in connection with the religious controversies. One was Dr. John Copcot, a fellow of Trinity and a university preacher in 1576, who in 1584 attacked Dudley Fenner's "Counterpoyson" at Paul's Cross, and three years later became master of Corpus. Christi. The other was Peter Baro, from the Isle of France, who had studied law at Bourges, and divinity at Geneva, being ordained by Calvin himself, and who in 1573 became a member of Trinity. In 1574 he was chosen Lady Margaret professor of divinity in the university, but during Brewster's residence objection was made to certain of his teachings.

Of men then or later prominent in a social or literary way there were many. Robert Devereux, even then second Earl of Essex, was in Trinity, and some eighteen months senior to Brew-

${ }^{1}$ H. Holland, Iconess. Fuller, Holy State, St.

2 Just. of Sep. 421.

3 Hist. 6. 
ster. He bore himself with rare courtesy towards his social inferiors, and, by his repeated interpositions on behalf of Sir William Davison, and by the presence in Brewster's library of a volume about him, ${ }^{1}$ a possible Cambridge acquaintance is suggested.

Of those more or less known in letters, at Pembroke, among the fellows, was Richard Harvey, later eminent as a judicial astrologer and an antagonist of Martin Mar-prelate. At Corpus Christi, a close contemporary with Brewster, was Christopher Marlowe, "the father of English tragedy, and the creator of English blank verse." At Queen's was John Harvey, a brother of Richard, and also a prognosticator.

There, too, was John Darrell, who, as a pretended exorcist, was degraded from the ministry and imprisoned; and whose case suggested the seventy-second canon of the Church of England, prolibiting ministers from undertaking exorcism without episcopal license. At King's, matriculated in the same year with Brewster, were Joseph Jessop, afterwards secretary to Sir Francis Walsingham and a learned physician; and George Brooke, youngest son of Lord Cobham. The queen had promised him the mastership of the Hospital of St. Cross, near Winchester. But, as King James refused to fulfil her promise, Brooke joined in the plot in which Raleigh was implicated and was beheaded.

At Clare Hall was Robert Greene, who in his way became the most popular writer of his day. At Trinity were Dr. John Still, to be master of the college, and author of one of the earliest of English comedies; Giles Ascham, eldest son of famous Roger; and William Barrett, who, in 1597, was "reconciled" to Rome, the "Lambeth Articles" being an outcome of the controversy which he had caused.

At St. John's were Robert Spaulding to be Regius professor of Hebrew and a translator of the "King James's" version of the Bible; and Andrew Downes, who, with his pupil, John Bois, was reviving the almost forgotten knowledge of Greek, and afterwards, with Bois and four others, was charged with the final

1 Bacon, Declaration of the Practices \&. Treasons attempted and committed by Robert, Late Earl of Essex and his Complices aguinst her Maiestie and her Kingdoms. Invent. 154. 
revision of the new version of the Bible. John Milward, to be chaplain to King James and Prince Henry, also was there; and at Magdalen was Sir Edward Loftus, to be the queen's prime serjeant-at-law in Ireland.

In addition to these were a few others, whom Brewster must have seen, who had more standing in the university but still frequented her halls. Everard Digby, of St. John's, gained prominence by philosophical works attacking the method of Ramus. Another at St. John's was Robert Stokes, who, adopting Separatist opinions, became the medium for the printing of several books by Barrowe and Greenwood on the Continent. Eleazer Knox, second son of John, also was at St. John's, and afterwards became a university preacher. At Magdalen was John Lyly, M. A., come over the year before from Oxford, whose fame rested largely upon his strained and stilted "Euphues." And, possibly, when the Scrooby lad first reached Cambridge, he found there, before their flitting, Robert Browne and Robert Harrison, ${ }^{1}$ the two apostles of that polity whose influence was to identify his own name imperishably with the annals of the New World.

Fifteen men can be identified who must have been Brewster's fellow-students at Peterhonse. One was Edmund Coote, who had only just taken his B. A. He is first heard from subsequently in 1596 as head-master of the grammar school in Bury St. Edmunds, where he published " The English School-Master." Then there was Robert Priest, who translated the "Stirpium Historiae Pemptades" of Rembert Dodoens, lis work becoming the foundation of " The Herbal, or General History of Plauts," of John Gerard, in 1597. Another was James Scruby, who became vicar of Cherryhinton, near Cambridge, and wrote sundry Latin verses. Another was Abraham Fleming, who preached eight times at Paul's Cross between 1589 and 1606, and was rector of St. Pancras, Soper Lane, in London. He became a voluminous anthor, and is reputed the first translator of Virgil's Bucolies and Georgics into English verse. ${ }^{2}$ And Reginald Bain-

1 See Cong. in Lit. 69.

2 Cnnningham, Handbook of Lond. ii : 621 . More than thirty printed books are catalogued to him and a much larger number of manuscripts. 
brigg became head-master at Appleby, and left valuable manuscripts, now in the Cotton and Lansdowne collections.

Another was John Morden, who, in April, 1581, while Brewster must have been in residence, in a disputation in the logie schools reflected on the Duke of Anjon, the suitor of the queen, and was imprisoned. Robert Bownd was chosen a fellow and, later, was expelled from his fellowship. He was a brother of Nicholas, the author of the "Sabbathum Veteris et Novi Testamenti," which precipitated the Sabbath controversy at the beginning of the seventeenth century. Charles Horne became M. A. in 1577 , held his place with unusual tenacity, being senior fellow in residence as late as 1595-96, and left some Greek and Latin verses. Miles Sandys held two prebends in the cathedral at York. He wrote some verses on Sidney's death.

Mark Sadlington succeeded Robert Browne in 1591 as master of. St. Olave's grammar school, and later became vicar of Sunbury, and wrote a book on the treason of Ducket and one upon Spanish acts in the West Indies. Nicholas Deane in 1599 was appointed a commissioner to suppress schism in the Province of York, and in 1602 became Archdeacon of Carlisle. Thomas Mudd, who became a fellow of Pembroke Hall, wrote a comedy, acted in the college, which " too saucily reflected on " the mayor of the town. After three days in the Tolbooth he apologized. Robert Sayer, getting into trouble by his papistical tendencies, finally became professor of divinity at Monte Cassino, and left eight or ten volumes of good work, from his point of view. The famous John Penry seems to have been matriculated at Peterhouse on the same day with Brewster. His leanings "then were towards Romanism, and he "berhymed Dr. Perne's new statutes, and made a by-word of his bald pate." He became a Puritan and started out upon that brilliant but brief career which was ended by his martyrdom at St. Thomas Watering on May 29, 1593. Fynes Moryson, the eminent traveller, was another, and his famous work ${ }^{1}$ is exceptionally entertaining and, for its date, instructive.

Before considering Brewster's history at Peterhouse, it will

1 An Itinerary Written by Fynes Moryson, Gent, , first in the Latine Tongue, and then translated by him into English, 1617. 
be worth while to examine the conditions of student life. In important respects its features differed from what now are known by similar names. In doing this the statements of two most learned and accurate works, ${ }^{1}$ both of Cambridge authorship, will be used freely.

The ancient university was a corporation of learned men associated for teaching, and no one else could teach in their domain withont their sanction, granted only upon proof of his ability. The test consisted of examinations and public disputations; the sanction took the form of a public ceremony, and the name of a degree; and the teachers, or doctor's, so elected, or created, lectured in the public schools. The degree was simply a license to teach. The recipient became, ipso facto, one of the ruling body, the corporation of the university. Such a university, as a corporation, did not house or feed its students. The only essential buildings were those required for its general meetings and ceremonies, a library and lecture rooms.

On the other hand, a college was a foundation endowed by private munificence for the complemental work of lodging and boarding poor young men, who desired university privileges but lacked means. Consequently, there eame to be as many colleges in connection with a university as the number of young men wishing to study there required, and as wealthy benefactors provided. Each college had its own buildings, and each was governed by its own statutes. The students from all the colleges attended the public lectures and disputations of the university, and, at first, the older students were expected to assist the younger in private study. As numbers increased and larger endowments permitted, lecturers were appointed for this purpose from the members of the college, and each college had its private exercises in preparation for the public ones of the university. Sons of well-to-do parents lodged and ate where they liked, under the general supervision of the university rules, and had no relation to any instruction other than the public teaching of the university. But in time the obvious value of collegiate training for the university exercises and the snperior

1 R. Willis and J. W. Clark, Arch. Hist. of Camb. 18\&6; and J. B. Mullinger, Univ. of Camb. from Earliest Times to Accession of Chas. I. 1873, 1884. 
comfort of the college buildings led even the sons of the wealthy to seek to share therein, paying rent and charges in some college rather than outside. ${ }^{1}$ Old members of a college also, who had lost their right to its freedom, sometimes were allowed to resume residence for further study.

The usual plan of an English college suggests its derivation from the monastery. Its general enclosure within walls; its disposition into courts; its refectory, kitchen and offices; its chapel and master's lodge; all have monastic analogies. Only by lodging its scholars in chambers, in place of a grand dormitory, does it differ essentially. This arrangement favored that gralualness of construction which was the almost invariable result of growth. One, two or three sides of a quadrangle could be built at the outset and would serve until what was lacking could be added. When Dr. Caius, physician to Edward VI. and to Mary and Elizabeth, refounded Gonville Hall, and established what since has been known as Gonville and Caius College, in Cambridge, he introduced a principle, which, although lacking approval at Oxford, has been adopted generally at Cambridge, the leaving one side of the quadrangle open. ${ }^{2}$

The system may be comprehended by studying Peterhouse as it was in Brewster's time. When Bishop Balsham founded it, in 1284, he secured two inns hard by the little church of St. Peter. These were called "Hostels, or literary inns." For a long time, such quarters were attached to many colleges. Soon after Balsham's death, in 1286, and with money left by him, a hall was built, and, by 1352 , a house was annexed to the hostels on Trumpington St., between them and the churchyard. Afterwards there were occasional additions, e. g., a library in 1431-48 and a kitchen in 1450, until 1467, when the college was completed for the time. Between then and almost the beginning of the seventeenth century there are traces of a bakehouse, (salt) fish-house, coal-house, lime-house, granary, hayhouse, wheat-loft, dove-cote, hen-house and observatory. The

1 "This privilege was scantily granted, and can hardly be said to have become general until after the Reformation." Willis and Clark, $\mathrm{i}$ : xv ; iii : 247.

2 Docs. Relating to Univ. and Colls. of Camb. ii : 262. 
original hostels seem to have survived, and, with the house first added, to have presented an unbroken front upon Trumpington St. The grounds were entered by the northeast corner through

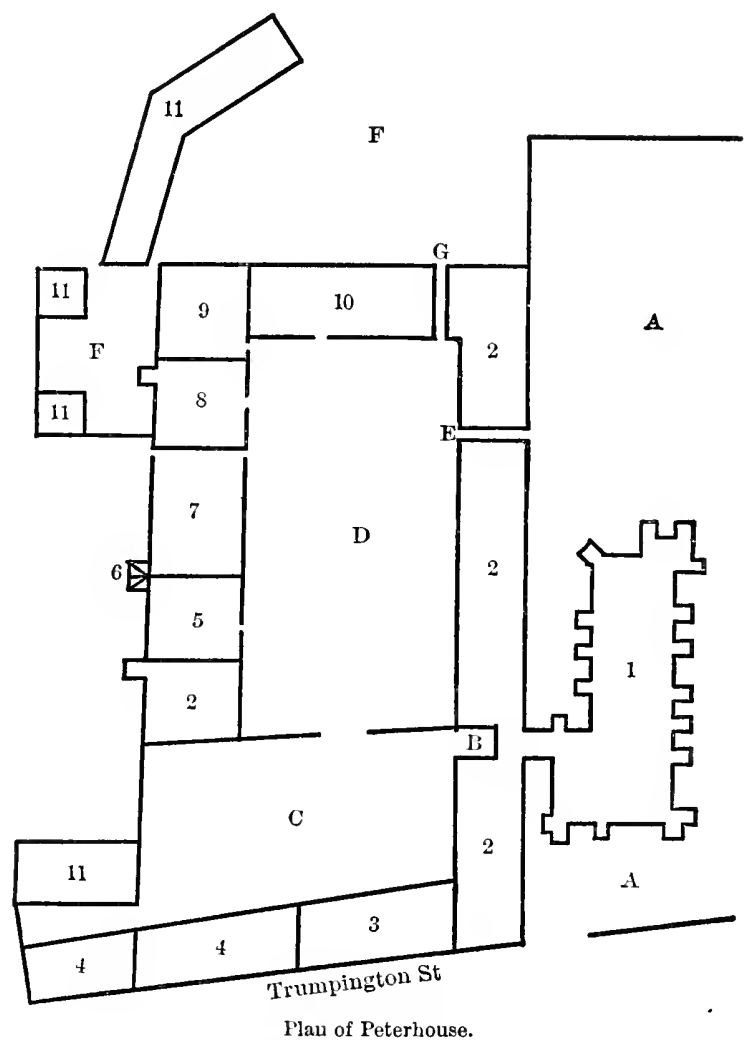
A, A. Churchyard.
B. Eutrance to college.
C. Outer Court.
D. Quadrangle.
E. Passage.
F, F. Exterior grounds.
G. Passage.
1. St. Peter's Church.
$2,2,2,2$. Students' rooms.

3. House first added.

4, 4. Original hostels.

5. Stone parlor.

6. Staircase.

7. Hall.

8. Buttery.

9. Kitchen.

10. Library building.

11, 11, 11, 11. Outbuildings.

the churchyard. Passing into this, one turned sharply to the left through a covered passage into the outer court. Next, unless he roomed in a hostel, he turned to the right throngh a fence into the quadrangle, which - although a little irregular, 
the south side being three feet longer than the north - was about 148 feet from east to west by about eighty-six from north to south. At this time it was without trees.

Making the interior circuit of it, starting at the southeast corner, one would pass first the windows of some students' rooms, and then those of the "stone parlor," the modern Combination Room, ${ }^{1}$ where, as there were no chimueys in the students' rooms, a fire was kept in cold weather. Next would come the hall, where all gathered at meals, and next the buttery, ${ }^{2}$ the kitchen completing the row. Following the hollow square northward, to the right, the library - excepting where a passage at its north end led to an exterior yard - oceupied the upper story of the whole side. Turning again to the right, he would find the whole distance - excepting another narrow passage, about forty feet from the west end, to the churchyard, with a sun-dial over its inner arch - eastward, back to the plaee of his entrance, occupied by dormitories, which, like the hostels, seem to have been two stories high.

To have gained an interior view, one would have entered first the common parlor, and found that this communieated by a door with the "high table" end of the hall, and was ornamented, as now, by a wainscoting of small oblong panels, the upper two rows of which were filled with portraits, on the wood, of past masters or benefactors. Of those now in existence twen'y-three ${ }^{3}$

1 In direct descent from the Pisalis or Calefactorium of the Benedictine monastery. At Oxford it went by the name of the "Common Room." The name Combination Room appears first in the Cambridge records in 1650.

2 From botelerie, a butlery or place for bottles. It opened into the dining-hall by a door cut in half, with a ledge on the top of the lower half to rest tankards on, which lower half was called the buttery-hatch.

3 These were:-

1. A view of the two original hostels . . . . . .

2. King Edward I. $\cdot \cdot \cdot \cdot 1083$

2. King Edward 1. • • • • • 1283

19. Mr. Lownde, D. D. . . . . 1519

3. Hugh de Balsham • • • : 1284

4. Simon de Montacute . . . 1344

5. Simon Langham . . . . . 1395

6. Thomas de Castro-Bernard . 1420

7. John Holbroke . . . . . 1430

8. Thomas Lane . . . . . . 1472

9. John Warkeworth . . . 1498

10. Thomas Denman. . . . 1500

14. William Martin . . . . 1519

15. Thomas Burgoyne . . . . 1520

16. John Edmondes . . . . 1527

17. Doctor Shirton . . . . 1580

18. The widow of Master Wolfe . 1540

11. Henry Hornbie . . . . 1516

19. Andrew Perne, D. D., then Master.

20. Sir Edward North . . . . 1564

21. Robert Smith . . . . . 1565

12. Ednunnd Hanson. . . . . 1516

22. Archbishop Whitgift . . . 1569

23. Henry Wilshawe. . . . $157 \mathrm{~s}$ 
may have been there then. Nearly every one was underwritten by a Latin distich. The floor would have been strewn with rushes. The furniture would have consisted of "a fayre long table of waynscott," with several forms, or benches. Passing on into the hall, he would have found himself on the dais, or raised platform, the room having an open roof of timber and a hanging of arras on the wall, at least behind the dais on which stood the high table for the master and fellows. At the other, the western, end was the principal door, on the right, opening into the quadrangle, and opposite to it one opening into the garden. In many colleges a passage from door to door was screened off, but at Peterhouse no screen was built until 1638. Crowning the roof over this passage was a bell-turet. The hall contained a large fireplace, painted in colors, and had a stone floor covered with rushes. It was furnished with heavy oaken tables, supported on trestles and bordered by equally solid oaken forms, the master only having a chair. These benches, however, were rendered more comfortable by leather cushions.

The buttery and kitchen, which filled out the sonth side of the range of buildings, need not detain us. The library oceupied the whole second story of the western end of the enclosure. It was completed in 1450. Abont twenty-five feet north from the door into the kitchen at the sonthwest corner of the quadrangle, was an entrance still admitting to the handsome stone "vise," or spiral staircase, nine feet in diameter, built 450 years ago by Reginald Ely, up and down which Brewster must have passed many a time. This library, now divided into students' rooms, had a row of equidistant, two-light windows on each side, and a window of three lights at the north end. It had been fitted with bookcases between 1447 and 1450. The facts that, as early as 1418 , it contained by catalogue 302 volumes, divided among seventeen subjects, ${ }^{1}$ and that Dr. Perne, already master for more

1 At that date a part of every such library was chained to the cases and a part was distributable for the use of the students. This catalogue of Peterhouse library in 1418 is interesting :-

\begin{tabular}{|c|c|c|c|c|c|}
\hline $\begin{array}{l}\text { uteresting } \\
\text { Theologry }\end{array}$ & & & $\begin{array}{c}\text { Chained. } \\
61\end{array}$ & $\begin{array}{c}\text { Free. } \\
36\end{array}$ & $\begin{array}{l}\text { Total. } \\
97\end{array}$ \\
\hline Nat. Philosophy & . & . & . 32$)$ & & \\
\hline Mor. " " & . . & . & & $\{19$ & 59 \\
\hline Metaphysics . & . $\cdot$ & . & 3) & & \\
\hline
\end{tabular}


than a quarter of a century when Brewster was there, was an active promoter of libraries, make it probable that this collection was especially well furnished.

Books reserved for library use were chained to the cases and placed on the shelves with backs inward, and a catalogue of those in each case was written on an oaken panel at its end.1 The unchained volumes were at the service of students for study in their rooms, and were guarded in chests having two locks, one key being kept by the master and the other by the senior dean. It was ten years after Brewster's matriculation before the new library was begun, and about fifteen before it was completed.

The whole northern side of the quadrangle, to the fence and the main entrance from the churchyard, was occupied by a range of students' rooms, which extended above and beyond this entrance to Trumpington St. There also were such rooms in the end of the row of buildings on the south side of the quadrangle, between the parlor and the outer court, as well as in the original hostels. At Peterhouse, as at Clare Hall and King's Hall, in that only two students were assigned to each apartment, the custom differed from that at St. John's, Trinity and Emanuel, and largely at Oxford, where there were three and sometimes four. A door from the quadrangle led into a narrow entry with stairs, and there was a suite of rooms on each side. This consisted of a common room, some eighteen by twenty feet, and two

\begin{tabular}{|c|c|c|c|c|c|c|c|}
\hline Astronomy. & . & . . & . & . & . 10 & & \\
\hline Alchemy . & . & . . & . & . & . 1 & & \\
\hline Arithmetic . & . & . . & . & . & . 1 & & \\
\hline Music . . & . & . & . & . & . 1 & & 15 \\
\hline Geometry. . & . & • & . & . & 1 & & \\
\hline Rhetoric . & . & & . & . & . 11 & & \\
\hline Logic . . & . & • & . & . & . 5 & 15 & 20 \\
\hline Grammar & $\cdot$ & - & . . & · & . 6$\}$ & $\int 13$ & 23 \\
\hline Poetry . . & - & - & · . & · & $4\}$ & & 20 \\
\hline History . & . & . & . . & . & . 4 & & 4 \\
\hline Medicine . & . & . & . . & - & . 15 & 3 & 18 \\
\hline Civil Law & . & . & . . & . & . 9 & 20 & 29 \\
\hline Common Law & & . & . . & . & . 18 & 19 & 37 \\
\hline
\end{tabular}

1 C. Wordswortl, Scholae Academicae, 4, n. In three collections in England books still are attached to the shelves by ehains: the Chapter Library in Hereford Cathedral; a library in the Parish church of All Saints in the same city; and the library of Wimborne Minster. 
small studies. The beds - sometimes two high beds, and sometimes one high and the other a "truckle," or trundle, bed, rolled under the other in the daytime - were in the large room, privacy being found only in the studies. The furniture, as shown by inventories, was extremely simple - the two beds, a leaden jug, and a rude bowl, a plain wooden table, two forms or a few stools or a settle, a cupboard, and wooden shutters for the windows, and in each small room a desk for writing and a shelf or two for books.

The master's quarters were over the parlor, and by an outside staircase he could descend directly to the parlor, hall and garden. He dined and supped with the students in the hall, sitting at the middle of the table upon the dais, and he had an extra bedroom for guests. College funds ordinarily were stored in a large oaken chest, strapped with iron bands and with several different locks requiring to open it the simultaneous presence of several officials, each with his own key. The common seal, the charters, royal letters-patent and similar valuables were guarded in the same manner. For the safe-keeping of these chests a special strong room was required, and in Peterhouse this was above the buttery, and the chests had three keys apiece, one held by the master, one by the senior dean and one by one of the fellows.

In addition to the exterior western enclosure with outbuildings, an irregular tract of land, perhaps 400 feet by 360 , skirted the buildings on the west and south, and contained a grove and the dove-cote, the observatory, a kitchen-garden and the tennis court. This was divided from the Coe Fen and the river Cam by a stone wall with a coping of red brick, built in 1501-2 and yet, considerably patched, in existence. Near its southwestern end still may be seen an ancient doorway, evidently a part of the original wall, which gave access to the fen and the river, and with which Brewster must have been familiar.

The earliest colleges had no private chapels. All students in them were, for the time being, legally members of the parish in which they lodged. As, at the outset, a college was essentially a religious community, most of whose members were preparing for holy orders, attendance upon church service was habitual, 
and it was important that the college be near a parish church. This is why Peterhouse originally adjoined the churchyard of St. Peter's. Bishop Balsham, uniting in himself the founder of the college and the bishop of the diocese, in 1285 appropriated the living of St. Peter's - rebuilt in 1352 and rededicated as St. Mary the Less - to the college, which was to receive the proceeds of the living, and to provide for the parish by a parochial chaplain appointed by the master and fellows. The church is 100 feet long and twenty-seven wide, without aisles or any division between nave and chancel excepting the base of an ancient screen cut down to the level of the pews. In Brewster's time there appear to have been in it about sixty "superstitious pictures, some popes and crucifixes, with God the Father sitting in a chair and holding a globe in his hand," which were removed in 1643. A side entrance, opposite to the easternmost passage from the churchyard into the college, offered easy access to the students. ${ }^{1}$

Such being the belongings of Brewster's own college, we are concerned next with those of the university, whither he used to go for his principal instruction, in company with the students of the thirteen other colleges. These were almost a quarter of a mile north along Trumpington St., and 100 feet, or so, down a passage on the left, known as Schools St., or St. Mary's Lane. Here stood the Schools Quadrangle, begun in the last quarter of the fourteenth century and completed apparently about 1475 , a large, two-storied erection surrounding a court. Externally it was about 150 feet in front by 100 in depth, the enclosed quadrangle being, perhaps, seventy-five feet by fifty. On the ground floor were a consistory on the left and a Doctor's vestry on the right of the front entrance, and over them was the small library. The large room on the left side of the quadrangle was devoted to the School of Civil Law, and above it was the great library. The corresponding room, longer, because it occupied the greatest width of the building, was used by the students in Divinity, and over it was the Regent, or Senate, House, for the meetings of the university authorities and for

1 The present chapel. in the middle of the outer quadrangle and fronting Trumpington St., where the old hostels have been removed, and connected with the two sides of the quadrangle by cloisters, was built in 1628-32. 
other important assemblies. The School of Logic occupied the ground floor of the building at the rear of the quadrangle, and above it, at first, was the "Humanities," or Terence School, later devoted to Civil Law, Greek and Rhetoric.

The terms and studies of the university remained as Elizabeth earlier had approved them. The student's year began on Oct. 10, with the Michaelmas term, continuing until the Christmas vacation, on Dec. 16. The second, or Lent, term began on Jan. 13 and extended until the tenth day before Easter, which in 1581 was Mar. 17. After the Easter vacation, of three weeks, the Easter term began, on Apr. 12, continuing twelve weeks and two days until the Friday after Commencement Day, always the first Tuesday in July. The day was so named because candidates for the higher degrees then were said to commence in those degrees. Then followed the long vacation of three months.

The prescribed studies for the B. A. degree were these: for the first year, Rhetoric; for the second and third years, Logic ; and for the fourth year, Philosophy; to be pursued in one's own college and by attendance at the university lectures. Furthermore, during this four years' course, the scholar's knowledge was to be tested by two university disputations in the public schools and two responsions in his own college. The Quadrivium, through which the Bachelor of Arts proceeded on his way to the M. A. degree, required the further study of Philosophy, with Astronomy, Perspective and Greek, and a completion of the college studies, with steady attendance upon all disputations of Masters of Arts and with three university responsions to an opponent Master of Arts, two similar college exercises and one college declamation. At this date, probably some of these later studies had been pushed back into the earlier years. Masson ${ }^{2}$ says that a generation later Greek was tanght regularly from the beginning.

It may be doubted whether the university teaching at this time were $u p$ to the average of those days in excellence. At any rate, this doubt was felt strongly by Walter Travers, who,

1 These less important examinations in one's own college were called the "Little-go."

2 Milton, i : 227. 
six years before, had spoken plainly from his own recent knowledge, a testimony apparently confirmed in the same year by Cartwright, his probable translator. The two said : ${ }^{1}$ -

That which was most liberallie and bountifullie geven for the maintenaunce off good lerning is abused to riott and idlenes: That the hiues for Bees, are become deñs for droanes: that They are no more, colledges off studentes, but monasteries and cloisters off idle and suoring monckes. . . .

The vniuersities ought to be the seede and the frye ${ }^{2}$ off the holie ministerie thorowghe out the realme: but now there is scarce one sent out into the churche in many yeres that is fitte for suche an office. It ought in deede to be like the Aple tres off Persia wheroff Theophrastus maketh mencion: which doth budde, blossome and beare fruit at all times off the yere: and bringeth furth some fruit which is allready ripe and some other buddinge, and newe growing ont. So the vniversities should hane some allwaies fitte, and as it wer ripe allready to take the ministery, a d some other ripening and budding oute: but now neither ripe fruit fallethe from the tree, neither is the blossome such as declareth any plenty or store to come hereafter. ${ }^{3}$

Probably Brewster was about entering his fifteenth year in the early winter of 1580 when he was matriculated. ${ }^{4}$ As at Peterhouse two usually occupied the same rooms, he must have been thrown

1 Full and plaine declar. iii.

2 The word "fry" means the swarm of young fish just from the eggs of the spawn, and was used of any immature growths. Full and plaine declar. 144, iii. verso.

3 Mullinger (ii : 262) refers to this utterance as illustrating "the unfairness and misrepresentation too common amoug the Puritan writers of the period," and mentions a letter of Cox to Bullinger in 1568 (Zur. Lets. I : 208) and one from Whitgift a few months before Archbishop Parker's death to him (Strype, Parker, ii : 326) declaring that Cambridge alone since the beginning of Elizabeth's reign had sent out at least 450 preachers, while 100 still remained there. Whitgift however does not assert, as Mullinger implies, that these were "competent" preachers.

4 His Leyden affidavit (see p. 505) fixes his birth in 1566 or 1567 , while the university statute (Statuta Acad. Cant. 207) seems to negative the latter year. $\mathrm{He}$ could not have been matriculated legally in 1580 unless born as early as 1566 . If his birthday had been Mar. 25, 1566, its New Year's Day, he still would have lacked 113 day's of having completed his "quartum decimum annum" on Dec. 3, 1580. Yet apparently as much license as that was not uncommon. John Cotton entered Trinity, Cambridge, at thirteen; John Davenport Brasenose, Oxford, before fourteen; John Norton Peterhouse at fourteen (Magnalia, iii : 14, 52, 32) ; Francis Bacon Trinity, Cambridge, at twelve years and three months (Dict. Nat. Biog. ii : 328), and George Cranmer Christ Church, Oxford, at about thirteen (Ath. $O x$. i : 700). Evidently the rule was disregarded in special cases. Mullinger (iv: 390) thinks the average age to have been sixteen. 
into intimacy with some fellow-student. Presumably it was one of longer standing than he. It is likely, however, that by Brewster's time, there were in the college one or more professors to instruct its members, so that young students no longer were dependent upon their more advanced companions. Archbishop Parker sail, in, or about, 1564, in regard to the Church of England and the universities: ${ }^{1}$

Every one of the colledges have their Professors of the tongues, and of the liberal sciences, (as they call them,) which do trade [train] up youth privately within their halls ; to th'end they may afterwar'd be able to go furth thence into the common schools [the university public exercises] as to open disputation, as it were into plain battail, there to try themselfe.

In the common schools of both the Universities, there are found at the King's charge, and that very largely, five Professors and Readers, that is to say, the Reader of Divinity, the Reader of the Civil Law, the Reader of Physick, the Reader of the Hebrew tongue, and the Reader of the Greek tongue.

And for the other Professors, as of Philosophy, of Logique, of Rhetorick, and of the Mathematicks, the Universities themselves do allow stipends unto them. And these Professors have the ruling of the disputations, and other school exercises, which be daily used in [these] common schools.

The daily routine would be much as follows. At five A. M., on the ringing of the college bell, the student would repair to Little St. Mary's to morning service, followed sometimes by a short homily from one of the fifteen fellows, the exercises lasting about an hour. The regular labors ${ }^{2}$ of the day then would follow - the various studies pursued within the college walls; and the university exercises, in the Schools building, lectures by the university professors, or public disputations. At ten or eleven o'clock they dined ${ }^{3}$ in the hall. The meal consisted of a joint of roast beef, mutton or veal, varied now and then by

1 Strype, Parker, iii : 111.

2 Probably the old eustom of having no breakfast still continued. Lever describes this (Arber's reprint, 1871, 122) at Paul's Cross in 1550. See also Stat. Acad. Cantab. 265.

${ }^{3}$ Clearly a change of the dinner hour from 10 to $11 \mathrm{\Lambda}$. M. ocenrred abont this time, and not to make room for breakfast but so that they "might lye in bed the longer." It was more than a century later that the dinner hour was pushed along to twelve. Wordsworth, Soc. Life at Eng. Univs. in 18th Cent. 124. 
boiled meat " hauyng a fewe porage made of the brothe of the same byefe, wyth salte and otemell, and nothynge els." On Fridays they had only fish. At Peterhouse it was preseribed as early as $\mathbf{1 3 4 4}$ that a passage of Scripture should be read aloud by a Bible-clerk while the eating proceeded. This custom still was in force in $1629^{1}$ and must have formed a part of Brewster's daily experience. After dinner there would be some declamation or dispute, and then, excepting for evening prayers in St. Mary's and supper at five o'clock, " not much better then theyr dyner," the students were their own masters, with restrictions. ${ }^{2}$

Excepting sizars on errands, they could go ont into the town only by special leave, and accompanied by a tutor or a Master of Arts; nor could they even converse with each other excepting in Latin, French, Greek or Hebrew. All but fellows were required to wear gowns of prescribed stuff and pattern, reaching to the ankles, and round eaps. Fellows wore square eaps. They could not frequent taverns, courts, boxing-matches, skittlegrounds, dances, bear-fights or cocking-mains. They were forbidden to go to Sturbridge Fair. They could not loiter about the markets or highways. They might not bathe in the Cam. ${ }^{3}$ They were prohibited from frequenting dice-houses and from playing with dice, ${ }^{4}$ and could play eards only during twelve days after Christnas, and then only moderately and at a proper time in the hall. Boating, football and cricket were not university sports, but archery was encouraged ${ }^{5}$ at Peterhouse. All infractions of these statutes subjected the offender, if a younger student, to corporal punishment; if an adult, ${ }^{6}$ to a fine, or, for the graver offences, to be discommonsed - i. e., shut out of the dining-hall — to be set in the college stocks, or to be expelled.

1 Audit Book, 1628-29.

2 Masson, i: 112-116. Wordsworth, Soc, Life, 438.

3 A regulation of 1571 condemned any Bachelor of Arts canght bathing in Cambridge to the stocks in his college hall for a whole day. Later, and perhaps at this time, there was a " cold-bath much frequented by the students" in the "Garden of Peterhouse."

+ Masson was misled in representing (i : 113) that dice were permissible at about Christmas. The language of the statute (xlvii), "alere nullo tempore," is definite.

5 "Butts are mentioned at Peterhouse in 1588-89, and again in 1613."

6 Mnllinger, i : 369. Only persons eighteen or more years old were considered adults. 
Such was the system. By its very strictness it prepares us to learn that, during the ten years since these statutes had been enacted, the officials had weakened steadily in enforcing them, while the daily habit of the place had relaxed their stringency still further. 'Two years before Brewster's membership the authorities found much fanlt with the students' " excessive ruffs," " apparell of velvet and silk," and "swords and rapiers;" and insisted that there was danger that the university "shall become rather a storehouse for a staple of prodigall, wastfull, ryotous, unlerned, and insufficient persons." 1

Of the studies which the new student pursued we have a fair knowledge. In Rhetoric, to which the first year was especially assigned, the lectures and instruction were founded upon Quintilian, Hermogenes and the orations of Cicero. The statutes of Elizabeth had made such modifications that Grammar-i. e., the Latin ${ }^{2}$ language as acquired by the study of Terence, Priscian, Boëthius, Donatus, Virgil or Ovid, with some training in verse composition - was left to the preparatory schools. But the requirement that it be used in the quadrangle and even on the street insured a facile, if not necessarily elegant, command of it. Greek had fallen almost into disuse at Cambridge. ${ }^{3}$ In the very year of Brewster's matriculation "the knowledge of the language in the former home of Ascham and Cheke ${ }^{4}$ had become almost extinct." 5 But, as Bradford testifies distinctly ${ }^{6}$ that Brewster at Cambridge gained "some insight in ye Greeke," he must have done his best with such facilities as he found. The rule of Elizabeth 7 required that the Greek professor interpret Homer, Isocrates, Demosthenes and Euripides, " aut alium ex antiquioribus," but that evidently was an ideal, rather than an actual, practice.

Mathematics, which had taken the place of Latin, also had been dropped for the most part; although a student conld hear

1 Mullinger, ii : 393.

2 Wordswortl, Schol. Acad. 83.

3 Mullinger, ii : 402 . The same was true in Italy. Hallam, Lit. Eur. (ed. 1S39) iii : 3 .

4 St. John's. But this hardly could have been true of one college without being measurably true of all.

5 Peck, Desiderata Curiosa, 32S. Hallam, Lit. Eur. i : 321, n. Mullinger, ii : 420.

6 Hist. 409.

7 Stats. Acad. Cantab. 228. 
lectures based upon the "Practica Arithmetice " of Jerome Cardanus, and the "De Arte Supputandi" of Cuthbert Tumstall. In Geometry he might have the definitions, axioms and a few of the easiest propositions of Euclid. ${ }^{1}$ So far as he was taught Astronomy, it was in the old system from the "Almagest" of Ptolemy; while for cosmical and geographical intelligence he still would be remanded to the "Timaeus" of Plato and the ancient notions of Strabo, Pliny and Pomponius Mela. It was not only permitted but quite common for the younger students to attend the free lectures of the later years. Thus Sir Simon D'Ewes, who spent only two years and a part of the third at St. John's, Cambridge, was in the habit, ${ }^{2}$

while yet but a freshman, of attending at the Divinity professor's lectures, and also at the Divinity Acts in the schools. He also attended the public lectures of old Downes in Greek (Demosthenes's "De Corona" being the subject) and of Herbert, the poet, in Rhetoric.

It is likely that the Scrooby lad broadened his base of study to some extent in the same manner.

It is not to be presumed that, at fifteen and sixteen, he was indifferent to recreation. Although the general tone of his subsequent manhood suggests that, even then, his was a serious nature, one cannot doubt that he shared in all the manly and honest English fun of the place. Undoubtedly he subsidized whatever was at hand within his college - the garden, the tennis court and the archery ground, ete. He sauntered by the observatory through the gateway, even then ancient, to the Coe Fen and the Cam. Duly authorized, he strolled about the town and looked up the other colleges. And he must have rambled off, three or four miles to the northwest, to Madingley, with its fine old hall; or, almost as far northeast to Sturbridge, which offered the different attractions of the greatest fair in England and the disused chapel of an ancient hospital for lepers; or southeast to Trumpington and the Gog-Magog hills, crowned by the ruins of an ancient camp with a triple entrenchment; or southwest to Grantchester, possibly the old Roman station of

1 The Elements of Geometry . . . of Euclide (now first) translated into the English toung, by $\mathrm{H}$. Billingsley, 1570 .

2 Masson, i : 228 . 
the neighborhood. But he took care to return before eight in winter and nine in summer, ${ }^{1}$ when the gates were locked.

Although the ceremony of "salting" the freshmen had been forbidden ten years before, such college customs die hard; and probably youthful ingenuity had invented a substitute not differing much from the original. Very likely Brewster underwent the discipline, as Bacon did at Trinity seven years before, and the Earl of Essex at the same college three years still earlier. ${ }^{2}$ At Oxford the freshmen were seated upon benches in the hall before their senior undergraduates, and were called upon, one by one, to mount the table and "speake some pretty apothegme, or make a jest or bull, or speake some eloquent nonsense to make the company laugh." The self-possessed and quick-witted, who did well, were rewarded with plenty of beer or sack. Others had to swallow large draughts of heavily salted water, or "cawdel." This was "salting." "Tucking" followed, the drawing blood from the chin, or under lip, by the sharp finger-nail of some upper-class man. All ended with the administration, by the senior cook, to all newcomers of an oath sworn upon an old shoe, which each was required to kiss reverently. The only fragment of this formula remaining is this :-

\section{Item tu jurabis, quod penniless bench non visitabis. ${ }^{8}$}

The costs fell upon the freshmen and were charged in the tutor's accounts. ${ }^{4}$

Probably during Brewster's residence at Peterhouse he also witnessed, in some college, another form of amusement which found favor occasionally with both the authorities and the students. At least as early as $1536,{ }^{5}$ the "Plutus " of Aristophanes

1 Stats. Acad. Cantab. 269. The winter is defined as extending from Sept. 29 to Mar. 25, the remainder of the year being summer.

2 Among his expenses (Cooper, Annals, ii : 352-356) is this in midsummer, 1577:

"Item, for my Lord at the saltinge, according to the custome, vijs."

${ }^{3}$ An Oxford oath - no doubt Cambridge had its equivalent - and the "penniless bench" was a seat for loungers under a wooden canopy at the east end of old Carfax Church, notorious as the "idle corner" of Oxford.

4 The student had to carry with him his year's supply, which usually was lodged in his tutor's hands and doled out to hin. Whitgift was Bacon's tutor, and from his accounts we learn what the ceremony cost the young philosopher.

5 Mullinger, ii : $73,75,430-431,319,431$. As to the "mysteries" and "moralities" of those days in England, see Hallam, Lit, Eur. i : 346 (ed. 1830). 
was performed at St. Joln's during Christmas week. The play was a favorite weapon of the Reformers when Christendom was straining to free itself from the bondage of the Popc. In the sixteenth century the "Pammachius" of Thomas Kirchmayer, which abounds in invective against Romish superstitions, was translated into English, and it was acted during Lent in 1545 at Christ's College. In 1586 John Smyth, ${ }^{1}$ at Great St. Mary's, inveighed against the custom of having plays in the colleges on not only Saturday, but even on Sunday, evenings. In the accounts and audit-books of the several colleges there is corroborative proof of this play-acting, and evidence that, in 1571-72, a comedy was performed in the hall at Peterhouse which it took twelve pounds of candles to light up. In Brewster's day the students also resorted sometimes to the inns, where plays were performed whose remote relation to decorum rendered them inadmissible to the colleges.

Perhaps the Commencement exercises also may be regarded as entertaining to the student just closing his freshman year, and merely a spectator. In 1581 they were on Tuesday, July $4 .^{2}$ The evening before and the day itself ${ }^{3}$ were the chief occasions of the year, and Cambridge was full of visitors and fat with feasts. The principal event was the conferring of the higher degrees $^{4}$ - M. A., D. D., LL. D., etc. From early morning till late afternoon of the day before, and during much of the day itself, there were disputations in Theology, Philosophy, and, usually, Civil Law, Medicine and Music, in crowded Great St. Mary's. Each debate was opened by a Respondent, and carried on by

1 It is at least doubtful whether this were the Separatist of Gainsborongh and Amsterdam. Mullinger asserts it (ii : 319), but Prof. Scheffer thinks that the Cambridge life of the famous se-Baptist was later, in 1586-93. Ms. letter.

2 This account is condensed mainly from Masson's record, i : 139-144.

3 Called the Vesperiae Comitiorum and the Dies Comitionum.

4 The conferring of the degree of B. A. did not, as with us, occur at Commencement, but earlier (Stats. ii.). At the beginning of the Lent term, the twelfth of residence and study, the quadrennium of undergraduateship closed and the scholar was ready to commence B. A. Having fulfilled the formalities, he then was declared by the Proctor a Bachelor of Arts, entitled to date back his admission to that degree to the beginning of the current year. In Milton's time, a generation later than Brewster's, Masson says (i: 140) that usually there would be between 200 and 300 candidates for the M. A., from two or three to twelve or fifteen for the D. D., and fewer still for the others. 
Opponents. There also was, specially connected with the philosophical disputes, a praevaricator, or varier, ${ }^{1}$ who indulged in drolleries and hits at the Dons. By the aid of his waggery the irrepressible desire to make a noise found excuse and vent. Wordsworth ${ }^{2}$ has printed one of these speeches from the original of 1631, and, although one cannot now unravel all the tangles of its allusions, evidently many sentences must have brought down the house. Frequently, also, there was something mirth-provoking in the mere subject of a grave discussion.

Thus in 1615, at a sort of extemporized Commencement for the entertainment of King James I., ${ }^{3}$ the thesis argued in philosophy was: Whether dogs could make syllogisms. The king was about equally fond of dialectics and of hunting, and he listened eagerly. Matthew Wren, then just thirty - to be Bishop of Hereford, Norwich and Ely — and John Preston twenty-eight, to become a Puritan, to recant and to serve as chaplain of Prince Charles, preacher at Lincoln's Inn and Master of Emanuel College - were the disputants. Preston opened in the affirmative :-

The major proposition present in the mind of a harrier is this : The hare has gone either this way, or that way;

With his nose he smells out the minor proposition : He has not gone that way;

Whence he concludes: Ergo. this way - with open mouth.

This was applauded. Whereupon the opponent, Wren, put himself to his distinctions : -

Dogs may have sagacity, but not sapience; specially in things concerning their belly, may be nasutuli non logici;

It is easy to see that :

This dog has place under this category:

Whence it follows:

Ergo. this harrier does not make a syllogism.

Preston was hastening to put his argument into another form,

${ }^{1}$ So called from his varying the question by a play upon its words or a trausposition of its terms.

2 Schol. Acad. 275-286.

8 Nichols, iii : 58. 
when the moderator stopped him and silenced both. Whereupon the king spoke forth :-

I had myself a dog, that . . . had light upon a very fresh scent, but considering that he was all alone, and had none to second and assist him in it, observes the place and goes away unto his fellows, and ... prevailed with a party of them to go along with him, and bringing them unto the place, pursued it unto an open view.

Then he begged to know what better the moderator could have done, and desired him to think either better of his dogs or not so highly of himself !

Usually it was two or three P. Mr. when these Acts and Responsions were finished. The ceremonies of graduation in the Arts followed, ten or a dozen of the Inceptors of King's College being attended to first. Then the Proctor said: "Reliqui expectabunt creationem in scholis philosophicis," and the remaining 200 , or so, crossed the street to the Schools building and were graduated more rapidly. The candidates for the degree of D. D. had been admitted at noon, and the Doctors of Law and of Physic followed the Masters of Arts; so that, by about five o'clock, all were ready for the closing hymn, after which they dispersed to that " havoc of meat and wine" with which, when the day was over, its fatigue was repaired. 


\section{CHAPTER II}

\section{GLIMPSES OF PUBLIC SERVICE}

Probably Brewster had not seen his home between his December entrance at Cambridge and his July departure. Commencement over, doubtless he started at once for Yorkshire, by the Great North Road, which ran directly by the entrance to the old manor-house and not more than nine or ten miles west of Cambridge. His ronte would have lain westerly, by Madingley and Hardwicke and through St. Neots, to Caxton, fifty miles from London and ninety-seven from Scrooby, and then, turning North, through Godmanchester, Huntingdon and Stilton, to Stanford and thence, by way of South Witham, Grantham, Newark and Tuxford to his own home-country and his father's door. The journey must have taken two or three days, according to the state of the roads which usually were very bad. A speed of above four miles an hour probably was exceptional.

Stamford had been brought into a certain rivalry with both Cambridge and Oxford. In the reign of Henry III. the lectures of the Carmelites on divinity and the liberal arts led to the erection of colleges there, and it became celebrated as a place of education. It is even declared that the buildings were magnificent and nearly a mile in circumference. ${ }^{1}$ In the fourteenth century disturbances occurred at Oxford, which issued in the migration of many scholars to Stamford, with some from Cambridge. This led to a royal mandate in the seventh year of Edward III., ordering all such students to return ; ${ }^{2}$ so that now some remnants of old buildings are all that Stamford has to show for this phase of its life.

1 Peck, Antiq. Annals of Stamford, viii : 44 ; x : 3.

2 Mullinger, i : 135, n. Merlin had prophesied long before: Doctrinae Studium quod nunc riget at Vada Boum [Ox ford] tempore venturo celelrabitur ad Vada Saxi [Stone ford, or Stamford]. 
Newark also had much to interest him. An old Norman stronghold, dating back to Egbert, king of the West Saxons, rebuilt in the early part of the twelfth century and still further reconstructed 100 years later, it long was known as the key of the North. The chureh of St. Mary Magdalen, with its beautiful tower, crowned with an octagonal spire, 223 feet high, was accounted then, às it is now, one of the finest, as well as largest, of parish churches. And the shapely Beaumond Cross, almost 100 years old, then adorned, as it still adorns, the market-place. Althongh his route did not lie through any specially picturesque districts, it did not lack many scenes of quiet rural loveliness.

Whether Brewster went back to Peterhouse in October is uncertain, although the presumption that he did so is strong. Bradford"s "History" supplies some indirect and vague testimony, and some whose directness is scarcely less rague. It states that " he spent some small time at Cambridge," ${ }^{1}$ and attained some learning, viz.: the knowledge of the Latin tongue and "some insight" into the Greek, and that then and there he was "first seasoned "with the "seeds of grace and vertue," after which he went to the Court and served "that religious and godly gentleman, Mr. Darison."

The phrase "some small time," taken absolutely, may mean but a part of one year; while, taken relatively to the frequent periods of seren, and, in some cases, twelve, fourteen, or even nineteen rears spent at the university, it may mean more than one year, or even than two or three years. The author of a modern memoir of Brewster says : ${ }^{2}-$

How long Brewster remained at Cambridge Unirersity is undefined; but, considering the many years usually passed there, and his probable age on leaving, the time indefinitely expressed in his friend's memoir, may imply a period sufficiently long, though not longer than, to take his first degree.

This implication is not probable. Had Brewster taken his B. A., there is no reason why the fact should not have place upon the uniiversity records. And, in view of the exaggerated respect then paid to such honors and of the porerty of the Plymouth Colony in that regard, it is incredible, if Brewster had taken 
his first degree, that Bradford, who must have known it, should not have mentioned the fact. Furthermore, if Bradford were aware that the period of Brewster's stay at Cambridge was less than the first year, already abridged by sixty days because of the lateness of his entrance, would he not have said "a few months"? As large preparation in Latin preceded entrance, little light shines from Bradford's words about Latin and Greek. As we have seen, the statutes assigned to the first year, mainly, Rhetoric ; to the second and third Logic ; and to the fourth Philosophy. So that, had he stayed through the entire twelve terms preceding the Bachelor's degree, even then he would have spent but little time with his classics.

Nor can we gain a conclusive hint from any custom of leaving at one time more than another on the part of those who abridged the full course. Many did leave thus. ${ }^{1}$ Oliver Cromwell went from Sidney Sussex, after a year there. Both Anthony and Francis Bacon migrated to Gray's Inn from Trinity at Christmas, 1575, having been matriculated in June two years before. Each man's case was a law unto itself. We therefore are forced to inquire whether we ean discover any suggestion of one time rather than another as the probable date of Brewster's leaving Cambridge. Bradford, without actually saying so, seems to imply that he went from Peterhouse into the service of Sir William Davison. Of course, Brewster might have left for some other cause and have entered Davison's employ subsequently. But, had he left the university for any other reason, probably Bradford would have intimated it.

Bradford says that Brewster "served ... Mr. Davison, diverce years, when he was Secretary of State." But, as Davison was not yet Secretary of State when employed in the Low Countries in the manner, as Bradford goes on especially to name, with which Brewster was associated, and, as he held that office less than six months, it is plain that Bradford's reminiscences, written many years afterwards, can be relied upon only

1 From the lists given by Masters (Hist. Corp. Chris. Coll. "Last app. 1-54) it seems that nearly or quite thirty per cent of all matriculated there up to almost 1750 left before taking a degree, and nothing seems to indicate that Corpus was exceptional in this respect. See Masson, Milton, i : 101. 
for general trustworthiness. We therefore must inquire, further, whether there were any occurrences in Davison's life such as to suggest one time rather than another for that transfer of Brewster from Cambridge to his employ which Bradford indicates; or any circumstances which may have led to an acquaintance prompting the elder man to seek, and the younger to consent to, the friendly relation which followed.

William Davison ${ }^{1}$ first emerges to notice in June, 1566, as private secretary to Sir Henry Killigrew, who was sent from the English court to Scotland.2 Killigrew was back and forth often during the next ten years. But whether Davison were attached to him personally or remained with the English legation in Edinburgh does not appear. At any rate, in or about 1570, he married Katharine, daughter of Francis Spelman, of Norfolk, an alliance which brought him into near relations with the Earl of Leicester, Lord Burghley, Sir Philip Sidney and Lord Bacon.

On Aug. 17, 1575, Killigrew urged that Davison be sent to Scotland as ambassador, and early in 1576 the latter was sent to the Low Countries to report on the prospect of a permanent peace between Spain and Holland, and on Aug. 2, 1577, he was appointed resident English agent at Antwerp. He made himself most acceptable to the States of Holland, and, on their appeal for a loan he engaged to obtain it; and in May, 1579, he seems to have secured them $£ 50,000$. At about that time he received the reversion of the place of Clerk of the Treasury and Warrants and Custos Brevium of the King's Bench, from which he gained no benefit, however, until the next reign. ${ }^{3}$

Early in 1583, when it was learned that La Motte Fénelon, a French envoy, was on his way to Scotland to arrange an alliance between James and the French, Davison was sent to Edinburgh with Robert Bowes to counteract the scheme. Apparent success attended this embassy, and Davison went back to London in May. But the circumstances which promoted the rising

1 Two facts suggest his humble origin: 1. that, in his later years becoming an expert genealogist, he seems to have written no genealogy of his own family ; 2 . that he received a grant of arms, which implies that he inherited none.

2 Memoirs of Sir .Tas. Melvill, 314.

3 July 25, 1607. Harl. Ms. 830: 115. 
of the Earl of Gowrie and the evidently growing strength of the French interest in Scotland led to Davison's recall. He was there in May and June, 1584, and in September he returned to London.

.We now have reached the first probable date for the beginning of acquaintance between him and young Brewster. If Brewster had remained at Peterhouse for three years, he would have gone home to Scrooby in July, 1583, so that probably he would have been at the manor-house when Davison might have paused there on one of his journeys. Brewster, then some seventeen or eighteen years old, must have been an attractive young man. So that we have but to suppose the envoy to have rested for a night at Scrooby, and it is easy to see that the two might have been drawn together in the most natural way. And, had Davison just then been in want of such a helper as Brewster seemed likely to become, and had the young man and his parents felt the not uncommon desire that he might obtain some post of honorable service under the government, it may have seemed wise for him to abandon the remainder of his university career and go up to the Court in the enrploy of so true a patriot, so sagacious a statesman and so religious a man as Davison was understood to be.

Of course, other ways of entrance upon the life which followed are within conjecture. His tutor at Cambridge may have moved in the matter. The Archbishop of York, whom his father was serving and whose occasional visits to Scrooby must have made him acquainted with the youth, may have suggested his advancement. But, in the lack of positive knowledge, and even of suggestion, the foregoing hypothesis seems possible and natural, and therefore reasonable. At all events, the autumn of 1583 and the following winter seem to have seen Brewster in London as a member of Davison's household.

But in what precise capacity? As to this some writers seem to have been misled. ${ }^{1}$ It cannot be assumed fairly that a young

1 Jeremy Belknap, who wrote 100 years ago (Amer. Biog. ii : 25s), represents Brewster as receiving the gold chain. Steele uniformly regards him as holding "office," and as in a place of "ligh trust," apparently as a sort of deputy under Davison (51-99). Hon. W. T. Davis said in the Baston Advertiser, Dec. 29, 1885: "The fact is that IVilliam Brewster was secretary of William Davison, who 
man who still lacked three or four years of his majority, without full education, and whose social position could not make special claim for public advancement, would have been appointed deputy clerk of the Privy Council or assistant Secretary of State. Bradford, still our sole informant, says $:^{1}$

He went to $\mathrm{y}^{\mathrm{e}}$ Courte, and served that religious and godly gentleman, Mr. Davison, diverce years, when he was Secretary of State; who found him so discreete and faithfull as he trusted him above all other that were aboute him, and only imployed him [employed him only] in all matters of greatest trust and secrecie. He esteemed him rather as a sonne then a servante, and for his wisdom \& godlines (in private) he would converse with him more like a freind \& familier then a maister. He attended his $\mathrm{m}^{\mathrm{r}}$ when he was sent in ambassage by the Queene into $\mathrm{y}^{\mathrm{e}}$ Low-Comtries, in $\mathrm{y}^{\mathrm{e}}$ Earle of Leicesters time, as for other waighty affaires of state, so to receive possession of the cautionary townes, and in token \& signe therof the keyes of Flushing being delivered to him [Davison] in her matis name, he [Davison] kepte them some time, and cōmitted them to his servaute [Brewster], who kept them under his pilow, on which he slepte $y^{e}$ first night. And, at his [Davison's] retmrne, $\mathrm{y}^{\mathrm{e}}$ States honoured him [Davison] with a goulde chaine, and his [Brewster's] maister comitted it to him [Brewster], and comanded him to wear it when they arrived in England, as they ridd thorrow the country, till they came to $\mathrm{y}^{\mathrm{e}}$ Courte. He [Brewster] afterwards remained with him [Davison] till his troubles, that he was put from his place abonte $\mathrm{y}^{\mathrm{e}}$ death of $\mathrm{y}^{\mathrm{e}}$ Queene of Scots; and some good time after, doeing him manie faithfull offices of servise in $y^{e}$ time of his troubles.

Now we have to add to the antecedent probabilities, which have been explained, these facts just detailed: 1. Brewster "served" Davison; 2. Davison liked him so much that he treated him more like a son than a servant; 3 . Davison's most familiar converse with him was "in private," as if their relative positions made open social familiarities hardly natural or wise; 4. Davison is called Brewster's "maister" three times, and Brewster twice is called Davison's "servante," besides being credited with " manie faithfull offices of servise" (to Davison) in the time of his troubles, that is, when he was a prisoner in the Tower or in disgrace in his London home and needed from Brewster little was a secretary of state under Queen Elizabeth, and not his servant in any sense of the word as used to-day."

1 Hist. 409. 
diplomatic or secretarial aid ; 5. Davison committed the keys of Flushing and the gold chain to Brewster for safe keeping, as he would to a confidential servant. And we may not forget that, more than a year and a half after their connection had been severed and Brewster had gone back to Scrooby, Davison spoke of himself as having been Brewster's "master." I All this accords best with the conchusicn that Brewster became Davison's confidential personal attendant, something more than a valet and something different from a private secretary, holding thus a position of constantly growing value and responsibility, one neither menial nor in any sense diplomatic, yet useful and, in its measure, honorable.

Young men then did not get on very fast. Three or four years earlier, on Dec. 29, 1580, Sir Henry Killigrew wrote to Davison :- -

Thanks for your friendly mention of my nephew. Pray use him in all things as a common servant $;^{2}$ he should be kept with a hard hand. When it is remembered that by " my nephew," evidently designating some one then abroad with Davison as an attendant, Sir Henry might have referred to Anthony or Francis Bacon, or to Thomas or Robert Cecil, afterwards Earls of Salisbury and Exeter, it is apparent that even young men of noble blood had little chance of entering the Ship of State throngh the cabin window. But, in whatever capacity Brewster served Davison, he certainly won entire confidence and rendered himself of great value.

The autumn of 1583 best fits all the probabilities as the date of the beginning of this service. In that case Brewster doubtless accompanied Davison back to Scotland soon after, in consequence of the confusion cansed by the rising of the Earl of Gowrie in Queen Mary's behalf and the growing strength of the French party. Davison's passports for return were signed in May, $1584,{ }^{3}$ but he does not appear to have reached London until September. He seems to have served a short time then as clerk of

1 S. P. Dom. Eliz. ecxxxiii : 48.

2 S. P. Dom. Eliz. Add. 26 . Killigrew's use of the term "servant" implies that it did not necessarily mean a menial. So does Davison's use of it in reference to Geo. Cranmer. See p. 298, n. 2.

${ }^{3}$ II arl. Ms. 291. 
the Privy Council.1 But late in November or early in December he was sent abroad once more. ${ }^{2}$

Philip II., of Spain, had been striving for years to reduce the Low Countries to obedience and to suppress Protestantism there. England could not help feeling an interest in the struggle, for the Pope had declared Elizabeth excommunicated and deposed, and had absolved her subjects from all allegiance to her. Thus far nothing but lack of power had prevented the Papists from overthrowing the government and putting Mary, Queen of Scots, upon the throne under Philip's protection. His intention to send a great fleet to conquer England had been proclaimed openly, while seminary priests and Jesuits were known to be plotting perpetually to kill Elizabeth; and the recent assassination of William the Silent had emphasized the dangers of the situation to the English people. Elizabeth was much perplexed. She distrusted the wisdom of the leading Netherlanders. She was reluctant to support any people in a conflict with their nominal sovereign, lest she furnish a bad precedent for use at home. She doubted the safety of sending troops out of the realm when any day might bring tidings of a formidable approaching invasion. Her frugal mind also shrunk from every extra expenditure. And she especially dreaded the inevitable calling of a session of Parliament.

But perhaps she could not altogether resist sympathy with the Dutch in their life or death struggle with Rome. Nor could she overlook the fact that the success of the rapacions, treacherous and inhuman Philip in the Low Countries would mean the certainty of the immediate advance upon England of the strongest power in the world, made stronger by that success. In a quiet way she already had done a little to aid the Dutch. She was strategist enough to know that, if war with Spain must come, it was both easier and safer to defend her own country in the Netherlands than on English soil after the Netherlands should have been conquered. Her ministers were essentially of one mind, althongh Burghley favored a more cautious policy than Walsingham.

Late in October, 1584, a serious deliberation took place in 1 Strype, Ann. iii, 1. 420.

${ }^{2}$ Motley, Un. Neths. i : 85. 
the Privy Council as to "whether her majesty should presently relieve the States of the Low Countries." An account of it survives in the handwriting of Burghley. ' The difficulties of such relief were recognized fully. Yet it was appreciated that the queen would be obliged to succumb to the power of Spain and the liberties of England be hopelessly lost if the Provinces should be left without help at Philip's mercy. Moreover, negotiations had been going on between the Low Countries and France, as well as England, and there was a possibility of their being absorbed into the dominions of Henry III. They preferred this to conquest by Spain. Elizabeth did not desire it, yet perhaps she might have assented to it as the lesser of two evils. All things considered, it was decided that a "wise person" should be despatelied to Holland to report whether an agreement had been made yet with France, and, if so, whether it included that the king of France declare war against Philip. Should this be the fact, the envoy was to express her Majesty's content that the Provinces were to be relieved thus from the tyranny of Spain. Otherwise he was to assure them that she would "strain herself as far as, with preservation of her own estate, she might to succomr them at this time."

He also was to make minute inquiries as to the condition of the Low Countries, how much money they could raise and how large an army and navy they would maintain. If possible, moreover, he was to arrange that, if Elizabeth went to their assistance, they should offer her the towns of Flushing and Middleberg and the Brill, "as gages for her expenses." Davison was selected as the "wise person" to perform this delicate and difficult work. He surely had superior qualifications. He had served the queen in Holland five years before. He had a wide acquaintance with its statesmen, and was a great favorite with them. Whether he spoke Dutch or not, he spoke French, ${ }^{2}$ which answered nearly the same purpose.

Early in December he was at The Hague, and there is no reason to doubt that Brewster attended him. On Dec. 8, he asked the appointment of a committee of the States-General, the Dutch parliament, with which he might confer. Negotia- 
tions began. But because of the perpetual and mysterious reluctances of Elizabeth and of the fact that the Duteh were just sending an embassy to offer the sovereignty of their Provinces to Henry III., long delays ensued. It was March before a definite refusal ended the French coquetry, and July before a dozen cautious Dutchmen, commissioned to make formal offers to the queen, arrived in London. It was a part of the policy of the English ministry during this long suspense to seem indifferent, if not reluctant, towards any alliance, and in April Davison was ordered home.

The succeeding negotiatious also were hindered greatly. The Netherlanders desired the queen to extend her sovereignty over Holland and to take her pay in the possession of the land, but she preferred coin to command. She would have nothing to do with the sovereignty, but demanded eventual payment in hard cash for every shilling to be expended, and, until payment, must have as solid security a cautionary town in each Province. Day after day passed while the two parties haggled, and Antwerp, besieged by the Spaniards, was left to its fate. At last, on Aug. 12, a provisional treaty was made and a part of the embassy at once left for Holland, bearing it home for ratification. Five days later, Aug. 17, Antwerp fell. The queen at once hurried Davison back to Holland to complete arrangements so that all might not be lost. He was to report her extreme regret that Antwerp had surrendered, but that its fall had not altered her determination. He was to promise 5000 foot soldiers and 1000 horsemen from England, but was to demand that the necessary garrisons for the cautionary towns be included in this general contingent. Some "person of quality" should be sent over in the queen's name to help govern the country, and the important fortified towns of Flushing, which guarded the entrance to the West Schelde and the approaches to Antwerp, and Brill, which watched the mouth of the Maas and the sea-way to Rotterdam, were to be garrisoned by her until she should have been reimbursed.

On this last point new complications arose. Incredible although it seems, it was November before the queen reluctantly consented that the two garrisons should be in ardition to the 
forces before agreed to be sent. Another hitch in the negotiations gave Davison serious trouble. Flushing was the property of Count Maurice of Nassau, and he naturally objected to the proposed arrangement. When this finally was adjusted and the temporary transfer of Flushing to English occupancy made, Davison received the keys in the queen's name. According to Bradford, who of course had the fact from Brewster, Davison turned them over for safe keeping to Brewster, who the first night slept with them under his pillow. Then there was a further delay in the sending over of the "person of quality" and of the governors of Flushing and Brill which led to something almost approaching anarchy, throwing upon poor Davison a grievous additional load. As no English money had yet been sent, he could keep the troops already there from starving only by using his own personal credit. ${ }^{1}$

Sir Philip Sidney was sent over in November to be Governor of Flushing, and Burghley's eldest son, Sir Thomas Cecil, was named as Governor of Brill. A small remittance of money and supplies also was made, but with the strictest orders that the garrisons were to do garrison work alone, and not until Dec. 9 did the Earl of Leicester sail from Harwich. He was welcomed at Flushing by Sidney and Count Maurice with a military and civic procession, and his striking presence at first disposed the plain Hollanders to exult over him as a national deliverer.

He soon started on a triumphal progress, presumably with Davison and Brewster in his train, reaching Middleberg on Christmas Eve, by the New Style - in use in Holland since Jan. 1, 1583 - where he received an enthusiastic welcome, and a great banquet. He returned the compliment the next day by a sumptuous repast. He and his suite, however, soon needed the benefit of all which they had eaten and drunk, for, sailing on the day after for Dordrecht, with a fleet of 200 vessels, with favoring conditions a voyage of less than a day, they were so delayed by a dense and chilly fog that the passage took five days, and they became so hungry, besides being almost frozen, that some offered vainly a pound of silver for a pound of bread. ${ }^{2}$ From

1 Cot. Ms. Galba. c. viii : 217.

2 Letter of Sir John Conway. S. P. Holl. Dec. 27, 1585. 
Dordrecht, however, they had a continuous ovation through Rotterdam and Delft to The Hague.

It must have seemed a strange sight to Brewster, but Dutch fancy and ingenuity ran almost mad in the effort to do hanor to the queen's envoy. Cannon thundered, bells rang, tar-barrels burned and Latin orations were delivered. Whales and other marine monsters were represented as horses for the champions in a tilt. There were dramatic portrayals of siege, famine and pestilence. Seven beautiful maidens personified the United States of Holland, offering golden keys, and seven others impersonated the Sciences, presenting garlands. Even a barber adorned his shop with seven score of copper basins, with a wax-light in each and a rose and a posy for the queen; and, among other manifestations as acceptable then as they seem extraordinary now, several Apostles stood on the bank while the Saviour was represented as walking on the water and ordering his disciples to cast their nets, the fish taken being presented to his Excellency! Leicester wrote home to Walsingham : ${ }^{1}$ -

Never was ther people I think in that jollyty that these be. I could be content to loose a lymme that hir majesty dyd se these contreys and towens as I have; she wold than think a hole subsedye well spent, but only to have the good assurance and commandment of a few of these townes. . . . And yf her majesty had not taken them at this nede, but forsaken them, she had lost them for ever and ever, and now hath she them, yf she wyll kepe them, as the cittysens of London, in all love and affection.

These preliminaries concluded, however, the Dutch statesmen proceeded to business. On Jan. 9, 1585-86, ${ }^{2}$ two of the Commissioners waited upon Davison to request a copy of Leicester's commission. The document was read, and it gave him absolute command of all the English forces in the Netherlands, with authority to summon from England whomsoever he might think likely to help him. On Jan. 11 the deputies of all the States waited upon him, Davison and several others of his suite being present, and offered him the office of absolute governor and

1 Leyc. Cor. 30.

2 Perhaps Mfotley gives the best consecutive account of these occurrences ( $U n$. Neths. i : $40 \%-457)$. 
general of all their forces, together with the disposal of their revennes. Leicester directed Davison to thank them warmly in French, and to add that he had no doubt that their action would lead the queen to increase her assistance. They might put fullest confidence in his intent to help them. He also asked them to reduce their proposition to writing.

On Jan. 14 Davison received the formal offer, and, Leicester, having gone to Leyden, it was there, apparently through the agency of Davison as interpreter and intermediary, that, on Jan. 22, the arrangement was consummated. Leicester was to be Governor-general of the United Provinces, to have supreme command by land and sea, and to exercise final anthority in matters eivil and political. It is interesting to remember that Brewster probably accompanied his master and was paying his first visit to the place which, a few years later, was to be associated so intimately with his own life.

Leicester then directed Davison to return to England at once to explain what had been done. Accordingly, Leicester having been inangurated with splendid ceremonies on Feb. 4, on Feb. 14 Davison, of course accompanied by Brewster, left for London. Probably it was on this occasion that the States-General manifested their profomd respect for the departing envoy by the gift of the gold chain.

Unfortmately, just then, when unusual reasons for haste existed, contrary winds detained him some five or six days. While he is delayed let us go back to consider a fact, as yet ummentioned, which was to affect seriously his welcome at the Court; and which furnishes the only explanation of that otherwise incomprehensible dilly-dallying of the queen, who procrastinated and prevaricated, haggling over every detail, leaving the English contingent to almost die of hunger, cold and nakedness; forbidding the few available troops to be sent into action; appointing Leicester to conmand and then prohibiting his exercise of authority; and whose utmost achievement exhausted itself in perpetually new endeavors to seem to do something for the Netherlanders without doing anything.

This missing link is made clear by contemporary correspondence, mainly preserved in the Spanish archives at Simancas. 
inaccessible until within the last half-century, and first studied by Motley. It is the fact that, during this whole period of alleged anxiety to aid the Duteh against Spain, the Machiavelian queen, unknown to her Privy Council, was engaged in a secret intrigue with the Duke of Parma, and with Philip himself, for a peace in which the Netherlanders should be sacrificed. ${ }^{1}$ Hence her strange willingness to delay the blow and to strike softly. Hence her insistence on the cantionary towns, that she might turn them over to Philip. And hence her towering rage when she discovered that Leicester had committed her openly to a more decided policy than she intended, and - a fact which he had concealed from Davison - had gone beyond the letter of his instructions.

Davison's letter to Leicester, written back from London, on Feb. 17-27, states that he was detained at Brill until Feb. 1121, and only anchored at " the Reculvers within Margate" by ten or eleven o clock the next day. Margate is two or three miles from the north-eastermmost projecting point of England south of the Thames, and the Reculvers is a cliff some eight or nine niles alongshore from it on the south shore of the estuary of the Thames. The stiff north-wester which had speeded them across the German Ocean would have been nearly dead ahead for the remainder of the voyage to London. Davison and Brewster therefore probably landed ${ }^{2}$ and took post-horses to Gravesend, at least forty-three miles. This was on Saturday, and they apparently arrived about midnight at Gravesend, where they doubtless took the tilt-boat for London, arriving early Sunday morning.

Bradford says that Davison not only committed his gold chain to Brewster's care, but commanded him to wear it as they rode through the country. It must have glistened around Brewster's neck, therefore, during that hurried winter afternoon and evening ride, through Reculver and the hamlet of Hoathe, into Canterbury, and so on, over the chalk lills of Kent, through Harbledown, with its ancient hospital for lepers, and Boughton,

1 Motley, Un. Neths. i: 488-532. Froude, xii : 38-78.

2 Steele $(72)$ interprets Davison's letter as declaring that they made the whole passage to London by water. It does not require that interpretation, and acquaintance with the localities, as well as Bradford's language about the gold chain, indicates that they landed at the Reculvers and posted to Gravesend. 
Preston, Ospringe, with its beacon and hospital ruins, and Bapchild, with its quaint old resting-place for Canterbury pilgrims, and Sittingbourne, Rainham, Chatham and Rochester, with its venerable Norman ruins, and Strood to the Thames at Gravesend.

Davison learned at once from Walsingham ${ }^{1}$ that Elizabeth had been made very angry by Leicester, and he found her so. She swore great oaths at Leicester for having disobeyed her absolute command - of which Davison now learned for the first time - and at Davison himself and Sidney for not having prevented it. Davison explained how necessary all had seemed to them. He even declared that he "might have been acensed of madness," had he dissuaded Leicester. It passed his comprehension why she should be in such a paroxysm of passion, for he had no suspicion of the unrevealed scheme which her old favorite unconsciously had thwarted. Other interviews followed. Davison maintained his courageous and candid defence, the queen gradually adjusted herself to the situation, and in time the storm was overblown.

Testimony to the conspicuous wisdom and inestimable value of Davison in the Low Countries is uniform and abundant. Sidney endorsed them in the highest terms. ${ }^{2}$ Leicester declared that he had done her Majesty notable service and wanted him sent back to Holland, for "without him I confess myself quyte maymed." And he pleaded again that: -

yf her majesty wyll shew me any favour, that thys may be one, to have Mr. Davyson retorn agayn to me, who I assure you ys the most sufficient man to serve hir majesty that I know of all our nation; for he knoweth all partes of these countreyes, and all persones of any accompt, with all their umores, and hath great credytt among them all here. And the better servyce shall he be able to doe yf yt may please hir majesty to gyve him such countenance as may encrease his credyt here, for here hath byn many brutes [rumors] and reportes of hir good intentyon toward him, and he wyll deserve any goodness she shall bestow uppon him, whatsoever yt be.

Davison soon resumed attendance in the Privy Council. On July 11, 1586, Walsingham, writing to Leicester, said : ${ }^{3}$ -

1 Leyc. Cor. $117,121$.

2 Cot. Ms. Galba. c. viii : 213.

3 Leyc. Cor. 67, 77, 343. 
She [the queen] is lothe to send a spetyall person to your lordship, and the Counsell of State there, in respect of charges; ${ }^{1} \ldots$ She seemeth to be dysposed to make Mr. Davyson my assystaunt in the place I serve. The gentleman [Davison] is very muche greeved with the dyslyke he understandethe your lordship hathe of him. ${ }^{2}$ For my own parte, I doe not fyude but that he hathe dealt well, bothe for the cause and towards your lordship, whos good opinion and favor he dothe greatly desyre.

Perhaps this disposition of the queen may explain the "brutes and reportes" to which Leicester had referred. Davison received congratulations upon his elevation before the middle of September, ${ }^{3}$ and was included, on Oct. 6 , as one of "our Principal Secretaris," in the warrant for the trial of Mary, Queen of Scots.4 His formal commission as such, however, was not dated at Westminster until Dec. 12.

On Oct. 7 Joln Carpinter wrote to Davison, begging the new Secretary to leave some place unfilled which might be given to his brother Cranmer's son George. ${ }^{5}$ George Cranmer, thus recommended by Davison's brother-in-law, was a nephew by marriage of Davison's sister, and therefore had a claim of affinity in addition to superior qualifications for office. He had been at Corpus Christi, Oxford, where he had Richard Hooker for his tutor, and for an intimate friend, Edwin Sandys, son of the Archbishop of York. Izaak Walton describes graphically a visit which they made to Hooker in 1585. Cranmer soon after wrote to his mole Carpinter a letter of thanks ${ }^{6}$ " for so honourable a

1 This illustrates the niggardliness of Elizabeth in the conduct of public affairs.

2 What is referred to is not apparent. Perhaps, when Leicester learned of the queen's indignation with him, he thought for a time that Davison had not defended him stoutly enough. If any misunderstanding existed, it was eleared up soon, for Leicester's allusions to Davison uniformly are warmly complimentary.

3 S. P. Dom. Eliz. cxeiii : 34.

4 Life, 40. "And also to our trusty and well-beloved William Davison, Esq., another of our Principal Secretaris, and of our Privy Couneil." A letter from Davison to Walsingham (Harl. M/s. 290: 174) says that it was not intended originally that Davison should belong to the Commission. His name was added because the language of the statute required that all the Privy Couneil be members.

5 S. P. Dom. Eliz. exciv: 19. Carpinter laad married Davison's sister, Anne, and Thomas Cranmer, nephew to the Archbishop, had married Carpinter's sister, Anne, so that George Cranmer, eldest son of Thomas and Anne, was nephew by marriage to Davison's sister.

6 Ibid. cxciv : 31. 
place of service," so that his immediate entrance into the Secretary's official household may be inferred. From the fact that, less than six months afterwards, Davison ${ }^{1}$ refers to Cranmer as representing him in his absence from the Court and sending to him thence her Majesty's suggestions, it is evident that, although apparently Brewster then had been in his service half as many years as Cranmer had been months, the latter oceupied the higher and more representative position.

Three or four months of prosperity and busy work followed, yet they were not without premonitions of a storm approaching. At this time Davison had a house in London, where he resided when not in daily attendance upon the Court, which rotated between Whitehall, Richmond, Hampton Court, Nonsuch, Oatlands and Greenwich, where the queen liked best to be, especially in summer. No doubt Edwin Sandys, then a prebend of York Cathedral, when visiting at his father's London house, would drop in now and then at Davison's to see George Cranmer, and thus, if Brewster had not made his acquaintance already at Scrooby, the two young men doubtless formed the friendship which elearly existed later between them.

1 Campbell, Davison, 371-372. “'The next morning I received a letter from Cranmer my servant, whom I left at court, signifying unto me her Majesty's pleasure." 


\section{CHAPTER III}

\section{THE FALL OF BREWSTER'S PATRON}

OUR story now turns to the Queen of Scots, Mary, danghter of King James V. and Mary of Lorraine. She was almost nine years yomnger than Elizabeth. ${ }^{1}$ Her father having died immediately after her birth, she was crowned before she had completed her first year. In 1548, when not yet six, she was betrothed to the Damphin Francis of France and taken thither. There, in the most corrupt court of Emrope, she passed her youth. At fifteen years and five months her marriage to the Dauphin took place. He became king on July 10, 1559, but died on Dec. 5, 1560, leaving Mary a widow when two days less than eighteen. Hor mother, queen-dowager of Scotland during all these years, died nearly six months before Mary's husband, and affairs in Scotland, where, on Ang. 25, 1560, under the influence of John Knox, Catholicism had been suppressed, summoned Mary home. Elizabeth denied her a safeconduct through England, but Mary managed to reach Leith.

As a matter of policy she assented to the continuance of the new creed and to some endowment of the Protestant ministry from the confiscated lands of the Romanists. It is needless here to follow minutely her checkered way. In less than seven years she had been married again to her consin Henry, Lord Darnley; had borne the son who succeeded Elizabeth on the English throne, and once more widowed, by Darnley's murder, had married his murderer; had been miserably separated from him ; had abdicated in favor of her son ; and had been im-

1 Henry VII. of England had three children, Arthur, Henry and Margaret. Arthur died young. Henry became the famous Henry VIII. Margaret married James IV. of Scotland. Their son, Elizabeth's consin, James V., married Mary of Lorraine, so that their only child, Mary, Queen of Scots, was second cousin to Elizabeth. If Elizabeth failed to marry and have offspring, Mary, if she survived Elizabeth, being nearest in blood would be heir to the English throne. 
prisoned in the island castle of Lochleven. In May, 1568, she escaped to Hamilton Palace, gathered 6000 men, revoked her abdication, and summoned Murray, the regent, to submit. Elizabeth offered her help if she would accept English mediation and seek no foreign assistance, but the message arrived too late. Murray routed Mary's forces, while she fled into Cumberland, where there still were plenty of Roman Catholics. She now was really a prisoner, and continued such for her eighteen remaining years, at Bolton Castle, Tutbury, Coventry, Sheffield Castle, Wingfield Manor, Tutbury again for a little while, and then, under Sir Anıyas Paulet, a stern Puritan, at Chartley Manor. And here she was when Davison became a Secretary of State in the autumn of 1586.

It has been intimated already that Elizabeth's irresolution towards the Low Countries was due partly to her desire for a compromise. Philip was not such an implacable Romanist as not to have an eye to the main chance. There was a middle party in France, which had reacted from the horrors of St. Bartholomew's Day without espousing the Hugnenot cause. And some close observers felt reasonably sure that the Pope, in his dread of an overmastering Spanish influence, might be persuaded to moderation. It was not yet clear whether the Romanist League were prepared to reduce all Protestant revolt at the point of the sword. If yes, then neither Holland nor England could afford to be either inactive or unallied. If no, then there might be something better in the near future than a Protestant alliance, whose approach towards vitality necessarily must bring on hostilities.

Spain really was too poor to invade England wisely. And neither were the English Romanists nor the Pope specially eager to see Philip's "claim" - he had been Bloody Mary's husband - materialized. This state of affairs confused English politics. On the whole, the queen favored possible adjustments so far as to be indisposed towards any policy of advance, in Holland or at home, vigorous enough to prevent them. She seems to have desired to help the Low Countries just enough to keep their heads above the waters of absolute absorption by Spain without going far enough to drive Spain or France to 
extremities. Burghley and Walsingham differed from her, and steadily urged a more spirited policy.

Meanwhile, an almost constant succession of plots for the release of Mary, the assassination of Elizabeth, or both, occurred, by the connivance of the large Papist element rcmaining in England with Jesuit emissaries from abroad. With all her faults Elizabeth was no coward. She derided all suggestions of personal danger, and trusted her Catholic subjects much more than her Privy Council did. She even maintained known Papists at the Court, probably relying for her safety upon the fact that through them she kept up her secret correspondence with Philip, which made it for their interest to not only spare but also defend her.

Walsingham knew almost everything that was going on. He had reduced espionage to a system. He had agents in the College of Cardinals, the Jesuit seminaries, the French embassy, the Spanish Court and the mansions of the chief Romanists in England, so that he knew when treason was brewing among them. It was a knowledge, however, which could be used but sparingly. He could not prove legally a hundred things of which he had no doubt. Nor could he set before her Majesty more than mere hints of his opinion on some disturbing matters. Furthermore, this sort of testimony often so conflicted with itself as to make a reasonable conclusion excessively difficult. For example, was the captive queen, around whom these plots were perpetually crystallizing, a party to them herself? Did she, in reality, favor the assassination of the queen regnant? If so, could that fact be brought home to Elizabeth so that her unfailing irresolution, heightened by the natural pleadings of kinship, could be animated to that conclusion which the great and loyal majority of the nation was ready to demand, that the public safety be secured by Mary's execution?

It became clear that, if this one matter could be settled, great gain of internal quietness would result, and Walsingham devised a subtle, widely-reaching scheme, ${ }^{1}$ to which he gained Elizabeth's consent. Mary was removed from Tutbury Castle to Chartley

1 All the chief details are given by Froude, xii : 228-300. Green, Hist. Eng. Pcople (ed. 1879), ii : 438. 
Manor, which was much more accessible. Moreover, it was not far from Burton-on-Trent, even then famous for its breweries. Walsingham obtained the confidential services of a son of a neighboring Romanist family, and through him entrapped Mary into a secret correspondence with Romanists at home and abroad, all of which was translated by Phillips, Walsingham's secretary, and copied. A Burton brewer sent a cask of beer weekly to Chartley for the special use of the captive queen and her attendants. A tight box containing the ingoing letters was hidden in the cask, the answers being substituted in the box when the empty cask went back to Burton. Phillips, residing at Chartley nominally to aid Paulet in his trust, deciplered and copied these letters in transit, and then forwarded the originals, apparently undiscovererl, and sent the copies to Walsingham. ${ }^{1}$

The plan worked perfectly. Mary and her correspondents felt certain of its safety. Yet assurance was made doubly sure by the use of a new cipher, but, as the key had to accompany the first communication, it fell into Phillips's hands. Writing thus, with an inagined absolute freedom on each side, each side betrayed itself. Most unfortunately, also, for Mary, just at this time what was known as the Babington Conspiracy ${ }^{2}$ was being hatched. Nearly a dozen young Papists, most of whom either were remotely connected with Elizabeth's houseliold or had access to her person, bound themselves together to kill her, Lords Burghley, Walsingham, Hunsdon, her first cousin, and Vice-chamberlain Knollys. The Prince of Parma was to swoop across the German Ocean upon Newcastle or Scarborough and free Mary; and a general revolution, aided by a contemporary invasion by Philip himself, was to make England once more a Catholic country with Mary upon the throne. This comprehensive plot was communicated to Mary by letters which, in Phillips's translations, probably were in Walsingham's hands as soon as, through the beer-barrel, they reached hers.

1 Proofs are in the State Papers, mostly in letters (Mary, Queen of Scots, Mss.) from Sept., 1585, to Aug., 1586, by Paulet to Walsingham and by T. Morgan to Mary, with their answers, etc.

2 Headed by Anthony Babington. The Pope - Gregory XIII. - sent them his blessing. Dict. Nat. Biog. ii : 308. Simpson, E. Campion, 157. Papiers d'Etat relatifs à l'histoire de l' Ecosse au XV Ie Siècle, etc. Bannatyne Pubs. v. iii. ete. 
The keen interest with which the secretary and Queen Elizabeth awaited Mary's reply can be imagined. They soon had it. She cordially approved the plan. She suggested methods. She devised preeautions. For herself, she said that fifty or sixty mounted men easily might carry her off when she went out to ride with her usual escort of but fifteen or twenty. They might set the house on fire at night and kidnap her in the confusion, in which case they must wear some badge easily recognizable. Or, when a cart was coming in with stores, it could be upset in the gateway and an ambushed force could rush in. As to the assassinatiou of Elizabeth, she, sail to Babington: "You will keep four men with horses saddled, to bring word when the deed is done that they may be here before my guardian learns of it," and "to prevent accident, let the horsemen choose different routes, that if one is intercepted another may get through." She spoke elsewhere of "their design being accomplished," referring to the same proposed murder. Still further, in the postscript $^{1}$ to her letter, she added: "I would be glad to know the names and qualities of the six gentlemen which are to accomplish the designment, for that it may be I shall be able, upon knowledge of the parties, to give you some further advice necessary to be followed therein." 2 These young conspirators were allowed to go ou until all needed proof was in Walsingham's possession, when they were arrested and the brilliant bubble burst.

On an August morning after Davison had resumed his seat

1 The genuineness of this postscript has been denied by Mary's defenders, but apparently in vain.

2 Ranke (Hist. Eng. i : 306) says: "If we enquire whether Mary Stuart knew of these schomes, and had a full understanding with the conspirators, there can be no doubt at all of it. She was in correspondence with Babington, whom she designates as her greatest friend. The letter is still extant in which she strengthens him in his purpose of calling forth a rising of the Catholics in the different counties, and that an armed one, with reasons for it true and false, and tells him how he may liberate herself. . . . In the letter we even come upon one passage which betrays a kuowledge of the plot against Elizabeth's life ; there is not a word against it, rather an approbation of it, thongh an indirect one." And, as to the postscript, he answers Tytler's suggestion (Hist. Scot. viii. App.) of its interpolation by saying $(307, \mathbf{n}$.): "What would have been the use of it [i.e. of interpolating it] as the letter even without this addition would have sufficed to condenin her." 
in the Privy Council, and just before he was promoted to a place beside Walsingham, Mary Stuart accepted an invitation from Sir Amyas Paulet to ride over to Tixall and hunt a buck. Her two secretaries, Nan and Curle, with other attendants, were in the party. They had almost reached their destination when a company of horsemen appeared. For a moment the ex-queen must have thought that her hour of victory had come. But it proved her hour of defeat and lumiliation. As the cavalcades neared each other, Sir Thomas Gorges ${ }^{3}$ rode forward from among the strangers and handed to Sir Amyas a royal order for the removal of Mary to 'Tixall and the arrest of the secretaries. Her quick wit divined instantly that all was lost, but her spirit was unbroken. She stormed and denounced, and challenged her attendants, if they were men and not cowards, to fight for her. But they had more sense.

She was taken on to Tixall, where she was kept for a fortnight. The secretaries were hurried off to London, and Sir Amyas, with Sir William Wade, who had ridden down with Gorges, hastened back to Chartley, where her entire correspondence and notebooks were secured and sent up to Court. Among other things were found the keys to no fewer than sixty ciphers which had been used in her correspondence. When the Privy Council read this mass of manuscript, which they did with minutest patience, they learned not only the true inwardness of Mary's character, but also her exact relation to the Roman Catholic powers, and how far many English noblemen had favored her pretensions to the throne.

This work of the Privy Council, early in September, 1586, must have been shared by Davison its clerk, although probably Brewster got little knowledge of it. Letters survive ${ }^{2}$ showing that before the middle of this month Davison was being solicited for office, as a Secretary of State. Camden ${ }^{3}$ made the suggestion that he was promoted to a secretaryship so that he might

1 Serenth child and youngest son of Sir Edward Gorges, and great-uncle of Sir Ferlinando, who is called "the founder of the State of Maine." Brown, Pedigre? of Sir F. Gorges, 5 .

2 S. P. Dom. Add. 297-298. S. P. Dom. Eliz. cxciii : 34; exciv : 8, 15.

3 Complete Hist. Eng. By Lord Herbert of Cherbury, Sir John Hayward, William Canden, etc., ii : 538 . 
become Elizabeth's scapegoat in the matter of the Queen of Scots. But there is ample proof that, for nearly three months longer Elizabeth had no idea of needing any scapegoat, because she fully intended to spare Mary's life. Moreover, another secretary was needed, and Davison had exhibited exceptional fitness for the position, and had earned it by long and brilliant service. The Earl of Essex afterwards wrote of him to King James : ${ }^{1}$ -

I must say truly that his sufficiency in council and matters of state is such as the Queen herself confesseth in her kingdom she has not such another ; his virtue, religion and worth, in all degrees, is of the world taken to be so great, as no man in his good fortune hath had a more commendable love than this gentleman in his disgrace.

And Lord Burghley declared : ${ }^{2}$

Sure I am, and I presume to have some judgment therein, I know not a man in the land so furnished universally for the place he had, neither know I any that can come near him.

Babington and his fellow-conspirators, crushed under an overwhelming mass of testimony, were executed at Tyburn in the last week of September.

Mary Stuart remained. Therefore the terrible and vexing problem, what should be done with her, remained. Elizabeth secretly wrote to her ${ }^{3}$ that if she would confess in a private letter and ask forgiveness, all should be pardoned. This appeal was unanswered. Paulet insisted that he could not be responsible for Mary's safe-keeping much longer at Chartley. Day after day the Council proposed expedients which her variable Majesty rejected. Her ministers insisted that Parliament must be summoned, and, as long as she could, she resisted that. At last she no longer could refuse to convene a court of inquiry, but could not decide then where it should meet or when, and the disgusted premier wrote: ${ }^{4}$ " With weariness of talk her Majesty hath left all off till a time I know not when."

Clearly, Elizabeth had embarrassed herself by past lenities, and that, too, in the face of the best public sentiment. ${ }^{5}$ When

1 Ayscough Mss. 410s: 23.

3 Camden, ii : 526.

2 Strype, $A n$. III. i: 512.

4 S. H. Dom. exciii : 28.

5 Upon the news of the Massacre of St. Bartholomew at Paris, Edwin Sandys, then Bishop of London and afterwards Archbishop of York, had written to Burgh- 
Mary had been dethroned by her own Scotch subjects, Elizabeth had offered her an asylum in England, and had befriended her after her escape from Lochleven. In 1568, when the famous "casket" letters had satisfied the Privy Council that Mary had assented to the murder of her second husband and afterwards had married his murderer, Elizabeth had hushed up the facts and thus had led the world to suppose her cousin imocent. And when, in return for this forbearance, Mary had plotted a Spanish invasion, with the incidental accompaniment of the queen's assassination, and Parliament had demanded that such continual unrest and danger be stopped in the only effectual way, Elizabeth still had interposed to save Mary. And, now that the same game had been played once more, the old morbid fear, lest she be accused of sterner treatment towards Mary than she herself had received from her own half-sister, seems to have tormented her. This, with her chronic habit of never doing until to-morrow what can be avoided to-day, appears to have lain near the source of those motives by which her extraordinary conduct now was actuated.

At last Mary was sent to Fotheringay Castle, in Northamptonshire; and, on Sept. 28, the commission to try her met at Windsor. For a month the experts had been going over the intercepted correspondence, with the result of absolnte assurance of her connection, always as a consenting and often as an originating force, with most of the recent troubles of the kingdom. Elizabeth declared the demonstration perfect and the inference unavoidable. She told the French ambassador that Mary had plotted to kill her. ${ }^{1}$ He, for his master, hoped that she would not be hard with Mary, and she replied that she could make no more promises. On Oct. 8 the twelve judges conferred at Westminster with as many peers as could be assembled and decided that Mary must be formally tried. Whereupon they, with all other peers of age in England, were required to gather at Fotheringay for that purpose.

ley - Sept. 5, 1572 - enclosing earnest recommendations of what should be done at once for the safety of the queen and the realm, the first of which was: "Furthwith to CUTTE OF theSCOTTISH QUENE'S HEADE : ipsa est nostri fundi calamitas." - Lans. Ms. 15: 41.

1 Egerton Papers, Oct. 4, 1586. 
The assize began on Oct. 12. As Walsingham, because of his close connection with the evidence, was obliged to attend, Davison remained at Court in waiting upon the queen. Still shrinking from the last extremity, Elizabeth now through Davison instructed Walsingham ${ }^{1}$ that, if Mary would confess in private, before the formal opening of the court, to one or more of the Privy Council, "her request was not to be refused." But Mary assumed the airs of injured innocence. ${ }^{2}$ And, as all the incriminating evidence was in the cipher handwriting of her two secretaries, she had the meanness to insist that, if they were guilty, she had not known of their crime. Her intention clearly was to capture the court by her womanly arts, which so seldom had failed her. So consummate an actress was she that she emphasized an indignant denial of plotting against the queen's life by bursting into tears as she exclaimed: "I would never make shipwreck of my soul by conspiring the destruction of my dearest sister." 3 All resulted in the only way in which an honest trial could result, in the unanimous conviction of Mary as having conceived and plotted Elizabeth's destruction.

Parliament, which, after having been prorogued twice, met on Oct. 29, considered the evidence down to its smallest particulars and thoroughly debated every debatable point ; and unanimously sent up to the queen their joint petition " that "a just condemuation might be followed by as just an execution." To this the queen replied ${ }^{5}$ that, so far as her own interests were concerned, she willingly would pardon her cousin now, if penitent; that she gladly would lay down her own life if England thereby could be better governed; and that her situation was so cruel and unprecedented that she must have time to reflect.

Froude states the perplexities of the case very well : ${ }^{6}$ -

To Protestant England the Queen of Scots was a menace of civil war and ruin. To Elizabeth, if individually dangerous, the Queen of Scots was also a political security. To put her to death would be at once dreadfully distressing to herself, and would be construed by the

1 S. P. Dom. Oct. 8.

${ }^{2}$ Cot. Ms. Calig. c. ix : 533.

3 S. P. Mary Q. of Scots. Narrative of Proceedings. Oet. 12.

${ }^{4}$ D'Ewes's Journals. Petit. of Parl.

${ }^{5}$ Speech of Q. Eliz. Camden, ii : 526. ${ }^{6}$ xii : 313. 
charity of the world into private revenge. The execution would involve an entire change of policy. The shifts which had served her so long would serve her no longer. For the remainder of the reign she was almost certain to be involved in war, while she would risk offending France and Scotland, whose friendship was of vital consequence to her.

After three days' delay Elizabeth requested Parliament to find "some other way." She seems to have favored an Act fixing the succession of her crown upon James VI. of Scotland, then twenty, the son of Mary by Lord Darnley, and remitting his mother to solitary confinement for life. But, after further discussion for a whole week, Parliament voted unanimously that the scaffold alone offered security, and sent the Lord Chancellor and the Speaker to the Court, then at Richmond, to urge that longer delay "would be likely to provoke the anger of Almighty God."

They found the queen still vacillating. Parliament adjourned until February, and the utmost that conld be gained from her was that their action, which had been kept secret until it "was more than a month old," was published. The effect was almost startling. For twenty-four hours all bells were ringing for joy in all steeples. London was ablaze with illuminations and bonfires lit up the land, the exultation of a now mainly Protestant people over what they took to be the assurance of a long delayed safety. The Court migrated to Greenwich for Christmas, and the sentence was sent down to Fotheringay by Lord Buckhurst and Secretary Beale, whom Mary received with defiance, and an embassy from Scotland and one from France appeared upon the scene.

Just at this juncture an exciting incident occurred, as to which Brewster may have shared Davison's experiences in some degree. Walsingham, indignant with the queen, especially because she had allowed him, as Sir Philip Sidney's security, to be ruined financially by having to pay Sidney's debts incurred on her behalf, had retired from Court to his own house at BarnElms. To him there came, on Jan. 10, 1586-87, one Stafford, with what seemed a cock and bull story of a fresh conspiracy to kill Elizabeth, to which M. Chasteauneuf, the French ambassa- 
dor in London, was privy. Stafford's repute was bad, and Walsingham shut the door in his face. Stafford at once went to Davison, who heard him through. Perhaps the younger secretary had as little real faith as his senior in the story, but he saw that the rumor might be played off against the French remonstrances in regard to Mary.

It was alleged that Du Trappes, Chasteaunenf's servant, and Cordallion, his secretary, had conspired, on Chasteauneuf's urgency, with one Moorly, a prisoner in Newgate, to kill the queen in order to serve the Queen of Scots. Moody was to explode powler under the queen's bedroom. ${ }^{1}$ Du Trappes was sent to the Tower and, on Jan. 12, Chasteauneuf was summoned to Burghley's house, Exeter House, Strand, where Burghley, Leicester - at home on leave from Holland - Vice-chamberlain Hatton and Davison were present. Chasteauneuf indignantly insisted that Stafford had made the original suggestion and had been threatened with exposure. On being confronted with both Stafford and Du Trappes, it appeared that the ambassador was at least so far connected with the plot, if there were one, as to have said nothing about it. The matter had force enough, and probably this was precisely what Davison foresaw, to prevent the king of France from meddling further with Mary's case.

Almost contemporaneously five envoys from the Low Countries arrived, to appeal for additional English aid both in troops and funds; a demand exasperating to the queen. On Jan. 28 they had audience in the Privy Council chamber at Greenwich, Davison being present, and her Majesty made some vigorous utterances in French. Two days later the entoys assembled again ${ }^{2}$ in Burghley's apartment in the palace, Davison being present, and the discussion was in Latin. In the manuscript report of these occasions a significant remark is accredited to Davison. Lord Admiral Howard asked if the Dutch could not aroid putting an army into the field just then, because England was likely

1 S. P. Dom. Eliz. exevii : 15. This statement is another proof that, in spite of the usual rigor of imprisonment, some prisoners now and then were allowed more or less liberty.

2 Hague Archives. Conference des Deputés avec les Commissaires de S. M. Feb. 17. 
to have her hands full at once with Spain. Then said Davison :-

We are on the brink of open war with Spain; with France, which is arresting all English persons and property within her dominions; and with Scotland, which countries are thought to have made a league on account of the Queen of Scotland, whom it will be absolutely necessary to put to death in order to preserve the life of her Majesty the Queen of England, and to be about to make war upon us. All this will cost us, in this current year, at least eight hundred thousand pounds sterling. Nevertheless her Majesty is sure to help you so far as she can, and I, for my part, will do my best to keep her well disposed to your cause, even as I have already done, as you very well know. ?

When the report of the Stafford conspiracy came out, it exasperated the public to an almost furions demand for Mary's immediate execution. But Elizabeth still demurred, although the death-warrant awaited only her signature and the Great Seal.

While matters were lingering thus the stinging news came that Sir William Stanley and his confederate, Rowland York, had betrayed Deventer and the fort of Zutphen to the Spaniards. The former was considered, next to Amsterdam and Antwerp, the most important mart of the Provinces. It was thriving with commerce and manufactures, and was the centre of the Dutch trade with the Baltic. The latter had been inmortalized a little before by the death of Sir Philip Sidney in fighting for it, and was the only fruit of Leicester's recent campaign. However he night mitigate these tidings to the royal ear, the sturdy English commonalty could contain themselves no longer. These places fell on Jan. 19, 1586-87, and on Feb. 1, by which time the slow-moving news had reached the English ear, Lord Admiral Howard, soon to lead the English ships against the Spanish Armada, waited upon the queen at Greenwich and told her plainly that it was unsafe to hesitate longer, and that the only safe course for her Majesty, the government and the nation was to execute Mary.

For the first time the queen seemed to be moved, and she bade him tell Davison, who, Walsingham still being in retirement, was sole Secretary in attendance, to bring her the war- 
rant. Howard at once gave Davison her message. Davison aecordingly procured the warrant, with other papers awaiting signature, and placed them before her. She asked him what he had, and he repliel, " Warrants and other papers." She inquired if the Admiral had not directed him to bring her the warrant for the execution of the Queen of Seots, and he handed it to her. ${ }^{1}$ She read it, signed it and laid it down for the bold signature to dry, explaining to lim that she had delayed so long that the world might see that the aet was done reluetantly, as a neeessity, and in neither malice nor revenge. She then ordered him to earry the warrant inmediately to the Lord Chaneellor for the Great Seal, ${ }^{2}$ showing it to Walsingham on the way, and then to send it down with all speed to the Commissioners. She direeted that the execution take place at Fotheringay, and absolutely forbade him to trouble her more about the matter until the deed should have been done. She also direeted him to manage all as quietly as possible, because of her own danger.

She eomplained of Sir Amyas Paulet and Sir Drew Drury, as if - no other interpretation is possible - they night have relieved her of this dreaded responsibility by poison or otherwise; and she had the assurance to ask Davison if they could not be prevailed upon, even then, to do her that favor. He was certain that they could not be. But she insisted so earnestly, putting into his month the very words which she would have used to them, that he was foreed to promise to state her wish to Walsingham. Stopping to see Walsingham, he reported what lad taken place and went on to Sir Thomas Bromley, the Lord Chaneellor, who affixed the Great Seal.

The next morning the queen sent Davison word that, if he had not been with the Lord Chaneellor already, he might forbear until he should hear further from her. He hurried to Greenwieh to tell her that, in accordanee with her express com-

1 The different accounts are here liarmonized, so far as possible, reliance being placed especially upon Davison's own. Cot. Ms. Titus, cvii : 48.

2 Fronde (xii : 346, n.) quotes a rumor that the Seal was affixed by the Lord Chancellor under the impression that he was certifying some petty warrant for the affairs of Ireland (Chasteauneuf au Roy. Mars. 1587). But, as Davison himself pleaded afterwards (Bodleian. Juridici. 7843: 862, 235) that the Lord Chancellor "by Sealing must needs haue knowledge," it may be doubted whether this were not mere Court gossip. 
mand and extreme urgency, the warrant had passed the Great Seal the previous afternoon. She sulked, and he asked if she had changed her purpose. She declared that she had not, but again suggested how Sir Amyas Panlet might relieve her. Davison replied that for any private person to take life was murder, and that the most open way was safest and best, if the act were to be done at all; whereat she swung out of the room. He comprehended the state of her mind so clearly that he at once told Sir Christopher Hatton, the Vice-chamberlain, all the circumstances ; adding that, as in the case of the Duke of Norfolk's execution, she meant to throw off the odium upon some one else; and that he was resolved to do nothing that conld leave the responsibility upon him. Hatton replied that he was heartily glad that the matter was so far advanced, and that any man unwilling to share the responsibility ought to be hanged. The two then went to Burghley, and the three agreed to report the matter to the Privy Council.

When the Council met they agreed that Elizabeth had done as much as reasonably conld be expected, and each declared his willingness to bear his share of responsibility. "They decided, especially as she had forbidden expressly that the subject be mentioned to her until all should be over, not to trouble her further, but to dispatch Robert Beale, Walsingham's secretary, and sometimes an acting Secretary of State, with the warrant to Lord Kent and Lord Shrewsbury, the Commissioners named to see it executed.

The queen made no allusion to the matter, excepting that one day she told Davison that she had been so vexed by dreaming the night before that Mary had been executed that she could have done to him "I wot not what." He inquired if she " had not a full and resolute meaning to go through with the said execution according to her warrant." She replied, swearing a vehement oath, that she had not changed her mind, but she wanted all done so as to relieve her of blame. She asked if any answer had come from Paulet, and suggested a certain Wingfield, who, she thought, would do the deed. Davison remonstrated that she must either endorse or disallow such an agent. If the former, she would assume a much more serious responsibility than by 
proceeding according to law. If the latter, she would do grievous injustice to faithful servants. The next day, Feb. 5, brought Paulet's answer. He could not leave upon his posterity the stain of his having taken life without full warrant of law. When Davison informed the queen, she sneered at Paulet as "precise." 1 But on Feb. 7, Davison having to see her on another matter, she "swore a great oath, that it was a shame for us all that it [Mary's execution] was not already done, considering that she [Elizabeth] had, for her part, done all that law or reason could require of her."

On Feb. 9 Henry Talbot brought to Greenwich the tidings that the once beautiful, and always brilliant and daring, Queen of Scots had been executed on the previons day. Elizabeth heard the news with calmness. She seems to have said nothing when the bells in all the steeples were ringing for joy. But she sent for Vice-chamberlain Hatton the next morning and complained that Davison had betrayed her. Davison was informed by the Privy Council of her charge. But, convinced of her purpose to lay her responsibility upon some one else, the accusation did not astonish, or at first, perhaps, much alarm him, especially as the other members of the Council freely avowed themselves jointly responsible with him. They advised him, however, to keep out of her way for a few days, which he did. But on Feb. 11 Elizabeth formally convoked the Council and rated them soundly. Burghley, who acknowledged that he had taken the lead, she particularly denounced. Davison, absent because of illness, she accused of violating her positive commands and ordered to the Tower. The Council begged her to pause, Burghley protesting with especial firmness. But she was inexorable.

Davison hardly could credit the rumor which reached him until Lord Buckhurst came with the warrant. The only clemency to be had was a short delay at home, and on Feb. 14 he was taken to those strong lodgings on the Thames bank, whither for more than a century no privy conncillor had been sent excepting upon the charge of high treason. Doubtless Brewster accompanied his master, for Bradford says distinctly :-

1 He was a Puritan or "Precisian," as they often were called. 
He afterwards remained with him [Davison] till his troubles, that he was put from his place aboute $y^{e}$ death of $y^{e}$ Queene of Scots; and some good time after, doeing him manie faithfull offices of servise in $\mathrm{y}^{\mathrm{e}}$ time of his troubles.

Davison soon was hardly in a financial condition to keep up his London honse with Brewster there acting for him, and his health was so poor ${ }^{1}$ that he must have needed an attendant; so that, as State prisoners in the Tower were allowed one or two retainers, probably the young man, then about twenty-one, served his master there in whatever capacity service was needed. If not resident with him, Brewster must have gone in and out daily. If lodged within the gates, probably he had a room in the Beauchamp Tower, assigned to retainers. Its windows looked down Great Tower St. as far as Allhallows, Barking, the church at which Pepys says that the Great Fire stopped.

The Tower was in charge of a Constable of high rank. In time his lientenant became the actual keeper. A bare room, with a stone or oaken floor, an iron-clamped door and a grated window or two, was furnished by the State. All else, even food, the occupant must obtain for himself. Probably Brewster's first service here was to superintend the procuring of a little furniture, with a few books and other comforts. As a Secretary of State Davison may have been permitted to be fed from the table of the lientenant, then Sir Owen Hopton, for which privilege, as for everything else, he would have had to pay smartly.

As soon as this committal to the Tower proved that the queen actually proposed severity, effort was not lacking to mollify her. While she still was infuriated towards himself, Burghley sent her an earnest appeal in behalf of Davison.

But her circumstances disposed her to be unyielding. Scotland years before had sought to dispose of Mary, but her dignity was hurt by England's action. And James, now twenty, whose acquaintance with his mother had been chiefly political, seems to have thought that it would look well were he to profess regret. Elizabeth sent Sir Robert Carey to him at Edinburgh

1 A few days before his arrest he had "an attack of palsy" and was "ill in bed" at home, and, more than a month after his imprisonment, he still was suffering from that attack and wore his left arm in a sling. - Nicolas, Life, 115, 116, 131. 
with one of the meanest letters which stain the pages of history. She said in it $:^{1}$

My dearest Brother: I would to God thou knewest . . . the incomparable Grief my Mind is perplexed with, upon this lamentable Accident which is happened contrary to my Meaning and Intention. ... I request you, that as God and many others can witness my Innocence in this matter, so you will also believe, that if I had commanded it, I would never deny it. I am not so faint-hearted, that for Terrour I should fear to do the thing which is just; or to own it when it is once done: No, I am not so base nor ignobly minded. . . . Persuade yourself this for Truth, that as I know this is happen'd deservedly on her part, so if I had intended it, I would not have laid it upon others. but I will never charge myself with that which I had not so much as a Thought of.

James hardly could equal her as a liar, but in thrifty meanness he was quite her peer. He had sold himself to her a twelvemonth before for "hounds, horses and $£ 5000$ a year" 2 and the prospect of succession to her throne indirectly held out, for which his mother had cursed him $;^{3}$ and, having received a copy of Mary's will, disinheriting him, seized at Chartley, he had intimated that he would make no trouble, and hoped that for the rest of her life she would be "so bestowed that she would have to confine herself to saying her prayers." 4 And, now that all was over, he suggested that, if Elizabeth would persist in her excuses to save his eredit, he would have nothing to do with Spain. The French had not forgotten that Mary Stuart had been a queen of France, and they now talked of war; while of course Spain was furious that all plotting for a Romanist insurrection in England around her as a centre was ended, and thence also came threats of strife.

How far Elizabeth really was alarmed may be a question. But it suited her to take advantage of all to shift the responsibility of Mary's death upon others. She almost dismissed her whole ministry. She meditated a charge of high treason against

1 Camden, ii : 536.

2 S. P. Scot. July 9, 1585.

${ }^{3}$ Lets. of Mary, Queen of Scots. Trans. from Coll. of Prince Lobanoff, Mar. 12, 1585. "If my son persists in this, you can assure him . . . that I will invoke the malediction of God on him."

${ }^{4}$ Eg. Paps. Oct. 4, 1586. 
Davison, but her judges declared that, since she had signed the death-warrant, he only could be charged with misunderstanding or contempt. She even proposed to send him to the Scotch, that they might wreak their rage upon him, but saw that this would be generally abhorred.

On Mar. 12 he was visited by Vice-chamberlain Hatton and John Wolley, Latin secretary to the Council, and five formal questions were put to him. ${ }^{1}$ The visit was repeated on Mar. 14 and again on Mar. 16. The clear design of these interviews was to obtain admissions to be used against him. But his cautions and honest answers offered no encouragement, excepting only that out of regard for her Majesty's reputation he remained silent as to Sir Amyas Paulet. Had his conscience permitted him to pretend to admit her representations, and throw himself upon her mercy, very likely she would have pardoned and restored him. As it was, his calm persistence left her no alternative but to abandon her own false position or to treat him as if really guilty.

Of course she did the latter, and a commission was appointed to try him. It had thirteen members, ${ }^{2}$ including Sir Christopher Wraye, Chief Justice, who presided as Lord Privy Seal, and Archbishops Whitgift and Sandys. It met in the famous Star Chamber on Mar. 28, 1587. At least four members, it is said, were known to be in sympathy with the enemy. ${ }^{3}$ Davison still had his left arm in a sling and obviously needed attendance, which Brewster seems most likely to have rendered; which service would have brought him face to face with some of the chief dignitaries of the land on a very exigent occasion.

The charge was of misprision and contempt. Davison was accused of having disobeyed the queen in showing the warrant, after it had been signed, to the Privy Council, and in abetting their sending it to execution without her knowledge and order.

1 Harl. Ms. 419 : 16 s.

2 Ms. in Caius Coll. Camb. A. 1090, 8: 267. Bodleian Ms. Juridici. 7843: 862, 235. J. S. Burn, Star Chamber, 59.

${ }^{3}$ Froude, xii : 373. "Of these Lumley and Worcester had been in every Catholic conspiracy since the beginning of the reign; Cumberland was in Ballard's [the Jesuit instigator of the Babington Conspiracy] list, and Crofts a pensioner of Philip. With a Conrt so composed he was condemned before he was tried." 
The prosecutor reminded Davison that he had testified that the queen had said that "she thought of some other course to be pursued." It must have required the utmost self-restraint for Davison to refrain from the true explanation of this phrase. But he loyally guarded her reputation, and simply said that he had acted as he thought the best interests of her majesty and the lingdom required. As for the secreey imposed, he had understood that to refer not to the Privy Council, of whom many must know and all had the right to know the facts, but to the public. He had told the Council that it was the queen's pleasure to have the warrant executed, and respectfully put himself upon her conscience whether he had not just cause for saying so.

He was acquitted unanimously of evil intent but condemned for malfeasance through haste, and was punished by dismission from the publie service, a fine of 10,000 marks - equivalent at our values to over $\$ 160,000$ - and imprisonment at the queen's pleasure. Perhaps this excessive fine was named in the confidence that her conscience never would suffer her to insist ipon its payment. But she exacted the uttermost farthing. Perhaps her greed could not resist the glamour of so large a sum. Poor Davison was ruined, and in addition, ill though he was, was left to suffer in the Tower indefinitely, probably little less than two years. The Earl of Essex bravely sought withont success to regain for him the royal favor; and he limself, on Dee. 7, 1590, vainly addressed to her a touching appeal "from my poor desolate house in London;" but, while she finally seems to have released him, she would do nothing else for him. When James succeeded, he was more just than she had been. But Davison did not long enjoy the little sunshine that brightened his declining years, dying at Stepney, Dec. 21,1608 . That he was a sincere, devout man, as well as a statesman of wislom and learning, is conceded. Indeed, the sternness of his integrity probably was the real cause of the queen's persistent hostility. He was too much an embodied conscience for her comfort.

Bradford makes it certain that Brewster clung to Davison for "some good time after" his condemnation and imprison- 
ment. Davison himself furnishes the first positive subsequent date in Brewster's life. In the State Papers survives an original letter, ${ }^{1}$ already referred to, from Sir Joln Stanhope to the exSecretary, dated simply Aug. 22. But Stanhope wrote as Postmaster-general and did not beeome sueh until June 20, 1590, while other circumstances fix the date as not later than that year. The letter answers a request from Davison that he would appoint young William Brewster post-master at Serooby, alleging objections. On its baek are memoranda in Davison's handwriting, one of which urges that Brewster already has had practical possession of the plaee above a year and a half. This implies neeessarily that Brewster had left Davison's employ and gone back to Scrooby as early at least as from Jauuary to March, 1588-89, a few weeks, possibly months, less than two years after Davison had been condemned and sent back to the Tower. Davison's letter of Dec. 7, 1590, to the queen, from his house in London implies that his imprisonment then was ended, but how long before then is not evident. Whether Brewster remained in his service until his release and went home afterwards, or something called the young man away before that time, we do not know. It looks as if the heavy fine, together with the large expense of the imprisomment itself, must have exhausted Davison's resources so far that he no longer could, or would, retain in his service one to whom such a position thenceforth could not promise advancement.

Although this connection ended very differently from their presumable expectations, the value of it to Brewster, especially in fitting him for the peculiar life which he was to live, must have been inestimable. To have been so long, at the most formative period of his eareer, in the family, feeling the example, and, as Bradford's testimony fairly implies, in some sense enjoying the intimacy, of so cultivated a scholar, so sagacious a statesman and so excellent a man as Davison undeniably was, was extraordinary good fortune. Close and constant attendance upon his master in the latter's official capacity at the Court and in Holland neeessarily involved, also, his becoming somewhat familiar with all the most notable personages in the two countries. $\mathrm{He}$

1 S. P. Dom. cexxxiii : 48. 
often must have seen the queen and her circle of lords and ladies. He must have known well - at least in the manner in which the attendants in the library of the British Museum, in London, to-day come to know many great scholars - Burghley, Walsingham, Bromley of the Great Seal, all the honorable lords of the Privy Council and the two archbishops.

He must have seen and heard Francis Bacon, ${ }^{1}$ then for the first time in Parliament; Sir Walter Raleigh, resplendent in high favor at Court; Sir Francis Drake, who was making the whole nation wild with excitement over the just completed first English voyage around the world; Sir Philip Sidney, whom Elizabeth called "one of the jewels of her crown" and sent to Holland among the distinguished men in whose train Brewster was; and the handsome, brilliant and notable, even if too ambitious, Leicester. And, when we remember that twenty-four years later he was to find refuge there, it is easy to see how specially instructive must have been his experiences in the Low Countries; although little can he have thought, when standing with his master by the clock-tower of St. Peter's in Leyden, that, by extending his hand, he conld almost tonch the very wall, across the narrow street, within which he was to find shelter for years, after he should have been driven out of his own land.

Nor would the knowledge of affairs unavoidably gained in such a service at such a time be less helpfully instructive; the familiarity with politics and statecraft, alike in their weightier principles and their practical methods and processes ; and, especially, the discrimination of motives and the observation of the true and high relations of conscience to a just public life. Who can tell how much Brewster's private knowledge of the nobility of Davison's consent to suffer wrongfully - even to the extent of wrecking his private fortune and bringing his public career to what must have seemed to most men an inglorious end, rather than to become accessory to conduct which he could not approve - may have had to do with heartening the young man himself for the life of long self-denial which he lived?

$1 \mathrm{He}$ brought over Bacon's volume, Of the Proficiencie and Advancement of Learning. 


\section{CHAP'TER IV}

\section{BREWSTER AT SCROOBY MANOR}

When Brewster returned to the Scrooby manor-house he soon found himself indispensable, even if he had not been summoned home, for his father appears to have been failing in health. As we have seen, the latter had been commissioned as bailiff and receiver of the lordship, or manor, of Scrooby on Jan. 4, 1575-76. In holding these offices he apparently became the legal representative of the owner, ${ }^{1}$ and this involved not merely collecting the annual rents and generally managing the estates, but probably also presiding over the manorial courts and the custody of records. Further, it is clear that for some undefined previous period this manor-honse had been a regular post-honse on the Great North Road, and its occupant post-master ; ${ }^{2}$ a fact adding much to his former duties.

In July, 1556, the Council took action in regard to "the postes betweene this and the Northe." 3 When the stages of this Great North Road from London to Scotland were established systematically in the reign of Elizabeth, Serooby was made the twelfth from London and, in the other direction, the fifteenth from Berwick-upon-Tweed. ${ }^{4}$ When Brewster, the father, died, in 1590, his son took his plaee as post. Such a postmaster, however, was not what the name now suggests. Letters then sent by post usually, if not always, were government missives, passed from messenger to messenger at each station; personal correspondence, so far as it existed, being left to go by

1 H. Hall, Soc. in Eliz. Age. The Steuard, 17.

2 The first English Post-master-general on the records was Sir Bryan Tuke, in 15.33. Very likely the route by Dover to the Continent was established first. But that to York, Berwick and Edinburgh surely must have been second.

${ }^{3}$ Enc. Brit. xix : 56(2.) S. P. Dom. Eliz. Add. xxvii : 116.

4 Hunter, Colls. 69. 
private hand. ${ }^{1}$ In connection with the carrying of government despatehes a system of forwarding travellers also grew up naturally. Horses much of the time unemployed for the one purpose served readily for the other. An additional service was the occasional sending of messengers on government business out on the cross-roads, and, although this might not be called for often, constant readiness for it had to be maintained. Into all this responsibility Brewster, who conld not have been much, if at all, over twenty-three, now entered.

Probably one of his last experiences in London must have been that of the wild excitement when, on the evening of July 19, 1588, signal fires flashed over the kingdom the tidings that the long expected, and, even by so brave a people, the much dreaded Spanish Armada had been sighted in the Channel. Doubtless he never forgot the sensations of the next sixty days, during which frequent expresses on foaming horses came plunging in from the coast, bringing tidings. Thrilling indeed it must have been to hear how that enormous expedition, conceived in the sin of Papal pride, brought forth in the iniquity of naval inefficiency, and now known to have been ill provisioned, ill armed, ill commanded and ill piloted, in spite of all its spirited fighting had melted away under the fierce attacks of the smaller but swifter and better handled English vessels and the stress of weather and of want, until its miserable remnant found its inglorious way baek to Spain.

It was then, in the dawn of a new, and in most respects more glorious, era for England that Brewster began to live again in Scrooby. Gladdened by the amazing victory which, mnder Providence, it had won, and assured that there no longer need be fear lest Spain should reduce the kinglom to vassalage to Rome, the nation sprang forward at once to a condition of material prosperity and intellectual advancement which speedily gained for the succeeding year's the title of " the golden age of merry England."

To men of Brewster's religious ideas, however, this new era was to prove little better than the old. The queen hated the new Presbyterian way. Yet she had no such devotion to the

1 In England, as late as the fifteenth century, drovers were the principal mediums of private correspondence.-Enc. Amer. App. xiii : 748 . 
State Church as to insist upon the subjection to it of any excepting Puritan dissenters. Remnants of Popery lingered in her own chapel. Romanist members of her own household were winked at in their disobediences, and Catholic country gentlemen were allowed to do much as they pleased at home. While Mary Stuart lived, the exciting centre of perpetual treason, and the Spanish Armada loomed in the future, Elizabeth had felt the strength of her throne to be in the Puritans, and sometimes had overlooked aberrations on their part. But that access of new solidity to the realm which dated from the downfall of the Spanish fleet modified all this.

Many Roman Catholies conformed, and not unnaturally demanded the full benefit of the by no means inconsiderable Romanism still dormant in the established ritual. The screws therefore were given a few additional turus. The bishops were ordered to see the ecclesiastical laws executed - against Precisians. The spiritual courts, for a time comatose, took on new vigor; and that pressure upon Separatists, which ended in martyrizing some and in driving multitudes out of the kingdom, was felt once more.

Naturally, the battle of the books began again, prelnded a little by Bancroft's audacious sermon at Paul's Cross attacking the Puritans. Indeed, Brewster may have carried with him down to Scrooby the lately issued dialogue by Udall, "The State of the Churche of Englande," or even a copy of Martin Marprelate's “Learned Epistle," which his former fellow-student, John Penry, had just contrived to get published.

Even if Brewster had not been summoned back to Scrooby, his presence there soon must have supplied a real need. From the beginning of 1589 , as a practical and permitted, although uncommissioned, deputy, he discharged ${ }^{1}$ his father's duty as the "Post of Scrooby," and received the fee therefor. Very likely he also acted as bailiff and eustodian of the property. It wonld be gratifying to know how far he had become a decided Puritan, and whether he took any special interest in the Martin Mar-prelate war. But no record survives to enlighten us. It is of some interest here to recall that George Sandys, son of the late Arch- 
bishop of York, and then less than thirteen, who was to be outdone by Fynes Moryson only as a traveller, no dloubt passed through Scrooby, and probably stopped at his father's former manor, on his way to be matriculated that summer at St. Mary's Hall at Oxford. In the last weeks of the same year, also, on Mar. 6, 1589-90, the Ecclesiastical Commissioners instructed the High Sheriff of Nottinghamshire ${ }^{1}$ to attach James Brewster and others for having "profaned and ruinated" the house and chapel of the Bawtry Hospital of St. Mary Magdalen, to which reference already has been made. This must have been a matter of considerable local interest, especially to William Brewster, and whether James were his relative or not.

In June, 1590, the Earl of Worcester went down to Scotland, stopping at Scrooby, where Brewster, the father, furnished him with post-horses. On his return, some weeks later, he found the old man dead. ${ }^{2}$ The York records show that on July 24, 1590, administration on his estate at Scrooby was granted to his son William $;^{3}$ his widow, Prudence, who alone, besides the son, is mentioned, declining the trust. In view of the interests involved, young Brewster went up to London soon after his father's death, to ask to be legalized in the place whose duties he really had performed for eighteen months. He was absent on this errand, as the widow said, when the Earl of Worcester stayed at the manor-house on his returu.

It happened that Thomas Randolph, Post-master-general, also

1 Hunter, Colls. 82. But why the sheriff of Nottinghamshire was addressed is not explained. Bawtry, and Harwortl, in which the hospital really stands, were then, as now, in Yorkshire. Perhaps James Brewster lived near by in Nottinghamshire.

2 Stanhope's letter. S. P. Dom. Eliz. cexxxiii : 48.

3 The record is this (Act Bk. for Deanery of Retford cum Laineham, s. d.): "Vicesimo quarto die mensis Julii 1590, Administracō oin̄ et Singnlo $\overline{\mathbf{r}}$ Bono $\overline{\mathbf{r}}$ Juriū et Creditō̄ que fuerunt Willmi Brewster nup. de Scrooby defunct Con̄issa fuit Willmo Brewster filio eiusdem dep. in forma Juris jurat. Salno Jure, ete. Prudentia Brewster Vid. Relea eiusdem Def. Administracōem hin $\overline{0}$ in se suscipere renunciant et recusañ. Et exhibūt Inven. solñt v. s. Et $\mathrm{d}^{-}$eus Wilìaus et alii obligantur. [On the twenty-fourth day of the month of July, 1590, administration of all and singular the goods, rights and credits which were of William Brewster, late of Scrooby, deceased, was granted to William Brewster, the son of the said deceased, sworn in form of law. Saving any other person's right. Prndence Brewster, Widow, the Relict of the said deceased having renounced and refused to take upon herself administration of the said deceased. And he exhibited an Inventory. Five shillings were paid. And the said William and others are bound.]" 
had just died, so that his successor, Sir John Stanhope, was new to his subordinates. One Samuel Bevercotes, Stanhope's cousin, applied to Stanhope to give the place to a friend of his, and Stanhope did so. Young Brewster understood that the position had been substantially his for a year and a half, and had been promised to him by Mr. Randolph, and therefore did not ask appointment to it from Stanhope, whom he did not know, but dealt with Mr. Mylls, the chief clerk, with whom he always had done his business. When he found that another had been commissioned over his head, he applied to Davison to intercede for him. Davison, who seems to have been at liberty then in London, remonstrated at once with Stanhope.

Stanhope replied with significant courtesy, ${ }^{1}$ and said that Brewster had not applied to him, and rather complained of that neglect. He added that he had been informed that it was not true that the young man had "had admyttance and use of the place in his father's tyme," nor did he know that Mr. Randolph had promised Brewster the appointment. He therefore had given it to another. But if any satisfactory way of retreat could be found, he would revoke the grant. Davison replied, showing that Brewster had held the place by Randolph's gift long before his father's death: as appeared from the record of his name in the roll with the other post-masters; from his receipt of the fee for the year and a half just past; from the testimony of his master - probably Davison himself - who had recommended him; from the evidence of Mr. Mylls, who was aware of the appointment, and had registered Brewster's name and paid him his salary: and from the fact that he had been performing the duties of the place for a year and a half, as the next post-masters on each side would testify. He urged that no exception could be taken to Brewster's honesty or efficiency ; that to remove him would be unkind in view of his great charges incurred for provision for the service in that "hard year," and would ruin him; ${ }^{2}$ and that it would be a harmful public example. For all which reasons he "ought to be no more displaced than the rest of the postes."

1 He addressed his letter to his "honorable frend, Mr. Secretary Daveson."

2 S. P. Dom. Eliz. cexxxiii : 48. 
So vigorous a statement from such a quarter clearly prevailed. Brewster was in full possession of the office at the earliest date to which the existing post-office records run back, A pr. 1, 1594; ${ }^{1}$ which implies that he had continued to hold it. He performed its duties for seventeen years.

The year 1590 must have been absorbed so largely by the special cares incident to the settlement of the estate and the consequent readjustment of all affairs connected with his office, that he could have had little opportunity for anything else. Nevertheless, he probably kept his ear open to the voices on behalf of reform in religion which were sounding in the kingdom, and his eye upon that literature which was urgent, if not eloquent, in that regard. Among the books which he left behind him at Plymouth was Barrowe's "Brief Disconerie of the False Church," already mentioned, which came out this year, and which, if studied by Brewster, may have helped to form his later opinions. Several other publications of the same year, which have been named, also may have influenced him.

Down to the close of the century few data remain which shed much light upon his life. Among events of which he probably heard, and which must have moved him more or less, were Browne's recantation and appointment as rector of Achurchcum-Thorpe, in September, 1591; the arrest of Barrowe and Greenwood in December, 1592, followed by their judicial murder in April, 1593, and by that of Penry in the following June; and the departure of Francis Johnson's church to Holland, completed by the winter of 1595 ; while the death of Henry Brewster, vicar of Sutton and Scrooby, near the end of 159798 , and the institution of James Brewster in his place early in 1598 occurred close at hand. In the literature towards which perhaps his mind was turning seriously were two or three light skirmishing volumes between Barrowe and Greenwood and Gifford and Sutcliffe; two bitter ones by Bancroft; the earlier books of Hooker's masterly work; and that treatise of Francis Johnson's, on "The Ministery of the Church of England," which Brewster seems to have brought to Plymouth; and one or two other works claiming brief mention hereafter.

1 Hunter, Colls. 66. 
His former fellow-servant, George Cranmer, may have sent him, in 1598, the letter ${ }^{1}$ which Craumer published to his revered instructo:, Richard Hooker, in which, without accepting fully the positions of the reformers, he urade decided concessions to them.

Brewster's own work was steady and must have been exacting. The earliest records of the Post Office mention him as in full possession of the Scrooby division from Apr. 1, 1594, through the century at a salary of twenty pence a day, or $£ 30$ 8s. 4d. a year, ${ }^{2}$ about $\$ 760$ in modern money. He seems to have married as early as 1591 or 1592. But, beyond the facts that his wife's first name was Mary, that she was about two years younger than he, ${ }^{3}$ and that she lived until some years after reaching New England, ${ }^{4}$ we have no details about her. Apparently their first child ${ }^{5}$ was borm in 1592 or 1593, and that they named him Jonathan, a Bible name then rare, seems to inclicate the progress of the parental mind along the path of Puritanism. A confirming hint is that the next child known to us, who seems to have been born before 1600, was called Patience, ${ }^{6}$ and that the second daughter of whom there is distinct trace, also probably born at Scrooby, just before the flight to Holland, was named Fear. ${ }^{\top}$ In some one of these years, also, Brewster's mother, Prudence, must have been borne from the old

1 Concerning the New Church Iiscipline. This edition, of 1642 , is said to be the first (Hanbury, Hooker, i: exxiii). But what motive led to its being printed first forty-two years after its anthor and its recipient both were dead? Moreover, Dr. Dexter's copy contains the endorsement, in a handwriting apparently of the time, "reprinted" 1642.

2 Hunter, Colls. 66.

${ }^{3}$ See p. $505 \mathrm{n}$.

4 Bradford, Hist. 451.

5 Admitted a citizen of Leyden, twenty-five being the age required, on June 30, 1617 (Poorter-Bk. 1603-3S, 107), which confirms his affidavit.

6 The two girls came to Plymouth in the Anne, in 1623, and then were approaching, if they had not reached, marriageable age. Patience married Thomas Prence in 1624, and Fear became the second wife of Isaac Allerton in 1626: These dates imply their birth at Scrooby.

7 "There was a meaning and purpose in the adoption of names such as these. The names previously used in England had been for the most part the names of holy men and women, who had been honoured by the Ancient Church, and placed by her in the Kalendar. They had therefore a relation to the abrogated system, and they contributed to keep up the memory of it, which the Puritans wished to see die away. They had recourse therefore to Old Testament names, and to such words as fear, love and patience."-Hunter, Colls. 142. 
manor-house to the little churchyard, where the shadow of the beautiful spire of St. Wilfred's still daily rests for a little while upon the unremembered spot.

In considering Brewster's progress towards Separatism it is needful, in the lack of much direct testimony, to study the suggestions of Bradford nearly, or quite, half a century later, as he mourned the recent loss of his lifelong friend. Referring to Brewster's leaving Davison's service, he says : ${ }^{1}$ -

Afterwards he wente and lived in $y^{\mathrm{e}}$ country, in good esteeme, amongst his freinds and $y^{e}$ gentle men of those parts; espetially the godly \& religious. He did much good in $\mathrm{y}^{\mathrm{e}}$ countrie wher he lived, in promoting and furthering religion, not only by his practiss \& example, and provocking and incouraging of others, but by procuring of good preachers to $y^{\mathrm{e}}$ places theraboute, and drawing on of others to assiste \& help forward in such a worke; he himselfe most comonly deepest in $y^{\mathrm{e}}$ charge, \& some times above his abillitie. And in this state he continued many years, doeing $\mathrm{y}^{\mathrm{e}}$ best good he could, and walking according to $y^{e}$ light he saw, till $y^{e}$ Lord reveiled further unto him. And in $\mathrm{y}^{\mathrm{e}}$ end, by $\mathrm{y}^{\mathrm{e}}$ tiranny of $\mathrm{y}^{\mathrm{e}}$ bishops against godly preachers \& people, in silenceing the one $\&$ persecuting $y^{\mathrm{e}}$ other, he and many more of those times begane to looke further into things, and to see into $y^{e}$ unlawfullnes of their callings, and $y^{\mathrm{e}}$ burthen of many anti-christian corruptions, which both he and they endeavored to cast of ; as $y^{\mathrm{ey}}$ allso did, as in $y^{\mathrm{e}}$ beginning of this treatis is to be seene.

Here are six intimations. (1.) Brewster from the beginning of his adult residence at Scrooby enjoyed the confidence and esteem of the neighborhood, and particularly of the more enltivated and religious people. (2.) He was recognized as distinctly on the side of good order and piety. (3.) He was active in endeavoring to have the gospel preached there. ${ }^{2}$ In other words, he was a Puritan. (4.) He bore even more than his fair share of the cost of such endeavors. (5.) He continued this for many years in substantially his old relations; that is, as a member of the State Church. (6.) Some special development of religious tyranny and the steadily increasing hopelessness of any improvement within the Church at last drove him, and others like him, on to Separation.

1 Hist. 410.

2 In the smaller towns and the rural districts sermons rarely were heard. 
So, then, when the first hour of the seventeenth century struck, William Brewster was thirty-five; a young husband and father; an officer of the queen; residing at Scrooby in the manor-house of an archbishop; having some university culture from Cambridge, enlarged by an experience of certain work at the royal Court, and broadened by an observation which had reached into the Tower as well as extended beyond the narrow seas; refined by some acquaintance with many good and great men ; recognized as religious and influential, and the subject of profound spiritual convictions which gradually were deepening towards the absorption of all the great aims of life. Yet he still was within the communion of the Established Church, and his hands were full of work of various kinds. So much, at the least, we can see.

The first great civil event of the new century was the death of the queen, on Mar. 24, the last day of 1602-3. Brewster must have had news of it long before most people in the North. As soon as her last breath was drawn, Sir Robert Carey, who had been waiting for the event, received the tidings from his sister, Lady Scrope, with a ring from one of the dead queen's fingers, with which, as his credential, he started at once for Edinburgh. ${ }^{1}$ He covered the more than 300 miles in three days and two nights. Scrooby was a little more than halfway, so that at some time on Friday, Mar. 25, Sir Robert must have halted at the old manor-house, and must have broken the great, if not unanticipated, news. On the next day, or the next but one, Thomas Somerset and Sir Charles Percy, the authorized messengers of the Privy Council, must have arrived at a soberer pace.

The opening years of the century seem to have been years of material prosperity for Brewster. On July 1, 1603, his salary as post-master was raised from twenty pence to two shillings ${ }^{2}$ a day. In 1605 we gain a glimpse of the manor-house as a posthouse under his charge. Sir Timothy Hutton, son of the Archbishop of York, slept there on a journey from York to London, and lunched there on his return. He noted ${ }^{3}$ that he paid the

1 S. R. Gardiner, Hist. Eng. i: 55.

2 P. O. Accounts. Hunter, Colls. 67.

${ }^{3}$ Surtees Soc. Pubs. Hutton vol. 197-204. 
Scrooby Post for a conveyance and guide to Tuxford ten shillings, and for a caudle, ${ }^{1}$ supper and breakfast seven shillings, ten pence. Returning he paid eight shillings for conveyance to Doncaster, and for "burned sack, bread, beer and sugar to wine" two shillings, with three pence to the hostler.

1 A hot drink, composed of wine, egg, bread, sugar and spices. 


\section{CHAPTER V}

\section{MORE CONTROVERSY ABOUT THE TRUE CHURCH}

THE first years of the century were comparatively peaceful. No doubt something of the fierceness of the old conflicts had burned out, but the obvious fact that the queen was nearing the end of her reign was not without influence. Mary Stuart's son, James VI. of Scotland, trained by the Scotch Presbyterians, was to suceeed her. The most bigoted officials of the English Establishment could not forget the ehange liable to happen on any day at Court, and its probable effect upon themselves. And the Dissenters, not without some hope, were content to bide their time. All was made easier, too, by the age of the Primate, then almost seventy.

The Papists took advantage of the lull to eirculate quietly some pleas against Protestantism, ${ }^{1}$ and in 1601 William Barlow, a chaplain to the Primate, soon to be Dean of Chester and, later, Bishop of Lincoln, replied ${ }^{2}$ to them.

In the same year a "Petition to the Queene for Association [union] in Religion," " 3 by Thomas Digges, was published posthumously. Its main contention is that if " all gentlemen, Magistrats, \& possessioners within this realme shall take the oth of association, for the defence \& perpetuation of religion," Romanist hopes and practices alike will be cheeked. But that this

1 One book was Certain Articles, or forcible reasons discouering the palpable absurdities, and most intricate errours of the Protestantes Religion, 4 to.

2 A Defence of the Articles of the Protestants Religion, in aunsureare to a libell lately cast abroad intituled, Certaine Articles, 4 to.

${ }^{3}$ Iumble Motives for Association to maintaine religion established ; etc., $16 \mathrm{mo}, 6$, 41 , xvii, xxiii. In spite of the fact that this is signed "By Thomas Diggs, Gentleman," the Dict. of Nat. Biog. attributes it to Wm. Bradshaw. Ath. Cant. connts it among Digges's volumes. As Digges died in 1595, and the work has an unsigned appendix dated "December, 1601," Bradshaw may have written the appendix and published the book. 
plan was not intended to extinguish Puritanism is clear from the appended appeal to the archbishops and bishops, which urges : -

Ye shal find tenne puritäs for one formalist [among the clergy of the land not non-residents and dumb dogs], d that one puritan doth more alloance the gospell, is suppresse popery, than tenne formalists. For he attends [to] his ministery, is not [to] multiplying or exchanging of benefices. He preacheth, not once a moneth, or lesse, but enery Saboth day, \& that, not to please the eare, but to moue the heart.

And, referring to a recent utterance, in a book called "Newes from Spaine \& Hollād," that, if the queen lived much longer, the Puritans would be extinguished, it replies:-

Nay much more possible \& likely it is, that the Puritan shall overcome the Protestant tha the contrary: For that the puritan buildeth directly vpo the protestants first grounds in religion, and deduceth thereof clearly, and by ordinary consequence, all his conclusions : which the protestant cannot denie by diuinity, but onlie by policy, and humaine ordination, or by turning to Catholique aumsweres, contrary to their oune principles. And theirefore it is hard for any man, sincerely to be a Protestant, but that he wil easily passe on also (more or lesse) to be a Puritan.

It was some English Romanist, probably, as the book ${ }^{1}$ has no imprint and resembles those from the secret presses of the Romanists, who replied to Digges, just before the queen's death. The quality of his censure is indicated thus:-

Then the lying spirit of Puritanes by which every basest fellowe is to prescribe Religion to the vniversall worlde, and no doctrine can be riaintained without that mans allowance, cannot be a maintenance but destruction to true Reuerence : as, to giue a shorte example in a briefe discourse, there haue beene by morall iudgement. 700 . sectes of Heretickes, which hane pleaded this kinde of Maintenance. Therefore it is oddes 699 , to one, that Puritanes will destroy and not maintaine Religion.

The genuine Estahlished Churchman sometimes was not much behind the Romanist in severity. For instance, Josias Nichols,

1 A Briefe Censure upon the Puritane pamphlet, entituled, Humble Motyues for Association, etc., $16 \mathrm{mo}, 14$. 
of Eastwell, Kent, at about this time argued ${ }^{1}$ that the religion of the State Church is the only true one, and insisted that "the pretended Religion of the Sea of Rome is a false, bastard, new, vpstart, hereticall and variable superstitious devise of man." 2 In the summer of the same year Nichols also set forth a vigorous yet kindly volume, ${ }^{3}$ in the main pleading the Puritan cause. It says that the name, as a reproach, really is more appropriate for the Papists, and declares : -

Who so feareth an oth, or is an ordinarie resorter to sermons, earnest against excesse, ryot, poperie, or any disorder, they are called in the vniuersitie prescisians, and in other places puritans.

It claims that the Puritan cause has been much injured by the Mar-prelate controversy, and condemns each side with equal severity. It insists that the godly preaching ministers are not enemies to the State; that they cannot but "ever love her Maiestie, and all the godlie wise Magistrates;" that the best good, and even the safety, of the queen and her government will be promoted by toleration of a "godlie ministerie," and that, in fact, the Puritans

by their chearefull obedience to God, and thankfull declaration of their loue vnto their prince, \& dutifull practise of iustice, equitie, trueth, mercie \& concorde, one with an other : shew them selues, the true and faithfull professors of Christes most blessed Ghospell.

His frank testimony as to the religious condition of the kingdom also deserves notice. In 1702 Cotton Mather said that, when Bradford was born, the people of Austerfield were "as unacquainted with the Bible, as the Jews do seem to have been with part of it in the days of Iosiah; a most Ignorant and Licentious People, and like unto their Priest." 4 Hunter says of this : ${ }^{5}$

As to the moral and religious state of the yillage in which he [Brad-

1 Abrahams Faith : that is. the olde religion. Wherein is tavght that the religion now publikely taught and defended by order in the Church of England, is the onely true catholicke, auncient, and vnchungeable faith of Gods Elect, ete., 1608, 4to.

2 Abrs. Faith. Title page.

3 The Plea of the Innocent: Wherein is Averred: That the Ministers and People Falsely Termed Puritans Are Injuriously Slandered for Enemies or Troublers of the State, ete., 16mo, 4, 11, 31, 98, 154, 251, 218, 226.

4 Mag. ii : 3.

5 Colls. 121. 
ford] was born, it was probably neither much better nor much worse than the other agricultural villages of England at that time were.

Whatever the state of things may have been in Ansterfield then, here is a candid and apparently devout man testifying thus of rural England in general in the last years of Elizabeth : -

We finde by great experience (and I haue now fiue and twentie yeares obserued it) that in those places where there is not preaching and priuate conferring of the Minister \& the people, the most part, haue as little knowledge of God and of Christ, as Turkes and Pagans. One would not thinke it so : seeinge they haue the holy scriptures read in a knowen tongue, and now and then Sermons quarterlie, yet surely it is true in verie many places. For I haue bene in a parish of foure hundred cōmunicantes, and marueiling that my preachinge was so little regarded, I tooke vpon me to conferre with euerie man and woman, before they receaued the communion. And I asked them of Christ, what hee was in his person: what his office : howe sinne came into the worlde: what punishenent for sinne: what becomes of our bodies being rotte in the grames: and lastlie, whether it were possible for a man to liue so vprightlie, that by well doeing he might winne heauen. In all the former questions, I skarse found tenne in the hundred, to haue anie knowledge, but in the last question skarse one but did affirme, that a mā might be saned by his own wel doing: and that he trusted he did so line that by Gods grace he should obtaine euerlasting life by seruing of God \& good prayers, \&c. Where I am, I hane bene 21. yeares, I hane euerie yere communed with such strangers as hane come into this parish, either house-keepers or seruauntes; and being small, there comes some yere not passing six, some tenne, and some yeares more. And truelie God is my witnesse, that $\mathrm{I}$ lie not, I haue founde some that haue comde from parishes, where there hath bene diligent teaching, to annswere me verie handsomlie in all these thinges : but I can hardlie renember anie one, which had continued vuder a Non-resident and rnpreaching ministerie, that had any knowledge, especiallie to tell what Christ is, or that we are saued by faith in him, and not by workes. Therefore I haue asked the like of others, whiche tooke the same paines as $I$ did, and they have affirmed to me the verie same.

He insists repeatedly that the policy of repression and subscription has been not only cruelly oppressive of good men, but also actually stimulating to vice and crime.

Dr. William Covell, then vicar of Sittingbourne, Kent, thought Nichols's volume needed answer. Yet in his much 
larger reply ${ }^{1}$ he neither refutes nor denies Nichols's charges, but argues that kings have authority over, and should have care for, church government; that the Church ought to have a discipline, but not that which the reformers desire; that the existing arrangements of the Church of England are good enough; and that toleration in the main would be intolerable. And, indicating how the hopes of many Separatists, that the new king would be more indulgent to them than the old queen had been, were regarded by many Churchmen, he says :-

In one word the Church camnot feare a more dangerous and fatall enemie to her peace and happines, a greater clond to the light of the Gospell, a stronger hand to pull in Barbarisme, and pouertie, into all our Land, a more furious monster, to breed contempt, and disobedience in all states; a more fretting Cankar to the very marrowes and sinewes of this Church, and kingdome, than the Anabaptist [he means Brownists, Barrowists and Separatists generally]; who is prond withont learning, presumptuous without authoritie, Zealous without knowledge, holy without Religion ; in one word a dangerous and malicious Hypocrite. Sundrie of these manifest and violent disturbers of the peace of this Church and the Common-wealth, were banished from amongst vs in the dayes of our late Sonereigne, we heare they are returnd; they make petitions, they hope for fauour.

The king on his way to London ${ }^{2}$ was approached by a Puritan deputation, bearing a petition ${ }^{3}$ of sumlry ministers of the Church of England desiring reformation, and anxious to reach the royal ear before the hierarchy could elose it against them. It commonly was called the Millenary Petition, as expressing the desires of a thousand suppliants. ${ }^{4}$ It represents this great

1 A Modest and reasonable examination, of some things in vse in the Church of England, ete., 160.4, 4to, 205, 212.

2 Apr. 4, 1608 .

3 The Humble Petition of the Ministers of the Church of England, desiring Reformation of certain Ceremonies and abuses of the Church. Fuller. Bk. x: 27; Collier, viii : 267 ; Perry, $372, \mathbf{n}$.

4 Strype (IThitgift, 5fin) says: "They were some hundreds short." Collier (vii : 279) says: "There wanted some hundreds to complete the number." Fuller (v: 265) says: "There were but seven hundred and fifty preachers' hands set thereunto, but those all collected only ont of five and twenty comnties." Hook (Lives Archbps. Cant. new ser. v: 179) calls it "the great lying petition." Gardiner (i : $163)$ more truly says: "The fact seems to have been that there were no signatures at all to it." In The Epistle Dedicatory to the True, Modest and Iust Defence of this Petition, in the British Musenm (Add. Ms. S97s), which was printed by 
body of the clergy not as "factions men affecting a popular" parity in the Church," nor "as Schismatikes ayming at the dissolution of the state Ecclesiastical," but as faithful Christians and loyal subjects who can do no less than acquaint him with their griefs. They request :-

1. That, in the church service, the signing of the cross in baptism, interrogatories put to infants and confirmation may be discontinued; that baptism be never administered by women ${ }^{1}$ that the cap and surplice be no longer imperative; that examination precede, and a sermon accompany, the communion; that certain terms, such as "priest," "absolution," and the like, with the ring in marriage, be discontinued; that the length of the service be abridged, the psalmody improved, the Lord's day kept, holiday ceremonies less insisted on, and uniformity of doctrine prescribed; that no Popish opinion be taught or defended; and that bowing at the name of Jesus, and the reading of the Apocrypha be not required.

2. That no ministers be authorized but able and sufficient men, and that they be required to preach diligently, especially upon the Lord's day; that those already in service, but unable to preach, be charitably removed or compelled to maintain preachers ; that non-residence be forbidden; that the lawfulness of ministers' marriage be recognized; and that subscription be required only to the Articles of Religion and the supremacy of the king.

3. That bishops who hold prebends, parsonages or vicarages, in addition to their bishoprics, relinquish them ; that beneficed ${ }^{2}$

Brewster at Leyden in 1615, it is distinctly said (13): "No copies of the sayd petition were delivered to any beside our selues, (excepting that only which was exhibited to your Majesty) since which time no copies at all were dispersed into any quarters of the realme, much lesse into all : neither before were any hands required to it, but only consent." Probably these "consents" had been received to the full extent claimed. Supplementary circulars seem to have been sent ont from London, on June 30 following, by Henry Jacob (see p. 4:38). See circular in the Oxford Answere (viii), and also O. Ormerod's Picture of a Puritane (S) and Henry Jacob's Reasons Taken out of Gods Word (v).

1 Becanse of the Romish belief that baptism is essential to salvation. ans midwife had been authorized to baptize a dying infant when a priest could not be summoned.

2 A benefice is an ecclesiastical living endowed with a fixed income, for the maintenance of a clergyman legally responsible for conducting divine service. Its clerical holder, when formally instituted, is a beneficed man. 
men be restrained from holding two or three benefices, and sometimes three or four dignities ${ }^{1}$ in addition; and that abuses in impropriations ${ }^{2}$ be remedied.

4. That church discipline be administered strictly according to the law of Christ, or, at least, that enormities be redressed, as that excommunication go not forth in the names of lay persons, or for trifles, or without consent of the pastor; that unreasonable fees be not extorted; that divers Popish canons, such as those forbidding marriage at certain times, be abolished; that the length of ecclesiastical suits be restrained; the oath ex officio ${ }^{3}$ be used more sparingly; and that licenses for marriage without banns be granted more cantiously.

There is nothing extreme here. There is no Brownism or Barrowism, and little of distinctive Presbyterianism. There is nothing threatening danger to Church or State. Had he met these petitioners comrteously and candidly, consenting to give their requests a fair examination, and, so far as they were well founded, to do what he could, without unwise interference with existing institutions, to grant them, the majority of those who had spoken through this document would have been satisfied; most of the worst existing tronbles would have been healed; and James might have reigned over a people in the main well united in him as their sovereign. But, with all his learning, he had not learned practical wisdom, and whatever sense he had was not common sense.

Puffed up with an enormous self-conceit, he had adopted the notion of the divine right of kings in its most extravagant form. He was fond of saying "No bishop, no king." The Establishment became to him but another name for a loyal and safe civil government. This of comrse threw him under the influence of the bishops, who used their opportunity to the utmost. Janies

1 As the rank of dean, archdeacon, canon or prebendary.

2 The appropriation of church revenues to lay or private use.

8 The process was to assume that a man was guilty of some offence, although no one had accused him of it, and then make lim swear that he was not gnilty. Blackstone says (iii : 27): "It was then usually denominated the oath ex officio, whereof the high commission Court in particular made a most extravagant and illegal nse; forming a court of inquisition, in which all persons were obliged to answer, in cases of bare suspicion." It was abolished, with the High Commission Court, in 1640. 
was ignorant of the English people. Indeed, he had had little means of learning the attitude of the nation upon the subjects of this address. A wiser man would have waited and would have abstained carefully from seeming to slight such a document. Probably the majority of the clergy, and doubtless a large majority of the laity, was far from sympathizing with the millenarians. Great difficulties would have hindered any serious attempt to modify the church services. But neither king nor bishops had any intention of even seriously considering the questions raised.

It was natural, perhaps, that the first public response should come from those specially clerical centres, the universities. On June 9 Cambridge passed a grace ${ }^{1}$ that whoever in that university should attack the doctrine or discipline of the Church of England should be suspended from all degrees already taken, and forbidden all others. And, some three months later, ${ }^{2}$ the authorities at Oxford issued a pamphlet ${ }^{3}$ making brief and bitter reply to the Petition. It attempts to prove that the abuses complained of deserve no severe reprehension, least of all such changes as these "absurd Brownists" — "weake in judgment," "factious Schismaticks," in their "insolent attempts," their " childish fallacies," their " scurrile pamphlets" - have "maliciously and iniuriously" made themselves " ridiculous" by urging. To grant their requests, it is insisted, would be

so preindiciall, both to the Civil state in general, and in particular, to so many of the very best of the Ministery; that if it shoulde take effect, ... it would breede a strange alteration in the one : and in the other it would for the present, not only impoverish vs, and our Vniversities, but make both them and vs, and the whole Cleargy very base and contemptible in the eies of our own people, as also a By-word \& a

1 Camb. Univ. Trans. during Pur. Controv. ii : 203. A "grace" is an act, rote or decree of the goveruing body. See p. 438.

2 The second edition of the Oxford tract contains a letter, dated Oct. 7, 1603, from the Cambridge dons endorsing the Oxford view, and the Oxford men, inserting it in their second edition, say that it reached them "immediately after" the printing of their first edition.

3 The Answere of the Vicechanclorr, the Doctors, both the Proctors, and other the Heads of Houses in the Iniversity of Oxford. . . . To the humble Petition of the Ministers of the Church of England, desiring Reformation of certaine Ceremonies and Abuses of the Church, 160\%, 4to, iv, 22, vii, iv, 9, 10, 26, 29, 29. 
skorne to our neighbour nations; And for succeeding ages, it would cut of all hope of a learned Ministerie, and of that grounded learning, which as yet is, and heretofore hath beene, the glorie and honour of this kingdome.

A few days after this "Answere" was published, Cambridge sent over a Latin letter ${ }^{1}$ endorsing the Oxford scorn. The Oxford men got out a new edition of their pamphlet, adding these contributions from Cambridge, and so between them public contempt was put upon the movement. One of the best modern English historians says: ${ }^{2}$ -

Their demands were treated with that cool insolence which scarcely deigns to argue with an opponent, and which never attempts to understand his case. It was taken for granted that no concessions could be made by the King, unless he were prepared for the establishment of Presbyterianism, and it was argued that the hearts of the people would be stolen away from their Sovereign by preachers who would be sure to teach them that the King's " meek and humble clergy have power to bind their King in chains and their Prince in links of irö, that is (in their learning) to censure him, to enjoine him penance, to excommunicate him; yea (in case they see cause) to proceed against him as a tyrant."

In only three respects was the king prompted towards action by this petition. First, in May he instructed the Primate to ascertain how many ministers in the land could preach, with the number of communicants and of recusants in every parish. Secondly, early in July he advised the universities to adopt the recommendation of the third clanse of the memorial, ${ }^{3}$ and devote part of the impropriated tithes to the maintenance of ministers who could preach. But Whitgift objected so strongly that nothing was done. Thirdly, he caused the famous Hampton Court Conference to be held.

The proclamation convoking this announced that the king had decided that he could best show his thankfulness to God by redeeming the Church from such scandals as existed in it. But it was his business to find out what they were; and he wanted the matter left to him. He particularly cautioned " reformer's,"

1 Introd. to second ed. of Answere, 1604.

2 Gardiner, i : 166.

3 Wilkins, Concilia. iv : 36S-369. Strype, Whitgift, ii : 470. S. P. Dom. ii : 3839. 
who, " under pretended zeal, affected novelty, and so confusion in all estates." He intended to "preserve the estate, as well ecclesiastical as politic," reforming only "abuses apparently proved."

Accordingly he summoned the Primate, ${ }^{1}$ eight bishops, seven deans, one archdeacon and one royal chaplain: and, to represent the Puritans, Drs. Rainolds and Sparks and Rev. Messr's. Knewstubs and Chaderton. ${ }^{2}$ It is plain that these divines were summoned ${ }^{3}$ less for any purpose of debate than for some outward seeming of fairness, and that they might be snubbed and silenced. Dr. William Barlow, Dean of Chester, afterwards published an official account ${ }^{4}$ of the Conference. The insolence which the reformers had to endure will become evident by a glance at some things which occurred, supplementing Barlow by others.

1 Strype, Whitgift, 485, 492. These members were Arch. Whitgift, Canterbury. Bishs. Bancroft, London; Matthew, Durham; Bilson, Winchester; Babington, Woreester; Rudd, St. Davids; Watson, Chichester; Robinson, Carlisle; and Dove, Peterborough. Deans Montagu, Chapel Royal, London; Ravis. Christ Church ; Edes, Worcester ; Andrews, Westminster ; Overall, St. Paul's ; Barlow, Chester; and Bridges, Salisbury. Archdeacon King, Nottinglam. Dr. Field, Chaplain to the king.

2 John Rainolds was fifty-fonr, had been edncated at Corp. Christ., Oxford, had made special study of the Romanist controversy, had been Dean of Lincoln and Master of Queen's, and now was President of Corp. Christ. An expert Greek and Hebrew scholar, the next year he was appointed by the king a translator of the new version of the Bible. Thomas Sparks took B. A. at Magdalen, Oxford, in 1570, became rector of Bletehles, Bucks, and later chaplain to the Bishop of Lincoln and Archdeacon of Stow. He became a noted Puritan. The king is said to have converted him back to conformity at this Conference. At all events, Sparks published, in 1607, A Brotherly Perswasion to unitie and uniformitie in judgment and practise, etc., 4to. John Knewstubs, then sixty-three, had been fellow of St. John's, Cambridge, where he had united in the weekly conferences for Bible study. In 1,79 he became rector of Cockfield, Suff., and was suspended in 158.3. He subscribed the Book of Discipline, and labored privately for reform. Lanrence Chaderton, also sixty-three, was a fellow of Christ's, Cambridge. In 1576 lie disputed on Arminianism with Baro. He preached the famous Fruitful Sermon at Paul's Cross, Oct. 20, 157\&, subsequently was preacher at the Middle Temple, and iu 1584 became the first Master of Emanuel, which position he held thirty-eight years. He also was a translator of the new Bible.

${ }^{3}$ See Brook, Lives of Purs. ii : 447 ; Barlow, Sum and Subs. 23.

4 The Svmme and Sibstance of the Conference Which it pleased his excellent Maiestie to haue with the Lords Bishops, and others of his Clergie, (at which the most of the Lords of the Councell were Present) in his Maiesties Pririe Chamber, at Hampton Court, Jan. 14, 1608, 4to. Reprinted, 1707, in the Phenix (i: 139-180). See also Fuller (v: 266); Dodd (ii : 326) and Letter of Tuby Matthew, Strype, Whitgift (iii : 402). 
The parties assembled at Hampton Court on Saturday, Jan. 14-24,1603-4. The four Puritans sat down upon a bench in the Presence Chamber, where they were left during the whole day; their only consolation being that three deans, the archdeacon and the chaplain shared their exclusion. The king made "an excellent oration of an hour long." He wanted no innovation in ecclesiastical order, but complaints had been made. If the alleged evils were dangerous, he would cure them. If frivolous, he would deal with those factious Puritans so that they would neither boast nor glory. He was holding this preliminary private interview with the bishops, so that, if anything needed to be done, it could be arranged beforehand.

He then referred to three subjects upon which he wanted light: the Prayer-book, excommunication, and the religious state of Ireland. Under the first head he asked whether confirmation implied that baptism were invalid without it, whether baptized infants needed to be examined in adult years, what absolution meant, and whether private baptism by women and laies were tolerable. As to the second, he inquired if men were excommunicated for too light causes and too often. As for Ireland, he wanted it planted with schools and ministers. The archbishop on his knees blessed God "for setting ouer vs a King so wise, learned and iudicious," and went on to "enforme his Maiestie of all these pointes." A general discussion of some hours followed, the king " disputing," as Dean Montagu wrote, ${ }^{1}$ " with the Bishops so wisely, wittily and learnedly, with that pretty patience, as I think never man living heard the like."

On Monday forenoon the four Puritans were called in. Only the Bishops of London and Winchester, ${ }^{2}$ with the deans and doctors, were present, excepting Prince Henry and Mr. Patrick Galloway, ${ }^{3}$ sometime of Perth. The king repeated part of his speech of Saturday, and informed the Puritans that he would hear them. They kneeled down and Rainolds spoke a "short preamble gratulatory," and then explained their desires in these four points :-

1 E. Law, Hist. Hamp. Ct. Pal. ii : 35.

2 Toby Matthew in Strype, Whitgift, iii : 404.

3 One of the king's Scotch chaplains. 
1. That the Doctrine of the Church might be preserued in purity, according to God's Word. 2. That good Pastors might be planted in all churches, to preach the same. 3. That the Church gonernment might be sincerely administred according to God's Word. 4. That the Book of Common Prayer might be fitted to more increase of pietie.

He had not proceeded far when Bancroft, Bishop of London, interrupted him, begged the king to enforce the ancient canon that schismatics are not to be heard, and sneered at the four Puritans for coming before the king " in Turky gounes, not in their Scholastical habites, suiting to their degrees." The king, however, had the justice to rebuke the bishop.

Without following the discussion, it is enough to notice that Rainolds and Knewstubs, who spoke for the Puritans, were subjected to a running fire of sneers and invective. One of their objections was " a meere cauil." Another suggested the remark, "a Puritane is a Protestant frayed out of his wits." Knewstubs was informed by James that he did not know what Knewstubs meant, and the lords, when appealed to, politely declared themselves equally uncertain. The king himself went rampant. ${ }^{1}$ He repeatedly aired his favorite saying: "No bishop, no king;" and said: "If these be the greatest matters you be griened with, I neede not haue bin troubled with such importunities and complaints." He joined in the sneers. He did not want the "subscription of Laikes \& Idiots." Speaking of Christian liberty, he declared: "I will none of that; I will haue one doctrine and one discipline, one Religion in substance, and in ceremony." He said of the objecting Puritans :-

I haue liued among this sort of men ... ener since I was ten yeares old, but I may say of my selfe, as Christ did of himselfe: Though I lined among them, yet since I had ability to indge, I was neuer of them; neither did anything make me more to condemne, and detest their courses, then that they did so peremptorily disallow of al things, which at all had been vsed in Popery.

And, in reply to some plea about the presbyters of the churches, he blazed out: -

A Scottish Presbytery which . . . as wel agreeth with a Monarchy, as God and the Devill. Then Jack \& Tom, \& Will \& Dick, shall

1 Sum and Subs. $30,46,66,71,72,79-83$. 
meete, and at their pleasures censure me, and my Councell, and all our proceedinges: Then Will shall stand vp, and say, it must be thus ; then Dick shall reply, and say, nay, mary [marry], but wee will hane it thus. And therefore, here I must once reiterate my former speech, Le Roy s'ainsera: Stay, I pray you, for one senen yeares before you demaund that of mee, and if then you find me purseye and fat, and my winde-pipes stuffed, I will perhaps hearken to you : for let that goxernement bee once vp; I am sure I shall bee kept in breath; then shall we all of vs, hane worke enough, both our hands ful. But Doctor Reyn[olds]. till you finde that I grow lazy, let that alone.

Barlow adds that, as James withdrew, he tartly remarked: "If this bee al that they haue to say, I shall make them conform themselves, or I wil harrie them out of the land, or else doe worse."

Even as smoothed over by the courtly phrasing of this prejudiced chronicler, the record renders it clear that the ling and the prelates gave the Puritans no fair chance; and, indeed, treated them with discourtesy. And, according to more impartial reporters, his Majesty and the bishops appear to even less advantage. After this second meeting, Sir John Harrington, of the Privy Council, wrote $:^{1}-$

The King talked much Latin, and disputed with Dr. Reynolds; but he rather nserl upbrailings then arguments; told them they wanted to strip Christ again, and bid them "away with their snivelling." Moreover he wished those who wonld take away the surplice, " might want limnen for their own breech." The Bishops seemed much pleased, and said his Maiestie spake "by the power of inspiration." I wist not what they mean; but the [inspiring] spirit was rather foul-mouthed.

The final session was on Jan. 18. The bishops and deans all were present, reinforced, by royal order, by the five Knights and Doctors of the Arches; ${ }^{2}$ the four Puritans being left sole tenants of the bench in the Presence Chamber. After the report of the archbishop and the bishops, recommending three or four trifling changes in the rubrics, discourse turned to the High Commission, and the king defended the oaths compurgatory and cx officio in case of certain offences. It will illustrate

\footnotetext{
1 Harrington's Briefe Notes in Nugae Antiquae, i : 181.

2 Sir Daniel Donne, Sir Thomas Crumpton, Sir Richard Swale, Sir John Bennet and Sir Drew Drury.
} 
the extent to which flattery could be carried by grave men in high station to cite Barlow's account of what followed the king's speech. ${ }^{1}$

All the Lords and the rest of the present Auditors, stood amazed at it: the Archbishop of Canterbury said, that undonbtedly his Majesty spake by the speciall assistance of God's spirit, The Bishop of London upon his knee, protested, that his heart melted within him, (and so hee doubted not, did the hearts of the whole Company) with ioy, and made haste to acknowledge unto almighty God, the singular mercie wee have receined at his hands. in giving us such a King, as since Christ his time, the like he thought hath not beene, whereunto the Lords, with one voyce, did yeeld a very affectionate acclamation. The Ciuilians present, confessed, that they could not in many houres warning, hane so judiciously, plainly, and accurately, and in such a briefe described it.

The ling then requested the lords and bishops to consult further on some minor matters, and, finally, the four Puritans were called in and told what had been determined. A little questioning and disputing was about to follow, when

his Majesty shut vp all with a most pithy exhortation to both sides for unity, perswading diligence in each mans place, without violence on the one party, or disobediēce on the other and willed them [the Puritans] to deale with their frieds abroad to that purpose: for his Majesty feared, and had some experience, that many of them were ticklish and humorous [capricious]; nor that only, but laborers to pervert others to their fancies; he now saw, that the exceptions against the Comunion Booke were matters of weaknesse.

Under the circumstances Rainolds and his colleagues felt that no more could be said; excepting that Chaderton begged that the wearing of the surplice and the use of the cross in baptism might be remitted to some ministers in Lancashire, who feared lest, were they driven to use them, some of their people would slide back into Popery. The king promised to inquire and that, if he received good testimony about these ministers, he would instruct the Bishop of Chester to be considerate with them.

Knewstubs then pleaded for a similar favor for "some honest Ministers in Suffolke." Whitgift had half uttered an answer

1 Sum and Subs. 96, 100, 104, 106. 
when James said sharply: "Let me alone with him," and went on : -

Sir, saith the king, you shew your selfe an uncharitable man, wee have here taken paines, and in the end haue concluded of an unitie, and uniformity, and you, forsooth, nust preferre the Credits of a few private men, before the generall peace of the Church.

Thus ended, in disappointment, injustice and insult, what easily might have been the brightest and most hopeful day which England yet had seen, to say nothing of its relation to the new reign from which so many had hoped so much. It was decided that that policy of brute force over the sonls of men, which many hoped would be left to the darkness of past years, should be kept alive to distract England for years to come. Whitgift, who had many noble qualities, although usually unfair and severe towards the Puritans, was near his end, and it may not be strange that his essentially narrow mind helped to shape what took place. But Bancroft was in his prime.

James disclosed his own spirit in a letter remaining in his own handwriting, apparently written the next day : ${ }^{1}$

We haue kept suche a renell with the Puritanis heir [here] these two dayes, as was neuer harde the lyke, quhaire [where] I haue pepperid thaime as soundlie as ye hane done the papists thaire; it waire no reason that those that will refuse the airie signe of the crosse after baptisme should hane thaire pursis stuffid with any mōe solide and substantiall crossis. Thay fledde me so from argument to argument without euer ansouring me directlie, ut est eorum moris, as I was forcid at last to saye unto thaime, that if any of thaime hadde bene in a colledge disputing with thair skollairs, if any of thaire disciples had ansoured thaim in that sorte, thay wolde haue fetchid him up [tied him up for a flogging] in place of a replye, and so shoulde the rodde have plyed upon the poore boyes buttokis. I have such a booke of thairs as maye uell conuerte infidellis, but it shall neuer conuert me, except by turning me more earnistlie against thaim.

1 Cot. Ms. Vespasian, F. iii : 71. This letter begins: "My lonest blake, I darre not saye faced 3" - which seems nonsense - and usually has been said to have been written to some unknown Mr. Blake in Scotland. But Gardiner (Hist. Eng. 174) notes that in James's cipher " 3 " always means "Northampton." He therefore regards the letter as written to Henry Howard, Earl of Northampton, who, although a Catholic, was a favorite with James, and had taken part in Cecil's gecret correspondence with him while he was still in Scotland. Gardiner reads the line thus: "MI howest black, I dare not say [black-] faced Northampton." 
As for the State Church, the net results of the Conference ${ }^{1}$ were these: the forbidding of baptizing by women; the insertion of "remission of sins" in the rubrie of absolution; the dilution of the term "confirmation" by the phrase "an examination of children;" the alteration of a few words in the Dominical Gospels; and a resolution that there be a revision of the Bible, which Rainolds has the credit of proposing. These gains only made a bad matter worse for the Puritans by convincing them that they had nothing else to hope for from the new reign. A few years more elapsed, however, before they reached the sad conclusion that even the most blameless and useful Christian life would not be permitted outside of the Establishment. And these continued to be years of discussion.

From the statesman's side came out, in 1604, a powerful volume $^{2}$ by Prof. William Stoughton, who had troubled Dr. Cosin and others, twenty years before, by his "Abstracte of certain Acts of parlement." It answers passages in Whitgift's reply to the "Admonition." It argues that the planting of a new ecclesiastical government will not subvert existing laws, because the whole Papal law is abolished by the twenty-fifth statute of Henry VIII. It insists that the Crown cannot give to prelates any power properly called spiritual; that the common manner of election in the old churches was by the people; and that there need be no fear lest the return to that practice work harm. As to the great question in what manner the proposed polity would affect the king, it says : -

Neither is there any cause for anie Monarch in the world, to feare the making of christian commō people, by familiar experience, to have the sence \& feeling of the principles and reasons of Aristocracie. For if a people hane once submitted their necks to the yoke of Christ, they can liue a peacable \& godly life, vnder all kinds of powers, because they knowe all kind of powers, to be the ordenance of God. But especially, there is not, neyther euer was, neyther euer can there be, any cause for any King, or Monarch of England, greatly (as the

1 Fuller, v: 304; Rymer, xvi : 565, 574.

2 An Assertion for true and Christian Church-Policie. Wherein certaine politike obiections made against the planting of Pastours and Elders in Enery Congregation, are sufficientlie aunswered, etc., 1604, 16mo, 40-81, 50, 205, 235, 359, 363. A second edition was published in 4to in 1642 by the author's son. 
Admonitor insinuateth) to feare, that the common people, will very easely transferre the principles, and reasons of Aristocracie, to the gonerment of the common weale; and therevpon bee induced to thinke that they hane iniurie, if they have not as much to doe in civill natters, as they have in matters of the Church.

Later it ingeniously turns this consideration end for end, urging that the people will not feel aggrieved if they have not as much to do with the Church as with the State. It was not in the power of books, however, to alter the king's intense dislike of Presbyterianisin.

The old direct controversy with the Papists kept droning on. In 1602 a reply ${ }^{1}$ to the Preface of the Rhemish Testament appeared, reprinted sixteen years afterwards by Brewster in its place in the folio which it introduces. It makes this point at the outset:-

The true religion being like the heauenlie bodies which neuer change: the Popish religion resembleth the earth, which as the potters claye is readie to receaue any forme. . . . Hereof it is that they which sometyme did so deadly hate the instruction of the youth, in the groundes \& principles of religion; that they coulde not heare the worde of Catechisme with patient eares: nowe in feare of a generall falling from them through opinion either of their blockish ignoraunce or sluggishe negligence; are constrayned both to write and teach their Catechismes.

In 1603 Dr. John Dove, a Christ Church, Oxford, man and rector of St. Mary Aldermary, London, published a volume, ${ }^{2}$ reprinted the next year, seeking to reconcile English Papists to the Church of England. He added a final word to Protestants, reminding them that the way "to restore them which haue fallen " is "by gentlenesse." Sir Francis Hastings, also an Oxford man, "a severe Puritan and Presbyterian," had published several small treatises in the Papal controversy which in 1602 called out a reply ${ }^{3}$ from Robert Persons, the famous Jesuit,

1 Sun Theo en Christo: The Ansvvere to the Preface of the Rhemish Testament. By 'T. Cartwright, 1602, $16 \mathrm{mo}, 63$.

2 A Persu'asion to the English Recusants, to Reconcile themselues to the Church of England, etc,, 1603, 4to. The Brit. Museum copy has on its title-page the autograph of some "Jo: Robinson." The date and authorship of the book make it likely that he was the Pilgrim, and the Library authorities so believe.

3 The Warn-Word to Sir Fr Hastinges Wast-word, 1602, Svo. 2d encounter, 33 verso, 197 verso. 
sometimes known as Nicolas Dolman. It terms John Foxe " the most famous lyer that ener perhaps took pen in hand ;" and claims the Roman Catholic Church to be a unit while the Protestants are divided scandalously.

In the same year Gabriel Powel, also of Oxford, sought to strike Rome and possibly to stimulate the king against Papists. His little book ${ }^{1}$ balances opposite considerations on confronting pages, thus appealing to the common mind with force. In 1604 many Roman Catholies memorialized the king, although not addressing him directly but circulating their memorial ${ }^{2}$ for popular effect. They asked only for lieense to practise their religion privately, and suggested that such permission would aid the ling against the "presuming, imperious" Puritan, and strengthen the throne by propitiating "all the Catholike Kings and Rulers in Christendome," who far outnumbered the Protestant sovereigns. This drew out an immediate reply, ${ }^{3}$ which urged reasons of State against what was asked, and objected also on "grounds of true Christian Religion;" following the appeal section by section and almost line by line. In $1605 \mathrm{Johm}$ Radford, who had been ordained priest at Douay in 1587 and sent home in 1589 to labor privately, printed a volıme ${ }^{4}$ which evidently aided in recruiting for the Pope in England. 5 It begins well, with declarations that there is but one truth, to be learned only of Christ. But, in answering the question, "How may I then an vnlerned man cliscerne the light of the truth," it artfully suggests that the Papal chureh is the only one of which Christ knows anything, and that "to goe to the heretiks Church is to deny Christ for Christ is the truth." Almost contemporaneously was reissued another earnest volume ${ }^{6}$ on the

1 The Catholites Supplication vnto the Kings Maiestie; for Toleration of Catholike Religion in England, ete., 1605, 4to, 39, 5.

2 A Supplication to the Kings most excellent Maiestie, Wherein, seuerall reasons of State and Religion are briefely tourhed, etc., 4to. Repr. in the reply to it, 3, 4, 5, 8 .

${ }^{3}$ The Supplication of Certaine Masse-Priests falsely called Catholikes, etc., 1604, 4to.

4 A Directorie Teaching the Way to the Truth in a Briefe and Plaine Discovrse against the heresies of this time, etc., 1605, 16mo, 1. 4, 497.

${ }_{5}$ Autobiog. of Fath. Thos. Manby, alias Rogers. Recs. Eng. Prov. Soc. Jesus, xi : 603.

${ }^{6}$ A Survey of the New Religion, Deterting Many Grosse Absurdities which it implieth, etc., 1605, 4to. Epis. to King: 13 ; Epis. to Comeil : $7,394$. 
Papal side, somewhat enlarged and with a special address to the Privy Council, by Dr. Matthew Kellison, then reading divinity lectures at Rheims and within a year of the presidency at Donay, which he held until his death. He labors to demonstrate the great difference between the Catholic religion and the new doctrines, but his work is a plea rather than an argument, and made very little impression. It was answered soon, and very sharply, by Dean Sutcliffe, of Exeter. ${ }^{1}$

One of the fellows of St. John's, Cambridge, was Thomas Morton, afterwards Bishop of Chester, Lichfield and Coventry, and Durham, who had held some public discussion with Romish reensants, and was urged by Bancroft, now Archbishop of Canterbury, to reply to a plausible recent volume ${ }^{2}$ by John Brerely - really James, or Laurence, Anderton, of Lostock, Laneashire. ${ }^{3}$ Morton prepared an elaborate argument ${ }^{4}$ defending the English Chureh, founded upon the concessions of Romanists and issued, in two parts, in 1605-6. It is very learned, and the Romanists could avoid its force only by the twofold plea that the Papal authors cited were not representative, and that the varions disagreements between them did not concern essentials. Sutcliffe ${ }^{5}$ aired his vocabulary of abuse once more, prompted by a tract of the Jesuit, Robert Persons, but neither said anything worth mention. Persons ${ }^{6}$ also paid his respects to Morton, in 1607 , scolding him for being a hypocrite and liar.

A quieter and wiser treatment of the Papists was offered by Richard Field, whose treatise ${ }^{i}$ on the Church has held a place in the literature of the English Establishment perhaps only

1 The Examination and Confutation of a certain scurrilous treatise entituled, The survey of the neve Religion, etc., 1606, tto.

2 The Protestants Apologie for the Roman Church, 1604, 4to.

3 Dodd, ii : 356-387.

4 Apologia Catholica ex meris Iesuitarum contradictionibus conflata, etc., 1605, 4to, and Apologiae Catholicae Pars Secunda, etc., 1606, 4 to.

5 The Blessings on Movnt Gerizzim, and the Curses on Movnt Ebal: or the Happie Estate of Protestantes, compared with the miserable Estate of Papists vnder the Popes Tyrannie, 4to, 380.

6 A Treatise tending to Mitigation tovvardes Catholicke Subiectes in England, etc., by P. R., $1607,179,237$.

' Of the Church. Four Bookes. By Richard Feild, Doctor of Dininitie, 1606, 4to, iii : 15, 16, 40, 72, 59, 54, 55; and The Fifth Booke of the Chvrch, Together with an Appendix, etc., 1610, 4 to. 
second to Hooker's. He rose to be a canon of Windsor and a chaplain to the king. He is said to have been a friend of Hooker in his last years. In 1606 he published his first part, the second following four years later. His style is in refreshing contrast to Sutcliffe's. He is fair and usually mild and courteous.

His first book defines the Church, the second describes it, the third identifies it, and the fourth expounds its privileges. The Church is the body of those whom God calls by knowledge and sanctifies by grace. But some are partial in knowledge, and therefore hereties; some not in unity, and therefore schismatics; some in unity, yet not in sincerity, and therefore hypocrites; all these being in the Church as opposed to infidels and open unbelievers. The true Catholic Church always is distinguishable from Pagans, Jews, heretics and schismatics by three essential notes: the profession of those supernatural verities which God has revealed in Christ, the use of such holy ceremonies and sacraments as he has ordained, and a union of men in this profession and use under appointed pastors. The Latin Chmreh used to be the true Church, but needed reformation when Luther came.

This true Church Dr. Field identifies with the Reformed Churches, which, although they neither are,

nor perhaps hereafter shall bee, in all, or the most parts of the worlde, yet are they catholique, for that they doe continuate themselues with that Chureh, which hath been, is, or shall bee, in all places of the worlde, before the comming of Christ, and uncloubtedly already hath beene in the most part thereof.

When the fifth book, treating of the office of the Church, came out, it indicated a moderation in marked contrast with Bancroft's High Church claims. If men of the spirit of Field had controlled affairs, the Puritans might have had some chance within the Church. But the bishops and the king - and over them a higher Power, for his own wise reasons - had decreed otherwise.

Two attacks of another sort upon Romanism in 1606 help to show the public dread of it. Much the more important is a little anonymous treatise ${ }^{1}$ suggested by a conversation at a dinner-

1 A Reporte of a Discourse concerning supreme power in afaires of Religion. Manifesting that this porcer is a right of Regalitie inseparably annexed to the Soutraigntie 
table. It argues against Papal supremacy in England. The other was by Oliver Ormerod, of Emannel College, Cambridge, and after'wards of Huntspill, Somerset, who, having issued the year before a "singular volume 1 "made dialogue-wise" against the Puritans, now printed a similar one ${ }^{2}$ against the Romanists. A passage from it illustrates the current style and the common line of argument. A rector finds a parishioner praying before a cross and accosts him : -

Minister: How now, neighbour, have I found you crouching to a Crucifix? ...

Recusant: . . . let me make an end of my prayers, and then I will come and conferre with you.

M.: No, neighbour, God loneth alacritie in his worke; excuses he much disliketh. The delay that Elizens made, let me go kisse my father, and those shifts in the Gospell, let mee goe burie my father, or take leaue of my frinds, are not admitted in the Lord's businesse: noe more is this of yours, let mee make an ende of my prayers.

$R$. : Yes, I pray you gine me leane.

$M I .:$ I pray you intreate me not; for I dare not give you leaue to commit idolatrie.

R.: Idolatrie? Do you charge me with idolatrie?

$M$. : It is an old saying, and $I$ see that it is true, not onely in corporall whoredome, but in spirituall [Prov. xxx: 20] an adulterous woman eateth; and after wipeth her month, and saith, I haue not committed iniquitie. With what face can you denie your selfe to be an idolator? hane I not taken you in ipso fucto?

$R$. : You hane taken me indeede praying before a crucifixe, but I hope you accomt not that Idolatrie.

M.: Yes, Saint Ambrose [de Obitu Theodos] telleth you, that to worship the Crucifixe is grosse idolatrie: and before him Arnobius made this answer in the behalfe of all true Christians [Adversus Gentes. Lib. 8] Cruces nec colimus nec optamus: vos plane qui ligneos deos consecratis, cruces ligneas, ut deorum vestrorum partes, forsitan adoratis. We neither worshippe crosses, nor wish for them,

of Euery State, etc., 1606, 8vo. Possibly this may have been a rudimentary issue of Sir John Hayward's Of Supremacie in affairs of Religion, printed in 1624.

1 The Pictore of a Puritane: or, a Relation of the opinions, qualities, and practises of the Anabaptists in Germanie, and of the Puritanes in England, etc., 1605, 8vo.

2 The Picture of a Papist: or, a Relation of the damnable heresies, detestable qualities, and diabolicall practises of sundry hereticks, in former ages and of the Papists in this age, etc., 1606, svo, 1. 
you that consecrate woodden Gods do happily adore woodden Crosses. as parts of your Gods. In a word, you may as instly be tearmed Chazinzarij \& Staurolatrae, as the Armenij: for you worshippe the Crosse of Christ as well as they.

$R .:$ No, we worship not the Crosse it selfe, but Christ that was crucified on the Crosse.

MI.: Yes, Thomas Aquinas, Alexander de Hales, Gregorie de Valentia, and the rest of your chiefest doctors doe teach, that Crucifixes are to bee worshipped with the very same worship, wherewith Christ himselfe is to be worshipped.

$R .:$ I Aunswere with Cardinal Bellarmine, that albeit Crucifixes are to be worshipped with the same worship; yet is it with respect to Christ: and that the worship passeth by the image to him.

$M$. : This shift will not serne your turne; for to co-adore the crucifixe with Christ, is palpable Idolatrie, as may be prooued by the determination of the Councell of Ephesus.

$R$. : How I pray you?

M.: Nestorius conceined the manhood of Christ to be a distinct persō from the word, or sonne of GoD: and withall he framed a co-adoration, whereby this manhood was to be adored with the word. Now the Counsell of Ephesus condemned this co-adoration: in like sort may we condemne your co-adoration of the crucifixe with Christ.

Of course there was discussion of general points of theology during these years, but it hardly needs mention here. The descent of Christ to the underworld, as to which, possibly in deference to the views of Calvin, the Third Article had been altered in the last revision under Parker, was discussed. Bilson ${ }^{1}$ and other's ${ }^{2}$ labored to refute Calvin, and Broughton ${ }^{3}$ took the other side, and even went so far as to write to Geneva upon the subject in Greek. ${ }^{4}$

1 The Svrvey of Christs Sufferings for mans redemption; and of his descent to Hades, or Hel for our deliuerance, 1604, fol.

2 A Treatise of the Sufferings and Victory of Christ, in the work of our redemption, etc., 1598, 16mo. Signed H. I., i. e. Henry Jacob.

A Briefe Answere vnto certaine obiections and reasons against the descension of Christ into hell, etc., 1604, 4 to.

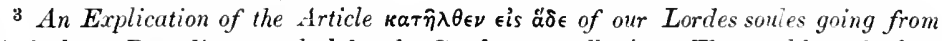
his body to Paradise; touched by the Greek, generally ádou, The vrorld of Soules ; termed Hel by the old Saxon, \& by all our translations: with a defense of the $Q$. of Englands religion, etc., 1605,4 to.

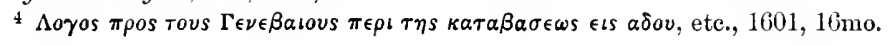




\section{CHAPTER VI}

\section{THE CONTROVERSY CON'TINUED}

Within the Establishment discussion upon points questioned by the Puritans and the Separatists went forward steadily. Among other volumes some unidentified breath — "I. F." blew a short blast in Latin upon a "Tuba Academica." " The writer is severe upon the Puritans as being specially obstinate, quarrelsome, and ambitious to appear better than other's. But evidently his book passed quickly into obscurity. To understand the full force of the general discussion, those acts of the government which provoked it must be noted. While Whitgift still was lying unburied at Lambeth, the king sent out a proclamation ${ }^{2}$ upon the Prayer-Book. He had been "importuned with informations, very specious," and "the complainers" had held assemblies without authority, and otherwise were "carrying a verie apparent show of sedition, more then of zeal." The Hampton Court Conference had been held, with "small effects." There really was no ground for any change, but, that the "public form" should "be free, not only from blame but from suspicion," it had been thought best "that some small things might rather be explained than changed." This had been done. A new Prayer-Book had been printed, incorporating these explanations; and now must be used "as the only publick form of serving God, established and allowed to be in this realm." And the new whip ended with this snapper:-

Last of all we do admonish all men, that hereafter they shall not expect nor attempt any further alteration in the common and public form of God's service, . . . for that neither will we give way to any to presume, that our own judgment hauing determined in a matter of

1 Tuba Academica, qua Patruın antiquorum defensionem Author liberè audacterque suscepit, etc., 11803, $16 \mathrm{mo}, 28$.

${ }^{2}$ Cardwell, ii : $76,79$. 
this weight, shall be swayed to alteration by the frivolous suggestions of any light spirit; neither are we ignorant of the inconveniences that do arise in gouernment, by admitting innovation in thinges once settled by mature deliberation.

A fortnight after this assumption of spiritual authority by the new monarch, Parliament and Convocation met for the first time under his reign. The king not only interfered beforehand in the elections, but also, in his speech at the opening of Parliament, attacked the Puritans. They were confused in policy, ever discontented with the government, and "scarcely to be endured in a well regulated Commonwealth." Such language was singularly ill-advised before a House of Commons of which it was said that three out of four were Puritans, or Puritanically inclined. ${ }^{1}$

Convocation spent its time mostly in discussing "such Canons, Orders, Ordinances, and Constitutions" as were thought needful. The result ${ }^{2}$ soon was published, and chilled the heart of every one who hoped for reform. It begins by condemning every one who impugns the king's supremacy over the Church or says that the Church of England is not a true and an Apostolical Church, etc. It further denounces all who separate themselves from the State Church, combine in a new brotherhood, and affirm that ecclesiastical rules may be made without the royal anthority. All such persons become excommunicates. Further, every parishioner must receive the communion at his rector's hands at the least thrice in the year, including Easter; and all students in colleges four times a year at least. Every candidate for the ministry must subscribe three articles ; asserting (1) the royal supremacy in all spiritual or ecclesiastical things as well as temporal; (2) that the Book of Common Prayer contains nothing contrary to the word of God, and that he himself will use it "and none other" in worship; and (3) that the Thirty-nine Articles are "all and every" agreeable to the word of God.

It also decrees that the licenses of all non-conforming minis-

I S. P. Dom. vii : 2.

2 Constitutions and Canons Ecclesiasticall, etc., 1604, 8vo, 3, 4, 7, 8, 9, 17, 18, 36$38,52,73,110,14 \%$. 
ters, remaining such after admonition, shall be void; that, on pain of excommunication, no religious meetings shall be held in private houses; and that all whom church wardens, questmen or assistants regard as schismatics shall be presented to the bishop's court. These stringent statutes are flanked by a royal proclamation that every minister should read them to his congregation in church once a year.

As Convocation was prorogued on July 9, this code of church canons probably was sent forth before the summer was over. As petitions had been offered both in Parliament and Convocation for reform in the Prayer-Book, and as many ministers evidently still retained their livings who favored the Genevan discipline, the king made a further effort for miformity. On July 16 he issued another proclamation, ${ }^{1}$ declaring that, the matter having been settled, conformity must be insisted upon and pretended reformers punished. Accordingly he gives them until the last of November to decide. Unless they conform by that date, they must "dispose of themselves and their families some other waies." He expects all church officials and civil magistrates to "do their uttermost" to bring about the desired result. The king received vigorous aid. On Dec. 4 Bancroft was consecrated as primate. His hard and narrow mind could conceive but imperfectly that the Puritans were acting from conscience. ${ }^{2}$ He therefore felt no compunction in sternly enforcing the law. Before the close of his first week with the Council he had begun this work.

Some Englishmen, however, would not submit to all this in silence. Acting with cantion, they managed to reach the public through the press with both profoundly reasoned and more popular appeals. One of the first of the latter was another dialogue, ${ }^{3}$ between a Puritan Old Protestant and a New Formalist, attributed to Rev. Samuel Hieron, of Modbury, Devon. ${ }^{4}$ The first speaker asks for the latest news, and is answered :-

1 Cardwell, ii : 80-84.

2 Wilkins. Concilia, iv : 410, 408-409.

${ }^{3}$ A Short Dialogue proving that the Ceremonyes and some other Corruptions now in question, are defended by none other Arguments than such as the Papists haue heretofore vsed: and our Protestant writers have long since answered, etc., 1605, 4to, 36,50 .

${ }^{4}$ Brook, Puritans, ii : 271. 
Old Protestant: Sir, I heare a very pitifull and generall complainte of well disposed people for the suspending, deprining, and silencinge of theyr preachers, especiallye in Northamptonshire, where very many have bine soe proceeded with, and I heare that the like course is taken also in other Countries [counties] in so much as it is certainely reported, that the number of such as are beprived [deprived], silenced, suspended, and admonished; amounts to the some of 275 . at the least: (which is a very lamentable thing, specially in so great a want) besides many others that are in questio, and many others who being of the same indgment \& practise are like to be talked withal, and in the same sorte proceeded with, when the Bishops will.

After explaining, in answer to New Formalist, that the Puritan of the day was none other than the True and Old Protestant, the author concludes by a reference to the painfulness of the situation. ${ }^{1}$

A second dialogue, ${ }^{2}$ by Samuel Gardiner, was on the other side. Irenaens thinks that Antimachus appears sad, and is told : - -

I am sad indeed, because I may not vse the liberty of my conscience, and because for conscience sake onely I am depriued of my lining.

Irenaeus fears that Antimachus is " not conformable" and has fallen under censure of the law, and learns that he has hit "the onelye argument" of his friend's tronbles. The inquiry proceeds : -

Iren. And why may not you with a good conscience digest the orders of the Church, as well as others, that are grane, and learned and are not to be tonched with Popery, for order and peace sake?

Antimachus mentions many reasons which they discuss; first agreeing that he who proves to have the weaker side shall yield. The priestly garments and the cross in baptism then are considered at great length, Irenaeus of course being the victor. Whether just or exaggerated, the author's picture of the situation probably had some foundation.

1 Twenty pages follow devoted to Certayne Reasons why it seemeth that the Preachers who refuse the Subscription and Ceremonies urged, should not for that the ir refusall be remooved from their charges, or inhibitted to preach: humbly offered to consideration.

${ }^{2}$ A Dialogue or Conference betweene Irenaeus and Antimachus, about the rites and Ceremonies of the Church of England, 1605, 4to, 1,54. 
The very Sowter [shoemaker] and cobler now adayes, . . . will bee so bold as to give a blow to them that are his head, with the fist of his eluishness. The Cooke, ... wil . . be sawcing Diuinity \& be too saucy with it : . . A frivolous Fidler, if hee be not harping vpon this string, the Churches gouernment, as the biasse of the worlde now goeth, is out of his element. Euery Tailor hath his shredding sheares for the ceremonies, and hath a measure of his owne for the matters of the Church. The Smiths prentise wil not stand out, but listeth to blow the coales of contention among vs. The common people will take rpon them to put on Aarons raiment, the Rochet and habite of a Bishop and Minister, and teach him what to do, and how to shape his sermons to sute their affections. Now to all of you, howsoere ye be stiled, that are of the brotherhood of these busie bodies, I wish more heede and attendance be given to your senerall vocations, and not so to leane your selues as you do, and take such vagaries with the prodigall sonne ... into so farre a countrey, the matter of Church gouernment being so farre and wide from your profession, and not to be spanned and fadomed by the length and reach of your discretion.

About this time appeared a closely reasoned anonymous argument, ${ }^{1}$ addressed to the Archbishop of Canterbury and the Bishops of London, Lincoln, Worcester, Exeter and Peterborough, inquiring whether a Christian magistrate have the right to give orders touching the worship of God, not having the word of faith for his warrant in the same; or to enjoin the use of any one garment as essential to ministerial service; or, if so, to enjoin such a garment not differing in matter and form from that already appropriated by "Idolatrous Priestes in their Idoll service?" Then, in an imaginary colloquy, the prelates insist that they do not take the things complained of from the Papists, but from their predecessors; and, in fact, are restoring these "superstitious abuses" to their ancient integrity. To which their questioners reply:-

Your Lordships argument of such ancientie, and of such integritie of these ceremonies, as declineth from that ancient, and in al poyntes and qualities certeyne and vpright forme of Gods worshippe...

1 Certaine Demandes with their grounds, drawne out of holy Writ, and propounded in foro conscientiae by some religious Gentl vnto the reverend Fathers, Richard, Archbishop of Canterbury, Richard Bishop of London, William Bishop of Lincolne, Garvase, Bishop of Worcester, William, Bishop of Exeter, $\&$ Thomas, Bishop of Peterborough, ete., 1605, 4to, 4, 64, 67, $6 \mathrm{~s}$. 
argueth rather corruption and noveltie, then eyther any ancientie or integritie.

And they finally declare :-

Ministers notwithstanding hate nothing more than Noveltie, and crave nothing so much as that the most certeyne and most single forme of Gods worship, left to the Cluurches, by the Apostle, without your many, and vncerteyne rites and ceremonies, might be restored, to her' primative and Apostolicall ancientie and integritie.

When November came, 300 ministers ${ }^{1}$ are said to have been deprived at once. They did not eease discussion, however. Early in December sundry ministers in the diocese of Lincoln appealed to the king. ${ }^{2}$ They objected to the Prayer-Book, first, that in different ways it was unscriptural and misleading; secondly, that it enjoined ceremonies contrary to God's word. As to ceremonies they said: "They cannot be used without iust cause of greife giuen to many of the godly, and scandall both to the weake brethren, and to the wicked," and explained and enforced this point at length.

Other ministers in other counties followed. Nor were they unsupported by the laity. On Feb. 9 the king was petitioned ${ }^{3}$ in aid of the deprived ministers by forty-fom gentlemen of Northamptonshire. Sir Francis Hastings, now a member of Parliament for Somerset, who had drawn up the paper, was confined to his country house. A few others met with similar treatment. And the king bade the universities admit no one to a degree thenceforth who had not taken the oath of supremacy and another oath ${ }^{4}$ of allegiance to the Episcopal, as opposed to the Presbyterian, ideal of church government.

1 Collier, vii : 321. Gardiner says (i: 213, n.): "The number has been esti: mated as low as 49; but the arguments in Vaughan's Memorials of the Stuarts seem to me conclusive in favour of the larger number. To the authorities quoted there may be added the petition of the Warwickshire ministers [S. P. Dom. xi : 68], who speak of 27 being suspended in that county alone; thongh the Bishop expressed his sorrow for that which he was forced to do."

${ }^{2}$ An Abridgment of that Booke which the Ministers of Lincoln Diocess delivered to his Maiestie upon the first of December last, being the first part of an Apologye for themselues and their brethren that refuse the subscription, and conformitie which is required. 1605, 4to. Passim and 49.

3 S. P. Dom. Jas. I. xi : 69, $95,74$.

4 S. P. Dom. Jas. I. xiii : 63. 
Considerable discussion followed. Thomas Hutton - a fellow of St. John's, Oxford, who later became vicar of St. Kew, in Cornwall, and a prebendary of Exeter - published two volumes ${ }^{1}$ against the Nonconformists, condemning them severely. A vigorous reply ${ }^{2}$ came out speedily from some unnamed author, who denies and disproves Hutton's imputations. It is needless to cite all the volumes which this discussion soon produced, although a glance at some titles ${ }^{3}$ suggests the extent and the character of the popular feeling. The deprived ministers had reason to complain of great injustice indirectly shown them. as well as in their exclusion from their livings. One of them spoke thus : ${ }^{4}$ -

Whereas our not approving by Subscription the former faultes is one and a cheefe cause for which so many of us are turned out ... yet in the sentences of our suspensions and deprivations, in pulpits, in courts, and in al places, by al sorts, and meanes, we are cried out on, as men that suffer iustly and for evil doing, for our disobedience to lauful authority in thinges lawful and indifferent.

1 Reasons for Refvsall of Svbscription to the booke of Common praier, vnder the handes of certaine Ministers of Deuon and Cornwall, ete., 1605, 4to.

The Second and Last Part of Reasons for Refusall of Subscription to the Booke of Common praier, etc., 1606, 4 to, 259.

2 The Remoouall of certaine Imputations laid vpon the Ministers of Deuon and Cornwall by one M. T. H. and in them, vpon all other ministers els where, refusing to Subscribe, 1606,4 to, 66 .

${ }^{3}$ For example : -

G. Powel. A Consideration of the Depriued and Silenced Ministers arguments, for their Restitution to the vse and libertie of their Ministerie, etc., 4to.

Certaine Arguments to perswade and provoke the most honorable and High Court of Parliament, etc. to pronote and advance the sincere Ministerie of the Gospell. as also Zealously to speake for the Ministers thereof now degraded, deprived, silenced or admonished, or afterward like to be called into question for subscription, ceremonyes, etc., 4to.

- [W. Bradshaw.] A Myld and Iust Defence of certayne argvments, at the last session of Parliament directed to that most Honorable High Court, in behalf of the Ministers suspended and deprived, etc., 1606, 4to.

J. Sprint. Considerations tonching the points in difference between the godly ministers and people of the Church of England and the seduced brethren of the Separation, 1607,4 to.

J. Sprint. Arguments: That the best Assemblies of the present Church of England are true visible Churches; That the Preachers in the best Assemblies of England, are true ministers of Clirist, 1607,4 to.

G. Powel. A R i joinder unto the Myld Defence, ete., 1607, 4to.

${ }^{4}$ S. Hieron. A Defence of the Ministers Reasons for Refusall of Subscription, etc., 1607, 4to, iv. 
In this diseussion William Bradshaw ${ }^{1}$ was conspicuons on the Puritan side. A graduate of Emannel, Cambridge, he had been tutor in the family of the governor of Guernsey, where he was leavened by Cartwright. He was a Puritan but no Separatist. Two of his books gained wide notice. One condemned the use of the cross in baptism, as the unlawful religious use of a Popish idol. The next year this was answered ${ }^{2}$ by Leonard Hutton, D. D., of Christ Church, Oxford, and vicar of Weedon Beck, Northamptonshire, in a very long but not specially important volume.

Bradshaw, in the "Myld and Iust Defence" attributed to him, pursued the censurer of the petition of the deprived clergymen along every blind lane and over every high fence of his argument. His chief distinction, however, is that, in 1605, he first stated definitely, ${ }^{3}$ as related to the general faith, the opinions of the Puritans, which he did because so many " absurd, erronious, scismaticall and Heriticall opinions" were attributed to them.

In his first chapter he affirms that they hold that the word of God is "of absolute perfection," and therefore that only forms of worship should be practised which it prescribes or directly warrants. In the second he defines a church and its

1 The following are attributed to him:-

A Treatise of Divine Worship, etc, 1604, 16 mo.

A Shorte Treatise of the Crosse in Baptisme, ete., 1604, 16mo.

A Consideration of Certain Positions Archiepiscopall, 1604, 16mo.

A Treatise of the Nature \&. Use of Things Indifferent, etc., $1605,16 \mathrm{mo}$.

English Puritanisme: Containeing: The maine Opinions of the rigidest sort of those that are called Puritanes in the Realme of England, 1605, $16 \mathrm{mo}$.

A Protestation of the Kings Supremacie, made in the name of the afficted ministers, etc., $1605,16 \mathrm{mo}$.

A Proposition Concerning Kneeling in the very act of Receiuing. etc., 1605, $16 \mathrm{mo}$.

Twelve General Arguments P'rouing that the Ceremonies Imposed upon the Ministers of the Gospel in England by our Prelates, are vnlawful. 1605, $16 \mathrm{mo}$.

2 An Answere to a Certaine Treatise of the Crosse in Baptisme, ete., 1605, 4 to.

${ }^{3}$ Eng. Pur. ii : 3, 4, 5-12, 12-21, 22, 24-32, 34. In 1610 a Latin version of this tact, translated and prefaced by William Ames, was printed at . Frankfort, as: Puritanismus Anglicanvs, Sive Praecipua Dogmata eorum, qui inter vulgo dictos Puritanos in Anglia, rigidiores habentur, 16mo. This of ten has been reputed to be Ames's treatise, and is reprinted as such in his own Opera Omnia (ii (2) : 471-506). Why it should have been appropriated thus does not appear. More than a centurs later Increase Mather (Disquis. Concern. Eccles. Councils, 1716, K. vi) declared the book to be "perfect Congregationalism." 
obligations, etc., agreeing substantially with Robert Browne. The third chapter deals with pastors and their duties, holding that they are the highest spiritual officers known to the Church ; that no pastor should bear civil office, to preach being his highest function; that he must interpret the Bible like any other book; that every church also should have a doctor [teacher], especially to instruct the ignorant, etc. In the fourth chapter it is explained that, in order to prevent a minister's being "as it were a Pope," the congregation is to choose elders, some of its "Granest, Honestest, Discreetest" men, "as Assistants unto the Ministers in the spiritual regiment of the Congregation."

The fifth chapter considers the censures of the Church. The keys are by Christ " committed to the aforesaid spirituall Officers and Gonerners, and unto none other." The extremest censure is not to be administered without the free consent of the whole congregation; church officers being as amenable as other's to all censures, and the civil magistrate having jurisdiction over him who forsakes spiritual communion with the Church. The sixth chapter defines more distinctly the weak spot of this polity, the relation of the civil magistrate to the Church. He has supreme power over all the churches. Yet he himself is a member of some particular church, and is as amenable to its government as the meanest subject. Apparently to make a point against Bancroft's new jure divino doctrine of the episcopate, Bradshaw insists that whoever holds that doctrine and denies the king's power to remove all the bishops, and to dispose of all their temporalities at his own pleasure, denies "a principal part of the King's Supremacy."

To add to the confusion there were many men of many minds, even among those reluctant to conform. One of these, Henoch Clapham, issued a plea ${ }^{1}$ for peace. Good people can manage to hear such as have subscribed. They preach the same gospel as before. Scruplers can take the sacrament safely, for it will not hurt them if unfit people commune at the same time with them. As to the genuineness of the Church, he urges:-

Pastorall preaching, administration of Sacraments, and publique

1 An Epislle lo such as be distracted in mynd in respect of present styrres in the Church, etc., 1605, 4to, 3, 4, 5. 
exercise of discipline, doe appertaine to the beeing of a perfect established Church. But before such establishment or Constitution, there is a true Church of beleeuers ; \& before such a Church also, there is som one, two or three visible Christians. A true visible Christian is one thing. A true visible Church a second thing: and a Chureh perfectly constituted, is a third thing.

From a different angle came an accordant plea, by Dr Thomas Sparks, of Bletchley, Bucks, already mentioned. He was one of the very small number who obtained "satisfaction" from the Hampton Court Conference. Hence this volume, which, endeavoring to minimize the differences until they should amount to little or nothing, reaches its climax in an exhortation to "vnitie of iudgment, and vniformitie of practise."

A vigorous anonymous utterance ${ }^{2}$ against the procedures of Bancroft and the Commeil also came from the diocese of Worcester. After a manly appeal to the Privy Council, there is a picturesque likening of the Church to a building shaken by a tempest, and the substance of the tract is expressed thus :-

Not to weare a Surplice in the ministration of Divine seruice, not to make a crosse in Baptisme, \& not to subseribe, \&e, in it selfe, is not a sinne against any commandment of God, nor a thing scandalous vnto the people: And seeing also the Parsons who refuse to weare and vse the same, be in euery respect men of good note, condition, fame, qualitie and behauiour,. . . we may lawfully (as we thinke) conclude in their behalfe, that... they ought to be respected and tolerated, rather then for their refvsall meerly standing vpon their consciences . . . to be suspended, excommunicated or deprived, yea and in so generall and doubtfull a case of conscience, vpon so slender a ground of periury or contempt, vpon persons every way so peaceable \& well qualified, and wherein no Scandall hath ensued, we suppose it can not be shewed among all the decrees and sentences recorded, among all the Popish canonists, that euer any Popish ordinaries, in any age haue rsed the like iudiciall rigour against any their Popish Priests.

The worm will turn. And one of these silenced ministers, John Burgess, who had been sent to the Tower for something said in a sermon at Greenwich, addressed to Bishop Chaderton

1 A Brotherly Perswasion to Vnitie, and Vniformitie in Ivdgement, and Practise, etc., 1607,4 to, $81-83$.

2 Certaine Considerations Drawne from the Canons of the last Sinod, and other the Kings Ecclesiasticall and statute law, etc., 160., 4to, xv, 51. 
an "Apologie," ${ }^{1}$ which seems to have been circulated in manuseript. Dr. Covell was ordered to answer it, and printed it paragraph by paragraph that he might do so. Burgess insists that he already has subscribed four times, and lawfully may refuse to subseribe again. So he says to his bishop: ${ }^{2}-$

I Now beseech your Lordship to remember, that most of us have beene peaceable in Israell; ... And say we cannot conforme in euerie poynt; you know who said ${ }^{3}$ the varietie of Ceremonies did commend the vnitie of faith: and would God you would thinke that our labour in the Church might doe more good in one yeare, then the Ceremonies will while the world standeth: and though in your wisedomes you thinke the retayning of them to make vnto the Churches increase and benefit, is it vnpardonable that we should thinke another course better?... O my good Lord will it not bee enongh to keepe safe and wellfenced your imrisdictions and personall dignities? not enongh to deuide the honors to your selues, and labours to us?

To this Covell replies that, if anything contrary to the word of God were imposed, the fact should be proved, assuming that such proof cannot be offered, adding ${ }^{4}$ that, if the ceremonies seem umlawful, even then to obey is better than to offer sacrifice, and that disobedience is rebellion.

About this time Dr. William Wilkes, a royal chaplain, joined the discussion. ${ }^{5}$ So far as he offers reasoning, he founds it upon the statement that

the iust constitutions of lawful Princes, are the setled boundaries of duty vnto their Subjects, and doe confine euery man within the lists of his particular obedience, as the land-markes in the fields doe limit out their inheritance.

In 1606 several Scotch clergymen, who had offended the king, were summoned to Hampton Court, where, as a means of

1 Reasons by way of an Apologie, deliuered to the $L^{d}$. Bp. of Lincolne, etc., Ms.

2 As printed by Covell in A Briefe Answer vnto certaine Reasons by way of an Apologie, etc., 1606,8 vo, 153 .

${ }^{3}$ Just who is meant is not clear. Possibly the apostle Paul (Eph. 4). Gregory the Great said (Lib. I., Epis. 43): "In una fide, nihil officit sanctae Ecclesiae consuetudo diversa; " and Ridley said (Reply to Hooker on the Vestment Controv. Letters of Bradford, Parker Soc. ii : 389): "Ancient authors do agree and say that these be reasonable causes, why ceremonies may vary, and that the variety thereof ought not to break the unity of faith."

* Briefe Ans. 15i-157.

5 Obedience or Ecclesiasticall Vnion, etc., 1605, 4to, iii : 3. 
grace to them, four English prelates were ordered to preach to them what are known as the Hampton Court Sermons. ${ }^{1}$ Bishop Barlow, of Lincoln, from Acts xx: 28, labored to prove from Scripture and the Fathers the superiority of bishops over presbyters and the inconveniences of parity in the Church. Bishop Buckeridge, of Rochester, from Rom. xiii : 5, maintained the royal supremacy in ecclesiastical matters, and offended the Scotch by classing Pope and Presbyterians together in the matter of encroachment upon princes. Bishop Andrewes, of Chichester, from the somewhat fanciful text, Num. x: 1, 2, Natie thee two Thimpets of Silver, of one whole pecce shalt thou make them, etc., tried to prove a king's authority to convene Councils.

Dean King, of Christ Church, came last, and his text was even more remote from his subject. Starting with the words, Solomon had a vineyard at Baal-hamon: he let out the vineyard unto keepers, etc., Cant. viii : 11, he argued that lay elders were unknown to the early Church, and that the Genevan scheme lacked warrant from either inspiration or precedent. Somehow the hard-healed Scotchmen strangely failed of useful conviction from these discourses.

Mingling with all these clerical voices of conflict were a few from secular sources. In 1604 Lord Bacon, then forty-three, published a small volume ${ }^{2}$ without his name, and dedicated to the king with an obsequionsness remarkable from such a man to such a man. It mattered little to the Puritans that he urged that reforms doubtless were needed; that church government ought to be varied to suit " time, \& place, and accidents ;" that, while the substance of doctrine is immutable, rites, ceremonies, and

1 One of the foure sermons preached before the King's Majestie at Hampton Court [Sunday, Sept. 21, 1606]. This concerning the Antiquitie and Superioritie of Bishops, fto.

A Sermon on Rom. xiii: 5 preached at Hampton Court [Tuesday, Sept. 23], before the Kings Maiestie, 1606, 4to.

A Sermon preached before the Fings Maiestie at Hampton Court Concerning the Right and Pouer of calling Assemblies. On Sunday Sept. 28, 1606, 4to, 54 .

The fourth Sermon preached at Ifampton Court on Tuesday the last of Sept. 1606, 4 to.

2 Certaine Considerations touching the better pacification. and Edification of the Church of England, Sro, 4.5, 8, 11, 12, 43. 
" the perticular Hierarchies, policies, and disciplines of Churches" should be "left at large;" that he wisely doubted many things to which, so long as the law covered them, he still in conscience would adhere; and that he anticipated great increase of prosperity, if but "the sword of the Spirit were better edged, by strengthening the authoritie and suppressing the abuses in the Church." It was something that such a man should concede even so much, but his concessions were not likely to have any practical influence.

A more impressive judgment survives from a man who hardly might be remembered but for his connection with this sulject. Among the books printed anonymonsly abroad in 1607 is one of his. ${ }^{1}$ It states that Thomas Lad, a Yarmouth merehant, was charged with attending a conventicle because, on a Sunday after service, he, living in the house of one Jackler, lately a preacher there, had joined with Jackler in repeating the substance of the sermons preached that day in church. Lad was arrested and forced to make oath as to what took place at this pretended conventicle; and, having answered twice on that oath before the Chancellor, was taken before the Ecclesiastical Commissioners to make further reply upon a new oath. He refused, unless allowed to see lis former answer, being aceused of perjury. For this refusal he was imprisoned without bail until brought to bar by a writ of habeas corpus from the King's Bench. Richard Maumsel, ${ }^{2}$ a preacher, also was charged with having been concernel in a petition to the lower house of Parliament; and, for refusing to take the oath ex officio, he too was jailed withont bail by the Commissioners until brought to bar by a similar writ. Nicholas Fuller pleaded for both.

He argued that their imprisomment plainly was in defiance of the statutes, and that even the statutes relied upon had no longer any legal force. He also emphasized the atrocity of the oath ex officio. But his plea did not avail.

1 The Argument of Master Nicholas Fvller, in the case of Thomas Lad, and Richard Mainsell, his Clients, etc., 1607, 4to, 1, 2, 3, ete.

2 Minister of Yarmonth (Brook, ii : 183), and author of The Tnlaufulnes of Realing. I'rayer, or, the Answer of Mr. Richard Mavnsel. Preacher, vnto certain arguments or Reasons, etc., 1619, Svo. It shows that, if a Puritan, he was not a Separatist. 
Francis Mason - Archdeacon of Norfolk - in 1607 entered the lists for the Establishment. Having preached at Norwich, on June 16, 1605, from I Cor. xiv : 40, he was induced to expand his sermon into a treatise. ${ }^{1}$ He writes like a good man, but he mixes metaphors amusingly, and his logic is not strong. One of his urgent reasons why all should conform is that Nonconformity helps the Brownists. Perhaps the weightiest suggestion in the book is under its forty-fourth head:-

We all acknowledge him [the king] to be supreme gouernour ouer all persons, \& causes ecelesiasticall and temporall : is he gouernoour of all persons, and shall he not gouerne you? Do you acknowledge him gouernour ouer all canses, \& shall he not appoint you whether your garments shall be blacke or white, round or square? Shall wee teach the people obedience, and be our selues examples of disobedience?

About this time "Thomas Whetenhall Esquier" also published a book ${ }^{2}$ which notes that the seven churches of Asia were true churches of Christ, although many corruptions had crept into them even then, and quotes, with comments, from seventysix authors, in proof of the need of reformation. He answers one main objection thus:-

The Kings Majestie . . . is peswaded that the governement and State of the Church wherein it was left in Q. Elizabethes time ... is fittest to remaine \& continue in this Realme of England. But I would aske, who hath perswaded the King so, but the Lord bishops whose great livings \& pompous estate they are so loath to leaue. To whom I will but deliver the wordes of MI. Calvine,... That the Churches of the whole Kingdome of England are not yet brought into so good order as all good men doe wish and desire, and at the first had good hope it would haue ben done, that I assure you doth exceedinglie grieue mee, but to the overcoming of all impediments it is needfull to haue an unveriable indeauour. But now it is convenient and a matter of very necessity, that the Queene should know and vnderstand that you doe willinglie remitt. and from your selues vtterlie reiect whatsoever sauoureth of earthly Lordship, that vnto the exercisinge of your spirituall function ye may stedfastly keepe a lawfull authoritie and such as is giuen you of God. Now therefore if

1 The Authoritie of the Church in making Canons and Constitutions concerning things indifferent, and the obedience thereto required, etc., 1607, 4to, iv: 15, 68, 66.

${ }^{2}$ A Discourse of the Abvses now in Question in the Chvrches of Christ, etc., 1606, 4 to, $1-4,188$. 
my Lords the Bishopes, according to $M$. Calvins advise would ioyne to gether and first crie vnto God for the salvation of their sonles, and then on their knees to desire his Maiestie to pardon their former offence, and humbly request him to take from them their great lyuings and pompons estate and vnlawfull superioritie over the Clumehes and make them like their fellow-ministers ; His Maiestie would surely say; now it is evident to all me and out of all doubt, that you seeke Gods glory and not your oune.

It hardly need be added that no mention occurs of any episcopal acceptance of this suggestion.

Under the relentless lead of Bancroft, Convocation now enacted a series of extraordinary canons, and defended them in a set treatise. ${ }^{1}$ But the king disliked some things about the politics treated therein, and forbade the treatise to be offered formally for his assent. It still remains, however, and is significant of the spirit in which the Church of England then dealt with Dissenters.

As before, in Martin Mar-prelate's time, the weapon of ridicule also was tried against the Puritans. A play ${ }^{2}$ was written by one Wentworth Smith, but it is vulgar and prosaic. It describes a Puritan widow smiling upon a possible second husband while her cheeks still were wet with tears for her first. The sneers at the Puritans are put into various mouths, yet have but one voice. For example : -

Ile sooner expect mercy from a Vsurer when my bonds forfetted, sooner kindnesse from a Lawier when my mony's spent: nay sooner charity from the deuill, then good from a Puritaine?

And again :-

He [the dead husband] would eate fooles and ignorant heires cleane $\mathrm{vp}$;

And had his drinck, from many a poor man's browe,

E'en as their labour brewde it?

He would scrape ritches to him most vniustly;

The very durt betweene his nailes was Ill-got:

And not his owne. . . .

1 This does not seem to have been published in full until 1690 , when Arch. Sancroft printed it under the title of Bishop Overalls Convocation Book. MDCVI, etc., 4 to.

${ }^{2}$ The Pvritaine, or the Widdow of Watling-Streete. Acted by the Children of Paules. Written by W. S., 1607, 4to, 6, 14, 24, 27. 
$\mathrm{Oh} ;-$ a Sermons a fine short cloake of an houre long, and wil hide the vpper-part of a dissembler, Church. I [Aye], he seem'd al Church, $\&$ his cōscience was as hard as the Pulpit!

And a nasal-voiced servant, when his master took off his gold chain, "sneakt it away, by little \& little, most Puritanically."

The difficulties and the diligence of the early Nonconformists are inclicated again by a volume ${ }^{1}$ written by Robert Parker, ${ }^{2}$ a fellow of Benet College, Cambridge, afterwards beneficed in Wilton, Wilts., who wrote earnestly against the cross in baptism. Being obliged to fly to Holland, he did the best he could, lacking "bookes and conference," and published there, in 1607, in two parts, a folio of 370 pages. The first part argues that the use of the cross in baptism is idolatry, superstition, hypocrisy and impiety. The second part accuses this practice of injustice, soul-murder, spiritual adultery, etc. Those for whom he speaks, however, are no Brownists, Anabaptists, or "Newfanglistes." His great urgency is :-

Whereas all meanes of Saboth pollution must be abolished, as God him selfe doeth gine example, in taking the Manna out of the way, when once it grew to be an occasion of Saboth-breach: and the ceremonies of present controversie are many wayes guiltier of his impietie: praye we against them, as Mr. Foxe prayed hartily once against the Surplice: It is pitie such baytes of poperie are left (saith he) to take christians in. God take them away frō vs, or els vs frō them: for God knoweth they be the cause of much blindnes and strife amongst men.

To show the methods which the Papists were taking to win the young and simple, he cites a ballad, "The Lament of the Crosse," to the tune of "The L. Courtneis dumps," which had been scattered abroad recently:-

1 A Scholasticall Discourse Against Symbolizing with Antichrist in Ceremonies : especially in the Signe of the Crosse, 1607, fol. iii, i: 177; ii : 113, 120, 115; i : 196,92 .

2 Father of Thomas Parker, one of the earliest pastors of Newbury, Mass. C. Mather says of him ( $\mathrm{Kag}$. iii : 143) : "It was the honour of that great man, to be the father of such learned books, as that of his De Politia Ecclesiastica, and that $O f$ the Cross; . . . yea, to be in some sort the father of all the nonconformists in our age, who yet would not call any man their father." 
Without the Crosse S. Augustine saith -

Reade him, and you may see -

No man is stedfast in the faith,

Nor Christened well may be.

No Sacrifice, no holy Oyle,

No washing in the Foute,

Nor any thing can thee assoyle,

If thou the Crosse doe want.

Christ crucified he doth affirme,

When that he rose from death,

Hath left his Crosse here after him,

For to increase our faith.

Children by it have Christendome,

The water blest also :

The holy Ghost appeares to some,

And gifts of grace bestow.

When that this Crosse is made aright,

Of them that hallowed be: ${ }^{1}$

Where it is not, there wanteth might,

For onght that I can see.

Saint Chrysostome, in likewise,

Perswades himself herein ;

And saith by this a man doth rise,

From death and deadly sinne.

The Crosse is at onr birth, saith he,

And where that we be fed :

The Crosse it is most meet, perdie, ${ }^{2}$

When that we shall be dead.

This book by Parker deserved, and had, wide influence, and that Brewster left a copy indicates that it may have had some influence npon him.

With all, there were not wanting earnest pleas from the reformers that they might receive common justice, at the least. As early as 1604 Henry Jacob made a general appeal. ${ }^{3} \mathrm{He}$ takes the bull by the horns in a dedication to the king. It is

1 That is, when the sign of the cross is made in baptism by a regularly consecrated priest.

2 A corruption of the oath Par dien.

8 Reasons Taken out of Gods Word and the best Humane Testimonies proving a Necessitie of Reforming Oor Chvrches in England, etc., 1604, 4to, v, iii-vii, iii, $1-57,57-80$. 
needful for those for whom he pleads to defend themselves. So he submits their cause to him whom they recognize as "the noblest pillar of the Gospell, and the greatest hope for the propagation and establishing thereof that is in all Christendom." This, by the way, is flattery as real as, if less fulsome than, either Wilkes's or Bacon's.

He then advances four propositions: (1) reform is needful; (2) for 200 years after Christ, Diocesanism was unknown, bishops outranking pastors only in priority and not in rule; (3) the New Testament Scriptures set forth the ordinary form of church government; and (4) that form, not being changeable by man, is alone lawful. Those whom he represents hold these principles but desire to exercise charity towards all. The tract concludes with an appeal to "all the godly, learned, and faithfull pastors of the severall Churches in England," in which he acknowledges distinctly that it is not enough to have and:to enjoy " the Preaching and Sacraments . . . without longing for and seeking further to walke in the perfect way, now that it is discovered." In 1606 he made further effort ${ }^{1}$ to secure a peaceful solution of the difficulties in another little quarto, ${ }^{2}$ also dedicated to the king:-

Your Maiestie professed before you came to the crowne, that you did equally ioue \& honor the learned \& graue men of either of these opinions: ${ }^{3}$ and it is no small heartes-griefe unto us, that, since your comming into this land, your Affections are so alienated \& estranged from us, . . . who, before we saw your face, laboured by all good meanes (not without some danger) to promote your Maiesties iust Title to this Crowne, and haue ever since carryed our Selnes duetifully towards your Maiestie, and peaceably in the seruice of God, and of his Churches. . . . May it therfore please your most excellent Iaiestie to reade this Offer, $\&$ to weigh in all the partes thereof the equitie $\&$ instice of it, \& the most certaine advantage that the truth (on which side soever it is) shall receiue by the acceptance of it: may it please you likewise to urge the Prelates, whom it deepely concerneth,

1 Brook (ii : 333) so decides, and there seems to be no evidence to the contrary.

2 A Christian and Modest Offer of a most Indifferent Conference, etc., 1606, 4to, iii, and passim.

${ }^{3}$ That is: those who favored government by elders, and those who preferred the existing polity. Basil. Lor. 6 . 
to admitt of it; and to secure by Royall protection those that shalbe Actors in it.

The "offer" was that the silenced ministers select six or eight, to be met by an equal number of representative prelates or clergy, to debate publicly sixteen propositions involving the points at issue.

Nothing could be fairer in letter or spirit than this proposal; yet nothing was more certain than that it would not be accepted. The necessity of publicly treating the reformers as on a level with their opponents would have forbidden it, had not the assumed infallibility of the State Church blocked the way effectually. The popular house of Parliament tried to mitigate matters, but its utmost was little. It stubbornly refused to do business on Sunday, even at the request of the Lords ${ }^{1}$ and although the Privy Council habitually met on that day after service. And as to religion, it said frankly:-

Your Maiesty should be misinformed if any man should deliver that the Kings of England have any absolute power in themselues either to alter religion (which God forefend should be in the power of any mortal man whatsoeuer) or to make any laws concerning the same, otherwise then in temporal causes, by consent of Parliament. . . .

When it met again, on Nov. 5, 1606, the Gumpowder Plot was agitating the nation, and the excitement against Roman Catholics was availed of for the framing a new oath of allegiance. Directly this touched only Popish recusants. Yet the king, in a volume ${ }^{2}$ to explain and defend it, also freed his mind about the Puritans. In his address to the fraternity of monarchs he says : -

As I ener maintained the state of Bishops and the Ecclesiasticall Hierarchie for order sake: so was I ener an enemy to the confused Anarchie or paritie of the Puritanes, as wel appeareth in my Basinikon دspos. . . . I cannot enough woonder with what bra:en face this Answerer ${ }^{3}$ could say, That I was a Puritane in Scotland, and an enemy to Protestants: I that was persecuted by Puritanes there, not from

1 Gardiner, i : 191, 205. S. P. Dom. viii : 70.

2 Premonition to Monarchs. Works (ed. 1610), 305.

${ }^{3}$ Bellarmine. James refers to the book of Matt. Tortus as that, some of whose statements he is answering, but as Tortus is "an obscure Authour, utterly unknowen to me," he is assumed " to be one person with Bellarmine." 
my birth only, but enen since foure moneths before my birth? I that in the yeere of Gon 84 erected Bishops, and depressed all their popular paritie, I then being not 18 yeeres of age? I that in my said Booke to my Sonne, do speak tenne times more bitterly of them nor of the Papists ; haueing in my second Edition thereof affixed a long Apologetike Preface, only in odium Puritanorum? And I that for the space of sixe yeeres before my comming into England, laboured nothing so much as to depresse their Paritie, and re-erect Bishops againe? . . . And surely I gine a faire commendation to the Puritanes in that place of my booke, when I affirme that I haue found greater honesty with the high-land and border theenes, then with that sort of people.

In the same volume this extraordinary sovereign also insists : "I do constantly maintaine that no man, either in my time, or in the late Queenes, euer died here for his conscience." To say nothing of Papists who had been offered up with every sign of a good conscience on their part, six Congregationalists had been hanged within sixteen years, besides twenty-five who in reality had been martyred in the foul London prisons, ${ }^{1}$ in addition to a never definitely determined number of others elsewhere in the realm.

An important side issue must not be overlooked. At the Hampton Court Conference Dr. Rainolds had "earnestly desired a straighter course " 2 for better Sabbath-keeping, to which suggestion "hee found a generall \& vnanimous assent." His proposition was symptomatic of a special reëxamination of the Sabbath question, begun at least eight years before. In 1595 a volume ${ }^{3}$ by Nicholas Bownd, rector of Norton, Suffolk, opened a controversy even yet hardly closed. He declares ${ }^{4}$ that the

1 Cong. in Lit. 206-207.

2 Barlow, Sum and Subs. 45.

3 The dortrine of the Sabbath plainely layde forth, and soundly proved by testimonies both of holy Scripture, and also of olde and new Ecclesiasticall uriters, etc., 1595, 4to. Republished in 1606 in two books as Sabbathum V'eteris et Novi Testamenti, 4to. Dr. John Hunt in Relig. Thought in Eng. (i : 152) says that this book was " first published in 1595 but suppressed until 1606," and also that the Sabbath controversy began with the Hampton Court Conference in 1603. But the first edition of Bownd's book was "quickly dispersed into the hands of men" and a new edition was called for in two years (1597). But the Ms. "miscarried," and the second issue was delayed until 1606. Moreover, the controversy had been stirred up seven or eight years before the Hampton Court Conference.

4 Sab. Vet. 7, 82, 88, 122, 128, 130, 185, 262, 211, 272, 280, 286, 330, 335, 339, $366,372,380,493$, and ( $2 \mathrm{~d}$ ed.) ix. 
seventh part of our weekly time is due to God, consecrated by him from the beginning. The day was changed by the Apostles from Saturday to Sunday, and its name altered to the Lord's Day. It should be a day of rest, worship and physical benefit. Magistrates must restrain men from Sabbath work. All recreations honest, and all delights lawful, for other days must be abstained from. Feasting is wrong, excepting that:-

Concerning the feasts of Noblemen and great personages . . . because they represent in some measure the Maiestie of God on the earth, .. much is to bee granted vnto them: yet they must remember, that as the Lord hath aduanced them, so they are to aduance the Lords worship.

We also must abstain from needless worldly conversation. The day is to be sanctified by worship, common prayer, public reading of the Scriptures, and the sacraments. It is a whole day of twenty-four hours, beginning not at evening but at morning. Meditation and private prayer should precede the public service, and works of mercy should follow it.

This treatise caused debate. The Romish Church — and multitudes remembered the nation as it was before the Reformation - of course had accustomed England to treat the remainder of Sunday after the church service as a holiday. The Reformation inevitably led to a reinvestigation of the whole subject of holidays and holy days in the light of the Bible, interpreted by that evangelical spinit which animated Puritanism. In the main, the Puritans accepted Dr. Bownd's argument as offering the true interpretation of the day. The first issue of the book soon was exhausted, but some accident prevented a second.

However, three other treatises soon followed, enforcing the same truth. Of these, one, ${ }^{1}$ by George Widley, - the others have not proved accessible, if they survive, - differs from Bownd's little, if at all, in doctrine, but is briefer. It merits attention because of the reasons given for one position which the Puritans of New England, at least, modified.

Wee begin om Sabbath at the dawning of the day, for these reasons : first, because Christ rose in the dawning it was necessarie (our

1 The Dortrine of the Sabbath, handled in foure severall Bookes or Treatises, ete., 1604,4 to, 61 . 
Sabbath being to be kept in remembrance thereof) that our day should then begin. Secondly, to put a difference betwixt the Tewish Sabbatl, and the true Christian Sabbath, it was needfull that ours should begiu at morning, when by the resurrection of Christ the world began to bee renewed: whereas the other began at night, when the world in the creation was finished. 'Thirdly, that the night following is accounted a part of the day precedent, we see Act. 20. vers. 7. . .

Such teaching aroused opposition from a few who wished to make it still more stringent, and from the great multitude who clung to the ancient Sunday customs, and who, repudiating Puritanism in other particulars, repudiated especially its Sabbatical strictness. Within a half-century of Dr. Bownd's book, more than a dozen authors ${ }^{1}$ entered the field, but their discussion was later than the period which we are considering.

Another volume, already alluded to, came out early in the century. In 1599, at Paris, Sir Edwin Sandys, after careful study of various countries, drew up a report of the state of religion where he had been. His manuscript was copied several times for his friends, and in 1605_- "from a spurious stolne Copie ... shamefully falsified" — it ${ }^{2}$ was printed anonymously

1 Three Questions Answered, etc. By Thos. Broad, 1621, 4to.

Tractatus de Sabbato, in Quo Doctrina Ecclesiae primitivae declaratur ac defenditur, 1627, 4to ; and Vindiciae Sabbathi, or an Answer to two Treatises of Mfaster Broads. By Geo. Abbot, 1641, 4to.

$A$ Discourse upon the Sabbath Day, etc., 1628, 8vo ; and $A$ Defence of that most ancient and sacred Ordinance of God, the Sabbath Day, etc. By Theophilus Brabourne, 1632, 4to.

A Learned Treatise on the Sabbath, etc. By Edward Brerewood. 1690, 4 to.

The Doctrine of the Sabbath Vindicated in Confutation of a Treatise of the Sabbath, uritten by E. B. against N. B. By Richard Byfield, 1681, 4to.

The Doctrine of the Sabbath, etc. By Bishop J. Prideaux. Trans. into English. 1634 , 4to.

A Treatise of the Sabbath-Day, containing a Defence of the Orthodoxall Doctrine of the Church of England against Sabbatarian-novelty. By Bishop Francis White, 1635 , 4 to.

A Soveraigne Antidote against Sabbntarian Errours : or, a Decision of the Chiefe Doubts and Difficulties touching the Sabbath, ete., 1636, 4 to.

1 Discourse of the Sabbath and the Lords Day, Wherein the Difference both in their Institution and their due Observation is briefly handled. By C. Dow, 1636, tto.

The History of the Sabbath. In two books. By P. Heylin, 1636, 4to.

The Doctrine of the Sabbath, etc., in divers Sermons. By G. Walker, 1698, 4to.

Sabbatum Redivivum, or the Christian Sabbath Vindicated. By D. Cawdry, 1645, 8vo.

2 A Relation of the State of Religion: and with what Hopes and Pollicies it hath 
in London. In spite of endeavors to stop the sale and punish the printer, it was twice reissued surreptitiously, so that three editions were "stolen into the world" before, in 1629, an anthentic and "perfect copy" 1 was printed, still anonymously, at the Hagne. It hardly can be doubted, both because of the subject and of his relations with the author, that a copy of the first printed issue soon came into Brewster's hands.

The work is only a part of what was proposed, being confined to Roman Catholic countries ; that which was to deal with " the churches reformed" being reserved and never completed. As to the likelihood of ehureh consolidation his conchusion is :-

And this is all I can say for any hope or meanes of this generall vnity ; and so must $I$ leave and recommend it to God, as being both our best and nowe onely remaining pollicie, to addresse our vnited and generall supplications to his divine power and maiestie: That it may please him, by that ever-springing fountaine of his goodnes and gratious mercie, even beyond all humane hope (if it may stand so with his blessed will) and by such meanes as to his Divine wisedome are ever in readinesse, to effeet those things which to mans wit may seeme impossible.

One labored treatise also demands mention. Thomas Rogers, rector of Horninger, Suffolk, who twenty-eight years before had published an exposition of the Articles of Religion, ${ }^{2}$ in which each article was dissected into propositions and each proposition epitomized analytically, reissued it $^{3}$ in 1607 , expanding some doctrinal heads, arguing all at large from church authorities as well as from Scripture and the Confessions, and arraying against each all such errors as opposed them. Of course this led him into the thick of the fight. He goes rapidly over the ground from Crammer's time, showing how factions have been increasing, although subscription has been three times enjoined upon

beene framed, and is maintained in the severall States of these westerne partes of the World, 1605, 4to.

1 Evropae Speculum, or A View or Svrvey of the State of Religion in the Westerne parts of the World, etc., 1629, 4to. Tepr. in 1692, 1637, 1688, 1673 and 1687, and, in Italian, in 1625, and in French, at Amsterdam, in $16+1$.

2 The English Creede, Wherein is contained in Tables, an exposition on the Articles which euery Man is to subseribe vnto, 1579 , fol.

${ }^{3}$ The Faith, Doctrine and Religion professed, and protected in the Realme of England, and Dominions of the same, etc., 1607, 4to, x, xviii, 92. 
them. Meanwhile these Nonconformists and Recusants have claimed perpetually that they differ in no doctrine from the Church. Moreover, they lately have

set vpon vs afresh again, by dispersing in printed Bookes .... their Sabbath Speculations, and Presbyterian (that is more then either Kingly, or Popely) Directions for the obseruation of the Lords day....

They ruinate, and at one blow beate downe all Times and Days, by just authority destined to Religious and Holy uses, besides the Lords day, saying plainly, \& in peremptory words, that the Church hath none authority, ordinarily, or from year to year perpetually to sanctify any other day to those uses, but onely the Lords day. . . . I haue read . . . how it was preached in a Market-Town in Oxfordshire, that to do any seruile work, or businesse on the Lords Day, is as great a sin as to Kill a man, or to commit Adultery. It was Preached in Somersetshire, that to throw a bowl on the Sabbath-Day, is as great a sin as to Kill a Man. It was preached in Norfolk, that to make a Feast, or Wedding-Dinner on the Lords Day, is as great a sin, as for a Father to take a Knife and cut his childs throat. ${ }^{1}$. . .

He catalogues the heresies arraigned, and cites in notes the passages on which he relies for proof. As to some thirty of the Thirty-nine Articles, he charges upon the reformers no divergence from the old-time doctrine. As to the others, however, especially those treating of the Church, the Ministry, and the Magistracy, he accuses Puritans, Brownists, Barrowists, Anabaptists, the Family of Love, and others, with diverse and scandalous unsoundness. On the whole, his volume was more likely to irritate than to convince.

It should not be overlooked that the new version of the Bible was in process of creation at this very time. We have seen that, at the Hampton Court Conference, Dr. Rainolds urged the importance of a new translation. Neither Parliament, Convocation, nor the Privy Council seems to have taken any action in the matter. Most of the translators - there appear to have been fifty-four at first, probably selected for the king's appointment by the Archbishop of Canterbury - bore

1 In extreme times extreme men say extreme things, and possibly these assertions could have been proved. But such was not the tone of the great body of those who argued for the hallowing of the Lord's Day. 
their own expenses; excepting that those who for nine months devoted their whole time to the final revision were paid by the Barkers, who enjoyed a long copyright upon the result. It took about four years to complete the first revision, which was referred to twelve of their number for a thorough reëxamination, after which about two years more, with the supervision of Dr. Miles Smith, a canon of Hereford, and Bishop Bilson, carried the version through the press.

It never was authorized or endorsed by Parliament, but upon its own merits, and particularly because it was nnencumbered by notes, it won its own way to its preëminence. King James did not suggest it, or pay a penny towards it, ${ }^{1}$ or recognize it officially in any way; his chief action in connection with it being the enforcement of rules aimed to prevent any gain to the Puritans through the result, e. g. : " The old ecclesiastical words to be kept, videlicet, the word 'Church' not to be translated "Congregation,'" etc. The good men, including Chaderton and Rainolds, who, between 1604 and 1609, ${ }^{2}$ while the controversy which we have considered was going on, quietly did this great work at their own charges, deserve the praise for what, because of a dedication prefixed to many copies, it has been common to call " King James's Version."

1 "We of ourself in any convenient time cannot well remedy it; " i. e., the emptiness of the treasury out of which the translators ought to have been paid. Cardwell, ii : $66,111$.

2 Arch. Bancroft notified the intended translators, June 30, 1604, of the king's pleasure "that they should, with all possible speed, meet together in their University and begin the same" (Anderson, 477). 


\section{CHAPTER VII}

\section{OTHER PILGRIMS AND THE EXODCS}

WE now return to Brewster at Scrooby. Something of that earnest controversy which we have traced must have agitated his retirement. That he must have taken special interest in some pleas by the Puritans it is safe to infer. We already have seen Bradford's record that, in his residence at Scrooby, Brewster won general esteem, was exceptionally active in promoting earnest religion, and long maintained substantially his old church relations, but that, at last, he became a Separatist. Probably, also, if his desire for evangelical preaching were unsatisfied at St. Wilfred's, ${ }^{1}$ he sought for it at first in neighboring churches of the Establishment.

While Brewster still was in Davison's employ, Richard Clyfton had been instituted at Babworth, seven or eight miles south of Scrooby. Here he began to preach Puritan doctrine before long, ${ }^{2}$ perhaps soon after Brewster had come back to the old manor-house. To all appearance Clyfton was first of the elergy of that region to seek to indoctrinate it in those warmer and stricter conceptions of religion which gradually led to Separa-

1 In the British Museum is an account of parishes near Doncaster, ten miles from Scrooby, about 1612, by Thomas Toller and Richard Clark, vicars of Sheffield and Braythwell. They enumerate 60 parishes, and find in them preachers "sufficient and painfull," 12 ; non-preachers, 42 ; negligent and insufficient, 26 ; scandalous ministers, 10 (Birch Add. Ms. 4293: 41). Another document recommends the erection of a college at Ripon, and declares that the people thereabouts are all ignorant of religion, having been untanght for above 30 years. Its presumed date is Nov. 1590. S. P. Dom. Eliz. cexxxiv: 35.

2 Some words by Clyfton in 1610, in reply to Smyth, indicate that Smyth had to do with Clyfton's conversion to Separatism. "As for any former truthes whereof you have bene an instrument of myne instruction ... I I am thankful to God for it. But, if you remēber, that truth that you informed me of was concerning the truenesse of this [Separate] Church whereof I stand a member, which you now hold to be Antichristian." Plea, 226. 
tion. He has high testimony as an able and $\operatorname{good} \operatorname{man},{ }^{1}$ whose labors overflowed the boundaries of his little parish.

Somewhat later John Smyth ${ }^{2}$ also went from his fellowship at Christ's College, Cambridge, and his subsequent office of preacher in Lincoln, to Gainsborough, in Lincolnshire, about ten miles east from Scrooly. His relation to the church in Gainsborough at first is doubtful. There is proof, however, that early in his residence there his mind was exercised upon current issues, and that he consulted others. Bradford declares that he was of able gifts. ${ }^{3}$ In 1601 Richard Bernard ${ }^{4}$ became vicar of Worksop, some ten miles south of Serooby. He was one of the Puritans who felt strongly the need of a deeper piety in the State Church, but who, after hesitation, settled back into zealous defence of it. In addition to the regular preaching of a few such men, possibly some lecturer now and then wandered into those parts and was welcomed at the manorhouse.

These religious convictions gradually drew together little sympathizing companies "of sundrie towns \& villages, some in Notinghamshire, some of Lincollinshire, and some of Yorkshire, where they border nearest together." ${ }_{5}$ Their experiences can be described best in Bradford's own terse words :-

When as by the travell [labor] \& diligence of some godly \& zealous preachers, \& Gods blessing on their labours, . . . many became inlightened by $y^{\mathrm{e}}$ word of God, . . . the worke of God was no sooner manifest in them, but presently they were both scoffed and scorned by $\mathrm{y}^{\mathrm{e}}$ prophane multitude, and $y^{\mathrm{e}}$ minsters urged with $\mathrm{y}^{\mathrm{e}}$ yoak of Subscription, or els must be silenced; and $y^{\mathrm{e}}$ poore people were so vexed with apparators, ${ }^{6}$ and pursuants, \& $y^{\mathrm{e}}$ commissarie ${ }^{7}$ courts, as truly their affliction was not smale; which, notwithstanding, they bore sundrie

1 Bradford, Hist. 10. Dial. in Young, Chrons. Plym. 453. Smyth, Paral. 2.

2 See Dr. Dexter's True Story of John Smyth, 1881.

${ }^{3}$ Hist. 9. Dial. Young, Chrons. 450.

4 A voluminous writer and, no doubt from his proximity to them, especially active against these Separatists. Smyth intimates (Paral. 2) that Bernard lost his place at Worksop for refusing conformity, but "revolted back."

${ }^{6}$ Bradford, Hist. 8, 9.

${ }^{6}$ Officers of an ecclesiastical court, who summoned persons to appear before the judge. Lee, Glossary.

7 The officer of a bishop who has been appointed formally to exercise spiritual jurisdiction in the bishop's name and on his behalf. Ibid. 
years with much patience, till they were occasioned (by $\mathrm{y}^{\mathrm{e}}$ continuance $\&$ encrease of these troubls, and other means which $y^{\mathrm{e}}$ Lord raised up in those days) to see further into things by the light of $y^{e}$ word of God: How not only these base and beggerly ceremonies were unlawfull, but also that $\mathrm{y}^{\mathrm{e}}$ lordly \& tiranous power of $\mathrm{y}^{\mathrm{e}}$ prelats ought not to be submitted unto.

We should note here a fact which has a considerable influence upon the early history of the Plymouth Colony. The men who constituted the nucleus of the movement which Bradford was describing were mostly in the common walks of life. They had inborn intelligence, good sense, solid habits of industry, frugality and self-reliance, and such rude education as was within their reach. Above all they had a regnant conscience. But not many were of "gentle blood." 1 Few seem to have been landowners. They had not even that expansion of the faculties apt to be bred by the aims and risks of commerce. In the main they were plain farmers ${ }^{2}$ whose names, excepting in a line or two upon the parish parchments at birth, marriage and burial, seldom went upon record. Hence the difficulty, after 300 years, of identifying them precisely. In many cases the first volumes of the parish records, ${ }^{3}$ which naturally would contain such notices, have been lost, or kept so carelessly that their contents often are illegible. A considerable examination of such records now remaining in the neighborhood of Scrooby has proved singularly barren of results. The Austerfield volume gives Bradford's baptism, and that at Harworth suggests a bare possibility as to George Morton. But this is nearly the whole story. Sutton-cum-Lownd, some four miles to the south, to which Scrooby is adjoined ecclesiastically, has records which, partly by the aid of James Brewster's apparently very careful copy, run back to 1538 . But the most diligent search reveals in it

1 In its old English sense this phrase means born into the class above the reomanry, and not obliged to work for a living, naturally implying some special degree of good breeding and education.

2 Bradford, Hist. 11.

${ }^{3}$ Parish records were first ordered to be kept in 15:38, and odd misapprehensions greeted them. The earliest parish record remaining at Serooby dates back only to 1695 , and at Babworth to 1623 . The Gainsborough records touch 1564 , but are illegible. 
no traces of the Pilgrim emigrants. ${ }^{1}$ Nor do archives of any other description offer much aid, the fact being that England then was largely destitute of records preserving the details of the daily life of her people.

The earliest existing Court Roll of the freehold and copyhold courts of the Archbishop of York, as lord of Scrooby Manor, runs back only to the year 1621.2 Nothing existed then corresponding to modern Registries of Deeds, by which, for example, William Bradford's sale ${ }^{3}$ of the property left him at Austerfield might have been traced, and the location of his house determined. The Act-books of the High Court of Commission for Ecclesiastical Causes are almost the only remaining resource, but are scanty in details, and suggest scarcely more than a halfdozen names as belonging to a movement which must have carried out of England several hundreds in all.

It appears to have been in $1602^{4}$ that the subsequent followers of John Smyth at Gainsborough united in an independent, separate church. There is evidence, although it is not conclusive, that Smyth was a preacher in Lincoln until March, 1605. ${ }^{5}$ He cannot have removed to Gainsborough much before the end of 1604, and Bradford rather implies that he did not become pastor of the church there until after the division into two churches in 1606.6 His views, apparently on going to Gainsborough and certainly soon afterwards, had an important rela-

1 Yet more than seventy names occur which are common in New England.

2 Raine, Blyth., 125.

3 "Here [in Austerfield] and in some other places, he had a comfortable inheritance left him of his honest parents. ... At the end of two years [after reaching Holland] he did, being of age to do it, convert his estate in England into Money." C. Mather, Mag. II : 3,4 .

4 Bradford names no year as the birth-date of Smyth's ehurch, but his nephew, Nath. Morton, who had his papers and his promptings, says (N.E. Mem.1): "In the year 1602 divers godly Christians ... entred into Covenant," etc. And Prince (An. i: 4) says: "I suppose he [Morton] had the account, either from some other writings of Goveruour Bradford, the Journals of Governour Winslow, or from oral conference with them, or other of the $1^{\text {st }}$ planters; with some of whom he was contemporary, and from whence, he tells us, he received his Intelligence."

5 Bernard, who knew Smyth well, declares that the book, $A$ paterne of true Prayer or exposicon 'ppon the lords prayer (1605), by John Smythe of Lincoln, was by Smyth, the se-Baptist. Powicke, H. Barrow, 245-249.

6 Hist. 9. 
tion to the history of the Pilgrims. They are made plain by a little manual, ${ }^{1}$ which he printed at Amsterdam a few years later, as well as by two other volumes ${ }^{2}$ soon written by him. In substance their essential features are these $:^{3}$ -

The visible church is a visible communion of two or more saints covenanted with God and each other to use freely all the holy things of God according to the Word for mutual edification and for God's glory. This is the only religious society that God has ordained on earth. Whatever company worships God without belonging to a visible church sins.

Visible churches, constituted according to the forged device of men, are idols, and to join them and worship God in them is to join to idols.

Three things are requisite to a true visible church : (1) true mattersaints ; (2) true form - inwardly, the spirit, faith and love ; and, outwardly, a covenant respecting God and the faithful; (3) true properties - communion in the holy things of God, and the power of our Lord Jesus Christ to receive, preserve and cast out.

Members are of two sorts, prophets and private persons. .Prophets are men endued with gifts fitting them to edify, exhort and console, and all who have such gifts may prophesy. Private persons are men, having the right to propound their doubts, to be resolved by the prophets; and women, who are to have their donbts resolved privately by their husbands at home, or by some other of the church. To this exercise of prophecy, unbelievers or non-believers may be admitted.

Officers are of two sorts, bishops and deacons. Bishops also are called elders or presbyters. Jointly they form the eldership or presbytery. They are of three sorts: pastors, teachers and governors. The first two can administer the sacraments. All must be apt to teach and all officially share the government of the church. The deacons and "widows" - women of at least sixty - collect and distribute the chureh's funds.

Officers become such by election, approbation and ordination. Election is by the majority vote of members in full communion. Approba-

1 Principles and inferences concerning the visible Church, 1607, 16mo.

2 Paralleles, Censtres, Observations, apperteyning to three several Writinges: (1) A Lettre uritten to Mr. Ric. Bernard. by Iohn Smyth. (2) A Book intitulerl, The Separatists Schisme published by Mr. Bernard (3) An Answer made to that book . . . by Mr. H. Ainsworth. By Iohn Sinyth, 1609, tto.

The Diferences of the Churches of the seperation, etc. By Iohn Smyth, tto.

3 Prins. and infs. $7,8,9,10$, etc. The following abstract is not an exact quotation, but is set in smaller type in order to save space. 
tion is finding the officer-elect to have been chosen according to rule; and every member must object what he can, especially those who did not vote for him. If valid objection be made, another must be chosen. If the objections prove trifling, the election is approved and if the objectors still oppose, they are to be censured. Ordination is the dedieation of the approved officer to his office by prayer, with imposition of hands and a charge. Ordination and imposition of hands appertain to the whole church, as do election and approbation, yet, for the sake of order, the fittest members ordain in behalf of all.

The church's treasury is holy. None without may contribute to it, and nothing gotten by wicked means may be received. Its use is specially for the saints - for holy things, e. g., the bread and wine for the Lord's Supper; and for holy persons, i. e., to support church officers and the poor, either of that church or of any other true chmreh.

The church's power of preserving appertains to every member. The pastor's chief endeavor must be to make the church zealous, holy and obedient; the teacher's to prevent ignorance and error ; the governor's to maintain order; the deacon's to see that none lack necessaries and that provision be made for holy things; the widow's to relieve the bereaved and ill ; the eider's to order the public actions of the church; the prophet's to resolve doubts and explain the scriptures; the pastor's and teacher's to moderate and determine all matters out of the Word; the members' to bear one another's burdens, admonish the unruly and excommunicate or restore the fallen.

Admonition is a duty. An excommunicated person is to be readmitted into communion upon repentance, yet special watch always must be kept over him.

Every true visible church is of equal power with every other. The erecting ${ }^{1}$ of visible churches appertains alike to princes and private per'sons.

Whatever is contrary to this order of the visible church is antichristian. Whoever erects another form is Antichrist, and whoever yields to any other constitution, laws, officers, ministry or worship is the servant of Antichrist.

This was Brownism and not Barrowism, probably in part because of the influence of Browne's books upon Smyth's mind during the nine months before he gained his full vision of Separation. ${ }^{2}$ Unlike most Separatists, he never repudiated, but

1 Smyth's word, used of course in the sense of founding the church itself, not of building its house of worship.

${ }^{2}$ Paral. 5, 6, s, 9, 101, 109, 135, 67. Difs. 28. Prins. and infs. 25, 19. 
rather welcomed, the name "Brownist." Perhaps he did not emphasize as much as Browne Christ's lordship over his people, to the degree that the vote of each church-member is only Christ's vote cast through him ; but he held the principle distinctly. He says in so many words that

the powre of Christ which we speak of is a ministerial delegated powre given to man : \& that the question is who is the first subiect of this ministerial powre, who receave it immediately from Christ: I say the body of the church is the first subject of it, \& I say that whatsoever the Eldership hath, it hath from Christ through the body of the Church, \& by the Churches disposition. . . . The body of the Church having al her powre from Christ retaineth \& keepeth it intire to it self, \& doth not so delegate it to any officers, as that she leeseth (loseth) it \& is deprived of it.

He states it elsewhere repeatedly with equal clearness.

As to the fellowship of the churches Smyth is less distinctly Congregational than Browne. He says nothing about synods or councils, and nothing directly as to transfers of membership; although the question is raised whether a church may suffer her officers to be translated from herself to other churches. Yet, in the clause concerning ministrations to the needy, reference is made to a possible duty towards the poor of "any other true church." In the stringent circumstances of these early Congregational bodies, springing into sporadic, solitary and precarious existence, other matters filled a larger place in their consideration than the mutual relations of their churches. But Smyth seems to have gone farther than Browne from the true wisdom as to churches and the civil power. Browne says: ${ }^{1}-$

They [the magistrates] may doo nothing concerning the Chureh, ... but onelie to rule the common wealth in all outwarde Iustice, to maintaine the right welfare and honor thereof, with outward power, bodily punishment, \& ciuil foreing of mé. And therefore also because the church is in a common wealth, it is of their charge: that is concerning the outward prouision \& outward iustice, they are to looke to it, but to coppell religion, to plant churehes by power, and to force a submission to Ecclesiasticall gouernement by lawes \& penalties, belongeth not to them. ${ }^{2}$

1 Treat. of ref. 12.

2 Ibid. 7. Booke which Shew. 11, 15. 
But Smyth, unable to disregard the glamour of the magistracy which still palsied most believers, declares it fundamental ${ }^{1}$ that Princes must set up churches and require all subjects who are fit for membership to join them. ${ }^{2}$

Whether all the "forward" believers of the region united with this chureh and remained in its fellowship during its stay at Gainsborough, we do not know. In one place Bradford rather implies ${ }^{3}$ that the " 2 . distincte bodys or churches" were contemporaneous; but on the whole his words seem best reconciled with the theory that the Scrooby people were not embodied separately until 1606, when the Gainsborough company went to Amsterdam. Smyth, who had received regular Episcopal ordination on taking his fellowship at Christ's College, renounced it and was reordained by his church. ${ }^{4}$

Bradford says that there were "others of note" in the Gainsborough company, but, althongh a long list might be made of those who afterwards had more or less to do with Smyth's fortunes, it is impossible to identify many conclusively with the beginning of the movement. Hugo Bromhead and his wife, Anna, seem to have been from North Wheatley, a few miles from Gainsborough. A letter of his in the British Musemm ${ }^{5}$ indicates that he had some education and was a vigorous rather than well-balanced thinker. This letter, dated about 1606, which therefore describes affairs wheu the company first reached Amsterdam, and before Smyth's restless spirit had introduced those radical changes which, as Bradford says, "buried themselves, \& their names," is specially interesting as it gives their order of public service :-

I. we begynne wth. prayer; after[wards] reade some one or tow chapters of the bible, gyve the sense thereof and conferr upon the same; that done we lay aside oure bookes, and after a solemne prayer made

1 Prins. and infs. 29.

2 Paral. 119.

3 Hist. 9, 10.

${ }^{4}$ He says (Paral. 102): "For I vtterly renounce your orders which I had from Wick $\bar{a}$, prelate of Lincolne, . . . \& I receaved \& do retayne my ministery from that partienlar Church whereof I am Pastor." This shows that he entered upon his fellowship during Wickham's bishopric at Lincoln-Nov., 15\$t-Feb., 1595. Bernard also says (Plaine Evids. 20) : "By and by in Brownisme he renounced [his Chureh of England ministry] \& was made minister by Tradesmen, and ealled himselfe The l'astour of the Church at Gainsborough."

5 Harl. Ms, 860: 70. 
by the I. speaker, he propoundeth some text owt of the Scripture and prophesieth owt of the same by the space of one hower, or thre quarters of an hower. After him standeth up the 2. speaker and propoundeth owt of the same text the like tyme and $\left[\right.$ way $\left.^{1}\right]$ some time more, some tyme lesse. After him the 3. the 4. the 5. so many as the tyme will geue leaue. Then the 1 . speaker cocludeth wth. prayer as he began with prayer ; with an exhortation to cotribution to the poore, wch. collection being made is also cōcluded with prayer.

This morning exercise begynes at eight of the clocke, and cōtinueth unto twelue of the clocke: the like courses and exercise is obserued in the afternoone from 2 . of the clocke unto 5. or 6 . of the clocke: last of all the execution of the gouerment of the church is handled.

Thomas Helwys ${ }^{2}$ and his wife Joan at one time were of Basford, Notts., some thirty miles southwest from Gainsborough. He lived to become the minister of a section of Smyth's divided congregation, and afterwards to lead his own people back to London, where he had some prominence among Baptists. Clearly he lacked culture suited to his aspirations, and Robinson describes him as ignorant. ${ }^{3}$ John Murton ${ }^{4}$ appears to have been a resident of Gainsborough ${ }^{5}$ and a little under age when the church was formed. He, too, grew into the ministry, and, like Helwys, finally opposed Smyth in Amsterdam; and he also returned to London, to minister to a Baptist church and to suffer imprisonment. $^{6}$ Three books ${ }^{7}$ indicate that he was a close student of

\section{Illegible in the $M s$.}

2 The Dict. of Nat. Biog. thinks him probably a son of William Helwys, of Askham, Notts., about ten miles southeast of Scrooby.

3 Robinson says this twice. Of Relig. Com. Works, iii: 175, 277.

4 In his marriage entry at Amsterdam, Aug. 23, 1608, he is put down as aged 25, which throws back bis birth to 1582 or 1583 (Puiboken, s. d.). He married Jane Hodgkins of Worksop. He was a furrier. His name sometimes was spelled Morton, but in his letters he spelled it Murton.

5 The record clearly is "Queynsborch," which suggests Queensborough ; but Prof. Scheffer, familiar with Dutch pronunciation, takes it for Gainsborough, which the probabilities certainly faror.

6 In the British Museum is a tract dated Nov., 1646, and entitled The Sealed Fountaine opened to the Faithfull, and their Seed, etc., by J. Wilkinson, addressed "by J. W. prisoner at Colchester against Iohn Morton, Prisoner at London." If the latter were Murton, as there is no reason to doubt, he must have been then between 60 and 70 years old.

i Objections Answered by way of Dialogue, etc., 1615, 16mo. Repr. by H. Knollys Soc. 1896.

A Most Humble Supplication of Many of the Fings Maiestys Loyal Subjects, ready 
Scripture, an independent and forcible reasoner, and not unacquainted with current literature.

James I. was on the throne within a few months after Smyth had associated his followers by covenant at Gainsborough. As we have seen, after the king's advent the screws of conformity were tightened steadily. The Millenary Petition, ending in the farce of the Hampton Court Conference; the elevation of the narrow and bitter Bancroft to the primacy; and other occurrences, resulting in the adoption of Bishop Overall's book by Convocation in the spring of 1606 , made it clear that England no longer was a tolerable home for a Separatist church. In the late autumn of that year, therefore, Smyth and his people appear to have gone over to Amsterdam, where Johnson's church already had been for about nine years.

Those left behind now proceeded to congregate themselves, ${ }^{2}$ doubtless in the chapel of the Scrooby manor-house, which was ready to their hands through Brewster's occupancy. We are not without suggestions of the method pursued. Fourteen years afterwards John Murton said : ${ }^{3}-$

Is this so strange to Iohn Robinson? do we not know the beginnings of his Church? that there was first one stood vp and made a couenant, and then another, and these two ioyned together, and so a third, and these became a Church, say they, etc.

Moreover, there can be little doubt that we have the language which they used. They agreed together ${ }^{4}$

to testify all ciuil Obedience by the Oath of Allegiance, or otherwise, etc., 1620. Also repr. by the H. Knollys Soc. 1896.

A Description of what God hath predestinated concerning Man, etc., 1620, $16 \mathrm{mo}$.

1 Prince (I: 19) implies the heginning of October. Bradford, from whom he seems to be quoting, mentions no date. N. Morton says nothing of it. But Prof. Scheffer, who has studied the whole subject minutely in Amsterdam, assigns the date as in the text ("in 't late najaar denkelijk October of November, 1606." De Brownisten te Ansterdam, 85).

2 When in the autumn of 1607 they began to remove to Holland, Bradford says (Hist. 10) "they had continued togeither aboute a yere."

${ }^{3}$ Descrip. 169.

4 Bradford, Hist. 9. Daniel Buck testified in 1593 (Harl. Ms. 7042: 399) that when he joined the church of which Johnson and Ainsworth became pastor and teacher, he promised "that he wold walke with the rest of $y^{t}$ Congregation as they did walke in the waye of the Lorde, \& as far as might be warranted by ye Word of God." Neal says (Hist Puritans (ed. 1837), i : 262) that Henry Jacob's church in 
to walke in all his wayes made known, or to be made known, unto them, according to their best endeauors, whatsoeuer it should cost them, the Lord assisting them.

Chief among this covenanting company was Richard Clyfton, ${ }^{1}$ who either had been ejected from Babworth, or, for conscientions scruples, had surrendered his rectorate, and whom probably they ordained their pastor. He still resided in Babworth in the antumn of 1598 when his youngest child, Eleazer, was born. Whether he remained there or removed at some time to Scrooby is unknown. But we do know that " by his paines and dilligens" he did " much good" in the region, "and under God" was " a means of $\mathrm{y}^{\mathrm{e}}$ conversion of many." Perhaps cares and persecutions aged him prematurely, for, bor'n in or about 1553 , he hardly can have been more than fifty-five when they went to Amsterdam; yet Bradford calls him "a grave and fatherly old man when he came first into Holland, having a great white beard."

Bradford himself comes next in our study. Brewster hardly can have fairly entered upon his new work in his old Scrooby home before the child, William Bradford, was born within three miles from the manor-house, with whom he was to be associated afterwards more intimately than with any other person outside of his own family.

Just northeast of the railway station at Bawtry a by-path leads across the country to Austerfield. It conducts one over rustic stiles and, in the season, through fields of waving grain towards a small hamlet, the dwellings of which intinate poverty

1616 confederated thus in Loudon: "Standing together, they joined hands, and solemnly covenanted with each other, in the presence of Almighty God, to walk together in all Gods ways and ordinances, according as he had already revealed, or should farther make them known to them." Winslow also describes (Hypoc. Unm. 92) the Massachusetts men, who, we know, copied in some degree from Plymouth, as covenanting " to walke in all his wayes revealed, or as they should bee made knowne unto them, and to worship Him according to his will revealed in His written Word onely."

1 Son of Thomas, of Normanton, Derbyshire. Married Anne Stuffen, of Worksop, in Sept., 1586, two or three months after becoming rector of Babworth. Had three sons and three daughters, all born in Babworth; the soungest, Eleazer, born Nov. 1, 1598. An old family Bible in the Taylor Institution, Oxford, contains details of his history and family, but gives no clue to his university. Dr. Dexter had a complete transeript of these notes, and Arber cites them. Story of Pilg. Faths. 05. 
but not pauperism, with a few of larger suggestiveness. After passing two thirds of the way through the village, he will discover on his right the little churchyard and the quaint old parish church, St. Helen's. ${ }^{1}$ Some things about it are unchanged since long before the date to which we now are taken back. It was built by John de Builli in the latter half of the twelfth century, and its Norman doorway, at the side, with a compound arch, zigzen and beak ornaments and a rude carving of a dragon, is assigned to that date. The exterior has not been greatly altered. In Bradford's time the inside evidently was a plain, boxlike room, with a narrow chancel extension. The rude oaken chancel railing apparently is several hundred years old, and some panes of glass in the windows nust have let in the light upon services here 300 , or even 400 , years ago. Within the last seven or eight years the church has been restored, and enlarged to its earlier size and shape by the addition of an aisle on the outside of the old north wall. Several pillared arches in that wall, filled in and plastered over, have been reopened. They seem to have been built up before his time. ${ }^{2}$

There were living in Austerfield about 1575 a William Bradford ${ }^{3}$ and a John Hanson. Apparently they were better off than their neighbors. They were the only residents assessed to the subsidy, Bradford being taxed on twenty shillings' annual value of land and Hanson on sixty shillings of goods, which implies that the former was the leading farmer and the latter the shopkeeper of the village. Hanson had married Margaret (or Mary) Gresham, July 23, 1560, and they had a daughter, Alice, born Dec. 8, 1562. No record of Bradford's marriage is known, but he seems to have been married and had three sons, William, Thomas and Robert, each of whom married and had issue. William married Alice Hanson on June 21, 1584. Thomas's mar-

1 So called as early as 1471 , according to a will of that date.

2 The old baptismal font is a hollowed block of stone some twenty-three inches in diameter at the top and about nine inches deep at the centre. It was superseded some years ago by a smart new one in Gothic style, and was appropriated by the clerk as a trough for his poultry. But since American attention has been attracted to the spot, it has been replaced in the church.

${ }^{8}$ These facts as to the Bradford family are mainly from Hunter's Collections and C. Nather's Magnalia, supplemented by Dr. Dexter's personal researches in the records. 


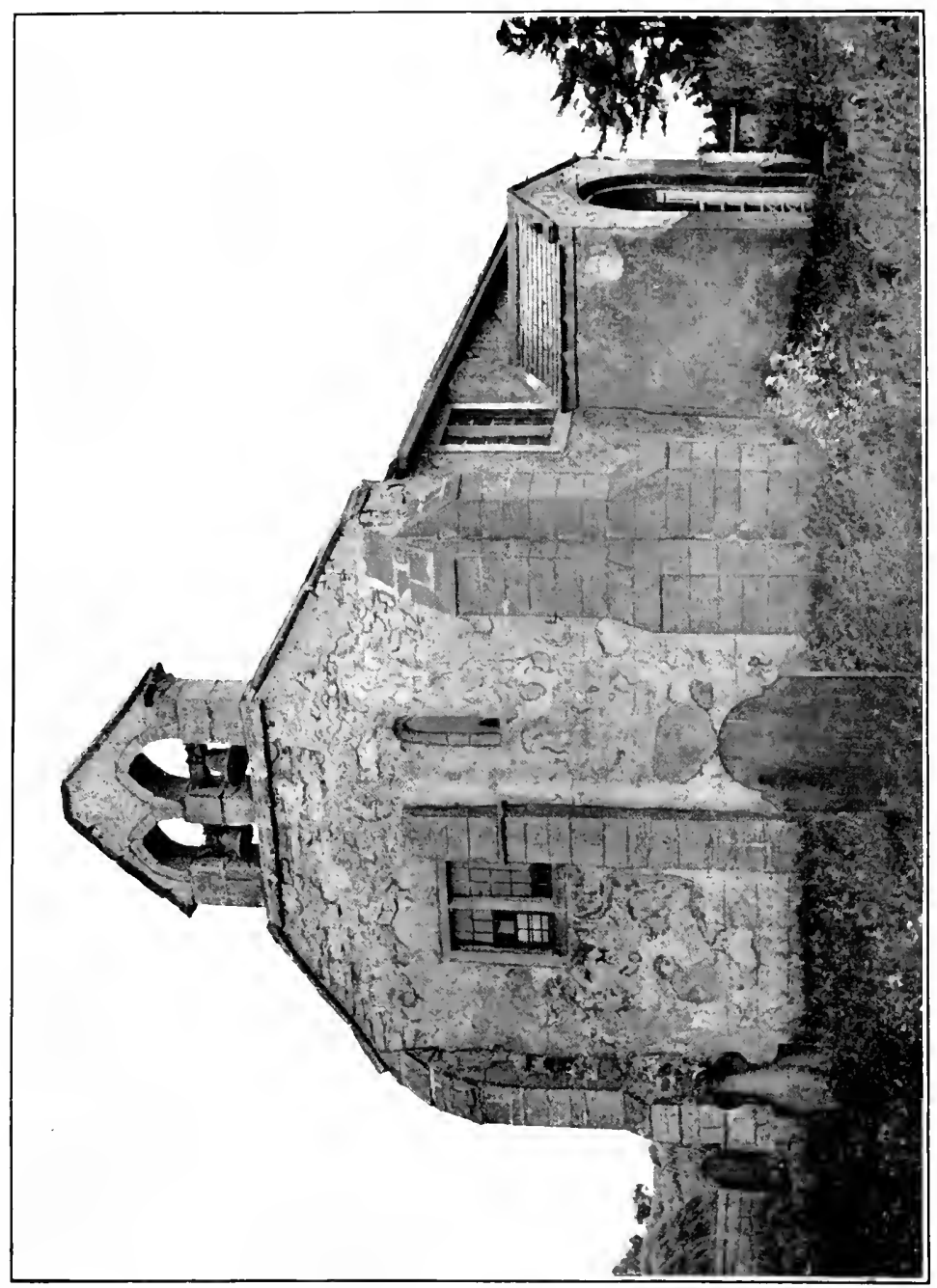

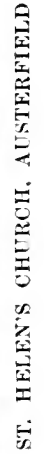




\section{,}


riage is not recorded, but he had a danghter, Margaret, baptized Mar. 9-19, 1577-78. Robert married Alice Waigestaff on Jan. 31-Feb. 10, 1585-86.

William and Alice Bradford had three children. The eldest was Margaret, baptized Mar. 8-18, 1585-86, who was buried the next day. The second was Alice, baptized Nov. 30, 1587. Nothing more about her is known positively, but various circumstances imply that she died while comparatively young, and the records note the burial, on Jan. 30-Feb. 9, 1607-8, of an Alice Bradford not otherwise accounted for. The third child, baptized at the old stone font, on Wednesday, Mar. 19-29, 1588-89, was to become historic. The record, made by the rector, Rev. Henry Fletcher, who performed the service, runs thus: "William sone of Willm Bradfourth baptized the $x^{\text {th }}$ day of March Amno dm. 1589."

Evidently this Bradford family had neither poverty nor large riches. Yet Robert Bradford plainly was of some consequence, ${ }^{1}$ and his will suggests something as to the family from which the future Governor of the Plymonth Colony came. The testator describes himself as "Robert Bradfourth, of Austerfield, yeoman." He makes an energetic declaration of his Christian faith, and leaves ten shillings to the chapel in Austerfield. He gives small legacies to two servants and to Thomas Silvester, rector of Aukley. He then bequeaths to his eldest son, Robert, the reversion of two leases held by him in Austerfield and Martin, his best yoke of oxen, certain household furniture, "the counter where the evidences are," and his corselet with all its belongings. The residue of the property is divided equally among his four children, who are made executors : Robert, then almost eighteen ; Mary, abont sixteen; Elizabeth, about twelve; and Margaret, about nine. He requests his neighbor, Mr. Richardson, of Baw-

1 He was buried Apr. 23, 1609. Aust. Par. Recs. Hunter (Colls. 105-109) gives an abstract of his will. Ankley, or Alkley, was a hamlet four or five miles northwest from Austerfield. Silvester's will, in 1615 , indicates that he had a library of English and Latin books, large for such a place in thóse days and possibly of some value to William Bradford in his youth. Martin, or Morton, is an old family seat, possibly then a parish or hamlet, adjoining Austerfield and Bawtry. George Morton, the Pilgrim, probably was born there. It still is so much of an estate that it was sold in 1891 for $\$ 150,000$. 
try, to take charge of Robert and Margaret during their minorities; William Downes, of Scrooby, of Elizabeth; and $\mathrm{Mr}$. Silvester of Mary. Hunter sums up his discoveries about the Bradford family thus :-

"Yeoman" [by which name they called themselves] implies a condition of life a little better than that which would now be indicated by the word. The yeomanry of England in the reign of Elizabeth formed the class next to those who were the acknowledged gentry using coatarmour of right. They lived for the most part on lands of their own. ... This will [that just referred to] shows the Bradfords to have been at this time intimately aequainted with the best of the people living in their neighborhood, if it be allowed that holding a lease from the Catholic family of Morton implies acquaintance with them. The Mr. Richardson. to whom he commits two of the children, was, next to the Mortons, the most considerable person then at Bawtry. ... On the whole it appears that the Bradfords of Austerfield, during the eighteen years that he [William] was living amongst them . . . associated with the best of the slender population by whom they were surrounded.

Local tradition associates a house still standing in Austerfield with this family. The lack of records of real estate transfers makes it impossible to demonstrate the truth of this tradition. Probably it deserves little eredit, yet it has endured for two or three generations, at the least. There are inscribed stones in the little churchyard but none of any Bradfords. In fact, excepting in the cases of the more recent graves or of a few comparatively older ones protected by monuments, to identify any grave is almost hopeless. ${ }^{1}$

Bradford was hardly more than sixteen when the Scrooby chureh was formed. Orphaned ${ }^{2}$ while yet a lad, his grandfather, William, and his uncles, Thomas and Robert, intended him for

1 In English churchyards stones more than from 75 to 100 years old seldom have legible inscriptions. Moreover, Gervase Milner, then parish clerk and sexton at Austerfield, said in 1865 that he seldom buried any one withont digging up a part of some one else. On the previous day, in opening a grave for an interment, he had exhumed bones and part of a coffin, and liad thrown earth over them until the funeral party was gone, and then replaced them upon the top of the new body in the old grave!

2 His father was buried on July 15, 1591, when the son was less than two years old. His mother appears to have been married again, on Sept. 23, 1593, to Robert Briggs, and may have died soon after. 
"the affairs of Husbandry" upon the farm which he inherited." But as a boy he was weak, and "soon and long sickness" indisposed him to farming, while also turning his thoughts and tastes from " the Vanities of youth." About 1602 the Seriptures made a lasting impression upon his mind, and soon after, under the influence of Clyfton's illuminating ministry, he decided that it was his duty to withdraw from the State Church, and to umite with the Separatists.

In this he encountered the bitter opposition of his uncles and neighbors, ${ }^{2}$ but his answer was : -

Were I like to endanger my life, or consume my estate by any ungodly Courses, your counsels to me were very seasonable: But you know that $I$ have been diligent and provident in my calling, and not only desirous to angment what I have, but also to enjoy it in your Company; to part from which will be as great a cross as can befal me. Nevertheless, to keep a good conscience, and walk in such a way as God has prescribed in his Word, is a thing which I must prefer before you all, and above Life itself. Wherefore, since ' $t$ is for a good cause that I am like to snffer the disasters which you lay before me, you have no canse to be either angry with me, or sorry for me; yea. I am not only willing to part with everything that is dear to me in this world for this cause, but I am also thankful that God has given me an heart so to do, and will accept me so to suffer for him.

There also are brief allusions to several others of the Scrooby company. Richard Jackson was one, and seems to have lived there. Late in 1607 he was cited ${ }^{3}$ before the High Court of Commission "for his disobedience in matters of religion," fined twenty pounds, and an attachment was ordered. The next Angust his case came up again and he was described as "late of Scrooby, now of Tickhill." Robert Rochester also was a resident of Scrooby, who, Hunter says, ${ }^{4}$ was dealt with as a Sepa-

1 We are remitted for most of the details of his life to the $N$. E. Memorial of Sec. Morton, of the Plym. Col., and to Cotton Mather's Magnalia. But Morton's mother was a sister of Bradford's second wife, and Morton had custody "of such Manuseripts as he [Bradford] left in his study, from the year 1620. unto 1646." It is likely that Mather had the benefit of some of these private sources of histors. as Prince afterwards had.

2 Mag. ii : 3.

3 Act-books of Commission, Dec. 1, 1607 ; Aug. 2, 1608.

4 Colls. 128, 126, 127. 
ratist by the Commissioners in 1608 . But no other mention of him appears. Francis Jessop also was one. He was a younger son of a good family in Worksop. Hunter says that it was literary ${ }^{1}$ and religious, professing itself Puritan, but only in the case of Francis going so far as Separation. He was married at Worksop, on Jan. 24-Feb. 3, 1604-5, to Frances White, supposed to have been a sister of Bridget White, who married John Robinson, Jane White, who married Randall Thickins, and Roger White, a member of the Leyden company after 1621, and perhaps earlier. Worksop is only nine miles from Scrooby, and Jessop, who must have been about twenty-eight, and these Whites may have been among those who formed the church.

Gervase Neville was another. Although in Amsterdam he went all lengths with Smyth into Anabaptism and Se-baptism, he deserves mention here, not only as one of the company, but also because there is a fuller account in his case than in that of any one else of the manner in which the Ecclesiastical Causes Commission Court dealt with these men. The following extract is from the official documents: ${ }^{2}$ -

Nov. 10. 1607. Office of Court against Gervase Nevyle of Scrooby. Informacion hathe bene geuen and presentment made that the said Gervase Nevyle is one of the sects of Barrowists, or Brownists, houlding \& mainteining erronious opinions \& doctrine repugnant to the Holie Scriptures \& Worde of God, for which his disobedience \& schismaticall obstinacie an attachment was awarded to William Blanchard messenger, etc., to apprehend him; by vertue whereof being by him brought before his Grace \& saide Associates [the High Court], \& charged with his errors \& daingerous opinions \& disobedience, his Grace in the name of himself haveing charged him therewith, as also with certain contemptuous speeches \& frequenting of conventicles and companie of others of his profession, he required him to take an oatl to make answere (so farr as he ought $\&$ was bounde by lawe) to certaine interrogatories or questions by them conceived \& sett downe in writeing to be propounded \& $[\mathrm{ad}]$ ministred unto him \& others of his bretheren of the separation \& sect aforesaid, which he obstinatelie \& uterlie refused,

1 Hunter is mistaken in calling Francis the author of the Discovery of the Errors of the English Anabaptists, 1623, 4to. That was "by Edmond Iessop, who sometime walked in the said errors with them." It may be added that Francis is recorded at Leyden as from "Rotherham and Sheffield."

2 Act-books, s. d. 
denying to geve his Grace answere, \& protesting very presumptuouslie $\&$ insolentlie in the presence of God againste his authoritie (and as he tearmed it) his Antichristias hiErarchie; but yet yealded to answere to the rest of the said Commissioners (excepting his Grace onelie) although it was by them shewed unto him that his Grace was cheefe of th' Ecclesiasticall Commission, by vertue whereof he was convented, \& they all did then \& there sit. And then, after divers godly exortacions \& speeches to him, they did propound \& reade the said interrogatories unto him, and presentlie sett downe his answere unto the same in their presences under his hand. And forsomuch as thereby, as also by his unreverent, contemptuous \& scandalous speaches it appeared that he is a very daingerous schismaticall Separ[at]ist, Browneist, and irreligious subject, houlding \& mainteyning divers erronious opinions, the said lord Archb. with his colleagnes aforesaid have by their strait warrant committed him, the said Gervase, to the custodie of the said William Blanchard by him to be therewith delivered to the handes, warde \& safe custody of the keeper or his deputie keeper of his Highnesses Castle of Yorke, not permitting him to have any libertie or conference with any, without spetiall license from three at the least of the saide Commissioners (whereof one to be of the quorum).

As Neville was in York Castle in the March following, the church, while in Scrooby, did not see much of him. Elizabeth Neal also is recorded in Leyden as from Scrooby, but no details are given.

One remains, cliefest of all, John Robinson. Apparently he was born in Lincolnshire, ${ }^{1}$ and perhaps at Gainsborough, ${ }^{2}$ in 1576 or 1577.3 Of his parentage or early training no account is known. He appears first at Corpus Christi, or Benet, ${ }^{4}$ College, Cambridge, in 1592.5

1 The Corp. Chris. register (Masters's Hist. Corp. Chris. List of Members, 41) says Lincolnshire, and Bishop Hall (Apol. against Brownists, 98) says: "Lincolnshire was your Country."

${ }^{2}$ So Hunter judges (Colls. 93). The Gainsborough parish records go back to 1564 , but the first volume is so illegible that the record, if there, cannot be identified.

${ }^{3}$ An inference from the record of his matriculation at Leyden: "Sept. 5, 1615. Coss. permissu [by leave of the magistrates] Joannes Robints [onus - evidently added afterwards]; Anglus. An.xxsix. Stud. Theol. Alit familiam [has a family]."

${ }^{4}$ So called because it had for its chapel the church of St. Benedict (St. Benet), and was bounded on one side by a street of that name.

5 Hasters (41) notes of one of five John Robinsons, connected with the college before 1677, " beneficed near Yarmouth in Norf. but being molested by the Ecclesi- 
Corpus Christi is north of Peterhouse on the other side of Trumpington St. Of the fifteen colleges ${ }^{1}$ it was fifth in age, having been founded in 1352 by members of the Guilds of Corpus Christi and the Blessed Virgin, apparently so that priests there educated might be obliged to celebrate without fees any masses desired. ${ }^{2}$ In $1573^{3}$ it had had ninety-one members, and in 1621 it had but 140 - a Master, twelve fellows, thirty-three scholars and ninety-four students - the average membership of the fifteen colleges then being about 180. John Jegon, to become Bishop of Norwich, was Master and Vice-chancellor of the university as well, Lord Burghley still being Chancellor. The college had a good, but not brilliant, record. Among its graduates were Richard Wolman, one of the canonists in the matter of the divorce of Henry VIII., a signer of the letter to the Pope, and part author of "The Institution of a Christian Man;" Matthew Parker, afterwards Archbishop of Canterbury; Sir Nicholas Bacon, Lord Keeper of the Great Seal ; Richard Fletcher, Bishop of Bristol and then of London; Christopher Marlowe, already mentioned; John Copcot, in his day Master of the College; and Thomas Cavendish, the third circumnavigator of the globe.

The church of St. Benedict, adjoining it, long served for its chapel, until Sir Nicholas Bacon built one. This was begun in 1579 , but not finished until nany years later, so that it is doubtful whether it were in use in Robinson's time. It was not consecrated until long afterwards. Hardly a fragment of the original church of St. Benedict now remains, excepting the square west tower, which is thought to be the oldest structure in Cambridge. Robinson must have been familiar with it. The Library then was an attic over the new chapel.

No important change had occurred in the university since Brewster's time. In 1588 the Vice-chancellor had complained of "the excesse and disorder of apparell," ${ }^{4}$ and Lord Burghley

astical Courts, removed to Leyden, where he sat up a Congregation upon the Model of the Brownists."

1 One, Emanuel (15S4), had been established since Brewster was matriculated in 1580 .

2 Mullinger, i : 247-249.

${ }^{3}$ Wordsworth, Soc. Life at Eng. Univs. 641. Foundation of Univ. Camb. Brit. Mus. Add. Ms. 11,720.

4 Lans. Ms. Wrii : 8.3 ; Harl. Ms. 7041: 199. 
had issued strict orders for reform. The most significant event had eoncemed Francis Johnson. In January, 1588-89, he preached a sermon which angered the anthorities. With Cutlsbert Bainbridge, who had offended similarly, he was imprisoned. Lord Burghley thought that the Heads took "a verie hard course," but they replied that the offenders assumed to possess new light from heaven, so that it seemed best to make an example of them. ${ }^{1}$ Johnson then appealed directly to Burghley.

It looks as if, by Burghley's advice, he made some reeantation ; ${ }^{2}$ but it was insufficient, and the Heads expelled him from the university. He appealed to the university itself, but was disallowed, and, as he would not depart, he was confined again. He appealed once more to Lord Burghley, and his appeal was seconded by "a supplication of Lxviij. scholars of the University of Cambridge," all masters of arts and mostly fellows, urging the dangers threatening the whole university if appeal from the sentence of the Vice-chancellor, expressly permitted by the statutes, should be disallowed. Of the signers, fourteen - one of whom was Anthony Wotton, afterwards first professor of divinity in Gresham College - were of King's College; twelve of Emanuel; eleven of St. John's; eleven of Trinity; nine of Clare Hall; seven including William Perkins, and Thomas Morton, afterwards Bishop successively of Chester, Lichfield and Coventry, and Durham — of Christ's; and four — of whom Thomas Brightman was one - of Queen's. This "supplication" was accompanied by a note from William Branthwayte - then fellow of Emanuel and afterwards a translator of the Bible, Master of Gonville and Cains, and Vice-chancellor - who declared that " the canse doth greatly concerne the hole body of the University, it being for the retayning of such privileges as by statute are graunted unto us." " 3 A new Vice-chancellor, Thomas Preston, now had assumed office, and the matter ended in Johnson's resigning his fellowship, and leaving the university early in $\mathbf{1 5 9 0 .}$

The Vice-chancellor's special anxiety was exeited because, as he asserted, the Puritan members in their sermons claimed the right of private judgment in religion, encouraged the persecuted,

1 Lans. Ms. Ixi: 8, 10, 12, 15, 16.

2 Brook, ii : $93 . \quad 3$ Ians. Ms. crii : 28. 
and compared the State Church unfavorably with the Presbyterian. 1 This evil condition he ascribed principally to "Mr. Iohnson's complottinge with his associates ;" which indicates that, for a young man under thirty, Johnson had a large influence; and that Robinson stood a fair chance of becoming leavened with Puritanism during his stay at Cambridge.

We can recover a few incidents which diversified his university career. He haraly had settled down to work when a wave of excitement swept over the colleges because of "the makeing of shewes, and playing of enterludes," with " bearebaytings and bulbaytings," etc., at the time of Sturbridge Fair. The Privy Conncil interfered after the players had become so insolent as to set up their bills upon the college gates. During his second year his own college, Corpus Christi, also was agitated by a controversy between Master Jegon and a majority of the fellows over the choice of a proctor. There was a great tumult in the Regent-house, "with laughinges, hemminges, hissinges, and clamorous speeches, violently keeping the doare against the said officer."

In December, 1595, Dr. William Whitaker, Master of St. Joln's, died. A controversy on predestination and free-will had been disturbing the university, which led to a conference at Lambeth between the Archbishop and Drs. Whitaker and Tyndal, and this produced the famous Lambeth Articles.2 The filling of Whitaker's place led to a struggle between the Puritans and non-Puritans, the latter triumphing and electing Dr. Richard Clayton. Moreover, there soon followed a contention almost precisely foreshadowing that to which Robinson himself was to become a party later at Leyden. Peter Baro, a Frenchman, had been made Margaret professor of divinity at Cambrilge. After nearly twenty years of service, objections by the more rigid Calvinists led to his withdrawal. His general doctrine appears to have been an anticipation of some tenets of Arminianism.

Robinson's later undergraduate years were marked by repeated conflicts between town and gown. In November, 1596,

1 Lans. Mss. Ixii : 42; lxxi : 83 ; lxxv: 7 ; lxxvii : 6; lvii : 87; lxxix : 59-69; ciii : 89,84 .

2 Schaff, Creeds of Christendom, i: $65 \mathrm{~s}$. 
the civil authorities of Cambridge complained to Lord Burghley of many misdemeanors on the part of members of the university ; and he instructed the masters of the colleges to correct them. But they disputed the charges. A year later, however, matters came to such a pass that the Heads notified him that they could not well endure them. Accordingly, great efforts were made for adjustment, but disturbances kept occurring for a long time. ${ }^{1}$

There remain in the Lansdowne Manuscripts notes of two kinds which reveal the status of the university during Robinson's membership. ${ }^{2}$ One supplies the subjects of disputation at a commencement in 1597 , containing eight topies in civil law, two in theology and ten in philosophy. The two in theology are these : -

Politica MLsis non sunt Christianis rebuspublicis obtrudenda [The peculiarities of the Mosaic economy are not to be insisted upon in Christian commonwealths]; and

Unio personalis non tollit carnis Christi circumscriptionem [Individuality of character does not interfere with a share in the communion of Christ's body].

Clearly those who suggested such themes were not anxious to promote Puritanism.

The other, in 1597, when Robinson probably was one of the "godlie and painfull" students of divinity, gives the number of students and preachers in the university:-

Studentes within the colledges in Cambridge . . . . 1950

Graduates . . . . . . . . . . . . 657 Preachers almoost all unprovided for $\quad . \quad \cdot \quad \cdot \quad . \quad . \quad . \quad .122$ Besides manie which be readie to be employed.

Of these there be:

Poore studentes which be verie godlie and painfull, and for lack of exhibicion shall be for-

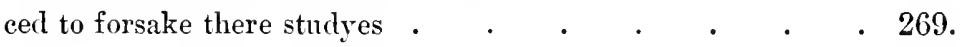

In 1598 Robinson became a fellow ${ }^{3}$ of Corpus, and presuma-

1 Sloan Ms. 3562: 36, 43,76; Harl. Ms. $7047: 81$.

2 1xxxiv: $101,100$.

3 Dr. Lamb in his reprint of Masters's Hist. of Corpus states that Robinson succeeded Mr. Morlę. 
bly took orders at the same time. ${ }^{1}$ As yet, therefore, he clearly was only a Puritan. How long he remained in residence upon his fellowship is unknown, as is the place where he began his ministry in comnection with it. Neal, who published in 1732, says that he was "a Norfolk divine, beneficed about Yarmouth," but gives no authority. Hunter thinks' ${ }^{3}$ that he may have been the Robinson who for a time - 1595 to 1608 - held the perpetual curacy of Mundham, some fourteen miles from Yarmouth; but Ashton declares ${ }^{4}$ that the name of that Robinson was Robert. It is only certin that John Robinson's labor's were,near Norwich, and probably in it, for at least a part of the time between 1600 and 1604 , and that he was suspended at last for his increasing nonconformity; his bishop being John Jegon, his former Master at Corpus. Robinson seems to have made an effort at first to retain some connection with the Church of England by using a leased chapel or through the mastership of some hospital, ${ }^{5}$ positions in which some special toleration might be expected. But this effort failing, it looks as if he preached for a little while in Norwich ${ }^{6}$ to a small Separatist congregation.'

If the statement of Dr. Lamb - who reissued Masters's "History of Corpus Christi" in 1831, and added to the former

1 "It is required that they [Fellows of Corpus] shall 'one and all' be in priests orders." Mullinger, i : 250.

2 Ed. 1844, i: 24t. $\quad 3$ Colls. $94 . \quad 4$ IForks of Robinson, i : xvi, $\mathbf{n}$.

5 J. Hall, Com. Apol. 115. Hall meanly says: "Neither doubt we to say that the Mastership of the hospital at Norwich, or a lease from that City (sued for with repulse) might have procured that this Separation from the Communion, Gouernement, and Worship of the Church of Eugland, should not hane beene made by John Robinson."

${ }^{6}$ Ames writes (Second Manuduction for Mr. Robinson, 29): "He [Robiuson] declared then [when he went to Cambridge in 1604 to resigu his fellowship] to ore of his acquaintāce, that he had been amogest some company of the Seperation before his Comming to Camb: \& exercising amongest them had renounced his former ministery."

7 Ainsworth's language (Counterpoyon, 240), if we knew any other fact corroborating it, would persuade us that it was in Norwich itself that Robinson had been beneficed, and that it was a portion of his former flock which followed him into Separatism: "Witnesse the late practice in Norwich; where certeyn citizens were excommunicated for resorting vnto and praying with Mr. Robinson, a man worthily reverenced of all the city, for the graces of God in him as your selfe [Mr. Crashaw] also I suppose will acknowledge, and to whome the cure and charge of their soules was ere while [some time before] committed." 
record of Robinson the statement that he resigned his fellowship in 1604 - be correct, it probably was then that he took the definite step of separation. Doubtless he was well informed of the growth of Separatism at Gainsborough, in connection with the labors of Smyth and Clyfton, and he may have been led thither, like Browne to Norwich, by such knowledge. Sadly leaving Norwich, he lingered a little at Cambridge, in order to resign his fellowship and renew some former acquaintances. William Perkins had died in 1602, and "heavenly" Paul Baynes had succeeded him as lecturer at St. Andrews, but Laurence Chaderton still was Master of Emanuel. Robinson has left a record of a part of this experience. ${ }^{1}$

Coming to Cambridge... I went [in] the forenoon to Mr. Cha[derton] his exercise: who, upon the relation which Mary made to the disciples of the resurrection of Christ, delivered, in effect, this doctrine, that "the things which concerned the whole church were to be declared publicly to the whole church [Matt. xxviii, Mark xvi] and not to some part only;" bringing, for instance and proof, the words of Christ, Matt. xviii : 17, Tell it to the Church: confirming therein one main ground of our difference from the Church of England, which is, that Christ hath given his power for excommunication to the whole church gathered together for his name, as $1 \mathrm{Cor}$. v., the officers as the governors, and the people as the governed in the use thereof; unto which church his servants are commanded to bring their necessary complaints. And I would desire mine opposite ${ }^{2}$ either to show me how and where this church is, having this power, in the parish assemblies ; or else by what warrant of God's word I (knowing what Christ the Lord commanded herein) may with good conscience remain a member of a church without this power (much less where the contrary is advanced) and so go on in the known transgression of that his commandment, Tell the Church?

In the afternoon I went to hear Mr. B[aynes] the successor of $M r$. Perkins, who, from Eph. v. and v. 7 or 11, showed the unlawfulness of familiar conversation between the servants of God and the wicked, upon these grounds, or the most of them: 1. That the former are light, and the other darkness, between which God hath separated. 2. That the godly hereby are endangered to be leavened with the others'

1 A Manumission to a Manuduction. The late Dr. Chas. Deane had the only known copy. It was reprinted in 1852 in 4 Mass. Hist. Soc. Colls. i : 165-194, 189.

${ }^{2}$ Dr. Wm. Ames, whose first Manuduction he is answering. 
wickedness. 3. That the wicked are hereby hardened, in receiving such approbation from the godly. 4. That others are thereby offended, and occasioned to think them all alike, and as birds of a feather, which so flock together. Whom afterwards privately I desired, as I do also others, to consider whether these very reasons make not as effectually and much more against the spiritual communion of God's people (especially where there wants the means of reformation) with the apparently wicked, to whom they are as light to darkness.

Robinson thought it a specially kind Providence that led him to hear these discourses, and was satisfied that, with his convictions, the only honorable course was that of avowed separation. And, when accused afterwards by Dr. Ames ${ }^{1}$ of inconsistency in attending the worship of the Established Church after he had separated from it, he defended both himself and his separation.

Probably it was soon after this visit to Cambridge that he joined the Separatists under Clyfton. How long it was before Snyth's company emigrated and whether Robinson ever belonged to them is unknown, the only clear fact being that, whatever associates he joined, it was for some time only as a private member. When the Scrooby people became a church, we have Bradford's word ${ }^{2}$ that he was a member, "a famous and worthy man . . . who afterwards was their pastor for many years."

We may think of these Scrooby Christians, then, as fairly organized in the autumn of 1606 , and as holding " their meetings every Saboth " in the manor-house chapel, notwithstanding all the "dilligence \& malice of their adversaries." But detection sooner or later was certain. So Bradford says frankly :-

They could not long continue in any peaceable condition, but were hunted \& persecuted on every side, so as their former afflictions were but as flea-bitings in comparison of these which now came upon them. For some were taken \& clapt up in prison, others had their houses besett \& wateht night and day, \& hardly escaped their hands; and $\mathrm{y}^{\mathrm{e}}$ most were faine to flie \& leave their howses \& habitations, and the means of their livelehood. Yet these \& many other sharper things

1 Manud. 9.

2 Hist. 10, 11. Bradford's use of the word "afterwards" here implies strongly, although it does not prove, that it was Clyfton who was the pastor of the church at Serooby. 
which affterward befell them, were no other then they looked for, and therfore were $y^{e}$ better prepared to bear them by $y^{e}$ assistance of Gods grace \& spirite.

During all this time Brewster steadily had held on his way in his place and work at the manor-house. On Tuesday, Mar. 31-Apr. 10, 1607-8, he received seventy-three pounds as salary for two years then ending. . Six months later, however, on Sept. 30, having resigned, he was succeeded by Francis Hall. Evidently the long-gathering storm was about to burst. The surrender of his position under government no doubt involved his withdrawal from the premises.

It may be noted, in passing, that Davison, who was buried on Dec. 24, 1608, still was in Stepney when Brewster laid down his office. If Brewster went up to London to adjust his accounts, he cannot have failed to call upon his former master, who was quietly awaiting his exchange of worlds. Not a Separatist hin self, he nevertheless was so liberal and devout, that an interview with him in the mellow ripeness of his last days would not disturb his old servant's loyalty to the cause to which now he was fully pledged.

Two months after his resignation, as appears by these records, Brewster was cited before the High Court of Commission : ${ }^{2}$

Dec. 1 [1607]. Office $v$. Richard Jackson par[ish]. Scrowbie. For his disobedience in matters of religion. Process served on him \& he gave his word to appear to day. Does not appear. Fined $£ 20 \&$ attachment ordered.

Same day. [Dec. 1, 1607.] Office v. William Bruster of Scrowbie, gen. Information is given that he is a Borrownist or disobedient in matters of religion. Process served and he gave his word to appear to day. Does not appear. Fined twenty pounds, and attachment ordered. . . .

December 15th. 1607. Office $v$. Richard Jackson, \& Wm. Bruester of Scroubie. For Brownisme. An attachment was awarded to W. Blanchard to apprehend them, but he certifieth that he can not finde them, nor understand where they are.

Another record furnishes the names of the Commissioners : -

Richard Jackson, William Brewster, and Robert Rochester, of Scrooby, in the county of Nottingham, Brownists or Separatists, for

1 Hunter, Colls. 67, 68, 131.

2 Act-books in York Registry, s. d. 
a fine or amercement of $£ 20$. apiece set and imposed upon every of them by Robert Abbot and Robert Snowden, ${ }^{1}$ Doctors of Divinity, and Matthew Dodsworth, Bachelor of Law, Commissioners for Causes Ecclesiastical within the province of York, for not appearing before them upon lawful summons at the Collegiate Chureh of Southwell, the $22 \mathrm{~d}$ day of April, anno Domini $1608-£ 60$.

It is not strange that the question of exiling themselves became increasingly urgent. Most of them ean have had only a vague notion of what would befall them should they emigrate. But they were willing to risk almost everything materially if they could be sure of liberty of conscience. And, whatever uncertainty overhung the future in Holland, to remain in England meant either absolute ecclesiastical submission or perpetual persecution. So, Bradford says : ${ }^{2}$

Seeing them selues thus molested, and that ther was no hope of their continuance ther, by a joynte consente they resolved to goe into $\mathrm{y}^{\mathrm{e}}$ Low-Countries, wher they lieard was freedome of Religion for all men; as also how sundrie from London, \& other parts of $\mathrm{y}^{\mathrm{e}}$ land, had been exiled and persecuted for $\mathrm{y}^{\mathrm{e}}$ same cause, \& were gone thither, and lived at Amsterdam, \& in other places of $\mathrm{y}^{\mathrm{e}}$ land.

No warm glow of romance gilded the project, but they undertook it deliberately in its utmost prosaic reality. To quote again the touching words of their own chronicler :-

To leave their native soyle and countrie, their lands \& livings, and all their freinds \& famillier acquaintance, it was mueh, and thought marvelous by many. But to goe into a countrie they knew not (but by hearsay), wher they must learne a new language, and get their livings they knew not how, it being a dear place, \& subjecte to $\mathrm{y}^{\mathrm{e}}$ miseeries of warr, it was by many thought an adventure almost desperate, a case intolerable, \& a misserie worse than death. Espetially seeing they were not aequainted with trads nor traffique, (by which $\mathrm{y}^{\mathrm{t}}$ countrie doth subsiste, ) but had only been used to a plaine countrie life, \& $y^{e}$ inocente trade of husbandrey. But these things did not dismay them (thongh they did sometimes trouble them) for their desires were sett on $y^{e}$ ways of God, \& to enjoye his ordinances; but they rested on his providence, \& knew whom they had beleeved.

1 Abbot became Bishop of Salisbury in 1615 and Snowden Bishop of Carlisle in 1616 Dodsworth was father of Roger Dodsworth, the great charter antiquary and the originator of the Monasticon.

2 Hist. 10, 11. 
Probably most of them had comparatively little to leave, yet for that very reason that little became all the more precions. Could they have embarked openly, that wonld have been one thing. But their actual experience was quite another. Bradford says :-

Though they could not stay, yet were $y^{e}$ not suffered to goe, but $y^{e}$ ports \& havens were shut against them, so as they were faine to seeke secrete means of conveance, \& to bribe \& fee $y^{\mathrm{e}}$ mariners, \& give exterordinarie rates for their passages. And yet were they often times betrayed (many of them), and both they \& their goods intercepted \& surprised, and therby put to great trouble \& charge, of which I will give an instance or tow \& omitte the rest.

There was a large companie of them purposed to get passage at Boston ${ }^{1}$ in Lincolin-shire, and for that end had hired a shipe wholy to them selves, \& made agreement with the maister to be ready at a certaine day, and take them and their goods in, at a conveniente place, wher they accordingly would all attende in readines. So after long waiting, \& large expences, though he kepte not day with them, yet he came at length \& tooke them in, in $\mathrm{y}^{\mathrm{e}}$ night. But when he had them \& their goods abord, he betrayed them, haveing before hand complotted with $\mathrm{y}^{\mathrm{e}}$ serchers \& other officers so to doe; who tooke them, and put them into open boats, \& ther rifled \& ransaked them, searehing them to their shirts for money, yea even $y^{e}$ women furder then became modestie; and then carried them back into $\mathrm{y}^{\mathrm{e}}$ towne, \& made them a spectackle \& wonder to $y^{\mathrm{e}}$ multitude, which eame flocking on all sids to behould them. Being thus first, by the chatchponle officers, rifled, \& stripte of their money, books and much other goods, they were presented to $y^{e}$ magestrates, and messengers sente to informe $y^{e}$ lords of $\mathrm{y}^{\mathrm{e}}$ Counsell of them; and so they were cōmitted to ward. Indeed $y^{\mathrm{e}}$ magestrats used them courteously, and shewed them what favour they could; but could not deliver them, till order came from $y^{e}$ Counselltable. But $\mathrm{y}^{\mathrm{e}}$ issue was that after a months imprisonmente, $\mathrm{y}^{\mathrm{e}}$ greatest parte were dismiste, \& sent to $\mathrm{y}^{\mathrm{e}}$ places from whence they came; but 7. of $y^{e}$ principall were still kept in prison, and bound over to $y^{\mathrm{e}}$ Assises.

Bralford declares elsewhere ${ }^{2}$ that Brewster was one of these seven.

In one way or another a portion of the church reached Hol-

1 A little over fifty miles in an air line from Scrooby.

2 Hist. 412, 13, 16. 
land during 1607, probably the year of the Boston endeavor above described; and in the spring of 1608 others tried again.

It so fell out that they light of a Dutchman at Hull, having a ship of his owne belonging to Zealand; they made agreemente with him, and acquainted him with their condition, hoping to find more faithfullnes in him, then in $y^{\mathrm{e}}$ former of their owne nation. He bade them not fear, for he would doe well enough. $\mathrm{He}^{\mathrm{x}}$ was by appointment to take them betweene Grimsbe \& Hull wher, was a large comone a good way distante from any towne. Now aganst the prefixed time, the women \& ehildren, with $\mathrm{y}^{\mathrm{e}}$ goods, were sent to $\mathrm{y}^{\mathrm{e}}$ place in a small barke. which they had hired for $\mathrm{y}^{\mathrm{t}}$ end ; and $\mathrm{y}^{\mathrm{e}}$ men were to meete them by land. But it so fell out, that they were ther a day before $y^{\mathrm{e}}$ shipe came, \& $\mathrm{y}^{\mathrm{e}}$ sea being rough, and $\mathrm{y}^{\mathrm{e}}$ women very sicke, prevaiked with $\mathrm{y}^{\mathrm{e}}$ seamen to put into a creeke hard by, wher they lay on ground at low-water. The nexte morning $\mathrm{y}^{\mathrm{e}}$ shipe came, but they were fast, \& could not stir till aboute noone. In $\mathrm{y}^{\mathrm{e}}$ mean time, $\mathrm{y}^{\mathrm{e}}$ shipe maister, perceiveing how $\mathrm{y}^{\mathrm{e}}$ matter was, sente his boate to be getting $\mathrm{y}^{\mathrm{e}}$ men abord whom he saw ready, walking aboute $\mathrm{y}^{\mathrm{e}}$ shore. But after $\mathrm{y}^{\mathrm{e}}$ first boat full was gott abord, \& she was ready to goe for more, the $\mathrm{m}^{\mathrm{r}}$ espied a greate company, both horse \& foote, with bills, \& gunes, $\&$ other weapons; for $\mathrm{y}^{\mathrm{e}}$ countrie was raised to take them. $\mathrm{Y}^{\mathrm{e}}$ Dutchman seeing $\mathrm{y}^{\mathrm{t}}$, swore his countries oath, "sacremente," and having $\mathrm{y}^{\mathrm{e}}$ wind faire, waiged his Ancor, hoysed sayles, \& away. But $\mathrm{y}^{\mathrm{e}}$ poore men which were gott abord, were in great distress for their wives and children, which they saw thus to be taken, and were left destitute of their helps; and them selves also, not having a cloath to shifte them with, more then they had on their baks, \& some scarce a peney aboute them, all they had being abord $y^{e}$ barke. It drew tears from their eyes, and any thing they had they would have given to have been a shore againe; but all in vaine, ther was no remedy, they must thus sadly part.

Comprehending the situation, the men on the beach, excepting the few needed to help the women and children, escaped before they could be arrested. The narrator continues:-

But pitifull it was to see $y^{\mathrm{e}}$ heavie case of these poore women in this distress; what weeping \& crying on every side, some for their husbands, that were caried away in $\mathbf{y}^{\mathrm{e}}$ ship as is before related; others not knowing what should become of them, \& their litle ones; others againe melted in teares, seeing their poore litle ones hanging aboute them, crying for feare, and quaking with could. Being thus appre- 
hended, they were hurried from one place to another, and from one justice to another, till in $y^{e}$ ende they knew not what to doe with them; for to imprison so many women \& innocent children for no other cause (many of them) but that they must goe with their husbands, semed to be unreasomable and all would crie out of them ; and to send them home againe was as difficult, for they aledged, as $y^{\mathrm{e}}$ trueth was, they had no homes to goe to, for they had either sould, or otherwise disposed of their houses \& livings. To be shorte, after they had been thus turmoyled a good while, and conveyed from one constable to another, they were glad to be ridd of them in $y^{e}$ end upon any termes; for all were wearied \& tired with them. Though in $y^{\mathrm{e}}$ mean time they (poore soules) indured miserie enough : and thus in $y^{\mathrm{e}}$ end necessitie forste a way for them.

The result of an examination of the shore from Kingstonupon-Hull to Great Grimsby is as follows: An air line drawn southeast from Hull strikes Grimsby at about sixteen miles. Of these the first two are across the Humber, and the remaining fourteen skirt an almost straight line of low, marshy shore, having no marked indentations and only six or seven little streams which drain the country from three to six miles back. The "creeke hardby," where the bark found refuge over night, must be looked for in the mouth of one of these streams.

Probably no radical change of this shore has taken place in the last 300 years, in which case the place which seems to meet the conditions best is Stallingborough, ${ }^{1}$ where are the Kiln ferry and light, four or five miles north of Grimsby. Here appears to have been "a large comone a good way distante from any towne." And the name, Nun's Creek, which the stream bears, may be due to some derisive or blundering association of the spot with its sheltering of this persecuted company of women. If this were the locality, probably the women and children with the goods were floated down the Idle to the Trent and down the Trent to the Humber, a circuitous journey of from sixty to seventy-five miles; while the men would "meete them by land" by a trudge of forty or fifty miles across country.

1 Arber says (94): "Local opinion would seem to faror East Halton Skitterhaven, in Lat. $53^{\circ}, 41^{\prime}, 30^{\prime \prime}$; because that is the only break in the specified coast line of Lincolnshire viz. between Hull and Great Grimsby : from which latter place it is distant some twenty miles." 
Bradford says that Robinson, Brewster and other principal members were among the last to reach Holland, having stayed to help the weakest over before them. If his words include Clyfton, as seems implied, we have the approximate date at which this first enigration of the Pilgrims was completed, as we know that Clyfton arrived in Amsterdam in August, 1608. ${ }^{1}$ To reach that city by sea from England then was an undertaking which in these days of rapid transit needs to be studied in order to be appreciated. After crossing the perhaps 200 miles of ocean it was necessary to skirt the sand-dunes of the Dutch coast for fifty miles or so, find and enter the difficult opening of the Marsdiep, which gave access to the Zuyder Zee; continue along its narrow and crooked channels, bordered by dangerous shoals, to the mouth of the $Y$, and encounter the intricacies of this a few miles farther to the city. Even in good weather, a long time and great patience were needed by those on a clumsy sailing vessel to accomplish so tortuous a course. To all of which storm and tempest sometimes made serious addition, as may be seen by referring to the experiences of those who got aboard that day in the Humber, but without their families and their goods. They

endured a fearfull storme at sea, being 14 . days or more before $y^{\text {es }}$ arived at their porte, in 7 . wherof they neither saw son, moone, nor stars, \& were driven near $y^{\mathrm{e}}$ coast of Norway ; the mariners them selves often despairing of life; and once with shriks \& cries gave over all, as if $\mathrm{y}^{\mathrm{e}}$ ship had been foundred in $\mathrm{y}^{\mathrm{e}}$ sea, \& they sinking without recov-

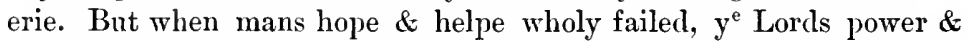
mercie appeared in their recoverie; for $\mathrm{y}^{\mathrm{e}}$ ship rose againe $\&$ gave $\mathrm{y}^{\mathrm{e}}$ mariners courage againe to manage her. And if modestie woud suffer me, ${ }^{2}$ I might declare with what fervente prayres they cried unto $\mathrm{y}^{\mathrm{e}}$ Lord in this great distres (espetialy some of them,) even without any great distraction, when $\mathrm{y}^{\mathrm{e}}$ water rane into their monthes \& ears; \& the mariners cried out, We sinke, we sinke; they cried (if not with mirakelons, yet with a great hight or degree of devine faith), Yet Lord thou canst save, yet Lord thou canst save; with shuch other expressions as I will forbeare. Upon which $\mathrm{y}^{\mathrm{e}}$ ship did not only recover,

1 " Richard Clyfton, with his wife and children came into Amsterdam in Holland, August 1608." Clyfton Bible. Taylor Inst. Oxford.

2 This is conelusive that Bradford was on board. 
but shortly after $y^{e}$ violence of $y^{e}$ storme begane to abate, and $y^{e}$ Lord filed their afflicted minds with shuch comforts as every one cañot understand, and in $\mathrm{y}^{\mathrm{e}}$ end brought them to their desired Haven, where $\mathrm{y}^{\mathrm{e}}$ people came flockeing admiring their deliverance, the storme having ben so longe $\&$ sore, in which much hurt had been don, as $\mathrm{y}^{\mathrm{e}}$ masters freinds related unto him in their congrattulations.

These two endeavors are all which this reticent chronicler describes. He intimates, however, that there were other similar experiences on a smaller scale, in which parties of the church were betrayed, surprised and intercepted. But, in a sense, at last all ended well.

In $\mathrm{y}^{\mathrm{e}}$ end, notwithstanding all these stormes of opposition, they all gatt over at length, some at one time $\&$ some at another, and some in one place \& some in an other, and mette togeather againe according to their desires, with no small rejoycing.

Nor was the cloud without its silver lining.

I may not omitte $y^{\text {e }}$ fruite that came hearby, for by these so publick troubls, in so many eminente places, their cause became famouss, $\&$ occasioned many to looke into $\mathrm{y}^{\mathrm{e}}$ same; and their godly cariage \& Christian behaviour was such as left a deep impression in the minds of many. And thongh some few shrunk at these first conflicts \& sharp beginnings, (as it was no marvell) yet many more came on with fresh courage, \& greatly animated others.

As the last detachment, of the feeblest with the strongest, was welcomed on the quays of Amsterdam by those earlier arrived, and as Clyfton and Robinson once more led their praises and their prayers, one wonders whether the pastor or the teacher did not borrow a verse from the experience of Paul: ${ }^{1}$ -

they that could swimme ... cast themselves first into the sea, and [went] ... out to land:

And the other, some on boardes, and some on certeine pieces of the ship : and so it came to passe that they came all safe to land.

1 Acts xxrii : 43, 44, modified a little. Gen. vers. ed. 1577. 


\section{BOOK V}

\section{THE PILGRIMS IN AMSTERDAM}


Now tonching our Cuntry, \& freinds, our answer is, that we deem the want of them a greivous losse, which we would also redeem at a great rate. Yet for our Cuntry, we do not forsake it, but are by it forsaken \& expelled by most extream lawes, \& violent proscriptions contrived, \& exequuted by the Prelates, $\&$ on their behalf. - Robinson, Of Relig. Commun. 39.

The suceesse of that pety Province of Holland (of which the Grand Seigneur proudly said, That if they should trouble him as they did the Spaniard, he would send his men with shovels and pick-axes, and throw it into the Sea) I cannot altogether ascribe to the ingenuity and industry of the people, but to the mercy of God, that hath disposed them to such a thriving Genius, and to the will of his providenee, that disposeth her favour to each Countrey in their preordinate season. - Sir Thos. Browne, Relig. Med. Sect. 17.

There were more Disputes, Contests, and Quarrels, amongst the few Brownists, and other Independant Sectaries, which resorted thither the latter end of Queen Elizabeth's, King James the First's time, and so on, than among the whole Dutch Nation ever since they Reform'd: 'T is unaccountable what impertinent Controversies arose between them, even to the Colour of Aaron's Ephod, whether it were Blew, or a Sea-green, which made an irreconcilable difference between their Pastors, and consequently the Flocks divided. - W. Baron, Dutch Way of Toleration, 10. 


\section{CHAPTER I}

\section{AMSTERDAM AS THE PILGRIMS FOUND IT}

Austerdan bestrides the Amstel where it merges in the $Y$, which continues the Zuyder Zee westward towards the North Sea. The city is a little more than fifteen English miles east from that sea, and a little less than fifty nearly south of the Marscliep, the narrow channel between North Holland and the island of Texel, which, until the recent completion of the Beverwijk Canal, furnished the main deep water entrance for its vast commerce. The city got its name-originally Amstelredam, the dam, or dyke, of the Amstel - from the river and the embankments at the outlet. About 1200 the place was a small fishing village. By 1300 it lined two streets - now the Warmoes-straat (Pot-herbs-street) and the Kalver-strat (Calvesstreet) - one on each side of the river, and its profile showed but a single lofty tower, that of the Oude Ferk (Old Chmrch), still standing. The town was shaped much like a horseshoe, a little widened at the heel. The pre-Reformation Amsterdam was that portion of the present city which extends along the $Y$ from the Geldersche (Golden) Quay, to the Haringpaklierij Tooren (Herring-packery Tower), and is girded by the Singel (girdle). The Amsterdam of 1600 had broadened until it included twelve bastions in its landward circuit and covered the territory which the Heerengracht (street of the gentry) encloses. Two further enlargements took place in 1611 and 1613, until it gathered in substantially what the Prinsengracht (Princes' street) now surrounds.

Two things caused these rapid and considerable enlargements. One was that sudden up-springing of trade due to the temporary destruction of Antwerp, then in Spanish hands, as a port of entry, when the States of Holland secured the forts on the Scheldt. The other was the immense stimulus to maritime enterprise, due 
to the geographical discoveries of that age, of which the Hollanders promptly took mercantile advantage. It is hard to appreciate now that in 1601 the Netherlands led the commerce of the world. When the twelve years' truce with Spain was signed in 1609, Amsterdam is said ${ }^{1}$ to have increased in twenty years from 70,000 to 130,000 people, and it more than doubled again during the next decade. Great territorial enlargement became inevitable; and for a time newcomers had to camp in temporary shelters outside of the walls, while streets were being laid out and houses erected. "As much land as a man's foot could cover was worth a ducat in gold."

Fynes Moryson visited the city twice within seventeen years of this date, and says $:^{2}$ -

Fine streets of this City are diuided with water: the River Tay flowes like a large and calme sea on the North side, where is a safe port, the traffick being great in this City, and at Midelburg since the passage to Antwerpe was stopped. Vpon the Hauen lies a field or market-place called Camp-platz, where the Citizens vse to behold their friends going to sea, and returning home. ${ }^{8}$ From this place towards the South lies Warmerstraat, a long and large street, between two rivers, which part of the City is called the New Ditch. The Merchants in summer meet vpon the Bridge, and in winter they meet in the New Church, in very great number, where they walke in two rankes by couples, one ranke going vp, and another going doune, and there is no way to get out of the Church; except they slip out of the doores, when in one of these rankes they passe by them. On the East side of the City there is a wall of stone, higher then the City, hauing a pleasant walke vpon it. In the same place are houses for exercise of shooting in gunnes and crosse-bowes: beyond this wall there is another of earth, and betweene these wals the new City was plotted out, where of few houses were then built, but since $I$ heare it is fully finished. Likewise on the South and West sides there be two like wals, and between them the plot of the said new City, in which many faire houses were then built. The fields on all sides without the gates being fenny and drouned with water, doe make the City more strong, but for this

I T. Contarini in Ms. archives of Venice (Motley, Un. Neths. iv: 551-552). Antwerp in the same time shrunk from 150,000 to 80,000 .

2 Itin. 41, 200.

8 A tower, called the Schreijer's Tooren (Criers' Tower) in allusion to the weeping on such occasions, stood at the junction of the Oude Gracht (Old Canal) with the $Y$. 
cause (they say) the foundations of the houses being laid in water, cost as much or more as the houses themselues. ${ }^{1}$ The river Amster . . . running from the South through three lakes, entereth this eity, and passing through it, fals into the River Tay on the North Side. The City hath five gates, which are shut at dinners and suppers, though the danger of the warre be farre from them.

There be two Churches in which they have two sermons on each second day, and foure on Sunday. The City lay in length from the North to the South, but adding the plot of the new City, it is of a round forme. The streetes are narrow, and the building of bricke, with a low roofe shewed antiquity. They haue two Almeshouses (called Gasthausen, that is, Houses for strangers) which were of old Monasteries. One of these houses built round, was a Cloyster for Nunnes, wherein sixty beds at this time were made for poore women diseased, and in another chamber thereof were fifty-two beds made for the auxiliary Soulders of England, being hurt or sicke, and in the third roome were eighty-one beds made for the hurt and sicke Souldiers of other Nations : to which Souldiers and Sickeweomen they giue cleane sheetes, a good diet, and necessary clothes, with great cleanlinesse, and allow them Physitians \& Surgions to cure them : and most of the Cities in these Prouinces haue like houses.

It held, even then, a foremost place among the busiest marts of the age. The famous bank of Amsterdam was established in 1609. The blight of Antwerp, Ghent, Bruges and other towns had crowded thousands of artisans into the North. So that what Motley declares to have been an unequalled development of industry had been realized in Amsterdam, Enkhuysen and other cities of North Holland, even during the bloodiest years of the Spanish war. The cruisers of the United Provinces blockaded the Flemish coast, so that hardly a poor herring-boat could run into places in Spanish hands; while the ships of Amsterdam were sailing and trading everywhere. Moreover, as early as 1578 Dutch merchants had opened trade with Kola and Archangel, and before 1600 Amsterdam had sent out three polar expeditions, all of which took leading rank among endeavors to discover a northeast passage to India.

Naturally, the population of Amsterdam became cosmopolitan. Still chiefly Dutch, it also included representatives of almost every known people. Intolerance elsewhere had driven thither

I The palace, built in 1648 as a town-hall, is said to rest upon 13,659 piles. 
so many Jews that they characterized one locality and had a synagogue. Many others also were refugees. They were liable, therefore, at least at first, to be very poor. It is greatly to the credit of the Dutch that, while themselves suffering by a dreadful and protracted war, they had established a system of partial support of such needy ones at their homes, in distinction from those who were cared for wholly in the almshouse. At about 1608 Pontanus estimated that in the newer part of the town, where apparently the poor most congregated, there were 1611 families assisted thus; of whom not more than thirteen per cent were Hollanders. This suggests the question why, at the beginning of the seventeenth century, Holland and, in particular, Amsterdam thus offered a refuge for the oppressed in conscience.

When Philip II. succeeded Charles V. on the throne of Spain, about the middle of the sixteenth century, the Netherlands, then known as Flanders, comprised seventeen provinces, in the main coextensive with the present Holland and Belgium. Each was a separate State under its own ruler, and, if temporarily allied with a neighbor, independent sovereignty still was maintained. Although these provinces did not all speak the same tongue, and ancient rivalries still prevented absolute fusion, a strong general resemblance existed, and many of their aims and sympathies were common. In each the consent of an Assembly made up from the elergy, the nobles and delegates of towns, was constitutionally indispensable to the imposition of any tax, and no one not a native of a province could hold office therein. The residents of these provinces seem to have been above the average of that time in self-reliance and a certain culture. That safety depended upon an ever watchful conflict with a threatening ocean stimulated the manlier elements of their nature. They were unsurpassed in skill and intrepidity as sailors, and their frequent and long voyages, while increasing their wealth, also enlarged their knowledge, and especially taught them that some seemingly impossible things can be done, and heartened them towards untried methods.

Such peculiarities always had hindered their union, compelling the sovereign for the time to content himself, so far as concerned them, "with the position — not too grateful to a Spanish 
despot - of head of a republic, or, to speak more properly, of a confederacy of republics." 1 'To be sure, there came to be a Supreme Court at Mechlin, with juriscliction, on appeal, over all provincial Courts. There also was a central and confelerate Assembly, the States-General. But its power was limited, and no subsidy recommended by it took effect within a province until confirmed by the provincial borly.

During the long reign of Charles V. considerable encroachment upon some of these privileges had occurred. As he was born at Glient, was fond of Flanders and liked to bestow high places upon Flemings, the Netherlanders tolerantly said little when he interfered with their rights. They could forgive much to a popular monarch, under whose almost boundless sway they could go up and down the earth safely and bring home the fat and sweet of every land. Moreover, his home policy so fostered husbandry and manufactures that Flanders contained no fewer than 350 cities, with more than 6300 smaller towns, ${ }^{2}$ healthy and vigorous with a diligent, hard-working population. ${ }^{3}$

These provinces guarded their local and individual rights so jealously that the Brabanters even qualified their oath of allegiance to the emperor by a clause nullifying it, should their peculiar privileges be disregarded. ${ }^{4}$ Women about to become mothers were known to journey to Brabant, that their children might be born into its franchises. ${ }^{5}$ Many from outside of the nation settled at Antwerp, whose merchants became the bankers of Europe. London capitalists had a factory there. There also were Portuguese, Italian, Hanseatic and Turkish companies; so that these great cities of the Netherlands learned something at least of many foreign tongues, customs and faiths. All this prosperity had its influence not only upon the middle but also upon the humbler classes. Guicciardini, who had lived more than a generation in the Netherlands, declared ${ }^{6}$ that it was rare to find even a peasant who could not read and write.

1 Prescott, Phil. II. i : 364.

2 F. Strada, De Bello Belg. i : 32.

${ }^{3}$ Guicciardini (207) assigns at this date to Ghent 70,000 inhabitants, to Brussels 75,000, to Antwerp 100,000, and estimates London at 150,000 and Paris at 300,000 .

4 Prescott, Phil. II. i : 371.

${ }^{5}$ Strada, ii : 61 .

6225 . 
When the Reformation broke out in Germany, its flying seeds found good soil over the border among these Netherlanders. Later, many foreigners, connected closely with the prosperity of the Low Countries, came thither from Protestant communities and brought the new ideas of religion with them. Young Flemish nobles also, who resorted to the University of Geneva, were apt to return home inoculated with Calvin's zeal against the Pope. So Charles V. awoke one day to the distressing fact that the dreadful heresy, which it had been a great object of his life to suppress, was rooting itself comfortably in his Dutch dominions, and he at once undertook to put it down by sheer force.

In March, 1520, he issued the first of a series of eleven "placards," 1 by which, through cumulative severities, he endeavored to eradicate Protestantism from Flanders by extirpating every person professing it. They decreed that every one convicted of heresy should be burned, buried alive or beheaded. The same terrible fate was proclaimed against all who read, copied or dealt in heretical books, who publicly or privately disputed on the Scriptures, or taught or advocated the doctrines of the Reformation. Every informer was to have half of the culprit's confiscated property. The courts were forbidden to show the slightest mercy, and it was made a penal offence to solicit any relief. ${ }^{2}$ Of course a branch of the Inquisition was established in Flanders, an eminent lawyer, a member of the Council of Brabant, being made inquisitor-general. But before long he was flying for his life. The emperor had to modify his plan, and four members of the secular clergy were made inquisitors, with the provision that no sentence could be pronounced by them without first receiving the sanction of some member of the provincial council. Even thus, however, the oppression was

${ }^{1}$ G. Brandt (Hist. Ref. Low Countries, i : 42) says : "The promulgation of it ... was a violation of the Privileges of the Land: for whereas formerly the old Counts of Holland never made any Laws of importance without consent of the Nobility and Commons; the Emperor by vertue of his own authority only, made this Placard at Worms, without ever communicating a matter of that weight to the States of the Land, otherwise than by requiring them to promulgate the same; which nobody durst oppose."

2 E. van Meteren, Hist. des Pays-Bas. 10. 
terrible. Great numbers suffered the loss of property and even life. ${ }^{1}$ But it was made so clear that it was not for the pecuniary interest of the emperor to press such a bloody policy, that it was relaxed; and in his last year he sorrowfully acknowledged ${ }^{2}$ that it had been a dismal failure.

Philip II., who succeeded him in 1556, was born in Spain, spoke only Spanish, affected Spanish ways, preferred Spanish officials, and in every way made himself a foreigner to his Dutch subjects. Without those amiable qualities which had led the Flemings to tolerate his father's mistakes, Philip also lacked all power of adjustment to circumstances in matters of conscience; his fundamental principle being that he could not, and would not, rule over "heretics." When he found that Protestantism had crossed the Pyrenees, ${ }^{3}$ he grasped it at once with the iron hand of the Inquisition, and burned and butchered until he had cleared the Castilian land of all suspected of it.

It is not needful to detail what followed. The works of Prescott, Motley and Young ${ }^{4}$ give the English reader graphic and trustworthy accounts of the successive steps by which the pitiless Philip, with the aid of the even more odious Alva, drove the Netherlanders into their terrible war. The confederacy of Dutch nobles, at first known as the Compromise, but which gloried in the scornful epithet hurled at them by the government, "the Beggars" — "Les Gueux;" the sudden storm of iconoclasm, which swept over the provinces, stripping more than 400 churches of their paintings, images and Romanist paraphernalia ; the commissioning of Alva, crafty, stubborn, insolent and savage, to march a Spanish army from Italy into the Low Coun-

1 Prescott (Phil. II. i : 379) discredits the usual statement that at least 50,000 were executed under Charles V. Grotius $(A n$. 12) puts the number at $100,000$. But a much smaller number is probable.

2 Prescott, Phil. II. i : 383.

3 Ibid. i : 417. Many may be unaware what a little history Protestantism at one time had in Spain.

${ }^{4}$ A modest volume (Hist of Neths. 1884), by Alex. Young, gives an always graphic and usually exact summary of Flemish affairs during this period; in the shaping of which he uses well some material not in Motley's or Prescott's possession. In certain aspects also C. M. Davies's Hist. of Holland and the Dutch Nation (1851) is valuable, and it has a good map. W. J. Hofdijk's Leyden's Wee en Zegepraal $(1573-74)$ also is a help. It was reprinted in 1874 at Leyden, and has two large ancient plates illustrating the siege of Leyden. 
tries to punish these misdeeds and to regulate affairs; the judicial murder of Egmont and Hoorne; the sending of 1800 men to the scaffold ${ }^{1}$ within three months; the condemning of citizens to torture unto death for singing the songs of Les Gueux, for having attended a Calvinistic funeral years before, or even for saying " one must obey God rather than man ;" and, finally, the sentence to death as hereties, on Feb. 16, 1568, of all the inhabitants of the Low Countries, excepting a few speeified, followed by Philip's order, on Feb. 26, that this sentence "be put in execution without favor or respect of persons," and by Alva's outrageous extortion of excessive and extraordinary taxes - these facts suggest how bitter injustice, without hope of redress, nursed a spirit of resistance ${ }^{2}$ until the Utrecht union of Holland and Zealand with five other provinces became the germ of the Dutch Republic and brought about a toleration in matters of religion elsewhere unknown.

The Reformation at first did not include the principle of liberty of conscience, but only transferred the custody of men's souls from the old to a new religion. It is therefore greatly to the credit of William of Orange, who now came to the front in Netherland affairs, that he was almost a pioneer in urging that religious persecution is useless and barbarous. When, then, in the summer of 1584, one of Philip's paid miscreants assassinated William, it is not hard to believe that in the fury of the hour and for long years afterwards, especially in North Holland, where the spirit of liberty showed itself most, a fugitive for the sake of conscience was able to find a safer refuge there than the world afforded elsewhere.

As early as 1569 the States-General agreed that liberty of conscience should be allowed to both the Reformed and the Roman Catholic, and about 1573 the Reformed religion, as taught at Geneva, was admitted into the public churches, and "the rest of the sects that endeavoured to promote the Reformation . . . had likewise their share of liberty of conscience, and the exercise of their Religion in private meetings."

Amsterdam, moreover, had special preëminence in this new

1 G. P. Fisher, Reformation, 302. Motley, Un. Neths. ii: 291.

2 Brandt, i: 266, 295, 298, 308, 463-468, 460, 338. 
catholicity. In May, 1578, a revolution there placed Reformed ministers in the churches which the Romanists formerly had occupied, and gave other denominations permission to worship in private. And, although such freedom often was opposed, on * the whole it was maintained. Burgomaster Hooft, who served at intervals from 1588 until the arrival of the Pilgrims, is said by Brandt to have told the city officials - in 1598, in the case of a velvet weaver, accused of teaching that Christ was a mere man, and that the common translation of the Bible was false that they ought to be careful lest they invade the liberty of others almost before they had recovered their own. He argued that no magistrate has authority in matters of faith, and insisted that the wisest course would be "to disturb no man on account of his conscience," according to the ancient custom of that city in particular.

Brandt remarks that in 1596 the magistrates of Amsterdam especially showed great favor to the Anabaptists, in spite of the clergy, explaining that

the Governours of that great Emporium, or mercantile city, looked, upon it as the most effectual means of promoting Trade, knowing those people to be very industrious, and that by their propagating all sorts of Manufactures, and Handicrafts, they brought great advantage to the said City.

Thus Amsterdam became famous as a refuge for the oppressed in conscience, and, naturally, was maligned therefor. A sample of its treatment by the satirists is this extract: ${ }^{1}$ -

They countenance only Calvinisme, but for Trades sake they Tolerate all others, except the Papists ; which is the reason why the treasure and stock of most Nations is transported thither, where there is full Liberty of Conscience: you may be what Devil you will there, so you be but peaceable : for Amsterdam is an "University of all Religions, "which grow here confusedly (like stocks in a Nursery) without either "order or Pruning. If you be unsettled in your Religion, you may "here try all, and take at last what you like best; if you fancy none, "you have a Pattern to follow of two that would be a Church to them"selues: Its the Fair of all the Sects, where all the Pedlars of Reli"gion have leaue to vend their Toyes, their Ribbands and Phanatique

1 Dutch Drawn to the Life (1664), 48. 
"Rattles: their Republick is more to them than Heaven; and God "may be more safely offended there than the States-General."

Probably Joseph Hall, afterwards a bishop, uttered the opinion of those English who had no sympathy with Amsterdam's peculiarities, when he said to John Smyth and John Robinson : ${ }^{1}$

Compare the place you have left, with that you have chosen; let not feare of seeming to repent over-soone, make you partiall. Loe, there a common harbour of all opinions, of all heresies; if not a mixture. Here you drew in the free and clear aire of the Gospell, without that odious composition of Iudaisme, Arrianisme, Anabaptisme: There you live in the stench of these and more. You are unworthy of pitie, if you will approve your misery. Say if you can, that the Church of England (if she were not yours) is not an heaven to Amsterdam. How is it then, that our gnats are harder to swallow, than their camels?

1 To Mr. Smith and Mr. Rob[inson]. Ringleaders of the late Separation at Amsterdam, 1634, i : 288. 


\section{CHAPTER II}

\section{EARLIER ENGLISH SEPARATISTS}

As has been said, ${ }^{1}$ the Separatist church organized in London in 1587, or thereabouts, was composed of disciples of Henry Barrowe, who appears to have received his first impulses from Robert Browne. But he sought to amend Browne's theory, particularly by substituting Calvin's and Cartwright's Presbyterian eldership, as set forth in the "True Description," for the practical democracy of Brownism. For a time their meetings were held in private houses, ${ }^{2}$ or in a garden-house near Bedlam, the Deptford or Ratcliffe woods, or those gravel-pits at Islington which had been so used in the days of Queen Mary. Some twelve or fourteen expounders ${ }^{3}$ labored with then. Twenty-five members ${ }^{4}$ are recorded, who, sometimes after long confinement, died in prison or a few days after release, the majority in Newgate. In 1592, Greenwood being out of prison on bail, they organized this fluctuating body at the house of one Foxe, a schoolmaster in Nicholas Lane, and subscribed a formal covenant. Francis Johnson was chosen pastor, Greenwood teacher, Daniel Studley and George Knyveton elders, and Christopher Bowman and Nicholas Lee deacons. Seven infants were baptized, and the Lord's Supper was administered. ${ }^{5}$

1 P. 203.

2 Harl. Ms. 7042, 55, 59-62, 66, 112, 114, 116, 399, 400.

3 Messrs. Colshill, Cooper, - or Cowper, - Egerton, Gardner, G. Johnson, Phillips, Forester, Settel, Smyth, Sparke, Stanhope and Wygginton.

${ }^{4}$ Robert Aweburne, John Barnes. Scipio Bellet, Robert Bowle, John Chandler, Nicholas Crane, "Father" Debream, Mr. Denford, Thomas Drewet, George Dinghtie, Margaret Farrar, Thomas Hewet, William Howton, Richard Jackson, Walter Lane, "Widow " Maynard, Judith Myller, John Purdy, Roger Rippon, "Widow" Rowe, Thomas Stevens, Jerome Studley, John Swaltee, Anna Tailour and Henry Thomson.

5 Johnson "tooke water and washed the faces of them that were baptized . . . saying onely . . . 'I do baptize thee in $y^{\mathrm{e}}$ name of the Father, of the Sonne, \& of the Holy Ghost,' withont useing any other ceremony ther in," and without godfathers 
Johuson's history, already outlined in part, had been somewhat remarkable. He was a son of John ${ }^{1}$ Johnson, sometime mayor of Richmond, Yorkshire, and was born in 1562. With his younger brother, George, he went to Cambridge, where he became a fellow of Christ's College. On Jan. 6, 1588, a sermon by him at St. Mary's, from I Pet. v: 1-4, on church govermment irritated the authorities. All ended in his retiring to Middleberg, like Browne earlier; where, unlike Browne, he was pastor of the English Merchants worshipping in the Gasthuis Kerk, ${ }^{2}$ and received $£ 200$ a year. He kept his eye upon those Dutch printing-offices whose aid the English Separatists sought. One day in 1591 he discovered a treatise by Barrowe and Greenwood in press at Dort. He was made the agent of its suppression and bumed the whole edition, excepting two copies, ${ }^{3}$ one of which he kept to read. But the wronged authors soon had their revenge. The reading of his copy made him doubt whether they were not right, after all. And he gave up his good position, songht out Barrowe in the Fleet, at London, and became a zealous convert to his Separatist views. Fourteen years later he reprinted the destroyed book.

On Apr. 6, 1593, Barrowe and Greenwood were hanged at Tyburn, and, at about the same time, Johnson and more than fifty of the little church were seized and confined. 4 But the authorities soon perceived that it would be wiser to banish Barrowists than to hang them. Before his martyrdom, which followed that of Barrowe and Greenwood in fifty-two days, Penry had advised the little church to emigrate together to some place where they could worship God in peace, ${ }^{5}$ and Barrowe left a legacy to

and godmothers. . . " Five whight loves or more, were sett upon $\mathrm{y}^{\mathrm{e}}$ Table, and the Pastor did breake $y^{e}$ breade, and then delyvered it unto some of them, \& the Deacons delyvered to the rest; some of $y^{e} s^{d}$ Congregation sittinge $\&$ some standing about the Table; and [then] the Pastor delivered the Cupp unto one $\&$ he to another till they harl all dronken, useing the words at $y^{e}$ delyverye therof, according as is sett down in the Eleventh of the Cor. $\mathrm{y}^{\mathrm{e}} 24$ verse."

1 In Cong. in Lit. (263) mistakenly called Jacob.

2 Steven. Hist. Scot. Ch. Rotterdain, 316.

3 Ibid. 42. But Gifford, who possibly had better information, sars (Short Reply, iii) : "Some few haue escaped, and are dispersed among their fellowes. Wherefore I hold it needfull to publish some answere."

4 Barrowe, Platform, 5:3-57. Letter of Johnson to Burghler. Lans. Ms. Ixxv : 50.

5 Waddington, John Penry, 173-175. From the Yelverton Mss. probably. Penry's 
the chureh as a body, presumably to aid this undertaking. During that summer and autumn this emigration began, although for nearly four years longer Johnson, with the elders and other members, was detained in the Clink. The fugitives made for Amsterdam, the foremost arriving before the close of that year. ${ }^{1}$

This company of first Separatist emigrants hardly can have exceeded fifty or sixty. ${ }^{2}$ Judging by their subsequent abodes, they probably settled in the newest part of the eity, on the east side near the Reguliers Poort (Gate leading out to the Monastery of Regular Friars), not far from the present Mint. ${ }^{3}$ Here there soon appears among them the man who on the whole was their finest character, who left the richest deposit in literature, and who for his humility and sweetness deserves worthiest remembrance, yet whose early life has been unknown until recently. Henry Ainsworth was born in 1569, or 1570, in Swanton-Morley, near Norwich. His father, Thomas, was a yeoman, and also appears to have had a daughter, Anna. Henry was matriculated at St. John's, Cambridge, where he studied one year. ${ }^{5}$ He migrated to Gonville and Caius, where, at eighteen, he was adunitted a scholar, on Dec. 15, 1587, Dr. Perse being his surety and tutor. Apparently he remained more than three years, ${ }^{6}$ but did not graduate. These were years of theologieal ferment, those of the Mar-prelate eonflict and in which Barrowe made his severest assaults upon the existing order, and that ferment agitated

daughter, Deliverance, for a time was in F. Jolnson's family at Amsterdam, and seems to have been a cause of contention there. G. Johnson, Disc. 131, 136.

1 F. Johuson, Inq. and Ans. 63. Hoornbeeck, Sum. Controv. Relig. 740. Selieffer, De Brownisten. 19.

2 Th. White (Discov. of Brounism, 21) speaks of " 27 , or thereabouts, euen one halfe of them, at that time, and that of the elder sorte," and seens to refer to the first comers.

3 The marriage records name the residences of the English members of this congregation married there, 1598-1617. Scheffer confirms this in a manuscript letter.

4 E. Axon, Henry Ainsworth, his Birthplace and his Death, 3.

5 The Register of Admissions to Gonville and Caius College (J. and S. C. Venn, 18S7). This gives Dec. 15. The University Registers record Ainsworth as matriculated as pensioner at St. John's, Dec. $8,15 \varsigma 7$. The difference in date may be due to an error in copring. Probably Roger Williams's misstatement (Bloody Tenent, 174), that Ainsworth "scarce set foot within a Colledge walls," was due to the long interval before Williams was at Pembroke.

${ }_{6}$ Mr. Venn, editor of Reg. of Admissions to Gonville and Caius Coll., says (Ms. letter) that Ainsworth remained there until Lady Day, Mar. 25, 1590-91. 
Cambridge. Dr. William Whitaker was Master of St. John's, and Dr. Thomas Legge of Gonville and Caius. The latter was a native of Norwich, and some acquaintance with the Ainsworths may have led to the transfer of the student, on his way to become a Puritan of the Puritans, from the domain of one supposed to lean towards the Puritans ${ }^{1}$ to that of one accused of favoring Popery. ${ }^{2}$

An old map of Cambridge shows that the tongue of land between Bridge and High streets then was called The Jewry; presumably because occupied by people of Hebrew deseent. This was directly across the street from St. John's and close to Gonville and Caius, and possibly Ainsworth laid the foundation in some one of those Jewish houses of that knowledge of Hebrew and its cognate tongues which gave his later labors lasting value and fame. ${ }^{3}$ That he remained a scholar on the foundation for more than three years is evidence of his diligence and capacity, so that his removal in the beginning of 1591 without his degree no doubt was due to scruples of conscience.

The various evidence in his case suggests as to his subsequent course that he went to London, as the headquarters of known dissent, embodied in the half-formed chmech of which Johnson became pastor with a second small company apparently under the lead of "one Collins," "and there fell into the "hands of authority," and went to hear a bishop or somebody else preach. ${ }^{5}$ Then he went to Ireland ${ }^{6}$ to begin professional labors, but after a year or two realized that, even there, the queen's hand was too heavy upon Dissenters to be endured safely, ${ }^{7}$ and shaped his

\section{Mullinger, ii : 339.}

2 Archb. Sandys wrote to Burghley on Feb. 11, 1581-82, asking him "to take order that Dr. Legge should take no more pupils to breed and train up in popery, adding that all the popish gentlemen in the north country sent their sons to be brought up in popery under him and. Mr. Swale [Pres. of Caius]." Ath. Cant.ii : 455.

${ }^{3}$ In 1877 W. Aldis Wright, Sec. of the English company of Old Testament Revisers, told Dr. Dexter that Ainsworth's Commentary on the Pentateuch and Psalms of ten had been helpful to that company.

4 R. Bancloft, Survay of the Pretended Holy Discipline, 428.

5 These extremists accused any one of their number who attended even a single service of the State Church of " apostating."

${ }^{6}$ Hoornbeeck, 740. John Shaw, Advice to Son. Ms. 451.

7 The Parliament of 1560 , which, after Bloody Mary restored to Ireland the ecclesiastical legislation of Henry VIII. and Edward VI., left the Clurch of Ire- 
course through London to Amsterdam; where we soon identify him with the experiences of the London emigrants. He took the office of teacher, which the martyrdom of Greenwood had vacated. But by their theory this office of itself possessed no power. The power was where the elders were. According to their confession of faith, it was an awkward fact that most of the ship was in Amsterdam while the rudder and steering gear were in London and divided there between the Fleet and the Clink Prisons. Hence, as George Johnson testifies, it was with difficulty that "the Church for 5. or 6 . yeares practised as the Pastor, Elders, and brethren, being in prison at London wrote unto them," special messengers occasionally going between. ${ }^{1}$

We now must glance at the fortunes of these imprisoned members. Confinement, more or less close, in noisome jails was not their only trial. The same morbid conscientiousness as to trifles which had ruined Browne's Middleberg enterprise appeared among them. In 1594 Francis Johnson, then in the Clink, became attached to Mrs. Thomasine Boys, ${ }^{2}$ a member of his church and a widow, who had considerable jewelry, some superior wearing apparel and $£ 300$ in money. Johnson's brother, George, in the Fleet, remonstrated that she was "much noted for pride, which would give great offence if . . . it should not be reformed." But Francis was "so inveighed and overcaried with the said M. T. B." that nothing could stop him, and their marriage, in the prison, soon followed. ${ }^{3}$

When the union was made public Francis was closely confined and his wife forbidden to visit him. Much excitement followed and great offence was taken at her dress and behavior.

land more dependent on the State than that of England. Hereties were made amenable to royal commissioners or Parliament without reference to any Synod or Convocation.

1 Roger Waterer was "to be chose \& appointed for a minister or messenger in affaires betweene the Church [in Amsterdam] and the Prisoners [in London];" and W. Asplin, David Bristoe, John Nicholas, Richard Paris, John Beacham, William Houlder and William Shepheard are suggested as "wandering starres," who went " up and doune, hither and thither to \& from England." Disc. 119, 32, 159. Inq. and Ans. 64.

2 Disc. 10, 94-114, 128, 180, 214.

3 They had at least one cbild, Perseverance, who married John Green, and, with him and three children, came to Charlestown, Mass., in 1632. Wyman, Charlestown Recs, i: 563. 
George vainly wrote her letters of expostulation. He urged other members of the church to deal with her, but they "were loth \& would not." He then reported to Francis that the ungodly world called her "a bouncing girl," and "in pride and vaine apparel" joined her with "the Bishop (as they call him) of London's wife." And he complained later that, her husband being in prison and the brethren in great need beyond seas, she wore " 3,4 or 5 golde rings at once, . . . so that many of $y^{\mathrm{e}}$ Saints are greeued;" and intimated that "her heart is not so mortified and sanctified" as it ought to be.

George sent this letter to her, so that her husband need not be troubled with it, but requested, in case of her failure to reform, that it might be forwarded to Francis. It was forwarded and it made him very angry. He " returned taunts and revilings, calling his brother fantastical, fond [silly], ignorant, anabaptistical, and such like, boasting of the modesty \& wisdome of his wife." More correspondence and recrimination followed. George, seeking to carry out the principles of the gospel, persuaded Thomas Settel and Daniel Studley, two other imprisoned members, to join him in his labor, and their compliance indicates that he had some justification. Kindly relations, however, were renewed for a time.

But a year or two later public offence was taken again at "the Pastor's wifes pride and his vanity thereabout," and strife broke ont afresh. In the midst of it the prisoners were released to be banished, pending which departure peace was made once more. Early in 1597 an English colony in North America was proposed, and certain merchants, plamning a voyage of fishing and exploration, and to settle in or near Rainea, ${ }^{1}$ got leave from the Privy Council to take "diver's persons whose minds are continnally in an ecclesiastical ferment," bonds being given that these never should return unless willing to conform. ${ }^{2}$ Accordingly Francis Johnson and Elder Studley were assigned to the Hopewell and George Johnson and John Clark to the Chancewell. The remainder made their way to Amsterdam. On Jume 27, the Chancewell having been wrecked, the expedi-

1 One of the Magdalen Islands in the Gulf of St. Lawrence.

${ }^{2}$ Reg. of Priv. Coun. Mar. 25, 1597. 
tion was abandoned," and early in September the four " exiles" landed at Southampton, whence they travelled to London and Amsterdam, where at last, in the autumn of 1597, the church was in one body together.

The newcomers found that those who had reached Holland hal made a fain start as a separate church in the midst of an alien community. But they had not escaped tribulation from without, or even from within. Apparently for ill-alvised attacks upon the Reformed churches of Holland, ${ }^{2}$ they had to seek shelter outside of Amsterdam for a time, and about $1595^{3}$ they lived at Kampen and then at Naarden. ${ }^{4}$ Once more domiciled in Amsterdam, they scarcely had settled themselves when some of them were led away by the Dutch Anabaptists, and the church, unable to restore them, cut them off; and but a short time afterwards they withdrew fellowship from others for "schisme." 5

Their new machinery was incomplete and ill adjusted. Its power of guidance and restraint was too weak for its power of propulsion. The reforming instinct was unsymmetrically strong, and they were so eagerly hospitable to new notions as contin-

1 Hakiuyt, Voyages of Eng. Nation (ed. 1810), iii : 242-249. G. Johnson, Disc. 109-113.

2 Attached to a minute of Feb. 4, 1607, in the records of the Eng. Ref. Church in Amsterdam is a note that at some previous date the Brownists had been "banished ont of the city" for "writing libels and scandalons attacks" against the Reformed churches. No trace of any such banishment appears after 1600, and this note seems to refer to some occurrence five years earlier.

${ }^{3}$ The date is indicated by testimonies locating them in these places. .

4 Taffinus and Arminius, then Amsterdam pastors, speak, on Mar. 3, 1599 (Praes. ac Erud. Vir. Epist. 79), of advice given these men before they went to Naarden and after their return. Th. White (Discov. of Brownisme, 15) acensed Deacon Bowman of cheating the poor of the church " of halfe that which the magistrates of Narden had given them weekelye." F. Johnson (Inq. and Ans. 46) acknowledges that abont eleven years before - i. e., in 1595 - the magistrates of Naarden helped their poor ; and G. Johnson (Disc. 151, 157) speaks of what took place " while the church was at Narden."

5 F. Johnson (Inq. and Ans. 63) admits the essential justice of White's charges (Discov. 21). In Trin. Coll., Cambridge, Library is a little book by Henoch Claphan, Theological axioms or conclusions: publikly controuerted, discussed and concluded by that poore English Congregation in Amsterdam: To whome H. C. For the present administreth the Ghospell, ete., 1597, $\frac{1}{4}$ to. No other explanation of the relation of him and his work to the history of Separatism in Amsterdam at this date is so probable as the supposition that his "poore English Congregation" was this cleavage from the First Church, that of Johnson and Ainsworth. 
ually to undervalue settled truths. They lacked sound judgment, and became an easy prey to plausible error. An observer, ${ }^{1}$ disposed to be fair, spoke of them at this time as " now miserably rent, devided and seattered." They suffered also from poverty. Even in a city where plenty of work was at hand their unfamiliarity with the language and the principal industries hampered them. George Johnson says that the brethren, of whom some had been students, lad to card, and spin, or to learn trades. They were not left absolutely to their own resourees. Barrowe had left them something, and money was sent them by friends in London and Middleberg, and even Barbary. ${ }^{2}$ But George Johuson, although neither " in dislaine nor discontent," calls the aid thus received "small," and adds "many weekes I had not above 6,7 or 8 pence the weeke to live upon." The neediest also profited, beyond doubt, as among the "poor dwellers at home " of the city, and personal charities sometimes mitigated the general hardship. Yet probably some suffered actual distress, while elearly all endured more or less privation. When, in the spring of 1599 , the officers of the church wrote to Junius at Leyden, they hoped that he would pity them " everywhere reproched; eaten vp in a maner with deep poverty." 3 Francis Johuson soon hired a large house near the Reguliers Poort. As he had sundry rooms to spare he may have been acting for others of the company also. Ainsworth 4 then was about twenty-six and unmarried. Some ten years later

1 J. Payne, Royall Exchange, 48.

2 Disc. 61, 60, 62. 87, 67. The church in Barbary was one of English merchants and was presided over by $\mathrm{T}$. Bernher, one of the signers of the appeal in behalf of Francis Johnson at Cambridge. He afterwards was complained of as having gone beyond sea "to be made minister by a presbyterie there." Lans. Ms. lxxix : 61.

s Certayne Letters, 46.

4 Dr. Steuart, in the memoir of Ainsworth prefixed to the Edinburgh edition (1789) of The Communion of Saints and An Arrow against Idolatry, states (xr), on the authority of a manuscript note in a copy of Ainsworth's Annotations in his possession, that "his external circumstances at Amsterdam, like those of the church in general, were very abject: He is said to have been Porter there to a bookseller, who first of all discovered his skill in the Hebrew language and made it known to his conntrymen." Brook (1813) seems to have copied this from Stenart, and it is referred to in the notes of later editions of Neal's Hist. of Puritans, although Neal himself (1732) does not seem to have heard of it. It has probability. 
he lived in the Singel near the Hei Poort ${ }^{1}$ (Gate on piles). and close to the old Lutheran Church.

Poor George Johnson, however, was not offered even a corner of the superfluity of Francis. Their differences over Mrs. Johnson soon broke out afresh. These were discussed with growing bitterness at intervals until August, 1598, when they resulted in the excommunication of George, ${ }^{2}$ soon followed by that of their father, who had joined them and had sought to make peace. George pleaded for an appeal of his case to the church in Norwich or to the Reformed churches on the ground. But Francis and the church persistently refused.

As for the odd methods by which a church constructed on the Congregational plan with Presbyterian equipments had to manage its affairs, George Johnson's pages also are instructive. $\mathrm{He}$ says : ${ }^{3}$ -

The next Lords day [Jan.22-Feb. 1, 1597-98] after exercise, $y^{\mathrm{e}}$ Elders propounded to $\mathrm{y}^{\mathrm{e}}$ Church choise of officers \& appointed $\mathrm{y}^{\mathrm{e}}$ Lords day following, ... Which day ... y $^{\mathrm{e}}$ Church nominated some [for deacons]. $\mathrm{y}^{\mathrm{y}}$ [the elders] also nom[inate]d others. In chusing some gave $y^{r}$ voices frely : others suspended : $\mathrm{Y}^{\mathrm{e}}$ voices being gath[ere]d for deacons, William Eiles \& Rolt Jackson had $\mathrm{y}^{\mathrm{e}}$ most voices, unto whom $\mathrm{y}^{\mathrm{e}} \mathrm{P}$ [astor] \& M. [Elder] Studley $\mathbf{w}^{\mathrm{d}}$ not consent, but $\mathrm{w}^{\mathrm{d}}$ have M. Mercer \& Jacob Johnson chosen, who had not above one or two free voices : $y^{e}$ P. \& M. Stud. sayg. $y^{t} y^{y} w^{d}$ give $y^{e}$ suspendd voices to the $[\mathrm{m}]$. \& so they shd have $\mathrm{y}^{\mathrm{e}}$ most voices. . . Ans [we]r was given to $y^{e}$ Elders $y^{t}$ election ought to be free; $y^{t} y^{e}$ suspendd voices ought not to be given more to one then another. Then $\mathrm{y}^{\mathrm{e}} \mathrm{P}$. said $\mathrm{y}^{\mathrm{e}}$ [suspended] voices were committed to $\mathrm{y}^{\mathrm{m}}$ to give where $\mathrm{y}^{\mathrm{y}}$ pleasd : it was ansd $\mathrm{y}^{t} \mathrm{y}^{\mathrm{e}}$ brethn ought not so to give over $\mathrm{y}^{\mathrm{r}}$ power ; as also $\mathrm{y}^{\mathrm{t}}$ no such

1 Puiboken, Mar. 29, 1607.

${ }^{2}$ George Johnson returned to England, probably in 1604, and, instead of going back to the Establishment, as charged (Ath. Cant. ii : 435), Francis declares (Inq. and Ans. 61) that he did not "contrary our generall cause and testimony against the Church of England," but was imprisoned for refusing to do so ; and in Durham jail (Clyfton, Adv. 14) he died "under their hands" for the cause of Separatism. His Discourse, printed at Amsterdam in 1603 , concludes abruptly at the bottom of page 214, his funds probably being exhausted. Bradford and Robinson both speak reproaehfully of him, but he was in his grave before they saw Amsterdam, and they necessarily took their impressions of him from his surviving enemies. Ainsworth had some sympathy with him and would not pronounce the sentence of excommunieation against him.

${ }^{3}$ Disc. 151. 
- order $\mathrm{c}[\mathrm{onl}] \mathrm{d}$ be shewed from $\mathrm{y}^{\mathrm{e}}$ worde to be used in choise of $\mathrm{ch}[\mathrm{urc}] \mathrm{h}$ off [ice $] r$; ; hereabout was some controversy but $\mathrm{y}^{\mathrm{e}}$ elders w[oul $] \mathrm{d}$. have $\mathrm{y}^{\mathrm{r}}$ wil therein : . . . unto wh[ic]h $\mathrm{y}^{\mathrm{e}}$ brethn wd not consent, and so for $\mathrm{y}^{\mathrm{s}}$ time $\mathrm{y}^{\mathrm{y}}$ agreed not in choice of Deacons. . . . [They, the elders] yeelded not ... to receive $\mathrm{y}^{\mathrm{e}}$ best, but deferred $\mathrm{y}^{\mathrm{e}}$ election, til at length [some weeks later] $\mathrm{y}^{\mathrm{y}}$ got there wil. 


\section{CHAPTER III}

\section{THE FURTHER HISTORY OF THE ANCIENT CHURCH}

THE English exiles in time adjusted themselves measurably to the industries of their new home. As they appear to have been largely from London and vicinity, probably more of them were artisans than of the later companies of Smyth and Robinson, who were mostly farmers. Thanks to the variety and precision of the Dutch records, we can get some authentic hints of their employments. A volume in the Amsterdam archives - Puiboken der Stadt, ${ }^{1}$ Aug. 1567-Jan. 1617 - contains marriage records, and differs from contemporaneous volmmes at Leyden in including the autograph signatures of the parties. Moreover, it mentions their occupations. A careful scrutiny has yielded the names of 118 Englishmen, mostly residents of the city, who were married there between Nov. 7, 1598, and Jan. 14, 1617.

Of these, there are 102 whose occupations are recorded. Forty-six different trades or professions are named. Twentynine are eredited with one person each: those of barber, carder, carpenter, cobbler, compositor, cooper, draper, engraver, foreman, furrier, goldsmith, hat dresser, ligatuur ${ }^{2}$-worker, mercer, minister, painter, pewterer, physician, printer, sailor's barber, seaman, sheath maker, silk ribbon weaver, smith's journeyman, Spanish chair maker, sword cutter, tobacco-pipe maker, turner in ivory, and wood sawyer. Eleven have two each: bombazine finisher, button maker, chandler, cutler, damask weaver, embroiderer, hod man, schoolmaster, smith, trunkmaker and turner.

1 The Amsterdam record of Wm. Bradford's marriage, Nov. 9, 1613, has his earliest known autograph signature (he was then twenty-three) as well as the only known autograph of his bride, then sixteen. The volume also contains autographs of other English people. Prof. Scheffer, the local antiquary, sent Dr. Dexter a transcript of these 115 records which include English names, and also published the same list in his De Brownisten te Amsterdam, 160-168.

2 A kind of fustian or bombazine. 
One, mason, has three. One, glover, has four. One, tailor, has six; and one, fustian worker, has thirty-eight. In the eighty-four marriage records where the bridegroom's age is given, the average is about twenty-six years and nine months. In the seventy-three cases where the bride's age is stated, the average is almost exactly twenty-four years. Evidently a large proportion of this English company was in comparative youth.

These records include the marriage of Henry Ainsworth $;^{1}$ of Deliverance, ${ }^{2}$ a daughter of Joln Penry ; of Elizabeth, ${ }^{3}$ a sister of Francis Johnson; of John Murton, ${ }^{4}$ already mentioned and afterwards a Baptist minister and anthor; of Daniel Studley, an original elder of Johnson's church; and three marriages of Jean de la Cluse, ${ }^{6}$ an elder of Ainsworth's company and an author. But only a few of the church can have been mentioned thus, and also English people must have been there who in no way were connected with the Separatists. Nevertheless, the facts just noted have a certain value.

After the church had adjusted itself a little to its new position, they translated their Confession of Faith ${ }^{7}$ into Latin, as has been noted already, that the Reformed ministers around them and the Christian world at large might understand their spiritual position. They dedicated the book to the members of the universities at Leyden, St. Andrews, Heidelberg, Geneva and elsewhere, becanse these scholars were able, and, presumably, willing, to convince them of their errors; and so that, if the Confession agreed with Scripture, it might be approved by silence or by letters of commendation.

A wholly new preface was designed to refute the natural pre-

1 To Marjorie (Hallett) Appleby, from Ipswich, widow of Richard, Apr. 17, 1607.

2 To Samnel Whitaker, from Somersetshire, May 31, 1011. He was 23 and she 21.

${ }^{3}$ To William Latham, from Sherburn, Yorks., Sept. 16, 1600. He was 36 and she 38 .

4 'To Jane Hodgkin, from Worksop, Sept. 9, 1608. He was 25 and she 23.

5 To Ursula Clark, June 24, 1614. Each had been married before.

6 As widower of Catharine de L'Epine, to Alice Dickens (?), Ang. 22, 1604; to Jacqueline May, from Wisbeach, May 5, 1609; and to Ann Harris, from Handborough (Hanbury, Worces.), aged 27, Nov. 29, 1616.

'Confessio Fidei Anglorum Qvorvndam in Belgia Exvlantivm, etc., 1598, i: 3, 5-14. See p. 208. 
sumption against its authors because, although the Reformation had appeared to prevail in England, English people, who claimed to be neither heretics nor schismaties, had exiled themselves. This was not because of a few defects, such as might characterize the purest earthly church; nor because of disaffection toward the government; but because: (1) the entire people, mostly Papists, had been included by wholesale, and without regard to spiritual fitness, in the Church, on the transfer of the nation from the sway of Mary to that of Elizabeth; (2) the same Popish clergy and prelacy were set over them as before; (3) most of the inferior clergy were unlearned and could not preach, so that the people remained as blind as under the Papacy; and (4) the administration of worship was largely that of the old mass-book turned into English. Therefore, to cleanse themselves from antichristian pollutions, they had refused to conform, and, unless they conformed, they were doomed to confinement in noisome prisons, from which there seldom was relcase excepting by death. They were thankful for a place of rest upon a foreign soil and desired charitable judgment.

The translation of this Confession into Latin and the composition of the new preface, although shared by the pastor, and possibly by his brother George, ${ }^{1}$ apparently was chiefly by Ainsworth. The forty-five articles of 1596 remained in substance unchanged. Four ${ }^{2}$ went into Latin without verbal alteration. Twenty-three ${ }^{3}$ conveyed the same idea as before with slight changes of form. Thirteen ${ }^{4}$ amended clauses for greater clearness. Four ${ }^{5}$ were rewritten to expand their meaning. One ${ }^{6}$ received a considerable addition to make it condemn semi-papal corruptions more fully. And also in ten, presumably because scholars especially were addressed, original Greek words of the New Testament were introduced which had not appeared in the English Confession.

1 Disc. 119.

2 Nos. $x x, x x i v, x x v$, and $x x x v i$.

3 Nos. iv, v, viii, x, xii, xiii, xv, xvi, xviii, xix, xxi, xxvi, xxvii, xxix, xxxi, xxxii, xxxiv, xxxv, xxxix, xl, xli, xlii and xlv.

4 Nos. i, ii, iii, vi, vii, ix, xi, xiv, xxii, xxiii, xxxiii, xxxvii and xxxviii.

5 Nos. xvii, xxviii, xliii and xliv. ${ }^{6}$ No. $\mathbf{x x x}$.

${ }^{7}$ Nos. ii (twice), vii, xiii, xv (twice), xvii, xix, xxviii, xxxiii, xxxiv and $x x x i x$ (three times). 
Of course copies were forwarded to the several institutions named. One reached the Professor of Theology at Leyden late in 1598 or early in 1599. Correspondence ${ }^{1}$ followed. Junius wrote to the church, on Jan. 9, 1599. As they had left him no alternative, he had to say that as to their doctrine he saw no need of a new Confession. If it were to defend themselves, nobody accused them. If they felt obliged to make public appeal, they should have addressed the Reformed churches of Amsterdam first. If wrong had been done them in England, as they had left England why not be quiet about it? If they desired to reform England, could they do so now, since they could not while there? He had no right to judge them, and strangers should not intermeddle. It had long been the conviction of good men that when truth of doctrine remains in a church, members ought not to separate from it rashly. If they would live faithful, devout lives, that would approve their cause more than published writings.

Junius sent this letter to the Dutch and French ministers of the Reformed churches of Amsterdam, to be read before delivery to the English Church. That church replied on Feb. 19. They had supposed that he would communicate their book to his colleagues. As for appealing first to the Reformed of Amsterdam, the rest which they enjoyed was due to the magistrates rather than the ministers, some of whom had denounced them as heretics and schismatics; had credited untruths about them which they had not been allowed to refute; and had taken no notice of their Confession when furnished in writing. They assented to much which he had said, but urged that he should give a helpful judgment.

On March 3 Taffinus and Arminius, pastors of the Walloon and one of the Reformed churches of Amsterdam, wrote to Junius. They went into details as to their embarrassments due to the presence of the exiles. One of the three elders of the English Church, Mr. Slade, an educated man, had become assist-

1 Praest. ac Erud. Vir. Epist. (ed.1704), 65-84. This, excepting the fourth letter and adding another by the Fratres, dated July 1, 1602, the Latin original of which escaped the compiler of the Pruest. etc., was translated into English and printed in 1602 as Certayne Letters, by one R. G. Brandt (i : 4S0), also cites them. 
ant master of a grammar school, ${ }^{1}$ which involved lis attendance upon the Reformed, the State, Church. This was "apostasy," and he was dealt with. ${ }^{2}$ The English drew up a statement of the vital differences which separated them from the Reformed churches. In condensed form these were quoted by Taffinus and Arminius thus : ${ }^{3}$ -

1. The constitution of the Reformed Church of Amsterdam lacks proper order, in that: (1) this church never meets together; (2) the ministers never sanctify the Lord's Day with the people; (3) the presence of the church-members can never be made certain ; (4) no public action can be rightly done. 2. Children of non-church-members are baptized, and there is no oversight of them as baptized members. 3. They employ in public worship formulas of prayer other than those enjoined by Christ. 4. The command of Christ in Matt. xviii : 15-17 is not properly observed. 5. God is worshipped in temples that have been consecrated to idols. ${ }^{4}$ 6. They do not support their ministry as Christ ordained (I Cor. ix : 14), but use the same manner with the Papists and others. 7. Their eldership is annual, not for life. 8. They marry in church, as if it were an ecclesiastical act, when it concerns the eivil government only. 9. They use a new censure of suspension, which Christ never required. 10. They consecrate certain days to the Nativity, the Resurrection, the Ascension, etc.

The two Amsterdam pastors discussed these articles and various collateral matters; intimated that they had urged the magistrates to enforce greater regularity in the relation of the Separatists to the State; and made it clear that the Fratres Angli were regarded as conceited, factious and disagreeable.

Junius replied to Johnson's church that if his counsel displeased them it could be disregarded. To this second letter of

1 Wagenaar, i : 416. Brandt, i: 479. White, Discov. of Brownism, 19.

2 G. Johnson, Disc. 213. He was suspended and then excommunicated. White, Discov. 19.

3 Praest. ac Erud. 79. Brandt (i : 479) adds an eleventh: "They receive for members of their Churcl impenitent persons, being excommunicated ; by which means the true Members become one body with those that are delivered to Satan. I Cor. $\nabla$ : 5 ; I Tim. 1 : 20."

4 The old churches in which the Papists had worshipped before the Reformation. 
his the church prepared a rejoinder, but laid it aside unsent. More than three years later, however, some one surreptitiously published in London an English translation of Junius's two letters, suppressing their replies. They then sent him this delayed answer with a third, on July 1, 1602.1 A few more communications closed the correspondence, leaving each side about where it had been at first. These exiles, when sending their Confession to the universities, asked approval either by silence or in writing. No response appears, excepting from Leyden, and even Junius's answer was susceptible of the interpretation that he had found nothing against their faith. Whether the exiles interpreted this almost unbroken silence — very likely that of contempt - into a general endorsement of their positions is not certain. But John Smyth said ten years later : ${ }^{2}$

Seing the Seperation have published the confession of their Faith ... \& the said Christian vniversities have not disalowed that their confession . . ., their silence is therfore in al equity to be accounted their consent : \& Mr. Iunius his silence what is it els to be esteemed but consent?

A local theological occurrence must have interested these English. In the summer of 1598 the city was excited by two reputed Socinian or Unitarian missionaries, Christopher Ostorod and Andrew Voidovius. ${ }^{3}$ The burgomasters seized their books and papers. The books were sent to Leyden for examination by the professors of divinity, who declared them heretical. Whereupon the Leyden magistrates sent them to the Committee of the States-General, who ordered them burned, and directed the authors to make off within ten days, also warning the Provinces to beware of the men. The curiosity of the deputies and others rescued the volumes, and the two suspects repaired to Friesland, where they privately printed a defence and complaint. Their treatment, although an exception to the policy of toleration, certainly demonstrated by its comparative mildness that the Dutch were not apt scholars of Spain in Inquisitorial severities.

Until James I. came to the English throne the church seems to have led a more peaceful life. Yet evidence survives that it was agitated repeatedly by controversies upon subjects now con-
1 Cert. Lets. iii.
2 Paral. 127.
${ }^{3}$ Brandt tells the story, i : 476. 
sidered insignificant. We know little of the Separatist Chureh in Norwich, excepting that, as George Johnson called it the elder sister of the London chureh, it probably sprang from Browne's labors; that a Mr. Hunt was its pastor; and that Johnson ineffectually sought to have his case referred to its friendly advice. ${ }^{1}$ One Mr. Woolsey, presumally a member of it, who was imprisoned for his faith in the Norwich jail, had abandoned meat, and wrote to the Amsterdam church, in 1601, in solemn anxiety to slip the yoke of his vegetarianism over its neck. But it declined.2

A dispute, a little later, also throws light upon the times. It was between Hugh Broughton and Ainsworth. Broughton took his B. A. at Magdalen, Cambridge, in 1570, subsequently becoming a fellow of St. John's and afterwards of Christ's. He became a proficient in Hebrew and Greek, and, going up to London, distinguished himself as a Puritan scholar and preacher.

In 1605 he printed in Amsterdam a little quarto ${ }^{3}$ urging a new translation of the Bible. He referred to "Aaron's ephod" (Exod. xxviii : 6), declaring the common translation wrong, because the Jews held silk as umclean, and that the ephod was made of wool. Ainsworth courteously disputed this in a letter to Broughton, ${ }^{4}$ who was very angry and reviled Ainsworth. Seven or eight letters were exchanged, but neither could convince the other. ${ }^{5}$

Meanwhile discussion of the great issues had been going on. In 1596 an argument by Henry Jacob, then, although inelined to Puritanism, a clergyman of the State Chureh ${ }^{6}$ had been sent

1 Disc. 205, 206.

2 A Seasonable Treatise for This Age: occasioned by a Letter written by one Mr. Woolsey, prisoner in Norwich, to the then Exiled Church at Amsterdam, etc., 1657, tto.

${ }^{3}$ An Advertisement of Corrvption in our Handling of Religion, etc., 1605, 4to, 6, S8, 4,7 .

4 Certayne Questions concerning: 1. Silk or Vvool in the High Priests Ephod; etc., 1605,4 to.

5 In his Annotations upon Exodus (1617) Ainsworth said "fine linnen twined" (xxviii : 6), and the late Revised Version has it "fine twined linen."

6 Brook sars (ii : 330 ) that Jacob "embraced the principles of the Brownists" and retired with them to Holland in 1593 . Yet here he is in 1596 defending the Church of England ; and, in 1600 , we find F. Johnson (Ans. to H. Jacob, iii) calling him "a Priest of the Orders of the Prelates," and "a member of that Church, yea a Minister of it, even a Priest of the Prelates creation." 
to Francis Johnson, still in the Clink, arguing that the Established churches were true churches. Several communications passed, and these arguments and replications were printed in $1599^{\circ}$ in a small quarto ${ }^{1}$ at Middleberg. As this was published especially for readers in the Low Countries, Johnson the next year sent ont a volume ${ }^{2}$ in answer.

The famous Millenary Petition has been described. It seemed desirable to have it supported as strongly as possible, and Jacob, who then was in London, undertook this work. On June 30, 1603 , he sent out circulars ${ }^{3}$ to clergymen supposed to favor the petition, "where unto a consent of as many as côveniêtly ue can get, is very behooueful." As we have seen, the university officials promptly came to the rescue of the assaulted Church, ${ }^{4}$ and spoke reproachfully of the Brownists. Possibly they had noted that the Amsterdam exiles had not included Cambridge and Oxford among the "celeberrimis Academiis Christianis" to whom they had made special appeal. After various complaints of Puritans and Brownists, they tartly declared :-

(To stop that mouth of iniquity, which is wont to traduce vs for $a$ dumb, vnlearned, Idoll Ministery) there are at this day, more learned men in this Land, in this one Kingdome; then are to be found among al the Ministers of the [Reformed] Religion, in France, Flaumders, Germany, Poleland, Denmarke, Geneva, Scotland, or (to speake in a worde) in all Europe besides.

This cold-water treatment toned up Jacob to the conviction that the Established Church was in perilous need of reform. He

1 A defence of The Chvrches and Ministery of Englande, 1590, 4to.

${ }_{2}$ An Answer to Maister H. Jacob his Defence of the Churches and Ministery of England, by Francis Iohnson an Exile of Iesvs Christ, 1600, 4to, 217. This states (200) that an ecclesiastical conmissioner - Mr. Justice.Wroth - said to W. Smith, "a great acquaintance" of Jacob: "Come to church - and be a Divell, if thou wilt!"

${ }^{3}$ The Epistle Dedicatorie of The Answere of the Vice-Chancelor, etc. in Oxford, ete. (viii) contains what purports to be an exact copy. That "H. I." was Henry Jacob is probable from what the Oxford men say of him: "When he lived among vs" (he was at St. Mary's Hall), and it is made certain by Jacob's own admission in his later work (Reasons Taken Out of God's Word, v) where he refers to the charge made by the Oxford men as leading him to justify himself by writing that book. Strype also (Whitgift, ii : 481) affirms that the "principal agent and special procurator" of the petition was "one Henry Jacob."

4 Ans. of Vice-Chan. vii : 12, 15, iv, 31. See p. 337. 
soon printed a little book in which, scattering no shot upon the Separatists, he ably defended four propositions, for substance these: ${ }^{1}$ (1) The State Chureh needs reform. (2) For 200 years after Christ the churches were ordinary congregations only, and the bishops purely parishional. (3) The Scriptures set forth beyond all extraordinary offices, etc., like Apostles - an ordinary form of ehurch govermment then in use. (4) That form, unchangeable by men, alone is lawful. That he already was nearing Barrowism is apparent from what he says of the proper management of ehurch affairs :-

In the maner heereof we hold this only to be necessarie \& ordinarie, that the Ecclesiastical Guides [of course the elders] there (apart fro the People) do first by themselves prepare and determine the whole matter, namely in such sort that the People may not neede to do ought afterward but only Consent with them, and freelie signifie their consent in it.

He saw, however, in view of Browne's shipwreck at Middleberg and the troubles of Johnson's church at Amsterdam, that this would be denomeed at once as opening the door to anarchy; so he suggested a remedy :-

If anie where it should fall out that this People thus guided, \& being so few, will yet presume to be in their Church-Elections, \& $c$. vnrulie and violent, then the Princes next dwelling Officers of Iustice may, and ought, to make them keepe peace and quietnes. Which thing how easie it is for the meanest of them to do, the simplest may perceaue. All which veritie being well considered, this Ecclesiasticall Governement questionles is most reasonable, yea necessarie.

The Amsterdam exiles also felt keenly that the shot from the English universities was aimed at them, and they returned it as soon as they could, the next year. ${ }^{2}$ After stating how they felt injured, they reprinted, in English, their Confession of 1596, and then replied to specific assaults. They abhorred the errors of Familists and Papists. They were accused of absurdity but no examples were given. And, in proof that their petitions to

1 Reasons Taken ort of Gods Word, ii, 28 .

2 An Apologie or Defence of sich Trve Christians as are commonly (but vniustly) called Brovvnists : Against such imputations as are layd vpon them, by the Heads and Doctors of the Vniversity of Orford, etc., 1604, 4to, 1, 2, 4-29, 30-118. 
the king were not "insolent and strange," they reprinted these and explained the occasions of their presentation; thus revealing. a passage of their history ummentioned otherwise.

The Millenary Petition was presented in April, 1603. During May and Jume, great hopes, and even expectations, doubtless were entertained that King James, because of his Presbyterian training, would favor the modification, if not removal, of those forms and usages which made the Church so obnoxious. Even the Catholics prepared a petition ${ }^{2}$ for toleration. These English exiles at once started a deputation to London to implore the king that they might return to England in peace. Probably Johnson and Ainsworth were sent, accompanied by an elder and a deacon, the importance of the mission justifying its cost. Separatists in England also joined them in this appeal. ${ }^{2}$

Their petition urged that they always had acknowledged the true theology of the State Church. A copy of their Latin Confession of 1598 was annexed. After some time they asked leave to explain their position further and to present fourteen particulars, showing the difference between them and the Church. Considerable more time having brought no reply, they besought the king not to let their " small number, contemptible estate or" many infirmities " dwarf the great truths which they advocated. Forty pages explained and supported the fourteen positions, and they concluded this third petition with a plea for treatment at least as fair as that granted to strangers. After additional weeks of delay, "an honorable personage" offered, if they could put the pith of what they wanted into a few lines, to show them to the king. So, for the fourth time, they tried, pleading for leave to practise their religious beliefs in England, leaving to the government the reform of abuses, and for a fair opportunity to discuss with representatives of the State Church the points at issue between them.

1 The Catholikes Supplication vnto the King's Maiestie; for toleration of Catholike Religion in England, etc., 1603.

2 The second petition began thus: "The humble Supplication of sundry your Maiesties faithfull Subiects, who have now a long tyme been constreyned eyther to live as exiles abroad, or to endure other grievons persecutions at home. for bearing witnesse to the truth of Christ against the corruptions of Antichrist yet remayning." Apol. 33, etc. 
How much longer they cooled their heels ineffectually around the outskirts of the Court cannot be toll. But it is safe to imagine them as gloomily journeying back to Amsterdam, in the summer or autumn, with their depressing tidings. At about this time, also, the church experienced hostility from certain former sympathizers. At some time after Johnson's church had reached Holland, a small company, essentially like-minded, arrived in Amsterdam, apparently from the West of England.1 Some twelve or thirteen, they joined the Ancient Church. Thomas White ${ }^{2}$ was their leader, with Thomas Powell as an active coaljutor. Some months later - as Johnson intimates because these men were not given office - they formed a second church.

This weakling enterprise soon died, and White returned to England and to the Establishment, and published a little book ${ }^{3}$ assailing his former associates. Johnson thought its accusations, which inchuded some of alleged immoralities, required reply. White then made gross charges against Johnson's church, and Johnson and Ainsworth, with seven or eight others, brought suit for slander ${ }^{4}$ against White and his wife, Rose, in the Dutch courts. But White proved his statements. Johnson and his associates were condemned in costs and charges, and the civil action dropped there. One cannot help believing, after

' Barrowe's Platform (140) contains a "Memorandum" of an event in 1604, which, whether or not it relates to White and his company directly, illustrates a similar experience. It refers to four persons, who, having been imprisoned three montlis for Separatism, were ordered to "take their oathes to depart the Realme within one moneth, and not to returne againe into any of the dominions of the late Queene, without leave from his Maiestie, or His Highnes Successors." They desired to be discharged without an oatl, or to swear with conditions. Finally they added to the oath the clause: "but if the performance of any dutie to Prince. Countrey, Parents, or the like, doe move me to returne, I will then be free of the Oath." The magistrates then bade them "pay their fees and be gone within a moneth."

$\because$ Thomas White and Rose Grimbrye (?) of London, widow of John Philips, published intentions of marriage in Amsterdam, Apr. 24, 1604, which fixes the date of his arrival as before that time (Puiboken). He is set down as from Sachtenfort (possibly Saddleworth, Forks.) and as twenty-six.

${ }^{3} A$ Discoverie of Brownisme: or A BRIEFE DECLARATION OF SOME OF THE errors and abhominations daily practised and increased among the English company of the seperation remanying, FOR TBE PRESENT, at Amsterdam in Holland. By Thomas White, 1605, 4to.

+ Proph. Schisme, 28, 31. 
weighing the evidence, that Johnson's company unconsciously had harbored a few reprobates. Certainly, it soon afterwards, by general cousent, cast out at least one.

Another who published a book ${ }^{1}$ and said his say as to Francis Johnson among others, was Peter Fairlambe, one of the early company which worshipped in the woods of Deptford and Ratcliffe. He seems to have been in the service of the Merchant Adventurers, in Dantzic, Denmark, the Low Countries, and even Barbary, also being banished for his religions convictions. In, or soon after, 1597 he returned to England and to the Establishment. His book is valuable for its list of publications on each side, including also certain unprinted manuscripts in circulation and having some pojular effect. In $1605^{2}$ Francis Johnson reprinted at his own cost that copy of the "Plaine Refutation of M. Giffards Booke intituled A short treatise against the Donatists of England," 3 by Henry Barrowe and John Greenwood, which had made him a Separatist.

We now have reached the date when, aside from such feeble and transitory assemblies as those of White and Henoch Clapham, ${ }^{4}$ Johnson's company ceased to be the sole English church in Amsterdam. Probably John Smyth and his followers arrived in October or November, 1606, and established themselves at once as "the Second English Church at Amsterdam." 5 Brad-

1 The Recantation of a Brownist, or, a Reformed Puritan, etc., 1606, 4to, iii, iv.

2 We owe knowledge of his connection with this reprint to Bradford, who says (Dial. Young, Chrons. 425) of Johnson: "Coming to live at Amsterdam, he cansed the same books, which he had been an instrument to burn, to be new printed and set out at his own charge; and some of ns here present testify this to be a true relation, which we heard from his own mouth before many witnesses."

${ }^{3}$ As he seems to have reprinted the title-page word for word, the book appears to the casual reader to be of the first edition, and has been so misunderstood and catalogued. But the Advertisement to the Reader fixes the date as fourteen years later.

${ }^{4}$ See p. 427 , n. 5 .

5 In Cong. in Lit. (312) the statement was accepted too hastily from Brook (ii : $196)$ and Barclay $(69,68)$ that Smyth and his company at first joined the First Church, that of Johuson and Ainsworth. But the probability is the other way. Sinyth says (Diferences of Churches, title-page) that that book is published partiy "for the removing of an vnjust calunuie cast vppon the brethren of the Seperation of the Second English Church at Amsterdam;" and Bradford (Dial. Young, Chrons. 450) says: "He [Smyth] was some time pastor to a company of honest and godly men which came with him out of England," and adds (Hist. 16) : "seeing how Mr. John Snith and his companie was allready fallen in to contention with $\mathrm{y}^{\mathrm{e}}$ church $\mathrm{y}^{\mathrm{t}}$ was ther before them." 
ford, who must have known many of them, as well as their general reputation in England and their history in Holland, says that they were " honest and godly men." Smyth himself was an impulsive man, who clearly attached his friends to him strongly. He could turn his hand to more than one thing, ${ }^{1}$ and was unselfish, benevolent, and courageous, never ashamed to own any wrong which he had discovered in himself, a good preacher and a scholar of some attaimments. He possessed many qualities of a great, as well as a good, man. Yet his mind was restless, his conscience morbidly sensitive about trifles, and his will fitful and fluctuating, not in its great purposes but in its relation to the data of perceptions and volitions on which, as a foundation, purposes stand. Bradford described him ${ }^{2}$ as truly as tersely thus: "His inconstancy and unstable judgment, and being so suddenly earried away with things, did soon overthrow him." Robinson condemned him severely ${ }^{3}$ for yielding to this vacillating temperament: " For Mr. Smyth, his instability \& wantonnes of wit is his syn, \& our crosse."

Soon after Smyth's company arrived still another English church was embodied in the city. There, as elsewhere, were British Presbyterian merchants. The authorities recognized them and assigned them for services the old Beguyn (Numnery) Chapel, on a court just off the Kalver-straat, still used by the same organization, now called the Scottish Church. The city also paid its pastor's salary. On Sunday, Apr. 29, 1607, John Paget was inducted into its ministry by John Douglas, chaplain of a Scotch regiment, assisted by three members of the Classis

1 Declar. of Faith of Eng. People, 42. "After a certain time (living at Amsterdam) he began to practise Physicke, (knowing that a man was bound to vse the gifts that the lord had bestowed vppon him for the Good of others) in administring whereof, he vsrally took nothing of the poorer sort: and if they were rich, he tooke but halfe so much as other Doctors did." It is worth noting here that Smrth evidently supported himself and took no salary. In his last book, The Retractation of his Errours, published in 1612, after his death, by the surviving members of his church, he says (40): "From that company of English people that came over together out of the north parts with me $I$ affirme thus much: That I never received of them all put together the value of forty shillings, to my knowledge since I came out of England." Of course he may have inherited some property.

2 Dial. Young, Chrons. 450.

3 Justif. of Sep. 58. 
of Amsterdam.' Johnson's people - who seem to have wolshipped for ten years in some house on the Groenen-Burgwal ${ }^{2}$ (Green Rampart) - now, by aid of English friends, were erecting a church building. This was upon a narrow passage opening at a right angle upon the Barndesteeg (Lane of burnings, i. e., of heretics), which runs from the Nieuwemarkt (New market) to the Oude-aijdls Achterburgwal (Old wide rear Rampart). The passage still retains the name Bruingang (Brownists' Alley). But misfortune pursued them. The records of the English, or Scotch, Church say, on Mar. 16, $1607:^{3}$ -

The beforesaid Brownist preaching-house, being half ready, God sent his strong wind most furious from heavens, and cast the house, only, and no other, flat down unto the ground: which was a sign that they do not build upon the rock, the true and wise foundation.

Apparently this was not only a chapel ${ }^{4}$ but a headquarters for the congregation. The building ${ }^{5}$ which took the place of this one, which was burned in 1662 , still stands. Its length is parallel to the alley, which is so narrow that one can touch both sides at once. It looks a little like a chumch and more like a tenement house. It is probable that, in addition to a large room for their meetings, it had smaller living rooms. ${ }^{6}$ That this disaster did not wholly crush their spirits is indicated by Ainsworth's marriage, only a week from the next Thursday. Moreover, during this year the church reprinted its Latin Confession of Faith, adding to it, also in Latin, those Points of Difference between themselves and the Church of England which they had offered to King James.'

I IV. Steven, Hist. Scot. Ch. Rotterdam, 273.

2 Wagenaar, ii : 174.

3 Supplied by Rev. John McIlraith, pastor in 1871.

4 The only suggestion as to its internal arrangement seems to be the statement (Proph. Schisme, 40) that the elders sat upon "a throne in a high and eminent place."

5 It was sold at auction on Jan. 9, 1867. The anction poster describes it as "of old called the English Brownist Church, standing in the Brownist Lane."

it 'The burial record of John Smyth in the Niewe Ferk (New Church) at Amsterdan, on Sept. 1. 1612, shows that he was borne to his grave from the bakehouse of Jan Munter. The late Frederik Muller, an expert antiquary, was positive that such establishments were used as the headquarters of these poor churches.

7 Confessio Fidei Anglorum, etc. They published simultaneously an edition in 
During the few quiet months while these two churches dwelt side by side the times were hard. Bradford, writing many years afterwards, could not forget what he knew about them. In that quaint "Dialogue between Some young men born in New England, and sundry Ancient meu that came out of Holland and Old England," which his nephew, Secretary Nathaniel Morton, copied into the Plymouth Church records, he says : ${ }^{1}$ -

Young Men: Indeed, it seems they have sometimes suffered much hardness in the Low Countries, if that be true that is reported of such a man as Mr. Ainsworth, that he should live for some time with nine pence a week. To which is replied by another, that if people suffered him to live on nine pence a week, with roots boiled, either the people were grown extreme low in estate, or the growth of their godliness was come to a very low ebb.

Ancient Men: 'The truth is, their condition for the most part was for some time very low and hard. It was with them as, if it should be related, would hardly be believed. And no marvel. For many of them had lain long in prisons, and then were banished into Newfoundland, where they were abused, and at last came into the Low Countries, and wanting money, trades, friends, or acquaintances, and languages to help themselves, how could it be otherwise? The report of Mr. Ainsworth was near those times, when he was newly come out of Ireland with others poor, and being a single young man and very studious, was content with a little. And yet, to take off the aspersion from the people in that particular, the chief and true reason thereof is mistaken ; for he was a very modest and bashful man, and concealed his wants from others, until some suspected how it was with him, and pressed him to see how it was; and after it was known, such as were able mended his condition; and when he was married afterwards, he and his family were comfortably provided for.

At this time the Ancient Church comprised "about three hundred communicants," to which number probably from 100 to 200 more of children, youth and non-communicant adults should be added. "Truly," says Bradford, "there were in them many worthy men." And he continues, "If you had seen them

English, thus entitled: The Confession of faith of certayn English people living in Exile, in the Low Countreyes. Together with a brief note of the special heads of those things wherin we differ fro the Church of England, etc. Reprinted in the year 1607. 16mo. A copy is in the Brit. Mus. Library. See pp. 208 and 432, n. 7.

2 Dial. Young, Chrons. 440. 
in their beanty and order, as we have done, you would have been much affected therewith." Daniel Studley, Stanshall Mercer, George Knyveton and Christopher Bowman were their elders, and David Bristow, M. Braithwait and Thomas Bishop their deacons. They also had a venerable and beloved deaconess, ${ }^{1}$ who kept children quiet during worship and ministered to the poor, ill and afflicted. No hint exists of the place where Smyth's "Second" church used to meet. Probably it was near its elder sister. Evidently the two churches had much friendly conference. ${ }^{2}$ So far as appears, their general views harmonized for a few months. Various records indicate that the new company comprised at least from seventy-five to a hundred members.

Clearly Smyth by nature was unusually hospitable to plansible new views of religion, and had an almost chivalric willingness to adopt them, wherever they might lead, which amounted to little less than recklessness. In England he had vacillated so that even Ainsworth said he had published "three sundry books wherein he hath shewed himselfe of 3 . several religions ;" and, in another book, had so contradicted himself that there was little need of "an other mans sword to peirce the bowels of his errour, when his own hand fighteth against himself." He was not long in the stimulating air of Holland before he began to diverge from the ordinary Separatist opinions, and eventually he lost the confidence of the great majority of the wise and good of his generation. His first notion was that translation of the original Scriptures necessarily results in an apocryphal writing, unlawful for use in worship. He, and his church following him, strove to persuade the Ancient Church to the same view. At least two public conferences were held, and at the second he offered a "writing" on the subject. This has been denied. ${ }^{3}$ But Ainsworth, then teacher of the older church, who wrote on the spot less than a twelvemonth later, surely must have known the facts, and says :-

1 Dial. Young, Chrons. 455.

${ }^{2}$ Clyfton, Plea, ix. "To the Elders and brethren were you [Smyth] most welcome, and glad they were of you, so long as you walked in the faith with them." Ainsworth, Defence, 2, iii, iv.

${ }^{3}$ Editorially in the Chicago Standard, July 1, 1880, and the New York Examiner and Chronicle, Ang. 19, 1880. 
There was one onely difference between M. Smyth and us, when first he began to quarrel; ... .

That difference was this. He with his followers breaking off comunion with us, ${ }^{1}$ charged us with synn for using our English Bibles in the worship of God ; \& he thought that the teachers should bring the originals the Hebrew and Greek, and out of them translate by voice. His principal reason against our translated scripture was this : No Apocrypha writing, but onely the Canonical Scriptures, are to be used in the Church, in time of Gods worship. Every written translation is an Apocrypha writing, \& is not Canonical Scripture. Therefore every written translation is mlawful in the Church in time of Gods worship. . . . A translation being the work of a mans wit \& learning, is as much and as truly an humane writing, as the Apocrypha (so commonly called) writings are, and seeing it hath not the allowance of holy men inspired, but is of an hidden authoritie, it may be justly called Apocrypha, \&c. And ther fore not to be brought into the worship of God to be read. ${ }^{2}$

That this point of the translation was the onely difference, as it is known to al that then heard his publik protestatio ; so his words in writing shew it. Translations written (sayth he) are not refreyned in the case of scandal, for we desired that they might be refreined for our sakes, that we might keep communion, \& it would not be yeilded.

So, if we would have layd aside our translated Bibles, communion (they say) should have been kept with us. ${ }^{3}$

Such a man almost certainly would go further, and we soon find him denying the propriety of using a book in either preaching or singing, thus : ${ }^{4}$ -

2. We hold that seing prophesying is a part of spirituall worship : therfore in time of prophesying it is unlawfull to have the booke as a help before the eye.

3. We hold that seeing singing a Psalm is a part of spirituall wor-

1 That is, between the two churches.

2 Diferences of Churches, 12.

3 Corroborated by Clyfton (Plea, v): "First calling into question, whether the scriptures being translated into other tongues, were not the writings of men. ... Then casting the reading of them out of the worship of God, affirming that there is no better warrant to bring translations of Scripture into the Church, and to read them as parts and helps of worship, then to bring in expositions, paraphrasts and sermons vpon the Scripture, seing all these are equally humane in respect of the worke, equally divine in respect of the matter they handle. Difs. 10. And, for the same cause, separated themselves from other Churches that did read and rse the same in their publike meetings." Also Hoornbeeck, Sum. Controv. Relig. 740.

4 Difs. iii. Def. 4. 
ship; therefore it is unlawfull to have the book before the eye, in time of singing a Psalm.

That part of public worship also was speedily discontinued, as we know from Ainsworth, who says :-

If it [singing] be an ordinary part of worship, why perform they it not, but quarrel with $\mathrm{vs}$, who accounting it an extraordinary gift now ceased, do content our-selves with joint harmonious singing of the Psalmes of holy Scripture.

This is confirmed by a letter of Hugo and Anne Bromhead, ${ }^{1}$ which describes their order of worship and makes no mention of singing.

Upon two other matters Smyth had reached conclusions at variance with those of the Ancient Church. One was that all elders should be pastors, lay-elders, so-called, being antichristian, and that the "informed presbyterie ... consisting of three kinds of Elders, Pastors, Teachers, Rulers is none of Gods ordinance, but mans device." The other was that contributions to the church treasury should be with " a separation from them that ar without; " giving being a part of spiritual worship. ${ }^{2}$

We have seen that Amsterdam was regarded as a hotbed of heresy, and no doubt many there were "come-outers" from almost every ancient faith. It was not a good place for any restless and unstable mau. It was not a good place for Smyth. He seems to have come very soon under the influence of Hans de Ries and Lubbert Gerrits, well-known Duteh Baptists, ${ }^{3}$ with results which speedily manifested themselves.

1 To W. Hamerton of London, 1609. Harl. Ms. 360: 70. The date of this undated lotter is indicated by the facts that it was written at Amsterdam and says: "there be divers books written by our pastors touching ... the diferences between us and the other churches here," which hardly was true before 1609 .

${ }^{2}$ Difs. iii. Def. 114.

3 Evans, Early Eng. Baptists, 211. 


\section{CHAPTER IV}

\section{THE PILGRIMS IN THE CITY}

$W_{E}$ now have reached the time when the last detachment of the Pilgrim company arrived in Amsterdam - Angust, 1608. Even among all the multifarious industries of the place, to maintain themselves was anything but easy. But they were equal to it. As Bradford quaintly says : ${ }^{1}$

It was not longe before they saw the griñe \& grisly face of povertie coming upon them like an armed man, with whom they must bukle $\&$ incounter, and from whom they could not flye; but they were armed with faith \& patience against lim, and all his encounters; and thongh they were sometimes foyled, yet by Gods assistance they prevailed and got $\mathrm{y}^{\mathrm{e}}$ victorie.

We are almost withont information as to their life during their scant year in Amsterdam. We do not know even their numbers, although there hardly can have been less than from 125 to 150 persons. ${ }^{2}$ Clyfton probably was their teacher. Robinson surely was their pastor. Presumably they then had no elder.

In Amsterdam they soon must have felt some spiritual disappointment. The Ancient Church was measurably at peace, but there were mutterings of a coming storm. Smyth's company also - which they must have known best, because of its Gainsborough origin - was much "drawn away" from its original views and already threatened with a permanent division. Possibly the Serooby company never undertook to settle permanently in Amsterdam, but made temporary arrongements until

1 Hist. 16.

2 Their application for leave to settle in Leyden. early in the next year, is for "one hundred persons, or thereabouts, men and women." Clyfton and his family, and probably others, remained; so that, if the phrase "men and women" were meant to exclude children from the account, the total number while in Amsterdam hardly can have been smaller than that suggested in the text. 
they could see light elsewhere. And it demonstrates their religious sincerity that their solicitude was wholly on that side, for, difficult although the struggle was in Amsterdam in regard to "their outward means of living and estats," it was unlikely that they could be equally comfortable elsewhere. Bradford's language ${ }^{1}$ implies familiarity with the preaching and teaching of Johnson and Ainsworth, whom probably he often heard. Yet Robinson's church nainly worshipped by itself and never was merged in either of the others. ${ }^{2}$ Apparently the three churches maintained their separate existence, officers and worship side by side, but with cordial fellowship. Yet the difficulty of accommodating the Pilgrim church by itself must have caused the occasional worship of some members with the Ancient Church.

Soon after Robinson's arrival a pamphlet letter, directed to Smyth and himself jointly as "Ringleaders of the late Separation at Amsterdam," reached them, by Joseph Hall, afterwards Bishop of Exeter and, later, of Norwich. It survives in a reprint, $^{3}$ seventy-three years later, and in Hall's works. It assumes that really there is no other side to the subject than his own. Its tenor is indicated by this passage: -

We hear of your separation, and mourne; yet not so much for you, as for your wrong: you could not do a greater iniurie to your mother, than to flie from her. Say shee were poore, ragged, weake; say she were deformed; yet shee is not infectious; Or if she were, yet she is yours. This were Cause enough for you, to lament her, to pray for her, to labour for her redresse, not to avoid her: This unnaturalnesse is shamefull; and more hainous in you, who are reported, not parties in this evill, but authors. . . . The God of heaven open your eyes, .. . otherwise, your soules shall find too late, that it had been a thousand times better to swallow a Ceremonie, than to rend a Church:

1 Dial. Young, Chrons. 445, 448, 455-456.

2 Bradford says (Ibid. 453) that Clyfton belonged to the Leyden chureh, but, unwilling to move from Amsterdam, was dismissed to the Ancient Church. Had these two churches been united during 1608, Robinson and the others leaving for Leyden would have had to be dismissed. Paget (Arrow, 58), who lived in Amsterdam at the time, says: "By such a reason as this you might prove that Mr. Robinson and his company separated from you at his first comming into this land, because they gathered a new Church apart from you [Ainsworth, etc.] in the same citie, you being here a Church before them."

${ }^{3}$ Letter concerning Separation, etc., 1681, i : 2S7-2S8. 
yea, that even whoredomes and murders shall abide an easier answer than Separation.

One of Robinson's next labors must have been the replying ${ }^{1}$ to Hall. There is no trace of any help from Smyth. He points out that Separation always is "very odions in the eyes of all them from whom it is made." Hence the "Church of England can better brook the vilest persons contimuing communion with it, then any whomsoeuer separating from it." Still, "Separation from the world ... is the first step to our communion with God, and angels, and good men." If the Separatists have given just offence, let them be blamed. But if "your Church be deeply drenched in apostasy, and you cry Peace, Peace, when sudden and certain desolation is at hand, it is you that do wrong." He and his people are not ungrateful to their mother Church. They have done to her only what she did to her mother, the Church of Rome. As to Amsterdam, they do not gather "churches by toune-rowes as they doe in England, and [hold] that all within the parish procession are of the same Church;" and they have nothing in common with Jews, Arians and Anabaptists but the streets and market-place. And he concludes:-

Lastly, the terrible threat you vtter against vs, . . . would certainly fall heauy vpon vs, if this answere were to bee made in your Consistory Courts, or before any of your Ecclesiasticall iudges; but because we know, that not Antichrist, but Christ shalbe our iudge, we are bold vpon the warrant of his word and testament . . . to proclaim to all the world separation frō whatsoeuer riseth vp rebelliously, against the scepter of his kingdome, as we are vndoubtedly perswaded, the Communion, gouernment, ministery, and worship of the Church of England doe.

Johnson printed this year ${ }^{2}$ a small quarto, most of which he had written before, ${ }^{3}$ to justify Separatism. ${ }^{4}$ And, late in that

1 "From the other, I received, not two moneths since, a stomakful [angry] Pamphlet" (Hall, Com. Apol. iv). The title was An Answer to a Censorious Epistle. No copy of the first issue of either has survived, but Hall in his Com. Apol. reprints, apparently entire, Robinson's answer to his first letter. Ashton also has extracted and consecutively arranged it in his Works of Robinson, iii : 401-420. Com. Apol. (margin) 3, and passim.

2 Ainsworth in his Counterpoyson, issued about Dec., 1608, refers (151) to this book as "lately published."

3 Pref. iii.

4 Certayne Reasons, and Arguments, prouing that it is not lawfull to heare or haue 
year, ${ }^{1}$ Ainsworth issued a more solid treatise ${ }^{2}$ on the differences between his people and the English State Church, replying especially to Sprint's "Considerations" and "Arguments," Crashawe's attack at Paul's Cross, and Bernard's book aimed at them. It is important for its candor, its scope, its conclusiveness, and the incidental value of its historical references. One of the last implies that Robinson had had charge of a Norwich church, and afterwards had labored with Separatists there or near by. It will aid the understanding of Ainsworth's position on some matters, which finally divided his company, to note his view of the church, the eldership and popular government. He says : -

The true church is a People called of God by the Gospel, from the world, rnto the Communion or fellowship of his son Iesus Christ, in whom they are coupled and built togither, to be the habitation of God by the spirit.

More particularly, they that are called of God, \& members of the church rniversal, are vnited and gathered into many churches or congregations, in severall cities and countries: every [all] of which churches being joyned togither in the profession and practise of the Gospel of Christ, have his power and presence with them, $\&$ is to convene or come togither in one, for the worship of God, and the performance of publick duties.

Neyther that ruling power of Christ, which the Puritans (whereby I suppose M. Bern[ard] meaneth the Christian reformed churches in other countries,) say is in the Presbyterie; doe we say is in the multitude; for we acknowledge Christ to have ordeyned a Presbyterie or Eldership, and that in every church ; for to teach and rule them by his own word and lawes; vnto whom all the multitude, the members, the Saincts, ought to obey and submit themselves, as the Scriptures teach.

So then, for popular government (which $M r r$. Bern. would traduce vs by) we hold it not, we approve it not ; for if the multitude govern, then any Spirituall Communion with the present ministerie of the Church of England, 1608, 4 to.

1 Crashawe's questions were dated May 21, 1608, and Bernard's book June 18, 1608 ; so that, allowing time for the latter to reach Amsterdam and for Ainsworth, with his other labors, to prepare his answer and send it through the press, it hardly can have been completed before the last month of the year by the Dutch reckoning.

2 Counterpoyson: Considerations touching the points in difference between the godly Ministers $\&$ people of the Church of England, and the Seduced brethren of the Separation, etc., 1608, 4to. Again in 1642. 115, 121, 176, 177. 
who shalbe governed? Christian liberty (which all have) is one thing, the raynes of government (which some have) is another thing. Smyth, arraigned by Hall as a "Ringleader" with Robinson in this Amsterdam separation, took no part in the reply. Even before Robinson's arrival he had become the "ringleader" of another separation, apparently resulting in non-communion with the Ancient Church for $\sin$ in using the English Bible in worship. His volume abont this, "The Diferences of the Churches of the Seperation," seems to have been issued at least two months before Robinson arrived, and it hardly could have been two months later ${ }^{1}$ when he took that famous additional step with which his memory is identified specially.

Soon after reaching Amsterdam he became convinced ${ }^{2}$ that their baptism in childhood was fatally defective in two respects. He decided that only those can be truly baptized who confess their faith with, and in, the rite, which infants cannot do; so that he and his company were unbaptized. ${ }^{3}$ Further, he felt that, having been handed down for centuries through a false church, genuine baptism had ceased among men - that so esteemed being but an empty form - and to hope to recover it was vain. ${ }^{4}$ The ordinance in its purity must be originated de novo, if that might be done Scripturally, and he decided that it could be, and must be. ${ }^{5}$ Accordingly he undertook it at once. Thus far, no question of the form of administration was raised. The first step was to clear the ground of all rubbish of the past. This was accomplished by a formal disavowal of the old

1 'The book is undated, but Prof. Scheffer says: "I put down the date of the issue of the Diferences as in the spring or summer of 1608 (Ms. letter, Jan. 21, 1882). $\mathrm{He}$ also dates the se-baptism " in October, 1608."

2 Apparently Hans de Ries, Lubbert Gerrits, or other Dutch Anabaptists, with whom Smyth and his people were affiliated later (Evans, i : 211), already had begun to leaven him with their views. Bradford says (Dial. Young, Chrons. 451): "He was drawn away by some of the Dutch Anabaptists."

:Char. of Beast, iii, v, vii.

4 'There were at least five reasons why they did not ask baptism of the Mennonites: (1) They could not be sure of the purity of even their paptism in the remote past. (2) The difference of language hampered them. (3) It is likely that they did not care to rank themselves at once with the Dutch Anabaptists. (4) They were hardly in full theological sympathy with the Mennonites. (5) To have been baptized by them may have involved joining their church.

${ }^{5} \mathrm{He}$ argued for it stoutly. Char. of Beast, 58 . 
baptism, and of their existing church estate, including the abdication by the officers of their official functions. They agreed together and declared publicly that they were no longer pastor, deacons and flock; no longer members of Christ's church; no longer baptized people; but simply individual Christians, desiring church quality, fellowship and privilege according to a new manner which their more enlightened consciences could approve.

That such a procedure was inevitable according to their new principles is plain. ${ }^{1}$ That it actually was taken by them there are four credible witnesses. First, Ainsworth, who must have known the facts, and who says, "He and his followers having dischurched themselves and dissolved their communion," 2 proceeded, etc. Secondly, Clyfton, who had known Smyth for years, who declared that Smyth's influence had helped to lead him into Separatism, ${ }^{3}$ and who, even after Smyth's apostasy, spoke of him as "lim that was deere vnto me," who was in Amsterdam at the time, who assuredly knew what took place, and who says :-

After this [separation from other churches which read and used the Bible in public service], they dissolved their Church, . . . \& Mr. Smyth being Pastor thereof, gave over his office, as did also the Deacons, and devised to enter a new communion by renouncing their former baptisme, and taking upon them an other, of man's invention.

\section{Thirdly, Robinson, long familiarly acquainted with all parties,} who declares : ${ }^{4}$ -

1 Inattention to this fact has involved some in error. The Chicago Standard on July 1, 1880, said: "In the company was another minister [Helwys] besides himself [Smyth], who had the same power to administer the ordinance which Smyth liad. Each could administer the ordinance to the other, and no cntting of the knot would be called for. Indeed, in such circumstances, the resort to such a proceeding as the solemn baptizing of himself by Mr. Smyth, in order to qualify himself to baptize the rest, is so irrational and absurd as to seem out of the question in the case of persons such as John Smyth and Thomas Helwys are upon all hands admitted to have been." This reasoning overlooks that: (1) Smyth had laid down his ministry for the second time and was waiting to be made a minister again more properly ; (2) up to this date Helwys never had been a minister; and (3), if both had been, and still were, ministers, it would have been an absurdity, after having denounced their former baptism and dissolved their church-estate as imaginary and false, to proceed, in virtue of a ministerial character solely dependent upon that imagination and falsehood, to perform ministerial acts.

2 Defence, 82.

3 Plea, 2, 5, 226. Ans. to Mr. Smythe's Epis. to the Reader, 1.

4 Of Relig. Com. 48. 
which [the process of the action taken] was, as I have heard from themselves, on this manner. Mr. Smith, Mr. Helw[ys]. \& the rest, haveing vtterly dissolved, \& disclaymed their former Ch : state, \& ministery, came together to erect a new $\mathrm{Ch}$ : by baptism.

And, fourthly, Bernard, writing within the next year, who insists : ${ }^{1}-$

By this triek is he [Smyth] dispastored, and is but among them as a priuate person, till he be againe elected; this is most true: And thus hath he beene off and on in the Ministerie two or three times. $\mathrm{He}$ was made minister by Bishop Wickam, that by and by in Brownisme he renounced; \& was made Minister by Trades-men, and called himselfe, The Pastour of the Church at Gainsbrough; this hath he lost againe by his Se-baptisticke way, till he be chosen againe.

After this preparatory action, they naturally tumed to Smyth, who had created the exigency, for deliverance. Robinson says ${ }^{2}$ that there was " some streyning of courtesy, who should begin," probably beeanse Smyth, with all his "forwardness," really was modest ${ }^{3}$ and very likely to urge Helwys or Murton ${ }^{4}$ to take the lead. But all looked to him, and he went forward. The manner of procedure is settled by testimony, uniform in character not only until the entire generation within whose knowledge the event occurred lad passed away but until two or three generations more had died, in fact until a time when only surviving documentary evidence could reverse its significance.

Much study, comparing and harmonizing all accounts, seems to lead to these conclusions. They met where they were accustomed to worship, ${ }^{5}$ included in the furniture of which room was

1 Plaine Euid. 20.

2 Of Relig. Com. S4.

3 Whoever reads The last Booke of Iohn Smith, called the Retractation of his Errours and the Confirmation of the Truth, will recognize this engaging element in lis character. The only known copy of the book is in the library of York Minster, England; but R. Barclay reprinted it in his Inner Life of Relig. Socs. of Commoncealth, 11S-125.

4 Murtou was in full sympathy with what was done. Descrip. of what God hath Predest. concern. Man, 1620, 159.

5 In Dr. Dexter's monograph, The True Story of John Smyth, the Se-Baptist, etc. (1881), it is conjectured (30) that the baptism took place in the river Amstel, the parties wading in a little way, and the water being lifted in the hand from the stream; it being perfectly clear that at that date nobody in Amsterdam, not even the Anabaptists, baptized by inmersion. Since then it has been made plain by Scheffer - who, as a professor in the Mennonite (Baptist) College in 
a three-legged stool, ${ }^{1}$ which held a basin of water. Ranging themselves around this stool, and without preliminary prayer, ${ }^{2}$ Smyth dipped up water in his hand ${ }^{3}$ and poured it over his own forehead in the name of the Father, Son and Holy Ghost. Then he repeated the ceremony in the case of each of the others - Helwys, Murton, Pygott, Overton, Bromhead, Jessop, Hodglins, Bywater, Grindal, Halton, etc., not forgetting Mary Smyth, Anma Bromhead, Ursula Bywater, the Dickens sisters and the other women - thus, according to their common conviction, giving to each a genuine reinitiation into the true earthly kingdom of God. ${ }^{4}$ Afterwards worship was held, end-

that city, must be presumed to have been a competent judge - that the baptism took place in the room ordinarily used for worslip.

1 Prof. Sclieffer states that the accompanying illustration reproduces an engraving by Cornelis van Sichem from a picture by Barend, who lived about 1535 and was commissioned by the city of Amsterdam to paint a set of pictures relating to the Anabaptists. These pictures were destroyed when the old State-house was burned, July 7,1652 , and survive only in van Sichem's engravings. Scheffer added: "As these were accurate copies, they shonld be regarded as faithful representations of events by one who witnessed them himself. The way in which the baptism is administered, by pouring water taken from the dish upon the head of the recipient, is without any question quite historical." As this was the Anabaptist method of baptism, it is unlikely that Smyth adopted any other. Moreover, Lubbert Gerrits, one of the principal Waterlanders of Amsterdam, in writing soon after to the church at Leeuwarden said (Evans, i : 212) of Smyth's people: "We . . . have summoned these English before us, and again most perfectly examined them as regards the doctrine of salvation and the government of the church, and also inquired for the foundation and form of their baptism, and we have not found that there was any difference at all, neither in the one nor the other thing, between them and us." Van Braght's work upon the Dutch Anabaptist Martyrs (Het Bloedig Toonell, of Martelaers Spiegel, der Doops-Gesinde of Weerloose Christenen, 1685, ii : 507) also has a statement made in 1570 to the Burgomasters' Court by Faes Dirksz, an Anabaptist, that those who baptized him did so in the name of the Lord, the Father, the Son and the Holy Ghost, and that the water was poured over his head from a dish.

2 Robinson says (Of Relig. Com. 4S): "Vnto which [baptism] they also ascribed so great virtue, as that they would not so much as pray together before they had it."

3 The picture plainly suggests this.

4 That the testimony of those qualified to testify is uniform is shown by these statements : -

(1) Snyth himself. In his last tract, pnblished after his decease (Last Booke, 37), he says: "Seeing ther was no church to whome we could Joyne with a Good conscience, to haue baptisme from them, ther for wee might baptise our selues: that this is so the Lord knoweth." And again (36) : "Maister Hel[wys]. saith that although ther be churches alreadie established, ministers ordained and sacraments administered orderly, yet men are not bound to Joyue to those former 


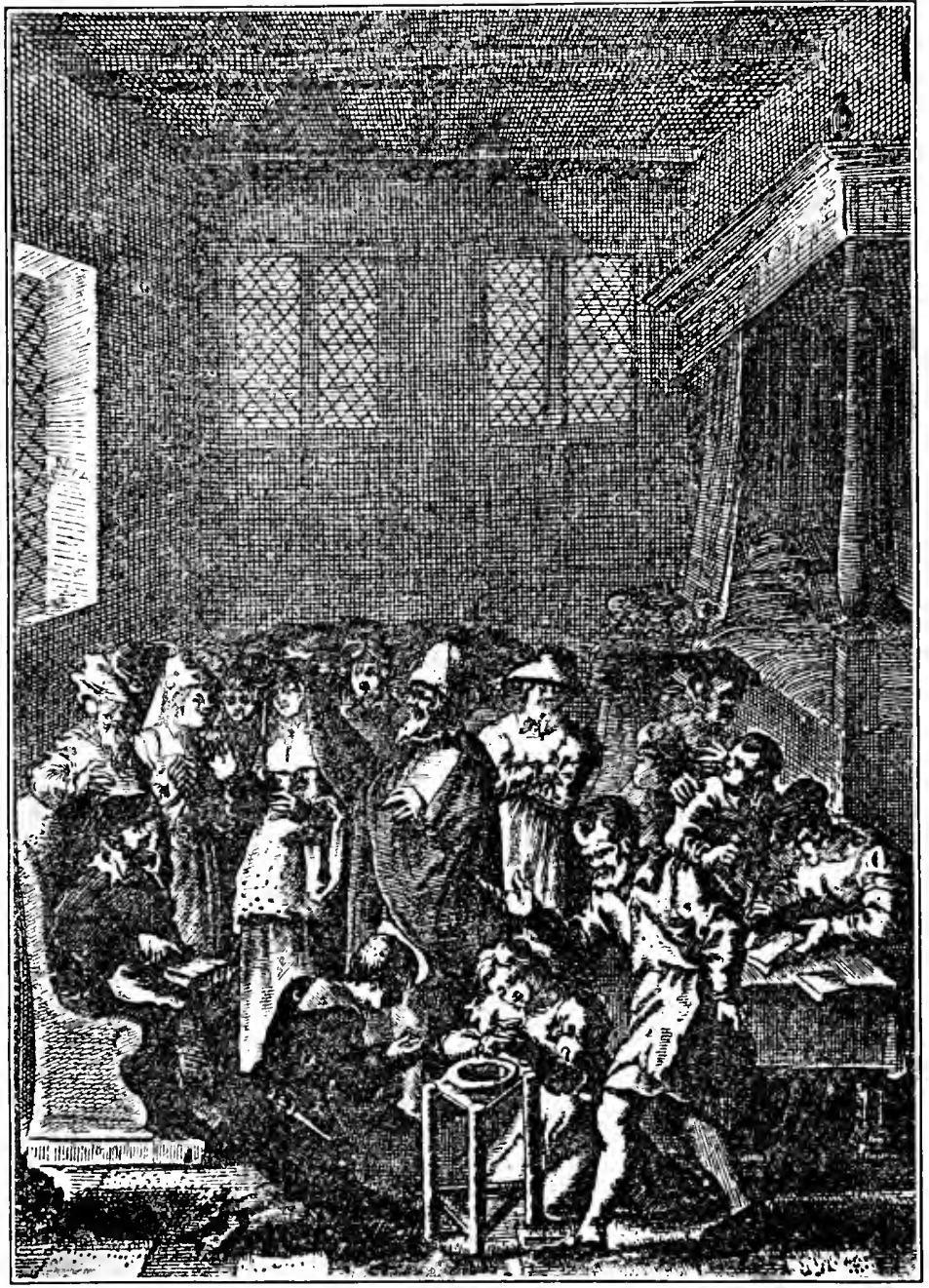

THE SE-BAPTISM 


\section{ing with the Lord's Supper; and at last they felt themselves} a genuine church of Christ, if the only one upon earth.

churches established, but may being as yet unbaptised baptise them selues (as we did) and proceed to build churehes of them selues."

(2) Ainsworth. IIe says (Defence, 69, 82) : "Mr. Smyth anabaptised himself with water... Having . . . thus doon to himself." "He . . anabaptised himself and then anabaptised others."

(3) Robinson. He states (Of Relig. Com. 48): "As I have heard from themselves ... Mr. Smyth baptized first himself, and next Mr. Helwis. \& so the rest, makeing their particular confessions."

(4) Clyfton. He was on the ground, wrote on the general subject, and refers again and again to Smyth's rebaptizing himself (Plea, 172, 178, 179, 180, 183, 185, 186,224 . Only important words are eited). "In your new baptising of your selves." "If you that baptise your self (being but an ordinary man) may this do, then may an other do the like, and so every one baptise limselfe." "And so Mr. Smyth was a Church, when he baptised himself, which is absurd to think." "And as for two baptising themselves or one an other, that can they not do withont ealling from God." "This new opinion inableth any man, be he master or servant to baptise himself." "Resolve me how you can baptise your self into the chnreh being out of it, yea and where there was no church?" "Seing you have already chaunged your mind again concerning your baptising of yourself." "As you have begunne to recall your baptising of your selfe (as we heare) in some respect, vidz. in that you baptised your selfe and others withont lawful calling;" etc.

(5) Henoch Clapham. He undoubtedly referred (Error on the Left Hand, 1608, 22) to Smyth when he described a man that "lined in Netherland, who running from the English Chureh here, to the Brownist; from the Browuist to a particular faction of his owne, whereto he did baptize himselfe; from that [as we shall see to be true of Smyth] to one sect of the Anabaptists, where they baptized him againe."

(6) Some person known only as I. H. In 1610 he published in London a Description of the Church of Christ, which is levelled against "one Maister Ioln Smith ... and a companie of English people with him now at Amsterdam in Holland, whome he hath there with himselfe re-baptised" (title-page) in which he asks (23) : "Tell us one thing Master Smith, by what rule baptised you your selfe ? . . You durst presume withont either word or example, to baptise your selfe."

(7) Bishop Joseph Hall. He says (Com. Apol. 1610, iv, 6) that he (Smyth) "hath washt of [f] thy [the Church of Englaud's] Font-water as unclean." "He hath renounced our Christendome with our Chnrel, and hath washt of his former water with new."

(\$) Richard Bernard. He says (Plaine Euidences, 1610, 17-20, 30, 314-315) : "He [Smyth] is a Se-Baptist, becanse hee did baptise himselfe." "I aske therefore whether the visible Church was among them or no, when Mr. Smith did baptise himselfe?" "By baptising of himselfe, ... he is become Mr. Smith the Anabaptisticall Se-baptist. . . . He did baptize himselfe." "M. Smith did baptize himselfe contrary to the scripture."

(9) Lubbert Gerrits. Writing in $\mathbf{1 6 1 0}$ to the church at Leeuwarden and referring to Smyth (see whole letter in Evans, i : 211-213), he says: "The act of baptizing by which be has baptized himself."

(10) Edmund Jessop. He says (Discov. of Errors of Eng. Anabap. 1629, 65) : "Mr. Smith baptized himselfe first, and then Mr. Helwis and Iohn Morton, with the rest. 
While still at Gainsborough Smyth appears to have had frequent conference with Bernard, then of Worksop; who had wavered on the edge of Separation, but now condemned it as "error \& schism." In the closing months of $1607^{1}$ the in-

"If I shonld now demande of you your warrant for a man to baptize himselfe; I much maruell where you would finde such a practise in all the new Testament of Christ."

(11) Ephraim Pagitt. He says (Heresiography, 1648, 75): "Mr. Smith . . . from a Protestant turned Brownist; and from a Brownist he turned Anabaptist; yea, a Se-baptist, and rebaptised himselfe."

(12) John Shaw. He says (Ms. Advice to his Son, 1664. Brit. Mus. 450): "One Smith ... flew so high that he turned not only Anabaptist but Se-baptist, and baptised himself."

(13) Ancient Truth Revived, or a true State of the Antient, Suffering Church of Christ, commonly (but falsly) called Brownists $(1677,36)$ says : "One Iohn Smith, first a minister in England . . . added Sin unto Sin and baptised himself; then he baptized one Mr. Helvish." So much for witnesses, including Smyth himself, in the same century. Their unanimity is unbroken. In those days nobody denied or questioned the fact of the se-baptism. Again and again during Smyth's lifetime and while Helwys and Murton still held the pen, the act was charged upon them as an ecclesiastical irregularity needing justification, but there is no trace of any attempt or desire on their part to deny it. But more than 125 years after the event, and when the sources of Nonconformist history were largely inaccessible, Thomas Crosby, writing a history of the English Baptists and confessing that the defences which Smyth wrote for himself were "not to be met with" (Hist. 1738, i : 98), suggested that the charge that Smyth baptized himself was not unlikely to be a report taken up "against him npon slender evidence, and after one had published it, the others might take it from him without any enquiry into the truth of it." Seventy-three years later Joseph Ivimey improved npon Crosby's suggestion and declared confidently (Hist. Eng. Bapts. 1811, i: 115): "There is no donbt but this silly charge was fabricated by his enemies, and it is an astonishing instance of credulity that writers of eminent talents have contributed to perpetuate the slander." Seven years later Adam Taylor said (Hist. Eng. Gen. Bapts. 1818, i : 8.5) almost the same thing. David Benedict thought (Gen. Hist. Bapt. Denom. 1848,330 ) that Smyth's method "is not very clearly stated," and presumed that the company first formed a church and then appointed Smyth and Helwys "to baptize each other and afterwards to baptize the rest." Mr. S. B. Underhill (Letter to Ir. Benedict in Watchman, Jnly 14, 1853) urged that Se-baptism means, not that they administered the ordinance to themselves. but that among them they commenced the practice of dipping. But the facts are that they were not dipped, and, according to contemporaneous testimony, that Smyth administered the ordinance to himself by sprinkling or affusion. Evans (Early Eng. Bapts. 1862, i: 204-20.1) submits some of the evidence, but is evasive. And the Chicago Standard, of July 1, 1880, claimed the whole story of se-baptism to be due to an honest misapprehension by John Robinson, who reported the "absurd" statement as "what he had thus heard," and it added : "There is no other theory of the matter, which in the light of history will stand the test." But, if it be possible to prove any fact by evidence, it is proved that Smyth baptized himself and then his people.

1 Paral. 2, iii. "Mr. Bernard had in his hands this lettre of myne six or seven 
dignant Smyth sent in manuscript to Bernard a hasty letter ${ }^{1}$ defending it. Six or seven months later Bernard replied in a book $^{2}$ which to those attacked seemed dangerous. In December following Ainsworth published his "Counterpoyson," already mentioned, which in large part answered Bernard. But Smyth thought it best to print his letter, and, "parallele-wise," to compare Bernard's book, Ainsworth's answer and the letter, which he did in January, $1609 .^{3}$ This was three months after his se-baptism, but he did not refer to that because "necessity enforceth the identity of this lettre without correction eyther of matter or wordes." He feared "least Mr. Bernard should say it is not the lettre he had from mee." Moreover, he had another book in hand, which offered better opportunity for urging his new views of baptism.

Early in 1608, before Clyfton left England, Smyth appears to have sent him in manuscript two "Anabaptistical Propositions." * One argued against infant baptism; the other that "Antichristians" converted are to be admitted into the true Church by baptism. Clyfton had replied, also in manuscript, on Mar. 14, 1608, and Sunyth had quickly ${ }^{5}$ rejoined. Perhaps hoping to win Clyfton by personal persnasion, Smyth did not hasten to publish his portion of this debate. But when, in August, Clyfton arrived, and all hope of converting him was abandoned, and when, six weeks later, the se-baptism had taken place, no reason remained why the plea for the new views should be longer reserved, but every reason why it should be published.

monthes before he published this his book." But the book is twice dated 18 June, 1608 .

1 Ibid. "This letter written to Mr. Bernard in private, vppon three dass."

2 Christian Advertisements and Counsels of Peace. Also Dissuasions from the Separatists Schisme, commonly called Brownisme, 160s, 16mo, i : 200.

${ }^{3}$ Parallelles, Censures, Observations. Aperteyning: to three Several Writinges, (1) A Lettre written to Mr. Ric. Bernard, by Iohn Smyth. (2) A Book intituled, The Separatists Schisme published by Mr. Bernard. (3) An Answer made to that book called the Sep. Schisme by Mr. H. Ainsworth. Wherevnto also are adioyned. (1) The said Lettre written to Mr. Ric. Bernard divided into 19. Sections. (2) Another Lettre uritten to Mr. A.S. (3) A third Lettre written to certayne Brethren of the Seperation. By Iohn Smyth, 1609, 4to. This is in the Bodleian Library, Oxford : in Queen's Coll., Cambridge, and the Yale Library (Dexter Collection).

4'Plea, 2, 213.

5 "I end writing this 24 March, 160s." Char. of Beast, 71. 
So it was issued a few days after that ${ }^{1}$ which replied to Bernard, although the date of the original preface of the previous year was unchanged. ${ }^{2}$ Its title ${ }^{3}$ indicates some feeling and proved offensive.

Clyfton's reply, ${ }^{4}$ in 1609, is invaluable for its incidental notices of this Amsterdam life. It is an unpremeditated proof of the influence which, in spite of his peculiarities, Smyth had, that his tractate published in 1608, "The Diferences of the Churches of the Seperation," received elaborate answer ${ }^{5}$ by Ainsworth after the se-baptism, and even after that happened which is to be spoken of next.

Scarcely had Smyth and his freshly confederated church become settled when he moved on to another plane of belief and action; first suspecting, and then affirming, that they had had no right to baptize and "church" themselves; so that, in fact,

their new washed companie is no true church, and that there cannot be in a church the administratio of baptisme \& other ordinances of Christ, without Officers, contrarie to his former judgment, practise \& writings.

Smyth, it was added, -

yet resteth not, but is inquiring after a new way of walking, (as the same persons affirme) breeding more errors, as is strongly suspected, and by his manuscripts partly appeares.

All ended for the time in the disruption of the new body, only about ten members ${ }^{6}$ maintaining it for a while, the majority going out after more truth.

1 Ainsworth says (Defence, 118): "A few dayes after [his late book called Parallelles, ete.] he [Smyth] setts out The character of the Beast."

2 This circumstance, with the fact that the letter to Bernard stayed unprinted some time, has caused confusion in the chronology of the bibliography of the writings of these men. The eredit of elearing it up is due to Scheffer.

3 The character of the Beast, or the False Constitution of the Church Discovered in Certayne Passages betwixt Mr. R. Clyfton \& Iohn Smyth, etc., 1609, 4to. The Bodleian has the only discoverable copy.

4 A Plea for Infants and Elder People, concerning their Baptisme: Or a Processe of the Passages between M. John Smyth and Richard Clyfton, etc., 4to. A little less rare than that to which it replies. It is in the Brit. Museum, the Bodleian, and the Dexter Collection at Yale.

5 A Defence of the Holy Scriptures, Worship, and Ministerie, used in the Christian churches separated from Antichrist, etc., 1609, 4to.

Clyfton, Plea, vi. 
At the beginning of the Reformation in Holland the Dutch did not enter much into minute criticisms of doctrine. The Calvinists gradually favored ecclesiastical indcpendence of the State. The Lutherans admitted the civil power to co-action. Strife resulted, with the limitation of the Church to a provincial organization. The Provinces were subdivided into Classes, each congregation being governed on the Presbyterian plan. And, as many young men, educated at Geneva under Calvin and his successors, became pastors of these congregations, they sought to control the Classes and the Synods in favor of rigid Calvinism. Towards the close of the sixteenth century, however, the Arminian Controversy began. The earliest theologians of the Reformation adopted Augustine's view of unconditional predestination. In the main Calvin had inculcated this, and Beza, who succeeded him at Geneva, had taught its extreme form. Melancthon's followers adopted a milder opinion which the Lutherans mostly accepted. In Holland, therefore, where Lutheranism early prevailed largely, a foundation was laid for the less strenuous view. But this dissent from rigid Augustinianism first gathered coherency and force under the influence of Arminius.

James Arminius was born at Oudewater in 1560 and was among the earliest students in Leyden University. The Merchants' Guild of Amsterdam paid for his education. Afterwards he studied at Geneva and Padua, and was in Rome when summoned, in 1588, to Amsterdam and ordained. There for fifteen years he was pastor, preacher and educator. Constitutionally mild, candid and liberal, he did not favor enforced uniformity. Consequently many thought him dangerous. When the Curators of Leyden University had to fill Junius's chair of theology, in 1602 , they finally chose him. But that choice aroused opposition. Francis Gomar, another professor of theology, especially opposed it. But the Curators insisted upon their choice.

Some conflict naturally occurred in treating controverted points before the students. Discussions on such themes arose often. The North and South Holland Synods wrangled over them. In April, 1608, Arminius and Uitenbogart, a minister at the Hague, memorialized the States to call a National Synod, affirming that they were charged with preventing one, and declaring 
that they neither had, nor did meditate the introducing any novelty, or anything contrary to the Word of God, but designed to adhere to the doctrine of the Christian Reformed Churehes.

Their petition was refused. Persistent misrepresentations so increased, however, that Arminius once more addressed the StatesGeneral, recounting his annoyances. One thing led to another until, on Oct. 30, 1608, by direction of the States, he met their Assembly and stated his views upon Predestination, Free Will, the Grace of God, the Perseverance of the Saints, the Certainty of Salvation, Perfection, the Divinity of the Son, and Justification; advocated some revision of the Confession and Catechism; and declared the two questions decisive as to every matter of theology to be: (1) Is it true by God's Word? and (2) Is it necessary to salvation? He pledged himself never to urge any doctrine not clearly demonstrable by the divine Word, disavowed any intent to tyrannize over others, and offered to resign rather than be the occasion of division. On Dec. 12 Gomar obtained leave to attend the States, accused Arminius of Pelagianism, Jesuitism and other errors, and also appealed for a Great Synod.

These appearances before the States were after the Pilgrims reached Amsterdam, and must have interested them. There also was going on, nearer to them, a procedure which must have arrested their attention. At Alkmaer the Classis, a minority only being present, undertook to thwart the purpose of the State to revise the Confession and Catechism by proposing a new pledge, binding ministers to declare those two formularies entirely in accord with the Scriptures and the fundamentals of salvation and to oppose whatever was contrary to them. Four ministers refused to sign this. One of the four was suspended at once by the Classis and the others after some weeks. Thereupon they appealed to the States-General to order the whole subject adjudicated by a provincial or national Synod. The States ordered the Classis not to molest them. The Classis replied that it was its own business, and carried the matter before the North Holland Synod, which condemned the four ministers.

Adolphus Venator, then minister at Alkmaer, also became 
involved. He taught some young men Latin and Greek, and had encouraged them to act the "Andria" of Terenee. He also had written a little treatise, called "Democritus," and an "Epithalamium," regarded by his severer critics as undignified. Not long afterwards he also was aeeused of morthodoxy and summoned before the Consistory. Finally he was suspended from his ministry, and the ehureh - which offered no objection to the interposition of the State when it could be used for church purposes - appealed to the magistraey to exclucle him. But the Council refused. The Classis protested. His two colleagues absented themselves when he preached. His deacons would only collect the alms, at the intermission in the sermon, ${ }^{1}$ and would not remain. He was not allowed to baptize. But the Council supported him, and the States sent two deputies to Alkmaer, who deeided

that the informations taken against him, with the proofs thereunto belonging are not sufficient to convict him: for which reason it was ordered on pain of discretionary punishment, that none should presume to charge or defame him therewith.

The affair helped to stimulate excitement in the Reformed churches, which was to culminate at the National Synod of Dort. Bradford intimates ${ }^{2}$ that, during the year spent in Amsterdam, they saw that eontention was about to disturb the Aneient Chureh. Some vagueness beclouded the conception which this first Barrowist ehurch had of the eldership. Yet the tendency

1 Dr. Dexter's journal has an entry concerning the service at St. Peter's Cathedral, Leyden, on Sunday, Aug. 13, 1865, from which the following extract is taken: "There was singing, then prayer (extempore) not long. Then the ninister ... began his sermon (from Mark $x: 13-16$ ) with an explication of the text,... and then announced his subject . . A As soon as this announcement was made, a little bell struck and they sang again, repeating some verses twice.... At the same time five or six men came in from a side door, with little velvet bags [at the ends of long rods] and circulated through the congregation taking a collection. ... They kept at it for at least half an hour - of course after the preacher had resumed his sermon - going to the same persons again and again. Nobody appeared to decline to contribute, but everybody bowed, as if in thanks for the courtesy of the opportunity. When a bag was filled ... . it was emptied rattlingly into a sort of coal-scuttle, which at the end was carried ont through the door by which the men had entered." Two separate collections always are taken; one for the poor, and another for certain church expenses. When there is a third it is for missions or some other special object.

2 Hist. 16. 
was strong towards Barrowism on this point, instead of Brownism. Pastor Johnson and those of his church who agreed with lim, evidently the majority, were advancing towards a strict Presbyterianism tending to exalt the office, and to increase and intensify the power, of the elders. The various, long-enduring and perplexing difficulties of the church appear to have created, probably in Jolmson's mind, a distrust of the multitude. Elder Studley, also, who especially seems to have influenced Johnson, intensely disliked any admission of the brethren to church control, and once, when some fifteen members were said to have conferred together against him, broke out," saying : "Here was a beginning to tread the pathwaie unto popular government the verie bane to all good order in Church, and Common weale." Bradford says of Johnson : ${ }^{2}$ -

$\mathrm{He}$, by reason of many dissensions that fell out in the church, and the subtilty of one of the elders of the same, came after many years to alter his judgment about the government of the Church, and his practice thereupon, which caused a division amongst them.

The explanation of this is in the next treatise by Johnson. Although not printed until 1611, it may have been written some time before, and it expressly refers to circumstances evidently reaching back to the year of the Pilgrims' stay in Amsterdam. He says $:^{3}$ -

Only twoo things there are, which for some causes I think needful to be mentioned and observed.

The first is, that the Papistes by insisting vpon the letter of the Scripture, have misvnderstoode and perverted the meaning of those wordes of Christ, This is my body, \&c. And as the Anabaptistes pressing the letter, have erred in like maner about other wordes of Christ recorded by the same Evangelist, where it is saide, Teach all nations, and baptize them: Sweare not at all: Resist not evill, etc. So have many of vs done likewise about these wordes of Christ: Tell the Church, etc.

The other is, that the misvnderstanding hereof, and the practise

\footnotetext{
1 An Advertisement concerning a Book lately published by Christopher Laune and others against the English exiled Church at A msterdam, 1612, 122.

2 Dial. Young, Chrons. 445.

${ }^{3}$ A short Treatise Concerning the exposition of those words of Christ, TrLL THE Church, \&c. Матт. 18. 17. 1611, 4to, iii : 6, 3, 4, 5, 12, 18, 17, 25.
} 
ensuing therevpon, hath bene a great meanes and speciall occasion of straunge opinions, and aberrations, of lamentable contentions and divisions, of opposing and despising the Elders governement, of emulation and debate among people, with sundrie other evills arising and spreading them selves daylie, to the great dishonour of God, and our oune continuall griefe, and trouble, and much reproach from others abroad.

He copies from the "Apologie," which, with Ainsworth, he had published for the church in 1604 , the statement ${ }^{1}$ that " the power of excommunication is in the body of the Church," with the principal reasons for it there given, and argues that they there had mistaken the mind of God. He urges that the word "church" often means the Assembly of Elders; that Christ was speaking to Jews, and that they would so understand it; that in the church here referred to women may speak, which they camnot do in the true church; that to understand the church as the tribunal would involve excessive attention to trifles, and would not promote the good order of government; that in Israel by this word ("church" or "congregation") was understood the Assembly of Elders, and that the New Testament precepts should be construed by those of the Old; that the elders are the church's officers and their actions are its actions; that all the members cannot meet, excepting on the Lord's Day when to settle controversies would not be proper; and, finally, that there is no Scriptural precept or example for excommunication by a church withont officers. He also notes that in their "Apologie" they had invited brotherly correction, promising reform when convinced; and inquires " if thus we should hear others from abroad, should we not do it also at home among ourselves?"

While Johnson was drifting off thus into a polity wholly unlike that which always had controlled the church, and was leading after him all whom he could influence, Ainsworth, the teacher, steadily held the faith as declared by them in their two "Confessions" and their "Apologie," and expounded habitually by all parties in repeated treatises, and thirty or forty of the company supported him. Although conceding real and considerable power to the eldership, they held distinctly that the membership of a

162,63 . 
church has important rights in its government. Ainsworth, however, was far from Brownism. He could only say: " "We give not to the people goverment, as before I have shewed, but a right and power to observ and doo all the commandements of Christ, touching his prophetical, priestly, and kingly office, by the Elders teaching, guiding and governing of them in the Lord." In his debate with Smyth he explains his view of the eldership thus : ${ }^{2}$

The Elders are to teach and rule the Church by Christs own word and lawes, as I have expressed. ${ }^{3}$ And herein I presuppose that both ${ }^{4}$ the Elders wil teach and rule according unto godlynes, \& the people will obey the godly doctrines \& directions of their Elders, without mislike or discontentment.

At the same time lie held fully to their Twenty-third Article, that as every congregation has power to choose and ordain its minister, so it has to depose, or even excommunicate, him. He also held to the Twenty-fourth Article, which expressly lodges the power to receive and discard members in "the whole body together of every Christian congregation." He remembered, moreover, that in the Third Petition, addressed to King James, they had insisted on these positions earnestly.

That these two parties, assured that their opposite conclusions were vital, especially as opening an ecclesiastical path unknown since the Apostles' time - a path which every one ought to tread - could not live long harmoniously in one church is evident. Naturally, the Pilgrims, seeing the tempest approaching, hurried to seek peace elsewhere. The Pilgrim church under Robinson had taken a long step towards the democracy of the earlier Brownism and the later Congregationalism. It had not discarded the eldership, and Robinson more than once sets forth the supposed value of this office. But in his church the officers

1 Animad. 13\%, 24. Robinson and Brewster a few months later speak of "some 30 of the brethren there," as acting with Ainsworth in the controversy that followed.

2 Def. 127.

${ }^{8}$ In his Counterpoyson (176), the previous December.

4 He should have said "both that." He was not referring to unanimity in the action of the elders, if there were two, but to action (1) of them, and (2) of the people, in harmony. 
had much less power, and the ordinary members much more, than on either Johnson's theory or Ainsworth's. Perhaps they might have continued to live in peace with Ainsworth. But trouble with Johmson and his upholders was certain to come.

As has been said, it was not with the prospect of worldly advantage, but quite the contrary, that the Pilgrims turned towards Leyden. They foresaw that its limited commerce would tell against them. But they were willing to adventure much for peace, and eager to develop their ideas of church life and to manage their affairs in their own way. Brewster unquestionably had been in Leyden twenty-three years before, and of course knew its attractiveness well, while both he and Robinson must have been specially drawn thither by the university. Early in February, 1609, no doubt by a committee including Robinson and Brewster, formal application was made to the civil officials of Leyden for the requisite permission.

In one of the folios ${ }^{1}$ in the Hall of Records in that eity their request ${ }^{2}$ is entered, and, translated, is as follows:-

To the Honorable the Burgomasters, and Court, of the City of Leyden:

With due submission and respect Ian Robarthse, Minister of the Divine Word, and some of the members, of the Christian Reformed Religion, born in the Kingdom of Great Britain, to the number of one hundred persons or thereabouts, men and women, represent that they desire to come to live in this city by the first day of May next, and to have the freedom thereof in carrying on their trades, without being a burden in the least to any one.

They, therefore, address themselves to Your Honors, humbly praying that Your Honors will be pleased to grant them free consent to betake themselves, as aforesaid. This doing, etc.

This is undated and unsigned, but the place of its entry and the action of the Burgomasters, written on the margin, fix the time. That action follows:-

The Court, in making a disposition of this present Memorial, declare that they refuse no honest persons free ingress to come and have their

1 Gerechts Dag-boek. G. 33 verso.

2 First brought to the notice of American scholars in an article on John Robinson, by Prof. N. C. Kist, of Leyden University, in the Nederlansch Archief voor Kerkelijke Geschiedenis for 1848, 369-107. 
residence in this city, provided that such persons behave themselves, and submit to the laws and ordinances : and, therefore, the coming of the memorialists will be agreeable and welcome.

This done by the Burgomasters in their session at the Council House the 12 day of February, 1609.
(signed)
J. van Hout.
Secretarius.

Probably during March and April those who were about removing were busy in preparing for their migration.

In the interval an event occurred which must have been hailed as a pleasant omen. The civil relations between the Netherlands, France and Spain never had been settled solidly. Henry IV. had been opposing the Dutch secretly, while avowedly their friend. A marriage project between a Spanish prince and one of his daughters was included in his schemes. But the children were very young, and it occurred to him that a truce, long enough to let them grow up and to enable him to argue the Dutch out of their high notions of liberty, was desirable.

In August, 1608, negotiations began. But Prince Maurice opposed it stoutly, and so intense became the popular opposition that by the end of September every hope of avoiding fresh hostilities seemed gone. Yet Sir Ralph Winwood, the English ambassador, urged that a truce was better than war, and that the kings of both England and France would guarantee its observance. In October a united effort in the same direction was entered upon by the ambassadors of England, France, Denmark, and other's. Party spirit rose to its highest. Libellous pamphlets abounded. Olden-Barneveld, Advocate-general of Holland, who favored the truce, was so disgusted that he resigned. The Assembly besought him to return, and his policy gained force. Prince Maurice also accidentally drew from Henry IV. a letter saying : -

I know the general affairs of Christendom better than is possible for you; I can judge this matter more justly than you can; and I know that a truce established and guaranteed as is proposed, will bring you more happiness than you can derive from war.

The public mind now swung in the other direction. Negotiations were resumed, and by Apr. 9 a truce for twelve years was 
signed. It was a victory for the Dutch. They secured recognized independence for twelve years, with the right to trade to the Indies, and they did not concede the freedom of Roman Catholic worship. There was joy among them, and the English exiles must have rejoiced with them.

A more domestic matter occurred during these last days in Amsterdam, the marriage ${ }^{1}$ of William Jepson and Rosamond Horsfield, both from Worksop, Notts. He was twenty-six, and a house-carpenter, and she was twenty-three. In each case it was the first marriage. The wedding was on Apr. 28, and they were prominent among the company in Leyden until their deaths a quarter of a century later. That she did not sign their marriage request implies her imperfect early education.

Doubtless their change of abode was made by water. Most of their way must have lain through the Haarlemmer Meer (Sea of Harlem), a lake some fifteen miles by seven. And when they were not upon its open surface they must have been gliding through narrow water-lanes with green and blooming borders. At last, entering one of the channels of the Rhine, they followed it into the very heart of Leyden, and perhaps to the very houses awaiting them.

1 Puiboken, s. d. The only other similar record during this period perhaps relating to the Pilgrim company is that of Henry Cullandt (Collins) and Margaret Grimsdike on July 22, 1608 , both from Sutton, Notts. 



\section{BOOK VI}

\section{THE PILGRIMS IN LEYDEN}


They were frangers and pilgryms on the earth.

For they that faye fuch thinges, declare plainly that they seeke a countrey.

And if they had bene mindefull of that countrey, from whence they came out, they had leasure to haue returned.

But nowe they defire a better, that is an heauenly: Wherefore God is not afhamed of them to bee called their God: for hee hath prepared for them a citie. - HeB. xi: 13-16. Gen. vers.

Such is our accord in the case of religion, with the Dutch reformed churches, as that we are ready to subscribe to all and every article of faith in the same church, as they are laid down in the Harmony of Confessions of Faith, published in their name: and one only particle (and the same not of the greatest weight) in the sixth article, touching the Scriptures, being conveniently interpreted, and conformably to itself, and the general judgment of the learned amongst them. - RoBinson, Just. and Neces. Apol. Works, iii : 8.

Much excellent use may be made of this History: As . . . That God's Children are like Starres, that shine brightest in the darkest night: Like Torches that are the better for beating: Like Grapes, that come not to the proof, till they come to the presse: Like Spices, that smell sweetest, when pounded: Like young Trees, that root the faster for shaking: Like Vines, that are the better for bleeding: Like Gold, that looks the brighter for scouring: Likie Glow-worms, that shine best in the dark: Like Iuniper, that smels sweetest in the fire: Like the Pomander, which becomes more fragrant for chafing: Like the Palm-tree, which proves the better for pressing: Like the Cammomile, which the more you tread it, the more you spread it. Yea God knoweth that we are best, when we are worst, and live holiest, when we die fastest; and therefore he frames his dealing to our disposition, seeking rather to profit, than to please us. - S. Clarke, Gen. Martyrol. Epis. to Reader. 


\section{CHAPTER I}

\section{THE CITY AND ITS HISTORY}

HoLland is not a country of magnificent distances, and he who visits Leyden in summer will not weary of gazing upon the green polders before he arrives. Leaving the station, he finds himself in the Station's Weg (Station St.) leading out westerly to several pleasant villages and the sea. Following this to the right for several minutes between coffee-liouses with inviting gardens, attractive residences and a few shops, he reaches a densely shaded avenue which crosses the Station's Weg. This is the Singel (Girdle), formerly, when Leyden lad walls and bastions, the counterscarp, now levelled and a beautiful promenade almost entirely around the city. Crossing this, and the wide canal which everywhere borders it, the location of the former city wall is reached. The territory here is covered on the left by the pleasure grounds of the Amicitia Club and on the right by the Plantation, where the new Hospital stands. Here the highway becomes the Steen-straat (Stone St.), and a few steps bring one to the Beesten-Markt (Cattle Market), a triangular space extending to the Galge-water ${ }^{1}$ (Gallows water), at the end of the Oude Vest ${ }^{2}$ (Old Rampart) canal.

Turning to the left across the Blaauve-poorts-brug ${ }^{3}$ (Blue Gate Bridge) over the expanse where the Oude T'est joins the Rhine, he reaches the mouth of the Haarlemmer Straat (Harlem St.), the principal street of the newer city, running parallel with the Old Rhine, perhaps 250 feet away, to the $Z i j l$ Poort (Zyl Gate), one of the two eastern exits. Turning again, to the right, and crossing the Rhine over the Borstel-

1 In 1608 the street was called Klei-weg (Clay St.).

2 Filling the place on the north which the city wall occupied between the second enlargement of the eity and the third.

3 Of blue stone. 
bmig (Brush Bridge), a short advance and another turn, to the left, deliver him in the oldest and principal thoroughfare, the Breede strat (Broad St.), which, with its extension, the Hoogewoerds (High Dike), intersects the earlier town and leads out towards Utrecht. On it are the City Hall, the Gemeenlandshuis van Rijnland, ${ }^{1}$ the Walloon Church - in a part of what then was the St. Catharine's Hospital - the Post Office, the halls of the Amicitia, Minerva and Concordia Societies, the Museum of Antiques, the Ethnographical Cabinet, etc. Here also are the Golden Lion and other hotels.

The general shape of the city proper, as defined by the Singel, is something between an ellipse and a parallelogram, a little less than a mile in average length by a little more than three quarters of a mile in average breadth, lying east and west. Its outline suggests the contour of an oblong palm-leaf fan, the Rhine, as it runs out on the west, representing the handle. The sides of this elliptical parallelogram are diversified by fourteen arrow-head projections, the old bastions, now the sites of the Observatory, the University Hospital, various manufactories, several cemeteries, and the Plantzoen, or public park. These green-banked bastions, by their irregular outline varying that of the encompassing water-lane and of the Singel beyond it, greatly enhance the picturesqueness of the town. Almost exactly in its centre is its only hillock, the $B u r^{\prime} g$, or citadel, an artificial circular mound in the point of land where the Old and New Rhines unite. It dates back to the shadowy period of history, is perhaps 150 feet in diameter at the summit, and rises high enough to look down upon the honses which separate it from the river. It is crowned by an old brick fort.

The Rhine enters Leyden on the east in two streams about three eighths of a mile apart, having divided near Leyderdorp, and leaves it on the west in one. But the Rhine water surrounds much of the city in the broad channels, the New Rhine and the Steenschur (Stone Storehouse Canal), which border the Singel, and passes through it in several streams; while small canals gridiron it and render almost every house convenient to water transit.

1 Occupied by the States of North Holland. 
The Leyden of 300 years ago is strikingly discernible to-day. Until a comparatively recent date the town declined, hardly feeling the impulse of commerce and manufactures. Down to almost the close of the thirteenth century the original city occupied only the space between the New Rhine, on the north and east, and the Steenschur and the Rapenburg (Gleaners' Fort Canal), on the south and west. ${ }^{1}$ The Burg was without the walls, across the river in a wood beyond where St. Pancras Church now stands. One conspicnous building then was an Orphan Asylum on the north side of the Breede-straat. St. Peter's, the City Hall, the Prison, s' Gravenstein (the residence of the Counts of Holland), the Gemeenlandshuis van Rijnland, and St. Catharine's Hospital were where they remain.

The first enlargement, in 1294, was due to the growth of the cloth trade. Many Flemings removed to Leyden on that account. It brought within the walls the space between the Old and New Rhines, as far east as the present Heerengracht (fashionable quarter), nearly doubling the enclosed territory. The second enlargement in, or about, 1355, on the north side, bordered the entire town from the Rapenburg, on the west, to the Heerengracht, on the east, and carried the north line up to the Oude Vest. It added more than fifty per cent to the inwalled territory, and made place for the Vrouwe Kerk (Church of the Virgin), now torn down, the St. Elizabeth's Hospital, the Insane Asylum, the Lepers' House and various convents or almshouses.

The third enlargement was on the south and west, in 1389. It extended in a rude semicircle, following the existing line and carrying the lower northwest corner out to the present Wittepoort (White Gate); whence it swept around southerly and easterly to the New Rhine by the Hoogewoerds-poort. It was larger than either former addition and included the sites of the Doelens (Garrison-house), the Convent of the White Nuns, now the principal university building, with the Celle-Broeders Klooster (Monks' Cloister) and the French College. ${ }^{2}$

1 A ground plan of this earliest form of the city is in Van Leewen's Forte Besgryving van het Lugdunum Batavorum nu Leyden (1672, 18mo), opp. 26 ; also a very fine one is in J. J. Orlers's Beschrijving der Stad Leyden.

2 On the Groene-hasegracht (Green Hares' Canal). 
The fourth enlargement was in progress while the Pilgrims were there, and began in 1610. It was on the north and northwest, extending the town as much as the third had towards the west and south. It added the large bastion where the University Hospital is now, with three or four more along the northern outline, but also stopped at the Heerengracht. A final enlargement took place in 1644, extending the whole eastern side and carrying the Zijl-poort and the Hoogewoerds-poort a long way east to their present positions. It added six bastions, which remain. ${ }^{1}$ As the result of its gradual and regular development and solidity of construction, and of the slight need, until recently, of tearing down or rebuilding, it is easy both to recover some idea of the city of 1609 and to find many genuine bits of it.

The history of the Low Countries has been outlined during their change from Romanist provinces of Spain to Reformed and independent states. Reference also was made to the composite character of the Dutch nation. We must consider now a little the chief features of the Dutch civil life.

To an extent unknown elsewhere, the Dutch constitution was founded upon and adjusted to a basis of independent local sovereignties, or municipal governments. Disregarding the Northmen, Dutch history begins in the eleventh century, with Dirk III., the first Count of Holland, who established himself on the Rhine and the Maas, and whose family ruled the country for almost 400 years, gradually becoming practically independent. Before the fourteenth century there were in Holland no estates and no general political life. The Count was the nation. Still, he recognized the people, whose money he needed. Over the open country he set his bailiffs, and over the towns his sheriffs. When grave matters arose the town bell summoned all to the public square and the vote of the citizens was given - a vague civic democracy. His demands for revenue modestly were styled his prayers for supplies. They were issued mostly to the towns, which gradually received liberties from him in return for taxes paid and troops furnished.

Thus, under William II. and Floris V. (1248-96) Dort,

1 Meursius has a map containing these enlargements well marked, excepting the last, which was made after the book was written. 
Delft, Iaarlem, Mirlleberg, Leyden and others became municipalities. Each was ruled first by the Count's judges, aided by a committee of one from each quarter of the town. The former administered justice, the latter ordered civic affairs, by degrees taking precedence. When Duke Charles died, these towns insisted upon concessions from his heiress, the Duchess Mary, which were granted reluctantly in the Great Privilege of March, 1477. During the last quarter of the sixteenth century the Provinces, imperfectly united in the States-General, gained steadily. Their sailors scoured all seas, their manufactures absorbed skill and industry from the decadent Spanish Netherlands, and the supremacy of their town governments made itself secure.

Each town was governed by a tribunal of two, three or four burgomasters - in Leyden four - and several judges - in Leyden eight. Its duties were to keep the fortifications in repair, to call out the militia, when needed, to levy taxes, and to administer the finances. The burgomasters had charge of the police, of the peace, of the munitions of war and of cleansing and victualling the town. The judges were a court laving " the low jurisdiction" in civil, and minor criminal, cases; and in some places, Leyden being one, they were empowered by special grant to try capital crimes. The Count had a representative in each municipality, the schout ${ }^{1}$ (sheriff), who watched over the Count's interests, brought suspects to trial, and made sure that the judgments of the burgomaster's' court took effect. There also was in every town a select body of citizens, the Town Council, originally created to consider vital matters. But in many places it became a mere nominating caucus.

Town government and privilege extended over a certain space outside of the walls. Territory not so included, generally called " open country," was under some noble or abbot, or governed by bailiffs representing the Count. Originally the chief nobles formed the Council of State, but towns, as they grew in importance, became, by deputies, members of the Council, each town having one vote. The whole body of nobles also had but one vote. The States-General met to consicler specific matters

1 C. M. Davies, Hist. Holland and Dutch Nation, i: 77. 
only. If a new subject arose, the deputies went home to consult; and no measure prevailed without the vote of the nobles and of every town.

The Dntch allowed nothing to cause neglect of education. In this the Reformed Church differed radically from the Romish. The latter resolutely opposed popular improvement." As late as 1567 the Reformed at Leyden were forced to promise that "neither they nor their Preachers wonld erect or open any Schools." But twenty years later, the Netherlands having gained some management of their own affairs, the Synod bade the Consistories, or assemblies of the ministers and elders of the Reformed Churches, to provide schools, with good masters, to train children of all classes in reading, writing, rhetoric and the liberal arts, as well as in the catechisin and the doctrines of religion; being especially careful to maintain enough theological students at the public expense. ${ }^{2}$ The public school ${ }^{3}$ became "the common property of the people, paid for among the municipal expenses:"

During the Spanish war Leyden was besieged. Under Don Francis Valdez a blockade was begun on Oct. 31,1573. Learning that the eity was somewhat short of food, the Spaniards surrounded it to starve it out. This investment had continned for nearly five months, when, on Mar. 21, 1574, the city, inconvenienced but not yet much straitened, saw the enemy march away to resist the invasion of Count Louis of Nassau.

But the Leydeners, assuming that Count Louis would win and that the Spaniards were gone finally, neglected the commonest dictates of prudence, enforced by the counsel of the Prince of Orange, and took no special measures to victual the town or to increase its military strength. They realized their folly on May 26, when - Louis's troops having been cut to pieces and he

1 In 1544 the people of Wesel took measures to open a school. But an edict from Brussels forbade the country to have any dealings with that place, on pain of the extreme penalty of the law. Moreover, in 1582 the king of Spain published a placard forbidding any person to study the sciences in the newly established miversity at Leyden, on pain of being "rendered incapable of any employment." Brandt, i : 81, 289, 387 .

2 Decree, Synod 1586, Arts. xvii-xix. Davies, ii : 202.

s Motley, Un. Neths. iv: 567. Brandt, ii : 10. 
himself killed at Mookerheyde - they saw Valdez reappear with 8000 Germans and Walloons, who soon threw their lines around the town, building sixty-two redoubts. ${ }^{1}$ There were in the eity but five eompanies of the burgher gnard, with a small corps of "freebooters," and the stock of food was far less than it should have been. But the people remembered that every additional arm holding a weapon would have involved a mouth needing to be filled daily, and appointed John van der Does — Janus Dousa in literature - their commander.

William of Orange, without sparing wholesome reproach, strove to eneourage them by pointing out that, could they defeat the Spanish purpose, they probably would improve materially the fate of their country and of unborn generations. The eonflict had become one of Protestantism and Christian liberty against the Papacy, the Inquisition and the bloodiest intolerance. Heaven surely would take their part and reward their patriotism. If they could hold out for three months, he felt sure of relieving them, and they pledged themselves to do what men could.

Valdez soon offered an amnesty. Excepting a few, specified by name, the entire body of the Netherlanders was invited to receive full forgiveness, upon condition of abjuring Protestantism. The invitation mistook the Duteh temper. Only two persons - so runs the extraordinary record - in the whole land aceepted it; a Utrecht brewer and a son of a refugee peddler from Leyden. With these contemptible exceptions, the whole nation scornfully rejected the offer.

Some besiegers knew persons inside the town and wrote to them, begging them to have pity upon "their poor old fathers, their daughters and their wives" by yielding to the inevitable. It throws light upon the remarkable manners of those days that from within the town absolutely no answer to all these missives went back, excepting this line, from the moral Apothegms attributed to Dionysins Cato:-

Fistula dulce canit, volucrem cum decipit anceps. ${ }^{2}$

1 The site of one Spanish camp still is to be seen. It is a triangular island in the Vliet near a bridge about a mile out of town along the continuation of the Heeren-straat.

2 "Sweetly plays the fowler on his pipe while he spreads his net for the bird." Meursins, 52. Hofdijk, Leyden's Wee, 81. 
It is needless to describe this doleful siege at length. By July the city had purchased all the food; and half a pound of meat, with the same weight of bread, was given daily to each fullgrown main, and to others in proportion. Valdez again made magnificent offers, but in vain, although many were dying and all were living upon the smallest allowance that would keep breath in the body. The Prince of Orange, failing to muster sufficient troops to defeat the besiegers, determined to cut the embankments excluding the sea and drown out the invaders. This meant utter ruin to the villages which dotted the polders. Yet that could be recovered from. "Better a drowned land than a lost land" 1 was the patriotic ery. The great sluices at Rotterdam, Delfshaven and Schiedam were opened and the dykes along the Maas and the Yssel were cut, and the ocean slowly invaded the land. Provisions were loaded upon 200 food vessels for the famishing town. But the waters deepened so slowly that it seemed doomed to perish before help could arrive. Dogs, cats and vermin became luxuries. As the natural result, the plague broke out and at least one fifth of those whom famine had spared soon died. The people bore all this with wonderful fortitude. But one day, in a fever-turn of irritation, inevitable at such a time, brave Burgomaster van der Werff was reproached and threatened by a few famishing wretches. He offered them his own body for food but swore that he never would surrender, and so inspired ${ }^{2}$ them with fresh courage that they went up on the ramparts and shouted defiance to the Spaniards. ${ }^{3}$

The ocean was first let in on Aug. 3. But the water around Leyden was not a foot deep on Sept. 1. By Sept. 11 a strong dyke five miles from Leyden was pierced and the relieving fleet sailed through. But the slow rise of the waters again stranded the fleet. Just then, however, on Oct. 1, a fierce gale came from the northwest, soon shifting to blow even more violently from the sonthwest. This raised the depth of the water to two feet, so that the vessels could proceed. The forts of Zouterwoude

1 Hofdijk, 125.

2 Motley, Rise, ii : 570, 557, 571. A beautiful park in Leyden is named after him and contains a statue of him with memorial bas-reliefs upon its pedestal.

${ }^{3}$ Fruytiers, 25. 
and Lammen, still in the way, were abandoned, and with the glorious dawn of Sunday, Oct. 3, 129 dreadful days after its second siege had begun, Leyden was delivered. ${ }^{1}$

Admiral Boisot entered the city by the Vliet. ${ }^{2}$ The poor famishing survivors dragged themselves to the canal borders and bread and meat were handed them. To a few the sudden revulsion was fatal. Some choked themselves in the hurry of satisfying their aching hunger. Some died of over-eating. But as soon as the first ravening of appetite had been mitigated, the magistrates led a devout procession to St. Peter's. Beautifully does Motley picture the scene $:^{3}$ -

The Admiral, stepping ashore, was welcomed by the magistracy, and a solemn procession was immediately formed. Magistrates and citizens, wild Zealanders, emaciated burgher guards, sailors, soldiers, women, children - nearly every living person within the walls, all repaired without delay to the great Church, stout Admiral Boisot leading the way. The starving and heroic city, which had been so firm in its resistance to an earthly king, now bent itself in humble gratitude before the King of kings. After prayers, the whole vast congregation joined in the thanksgiving hymn. ${ }^{4}$ Thousands of voices raised the song, but few were able to carry it to its conclusion, for the universal emotion, deepened by the music, became too full for utterance. The hymn was abruptly suspended, while the multitude wept like children. This scene of honest pathos terminated, the necessary measures for distributing the food and for relieving the sick were taken by the magistracy.

By order of William of Orange the neighboring towns were called upon at once for contributions to set Leyden on its feet again, and Delft alone gave the value of 2000 gilders within two days. Moreover, by a kind Providence, on the day after Leyden was relieved the wind drove back the waters to their accustomed channels, making it easy to repair the damages.

The moral effect of this life and death grip upon civil liberty and the Reformed religion by which Leyden had held Spain at bay so magnificently, and of the vast sacrifices of the States which had saved her, was very great. The whole Netherlands

1 Bor, Nederlantsche Oorlogen, vii : fol. 62.

2 A river which enters the town on the south side.

3 Rise, ii : 576.

4 Psalm ix. Hofdijk, 230. 
was nerved to a new obstinacy of resistance. And Spain learned that, after all her enomous expenditures of money and men for so many years, she had made no progress in subduing the Dutch. Their spirit was indomitable, while, so far from being destroyed, the Reformed faith was indestructible. Beyond question, Leyden's fiery trial had done a great service to all the States.

This William the Silent and the States themselves were quick to recognize. An annual fair, beginning on Oct. 1 - Oct. 3 to be a solemn festival - was established. And on Feb. 6, 1575 , a charter was granted founding a miversity in Leyden in recognition of the patriotism of its citizens. It illustrates afresh the anomalous condition of things that in this very act of celebrating successful rebellion against Philip, the Hollanders still maintained the fiction of his sovereignty; this charter declaring the grant of power to emanate from him. ${ }^{1}$

The recent overthrow of the Roman Catholic Church had released much property to the State. The new miversity was well endowed from this at the outset, and for its abode was given the empty cloisters of St. Barbara, on the corner of the Rapenburg and the Valdersgracht (Fullers' St.), the present Langebrugge (Long Bridge), the same premises afterwards appropriated to be the Prinsenhof (public guest-house for royal visitors). Measures were taken immediately to secure eminent instructors. Van der Does, who had commanded ably during the siege, and whose genius and learning also commended him specially, was appointed its first Curator. He had studied at Lier, Delft, Louvain, Douay and Paris, and had wide acquaintance with scholars.

Early in 1575 a grand festival of institution and inauguration was held. Even its minuter details are described in contemporary documents. It was on Feb. 8.2 It began at seven A. M., with a religious service in St. Peter's. At nine a grand procession was formed in the Breede-straat in front of the City Hall, including the four battalions of civic troops, two as its

1 Van Mieris, iv : 514.

2 Motley (Rise, ii : 580) gives the date as Feb. 5. Young (Hist. Neths. 175) makes the same error. But the contemporary and early authorities are explicit; e. g., "die octavo Februarij" (Meursius, 18). So Orlers, i : 195 ; Van Mieris, ii : 545 ; Fabricius, 24. 
van and two as its rear guard. Religion, Law and Medicine were represented in the picturesquely typical fashion of the time. Minerva was there, in full armor, with Aristotle, Plato, Cicero and Virgil; while a host of local and other dignitaries followed in brilliant robes of office. The whole city was decorated, and all manner of exultation exhibited itself in ways which taxed heavily the Latin of the chronicler.

The procession moved eastward along the Breede-straat and its continuation the Nobel-straat (Noble St.), under a triumphal arch upon the Hoogewoerds bridge, and then swept to the right, following the curve of the Steenschur around to the Nonnen-brug (Nuns' Bridge), which it crossed, under a second arch, passing then along the Rapenburg to a final arch crowning the bridge over the Valdersgracht and to the St. Barbara cloister, its destination. The inaugural address was delivered by Caspar Coolhaes. Educated at Düsseldorf, he had been ealled to the great church in Leyden just before the siege, and now, at thirty-eight, became for a time the acting professor of Theology in the university. This service concluded, the procession resumed its march, traversing the Breede-straat again, and making a circuit through the north part of the city, finally disbanding at the junction of the Oude Vest and the Rhine.

The wise policy was pursued of winning fame for the new university by making it worthy of fame. This was done by securing, so far as possible, teachers already renowned. The first Curator, van der Does, was a great attraction, and Ludovicus Cappellus, who had been professor of Civil Law at Bordeaux and later pastor of the great churches at Paris and Meaux, early undertook a professorship of Theology. Justus Lipsius was the first professor of History, editing Seneca and Tacitus, and sending out from the Plantin press at Antwerp various works whose elegant scholarship excited universal admiration. John Drusins filled its chair of Oriental languages for nine years, having gone thither from Oxford with a reputation which attracted students from all Protestant countries. Moreover, for his last sixteen years, the famous Joseph Justus Scaliger was its professor of Belles-Lettres; the man of whom Mark Pattison said that, when he died, "the most richly stored intellect which 
had ever spent itself in acquiring knowledge was in the presence of the Omniscient."

The young institution did not remain long in the St. Barbara premises. For some reason it was moved east, apparently in September, along the Rapenburg to the chapel of the Falyde Beguynen (Veiled Nuus Convent), where the Library now is. Here it remained until 1581, when it was transferred across the canal to the deserted premises of the Witte Nonnen (White Nuns), opposite the end of the Kloksteeg (Bell Lane), where its principal building is to-day. Very likely the larger possibilities of securing land for the Botanical Garden -- which, under the renowned Peter Paauw soon became famous - influenced this final selection.

The religious perturbations of the land, already alluded to, were increased in Leyden by differences between the Reformed ministers. Peter Cornelison wanted elders and deacons named by the Consistory independently of the magistrates. Coolhaes thought that, upon nomination by the Consistory, the civil authorities should approve. The magistrates naturally sided with Coolhaes. Out of this difference ${ }^{1}$ grew a wider one, in a way precluding the Arminian difficulties. Coolhaes avowed unusually liberal views of infant baptism, the Lord's Supper, and election, and paroxysms of indignation, now difficult to be understood, were exhibited.

Of course Leyden also watched interestedly that great series of events, between the Pacification of Ghent, in 1576, and the Act of Abjuration, of 1581, by which Holland and Zealand formally threw off the Spanish yoke, acknowledging the divine right of kings, yet insisting that Philip had forfeited all rights by his tyranny. But almost the only special event in her own history was one in 1587 , connected with the disgraceful record of Leicester's later months in the Netherlands as Queen Elizabetli's representative.

Most of the Brabanters and Flemings attracted to Leyden were rigid Calvinists. But the tremendous pressure of the siege had so pulverized religious distinctions that a Papist who had fought and starved for the common liberty was regarded almost

1 Brandt, i : 367. 
as one of themselves by his Protestant comrades, and a Protestant as a Papist by his compatriot Romanists. The records show that one or two magistrates were Romanists, while not only was a public school kept by a Romanist, but even old Burgomaster Van der Werff sent his son to it. Yet in time religious differences grew bitter and affected civil affairs. Leyden had taken open issue with the Synod held at Dort in 1581, and had supported Coolhaes, in defiance of its excommunication. Multitudes withdrew from the Leyden churches. The Lord's Supper was discontinued for more than eighteen months, and, when resumed, in 1582, scarcely 100 persons at first attended. ${ }^{1}$ The place seemed a favorable hotbed for the seeding of sedition, and, when that illustrious Calvinist, Leicester, began plotting to gain possession of some important cities to reëstablish his waning power, his friends in Leyden made a serious effort to effect a revolution in his favor. Jacques Volmar, a deacon of the Reformed Church; Adolph van Meetkerke, formerly President of Flanders, whom Leicester had made a member of the Council of State, but whom the States had removed; Cosmo de Pescarengis, a Genoese captain ; Dr. Hadrian Saravia, a professor of Divinity and preacher in the French church, and others entered into the scheme.

Captain Nicolas de Maulde, who commanded the Leyden forces and had been disgusted by the way in which the Sluys garrison had been sacrificed a little while before, also joined the plot. Early on Sunday morning, Oct. 11, 1587, he was to march his troops to the City Hall, where he was to meet a body of armed citizens. Together they were to seize the City Hall in the name of the Earl and publish a placard announcing their object. But the Genoese captain was imprisoned for debt ${ }^{2}$ just then, and one conspirator, alarmed thereby, revealed all that he knew to the authorities. Although De Meetkerke, Saravia and others, made their escape, Volmar and De Maulde were arrested. They claimed that they had acted under Leicester's orders. But of course they could produce no written proof, and, in any case, he left them to their fate. Volmar, De Pescaren-

1 Brandt, i : 382.

2 Brandt says (i : 420) : "Being suspected of some other crime." 
gis and De Maulde were beheaded on Oct. 26. In the case of De Maulde, who is said to have been young and handsome, an ancient custom was violated, the entreaty of a noble lady, who claimed his life by demanding him as her husband on the scaffold, being denied. The magistrates were inexorable, and it even was whispered ${ }^{1}$ that of the two fates De Maulde preferred the axe. The severity shown in this execution illustrates the revulsion of the popular feeling in regard to Leicester.

In 1600 Leyden replied to questions of the nobles about the Lutherans that they "were the best Patriots of the State, and . . ought to enjoy the fruits of what was formerly conceded to them." In 1605 the Classis of Dort requested the Synod of Rotterdam to discuss the disputes abont the doctrines of the Reformed Churches. This was supposed to be aimed at Arminius, and it prompted the Curators of the university to inquire of the Divinity professors whether such disputes occurred. To which the three professors, Gomar, Arminius and Trelcatius, ${ }^{2}$ replied that possibly they did occur among the students, but there were no differences between themselves.

Reference has been made already to the contentions between Gomar and Arminius. But they did not reach their height until after the Pilgrims had settled in Leyden. The air of Holland, however, was surcharged with excitement, centring about these two men, and there was a skirmish of pamphlets.

1 Bor. xxiii : 97.

${ }^{2}$ Lucas Trelcatius, Jr., successor of his deceased father. 


\section{CHAPTER II}

\section{LEYDEN UNIVERSITY AND ITS GREAT MEN}

So far as the theological or the political atmosphere was concerned, the Pilgrims probably saw little difference between Amsterdam and Leyden. Although much less famous commercially than Amsterdam, Leyden was a busy city of about 50,0001 people, unlike Amsterdam in the predominance of manufactures, particularly of woollen cloths, and especially in its decided element of student life. Serge, baize, bombazine, fustian and something like modern " rose blankets" were the staples. The Oude $V$ est canal became a favorite resort of the cloth-makers, and on fine days one could see on its borders great numbers of people scouring their cloths and then drying them upon frames attached to the houses; a sight, indeed, not unknown now in connection with laundry work.

Forgetting that the idea of weaving by machinery was not evolved until the eighteenth century, ${ }^{2}$ and that not until the nineteenth was there a power-loom, some have imagined Leyden at this time as having huge mills. But weaving then was done in private houses, a hand-loom and a spinning-wheel being household articles nearly as indispensable as a brass kettle. Different headquarters also were provided for different sorts of cloth, Baaihalle, Fusteyn-halle, Laken-halle, Saai-halle (baize, fustian, cloth, and serge-halls) and the like, to which the fabric was taken to be inspected and stamped by the proper officials.

The first task of the Pilgrims was to find homes, and their chief nembers no doubt counselled together in order to secure for Robinson quarters spacious enough to enable them all, with

1 The Enc. Brit. sass (xiv : 495) that the population was much more than 50,000 in 1623 , and was estimated at 100,000 in 1640 .

2 In 1745 Jacques de Vancanson nearly completed the great invention, but missed it. Enc. Brit. x xiv : 465 ; xiii : 539. 
some crowding, to meet there for worship. Possibly a few found shelter in property owned by the city. That confiscation of Romanist convents, etc., to which reference has been made, sometimes carried with it the title to many small tenements. For example, the ground plan ${ }^{1}$ of the premises of the Falyde Beguynhof shows that there were some fifty small houses, grouped about the central court and the chapel. Probably the State, or eity, sold such dwellings now and then, but obviously a few years before Robinson's company arrived it still held control of a number of them. If some Pilgrims, and perhaps Robinson himself, found shelter there, it would suggest one reason why, two years later, they pitched upon the almost adjoining property as their headquarters.

Their distribution among the industries of the place is suggested by the various volumes of public records covering the period between 1609 and July, 1620, which will be described later. Of course it is not possible to associate all the English then in Leyden with Robinson's company, but probably the major portion of them had some connection with it; a connection rendered almost certain for many, as to whom other evidence is lacking, by the presence with them on various occasions, as witnesses, sponsors or sureties, of those known to have been Pilgrims. Although no hint occurs as to how some well known members of the company, e. g., Thomas Blossom and John Carver, employed themselves, the records mention the occupations of 131 persons, whose names or other details concerning whom imply their English connections, and eighty-six of whom are known to have belonged in some sense to the Pilgrim company. Concerning the others, who cannot be proved to have been members of it, if at all, until after the departure, in July, 1620, of those who came to America, there also is considerable information.

Among these 131 persons fifty-seven occupations were represented - taking them as recorded, although several are almost identical — as follows: baize weaver, two; baker, one; block maker, one ; bombazine weaver, three ; brewer's man, two ; bunting maker, one; cabinet maker, one; camlet merchant, two; candle maker, one; card maker, one; carpenter, one; cloth

1 Platte-grond van 1578. In Leiden voor 300 Jaren. Nos. 8, 33. 
draper, one; cloth filler, one ; cloth maker, one ; cloth merchant, three; cloth weaver, one; cloth worker, one; clothier, two ; cobbler, two ; cooper, one ; draper, one; engraver, one ; fustian weaver, four ; glove maker, three ; grocer, one ; hat maker, four ; jeweller, one ; leather dresser, one ; leather worker, one; linen weaver, three; lock maker, one ; looking-glass maker, two ; mason, two; merchant, five ; minister, one ; polisher, one ; printer, four ; pump maker, one; real estate dealer, one ; ribbon weaver, three; say ${ }^{1}$ weaver, twenty-two; shoemaker, two; shop keeper, one; silversmith, one; smith, one ; stocking seller, one ; student, three; tailor, five; tallow chandler, one; tobacco worker, one; tobacco merchant, three; tobacco-pipe maker, three; twine maker, one; watch maker, two; wood sawyer, one; wool carder, five; wool comber, eight. ${ }^{2}$

That they engaged in such humble employments as some of these was dne to the three facts that many of them had been men of lowly station in England; that most of them, having been farmers, now had to turn to such trades as conld be learned easily; and that, in most cases, having been compelled to sacrifice much of whatever property they had in order to escape from England at all, they were poor and were obliged to accept at once whatever work could be found. The records show, however, that, althongh two or three of those who remained in Leyden after 1620 seem to have failed to prosper, being entered in the census of Oct. 15, 1622, as "too poor to be taxed," most of the

${ }^{1}$ Say, or saai, probably was a coarse, thick woollen fabric, like that of a blanket.

2 Arranged in the order of numbers they are as follows :-

Baker, block maker, bunting maker, cabinet maker, candle maker, card naker, carpenter, cloth draper, cloth filler, cloth maker, cloth weaver, cloth worker, cooper, draper, engraver, grocer, jeweller, leather dresser, leather worker, lock maker, minister, polisher, pump maker, real estate dealer, shop keeper, silversmith, smith, stocking seller, tallow chandler, tobacco worker, twine maker and wood sawyer, one each.

Baize weaver, brewer's man, camlet merehant, clothier, cobbler, looking-glass maker, mason, shoemaker and watch maker, two each.

Bombazine weaver, eloth merchant, glove maker, linen weaver, ribbon weaver, student, tobaceo merchant and tobacco-pipe maker, three each.

Fustian weaver, hat maker and printer, four each.

Merchant, tailor and wool carder, five each.

Wool comber, eight.

Say weaver, twenty-two. 
company, although in many eases, as Bradford declares, ${ }^{1}$ only after a severe struggle, raised themselves above actual want. Some engaged in several different occupations successively, and ordinarily with improved fortunes.

As for their dwellings, if the same period - from May, 1609 to July, 1620 - be examined, mention is found in seventy-four cases, including two successive residences in eleven instances and three in two instances. But in three or four cases ownership rather than occupancy may be implied. Forty-six ${ }^{2}$ are those of Pilgrims, but only eight ${ }^{3}$ of these became Mayflower passengers. Nine ${ }^{4}$ others are recorded before 1620 of persons who may have belonged to the company, and the census of Oct.15, 1622, names the residences of fourteen more who are known to have been, and of five ${ }^{5}$ who may have been, Pilgrims before the departure; most of whom probably had lived before 1620 where 1622 found and recorded them. Clearly they gravitated towards St. Peter's and its neighborhood, a most desirable locality. Three fourths

1 Hist. 17, 19, 22-23.

2 In the Achtergracht, W. Bradford, 1617. Barbarasteeg, T. Rogers, 1620. Bogertsteeg, J. Spooner, 1616. Boisstraat, R. Cushman, 1616. Coepoortsgracht, J. Keble, 1614. Duarsheerensteeg, H. Collet, 1612; J. Keble, 1614. Groenensteeg, IV. White, 1615. Groenhasegracht, W. Jepson, 1614; W. Minter, 1614; W. Robertson, 1614; R. Simmons, 1619. Hontmarckt, R. Cushman, 1616. Hoogewoerd, R. Peck, 1609. Jacobsgracht, T. Willet, 1615. Korte Heerensteeg, H. Collet, 1614. Marendorp, R. Peck, 1610; Eliz. Pettinger, 1610; W. Pontus, 1610. Marepoort, S. Fuller, 1617. Middleberg, J. Carver, 1609. Nieuwestadt, E. Chandler, $1619 ; \mathrm{S}$. Lee, 1619. Nieuwesteeg, S. Butterfield, 1617; R. Thickins, 1615. Nonnensteeg, R. Cushman, 1616. Pieterskerkgracht (Kloksteeg), I. Allerton, 1620; J. Allerton, 1616 ; T. Blossom, 1617; T. Brewer, 1615; J. Brewster, 1619; Hary Butler, 1611 ; S. Fuller, 1615 ; E. Jessop, 1618; R. Peck, 1619; J. Robiuson, 1612 ; W. White (another), 1618. Stinksteeg, W. Brewster, 1609. St. Ursulasteeg, W. Brewster, 1609. Styensteeg, E. Jessop, 1615. Uiterstegracht, R. Masterson, 1614 ; W. White, 1616; R. Wilson, 1614. Veldestraat, J. Jeuney, 1618. Vliet, Z. Barrow, 1616. Near Vrowekerk, Mary Butler (another), 1616.

3 I. Allerton, J. Allerton, Bradford, Brewster, Carver, Fuller, Rogers and White (the first-named).

4 The nine are: Achtergracht, J. Leighton, 1613. East Rapenburg, T. Edwards, 1616. Mirakelsteeg, S. Singleton, 1617. Nonnensteeg, P. Edwards, 1610 ; H. Richard, 1614. Noordende, D. Crickett, 1616. Pieterskerkgracht, J. Ainsworth, 1618 ; J. Bailey, 1616. Sonnerveltsteeg, J. Robertson, 1613.

5 The fourteen are: J. Spooner, in the Ketelboersteeg, and Z. Barrow, R. Chandler, J. Crips, J. Dunlıam, D. Fairfield, E. Horsfield, J. Hurst, W. Jepson, W. Pontus, A. Price, S. Tracy, R. Wilkins and T. Willet in the Zevenhuysen. The five are: P. Cushman, in the Oostnieuvelant, and Josephine Brown, $\Lambda$. Garretson, Susanna Halton and J. Smith in the Zevenhuysen. 
of them lived not more than a quarter of a mile from the house on the Kloksteeg, under the very shadow of St. Peter's and only a stone's throw from the university, which became their headquarters and where Robinson lived until he died. Leyden then was a specially agreeable place of residence. Bradford called it "a fair \& bewtifull citie, and of a sweete situation." And a French ehronicler, who wrote from intimate knowledge, said, "The City of Leyden is, without contradiction, one of the grandest, clcanest, and most agreeable cities of the world."

Some of its more conspicuous features still characterize it. They found two great Reformed churehes, in which they may not have worshipped much, but under which they buried their dead. Near the centre of the original city was the huge, but severely plain, cathedral, the Pieterskerk. This was partly surrounded by a dozen quaint little houses, nestling up against it, erected in 1593, for the use of subordinate officials, and occupied when the Pilgrims were there. A few memorial tablets within the building then were in place, among them those of Rembert Dodonaeus and John Heurnius, famous university professors.

Northwest from the Pieterskerk, on the other side of the Rhine, was, and still is, St. Pancras, near the Burg and therefore often called the Hooglandsche Kerk (Church of the Highlands). Probably the only monument of any distinguished person then buried there is that, dating back to 1604 , of burgomaster Van der Werff. In addition to these two great Reformed churches there was, also across the Rhine and on the present Haarlemmer-straat, the Lieve Vrowe, or Marie, Kerk, now destroyed, dedicated in 1365 to the Virgin, and after the Reformation the gathering place of the French and Walloons. Probably few monuments adorned its interior in 1609, although it contained the fresh graves of two university professors; the great Scaliger, since transferred to the Pieterslierk, and Carl Clusius.

Next to the cathedral the most important building was, and is, the Stadt-huis, or Raad-huis (City Hall, or Senate House), on the Breede-straat; a long, picturesque structure adorned

\section{Les Delices de Leide, 1.}


with grotesque pinnacles, and an elaborate tower containing a sweet chime of bells. The date of its construction is unknown. But it was rebuilt in 1481, and again, in part, in 1577 and 1597. There are two side doors at the street level and an imposing main entrance between them by steps up to the next floor. Above one of the side entrances is a wall tablet with the legend : ${ }^{1}$

Bewaert Seeer Şolland :

En zalidyt Reyden;

followed by this enigmatical inscription $:^{2}-$

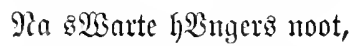

Gebracht hadbe te boot

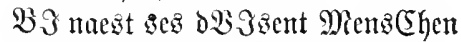

2Urzt (5oot dent Seer Serbroot

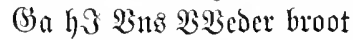

Coo

Moreover, a mosaic arrangement of the pavement in the street called attention to the arms of the city, the date of the siege, 1574, and the motto: Niet jondor (300. ${ }^{3}$

Two pictures still hang within which must have been there in the Pilgrims' time, and on which, no doubt, they looked somewhat askance. One, by Cornelis Engelbrechtszen, represents in the middle panel the Crucifixion and on the two sides the Sacrifice of Abraham and the Brazen Serpent. Formerly it was the altar-piece of the Klooster-Marienpoel (Convent by the Mary's Pool). The other is a Last Judgment by Lucas van Leyden. This picture, ${ }^{4}$ also a triptych, in pre-Reformation days adorned the high altar of St. Peter's.

1 "God keep Holland: And bless Leyden."

2 This contains 129 letters, corresponding to the number of days of the siege, and the sum of its capitals when added is said to equal 1574, the year of the siege (Van Mieris, ii : 364). A rongh translation is as follows:-

\footnotetext{
"When the black famine

Had brought to death

Nearly six thousand people,

Then the Lord God repented

And gave us bread

As much as we could wish."
}

3 "Not without God."

4 Other pictures of later dates on the walls touchingly suggest striking incidents of the siege. 
Among other buildings of note there were, clustering around the eathedral, on the north the Lokhorst, or mansion of the Counts of Holland, and the Gevangenhuis, or prison; and on the south the Comanderie, the ancient residence of the Order of Hospitaller's, or of St. John of Jerusalem, and, a few steps towards the Rapenburg, the buildings of the Falyde Beguynhof, and a little farther west the old chapel of the White Nuns, where the main instruction of the university was given. Then there were the Gemeenlandshuis, or hall of the deputies of the United States of Holland, a little west of the City Hall on the opposite side of the Breede-straut; the Priusenhof, the same convent of St. Barbara where the university had had its begimning, then used for the entertainment of distinguished visitors; and the Doelen, or headquarters of the municipal guard, where the Naval Training School now is.

There also were the Leproos-huis (Lepers' Hospital), in the extreme northwest corner of the second enlargement of the town; the Pest en Dol-huis (Plague and Insane Hospital), just northwest of the Vrowenkerk; and the Wees-huis (Orphans' Home) near St. Pancras. Scattered about the town, also, were other structures formerly convents, nunneries, or hospitals. Moreover, just behind the Lokhorst was the Groote School, a free school. The building had been refitted finely at the close of the sixteenth century, and the inscription ${ }^{1}$ over its entrance :-

\author{
Pietati, Linguis, et Artibus \\ Liberalis, S. S. P. Q. Lug. \\ dunensis Restau. C. \\ Anno. CID.ID.C
}

must have given them a wholesome reminder of the close relation of a free school to a free state.

The university had found its permanent quarters in the Convent of the White Nuns. Its premises were a heterogeneous group of buildings, but they fairly met the growing needs of the young institution. Some of its first professors have been mentioned. Among the others, Petrus Tiara, skilled in the

1 Van Mieris, ii : 442. "To Piety, the Langnages and Liberal Arts, the Senate and People of Leyden have rebuilt this Structure. In the year 1600." 
Greek, was its earliest Rector Magnificus. John van der Does — Janus Dousa - its earliest Curator, was "a living library, and a walking museum."

Eleven distinguished divines had taught theology there and had died or removed. Lucas Trelcatius, Sr., and François du Jon - Francis Junius - perished by the plague about 1602, each, especially Junius, with an honorable fame.

Some early instructors withdrew, sometimes because they could not well refuse invitations from rulers to whom they owed allegiance. Ludovicus Cappellus was called away by the Count Palatine in the next year. Caspar Coolhaes was summoned back to the ministry at St. Peter's as soon as his successor could be secured. William Fengeraeus was recalled to France in 1579. Lambert Danaeus, a Genevan graduate, was transferred to Ghent in 1582 after a year at Leyden. Hadrian Saravia, a rare theologian and linguist, foolishly became involved in the plot in favor of the Earl of Leicester in 1587. Charles Gallus, from Arnheim, who had studied theology with both Calvin and Beza, accepted a chair of theology at Leyden in 1587, but retired in 1591 .

The other professorships had suffered fewer changes. In law three noted men had completed their service. Hugo Donellus, who had taught at Geneva, Heidelberg and elsewhere, began legal instruction at Leyden and labored successfully for eight years. Julius Beyma came to Leyden from Wittenberg and taught for fifteen years; and Cornelius Neustadius, one of her own doctors of law, taught and also served as Curator for over thirty years. In medicine, too, three famous men had done their work. Peter Forestius, founded the medical department, but withdrew soon. Gerard Bontius, associated with Forestius, always read Galen and Hippocrates in their originals, and in practice had no superior. John Heurnius, of Utrecht, coming to Leyden at thirty-seven, served also as Rector Magnificus for almost the entire twenty years until his death in 1601 .

Nor should the venerable Hebraist, Francis Raphelengius, with his quarto Arabic Lexicon, be forgotten; nor his even more Orientally learned colleague, John Drusius, who had taught Hebrew, Chaldaic and Syriac at both Cambridge and Oxford when he was twenty-two, and was professor of the Oriental tongues at 
Leyden from 1577 to 1585 . Justus Lipsius was first to teach history, becoming a professor in 1579. It is said that he offered to repeat the whole of Tacitus with a dagger at his breast, to be thrust home should he misquote or even hesitate. Apparently he was secretly a Romanist and surely died in that chureh. Paul Merula, of Dort, was his successor, and after fifteen years of service, received, when he died in 1607, the epitaph: "Ave et Salve, Vir paucis comparande." Logic had the service of Peter Molonacus, educated at Sedan and Paris, for six years from 1592 until he was called to Paris by Catharine, the sister of Henry IV. And Carl Chusius had ended a long life of levotion to natural science by teaching botany at Leyden for sixteen years. He left his impress distinctly upon the still famous Botanical Garden.

To turn from the dead or withdrawn to the living and resident, Robinson must have found one who had been there from the beginning, Cornelius de Groot, or Grotius, an uncle of the great Hugo. He taught philosophy first, but afterwards civil law. He had been Rector Magnificus six times, and was the oldest in service, although not in age, of the fifteen who can be identified as carrying on the university work at that time. $\mathrm{He}$ had two colleagues, Everard Bronckhorst and Gerard Tuningius, the former of whom had been twenty-two and the latter nineteen years in service. Bronckhorst had been a professor at Erfurt and Wittenberg, and in 1587 went to Leyden for the remainder of his life. Tuningius was much younger, a native of Leyden and a graduate of the university, who began to serve his alma mater at twenty-four, and it was said that when he opened his mouth the university itself seemed to speak. He then was fortythree and he died the next year. The two shining lights in theology were Francis Gomar and Jacob Arminius, already mentioned. The former was forty-six, and had served fifteen years. The latter was two years older, although nine years the junior in office.

There were three instructors in medicine, Peter Paauw, Aelius Everardus Vorstius and Otto Heurnius, who were respectively forty-five, forty-four and thirty-two, and had been twenty, eleven and eight years in service. Paauw had studied at Leyden and 
Paris and had been a professor at Rostock, afterwards studying anatomy in Italy. He had eome to Leyden in 1589 and had done a great work there in the Anatomical Museum and the Botanical Garden, as well as by his direet instruetions. Vorstius, having studied at Leyden, Heidelberg and Cologne, in 1598 settled for the balance of his life - he died in 1624 - at Leyden. Otto Heurnius was the oldest son of John. Educated at Leyden, he beeame teacher of philosophy in 1599, and, when his father died in 1601, took his place.

In the languages, also, there were three professors, Bonaventura Vuleanius in Greek, William Coddaeus in Hebrew and Daniel Heinsius in the Oriental tongues. Latin was used rather than expounded. Vulcanius was born in 1538. His education at Louvain, Basle and Geneva was continued by translating the Greek fathers into Latin in the serviee of Cardinal Mendoza in Spain and his brother Ferdinand, Archdeacon of Toledo. In 1581 he was called to Leyden, where he taught for thirty-three years, becoming emeritus in 1610. He was the oldest of the faculty, being seventy-one. Coddaeus was born in Leyden in the year when the university was founded. His diligence in Greek and Hebrew led the authorities, after the death of Raphelengius in 1601, to advance him to the latter's place. Heinsius was one of the most famous scholars of that age. He studied at Franeker and Leyden, where he became a favorite with the great Scaliger, van der Does, St. Aldegonde and Merula. At eighteen he began to teach languages, afterwards politics and history, and, still later, the Oriental tongues.

The third oldest in the faculty was Rudolf Snellius, then sixty-three, who had taught there thirty years. Educated at Heidelberg, Cologne and Marburg, he began teaching the humanities at Leyden in 1578 and later Hebrew and mathematics. Dominicus Bendius was professor of history and Roman law. He had taken his LL. D. at Leyden in 1585, in which year he was sent to England as one of the deputation to Queen Elizabeth, and formed a special friendship with Sir Philip Sidney. He was appointed professor of eloquence at Leyden in 1603. Gilbert Jaccheus was born in Aberdeen and edncated at St. Andrews and in Germany. He taught philosophy. At this time 
Reinerus, a son of the famous Gerard Bontius, also was teaching natural philosophy here. Clearly, this Leyden faculty included many remarkable men from the beginning. The famous Graevius, himself one of the greatest classical scholars of the seventeenth century, declared that more eminent men, holding the front rank for intellect and erudition, had flourished in that university than in all others in Europe. Sir William Hamilton also affirmed ${ }^{1}$ that " Leyden has been surpassed by many other Universities, in the emoluments and in the number of her chairs, but has been equalled by none in the average eminence of her professors ;" and Mullinger, the learned historian of Cambridge, has called" it "the most famous Protestant seat of learning in the seventeenth century."

The number of undergraduates soon became large, and, although the Dutch no doubt always were in the majority, students came from England, France, Germany, Hungary, Poland and even Russia. They found quarters as best they could, and the town was crowded with them. Doubtless the ordinary laws of supply and demand soon made the cost of shelter and food a serious matter, which probably had something to do with an important development which soon followed. In $1591^{3}$ the authorities of West Friesland warned the States that comparatively few young men were becoming divinity students. As this warning was echoed from other quarters, it was determined to found a college of theology with accommodations for thirty-one students. It was recognized that, without some general training in other studies, it is difficult to become a good theologian, and therefore the college was given an intimate relation to the university. Its opening ceremonies, on Oct. 6, 1592, were less grand than those in 1575 , yet were impressive.

Sermons were preached in the three great churches. Pieter Hack discoursed in St. Peter's, Henry Gallus in St. Pancras, and Daniel de Nielles, in French, in the Vrowekerk. John Cuchlinus was the head of the new college. He had preached for eighteen years at Amsterdam. His ability was so evident that all turned to him to found the new enterprise at Leyden,

1 Disserts. and Discussions, 375, 364.

2 ii : 212, n.

3 Orlers, i : 218-249. 
and he reluctantly consented and bore his part on this occasion. After these sermons, a procession was formed in front of the City Hall in which walked the chief dignitaries of Church and State, as well as the university professors. The march ended in the large hall of the university. Jan van Hout, Secretary of Leyden from 1564 to 1609, read a paper, and Cuchlinus delivered a Latin oration. All was concluded by a feast.

The place assigned to the college was the old convent of the Celle-broeders (Cell-brothers), on the west side of the Cellebroeders-gracht. New buildings appear to have been erected in a quadrangle enclosing a square, and some university buildings now occupy the site.

Cuchlinus, however, as soon as the college had begun to run smoothly slipped back to Amsterdam. He was succeeded by Jeremias Bastingius. After study at Geneva and Heidelberg and a ministry in Antwerp, he had been driven out by the Spanish troubles. He filled the place of Cuchlinus well for about five years, dying in 1598. He left a theological treatise ${ }^{1}$ which was translated into English at Cambridge. Then the anthorities recalled Cuchlinus, and he served most acceptably until, in 1606, during a discourse on the Divine Obedience, he was seized with paralysis of the tongue "et in coelestem patriam migravit." He was succeeded by his son-in-law, Peter Bertius, educated partly in England, who taught philosophy, and had been three years at work.

This experiment worked so well that the Walloon churches, stimulated by a legacy of 48,000 florins ${ }^{2}$ and aided by the States, dedicated a smaller institution for French students on May 30, 1606.3 The service, which included the inauguration of Daniel Colonius, who had been minister of a French and Dutch church in Rotterdam, resembled the other in general. The inaugural oration was by John Polyander, then pastor of the French Church at Dort and afterwards a theological professor' at Leyden. Colonius served until 1635, during the

1 An Exposition or Commentarie vpon the Catechisme of Christian Religion Which is taught in the Schooles and Churches, both of the Lowe Countries \& of the dominions of the Countie Palatine, 1593, $16 \mathrm{mo}$.

2 From N. Halletus. Meursius, 39.

3 Orlers, i : 238. 
whole of Robinson's residence. The quarters of this French College were east of the Doclen on the Groene-hase-gracht (Green Hares' St.). In addition to the twenty or thirty highly educated men in these chairs and the pastors of the various churches, there were others, among whom was Peter Scriverius, a poet and historical scholar. He was well known in Holland as late as 1652 , and was a co-resident with Robinson.

These English people also must have met, even if unconsciously, several persons who won fame in a field in which the Pilgrims had little knowledge and perhaps less interest. Three or four artists, whose names the world does not forget, must have come often within their vision. Esaias van der Velde seems to have been working in Leyden. Adrien van der Venne was studying at the university, preparatory to a life of art, and his strong religious sympathy with the Puritans suggests the possibility of intercourse with them. Somewhere about the streets they also may have seen a lad of thirteen, to gain fame as Jan van Goyen, as well as the young Jan Lievensz, afterwards well known in London; and also the child Rembrandt van Rijn, who was to become the prince of Dutch art and one of the greatest painters in history. 


\section{CHAPTER III}

\section{THE PILGRIMS' FIRST YEAR IN LEYDEN - 1609}

No journals or other personal records by any of the Pilgrims have come to light to tell us of their life in Leyden. Bradford's History assigns to this portion of the narrative only forty-two pages, ${ }^{1}$ of which all but four are devoted to "the reasons \& causes of their removall;" while Winslow allots it not even three." Such a man as Robinson probably kept a diary, and Brewster, Bradford and Winslow may have done so. There is little likelihood, however, that any such treasure-trove is to enrich us.

Lacking such help, the historian must make the best of the meagre hints to be had. Until the middle of the last century Leyden was practically unknown by American scholars, and the occasioual references to it concerning the Pilgrins often were misleading: ${ }^{3}$ But in 1842 Mr. George Sumner made careful inquiry on the ground, and his observations were published in 1846 as "Memoirs of the Pilgrims at Leyden." 4 His principal objects were to correct depreciations of the Pilgrims and to amend some too favorable statements ; to show that Prince had been misinformed as to their having. had a church allowed them for worship, and as to the circumstances of Robinson's burial; and to state that the record of his interment had been found, and also that he had been admitted to the university.

Ten years later Mr. W. F. Bartlett published "The Pilgrim

$117-59$.

2 Hyp. Unmask, SS-90.

${ }^{3}$ Prince says (Annals, i: 160) "the City had such a value for them [regarded the Pilgrims so highly], as to let them have one of their Churches, in the Chancel whereof He [Robinson] lies Buried." Mrs. Adans (Letters of Wife of John Adams, ed. 1540, 34S) also says: "I visited the church at Leyden, in which our fore-fathers worshipped." Both were misled by tradition. See also Marshall's Life of Washington (i : 9:3), Bozman's Maryland (376), and, for a reply to such suggeștions, Holmes's Annals (i : 572).

4 3 Mass Hist. Coll. ix : $42-74$. 
Fathers," going over the ground which they had trodden and devoting twenty-six pages to Leyden. But he added little, if anything, of original research. The next contribution of value was in 1859, when Hon. Henry C. Murphy - who had represented the United States at The Hague, had made personal investigation at Leyden and had employed officials of that city to aid him - published his results in three numbers ${ }^{1}$ of the "Historical Magazine," of New York. His discoveries included fourteen marriages, three admissions to citizenship, the deed ${ }^{2}$ of the house purchased by Robinson and his associates, a bit of a fucsimile of a map of 1670 showing the spot, the letter in which the Pilgrims asked leave to remove to Leyden, and some less important matters. Apparently he supposed that he had exhausted the sonrces. ${ }^{3}$ The investigations for this work were begun in 1863 and have been continued until the present time. ${ }^{4}$ They have involved eleven visits to Leyden, have included prolonged and repeated personal examination of the records, and have resulted in considerable additions to the facts.

It remains to rednce what has been accumulated thus to chronological order, and to determine what light is thrown upon the life of the men and the nature of the enterprise. From this point, although it will be important to follow contemporary public affairs, our study must be devoted chiefly to the revelations of these records. But first, a few words about the records themselves.

There are in Leyden more than a score of different sets of books, officially kept to meet the regular demands of public affairs and ruming back to the beginning of the seventeenth

1 Sept., Nov, and Dec., 1859, 261-263, 330-335, 357-359.

2 The publication of the deed, in Nov., 1859, had been anticipated by the remarks of Geo. Sumner at the laying of the corner-stone of the moniment in Plymouth on Aug. 2, 1859, reported in the Boston papers of Aug. 3.

3 He said on Apr. 6, 1863, in a private letter to Dr. Dexter: "I spent sereral days in a personal examination of the books with his [Baron J. C. Rammelman Elzevir, Archivist of Leyden's] assistance, and endeavored to obtain all that is there extant."

4 1905. Dr. Dexter's visits, varying in length from a few days to a month, were in $1865,1871,1872,1876,1884$ and 1857 . They have been supplemented by my own - in 1S91, 1901, 1902, 1904 and 1905-affording me seven months of careful study of the various records (including some which Dr. Dexter did not find accessible) and resulting in some further discoveries of facts. 
century, in which the Pilgrims left traces. That the happenings thus recorded often are comparatively insignificant does not prevent them, in the absence of other testimony, from having considerable historical value. The books are these:-

1. The Kerkelijke Houwelijksche Proclamatie Boeken, records of betrothals ${ }^{1}$ of persons belonging to the State Church.

2. The Echt Boeken, or betrothal records of persons not belonging to the State Church, which therefore include most such entries relating to the Pilgrims. Each record usually includes most of the following particulars: (a) the date; (b) the name of the intending groom; (c) his residence; (d) his occupation; (e) the fact whether, or not, it is his first marriage; (f) the name of at least one accompanying witness; $(g)$ the name of the bride; (h) her residence; (i) whether, or not, it is her first marriage; (k) the name of at least one witness for her; (l) the dates of the three publications of the banns; $(m)$ the subsequent date of the marriage itself; and $(n)$ the names of the officiating magistrates.

3. The Trouw Boeken, additional, and often parallel, betrothal records.

4. The Pui Boeken, still another set of marriage records.

5. The Registers van de Overledene Personen begraven binnen der Stadt Leyden, or burial records; which profess to include the interment of every person buried in Leyden since their first date. Often, but not always, they state the residence of the deceased.

6. The Blaffaarden van den Hoofd Kerken, containing receipts of burial-fees in St. Peter's.

7. The Records of the Owners of Graves in St. Peter's.

8. The Kaartenboeken van Straaten, etc., including streetplans, with the dimensions of lots and names of owners and occupier's.

9. The Tweede Register vervaltende Zevenhuyzen and the Tweede Register Zuid Rapenburg, containing records of ownership and transfers of estates in those neighborhoods, with many details.

1 Betrothals had more prominence than marriages, the latter merely being regarded as consummating the former. 
10. The Bon of Wijk Registers, or ward registers, with names of families, etc.

11. The Registers der Burgers in het Hoofdgelt betalende, or lists of citizens paying a poll-tax, etc.

12. The Census, taken October 15, 1622.

13. The Poorter Boeken, or records of eitizenship, giving the names of all persons who took the oath of eitizenship and became invested with its privileges. These usually specify: (a) the name of the person; (b) his occupation; (c) his residence; (d) the names of his two guarantors; (e) the fact of the payment of his fee; (f) the names of the schepenen, or sheriffs, who superintended the transaction; and (g) the date.

14. The Procuratie and the Groot Procuratie Boeken, or records of powers of attorney.

15. The Getuignis Boeken, or records of affidavits.

16. The Inbreng Boeken, or records of agreements to sell property.

17. The Kustingboeken met Overstelling, the Protocol van Warbrieven, the Protocol van Schult en Rente Brieven, and the Protocol van Opdrachts, different series including records of sales of houses, lands, etc., deeds of transfer, etc.

18. The Hypothek Boeken, or mortgage records.

19. The Gerechts Dag Boeken, or court day records, in which are such matters as the request for leave to reside in Leyden.

20. The Burgmeester's Dag Boek, which preserves details of the burgomaster's official doings.

21. The Register van Binnen Wachters, or roll of the nightwatch, or city guard; and

22. The various university records, including its Register of Matriculations and its Criminal en Civil Ding Boeken, noting the relation of the university tribunal to criminal and civil affairs.

The value as testimony of these records often is impaired, however, and not infrequently is destroyed, by the fact that in Leyden all English names seem to have been written by the Dutch officials according to sound, and never from memoranda 
supplied. 1 Thus an entry easily became uncertain. Apparently few errors were made as to the transactions, but many and grave blunders clearly were made in the names ${ }^{2}$ of the individuals involved. The recording official, unfamiliar with English, naturally spelled their names from his Dutch point of view. Instead of wonder that so many uncertainties obscure the subject, there is reason for gratitude that so much of substantial value can be recovered.

It seems probable that the migration from Amsterdam was completed early in May, 1609, perhaps in its first week, and that they were sufficiently settled by the second Sunday of that month, May 10, to hold services. On that day it is likely that they crowded, almost without exception, into Robinson's house, wherever it may have been, and united in worship. Robinson had been their pastor for some time, but before long, and perhaps then, they first completed their organization by calling Brewster to his aid, as elder. Says Bradford: ${ }^{3}$

Being thus setled (after many difficulties) they continued many years in a comfortable condition, injoying much sweete \& delightefull societie \& spirituall comforte togeather in $\mathrm{y}^{\mathrm{e}}$ wayes of God, under $\mathrm{y}^{\mathrm{e}}$ able ministrie, and prudent governmente of Mr. Iohn Robinson, \& Mr. William Brewster, who was an assistante unto him in $y^{\mathrm{e}}$ place of an Elder, unto which he was now called \& chosen by the church.

At about this time Bradford, now a little more than nineteen, must have learned, very likely as his first tidings in Leyden from England, of the death of his uncle, Robert Bradford, of Austerfield. ${ }^{4}$ Probably it took place while the company was in the act of removing. As William's father, who had inherited the eldest son's share of his own father's property, presumably

1 There seems to be no book at Leyden containing autograph signatures of persons able to write, like one at Amsterdam.

${ }^{2}$ In the cases of names as to which other means of identification exist it is possible to point out these departures from accuracy. For example : -

Bradford = Bredfort, Breefort, Kadfort ; Butterfield = Botherfylt, Butterfelt ; Cushman $=$ Coetsman, Fousman, Fouztman ; Fuller $=$ Foller, Veller, Volijer ; Goodman $=$ Coedmoer $;$ Robinson $=$ Robartse, Robbenson, Robbensoon, Robberts, Robbert son, Robens, Robinsz, Robints ; Southworth $=$ Houthward, Sadtwoot, Sodert, Sodt waert, Soldwaert, Southward, Soutwaert, Sudtwert, Sutuaert ; Thickins = Dekins, Thickens, Tickins, Tykyns.

${ }^{3}$ II ist. 17.

4 See p. 389. 
had handed it down to his heirs, and as William's mother's father, John Hanson, also had been one of the more prosperous residents of the place, beyond doubt there was property of some value, very likely under this deceased uncle's oversight, awaiting the young man's acquisition of the right at lis majority to dispose of it. This, indeed, is matter of direct testimony, but the time for the exercise of that right had not yet come.

Turning now to the public records for 1609, the first three items relating to the Pilgrims had place in the second month of their residence, and concerned Brewster. On June 12 a power of attorney is recorded, ${ }^{1}$ in Dutch and Latin, by which Ann Peck, born at Launde (Lownd), Notts., and her guardian, William Brewster, give to Thomas Simkinson, a merchant at Hull, power to receive seven pounds sterling, which she had deposited with Mr. Watkin, pastor at Clarborough, ${ }^{2}$ when she left England. Again on Saturday, June 20, there is recorded the burial ${ }^{3}$ in St. Pancras of " a child of William Brewster, dwelling in the Stinksteeg" " (Stench Lane).

Again, on Thursday, June 25, we find an affidavit ${ }^{5}$ which furnishes the only known authority for certain dates. The following is a translation:-

There appeared before the undersigned sheriffs William Brewster, Englishman, aged about forty-two years; Mary Brewster, his wife, aged about forty years; and Jonathan Brewster, his son, aged about sixteen years, confirming successively upon oath, being judicially summoned by the bailiff, at the requisition of Bernard Rosse, Englishman, living at Amsterdam ; that is it true and to them known that the plaintiff [Rosse] has lately carried to their house. situated in the lane called St. Ursula's, a bale in which were several pieces of English cloth, etc.

Doubtless the parties to this affidavit were Elder Brewster, his wife and their oldest son; and, as the handwriting is distinct in

1 Groot Proc. Bk. D. 16, and (Latin) 230, vers. After the first of each kind, these references, excepting in special cases, will be omitted. But all are in my possession.

2 About seven miles southeast of Scrooby.

${ }^{3}$ Reg. Over. Pers. iii : 8, vers. Not necessarily an infant. Any minor unmarried child was so described.

4 A short lane near the Hoogewoerds Bridge. Orlers, i : 78.

5 Getuig. Bk. K. fol. xxvi, vers. 
both the Dutch and French ${ }^{1}$ records, the figures may be accepted as fixing their ages within a year. This entry also shows that, since the preceding Saturday, Brewster had removed from the unpleasant Stink-steeg to the more agreeable St. Ursula's lane, in the extreme northwest corner of the city. The circumstance suggests the migratory tendency inevitable at the first settling down of 100 or more people in a strange and already crowded town, and that at first some, if not all, had to make the best of whatever quarters they could find. The remainder of the affidavit ${ }^{2}$ is unimportant, merely indicating that Brewster already was engaged in some industry ${ }^{3}$ allied to that whel then characterized the town.

It is possible, and indeed probable, that on July $10 \mathrm{John}$ Carver buried a child in St. Pancras, ${ }^{4}$ but the indistinctness of the record throws doubt upon the last name. The fact of such an interment should be noted, however. Apparently the first betrothal at Leyden among them took place on Oct. $1,1609 .{ }^{5}$ Most of the record follows :-

Robert Peck. fusteynwerker, yongman uit Engeland, wonende alRobert Peck, fustian weaver, haer op de Hoogewoerd in de blaauwe Leenverik, vergezelschupt met Jan Jennee en Jacobus Herst ayn bekenden; met, never before married, from England, dwelling here upon the Hoogewoerd in the Blue Lark, accompanied by John Jennings ${ }^{6}$ and Jacob Hurst, his acquaintances, [and] with

1 Another volume, Reg. des Temoins, etc., K. fol. 26, gives a French translation of this affidavit.

2 The sheriffs, or aldermen, before whom the affidavit was taken, were A. Jaspar van Vesanevelt and A. P. van de Werff. There were five pieces of English cloth in the bale. When opened one piece was found damaged. Apparently the damaged part had to be ent off and sold as a remnant, and the object was to adjust the matter fairly.

3 Bradford implies (Hist. 412) that at first Brewster had a somewhat hard time: "Affter he came into Holland he suffered much hardship, after he had spent $\mathrm{y}^{\mathrm{e}}$ most of his means, haveing a great charge, and many children; and, in regard of his former breeding $\&$ course of life, not so fitt for many imployments as others were, espetially such as were toylesume $\&$ laborious. But yet he ever bore his condition with much cherfullues and contentation."

1 Reg. Over. Pers. 3: 10.

5 Echt $B k$. A. 152 , vers.

${ }^{6}$ It has been accepted that Jennings, and not Jenny, was the witness here, in spite of the spelling of the name, probably becanse Jennings is more likely to have been in Leyden in 1609 . But it is not certain that Jenny was not the witness. 
Ieanne Marit, jongedochter, Jane Marit [Merritt] never beuit Engeland, vergezelschapt fore married, from England, acmet Dorotea Ament, haar be- companied by Dorothy Ament kende. [Hammond], her acquaintance.

They were married on Nov. 21. Robert Peck was a brother of Ann, the ward of William Brewster, and John Jennings, who also at this time was a fustian weaver, was from near Colchester, and was a faithful member of the company for the next thirty years.

As many descendants of the Pilgrims may be interested to learn the exact terms in which their ancestors were married by the Leyden magistrates, an official form, set down in the beginning of one of the volumes of marriage records, ${ }^{1}$ is translated here, as follows : -

This day have appeared before $\mathbf{N}$. and $\mathrm{N}$., magistrates of the city of Leyden, A. of the one part, and B. of the other part; the said parties and each of them, freely and without constraint or persuasion of any, acknowledging and declaring that by hand and mouth they have entered into engagements of espousal and marriage; and to this end the said A. has by these presents given, and gives, his faith and fealty to the said B. and acknowledges, holds and takes her for his wife and lawful spouse. In like manner the said B. also, in virtue of these promises has given, and gives, her faith and fealty to the said A. whom she takes, holds and recognizes as her spouse, lord and lawful husband. Each of them promises respectively and reciprocally, that, neither by regret, love, design, nor for any other cause or occasion, will either ever abandon the other, but on the contrary, that they will live peaceably, amicably, and with concord together as true children of God (in His fear) following His ordinance for such and so long time as this present union be not dissolved and made void by death. In testimony of which they have invoked and called upon God Almighty, praying that it will please Him to bless, with His Holy Spirit accompanying and crowning, their marriage with His grace and favour.

Done before the said magistrates at Leyden, etc.

I Echt Boek van de geene die op het Raethuys haare geboden verzoeken, $\mathrm{B}$. fol. 1. This record states that this form of marriage began to be employed in 1611. But Brandt implies (ii : 11) that it was substantially in use ten years earlier. At any rate it must have been used during almost the entire residence of the Pilgrims at Leyden. 
The next record touches the university life. But it is a mere entry that on Oct. 27, 1609, George Rogers, an Englishman, was matriculated in medicine. ${ }^{1}$ He was twenty-five and lived with Thomas Blossom. To oe under Blossom's roof meant that he had opportunity of meeting the Pilgrims, and possibly he was one of them.

Before this first year ended one more of the company appeared upon the records, Roger Wilson, then twenty-five. He is known from the Leyden archives only, but is referred to nearly thirty times during ten years. He was born at Sandwich, Kent, in 1584, and was baptized in St. Clement's Church. ${ }^{2}$ When and how he became interested in Separatism is unknown. He is found with Robinson's church in Leyden, soon after their arrival, as one of their working force, and appears to have been the first to receive the privileges of citizenship. One difficulty which the Pilgrims encountered was that, while the lowest kinds of hard work were free to them, if they could find employers, skilled labor had to submit to conditions. An extract from a private letter ${ }^{3}$ from Mr. Motley, written in 1871, at The Hague while he was studying Dutch history, is pertinent. $\mathrm{He}$ says :-

I cannot doubt that the motive for members of Robinson's conpany to become citizens, was for business purposes. Leyden from the earliest times was famous for its cloth manufacture. . . A And there, and in Dordrecht and many other towns, it was provided as far back as the twelfth century, that no man should deal in cloth that was not a member of the guild.

To be a member of a guild the right of citizenship was an essential requisite. . . The same rule would apply to the many other trades and manufactures then flourishing in the Netherland Republic; as dyers, silversmiths, printers, booksellers, linen-weavers, cabinet-makers, etc., for all which guilds the Letters Patent may be found among the various charters [Handvesten] of the cities.

To become a citizen one had to be twenty-five. At least two guarantors, themselves citizens, were required, and the payment

1 Reg. Matric. s. d.

2 Certified by Rev. A. M. Chichester, vicar of St. Mary's and St. Clement's, in April, 1875.

${ }^{3}$ In Dr. Dexter's collection. Dated 24 Aug., 1871. 
of three florins and twenty stivers. The "poorter's" oath also had to be taken before two magistrates. The record of Wilson's admission, a sample of the many others, is as follows:-

Rogier Wilson, bakker, van Roger Wilson, baker, from Sundwitz in Engelant, is.op de Sandwich in England, is upon getuygenisse en borchtochte van the testimony and surety of MatMathys Iuns ende Pieter Boey, thias Jones and Peter Boey, adals poorter aangenomen.

tendage voore.

$8 \mathrm{Fl} . \Omega 0 \mathrm{~s}$.

7 Dec. 1609 . mitted as a citizen.

On the same date as the next previous entry.

3 Florins, 20 stivers.

7 Dec. 1609.

The oath taken, translated, was this: ${ }^{1}$ -

This you swear: that you will be loyal and faithful to the country of Holland, and to your fellow-citizens in this city; that you will be obedient to the Sovereign Estates of Holland, and the Burgomasters of this municipality; that with all your power and might, to your best knowledge, you will help to maintain and strengthen the rights and privileges of the country, and of this city ; and that in case there shall come to your knowledge any attempt or deliberation of deed or word tending to the prejudice of these nnited countries called the countries or towns of the land, and more especially of this said town [Leyden], you will immediately make it known to the Burgomasters of this city. And, further, that you will do, and refrain from doing, all that it becomes a good and loyal dweller in this town to do, and to refrain from doing.

So help you God; and His Holy Word!

[To which was responded] Thus truly I swear: God being my Helper.

So much for the suggestions of the archives as to the fortunes of individuals of the company during 1609. Few and brief although they are, they afford some welcome light. For succeeding year's, although never abundant, they are more numerous and diversified. Meanwhile, their personal concerns cannot have engrosser the Pilgrims to the suppression of their watcliful interest in public affairs, especially theological.

Among early occurrences of this sort must have been a public disputation ${ }^{2}$ on July 25, 1609, on the calling of men to salvation. The ferment as to certain points of doctrine which were

\footnotetext{
1 Poorter Bk. F. 45, and fol. 1.
}

${ }^{2}$ Brandt, ii : 55, etc. 
debated hotly between the rigid Genevans and those of milder views has been mentioned, as well as the fact that these differences had showed themselves in Leyden between the friends of Gomar and those of Arminius. This disputation was one of a series of public discussions. Arminius was the speaker, and denied that men are converted by an irresistible divine force. Afterwards Gomar, addressing him, exclaimed: "Never did I hear in this University such language, and arguments so effectually opening the door to Popery. . . . I will refute you publicly." Arminius replied that in no way had he favored Popery, and that the theory that God exercises a resistless force in man's salvation was contrary to Scripture, to ancient belief and to the Reformed Confession and Catechism.

The next month the States called the two professors before them, each being accompanied by four ministers. After conference as to the revision of the Confession, Gomar objected to dispute such questions before the civil authorities, but offered to debate with Arminius in an ecclesiastical assembly, to which the States might send deputies. The States preferring, however, that the matter should go on as begun, Gomar yielded, on condition that each party should transmit his papers to the Synod to be judged ecclesiastically, to which Arminius readily consented. Gomar began with Justification, as to which Arminius affirmed entire agreement, merely preferring to use Scriptural language. As for Predestination, Grace, Free Will and Perseverance, discussion brought them no nearer than formerly, but the Conference was ended soon by the illness of Arminius.

The States then demanded the judgment of the witnesses, and particularly suggestions how to heal these antagonisms. Gomar's friends declared that the only effectual restoration of peace must be found in a national or provincial Synod, undoubtedly expecting to secure a majority therein and silence their opponents by law. But the friends of Arminius claimed that he had the whole tenor of the Gospel on his side. J. Uitenbogart, a pastor at The Hague, was spokesman for the latter. He made a speech, remarkable for its comprehensiveness and candor, ${ }^{1}$ pointing out that the Confession and Catechism had been drawn

1 Brandt, ii : 55, etc. Uitenbogart, 471, ete. Triglandus, 417, etc. 
up at first merely as convenient helps and had no right to the authority claimed for them ; and that, if a Synod should be held, it should deal amicably with existing differences and see what could be done to check Popery, and restore the weakening discipline of the Chureh.

Clearly the States-General on the whole sympathized with Arminius. They emphatically ordered the Classis of Alkmaer to restore its excluded ministers, especially Venator. But, while the obdurate classis was studying how to reaffirm its refusal safely, the somewhat sudden death of Arminius altered matters for a time.

It is difficult to estimate justly any marked individuality exposed to the conscientious misunderstandings of a period of active theologieal conflict. Moreover, at this time piety was regarded extensively as, if not synonymous with, at least inseparable from dogmatic belief, and the rigidly orthodox were positive of the Heaven-declared authenticity of their views to the last jot and tittle.

Arminius was born three years before the English Church settled down upon the Thirty-nine Articles. He was at Leyden university when his patron, Rodolph Snellius, was teaching there the philosophy of Ramus with all the zeal of a new convert. The ardent young man naturally accepted the fascinating novelty. Subsequently, at Geneva, his advocacy of it made him uncomfortable and he retired to Basel. Afterwards, before he was ordained at Amsterdam in 1588, although modifying his utterances, he still held to the Ramist scheme. This made it easy for him to welcome new methods of stating old truths, and also rendered him suspicious to conservative minds, and soon the subject of calumny. Just as he was conciliating the general regard, in the year following his ordination he was called upon for a special service. ${ }^{1}$ Richard Koornhert denounced the doctrine of unconditional predestination, and Arnold Cornelius and Reinier Donteklok, opposing him, claimed that God's decree, instead of preceding and determining, succeeds and results from the Fall. This was in the teeth of strict Genevan theology. Arminius, recently from that seat of orthodoxy, was requested to correct them. He took the task in hand. But the longer he reflected,

1 Brandt, i: 386. 
the greater grew his difficulties. He did not complete the work. The more he studied, the more he also inclined to assert man's freedom and to limit the range of the unconditional decrees of God. Of course his orthodoxy soon was questioned, and when, subsequently, he expounded the Epistle to the Romans, his cautious statements led to the charge of Pelagianism. That he afterwards opposed the requiring all minister's to sign the Creed and Catechism annually increased this distrust.

These suspicions distressed him. Upon all the fundamentals of the Gospel he agreed with his accusers. He did not think vital the few points in which he differed from them, and his sensitive nature "felt a stain like a wound." His friends believed that the clamor against him really caused his death. He died on Oct. 19, 1589, and was buried in St. Peter's on Oct. 23. He is supposed by many to have been the originator and first example of that rationalistic latitudinarianism which in the nineteenth century commonly was known as Arminianism. As well might George Washington be stigmatized as a communist because he was a republican. The testimony, more than seventy years ago, of a distinguished American scholar, Moses Stuart, is significant. He said : ${ }^{1}$

In reference to what is now, and has for a long time been, called Arminianism among us, we may well and truly say, that Arminius hinself was no Arminian.

Arminius himself, to use the language of the present times, was merely a moderate Calvinist; and moderate, too, in a very limited degree; for on most points he seems to have been altogether as strenuous as Calvin himself.

A careful examination of Arminius's own statements 2 shows that he held fully and firmly the divinity of Christ; the depravity of man ; the perfection of the Word of God, in itself, as a rule for man; the doctrines of grace and free will; salvation of the redeemed through the blood of Christ; regeneration by the Holy Spirit; and eternal punishment. Although more rigid than they upon important points, he was essentially what would be

1 Bib. Repos. 1831, i: 301, 304.

2 Jacobi Arminii, Opera Theologica, 1629, 4to (Leyden), and 1631 (Frankfort); The urks of James Arminius, D. D., formerly Professor of Divinity in the University of Leyden, translated from the Latin in three volumes, 1853 (Auburn and Buffalo). 
ealled now a New School Calvinist; while Gomar and his sympathizers were far more conservative than any modern Old School Calvinist. The university corporation placed upon its records an elaborate testimonial ${ }^{1}$ to the public ability and private worth of Arminius.

Although his death removed the most prominent advocate in Holland of the more liberal view of the Reformed ereed, it did not allay the excitement. The Classis of Alkmaer continued contumacious, supported by that of Enkhuyzen, which moved for a formal remonstrance to the States, and requested the ealling of the long-desired Synod. The States replied sharply that the Synod would have been convoked already, had the Alkmaer churehes obeyed a reiterated command. They must obey. After obedienee, the most advantageous ecclesiastical gathering should be called.

A glance baek to Amsterdam shows that this year a correspondence, ${ }^{2}$ printed in 1615, was opened between Henry Ainsworth and a Romanist priest of the same family name, ${ }^{3}$ although not known as a kinsman. John Ainsworth, in Newgate prison, sent out a manuseript, on man's justification, with the wish that Henry would reply. Henry responded, and six letters followed and as many answers. All are kindly for those days. The Barrowist contended that all religious differenees shonld be settled from the Seriptures. The Romanist insisted that the bare text of Scripture can be made a sufficient rule of faith only by the Pope's ruling. Each was tenderly anxious for the other's salvation, but the discussion seems only to have fortified each in his own views.

1 Brandt, ii : 62, 64 .

2 The Trying Ovt of the Trvth: Begunn and Prosequuted in Certayn Letters or Passages between. John Aynsworth and Henry Aynsworth, etc. 1615. 4to.

${ }_{3}$ Probably John Aynsworth was the man enrolled, Apr. 1, 1602, among the Angli Pauperes at Douay as Joannes Amswortus, Londinens, and subsequently as Ioannes Aynsurorthus, sent thence to England in 1608 (T. F. Knox, First and Second Diaries of Eng. Coll. Douay, 1878, 284, 34). Whether he were the "Mr. Ainsworth, priest," spoken of (Recs. Eng. Provs. S. J. vii : Pt. 2, 10s8) as at Wisbeach Castle in June, 1615, is uncertain although probable. Probably he was the John Ainsworth whose answers, on Mar. 20, 1614, with those of twenty-one other priests in Newgate, as to allegiance are in Tierney's Dodd (iv : eciv). H. Ainsworth says (Trying Ovt, 3) of J. A. "Whom for nation and name, (\& I know not vvhither also for neerer alliance) I regard as is meet." 


\section{CHAPTER IV}

\section{THE SUCCEEDING YEARS - 1610}

TIE year 1610 with the exiles no doubt was one of comparative prosperity. The fourth enlargement of the city took place then. All industries must have felt some impulse from this growth and the least skilful Englishmen must have been able to take advantage of the increased demand for labor. Possibly some of the company found homes in houses in the new quarter.

There were only two weddings among them. One was that of William Pontus and Wybra Hanson, the first marriage of each. He was a fustian weaver and lived on the premises of one Donver, who had a great brewery on the present Haarlemmer-straat. The name of Hanson was well known around Austerfield. It was that of Bradford's mother, and Wybra may have been his relative, although he is not recorded as present on this occasion. Possibly she had emigrated under his care. The betrothal was on Nov. 13 and the witnesses were William Brewster and Edward Southworth, Roger Wilson, Susanna Fuller (sister of Samuel), Jane White (Mrs. Robinson's sister) and Mary Butler. They were married on Dec. 4. The other, on Dec. 31, was that of John Jennings and Elizabeth Pettinger, and neither had been married before. He too was a fustian weaver, from somewhere near Colchester. In after years he is described as merchant, stocking weaver and tobaccodealer. She and her sister, Dorothy, came from "Moortel" in England. The betrothal was on Dec. 17, in the presence of Edward Southworth, Roger Wilson, Jane (Mrs. Robert) Peck and Anna (apparently Mrs. Bernard) Ross.

Only a single death is recorded and there is uncertainty as to that. On Nov. 27 there was buried in St. Peter's " a child of Jonathan William's son, living on the church street." If we 
knew that Jonathan Brewster had been married, the natural interpretation of this entry would refer it to a death in his family, which lived on that street; and if the name were Jonathan William's son Brewster, as it is on his admission to citizenship in 1617 , it would be clear that he is referred to. Jonathan was not a Dutch name, and appears only once or twice during many years in connection with Englishmen in Leyden, and with no one else likely to have been referred to at this time. In view of the common Dutch custom of designating a man merely as his father's son, onitting the last name in each case, there seems no doubt that Jonathan Brewster is meant; although no record of his marriage ever has appeared, and at this time he cannot have been much over seventeen years old, ${ }^{1}$ which render's his having been married long enough to have a child improbable, although not impossible. On the other hand, he certainly buried his wife on May 10, 1619.2 He may have had an early attachment in England, and expediency and convenience may have led to marriage, even at his early age. Such marriages were not unknown. Dorothy May was only sixteen when she became Mrs. William Bradford. On the whole, therefore, it seems quite certain that Jonathan Brewster had been married and that this was his child.

Six known members of the company became citizens in 1610 . Bernard Ross was admitted on Apr. 2, guaranteed by Roger Wilson and Mahieu van der Mersche, the latter evidently Dutch. Of course at first the English applicants for citizenship had to rely to some extent upon the endorsement of Dutch acquaintances. Later they were able to testify in behalf of one another. William Lisle was admitted on June 21, guaranteed by Nicholas Hawley and Roger Wilson; Abraham Gray on June 25, guaranteed by Lisle and Wilson; and John Turner on Sept. 27, vouched for by Lisle and by Peter Boey, who had guaranteed Wilson in the previous December. It is unknown whether Boey were a Dutchman or some Englishman, and perhaps a Pilgrim, whose name was misunderstood. William Robertson was admitted on Dec. 3, endorsed by Ross and Wilson; and Henry Wood on Dec. 10, endorsed by Gray and Wilson. Ross, who lived in Amsterdam when he sent the cloth to Brewster in 
June, 1609, had removed to Leyden. Presumably he is the man of that name, described as a leather merchant, who made a deposition in April, 1616. Lisle was from Yarmouth, but his employment is not stated. Gray was from London, and was a cobbler. Turner was a merchant. Robertson was a leather dresser, and was thirty-seven. Wood was a draper, and became one of the four or five purchaser's of Robinson's house.

A note of one business transaction also exists. On Mar. 12 Thomas Blossom, from Cambridge, gave to his wife Ann - who had inherited several houses with land in Cambridge from her mother's father by will - power of attorney to transfer them to any persons to whom by English law they might be sold, and, specially, to sell two houses in the parish of St. Giles.

This must have been a busy year for Robinson, for, in addition to whatever secular employment he perhaps may have followed for his support, in whole or in part, and to his ministerial labors, he completed and had printed ${ }^{1}$ his "A Ivstification of Separation," a quarto of 480 pages. It was against Bernard's "The Separatists Schisme," and also against his "Christian Advertisements and Counsels of Peace," published in 1608, and already mentioned, which, although a little book, had attracted considerable notice. In the latter, especially, Bernard dissuades from Brownism because of its novelty, its schism, its abuse of Scripture, its non-approval by the Reformed churches, God's judgments against it, its ill success, etc.; and alleges that it condemns all former Christian profession, refuses to join with imperfect men, wrests the Scriptures, etc. He also advances eight propositions against Brownism: that the English Church is a true church; that a particular church should not be expected to be free from false professors; that popular government is unwarrantable; that "tell the church" means tell the church governors; that a man is not polluted by the sin of another; that the Established ministers are true ministers, while the Separatists are not "lawfully made;" that the regular

i The book names no place of issue, but as yet the press was more within reach of the exiles in Amsterdam than in Leyden; and Fowler (Shield of Defence, 8) says that "Mr. Th[orpe] bath had a hand in the printing of Mr. Robinson's book against Mr. Bernard." Giles Thorpe was a deacon of Ainsworth's church, and a printer who avowed responsibility for several Separatist volumes. 
worship in England is not ilolatrons; and that " stinted and set prayer" is lawful. Finally, it stigmatizes twelve more alleged "opinions of the Separators" $"$ as "far-fetched conclusions, from unsound premises."

Both Ainsworth and Smyth had answered it in volumes ${ }^{2}$ largely devoted to other things. But Robinson felt that it needed further criticism, and the more, probably, because some of the English at Leyden and Amsterdam had been Bernard's parishioners formerly. This labor also led Robinson directly to defend the reasonableness of his views. While he was printing this reply, Bernard sent ont a second volume ${ }^{3}$ elaborating his positions; so that Robinson introduced into his own treatise some comment upon this second book also.

He certainly did thorough work in this reply, answering in detail Bernard's assaults upon Separatism, especially for the benefit of the common mind. The volume is one of the most important from Robinson's pen. Doctrinally, for substance, he frankly associates his church with that of Johnson at Amsterdam.

His tolerance is as conspicuous as it was unusual. For example ${ }^{4}$ -

I am verily perswaded there are in many congregations [of the English Church] many that truely fear God: (and the Lord encrease their number, and graces) and if they were separated from the rest into visible communion, I should not doubt to account them such cogregations, as vnto which God had given his sacraments. . . .

I doubt not but the truthes taught in Rome have been effectuall to the saving of many.

A similar Christian appreciation breaks out like sunlight in his characterization of his own church :-

If ever I saw the beauty of Sion, \& the glory of the Lord filling his tabernacle, it hath been in the manifestation of the divers graces of God in the Chureh, in that heavenly harmony, and comely order,

1 Disswasions from the Way of the Separatists . . . commonly called Brownisme; better known as The Separatists Schisme, 150, 151.

2 Counterpoyson and Paralleles.

${ }^{3}$ Plaine Euidences: The Church of England is Apostolicall; the Separation Schismaticall, ete. 1610,4 to.

* Justif. of Sep. 319, 460, 212, 78, 84, 274, 140,79. 
wherein by the grace of God we are set and walk: wherein, if your eyes had but seen the brethrens sober, and modest carriage one toward an other, their humble, and willing submission vnto their guides, in the Lord, their tender compassion towards the weak, their fervent zeal against scandalous offenders, and their long suffering towards all, you would (I am perswaded) chaunge your mind.

His style throughout is notable for its terse and pithy expressions and the quaint homeliness of its interpretations and applications. Sometimes he indulges effectively in sarcasm, as in his reply to Bernard's criticism of the Brownists for their excommunications : -

Indeed no man can challendge Mr. B. \& his church of Worksop for any such heady and rash excommunications, they are very moderate this way, and can beare in communion with them any graceles person whomsoever til his dying day, and then commit ful charitably the body of their deceased brother to the graue, with a devout prayer for his joyfull resurrection: so charitable are they both to the living and the. dead.

$\mathrm{He}$ "carries the war into Africa" skilfully by printing in full a paper which Bernard, when almost a Nonconformist, had given him containing in Bernard's own writing eight reasons to prove the bishops antichristian; and by the following home thrust : -

Once you know Mr. B. you did separate from the rest [of your parish] an hundred voluntary professors into covenant with the Lord, sealed vp with the Lords supper, to forsake all knowne sinn, to hear no wicked or dumb Ministers, and the like, which covenant long since you have dissolved, not shaming to affirme you did it onely in policy to keepe your people from Mr. Snyth.

He also uses the reductio ad absurdum effectively, thus:-

A man may go out of these countryes wher I now live, as many do, and hyre a house in any parrish of the land [England]; he is by the right of his house, or ferm, a member of the parish Church, where he dwels. yea though he have been nousled [nursed] vp all his life log in Popery, or Atheism, \& though he were formerly neyther of any Church, or religion. Yea though he should professe that he did not look to be saved by Christ onely, and alone, but by his good meanings, and well doings: yet if he will come, \& hear divine service he is matter, true as steel for your Church : ... 
And what if the Lord should now rayse vp a company of faythfull men and women in Barbary, or America, by the reading of the seriptures, or by the wrytings, conferences, or sufferings of some godly men, must they not separate themselves from the filthines of the heathen to the Lord? . . . nor have any communion together for their mutuall aedification, and comfort, till some vagrant Preist from Rome or England be sent vnto them to begin theyr Church matters with his service book? . . Nay if this were a true ground, that Church matters might not be begun without officers, it were impossible that such a people should ever eyther enioy officers, or become a Church, yea I may safely ad, that ever there should be in the world after the vinversal visible apostacy of Antichrist, any true eyther Church, or officers.

His argument antagonizes Beruard's positions one by one and reinforces ably the general doctrinal claims of the Separatists. At this time he agreed with the other Separatist churches in all main particulars, even disfavoring the hearing of the gospel, however purely preached, from the pulpits of the Establishment. Thus he says :-

Now for the demaund [made by Bernard, whether they would listen to his sermons if he preached nothing but the true word of God] ... As it was vnlawfull to communicate with Corah or with Vzziah though they burnt true incense, or with Ieroboam's Preists though they offered true sacrifices, so it is vnlawfull to communicate with a devised ${ }^{1}$ ministery, what truth soever is taught in it.

Not only was his first edition exhausted, but the book was reprinted fourteen years after his death.

There is some evidence that it was this year to which Bradford refers in saying: ${ }^{2}$ "We some of us knew Mr. Parker, ${ }^{3}$ Doctor Ames, and Mr. Jacob in Holland, when they sojourned for a time at Leyden." Henry Jacob certainly was in Leyden in this year, as he dates a preface, ${ }^{4}$ printed by a Leyden

1 From the French diviser (to divide). A ministry which, through its relation to a patron who holds its gift as a part of his property, is a "hireling" ministry.

2 Dial. Young, Chrons. 499.

${ }^{3}$ Robert Parker, educated at Benet College, Cambridge, held the benefice of Wilton, Wilts. Offending by writing A Scholasticall Discourse Against Symbolizing with Antichrist in Ceremonies: especially in the Signe of the Crosse (1607, fol.), he took refuge in Holland, where he became ehaplain to the garrison at Doesborgh. See p. $36 \%$. Ames was the famous Amesius.

4 'To The Divine Beginning and Institution of Christ's true Visible or Ministeriall Church, ete., $12 \mathrm{mo.}$ 
printer, " From Leyden. Decemb. 20, An ${ }^{\circ}$ 1610." And Matthias Nethenus, in the preface ${ }^{1}$ to Ames's Latin works in 1658, says that Ames was driven from England for his Calvinism and that certain English merchants sent him and Parker to Leyden to write against the English hierarehy. The three men must have been there together. But Ames had small patience with Separatism, and Parker presumably was making those researches which increased the force of that Latin plea ${ }^{2}$ for Presbyterianism which, cut short perhaps one half by his death in 1614, was printed at Frankfort in 1612. Jacob, too, being charged with leanings toward Brownism in the book ${ }^{3}$ which he then was publishing, deniêd the charge two years afterwards. Doubtless, therefore, Robinson had to cultivate the grace of meekness in order to enjoy intercourse with these visitors. In the university eircle the chief event was the election of Conrad Vorstins, professor and pastor at Steinfurt, in July, as the successor of Arminius, but months passed before his acceptance.

This year also was eventful among the English at Amsterdam. Having formally unchurehed his old church and renounced his former ministry, and having rebaptized himself and his people, and so reorganized them into another church, Smyth soon admitted that their " new-washed companie " was " no true church." This vacillating course speedily led to the division of his organization. About ten ${ }^{4}$ members stood firm, but the majority who sided with Smyth, probably not many more than thirty, ${ }^{5}$ among whom Hugo Bromhead and Thomas Pigott were chief, departed, and were excommunicated by the minority, headed by Helwys and Murton, for heresy. ${ }^{6}$ Thus thrust out of all church

1 Gul. Amesii SS. Theol. Doct. etc., i: vi-ix. Also Dict. Nat. Biog. Arts. Ames and V. Cary.

2 De Politeia Ecclesiasticae Christi, et Hierarchica opposita, Libri Tres, ete., ed. 1693 , iv. Parker's lack of sympathy with Robinson is shown in a citation in C. Lawne's Proph. Schisme, 68-70.

3 A Declaration and Plainer Opening of certain points, with a sovnd confirmation of some other, contained in a treatise intituled The Diuine Beginning, etc., 1612, 5 .

+ Clyfton, Plea, vi.

5 The names of sixteen men and sixteen women are attached to a document in the archives of the Mernonite College, Amsterdam, which seems to have had a place in these negotiations and is printed in The True Story of John Smyth, the Se-Baptist, 30.

- A Declaration of the Faith of English People remaining at Amsterdam in Hol- 
life, Smyth and his little band applied for admission to a Mennonite, or Waterlander, ${ }^{1}$ church in Amsterdem. Objection was made that they had baptized themselves unwarrantably, whereupon, by their document ${ }^{2}$ alrealy mentioned, they confessed their error and pleaded to be taken back into the true Church of Christ. But Helwys, Murton, William Pigott and Thomas Seamer, representing those who had excommunicated them, protested ${ }^{3}$ against their reception. Counsel was songht from a sister church in Leeuwarden. The letters still exist. The Leenwarden church delayed and evaded, the matter dropped for the time, and poor Smyth appears to have passed the brief remainder of his life in an unchurched state ${ }^{4}$ although his people renewed their application successfully three years after his death. ${ }^{5}$

The long threatened outbreak in the Ancient Church oceurred about December, ${ }^{6}$ 1609, and 1610 was hurid with it. It was due to the incompatibility of two hostile polities at work in one body. John"son, and Elder Studley, with those whom they led, were crowding their system constantly over towards its Presbyterian side, exalting the powers of the eldership and ignoring the rights of the brotherhood, until they reached the position that a local church has no power excepting to elect elders. ${ }^{7}$ It eannot

land, 1611, 16. Another book was printed in 1612 with the same title. The first was by Helwss and his company; the second by "the remainder of Mr. Smyth's Company," and published after his death. The only known printed copies of either are in the York Ninster Library, but manuscript copies are in the Dexter Collection at Yale.

1 These perhaps might be styled Liberal-Quaker-Baptist. They baptized by sprinkling or affusion and disregarded doctrinal controversy. As Mennonites they got their name from Menno Simons; as Waterlanders from their location in North Holland.

2 This confirms the fact of the se-baptism-"quod incorperint se ipsos baptizare," ete. Orig. Ms.

3 This correspondence is in the Amst. archives, and is printed by Evans (i : 209), but with an error of a year in the date.

4 Evans represents the application as successful at this time. But Scheffer says that Evans has confounded this one with a later application, made in 1615.

5 Scheffer, Ms. letter.

6 The secession of Ainsworth and his friends seems to have been at about Christmas, 1610, and he says (Animad. 137) that they had "a twelv moneths' dispute," which throws its beginning back to December, 1609.

7 Without assigning chapter and verse, excepting when verbal citation is made, this account is drawn from close comparison and harmonization of Clyfton's $A d$ vertisement (22-35), Johnson's Treatise of the Ministery (112-114) and Treatise con- 
even ordain them. It cannot cast out an offending member or depose an erring elder. All church power is in the eldership. ${ }^{1}$ The practical issue of this, of comrse, would be worse than govermment by an aristocracy, giving control perhaps to a triocracy. As Ainsworth said : ${ }^{2}$ -

Touching their hierarchie the Eldership they wilnot I think deny, but the greater number of voices among them must prevayl. Now that being so, a Church having a Pastor, and a Teacher that are learned, and 3. or 4. ruling Elders, which are as unlearned as the other of the people, taken of trades men and the like: these 3. or 4. Rulers (whose power they have proportioned with the Princes of Israel) shal by their number of voices cary matters [i. e., in the body of the elders], though it be against Pastor, Teacher, and 500 brethren. Yea, these [three or four ignorant men] may excommunicate or depose the Pastor and Teacher, and cast out of the brethren: but none can excommunicate them, or depose them joyntly from their offices. The utmost that we can find these men to allow the Church in these exigents, [exigencies], is, when they have doon al they can, to separate ${ }^{3}$ from them: and this power any man hath in the church of Rome.

Still further, Johnson and his adherents refused to heed the thirty-eighth article of their Confession, which required churches in difficulty to have the counsel and help one of another in all needful affairs. Not venturing to deny the principle absolutely, they objected whenever its employment was sought. Ainsworth, Jean de la Cluse and others remained faithful to the mild Barrowism of their original Articles of 1596 . As to the crucial question, Ainsworth suceeeded better in reëmphasizing than in explaining the popular side of their mixed polity. The most which he could say was this : ${ }^{4}$ -

We give not to the people goverment, as before I have shewed, but a right and power to observ and doo al the commandements of Christ, touching his prophetical preistly and kingly office, by the Elders teaching, guiding and governing of them in the Lord.

We ... distinguish the government, and the power: acknowledging government to be by the officers; but power in the whole body of the Chureh.

rerning the 18th Matthew (23-30,123-138), and, especially, Ainsworth's Animadversion (passim) and Robinson and Brewster's letter therein (139-136).

1 Adv. 34.2 Animad. 39.

4 Animad. 24, 10, 34, 39, 109, 132. 
But his effective opposition to all endeavors to nentralize the rights of the people in the practical administration of the church showed that, hat he lived when democracy was a conceded possibility, he probably would have been a democrat.

After contention had begun to blaze, Ainsworth's party made three propositions. They offered to remain quietly in the Ancient Church if by common consent no change should be made in its working processes. But this was declined as leaving " the ordinance of God touching the eldership to be troden underfoot." They next proposed "a peaceable parting; and to be two distinct congregations," in brotherly fellowship. But this was refused unless they would leave Amsterdam. The third proposal was to seek counsel from the Leyden chureh. But this, too, was rejected, partly as the Leyden church " was in the same error," and partly because counsel could be had from the Reformed French or Dutch chmrehes of Amisterdam - to which it was a sufficient answer that they could not discuss the controversy in English. Johnson's party at last said, however, that, while they could not authorize the plan, or even approve it, if the Leyden church were to come, they would "permitt" that.

"Some 30. of the brethren," Ainsworth apparently not being among them, then wrote to the Leyden church, asking its help. Robinson and Brewster first replied to the whole church, declining to interpose unless they were properly called and with " best hope of good issue." Several letters passed, all ending in the stubborn " they would not approve, but onely permit." Robinson and Brewster then went, as individuals. Finally, on Ainsworth's solicitation, they went representing their ehureh and " with some vehemeney" reproved what was judged evil. The Ancient Chnreh had deposed Ainsworth and other Elders and brethren, an action which the Leyden men induced them to rescind.

The Leyden church proposed a mildle course, that offences be dealt with first by the elders as church governors, and, this failing, that then they be judged by the whole church. But this was unacceptable. Johnson finally almost solved the difficulty by proposing the free dismission of dissatisfied members to Leyden. His church agreed. Ainsworth and his friends " did never 
desire, but for peace sake, consented." The Leyden church agreed, and sent its officers to Amsterdam once more to ratify the plan, and it was approved again by Johnson and his adherents. But suddenly the latter, giving no reason, revoked their repeated assent unless Ainsworth and his friends would remove to Leyden. This they could not promise because, as they plaintively said: "We could not tel before we came thither \& tried, whether there would be meanes found for our living there, or no."

It now was evident to the minority that all ordinary expedients were exhausted. Yet, they still exercised a noble patience, winning praise from the Leyden men for "Mr. Ainsworth's great moderation, upō whom the rest did much depend." Each party appealed again to the Leyden church, but it made no reply. Finally, on Dec. 25, 1610, the dissidents withdrew, and, oddly, they obtained for their meeting-place a former synagogue, only one door from the Ancient Church. The Johnsonians now formally deposed Ainsworth again from the Teacher's office, and excommunicated ${ }^{1}$ the seceders.

The Pilgrims also must have continued to watch the wider theological conflict. This year brought in a new party name. Those ministers who believed that Arminian notions were undermining the common faith persistently urged their Classes and Conventions to adopt declarations of absolute submission to the Catechism and Confession. This annoyed all who had doubts abont these formulas, and wished them revised by a Synod. A number of them framed a remonstrance to the States. They complained that they were falsely suspected. They sought no alteration in religion. They simply wished it recognized offcially that their subscription to the Confession and Catechism ought to be interpreted as being to those formulas as far as they were Scriptural. They specified doctrines which seemed unscriptural, adding their own views as to election, the redemptive

1 Baillie says (Dissvasiue, ed. 1655, 7) that each party excommunicated the other. But Lawne (Proph. Schisme, 62) and Paget (Arrow. 94) confine this action to the Johuson party; and Cotton (Way of Cong. Chhs. 6) expressly says, as is the truth beyond all question: "Mr. Ainsworth and his company did not excommunicate Mr. Johnson and his, but onely withdrew from them, when they could no longer live peaceably with them." 
office of Christ, divine grace and perseverance. The Confession and Catechism, if interpreted as they suggested, not only would " remain unhurt," but would furnish a basis for harmony and union with all the Reformed Churches. They begged the States to summon a Synod, or, at least, to insist upon forbearance and toleration. And since this Remonstrance might be misconstrued, they prayed the States to defend them, particularly from clurch censures. The parties to this historic doement, drawn up by Uitenbogart, thenceforth were called the Remonstrants.

On its presentation to the States a consultation took place upon the wisdom of holding a provincial Synod immediately. The majority favored the Remonstrants. But, as it was almost certain that such a Synod would be controlled by the antirevisionists, it was decided to postpone it and to require the Classes and churches not to annoy anybody about these lately contested points. Such orders were issued, but often were disregarded, especially in Leyden, where the Classis defied them. On the examination of Cornelius Tetrode, a Leyden student, it insisted that Adam fell necessarily, because of a previous divine decree; that the regenerative force is irresistible; and that, should a believer be guilty of drunkenness, adultery and murder, he could not die before being converted and recovered. Formal complaint of this was made to the States, who sent two of their members, with three city officials, to interview the Classis, who demanded a categorical answer whether the Classis would obey or not. Festus Hommius, pastor of the Walloon Church in Leyden, kept them at bay six hours, but the vote favored the States, and Hommius promised to labor for peace. A few days later much the same thing took place at Bodegrave.

At about this time the deputies of the Synods of North and South Holland complained against the resolution of the States, pledging themselves to prove the positions of the Remonstrants contrary to Scripture, the Confession and the Catechism, and praying for a provincial Synod. The States still opposed a Synod, but on Dec. 23 they arranged a conference between representatives of the two parties. Late in this year Simon Episeopius was called to be minister of Bleiswick. But at his examination, the Consistory of Amsterdam, whose members 
differed from him upon predestination, alleged his credentials insufficient. After a delay of three weeks, the majority of the Classis declared the credentials satisfactory and went on with the examination. The minority retired, protesting, and a few seceded from the Classis.

In secular respects also this year was eventful. The early spring witnessed unprecedented tempests and inundations. A third of Holland was under water, causing immense loss. It became difficult to collect taxes and meet the public expenses. Moreover, in February an insurrection, headed by one Dirk Kanter, broke out in Utrecht, aiming to sever that city with its province from the confederacy and relying to some extent upon the Romanists. The power was seized and the offices transferred. Prince Maurice marched over with troops, but Kanter managed to secure his confirmation of the new régime. After the prince had returned to The Hague, however, the new Utrecht authorities began to "reform" matters. The States vainly tried negotiation and finally sent Frederic Henry, younger brother of Maurice, with more troops and orders to reduce the rebellion at any cost. Kanter and his friends discreetly accepted banishment, and the former state of things was resumed. Oddly, there appeared in connection with this business something undeniably like a democratic tendency. Winwood, the English ambassador, says : ${ }^{1}$ -

During this contestation which we have had with the Town of Utrecht, there have been some who would have broached this Heresy amongst us, that not the States, but the common People, the ordinary Burgher, the Schipper [skipper], the Foremen and in one Word, the Riffraff of the Country, are the Masters of the Provinces: They are the greater Part, they bear the Burden of the Imposts and Taxes, they were the first that did shake off the Yoke of Spaine, and in them the Power doth consist, at their Arbitrament to make the Magistrate and to depose him,... a and in consequence, to alter, fashion and settle the Government of the State.

The chief political event of the year to the Low Countries was the campaign ending in the capture of Jülich. The death of the Dulse of Cleves, in 1609, had brought the long struggle

1 Memorials, iii : 139. 
between the Romanists, Lutherans and Calvinists to a head, and the States, with Henry IV. of France, interfered. On the eve of leaving Paris, the king was assassinated. This modified but did not prevent the intended campaign. On July 13 Prince Maurice, with 13,000 foot, 3000 horse and thirty pieces of artillery marched straight and alone for Julich, and had nearly reduced it when the Marshal de la Chartre came up with 8000 or more French troops. The place soon surrendered, and the citadel was placed in the hands of the Protestant Princes of Brandenburg and Neuburg. A governor in their interest was appointed in the province, and the troops of the States returned home, having won a victory without losing a man. It placed Protestantism in command of territory valuable in itself, and invaluable in its extension of the frontier to a safer distance and in its strategic importance as facilitating communication between the Dutch and the Protestants of Central Germany, thus giving to the Protestants greater influence throughout the border provinces. The Pilgrims were no more likely thau many others to grasp its full significance, but, as it was a victory for Protestantism, they must have rejoiced in it.

In England Parliament was in session twenty-three weeks, from Feb. 9, but did little beyond disputing with the king over money for his needs, largely debts recklessly incurred, and about the royal prerogative. James was determined to get all that was to be had and the Commons to check his extravagance and to insist upon their political rights. One proposition growing out of grievances urged by the lower House was that the deprived ministers be permitted to preach, if they would not criticise the Established Church, but it was flatly refused. In general, it was asked that the power of the ecclesiastical courts be restrained by statute, but James declared that he would see that no abuses took place, which amounted to nothing.

When Parliament reassembled, on Oct. 16, the former strife went wearily on. The Commons - fresh from the people, with whom James's prodigality was most unpopular - simply growing more determined and the king more angry. Thus began that long contest between the throne and the people which was closed only near the end of the century, under William of 
Orange, by the victory of the Commons. The news of the assassination of Henry of Navarre led to the tightening of the policy against recusants. The Romanists had the worst of it, but Protestants also suffered. One new feature was a penalty upon married women refusing to commune in the Established Church. They were to be imprisoned unless their husbands paid ten pounds a month in their behalf. In June the king at last destroyed the independence of the Scottish Church. By threats of fine and imprisonment against his opponents and by packing the Assembly with his adherents, the reluctant clergy having been openly terrorized, he established Episcopacy in Scotland; that is, under the shadow of Episcopacy he established his own anthority over the Presbyterian assemblies. To the Pilgrims matters at home must have seemed to be going from bad to worse. 


\section{CHAPTER V}

\section{THE SUCCEEDING YEARS - 1611-1612}

The first and most important event in 1611 in the Pilgrim history was a movement to purchase an estate in the Kloksteeg (Bell Lane). Forbidden to worship in any ordinary chureh or chapel, they were restricted to some house. Naturally this would be one of their own, and presumably Robinson's. Doubtless they had been seanning the city to find some purchasable dwelling, large enough to accommodate their assemblies and fairly central and reputable in situation. If, moreover, one could be had with land enough for a few cottages, where some of their families could live, perhaps all which they could expect wonld be secured. Such a house they found.

The earkiest record connecting it with them is on Jan. 27, when John Robinson, "minister of God's word of the English congregation," William Jepson, Henry Wood and Jane White, " not married at this time but assisted by Nicholas White, ${ }^{2}$ jeweller," agreed to buy of Johann de Lalaing the house called the Groenepoort (Green Door). The record of the completion of the bargain is dated May $5,{ }^{3}$ and is translated here:-

We, Pieter Arentsz Deyman and Amelis van Hogeveen, aldermen in Leyden, certify that Mr. Johann de Lalaing has appeared before us, declaring for himself and his heirs that he has sold, and by these

1 Inbreng Bk. M. 18 verso. Two vols. are labelled M, and this record is in one only.

2 "Assisted" probably means vouched for as financially competent. If he had furnished money the fact almost certainly would have been stated. No further reference to him has been found, excepting that Nicholas Peck, when matriculated on Dec. 7, 1611, lived with him. He may have been a relative of Jane White, Mrs. John Robinson and Roger White.

3 Prothocol van Waerbrieven, MM 105. In the Tueede Reg. Zevenhuysen (161) the briefer record of the sale is dated Mar. 14. But the iuternal evidence seems to establish the date as May $\check{5}$. 
presents does sell, unto John Robinson, minister of God's word of the English congregation in this city, William Jepson, Henry Wood and Randall Thickins, who has married Jane White, together jointly, and each for himself an equal fourth part, a house and garden, with grounds adjacent on the west and south sides thereof, standing and being in this eity on the south side of the Pieterskerkinof near the belfry, ${ }^{1}$ [which house has been] named from old times the Green Door. Bounded by and having situated on the one side eastwardly a certain small room which the appearer [Lalaing] reserves for himself, being over the door of the house hereby sold; next thereto is William Symonson van der. Wilde and next to him is the residence of the Commandery; and on the other side to the west having the widow and heirs of Huijck van Alckemade, and next to him the appearer himself, and next to him is the Donckeregracht ${ }^{2}$ [Dark, or Covered, Canal] which also bounds the aforesaid grounds; and next is the Veiled Nuns Court (stretching from the [Pieters]kerkhof before mentioned to the rear of the Fulyde Beguynhof before named). ${ }^{3}$ All and so as the aforesaid house is at present built and made, used and occupied, with everything thereto attached, fastened to the ground or nailed, to him the appearer belonging, subject to a yearly rent-charge of eleven stivers and twelve pence payable by the tenant to the Heer van Poelgeest. And lie the appearer promises to warrant and defend the aforesaid house and grounds, subject to the before named rent-charge from all other incumbrances with which the same might be charged, and burdened for a year and a day and forever, as is just; hereby pledging thereto all his goods moveable and immoveable, now owned or to be owned by him, without any exception whatsoever. Further, the appearer hereby acknowledges that, with regard to the aforesaid sale, he has been fully satisfied and paid the sum of eight thousand gilders, the last penny with the first, of forty groats each; two thousand being paid down, and five hundred to be paid on May day, 1612, as the first year, and annually thereafter until all be paid, being secured by a mortgage. And all this in good faith and without fraud. In witness whereof we have appended our seals on the fifth of May of the year 1611 .

\section{Signed I. Swanenburch.}

1 The low tower, built for the bell after the spire of the cathedral fell in 1512, in the little square in front of the cathedral.

2 As convenience dictated, the small canals were arched over, in some cases becoming streets.

3 This parenthesis is in the margin of the docnment, and evidently was intended to declare that the estate sold, and not that of the Falyde Beguynhof, extended as described. 
Desirability of position and convenience of access were combined well in this estate. It was just across the $K^{2}$ loksteeg a narrow but somewhat important street — from the cathedral and but one door from the Commandery. The little square in front of St. Peter's alone separated it from the old palace of the Counts of Holland, and it was but a few steps from the university and under the very shadow of its library. It was fairly central, and was reached from all directions by converging streets. Winslow says ${ }^{1}$ that it was spacions, and examination of the documents shows that a considerable lot went with it.

There was the usual small garden at the rear of the house and of the same wilth, and the language of the deed, " with grounds on the west and south sides thereof adjacent," implies adjoining land, and the Caerte van Heeren Straet, Salomons Straet, Clock Steeck met

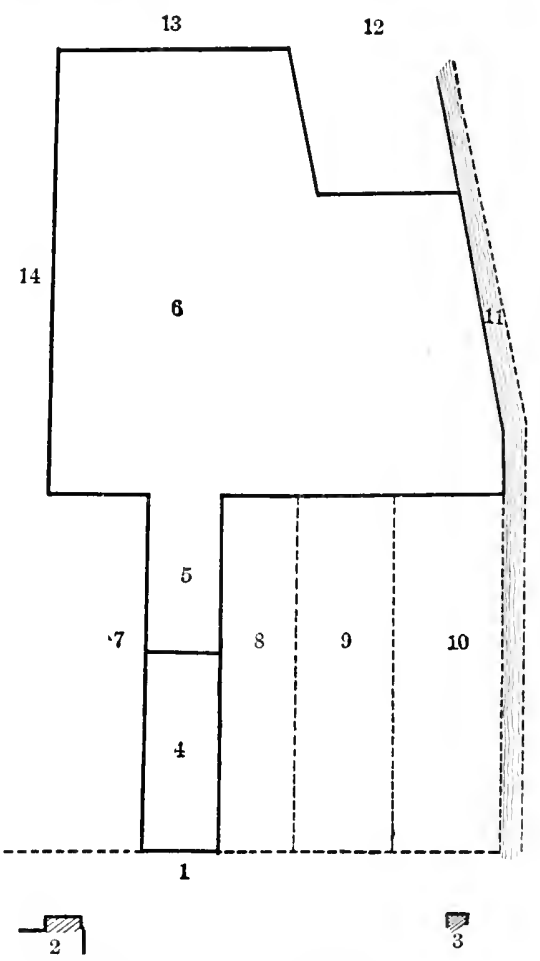

1. Ir loksteeg.

10. Estate of Dirck van

3. Corner of Belfry. between 1578 and 1611 by

4. Robinson's house.

5. Garden. de Lalaing.

11. Donekeregracht.

6. Additional lot. 12. Fulyde Beguynhof and

7. Estate of van der grounds.

Wilde. 13. Tenements belonging to

8. Estate of van Alcke- the Falyde Begulynleof: made.

9. Estate of de Lalaing.
14. Land of the Command ery.

1 "Onr pastor's house being large." Hypocrisie Vnmasked, 90. The accompanying photograph shows the front of the house, built in 1683 , on the same site, and also the small tablet, inserted in the wall under the right-hand arched window in 1865, by Dr. Dexter and Prof. G. E. Day, D. D., having this inscription : -

On this spot

Lived, taught and died

John Robinson.

1611-16.5. 
de Zuyt ende West zijd van't Pieters Kerckhof (Map of Heeren St., Salomon's St., Kloksteeg and the south and west side of the Pieterskerk) in the admirable Cart bouc van Straaten binnen dieser Stadt ${ }^{1}$ (Book of maps of streets in this eity) of 1578 , or thereabouts, suggests some idea of the size and shape of this estate.

It was irregular, but had an extreme length of about 300 by an extreme width of about 150 feet. Its front on the $K$ loksteeg was only twenty-five and one half feet, the width of the house and of the garden. But behind this garden was an open lot, which would have been almost square, and nearly 150 feet long and wide, had not the Fulycle Beguynhof cut off a corner some fifty-five by fifty feet at the southwest. It is not easy to see how its description as extending from the Pieterskerkhof in front on the worth to the rear of the Falyde Beguynhof as its southern line, and as being partly bounded by the Donckeregracht, can be reconciled with the other conditions named and with the suggestions of the chart, unless its outline approximated that suggested above. The estate must have included about a half-acre of land.

The price agreed upon was 8000 gilders - $\$ 3200$, equal in modern value to about $\$ 16,000$ - of which 2000 gilders were paid and the balance, secured by mortgage, was to be discharged at the rate of 500 gilders annually, on May 1. A small sum also was to be paid yearly, apparently as ground-rent, to the Seigneur of Polheest. ${ }^{2}$ Moreover, the house, when sold, was under lease to another party, having a year more of residence, and he was to pay 228 gilders rent for that year. Doubtless one reason for the purchase of a property thus encumbered was to secure a situation so admirably suited to all their desires. Presumably they immediately occupied the land. Jepson, one of the purchasers, was a carpenter, and it is likely that as soon as possible he built some cottages upon these grounds. At all events it is certain from the records that twenty-one houses were built on the open lot after this purchase and before $1647 . .^{3}$ And that as many as

1 Published in fac-simile in a handsome folio in 1874 by W. Pleyte, in his Leiden voor 300 jaren, etc.

2 A village two or three miles west from Leyden.

\& Tweede Reg. Zeven. 161-171. One of these little houses was sold in 1675 for 18.5 gilders, another for 150 , and another for 100 . Ten were sold in 1678 for 1125 gil- 


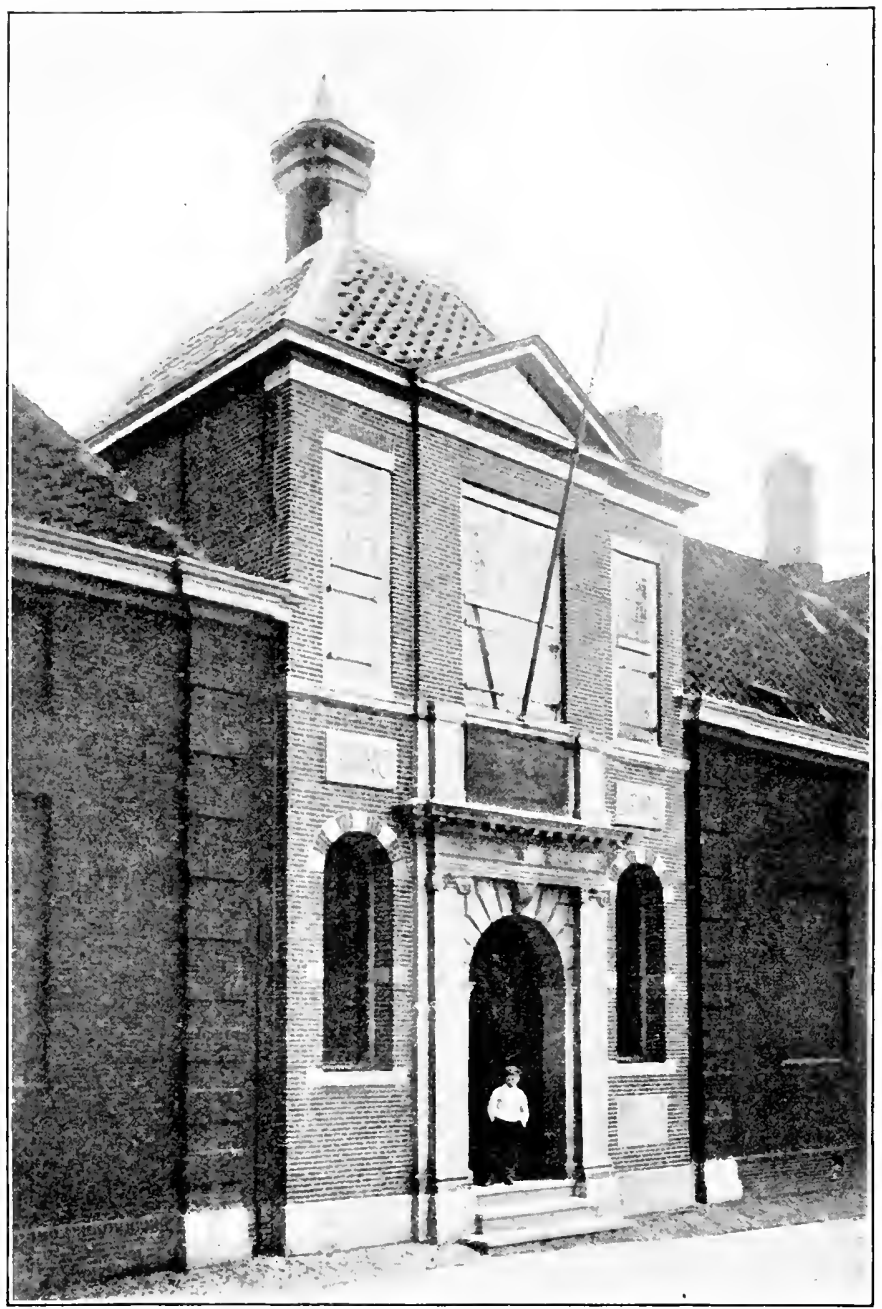

PESYNS-HOF, ON THE SITE OF ROBINSON'S HOUSE 
twelve families of the company are recorded as living there, and that at least as many more are mentioned as living close to the cathedral, as they naturally would be spoken of if living on this estate, probably inplies that these dwellings were erected soon.

The weddings in the company this year numbered five. On Apr. 1 Randall Thickins ${ }^{1}$ and Jane White were betrothed in the presence of John Robinson and his wife, Bridget, believed to have been Jane White's sister, William Brewster and Rosamond (Mrs. William) Jepson. Thickins was from London and was a looking-glass maker, and probably became a printer later, in connection with Brewster and Brewer. The White sisters are thought to have been from Beverly, Yorks., or Worksop, Notts. The wedding was on Apr. 21. On July 29 William Bassett, from Sandwich, widower of Cicely Light, was betrothed to Margaret Oldham, the witnesses being Edward Southworth, Roger Wilson, Wybra (Mrs.) Pontus and Elizabeth Neal. They were married on Aug. 13. Bassett was a master mason. He had been betrothed on Mar. 19 to Mary Butler, from Norwich, with William Brewster, Roger Wilson, Anna Fuller and Rose Lisle as witnesses, but she had died before their weddingday. His second wife, also, died before 1621, for he came to Plymouth in that year in the Fortune, accompanied by a third wife, Elizabeth. ${ }^{2}$ As there is no record of his third marriage in Leyden, she must have lived somewhere else. On Oct. 7 Isaac Allerton and Degory Priest were betrothed, and on Nov. 4 they were married. Allerton's bride was Mary Norris, said to have been from Newbury, and they were accompanied by Richard Masterson, Edward Southworth, Dille (doubtless Priscilla)

ders, one in 1681 for 129 and six for 600 . Some evidently were larger than others, although the difference in prices also may have been due to difference of condition. It should be noted here that at present little houses surround the garden. as in all Dutch "hofs," so that the spot nust look very much as it did in the Pilgrims" time.

1 Echt Bk. A. 166. In the Dexter Collection at Tale is a fac-simile of 'Thickins's name as written on the fly-leaf of a book in the British Museum, by John Robinson. Dr. Dexter thcught that this is not Thickins's own signature, but that it was written by Robinson on giving Thickins a cops of the book. The writing resembles that of what Dr. Dexter believed to be an autograph of Robinson in his possession, and, at any rate, settles the spelling of the name as Thickins, and not Dickens.

${ }^{2}$ Goodwin. Pilg. Repub. 191. 
Carpenter and Auna Fuller. He was from London, and was a tailor. With their three children, Bartholomew, Remember and Mary, they came to America in the Mayflower. Priest also was from London, and was a hat maker. His bride was Sarah, a sister of Allerton, and already the widow of one Jolnn Vincent. Their witnesses were Samuel Fuller, William Lisle, Rosamond (Mrs. William) Jepson and Mrs. Thickins. He also became a Mayflower passenger, but his wife and their two daughters, Mary and Sarah, remained behind, and after his death at Plymouth, she became Mrs. Cuthbert Cuthbertson, and came with him and her daughters to Plymouth in 1623. The fifth couple to wed were IVilliam Buckram and Elizabeth Neal. They were betrothed on Nov. 30, in the presence of William Butler, Abraham Gray, Mrs. Robinson and Mrs. Thickins, and were married on Dec. 17. He was a block maker from Ipswich, and had lost his first wife, Judith. Elizabeth Neal was one of the few members of the company recorded as from Scrooby.

Apparently the only death during the year was that of Mary Butler, just mentioned. She lived on the Pieterskerkgracht, and was buried in St. Peter's on Apr. 11. The only man admitted to citizenship who can be identified as one of the company was Bartholomew Smith. He took the oath on Apr. 5, guaranteed by John Carpenter and Jacob Stevens. He was a merchant from London, and seven years later he seems to have become a tobacco-pipe maker. On Nov. 4 Robert Cushman, from Canterbury, a wool-comber, bought of Cornelis Ghysberts van Groenendael a house on the west side of the Nonnensteeg, a short street continuing the Kloksteeg beyond the Rapenburg southerly to the Achtergracht (Back St.). Although in a good neighborhood, being close to the university, it must have been quite small, for its price was but eighty gilders down, with annual payments thereafter, bringing up the whole sum to about 180 gilders.

In the university the year witnessed the entrance of Peter Cunaens, a Leyden graduate who had studied subsequently in England, upon twenty-seven years of service, as professor first of Latin and afterwards of political law; and of John Polyander, educated at Heidlelberg and Geneva, and for twenty- 
two years a pastor at Dordrecht, upon a professorship of theology.

A correspondence took place at this time between William Ames and Robinson about Christian fellowship. Three letters have been preserved, ${ }^{1}$ two by Ames with one by Robinson. Ames argued that it is a duty to commune with any one who is in commumion with Christ; and that the point is yielded when those who are about to form a church hold practical communion with each other upon that subject. Robinson denied that external communion necessarily follows the discerning of inward communion with Christ. The chief theological event of the year was the dispute about Conrad Vorstius. As has been said, he had been elected in 1610 to the theological chair vacated by Arminius. He was then a little over forty. He had been offered a theological chair at Geneva, but preferred to go to Steinfurt, where he soon acquired fame. While there complaints were made against his soundness, and he went to Heidelberg and stated his views to those who had authorized him to teach, and the faculty merely blamed him for some youthful expressions. In 1610 , however, he published at Steinfurt a volume ${ }^{2}$ which renewed the subsided clamor. Beyond question the Leyden authorities, while they doubtless expected him to favor the general views of Arminius, believed him free from all Socinian taint, and, had he remained at Steinfurt, probably he would have died in the odor of orthodoxy. But he reached Leyden just when a violent conflict was beginning, and the question whether he should be one of the teachers of theology there thrust him, his opinions, utterances and tendencies, pitilessly under suspicion and prejudice. Soon after his name was first proposed, a clamor was made against him which, on investigation by the States and the university Curators, came to nothing. In May, 1611, however, six ministers claimed that he had published unsound doctrine, but the States were unconvinced and he was duly installed.

In August, and before he had begun lecturing, a swarm of

1 Printed by C. Lawne and his associates in Proph. Schisme (47-54). There is no reason to suspect their genuineness.

${ }^{2}$ Tractatus Theologicus De Deo, etc. 1610. 
pamphlets began a new attack, and King James, having read his treatise on the nature of God, wrote to Winwood, calling Vorstius a "Monster" and a "viper" and his opinions "monstrons blasphemie and horrible Atheisme" and ordering Winwood to warn the States " how infinitely wee shall bee displeased if such a Monster receive advancement in the church." The States considered the matter. The king soon wrote again, threatening to consult other Reformed Churches "how to extinguish and remand to hell these abominable Heresies." Meanwhile no Englishmen would be allowed to repair to "so infected a place, as is the Vniversitie of Leyden." On Dec. $19 \mathrm{~W}$ inwood transmitted another protest, and James even had the books of Vorstius burned in St. Paul's ehurchyard in London and at Cambridge and Oxford.

One needs to remember who James I. $^{1}$ was, whom Henry IV. of France called "the wisest fool in Christendom," in order to appreciate the absurdity of such complaint of a man who had written a volume to clarify and elevate the popular idea of the divine nature. That this absurdity was not unrecognized is plain from the fact that the end of the year left the States still treating Vorstius as a professor in quality and honor; although, because of political considerations, he refrained from public instruction. The near presence of such a suspect and the progress of such a controversy must have interested the Pilgrims, especially their pastor.

At Amsterdam, early in the year, four members of the church remaining with Jolmson, left abruptly and joined the English Reformed Church. ${ }^{2}$ The elders of the abandoned body failed to secure their attendance in private session, but on $\mathrm{July} 9$ the offenders appeared before the church as a whole. Charges and countercharges of schism and other sins were made and the meeting did no good. Before the end of the following January Clristopler Lawne, John Fowler, Clement Sanders and Robert Bulward were excommunicated. The bitterness apparent in

1 J. R. Green admits that James was a ripe scholar, yet adds (Hist. Eng. People, iii : 55$)$ : "He had in fact the temper of a pedant, a pedant's conceit, a pedant's love of theories, and a pedant's inability to bring his theories into any relation with actual facts."

2 Proph. Schisme, 1-6, 20, \$.2. 
this trial also showed itself otherwise. ${ }^{1}$ John Trappes, of Ainsworth's company, offered to prove before magistrates "that there is probable murder, and approved whoredomes maintained or suffered in M. Johnsons Church," and Elder de la Cluse endorsed the charge. During the year Johnson defended his new view of church polity in a quarto, expounding the eighteenth chapter of Matthew so as to justify his interpretation. He says : ${ }^{2}-$

Where [in their ancient Confession of Faith] it is saide, that by those wordes (Tel the Church) Christ meant not the Presbyterie (that is the Congregation of Elders), it [that Confession] is vnsounde, and can not be warranted by the Scriptures.

Here should be mentioned "A note of some things called into question and controverted in the exiled English Church at Amsterdam," an undated pamphlet of four pages of which only one copy ${ }^{3}$ is extant, and which, in an ancient handwriting, is assigned hypothetically to 1611 . From internal evidence it cannot have proceeded from the Johnson party, since it aims " not to abridge the brethren of their assent or any right that doth apperteyne vnto them by the word of God." But it concedes that it is a mistake to infer from the eighteenth of Matthew that the elders may not admonish an offender, and that he may not be excommunicated should he despise their admonition. Perhaps it was an utterance of the Ainsworth party when they were striving to concede all they could to Johnson without absolutely disfranchising the church.

Smyth, with the few who had clung to him, found refuge in a bakehouse ${ }^{4}$ belonging to Jan Munter, a friendly Waterlan-

1 Lawne (Proph. Schisme, 83) tells the following, which, even after all due deduction, indicates what some of these men were like: "Thomas Cocky and Iacob Johnson, two men of note amongst them [the Ancient Church], both of them prophets, falling into variance one with another, one of them brings in before the Church a List of fifteene lyes wherewith he charged the other; the other againe, to requite his paines, brings in at the next turne against him a List of sixteene lyes; betwixt them both they make vp the summe of 31 lyes."

"A Short Treatise Concerning the Exposition of those Words of Christ "Tell the Church," etc., Matt. 18, 17, 1611, 4to, 7.

${ }^{8}$ In the Prince Collection in the Boston Public Library, where it is bound up with Johnson's Short Treatise, 3, 4.

4 Some churches then, says Frederik Muller, had peculiar bakehouses to make. 
der. ${ }^{1}$ Helwys, Murton and their associates, after purging themselves of Sinyth and his adherents, continued in Amsterdam. In 1611 they printed "A Declaration of Faith of English People remaining at Amsterdam in Holland" 2 to justify their course which they thought a middle one between that of the companies of Johnson and Ainsworth and that of Smyth - and to gather the scattered English believers to themselves. They set forth their creed in twenty-seven articles. It was Calvinistic on the Trinity, the Fall and the Atonement. It was Arminian on Predestination and Falling from Grace. It was Separatist in its doctrine of the Church. It sided with Ainsworth on Church Government and the Eldership. It was with the Mennonites in denying Infant Baptism. It differed from Smyth's latest views as to Oaths and the Magistracy. It contained an affectionate tribute to him, yet bore testimony against his errors. Helwys, moved by the current Arminian discussions, also prepared two other books, whose titles suggest their significance. ${ }^{3}$

In England the year was unmarked in ecclesiastical matters. Thomas Bilson, then Bishop of Winchester, printed a new edition, in Latin," of what his biographer terms his " superfluously learned and unattractive" 5 "Perpetual Government of Christs Church," of 1593 ; a book which, nevertheless, is called even now "one of the best defences of the divine right of Episcopacy." 6 The supreme literary and religious event of the year was the first issue of the revised Bible. Scholars like Ainsworth and Robiuson must have watched for it. Yet it is not certain that any copy of either of the two folio ${ }^{7}$ editions of this year reached bread for the poor. This building niay have been such a one, and also may have sheltered poor members. Evans, i: 220.

1 Ms. letter of Prof. Scheffer.

2 The only known copy is a $16 \mathrm{mo}$, in the York Minster Library, Eng. But it has been partly reprinted in Crosby's Hist. Eng. Bapts. (ii : App. 1) and in the Hansard Knollys Society's Confessions (3-10).

${ }^{3}$ A Short and Plaine Proofe by the Word and Workes of God, that Gods Decree is not the Cause of anye Mans Sinne or Condemnation, etc., Svo.

An Advertisement or Admonition unto the Congregations which men call the $N e w$ Fryelers, etc., 16 mo.

* De Perpetua Ecclesiae Christi Gvbernatione in qua tractanter Patria potestas quam Deus primum in Patriarchis pro regenda Ecclesia sua instituit, 4 to.

C Dict. Nat. Biog. v: 44.

6 J. Hunt, Relig. Thought in Eng. i: 88.

7 It was long supposed that only one edition was printed in 1611 , and Anderson 
Amsterdam or Leyden. Probably they knew that one rule of the revisers was this: "The old ecclesiastical words to be liept: as the word 'Church' not to be translated 'Congregation,' 1 etc." At any rate the Pilgrims long clung to the Genevan version, and it was nearly half a century before that of 1611 established itself as the Bible of English-speaking people.

Of much more interest to them then, no doubt, was a volume ${ }^{2}$ by Barrowe, which has a little of the old Martin Marprelate flavor. Like issues of the fifteenth, and many of the earlier ones of the sixteenth, century, it carries its date, "MDCXI," on its last page; that on the title-page being the year of the martyrdom of that principal anthor from whom it was named. It is a dialogne on religion between Desiderius, an imperfectly enlightened and somewhat prejudiced inquirer, and Miles Micklebound, a well-informed and fairly candid Separatist. Its object apparently is only to render available apt quotations from Wiclif, Hooper, Fenner, Cartwright and others; a letter written in 1594 by a Brownist in Ireland to a Mr. Wood, a Scotch preacher there; two petitions, one by Barrowe and the other by some umnamed person ; and, especially, the "first part" of a "Platforme" remaining in Barrowe's manuseript, the publishing of which it was thought would greatly aid the truth and which fills exactly one third of the book and vitalizes its title. ${ }^{3}$

so states (Annals, ii. Chron. Index. xxii). But Henry Sterens in The Bibles in the Caxton Exhibition $(1877,109-111)$ proves that there were two, and that they were distinguished oddly by different readings - " "he went" and "sle went" - of Ruth iii : 15. whence they have become known as "the great He Bible" and "the great She Bible."

1 Anderson, ii : 377.

2 An apparently unique copy is in the British Museum. Mr. Henry Barrowes Platform: which may serve as a Preparative to urge away Prelatisme: with some other parts of Poperie, etc. 1593. $18 \mathrm{mo}$.

${ }^{3}$ In discussing communion between Christians, Desiderins refers (143) to the fact that some Brownists hold private communion, with those with whom they cannot in conscience commune publicly, to be right, and wants Miles's judgment as to that. Miles replies: "For their opinion I would have my jndgment spared at this time: Onely this I say, that their difference is not such as onght to make any division between them."

The copy in the British Museum contains this marginal note in the handwriting of the period: "This answer concerning private communion is not in Barrowe's [manuscript?] neither do any of us approve of it: but it is the corruption of the printers." 
There are added a Memorandum, dated 1604, showing the severity of the English government towards the Separatists, and an anonymous Writing, justifying marriage by others than the clergy. The Platforme is a vigorous argument against the hierarchy.

\section{2.}

The archives reveal comparatively little about the Pilgrims during 1612. There were only three weddings. William White and Susanna, or Anna, Fuller were betrothed on Jan. 27, with her brother, Samuel, William Jepson and his wife, Rosamond, and Sarah (Mrs.) Priest as witnesses. They were married on Feb. 11. White was a wool-carder. George Morton and Juliana Carpenter were betrothed on July 6, in the presence of his brother, Thomas Morton, Roger Wilson, Alice Carpenter, her sister, and Anna Robinson. He was a merchant from York and withont much doubt originally from Harworth, near Bawtry and Austerfield. She was a daughter of Alexander Carpenter, from Wrington, Somerset. Their marriage took place on July 23. They came to Plymonth in 1623, in the Anne or Little James, with their four children, Nathaniel, Patience, John and Sarah. Edward Pickering, also a merchant, and from London, and Mary Stubbs, ${ }^{1}$ from Stromsey, were betrothed on Nov. 24, accompanied by Henry Marshall, George Morton, Randall Thickins, Roger Wilson and Agnes and Alice Carpenter, Juliana's sisters. They were married on Dec. 15 .

On July 20 William Bridgman buried a child in St. Peter's, and no other death in the company is chronicled. William Bradford became a citizen on Mar. 30, endorsed by William Lisle and Roger Wilson, and Henry Collet on the same day, endorsed by Abraham Gray and Richard Masterson. On Mar. 21 Henry Collet bought a house on the Dwarsheerensteeg in the Zevenhrysen, from Thomas van Oudemarck, and on Apr. 19 Robert Cushman bought another house near by in a place on the south side of the Nonnensteeg from Cornelis Ghysberts van Groenendael, Richard Masterson becogning surety for him, for

\footnotetext{
1 Her last name seems to be written "Stuvvs" in the records.
} 
780 gilders. He paid 200 gilders down and 100 more were to be paid in a year and the balance later, with five gilders annually as ground-rent to the city. On May 1 the purchasers of the house on the Kloksteeg received possession of it and undonbtedly Robinson moved in at once. Possibly they already had constructed a chapel, for use in worship, within, or as an addition to, the main house. As Bradford says ${ }^{1}$ that before they left Leyden the church numbered nearly three hundred, and I'inslow that they met in Robinson's house, unless this were much larger than the known facts indicate, some addition must have been made. Probably their first really well accommorlated worship since reaching Leyden was on the next Sabbath, May 6.

It is worth while to try to realize to ourselves the character of their Sabbath services. Clyfton, to whom the whole movement was largely due, and who was pastor or teacher of the chureh in Scrooby, but who remained at Amsterdam, left two descriptions, essentially the same; one in his "Plea for Infants" (1610), ${ }^{2}$ and the other in lis "Advertisement" (1612). ${ }^{3}$ As the two volumes were in manuscript for some time previous to these dates, as Clyfton belonged to the Ancient Clumeh in Amsterdam after the other Pilgrims left, and as there is no evidence of any difference in the order of service between this church and Robinson's, presumably the form here given is that used in Leyden. The two versions, the longer one being taken from the "Plea" and the briefer from the "Advertisement," are as follows:-

1. Prayer and giving thanks by the Pastor or Teacher.
1. For prayer \& giving of thanks, that is publiquely performed by our Pastor or Teacher, who invocate the name of Gol \& praise him for his benefits, as the spirit directs their harts to conceive and giveth utterance, \& that withont the use of any book during that

1 Dial. in Young, Chrons. 455, etc., and Hyp. Vnm. 90.

2 Ans. to Smyth's Epis. to Reader, 10, 11.

${ }^{3}$ xiv. See p. 384 . 
action, according to these Scriptures, Rom. 8.26.27. Eph. 6, 18, 19. Col. 4. 2. Act. 6. 4. Nmm. 6, 23. 24.-27. Nehem. 9, 3-38. Ezra 9, 5-15. \& 10. 1. Ioel 2, 17.

2. Reading of two or three chap2. They read the holy scriptures, ters of the Bible, with brief Explanation of the same, as the time may serve. translated into oul owne language, some two or three chapters or moe, as tyme wil serve, shewing briefly the meaning thereof. Which is warranted by these Scriptures. Neh. 8, 3-8. Deut. 31, 11. Act. 15, 21. Col. 4, 16. I Thes. 5. 37. 1 Tim. 4, 13.

3. The singing of some of the Psalmes of David.

4. A sermon - that is, the pastor or teacher expounds and enforces some passage of the Scripture.
5. The singing againe of some of the Psalmes of David.

6. The sacraments are administred, - that is, the Lords Supper on stated Lords Days, and baptism whenever there might be a candidate.
3. The Pastor or Teacher taketh some Scripture, which they ordinarily follow, and after the reading thereof, do expound and apply the same, by doctrine, exhortation, \&c. to the further edification of the church: according to these Scriptures. Luk. 4. 16-21. Act. 8. 35. \& 13.15, and 26. 7. 1 Tim. 4,13. 2 Tim. 4, 2. And together with the preaching of the word, the Sacraments are administred after the rules of Christ, with prayer and thankesgiving, according to these Scriptures: Matt. 28, 19. I Cor. 11, 23. \&c. Act. 20, 7. \&e.

4. Some of the Psalmes of David, before and after the exercise of the word (the same being first read and opened by the Pastor or Teacher,) is sung of the whole church together to the praise of God, and our own edification, according to these Scriptures: Eph. 5, 19. Col. 3, 16. Matt. 26, 30. Act. 16, 25. Psal. 95. \& 92, 1 . \& 66. 2. \& 89. 1. 
7. Collection is then made, as each one is able, for the support of the officers, and the poor.
Lastly, each one as he is able, contributeth to the Treasurie, whereby the Officers \& poor of the church, are maynteyned: according to these Scriptures: I Tim. 5, 17. 18. I Cor. 9, 7-14. Gal. 6.6. I Tim. 5. 16. Luk. 22. 1, 2. 3. 4. Matt. 26, 9. 10. 11. Act. 2, 42. 45, 46. \& 4, 34. 35-37. I Cor. 16. 1, 2. 2 Cor. 8, 4, 15. And this is that worship and service we publikely practise, which Mr. S $[$ myth]. calleth false worship: how truly, let the Reader now judge.

Probably they also used that version of the Psalms which their friend Ainsworth had just prepared. At any rate they brought it to Plymouth, where it continued in use for seventy years. A copy was left by Brewster. As issued in this year, it was a vellum-covered quarto ${ }^{1}$ of 352 pages, from the press of Deacon Giles Thorp. It contained a new prose translation from the Hebrew ; a translation in metre; "singing notes," mostly taken from "former Englished psalms" or the "gravest and easiest" of the French or Dutch tunes; and expository annotations. It is likely that the Twenty-third Psalm was chosen on this first Sabbath to express their gratitude and trust. Rude although their version of it seems now, it helped them to praise with a fervor which led Winslow, a generation afterwards, to revert to the singing of such psalms by that people in that place as " the sweetest melody that ever mine eares heard." 2 Very likely they also sang the One Hundredth Psalm on that occasion.

It should be noted that apparently the Pilgrims, when they had any distinctively church action to take, took it on the Sabbath at the close of worship, as entirely appropriate. Ainswortl, whose general views closely resembled theirs, declares: ${ }^{3}$ " The Church judgments are the Lords works, not ours, and there-

1 The Book of Psalmes: Englished both in Prose and Metre. With Annotations, etc., 1612. Four editions are in the Dexter Collection at Yale.

2 Hyp. Vnm. 91.

3 Animad. 44. 
fore fittest to be doon on the Lords day." And Robinson bears similar testimony : ${ }^{1}$ -

This whole proceeding we make, and use ordinarily on the Lord'sday, as being properly the Lord's work, a work of religion, directly respecting the soul, and conscience: and of spiritual nature, as being an administration of Christ's kingdom, which is not of this world. John xviii : 36 . And this also when the whole church is gathered together, as which it concerneth many ways. I Cor. iv : 4, 5 .

Apart from the Pilgrims, the earliest important event in Leyden was the call of Simon Episcopius to teach theology in the university. Vorstius, although appointed successor to Arminius, had not been allowed to assume office, and in February the Curators elected Episcopius, then twenty-nine. In part this choice was a matter of avowed policy, to exemplify toleration by providing two professors of theology of opposite opinions. John Polyander, Gomar's successor, was more amiable than he, although holding substantially the same views. But between him and Episcopius, the foremost disciple of Arminius, entire sympathy was impossible. Episcopius delivered his inangural address, on Feb. 23, on the theme, "How Best the Kingdom of Christ among Men May Be Built Up." The topic suggests a typical feature of his belief - that the central idea of Christianity is practical rather than theoretical; while the watchwords of his exhortation were these three, truth, justice, peace, which represent his spirit.

Meanwhile Vorstius had been summoned to The Hague by John of Barneveldt, the chief executive of Holland, to defend himself before the Provincial Assembly. Early in March he was heard and satisfied most of his anditors, but in vain. King James had demanded his exclusion from Leyden, ${ }^{2}$ and, disinclined although Barneveldt was to submit to James's dictation, the theological, and especially the political, complications of the time seemed to require the sacrifice of any mere individual. Vorstins was ordered to choose some other residence than Leyden or The Hague and to prepare a written reply to his accuser's, eighteen months being allowed him. Accordingly he settled at Gouda.

1 Horks, iii : 187.

2 Ms. Resolutions of the Court of Holland, at The Hague: Feb. 27, 1612. 
In the English colony at Amsterdam the most prominent event of the year was the death, in August, of Smyth, then not far from fifty. He died of quick consumption and was buried in the Nieuve Kerk on Sept. 1.

Earlier in the year several members of Ainsworth's portion of the Ancient Church took legal measures to expel Johnson's ${ }^{1}$ followers from the meeting-house built for the original church. It will be remembered that in, or about, 1607 that church had been assisted from England to erect a building which Johnson and his friends still occupied. It had been an implied, if not an expressed, condition that the church should adhere to its original creed. After the separation in 1610 the question rose, which party retained the right to the building. Ainsworth and his supporters agreed publicly that they "would rather bear the wrong, than trouble the Magistrate with our controversie," and, as a body, they took no other action. But two men and one woman of their number, being chief owners of the building, felt unable to submit to the loss of their interest in it. After endeavors to arrange for an amicable sale to those in possession had failed, and when the Johnsonians also had refused arbitration, even after being urged by the Burgomasters, Ainsworth's church did not forbid these individual owners to maintain their legal and moral rights. No actual record of the decision has been found, but there is evidence that the Ainsworth party was in possession soon after ${ }^{2}$ and that the Johnsonians were elsewhere. ${ }^{3}$

A bout midsummer there was published in London a scurrilous tract, already referred to, "The Prophane Schisme of the Brownists or Separatists, with the Impietie, Dissensions, Lewd, and Abhominable Vices of that impure Sect," ${ }^{4}$ purporting to be by four excommunicated members of Johnson's church. ${ }^{5}$ It con-

1 Animad. 2-3.

3 Shield of Def. 33. Hoornbeek, Sum. Controv. 740.

2 Paget, Arrow, 304.

4 The preface to Robinson's book hints that Ames and others in sympathy with him were the real authors of the tract passing under the name of Lawne, ete. A few months later these same writers, excepting Lawne, published at Amsterdam $A$ Shield of Defence against the Arrows of Schisme. In the preface they complain of injury done them in the tampering with the text of their former book by sone unnamed person, through whose intervention it was published.

5 See p. 536. 
sists mainly of accusations against that church and its officers. Several incidental references to Robinson and other Pilgrims appear, and there is quoted a part of the correspondence between Ames and Robinson about Christian communion, already referred to. Later in the year this pamphlet was answered by Clyfton in "An Advertisement concerning a book lately published by Christopher Lawne and others," in which the accused are defended, Studley contributing a statement. ${ }^{1}$

Another publication by an English exile in Holland was Henry Jacob's "Declaration and Plainer Opening of Certain Points . . . contained in a Treatise intituled, The Divine Beginning . . . of Christes true, visible and ministeriall Church." It is a letter to a friend in England, dated at "Middleborough," Sept. 4, 1611, to deny having joined the Separatists and to explain further his doctrine of the church. An undated pamphlet, edited by Thomas Pigott, also was issued, probably in the winter of 1612-13, with the title substantially as follows: "A Declaration of the Faith of the English People remaining at Amsterdam, being the remainder of Mr. Smyths Companie. With an Appendix giving an account of his sickness and death." It includes Smyth's last book, "The Retractation of his Errours." The Confession of Faith is memorable as an early Baptist creed.

In England a contract was signed in May for the marriage of King James's only surviving daughter, the Princess Elizabeth, then fifteen, to the young Elector Palatine, conspicuous in the Union of German Protestants, with which James had just formed a treaty of alliance.- The match hardly was brilliant, but the king's preference of a Protestant son-in-law eventually led to the establishment of the Protestant succession on the British throne.

King James's alacrity in advocating the persecution by another government of its heretical subjects has appeared in the case of Vorstius. He also applied his principles unflinchingly at home. In March one Bartholomew Legate, a professed Arian, was convicted of heresy, upon James's instigation, and was

1 In 1613 another pamphlet appeared in London over Lawne's name, entitled Brownisme turned the In-side out-ward. It is less personal, and, although dealing with matters treated in the former pamphlet, it adds little to the facts. 
burned at Smithfield, having the melancholy distinction of being the last of a long list of Englishmen to suffer this fate there in the name of religion. This year also were printed at Oxford for the first time the arguments of Walter Travers and Richard Hooker, before the Privy Council in 1591, on the doctrinal differences between Calvinism and the Church of England. 


\section{CHAPTER VI}

\section{THE SUCCEEDING YEARS - 1613-1616}

The year 1613 found the Pilgrims well settled in Leyden. They had become so far identified with its life as to feel measurably at home. The struggle for a living still was severe. But their increasing familiarity with the language and customs of the people and their unfailing good repute had removed, or modified, some early hindrances of their prosperity, and certain perils which threatened their welfare later had not yet become apparent. They prized especially their religious freedom.

Five weddings occurred. On Mar. 15, Samuel Fuller, widower of Alice Glascock, was betrothed to Agnes, one of Alexander Carpenter's daughters. They were accompanied by Alexander and Alice Carpenter, her father and sister, Edward Southworth, William White and his wife, Susanna, and Roger Wilson. They were married on Apr. 24. Fuller was a sayweaver and from London. Later he served the Pilgrims well as a physician. Thomas Morton has said - upon what authority is unknown - that he was born at Wrington, Somerset, from which the Carpenters had come, and had been bred a butcher. ${ }^{1}$ On May 7 Edward Southworth and Alice Carpenter themselves were betrothed in the presence of Fuller, Thomas Southworth, Edward's brother, Roger Wilson, Elizabeth (Mrs. John) Jennings and Anna (probably Mrs.) Ross. The marriage was on May 28. On Nov. 1 Henry Collins and Mrs. Jennings's sister, Dorothy Pettinger, were betrothed, accompanied by William Bradford, Edward Southworth, Mrs. Jennings and Mrs. Ross, and they were married on Nov. 20. Collins lived in Amsterdam and was a bombazine-weaver. He had lost his first wife, Margaret Grimsdike. He and his first wife both were from Sutton, Notts., near Scrooby, and he is recorded ${ }^{2}$ in Amsterdam as hav-

1 New Eng. Canaan, III. 18, 152.

2 Doop, Trouw en Begrafenis Regs. 666: 68. 
ing shown "a certificate of nativity in the hand of Richard Clyfton, minister at Sutton," the contents of which also were " eutered in Sutton."

The next wedding took place in Amsterdam on Dee. 10. It was that of William Bradford, who was betrothed there on Nov. 9 to Dorotliy May, ${ }^{1}$ a danghter of Henry May, from Wisbeach, Cambs., who witnessed their banns in Amsterdam. They were betrothed again at Leyden, unaccompanied and "by attestation upon their own behalf," on Nov. 15. The Leyden records report the marriage with the note "No certificate left." Bradford was twenty-three and she was only sixteen. She accompanied him to America in the Mayflower but was drowned at Provincetown. They left their only child, John, behind them, and he came over in 1627. Bradford afterwards married Edward Southworth's widow (Alice Carpenter), but there is no anthority for the tradition that they had been lovers in youth and had been separated. In 1625 Henry May lived in Leyden, and very likely was the Mr. May prominent in the Ancient Church in Amsterdam as early as 1598, and who in 1622 was Jean de la Cluse's fellow-elder in Ainsworth's branch of that church. The last marriage was that of Moses Fletcher and Sarah Denby, on Dec. 21, after betrothal on Nov. 30 attended by Bradford, William Lisle, Mrs. Priest and Margaret Savory. It was a second marriage in each case, he having lost his first wife, Maria Evans, and she her first husband, William Denby. Fletcher was a smith, and he came over in the Mayflower, leaving her in Leyden.

No one known as a member of the company is entered as having died this year. Only two became citizens: William Minter on May 3, guaranteed by Abraham Gray and Roger Wilson : and Edmond Chandler on Nov. 11, by Wilson and Henry Wood. On June 13 Thomas Smith, then forty-six, and Anthony Fretwell, then thirty-six, made affidavit in behalf of Joseph Freeman. Smith was a wool-comber from Colchester and had been a deacon of "the English church" at Amsterdam, but of which church is unknown. Presumably he belonged to the company in Leyden, and Fretwell and Freeman may

1 D., T. and B. Regs. 667: 52 and Pui Bk. s.d. (Amst.) Echt Bk. B. 25. (Leyd.) 
have been Pilgrims, but there is no other indication of the fact.

Changes in the university were few. The veteran professor of Mathematics, Rudolf Snellius, died in March, after thirtyfour years of service; and Dominicus Baudius, professor of History, in August, having taught ten years. The Faculty of Philosophy was strengthened by the appointment to his father's chair of Willebrord Snellius, son of Rudolf, then twenty-two, who already had lectured for three years. Episcopius continued his teaching without incident. But in April he visited Amsterdam, to be sponsor for his brother's eldest child, and a surviving letter ${ }^{1}$ says that the officiating minister travelled outside the printed form of service, trying to entrap him into Calvinistic admissions; while the clergy were rude and the populace offered gibes and violence.

Concerning the English in Amsterdam little appears. Probably it was in this spring that Francis Johnson, with certain followers, migrated to Emden. Not all of his adherents, however, removed with him, and evidence that Clyfton remained behind is the record ${ }^{2}$ of the death of his wife, Anne, in Ansterdam on Sept. 3, 1613, aged fifty-eight. Ainsworth's " Animadversion," already referred to, appeared this year. It explains their. recourse to law about the meeting-house, and justifies the doctrinal differences which led to the separation. All references to the Leyden church are friendly. Robinson and Brewster contribute an account of the part taken by them, and Robinson also answers objections by Johnson to his former writings on church govermment. There was no other fruit of Robinson's pen this year, and one Leonard Busher, apparently leader of some Anabaptist secession in Amsterdam, ${ }^{3}$ complained ${ }^{4}$ in 1614 that Robinson "hath had a writing of mine in his hands above six months, and as yet I can get no answer." This year another book by Jacob on church government was printed, perhaps at Geneva. Its scope is indicated by its title: "An Attestation of many Learned, Godly, and famous Divines, Lightes of Reli-

1 Brandt, ii : 127-129. 2 Clyfton Family Bible. Oxford. Taylor Inst.

${ }^{3}$ C. Lawne, Proph. Schisme, 56.

4 Religion's Peace, in Tracts on Liberty of Conscience. Hans. Knollys Soc. 52. 
gion, and pillars of the Gospell, iustifying this doctrine, viz. That the Church-governement onght to bee alwayes with the peoples free consent. Also this, That a trne Church vnder the Gospell contayneth no more ordinary Congregations but one," etc. The prefatory epistle is dated $18 \mathrm{July}, 1612$. A copy was in Brewster's library.

The controversy in the Dutch Church grew hotter. At the end of February six eminent ministers - including Hommius, for the Conservatives, and Uitenbogar't, for the Remonstrants, vainly conferred at Delft. While the States were trying to heal the breach, a letter arrived from King James declaring a complete reversal of opinion since the case of Vorstius! He now wrote of the opinions in dispute: "We do not perceive either of them to be so absurd as not to consist with the truth of the Christian faith, as well as with the salvation of men's sonls." 1

In England theological literature this year included no important works. Only two deserve notice: "The Auncient Ecclesiasticall Practise of Confirmation confirmed," by Dr. George Hakewill, chaplain to Prince Charles, written for the prince's confirmation in Easter week ; and the first two volumes of Thomas Jackson's valuable commentary on the Apostles' Creed. But, in general literature, the year saw the first editions of Drayton's "Polyolbion " and Purchas's " Pilgrims."

State affairs also were of small interest. The Elector Palatine married the Princess Elizabeth at Whitehall on Sunday, Feb. 1t, and by the end of April the young couple had reached The Hague on their homeward way, where, on May 16, he witnessed the signing of a treaty of alliance, agreed to, at James's request, by the States of Holland and the princes of the Protestant Union in Germany. Prince Frederick then hastened home, and Elizabeth, proceeding more leisurely, spent the night of May 21 at the Prinsenhof in Leyden, being received with "a glad and Royall welcome," the Pilgrims surely being interested spectators.

In March three commissioners were sent to London ${ }^{2}$ by the Dutch Company of East India Merchants in an unsuccessful

1 Winwood, Mems. iii : 452 .

${ }^{2}$ Cal. S. P. Colon. E. Indies. 1513-1616, 64. Gardiner, ii : 201. 
attempt to arrange differences between that body and the English East India Company. By order of the States, Hugo Grotius, who, although under thirty, already was eminent in both law and literature, went with them ; and interesting glimpses of the great Dutch scholar in English society are afforded in the diaries of Casaubon and the letters of Archbishop Abbot.

\section{4.}

The next year, 1614, was uneventful. There were only three marriages. Roger Wilkins, a wool-carder, was betrothed to Anna Hardy, daughter of Anna Hallett, on Mar. 28, accompanied by John Keble, Roger Wilson, Sarah Carey and Mrs. Hallett. They were married on Apr. 12. She was either a widow or the daughter of Mrs. Hallett by a former husband. Samuel Terry, a say-weaver from Caen in Normandy, was betrothed to Mildred Charles on May 16, with Samuel Fuller, Roger Wilson, Mary (probably Mrs. William) Ring and Mrs. Thickins as witnesses. Their wedding was on May 31. Terry apparently was a Walloon and was admitted to the Pilgrim Church ${ }^{1}$ from the French Church in Leyden, but when is not recorded. Probably it was at about this time and because of his marriage to a Pilgrim. John Jenny, a brewer's drayman, from Norwich and more recently from Rotterdam, was betrothed to Saralı Carey, from "Moncksoon," on Sept. 5, Roger Wilson and Jane Lee accompanying them. The marriage was on Nov. 1.

The only recorded burial is that of a child of $\mathrm{John}$ Keble on July 23 in St. Peter's. As Keble apparently had been married before settling in Leyden, and possibly long before, this child is more likely to have been well grown than an infant. Isaac Allerton's is the only discoverable admission to citizenship. It took place on Feb. 7 and Roger Wilson and Henry Wood vonched for him. In respect to business matters it is noted that on Jan. 2 Richard Masterson, wool-comber, from Sandwich, bought a house of Roger Wilson for 800 gilders. It was on the Uiterstegracht (Outermost St.), almost on the eastern border of the city. On Mar. 28 Henry Collet sold to John Keble 
the house on the Dwarsheerensteeg which he had bought in March, 1612, from Thomas van Oudemarck. On Sept. 10 William Minter bought a house on the Groenhasegracht from William Jepson for 850 gilders, and Jepson's deed of sale declares that William Robertson owned the next house on one side.

No changes occurred this year in the university proper. But Girard John Vossius, master of the Latin School at Dort, became regent of the Dutch Theological College in Leyden in place of Peter Bertins. He was thirty-seven and became famous for his elegant scholarship.

During this year Robinson published his work, "Of Religious Communion, Private, \& Publique," etc. In the preface the occasion of this writing is traced to Lawne's "Prophane Schisme of the Brownists," in 1612, to which Ames had contributed the private correspondence ${ }^{1}$ on fellowship. Robinson felt that this unauthorized publication did not state his views fully, and accordingly wrote this treatise. His chief aim is to show ${ }^{2}$

that we, who profess a separation from the English national, provincial, diocesan, and parochial church, and churches, in the whole formal state and order thereof, may notwithstanding lawfully communicate in private prayer, and other the like holy exercises (not performed in their church communion, nor by their church power and ministry,) with the godly amongst them, though remaining, of infirmity, members of the same church, or churches, ${ }^{3}$ except some other extraordinary bar come in the way, between them \& us.

This indicates a milder doctrine, showing that his Separatism tended to become more liberal.

His treatise gives incidentally some interesting details of the practice of the church in Leyden. It is noticeable that he disavows "popularity," i. e., democracy like that of modern Congregationalism. He says :-

The government of the church, then, as it is taken most strictly for the outward ordering, directing and guidance of the same church in her affairs, ... we place in the bishops, or elders thereof, called by

1 See p. 585. 2 Works, ed. 1851, iii : 2, 134-138.

3 Quoted as printed. The second parenthesis doubtless should begin with "though." 
Christ, and the chureh to feed, that is to teach, and rule the same. . . . Which their govermment, and the nature thereof, I will plainly lay down in such particular's, as wherein the people's liberty is greatest: which are reduced to these three heads: 1 . Exercise of prophesying: 2. Choice of officers: and 3. Censuring of offenders.

As to prophesying, he declares that " the officers, after their ordinary teaching," give the other church members opportunity to ask questions, to state doubts, or to exhort. Thus the people have a certain liberty, yet "the officers govern." As to the choice of officer's, he says :- -

We do take for our directions the practice of the apostles, and apostolical church, Acts i. and vi. and xiv, ... We do read, Acts vi, how the apostles call together the multitude; show them the necessity of choosing deacons, what their work is, and how they must be qualified, and how many they would have chosen: whom, being chosen accordingly, by the multitude, they ordain, ... Where it is evident, that though the calling did chiefly depend upon the multitude, yet did the government of the whole action lie upon the officers. Conformable whereunto is our practice, so near as we can, upon the like occasion.

As to censure, he says: "We propound to ourselves the rule of Christ, Matt. xviii. 17," etc., and explains its application. He adds, as to the mutual relations of officers and people:-

But for that the officers are frail men, and those "not lords over God's heritage," as are princes, and magistrates over their subjects, but ministers and servants of Christ the husband, and the church the wife, whom the thing concerns in their places, as well as them, 1 Pet. v. 3 ; 1 Cor. iv. 1 ; 2 Cor. iv. 1, 5, we think it lawful for the brethren, either doubtful of anything in the officer's administration, to propound their doubt for satisfaction; or seeing them failing in any material thing, to admonish them of their duty and that they "look to their office," Col. iv. 17, or, if need stand, to supply the same for the further clearing of things.

Then follows the passage, already cited, ${ }^{1}$ about transacting such business on the Sabbath. Evidently the usage of the Pilgrim Church was more liberal than that of the Ancient Church, and essentially like that of Ainsworth's church. It was on the way to, but had not yet reached, the more democratic positions which it came to hold in America. This treatise was answered in 
November by a pamphlet of ten pages, printed at Dort, entitled "A Manudiction for Mr. Robinson, and such as consent with him in privat communion, to lead them on to publick." It was unsigned, but is known to have been by Ames. He also printed anonymously at Dort a work by William Bradshaw, "The Vnreasonablenesse of the separation Made apparant by an examination of Mr. Iohnson's pretended reasons, published in 1608," a forcible statement of the Puritan, as opposed to the Separatist, view of membership in the English Church.

Of the English in Amsterdam the most noteworthy record is that of the successful renewal, on Nov. 6, by the remnant of John Smyth's followers, some thirty, of their appeal for admission to a Waterlander church.

The breach between the Remonstrants and the Contra-Remonstrants widened. Appeals to the States led to the passage in January of an ordinance, drawn by Hugo Grotius, which defined the limits of permissible doctrine in regard to predestination, but vainly.

English theological literature was unimportant, and the principal additions to general literature were Raleigh's " History of the World" and the first instalment of Chapman's translation of the Odyssey. Napier's first exposition of his invention of logarithms also appeared. Little happened politically. Parliament met on Apr. 5, but quickly refused supplies for the treasury until its grievances had been redressed, particularly as to the claims of the Crown to levy impositions upon merchaudise without Parliament's consent. A wrangle between the two houses ended in dissolution on June 7. The sinister result was that the king was led thereby to turn to Spain for alliance and aid.

\section{5.}

The matrimonial history of the company for 1615 includes four entries. Roger Chandler, from Colchester, a say-weaver, and Isabella Chilton, from Canterbury, were betrothed on May 22, with Roger Wilson, Catherine (Mrs.) Carver, and Sarah (Mrs. William) Minter as witnesses. The wedding was on July 21. Samuel Butler, a merchant from Yarmouth, and Sarah 
Porter, from "Mindelton," Suff., were betrothed in presence of Samuel Fuller, William and Rosamond Jepson, and Sarah Minter on Aug. 7, and were married on Aug. 25. Sept. 16 witnessed the betrothal of Edmond Jessop, from Ackworth, Yorks., a bombazine-worker, the three months' widower of Ellen Underwood, to Abigail Hunt, from Guernsey, accompanied by Samuel Fuller, William and Rosamond Jepson, and Mary (probably Mrs. Henry) Wood. They were wedded on Oct. 3. Eight years later he became the anthor of "A Discovery of the Errors of the English Anabaptists." James Kingsland, a clothier, and Ellen Carlisle, a sister of James Carlisle and Anna (probably Mrs. Bernard) Ross, from Hull, also were betrothed in the presence of Robert Joy, Bartholomew and Doreas (doubtless Mrs.) Smith, and Anna Ross on Nov. 27, and were married on Dec. 12.

The burial list this year is the longest thus far. On Jan. 25 Randall Thickins, then living on the Nieuvesteeg, buried a child in St. Peter's. It must have been young, and no other child of his is recorded. In the same place, on June 15, Ellen Underwood, from Ackworth, Yorks., the first wife of Edmond Jessop, was laid to rest. He then lived in the Styensteeg (Stone Lane). Three days later, on June 18, William White, Samuel Fuller's brother-in-law, then resiling in the Groenesteeg (Green Lane), buried a child in St. Pancras; and only eleven days afterwards, on June 29, poor Fuller buried a child of his own in St. Peter's, and laid his wife beside it in four days more, on July 3. He lived then close at hand in the Pieterskerkihof. And on July 10 Thomas Willet, who lived on the Jacobsgracht, buried a child, also in St. Peter's.

Five more men in the company took the oath of eitizenship: John Keble, from Canterbury, wool-comber and say-draper, on Apr. 27, on the guaranty of Edmond Chandler and Henry Wood ; Alexander Price, eamlet-merchant, on May 18, on that of Roger Wilson and Wood ; Thomas Smith, from Colchester, cloth-merchant and ex-deacon, on July 29, on that of Jan Questroy Peters and François van der Becke; Samuel Lee, hatmaker, on Oct. 19, on that of Bradford and Wilson; and Degory Priest, from London, also a hat-maker, on Nov. 16, on that of Isaac Allerton and Wilson. 
On Feb. 17, Thomas Brewer, ${ }^{1}$ then thirty-five, was matriculated in letters in the university, and John Robinson, the Pilgrim pastor, received permission on Aug. $5^{2}$ to become a member of that institution. Rev. Robert Durie, an Englishman of fifty-five, who had come to Leyden, to be the first pastor of the Reformed Scotch Church, at almost the same time with Robinson, had been matriculated on Apr. 27, 1610. The reason of his speedy admission to university privileges doubtless was that his church was in direct fellowship with the Dutch Establishment, and had its house of worship and his salary provided by the State. Admission to the university then involved some exemptions from taxation and from service in the city guard, as well as a free annual allowance of beer and wine. ${ }^{3}$ The Rector Magnificus for this year was Cornelius Swanenburgius, professor of Law, and on Sept. 5 he admitted Robinson to the coveted enrolment. The record of admission describes Robinson as "An. xxxix," which means not aged thirty-nine, but in his thirty-ninth year. The phrase is of importance since it is the only known record on the subject.

In this year Robinson replied ${ }^{4}$ to Ames's pamphlet of the previous November. His title was "A Manumission to a Manvdvetion, or Answer to a Letter inferring Publique communion in the parrish assemblies upon private with godly persons there." He insists earnestly that private Christian fellowship with members of other churches does not involve formal public communion with those churches. He answers his opponent's questions and expands some arguments, especially on the status of the priest in the Church of England. The two main questions, in his view, are whether the jurisdiction of bishops in their dioceses is lawful or not, and whether parochial ministers in England preach by authority of the bishops or not. Of course he answers the first negatively and the second affirmatively, and his reasoning reveals his attitude towards the administration of the Church of England.

Before the year ended, Ames, still anonymously, followed up

1 Univ. Recs. s. d.

2 Burgmeester's Dag Bk. B, 272.

${ }^{3}$ Sumner, Mass. Hist. Soc. Colls. iii. ser. ix: 57, 72. Dexter, Cong. in Lit. $3 \mathrm{SS}$

${ }^{4}$ Reprinted in Mass. Hist. Soc. Colls. iv. ser. i: 165-194. 
his justification of the ministry of that ehurch by "A Second Manvdvetion, for $\mathrm{Mr}_{\mathrm{r}}$. Robinson. Or a confirmation of the former in an answer to his manumission." It is a detailed reply to Robinson with little novelty of topic or treatment. Among other publications of the year appealing specially to the Pilgrims was the controversial correspondence between Henry and John Ainsworth, written in $\mathbf{1 6 0 9}$ and already referred to. ${ }^{1}$

A peculiarly exciting disturbance, in connection with the persecution of the Remonstrants in the National Church, occurred in Amsterdam, where Simon Goulart, the younger, who for fourteen years had been a pastor of the French Walloons, and now was about forty, was suspended by his Consistory for defending Remonstrant innovations in doctrine.

At King James's request the negotiations attempted in 1613 between the Dutch and English East India Companies were resumed early in 1615 at The Hague, but were closed prematurely by the Dutch demand for a joint warfare upon Spain because of her aggressive course in the East Indies. Such action was impossible for the British king just then, for a marriage between the heir-apparent and the Spanish Infanta was under consideration.

The most important theological works of the year in England were William Bradshaw's "Treatise of Justification" and George Carleton's "Directions to know the True Church," the latter being aimed specifically at the Romanists. A notable illustration of the spirit in which ecclesiastical offences still were liable to be treated in England occurred this year. Edmond Peacham, a Somersetshire rector, was charged with railing at his bishop and with treasonable writings. He was actually, although ineffectually, tortured, and of this barbarity persons no less eminent than Lord Bacon and Archbishop Abbot were witnesses, if not instigators.

\section{6.}

The next year, 1616, was somewhat more eventful, owing to the current theological differences. But the internal history of 
the Pilgrim body was much like that of the preceding years. Roger Wilson, who had officiated as a witness at so many betrothals, was the first to need similar service this year. He was betrothed to Elizabeth Williams on Nor. 11, accompanied by her brother, Thomas Williams, afterwards a Mayflower passenger, and by Elizabeth Spalding. They were married on Mar. 26. Whether or not Henry Wilson was a relative of Roger is not known, but he was the first to follow Roger into matrimony, being betrothed on May 13 to Elizabeth Nicholas, in the presence of John Carver, William Jepson, Mrs. Bradford and Sarah (Mrs. William) Minter. He was from Yarmouth and was a pump-maker. She also was from Yarmouth, and their wedding was on May 28. Zechariah Barrow, who had lost his first wife, Ellen, and was a wool-carder, was betrothed to Joan Barrow on June 16, with John Crackstone, Moses Fletcher - both of whom came over in the Mayflower - and Mrs. Pontus for witnesses. They were married on July 2. John Spooner, a ribbonweaver living on the Bogertsteeg (Bogert Lane), who had buried his first wife in the spring, and Ann Peck, the ward of William Brewster, from Lownd, were betrothed on Nov. 9, accompanied by Samuel Lee and Elizabeth Spalding, and were married on Dec. 24.

The dead of the year numbered seven. Robert Cushman, then living on the Nonnensteeg, buried a child in St. Peter's on Mar. 11. Mrs. John Spooner (Susanna Bennett) was interred in the same place on Mar. 28. John Allerton, living in the Pieterskerkhof, buried a child there on May 21. Another Mary Butler, the one who had witnessed the banns of William and Wybra Pontus, also was buried there on July 16. Poor Cushman was called upon to part with two more of his stricken family in October. His wife, Sarah, was buried in St. Peter's on the 11th and another child on the 24th. Since March he had removed from the Nonnensteeg to the Boisstraat. William White also buried another child in St. Pancras on Dec. 21.

On June 3 Thomas Smith and Joseph Lambertson guaranteed Joseph Crips for citizenship, and on Dec. 16 John Keble and William Minter performed the same service for William Jepson. On Apr. 11 Bernard Ross ${ }^{1}$ made a deposi-

1 Proc. Bk. ad lites, A, s. d. 
tion in regard to his lawsuit with Joseph Lewis. He was obliged to go to Amsterdam and England and was afraid that Lewis might take advantage of his absence to try to get the case decided against him.

Outside of the Pilgrim congregation an event in which they must have felt some interest was the death of Robert Durie, minister of the Reformed Scotch Clureh, who was buried in St. Peter's on Sept. 16, aged sixty-one. At this date his more famous son, John Durie, was about twenty.

In the university circle this year witnessed some specially vigorous attacks upon Episcopius, the most important being instigated by Hommius. A formal investigation of the charge of Socinianism was leeld before the Curators of the university and the Burgomasters, but the result satisfied neither party.

Probably it was not far from this time that Robinson disputed publicly with Episcopius, especially in one formal debate. It is much to be regretted that so little is known about an event so significant in itself and so full of interest to the Pilgrims. The invitation to represent the conservative party was a tribute at once to Robinson's conceded ability as a reasoner and a public speaker, and to his growing prominence in the intellectual and theological fellowship of the city. It was a notable mark of respect and confidence which must have gratified him and all his company, apart from the fact that it necessarily added to their good repute as a body. Nor can the advantage of snch an invitation have remained merely local. Throughout Holland interest in the current discussions was so great that such a debate was followed widely and with keen attention, and Robinson must have become known much more generally and favorably than before by his mere selection to encounter so distinguished a champion as Episcopius. But his characteristic modesty, shared by his friends, prevented any, excepting the most scanty, record of the affair from being handed down.

In marked contrast to what was customary, he had taken pains to hear both sides, frequenting the lectures not only of Polyander, with whom he agreed, but also of Episcopius; "by which means," says Bradford, ${ }^{1}$

1 Hist. 20, 21. 
he was so well grounded in $y^{\mathrm{e}}$ controversie, and saw $\mathrm{y}^{\mathrm{e}}$ force of all their arguments, and knew $y^{e}$ shifts of $y^{e}$ adversarie, and being him selfe very able, none was fitter to buckle with them then him selfe, as appered by sundrie disputs; so as he begane to be terrible to $\mathrm{y}^{\mathrm{e}}$ Arminians.

Apparently several minor discussions took place, in which Robinson participated to the great satisfaction of the conservatives, and, spurred on by these, Episcopius "put forth his best stringtl, and set forth sundry Theses, which by publick dispute he would defend against all men." It was this challenge, especially, which Robinson was persuaded to take up. He was reluctant to serve. "He was loath, being a stranger." But it was urged by Polyander and the "chiefe preachers of $y^{e}$ citie" that "such was $y^{\mathrm{e}}$ abilitie and nimblnes of $y^{\mathrm{e}}$ adversarie, that $\mathrm{y}^{\mathrm{e}}$ truth would suffer if he did not help them." So he yielded.

However radically Episcopius may have differed from Robinson, he probably had no occasion to complain of unfairness or discourtesy on Robinson's part, which must have been an un. usual experience. Bradford says further of Robinson :-

The Lord did so help him to defend $y^{e}$ truth \& foyle this adversarie, as he put him to an apparent nonplus, in this great \& publike audience. And $\mathrm{y}^{\mathrm{e}}$ like he did a 2 . or 3 . time, upon such like occasions. The which as it caused many to praise God $y^{t}$ the truth had so famous victory, so it proeured him much honour \& respecte from those lerned men \& others which loved $y^{\mathrm{e}}$ trueth.

Doubtless Episcopius was as conscientious as Robinson, and allowance must be made for the natural predisposition of Brarford and Winslow, the only reporters of the affair, in favor of their pastor. Yet probably there is no reason to doubt their statements that Robinson generally was regarded as having had the best of the argument. Indeed Bradford adds that, "were it not for giveing offence to $y^{\mathbf{e}}$ state of England, they would have preferd him otherwise if he would, and [if he would have] alowd them [they would have shown him] some publike favour."

From Amsterdam came the news of the death, on May 20, of Richard Clyfton, aged about sixty-three, the original pastor or teacher of the Scrooby church. To the Pilgrims, especially to 
those from Scrooby and vicinity, who had been identified with the formation of the church and its earliest struggles and perils, this news must have caused genuine sorrow. He was the first of their original leaders to be taken away, and, althongh during the seven years since they had left Amsterdam, most of them probably had seen him seldom, they cannot have failed to continue to regard him with respect and affection. He remained with that portion of the Ancient Church which adhered to Francis Johnson, and he took some part in the controversies which have been described. ${ }^{1}$ But he does not appear to have been bitter in spirit. How far he sympathized with Johnson's extreme views is uncertain. Although ready to make sacrifices for his convictions, his natural disposition evidently was peaceable. Apparently he aged prematurely, and he may have preferred to acquiesce to a large degree in what he could not help rather than to contest it, but there is no evidence that he did not maintain cordial relations with the Pilgrims as long as he lived.

During the year Henry Ainsworth carried through the press the first instalment of his valuable exegetical work, "Annotations upon the first Book of Moses, called Genesis." There was issued also, under the care of Dr. Ames, a learned treatise, De Politeia Ecclesiastica Christi, et Hierarchica opposita, Libri Tres, written by Robert Parker, who died before its publication. A copy of it is named in the inventory of Brewster's library, which also inclndes another book printed this year, "The Revelation of S. John illustrated . . . By Thomas Brightman. Imprinted at Leiden, by John Claesson van Dorpe, at the Signe of the golden Sunne. Anno 1616."

In March a new English ambassador snceeded Winwood at The Hague, Sir Dudley Carleton. His correspondence for the next dozen years contains much of great interest in relation to current Dutch history. A sentence in his letter of instructions ${ }^{2}$ emphasizes the hierarchical claims of King James :-

1 Arber condemns Clyfton (Story Pilg. Faths. 116) as countenancing Studley's faults in the Advertisement, and declares that Clyfton retracted his own condemnation of Lawne's Prophane Schisme. His authority is Paget (Arrow. 4). But his quotation does not make it certain that Paget refers to Clyfton, and he accepts Lawne's accusations against the Ancient Clunreh as trustworthy too readily.

2 Letters from and to Sir D. Carleton, ed. 1780, 6, 82. 
In Holland there lately have been violent and sharp contestations amoug the towns in [the] eause of religion, which we fear are rather for the time allayed than quenched and extinguished. If therefore they should be unlappily revived during your time, you shall not forget, that you are the minister of that master, whom God hath made the sole protector of his religion.

Carleton's despatches this year refer often to the religions dissensions; and the last one, on Dec. 29, calls attention to the schism then at its height in Leyden, "where they have divided their churches betwixt the orthodox and Arminian factions, the one refusing to communicate with the other."

In this year Henry Jacob returned to England and organized in Sonthwark a church on Congregational principles which generally is accounted the mother church of the modern English Independents, or Congregationalists. At the same time he published, but anonymonsly, a declaration of principles, "A Confession and Protestation of the Faith of certain Christians in England. . . . Also an Humble Petition to the King's Majesty for toleration therein." In the Established Church the most conspicuous publication was Dr. Richard Mocket's Doctrina et Politia Ecclesiae Anglicanae, which was charged with heterodoxy and burned. The general literature of the year inchuded a collection of the "Works" of King James, edited by Bishop James Montagu, of Winchester; and, of much more importance to the Leyden Pilgrims, as matters turned ont, Captain John Smith's "Description of New England," with a map of the coast as alleged to have been surveyed by him in 1614 .

The year also was marked in England by the downfall of the reigning favorite, the Earl of Somerset, and the rise of a more dangerous successor, George Villiers, whose influence fostered the Spanish match. But an equally memorable fact in the view of posterity is the death of Shakespeare on Apr. 23 at Stratfordupon-Avon. 


\section{CHAPTER VII}

\section{THE SUCCEEDING YEARS - 1617-1619}

Coming events of serious importance began to cast their shadows before during 1617. Gradually it was becoming evident to the Pilgrims that Holland did not, and could not, afford the sort of refuge and opportunity which they desired. Reluctant though they were to emigrate again, and uncertain though they were where to go, they seem to have decided this year that their very existence as a church, and even as a body of English people, depended upon some such a step. Meanwhile their life went on much as hitherto.

There is no record of the death of the first Mrs. John Jemnings (Elizabeth Pettinger), butshe must have died before this year, as her husband was betrothed again on Mar. 3, this time to Rose, a daughter of William Lisle. The friends present were John Carver and Rosamond (Mrs. William) Jepson. They were married on Mar. 23. At this time Jennings was a merchant. Samuel Fuller, who had lost his second wife (Agnes Carpenter) the year before, also was betrothed again on May 12 to Bridget Lee, accompanied by Josephine and Samuel Lee, her mother and brother, and they were married on May 27. Two others of the company, Cuthbert Cuthbertson, a hat-maker, and Elizabeth Kendall, also were betrothed, in presence of Elizabeth and Edward Kendall, her mother and brother, on May 12, and were married on May 27. As Cuthbertson had been living with Lee, there must have been some intimacy between these two couples, and probably there was a double wedding.

Henry Collet, whose first wife had been Anna Harris, and Alice (Thomas), the widow of John Howarth, were betrothed on May 19 and wedded on June 3, the witnesses of the betrothal being John Crackstone, Thomas Harris - Collet's brother-inlaw - and Isabel (Mrs. Roger) Chandler; and on June 5, Robert 
Cushman married a second wife, Mary Singleton; their betrothal, when John Keble and Mrs. Carver had attended them, also having been on May 19. John Reynolds, from London, a printer employed by Brewer and Brewster, and Prudence Grindon, also from London, were betrothed on July 28, in presence of Mary (Mrs. William) Brewster and her son Jonathan and Mary (Mrs. Isaac) Allerton, and were married on Aug. 18. Stephen Butterfield, from Norwich, a say-weaver, and Rose Singer, from Yarmouth, were betrothed on Oct. 13, Abraham Gray and Sarah (Mrs. William) Minter accompanying them, and were married on Oct. 30 ; and Henry Jepson, from Worksop, Notts., a brother of William and a say-weaver, and Jane Powell, from Maldon, Essex, were betrothed on Dec. 8, with Henry Wood and Jane Lee for witnesses; and their wedding took place on Dec. 23 , or very soon afterwards, that being the date of the third and last publication of their banns.

On Apr. 12 Thomas Blossom, who lived in the Pieterskerkhof, buried a child in St. Peter's, and on Nov. 11 another child of John Carver, then living on the Middlegracht, appears to have been buried in St. Pancras, although in this instance again there is doubt about the name. Thomas Tinker, a wood-sawyer, was admitted as a citizen on Jan. 6, being vonched for by Abraham Gray and John Keble ; and Jonathan Brewster, described as a ribbon-weaver, on June 30, on the guaranty of two Dutchmen, Isaac de Syde and Sebastianson van Hout.

Not much light falls upon the business transactions of the Pilgrims this year, but on June 12 we find William Bradford ${ }^{1}$ borrowing 400 gilders from Jan van Griecken, a goldsmith, at six and a quarter per cent interest, on his house in the Achtergracht as security; and on Inne 17 Thomas Brewer buying from Johann de Lalaing the Groenehuis (Green House), on the Pieterskerkhof and next but "one to John Robinson's. He paid 600 gilders down and agreed to pay 131 and a quarter gilders annually.

Just when Brewer and Brewster staited as printers is not recorded. But it must have been as early as this year, or even 1616 , for at least four volumes can be traced to their press at

1 Prot. Schult. en Rent. N. 365, verso. 
this time, two in Latin and two in English. The Latin imprint gives their place of business, "in Vico Chorali," i. e., in the Koorsteeg (Choir Alley). The books are Dr. Ames's Ad Re. sponsum Nic. Grevinchovii Rescriptio contracta, a 16mo; Thomas Cartwright's Commentarii Succincti \& Dilucidi in Proverbia Salomonis, etc., a 4to; "A Full and plaine Declaration of Ecclesiastical Discipline," probably by W. Travers; and "An Abridgment of that Book which the Ministers of Lincoln Diocess delivered to his Majestie upon the first of December 1604."

Turning to their general affairs, their uneasiness in the inevitable conditions of Dutch life now becomes apparent. Bradford paints the shadows in the picture and Winslow confirms him. Clearly the Pilgrims were disappointed by their Dutch experiment in several important respects. Their original hope of receiving considerable accessions from England had not been realized. Bradford says that "few in comparison would come to them, and fewer that would bide it out and continew with them," such newcomers finding themselves unable, or unwilling, to

endure $y^{e}$ great labor and hard fare, with other inconveniences which they [the Pilgrims] underwent \& were contented with ... yea, some preferred \& chose $y^{\mathrm{e}}$ prisons in England, rather then this libertie in Holland, with these afllictions.

When it is recalled what the English prisons were, a strong and saddening light is thrown upon the condition of the Pilgrims in Leyden. That some had attained to a modest measure of prosperity must be true. But such testimony - written calmly by one who knew all the facts thoroughly - makes it clear that others had failed to lift themselves out of comparative poverty and hardship.

Moreover, old age was stealing upon many. The danger also grew greater daily of absorption into the Dutch nation and of losing their English characteristics, to which they clung with intensest loyalty. The strain of their life was ruining not merely the happiness but even the bodily vigor of their children, and inevitable moral temptations had proved too much already for some. Nor could they bring themselves to abandon the mission- 
ary purpose which they had cherished from the first, that they might demonstrate somewhere the value to mankind of a pure and democratic church. In Bradford's words :-

A great hope \& inward zeall they had of laying sone good foundation, or at least to make some way therunto, for $y^{e}$ propagating \& advancing $y^{e}$ gospell of $y^{e}$ kingdom of Christ ...; yea, though they should be but even as stepping-stones unto others for $y^{e}$ performing of so great a work.

But it was useless to expect to accomplish this purpose in Holland, especially just then. Winslow's testimony ${ }^{1}$ also should be quoted :-

Considering amongst many other inconveniencies, how hard the Country was where we lived, how many spent their estate in it, and were forced to return for England; how grievous to live from under the protection of the State of England; how like wee were to lose our Language, and our name of English ; how little good wee did, or were like to do to the Dutch in reforming the Sabbath; how unable there to give such education to our children, as wee ourselves had received.

Furthermore, they remembered that the truce with Spain would expire soon, and they had heard too much of the terrors of the earlier struggle to wish to risk their renewal. Bradford adds, although his words apply to the next two or three years better than to this : -

There was nothing but beating of drumes, and preparing for warr, the events wherof are allway uncertaine. $\mathrm{Y}^{\mathrm{e}}$ Spaniard might prove as cruel as the salvages of America, and $\mathrm{y}^{\mathrm{e}}$ famine and pestelence as sore hear as there, \& their libertie less to looke out for remedie.

Reluctantly, therefore, but more and more clearly, they reached the conclusion that they must leave Holland. Long and earnest discussions ensued and they seem to have decided to go to some part of America. But Bradford leaves it doubtful how far they were agreed. He says, "it was fully concluded by $y^{\mathrm{e}}$ major parte to put this designe in execution;" but whether the minority were large or small, and whether it strongly opposed this conclusion or only felt unable personally to help fulfil it, is left uncertain; and whether he means the design of emigrating at all, or that of seeking a home in America, is not plain. 
Then the question arose, where in America to go. Apparently the choice lay between Guiana ${ }^{1}$ and some part of the North American territory granted in 1606 to the Virginia Company, and it was decided to attempt an independent settlement under the Virginia government. But, as the Jamestown colony was controlled by Churchmen, an effort was made to secure, from King Jannes a pledge of religious freedom.

For this purpose Robert Cushman and Deacon John Carver were sent to London in the summer ${ }^{2}$ or autumn of this year, to negotiate with the Virginia Company. They submitted to the Council a somewhat remarkable paper, ${ }^{3}$ subscribed in behalf of the Leyden church by Robinson, its pastor, and Brewster, its elder. This document presents, in seven propositions, or articles, the position of the Pilgrims as to the English government and, especially, to the Established Church. It specifically assents to the Articles of the Church of England and acknowledges the king's anthority and that of the bishops and other ecclesiastical officers. It follows here in full :

Sever Artikes which $y^{e}$ church of Leyden sent to $y^{e}$ Counsell of England to bee considered of in respeckt of their judgments occationed about theer going to Virginia, Anno 1618.

1. To $y^{\mathrm{e}}$ confession of fayth published in $\mathrm{y}^{\mathrm{e}}$ name of $\mathrm{y}^{\mathrm{e}}$ Church of England \& to every artikell theerof wee do $\mathrm{w}^{\text {th }} \mathrm{y}^{\mathrm{e}}$ reformed churches wheer wee live \& also els where assent wholy.

2. As wee do acknolidg $y^{\mathrm{e}}$ docktryne of fayth theer tawght so do wee $y^{e}$ fruites and effeckts of $y^{e}$ same docktryne to $y^{e}$ begetting of saving fayth in thousands in $\mathrm{y}^{\mathrm{e}}$ land (conformistes \& reformistes) as $y^{e}$ ar called $w^{\text {th }}$ whom also as $w^{\text {th }}$ our bretheren wee do desyer to keepe sperituall communion in peace and will pracktis in our parts all lawfull thinges.

3. The Kings Majesty we acknolidg for Supreame Governor in his Dominion in all causes and over all parsons [persons], and $y^{t}$ none maye decklyne or apeale from his authority or judgment in any eause whatsoever, but $\mathrm{y}^{t}$ in all thinges obedience is dewe unto him

1 Their attention may have been drawn thither by Raleigh's fascinating narrative, published in 1596, and perhaps also by Robert Harcourt, who was there in 1609 and published his account in 1613-14. Bradford, Hist. 27, n.

2 Not until after June 5 , as Cushman was married on that day in Leyden.

3 A copy, preserved in the State Paper Office, London, was published for the first time in 18.7 by Hon. Geo. Bancroft. Colls. N. Y. Hist. Soc. 2 d ser. vol. 3. pt. 1, $301-2$. 
ether active, if $\mathrm{y}^{\mathrm{e}}$ thing commanded be not agaynst Gods woord, or passive yf itt bee, except pardon can bee obtayned.

4. Wee judg itt lawfull for his Majesty to apoynt bishops, civill overseers, or officers in awthoryty onder him, in $\mathrm{y}^{\mathrm{e}}$ severall provinces, dioses, congregations or parrishes to oversee $y^{\text {e }}$ Churches and governe them civilly according to $y^{\mathrm{e}}$ Lawes of $\mathrm{y}^{\mathrm{e}}$ Land, untto whom $\mathrm{y}^{\mathrm{e}}$ ar in all thinges to geve an account \& by them to bee ordered according to Godlynes.

5. The authoryty of $\mathrm{y}^{\mathrm{e}}$ present bishops in $\mathrm{y}^{\mathrm{e}}$ Land wee do acknolidg so far forth as $y^{\mathrm{e}}$ same is indeed derived from his Majesty untto them and as $y^{\mathrm{e}}$ proseed in his name, whom wee will also theerein honnor in all things and lime in them.

6 . Wee beleeve $y^{t}$ no sinod, classes, convocation or assembly of Ecclesiasticall Officers hath any power or awthoyty att all but as $y^{e}$ same by $\mathrm{y}^{\mathrm{e}}$ Majestraet geven unto them.

7. Lastly, wee desyer to geve untto all Superiors dew honnor to preserve $y^{\mathrm{e}}$ unity of $\mathrm{y}^{\mathrm{e}}$ speritt $\mathrm{w}_{\mathrm{th}}$ all $\mathrm{y}$ feare God, to lave peace $\mathrm{w}^{\text {th }}$ all men what in us lyeth \& wheerein wee err to bee instructed by any. Subscribed by

\section{Jolnn Robinson \\ and \\ Willyam Brewster.}

At first glance these propositions seem to concede some points for which the Separatists had contended vigorously, but examination reveals the adroitness of their language. Undoubtedly the anthors saw that their only hope of obtaining the needed concession lay in minimizing their differences with the State Church, and in going just as far towards submission as they could without actual surrender. They could put their own Calvinistic interpretation upon the Thirty-nine Articles, and thus accept them. Their chief difficulty lay in assenting to the authority of the king and the bishops, and here, if their words are studied, it is plain that they discriminated carefully between civil and spiritual authority. The former they conceded, but they were non-committal as to the latter. The sixth article is hardest to be reconciled with their previous views. They may have been willing to yield the point, or some interpretation of their language, not readily perceptible now, may have been in their minds. Both what they said and what they left unsaid are significant. As Baucroft implies in his introduction to this doc- 
ument, they wished to avoid a conflict with the king and the hierarchy, especially just then, and to go to a land where, whatever nominal anthority the latter might have, they would be much less likely, and perhaps nnable, to hinder the Pilgrims from assuming ecclesiastical self-control. The earliest date in connection with these negotiations is in a letter of Nov. 12, preserved by Bradford, from Sir Edwin Sandys ${ }^{1}$ to Robinson and Brewster, and transmitted by Cushman and Carver on their return from their mission. The answer, also quoted by Bradford and dated at Leyden on Dec. 15, was carried by Carver and another on going again to London in that month to press the negotiations.

The breach between the Remonstrants and the Contra-Remonstrants continued to increase. The two parties were led, respectively, by John of Barneveldt, the Advocate of Holland, and Prince Maurice, the Stadtholder and Captain-General. A vital practical question was that of ealling a National Synod. This Prince Maurice advocated, for personal reasons. But Barneveldt opposed it, as unconstitutional, and carried a vote on Ang. 4 in the States of Holland, the most important province, forbidding it. In Leyden the magistrates sympathized with the Remonstrants, althongh a majority of the inhabitants were on the other side. The vote, however, quickly was declared illegal by the Grand Council and on Nov. 11 the States, although only by a bare majority, approved a National Synod for the next year. Add now to these turmoils the threatenings of disorders in the neighboring German states, which soon resulted in the outbreak of the Thirty Years' War, and it is no wonder that the English Pilgrims were looking for a new refuge.

To them the most important publication in Holland must have been Francis Johnson's last addition to the long controversy between Ainsworth and limself, "A Christian Plea, conteyning three Treatises, I. The first, tonching the Anabaptists. II. The second, touching such Christians, as now are here, com-

${ }^{1}$ In the eighth Report of the Royal Commission on Hist. MSS. (App. Pt. ii : 45) is an extract from a note by Sir Nathanael Rich (?) to the effect that he had heard that Sir Edwin moved the Archbishop of Canterbury to "give leave to the Brownists and Separatists to go to Virginia, and designed to make a free popular State there, and himself and his assured friends to be the leaders." 
monly called Remonstrants or Arminians. III. The third, touching the Reformed Churches." On the title-page he styles himself, "Pastour of the auncient English church, now sojourning at Amsterdam," which indicates that he had returned from Emden and still ministered to some remnant of his followers.

In the mother country the chief contribution to current religious discussions was John Darrell's "A Treatise of the Chureh, written against them of the Separation, commonly ealled Brownists, wherein the true doctrine of a Visible Church is tanght," ete. He is familiar with the various divisions in the church at Amsterdam, and with Robinson's relation to them. ${ }^{1}$ In this year appeared that interesting "Itinerary," by Fynes Moryson, referred to in earlier chapters; and on June 12, Sir Walter Raleigh set sail on another voyage to Guiana, in the illusory hope of regaining royal favor by discovering gold.

\section{8.}

Nothing which happened in Leyden during 1618, excepting the share of the Pilgrims in the negotiations about their intended emigration, can have been so interesting to them, especially to Robinson, as the great Synod of the National Chureh of Holland, held at Dort, or Dordrecht. But some particulars of their history claim first mention.

This year there were six weddings. Edward Winslow, from London, born at Droitwich, near Worcester, in Octóber, 1595, and destined to become famous in connection with the Plymouth Colony and even in the public service of his native land, but at this time a printer in Leyden, was betrothed on Apr, 27 to Elizabeth Barker, from "Chatsum," in presence of Isaac and Mary Allerton, Jonathan Brewster and Jane Hazel, a niece of the bride. They were married on, or soon after, May 6. They both eame over in the Mayflower. Apparently Winslow belonged to an English family higher in social standing than those of most of the other more eminent Pilgrims and had been attracted to the company while travelling for pleasure. On June 15 Samuel Lee, a hat-maker, and Maria Nash were betrothed,

1 Ded. Epis. vi, and 155. 
accompanied by Israel Nash, probably her father or brother, and Elizabeth Jones, and they were married on June 30. On July 4 Bartholomew Smith, from London, then a tobacco-pipe maker, who had lost his first wife, Dorcas, was betrothed again to Elizabeth Carlisle, ${ }^{1}$ from Hull, widow of James Carlisle, with Bernard and Anna Ross for witnesses. The date of their wedding is not named.

Ten days later, on July 14, the two daughters of Thomas Willet, from Norwich, were betrothed: Rebecea to Daniel Fairfield, from Colchester, a son of Jacob Fairfield and a sayweaver, with Roger Simmons and Mary Allerton as witnesses; and Sarah, whose first husband, William Minter, had died, to Roger Simmons, from Sarum, a mason, with Thomas and Alice Willet, her parents, and John Carver and Daniel Fairfield as witnesses. Daniel and Rebecca were married on Aug. 4 and Roger and Sarah on Aug. 18. The last of the six weddings was on Dec. 22, that of Thomas Smith — not the cloth-merchant and ex-deacon, but another-a wool-comber, from "Berry," and Anna Crackstone. They had been betrothed on Dec. 12, accompanied by John Crackstone, her father, and Patience, one of Brewster's daughters.

The first death was that of Mrs, William White, living in the Pieterskerkhof - the wife, not of Samuel Fuller's brother-inlaw, the wool-carder, but of another, a tobacco-merchant. She was buried in St. Peter's on Jan. 27. John Robinson was next to be stricken and he buried a child in the same place on May 15. This child, or another who was buried there on Feb. 7, 1621, may have been the Anna Robinson, not otherwise accounted for, who had witnessed the banns of George Morton and Juliana Carpenter on July 6, 1612. On June 16 John Jenny, then living in the Veldestraat (Field Street), buried a child in the same church; and Edmond Jessop, living in the Pieterskerkhof; one on July 24. Thomas Brewer's sad experience also must have awakened their keenest sympathy. He buried one child in St. Peter's on Ang. 30 ; another, a son, on Oct. 3 ; and his wife her'self on Oct. 20.

Thomas Rogers, a camlet-merchant, became a citizen on 1 Herk. Houw. Proc. Bk. H. 296. 
June 25, his guarantors being William Jepson and Roger Wilson; Andrew Sharp, a cloth-worker, on Aug. 24, his being Wilson and Alexander Price; and Henry Stafford, a tallow-chandler, on Nov. 26, his being Samuel Lee and George de Paau.

Negotiations about emigration made little progress. Bradford preserves a letter, of Jan. 27-Feb. 6, 1617-18, from Robinson and Brewster to Sir John Wolstenholme, ${ }^{1}$ a leader in the Virginia Company. It implies that objections to the ecclesiastical order of the Pilgrims hindered favorable action by the Council ; and enclosed were two additional statements of the attitude of the Leyden church. Either was to be used, as Sir John might see fit, and the briefer one, which they preferred, ended thus: "The oath of Supremacy we shall willingly take if it be required of us, and that convenient satisfaction be not given by our taking the oath of Allegiance." Bradford and Winslow intimate that Sir Edwin Sandys, in the Virginia Company, and Sir Robert Naunton, who became Secretary of State in Jamuary, 1618 , were special friends at this juncture. They state further that the king was urged to connive at their emigration without sanctioning it openly; but Winslow says that his Majesty directed a conference with Archbishop Abbot, of Canterbury, and Bishop King, of London, and that this led to negotiation with the Virginia Company.

Bradford adds a letter, of Feb. 14, apparently to Robinson and Brewster, from the agent to whom the delivery of the letter to Sir John Wolstenholme had been entrusted, one Sabine Staresmore, a young convert to Independency, who was a member of the Southwark church founded in 1616 by Henry Jacol, and subsequently ${ }^{2}$ of Robinson's church in Leyden, and in 1622 of Ainsworth's church in Amsterdam. A later letter, of Sept. 4, from Staresmore to Carver, written in "Wodstreete Comp-

1 Alex. Brown claims [Genesis of U. S. ii : 1058] some reason for thinking Wolstenholme a relative of John Robiuson, but does not prove it. See also p. 984 .

2 After 1619, when he published a small book in London on The Unlawfulness of Reading in Prayer. His letter to Carver refers to the fact that one Francis Blackwell, one of Johnson's adherents, at some previous time in 1618 led away some of the latter's remaining people. They submitted to the English ecclesiastical anthorities and appear to have betrayed Staresmore. They set out to join the Virginia Colony, but mostly perished. 
ter," a London prison, he having been arrested for attending a Separatist meeting, also is given by Bradford.

Brewer and Brewster continued their printing in Leyden, and the books issued generally were of a sort commending their views. The several volumes traceable to this origin in 1618, although none state the place of printing or the publishers' names, were these: "A Confvtation of the Rhemists Translation, Glosses and Annotations on the New Testament . . ." by Thomas Cartwright; " "Certain Reasons of a Private Christian against Conformitie," by Tho: Dighton, Gent.; "A Little Treatise vpon the first verse of the 122. Psalme," by R. Harrison, a reprint; "A Godly Sermon vpon the 3.4.5.6.7. and 8. verses of the 12. chapter of the Epistle of S. Paule to the Romans ..." attributed to L. Chaderton ; "A Trve, Modest, and Iust Defence of the Petition for Reformation," (in 1603); "The Peoples Plea for the Exercise of Prophesie," 2 by John Robinson; Hieronymi Philadelphi de Regimine Ecclesiae Scotianae Brevis Relatio, (by David Calderwood, then an exile in Holland); and De vera et genuina Jesu Christi Domini et Salvatoris nostri Religione.

Carleton's despatches show how violent were the religious outbreaks in Leyden meanwhile. At length, on Oct. 23, the Prince of Orange summarily dismissed the entire magistraey, appointing in their stead pronounced Contra-Remonstrants who would vote with the orthodox in the States, and, on Ang. 29, John of Barneveldt, Grotius and other Remonstrant leaders were arrested. Meantime preparations for the National Synod went on, and for the Pilgrims two preliminary publieations must have had significance. One was an edition of the "Articles of Faith

1 This has a preface, "The Publisher to the Stvdious Reader," probably from Brewster's own pen. Of special interest is its reference to the chief inspirer of the work, Sir Francis Walsingham, as " a man of eminent place and power, who herein as in other affaires, was accounted the mouth and hand of the late Queen and state."

2 Against John Yates, minister of the Church of England in Norwich, who had published his book the previons year to prove "ordinary Prophesie in publick out of office, vnlawfull." Robinson's preface is addressed "To my Christian Friends in Norwich and thereabents," and the argument is an expansion and confirmation of a portion of that in his Justification of Separation, which Yates had criticised. 
of the National Church," 1 with full citations of all interpretations by different theologians, published by Hommins, apparently Robinson's most intimate friend. The other, ${ }^{2}$ by Ames, was a confutation of the arguments of the Remonstrants on the five Articles specially disputed.

On Oct. 18 a general fast was held, and on Nov. 13 the Synod opened. There had been six such Synods earlier, between 1568 and 1586 , of which the third and fourth also har been held in Dort. The importance of this one lay in its aim to establish a new and more definite standard of orthodoxy for the Reformed Church. Its interest for the Pilgrims must have been increased by their knowledge of some men deeply concerned in it, especially Episcopius, the leader of the Remonstrants.

The Synod included nineteen members from the Reformed Churches of Switzerland and Germany, and five British. Of the latter, selected by the king, the chief were Bishop Carleton, of Llandaff, Dean Hall, of Worcester, Robinson's former antagonist, and John Davenant, Professor of Divinity at Cambridge. A spectator, who left valuable reports, was John Hales, on leave of absence from his fellowship at Merton, Oxford, Carleton's chaplain, and sent by him to watch the Synod. Ames also was present, as a paid theological adviser to the Contra-Remonstrants.

Organization was perfected on Nov. 14. Johannes Bogerman, minister of Leeuwarden, an active Contra-Remonstrant, was president. Festus Hommius was one of the two secretaries. The principal topics of discussion for three weeks were a new translation of the Bible, the best mode of catechising, the baptism of children of heathen parents, the training of ministerial candidates, and the reform of free printing. Meanwhile, representative Remonstrant clergy, Episcopius being the chief spokesman, had been cited to defend their opinions, Gomar and Bogerman mainly replying.

In Amsterdam the earliest event of note was the death of

1 Specimen Controversiarum Belgicarum, etc. 1618. 4to. The preface is dated Oct. 8.

2 Coronis ad Collationem Hagiensem, etc. 1618. 4 to. 
Francis Johnson, who was buried there on Jan. 20. A letter, ${ }^{1}$ of that date, from Matthew Slade to Carleton says :-

This day we have buried Master Francis Johnsox, a man that hath, many years, been Pastor of the Brownists: and (having cast himself, and drawn others, into great troubles and miseries, for their opinions and schism) did, a few days before his death, publish a Book; wherein he disclaimed most of his former singularities and refutel them. To which Work, he hath also annexed a brief Refutation of the Five Articles [of the Synod of Dort].

The very title of this book is unknown. How far Johnson recanted never is likely to be shown. At the end of the year, also, a volume, already quoted from, was published there by Joln Paget, entitled, "An Arrow against the Separation of the Brownists," containing a controversial correspondence between him and Ainsworth from July, 1617, until December, 1618, and treating mainly of the views of the Amsterdam Separatists. Paget refers to Robinson's opinions as justifying lis own criticisms of Ainsworth.

In England the chief theological work probably was by John Sprint, minister of Thornbury, Gloucester, entitled "Cassander Anglicanns; Shewing the Necessity of Conformity to the prescribed Ceremonies of our Church, in Case of Depriuation." Brewster left a copy, and its argument, by one who had refused conformity until threatened with deprivation, is refuted in the preface to Brewster's edition of the "Trve, Modest, and Iust Defence of the Petition for Reformation."

\section{9.}

During 1619 the plan of the Pilgrims to emigrate took a more definite shape, but arrangements were not completed. Their more personal records include four marriages. Two couples were betrothed on Sept. 16: Roger Wilkins, the widower of Anna Hardy, and a wool-carder, to Margaret Barrow, with her father, Zechariah Barrow, Isaac Allerton and Rose (Mrs. Stephen) Butterfield for witnesses, their wedding occurring on Oct. 5; and John Groodman, the widower of Mary 1 S. P. Holl. 123. Cited by E. Arber, Story of Pilg. Faths. 129. 
Backus, a linen-weaver, and Sarah Hooper, with Samuel Fuller, Rosamond (Mrs. William) Jepson and Fuller's sister, Susanna (Mrs. William) White for witnesses, they being married on Oct. 10. The other two couples may have had a double wedding. At any rate they were betrothed and married on the same days, Nov. 8 and 23. Richard Masterson, from Sandwich, a wool-carder, married Mary Goodale, from Leiston, Suff., their witnesses being John Ellis, William Talbot, Mary Finch and Elizabeth, wife or daughter of John Keble ; and Thomas Jones, from Dorehester, a say-weaver, married Anna Swift, from Yarmouth, theirs being Robert Robertson and Margaret Savory. Four deaths are recorded. On Feb. 18 Samuel Lee, then living in the Vieuwestadt (New Town), buried a child. So did Edmond Chandler on Mar. 26. On May 10 Jonathan Brewster, living in the Pieterskerkhof, laid his wife to rest; and Sept. 12 Robert Peck, living in the same place, also buried a child. All these interments were in St. Peter's.

William Ring, a say-weaver, was sworn in as a citizen on June 7, vouched for by William Bradford and Alexander Price ; and on Dec. 2 Christopher Ellis, vouched for by Frederick Jones and Quiryn Mees. On Mar. 20 Richard Masterson had occasion for guarantors of his good credit, and John Ellis, his brother-in-law, then fifty and a wool-comber, and Roger Wilson, then thirty-four, endorsed him by affidavit before the authorities. On an unnoted day in April Samuel Lee, then thirty, and Degory Priest, then forty, deposed to their knowledge of Nicholas Claverly, ${ }^{1}$ pipe-maker, who had lived in Leyden for four years; and on Aug. 21 John Brown, a woolcomber, and Robert Robertson, from Colchester, a polisher, made affidavit in behalf of Robert Allerton, a Scotchman, who had lived there twelve years. Whether he were related to Isaac, or John, or both is mnknown. On Apr. 19 William Bradford sold his house, on the north side of the Achtergracht between the Paradissteeg and the Bouwen-Louwensteeg (a personal name, e. g., Smith's Lane), to Jan des Obrys for 1120 gilders. Robert Cushman sold to John de Later on Sept. 19 the house on the Yonnensteeg which he had bought in November, 1611,

\footnotetext{
1 This entry is crossed out.
} 
for the same price paid for it, 180 gilders. On the next day, Sept. 20, Roger Simmons sold to Jacob Cornelis de Haas for 746 gilders, more than 100 gilders less than Minter had paid for it in 1614, the bouse on the Groenehasegracht which his wife, Sarah, had inherited from her first husband, William Minter; and William Robertson is mentioned again as owning the next house on one side.

During 1619 the publications of Brewer and Brewster got them into trouble, as will appear. We know of only four books printed by them: "The Second Part of a Plain Discovrse of an Vnlettered Christian. By Tho. Dighton, Gent. ;" "An Ansvver to the Ten Covnter Demands, propovnded by T. Drakes." By Wil. Euring ; " Perth Assembly," by David Calderwood ; 2 and Robinson's "I Iust and Necessarie Apologie." 3 This last tract shows the general harnony between Robinson's church and the Dutch Reformed churches. He endeavors to minimize the differences, which he tabulates somewhat thus : the conception of the church; the baptism of children of non-members; the use of a liturgy; the office of elders; the keeping of certain holy days; the allowance of marriage by ministers; the observance of the Sabbath; the allowing members to prophesy in public; the treatment of church buildings as consecrated; and the comparative regard for the magistrate's authority in religious matters.

1 Notable for two passages. One (S) professes loyalty to the king's government in the very language of the third of the seven Articles submitted in 1617 by Robinson and Brewster in behalf of their church. In the other (36) the author refers to a suggestion of removal to Virginia, and sass : "When some of ours desired to haue planted ourselues there, with his majesties leaue upon these three grounds, first, that they might be means of replanting the gospel amongst the heathens. Secondly, that they might line vnder the King's government. Thirdly, that they might make way for, and unite with others, what in them lieth, whose consciences are grieved with the state of the Church in England: the Byshops did by all means oppose them, and their friends therein." These passages suggest that the writer was in intimate relations with the Leyden chureh. But his name is otherwise unknown. He professes (iv) to "have not been brought up among the Muses, but Mariners," and ( 7 ) to be writing "here in England." His name may have been fictitious.

2 Published before Jnly. For evidence of Calderwood's authorship see E. Árber, Story Pilg. Faths. 181, 238-242.

3 An English translation by the anthor appeared in 1025, A Iust and Necessarie Apologie of certain Christians, no less contumeliously then commonly called Brownists or Barrouists. Ito. 
The volume commands respect for its scholarship, dialectic skill and gentleness.

Negotiations with the Virginia Company were resumed, apparently in April. Cushman went to London again, this time with Brewster. On May 8 he reported to the church that progress had been balked by obstacles in the Virginia Company. Sir Thomas Smith had been superseded as treasurer and governor by Sir Edwin Sandys, and Smith's indignation threatened a long wrangle, while advices from Jamestown were likely to absorb the Company's attention.

At the next meeting, however, on Wednesday, May 26, one Mr. Wencop, commended to the Company by the [late] Earle of Lincolne, intending to goe in person to Virginia, and there to plant himselfe and his associates, presented his pattent now to the Cort; $w^{\text {ch }}$ was referred to the Committee that meeteth upon Friday morning at NIr. Treasurer's house to consider ;

and Bradford says that the patent which the Leyden agents were seeking

by the advise of some freinds . . was not taken in $y^{\mathrm{e}}$ name of any of their owne, but in $\mathbf{y}^{\mathrm{e}}$ name of $\mathbf{M}^{\mathrm{r}}$. John Wincob (a religious gentleman then belonging to $\mathrm{y}^{\mathrm{e}}$ Countess of Lincoline), who intended to goe with them.

Of Wineob we know no more; nor do we know the Earl of Lincoln, who died in January, 1619, as interested in these exiles. On June 9 Wincob's patent was sealed, and probably Brewster and Cushman then returned to Leyden.

The next testimony comes from Carleton, ${ }^{1}$ and has to do with the press of Brewer and Brewster. On July 27 he writes :-

I have seen, within these two days, a certain Scottish book, called Perth Assembly, writter with much scorn and reproach of the proceeding in that kingdom concerning the affairs of the church. It is without name either of author or printer; but I am informed it is printed by a certain English Brownist of Leyden, as are most of the puritan books sent over of late days into England : which being directly against an express placart of the states-general, which was published in December last, I intend (when I have more particular knowledge of the printer) to make complaint thereof, conceiving that his majesty will not dislike I should do so.

1 Letters, 379-390, 423. 
On Aug. 1, he writes that,

in search after that book, I believe I have discovered the printer of another, De Regimine Ecclesice Scoticance . . . ; and that is one Willian Brewster, a Brownist, who hath been for some years an inhabitant and printer at Leyden, but is now within these three weeks removed from thence, and gone back to dwell in London; . . . as I am informed, he hath had, whilst he remained here, his hand in all such books as have been sent over into England and Scotland; as particularly a book in folio, intitled, A Confutation of the Rhemists Translation, Glosses and Annotations on the New Testament, anno 1618, was printed by him: so was another in decimo sexto, De vera \& genuina Jesu Christi . . Religione.

According to Carleton, then, Brewster returned to London about July 11, but on Aug. 1 (Ang. 11 in Holland) Naunton ${ }^{1}$ reports that Brewster is "frighted back into the Lowe Countries by the Bishopps pursivants." But Carleton replies on Aug. 30:-

I have made good enquiry after William Brewster at Leyden, and am well assured, that he is not retumed thither; neither is [it] likely he will, having removed from thence both his family and goods.

This was the end of Brewster's printing, and apparently of Brewer's. The evidence indicates that Brewster avoided arrest and remained in England until the Pilgrims arrived there in 1620, joining them then for the voyage to America. It now was Brewer's turn to be harassed and the University " Register" describes, on Sept. 21, a seizure of his types, and an examination of his library to discover what he had printed. The next day Carleton writes as follows : -

In my last [not preserved] I advertised your honour, that BREwSTER was taken at Leyden, which proved an error, in that the schout [bailiff]... being a dull drunken fellow, took one man for another. But BREwer, who set him on work, and being a man of means bare the charge of the printing, is fast in the University's prison. . . . I expect to-morrow to receive his voluntary confession of such books, as he hath caused to be printed by BREwster for this year and a half, or two years past.

I S. P. Dom. 1619-23, cx: i. 
Six days later he reports Brewer's cxamination as unsatisfactory, and adds :-

I have now used the Prince of Orange's anthority, who hath spoken limself to the rector ${ }^{1}$ of the university, not to give the prisoner liberty until his majesty's pleasure be known concerning him, which the rector doth promise shall be fulfilled, notwithstanding that the whole company of Brownists doth offer caution for BREwer; and he being a university-man, the scholars are likewise stirred up by the Brownists to plead privilege in that kind when caution is offered... .

It appeared that this BREwER and BREWSTER, whom this man set on work, laving kept no open shop, nor printed many books fit for pnblic sale in these provinces, their practice was to print prohibited books to be vented underhand in his majesty's kingdonıs.

Carleton seems to be correct. Apparently their earliest issues were in 1617,2 and they attempted little or no general printing, but confined themselves to theological or ecclesiastical works, such as were "prohibited" in England. At first they printed the address of their office, but soon omitted it. That Brewer's imprisonment violated the university privileges is probable: and ordinarily, if his arrest had occurred at all, such remonstrances would have prevailed. But, although the Dutch went as far as they dared in disregarding King James, the end of their truce with Spain was near, and in this ease, as in others already mentioned, political considerations controlled them. Finally, at Carleton's request, Brewer was sent to England in December.

He went, however, voluntarily and not as a prisoner, although under oversight. Moreover, the English government had to agree to pay his expenses and send him back within three months. And William Lisle, ${ }^{3}$ and one Jenkins, probably a Pilgrim but not otherwise mentioned, accompanied him.

Meanwhile other stirring events had occurred. On Jan. 14 the Synod at Dort dismissed the committee of Remonstrants in disgrace, their answers and bearing having displeased the prejudiced majority. On Sunday, Apr. 14, the outcome of the Synod being foreseen, all Reformed churches in Leyden were

1 Reinier de Bondt, Professor of Medicine.

${ }^{2}$ But apparently they began work by Oct., 1616. Arber, 237.

${ }^{3}$ Letter of Sir $W$. Zouch, Arber, 227. 
occupied by the Contra-Remonstrants, supported by the new magistrates. Ten days later, the Dutch members of the Synod sentenced the Remonstrants, expelling them from all stations in the Church and the universities. Finally, on May 6, the canons adopted respecting the five mooted points of doctrine were announced, and three days later the assembly ended.

Episcopius was driven from the country, and his university chair was vacated. Of other changes in the teaching force, due to this cause, the chief was the dismission of Peter Bertius, Professor of Ethics. Another, destined to have influence upon Robinson's opinions, was Ames's removal to Leyden to take the place of Hommius as overseer of theological students educated for the ministry by certain Amsterdam merchants, Hommius succeeding Vossius as Regent of the Theological College.

The chief contribution to the literature of the Arminian controversy was by Pierre du Moulin, a Reformed minister of Paris, a delegate to the Synod of Dort but unable to attend, who now published a work, Anatome Arminianismi, seu, Envcleatio Controversiarvm Qvae in Belgio agitantur. ${ }^{1}$. . . Little else of theological importance appeared, but there came out a tract by their London fellow-disciple, Sabine Staresmore: " The Vnlawfvlnesse of Reading in Prayer. Or, the Answer of Mr. Richard Mavnsel Preacher vnto certain Argvments or Reasons, drawne against the using, or communicating, in, or with the Booke of Common Prayer, etc." The author mentions an interview with Mr. Maunsel, and adds :-

I asked you whether you would undertake a conference with Mr. Robinson, who I conceived was like to come over [to England] about the Virginia voyage, and then you did in plain words refuse it, upon no other ground, then because he was a Brownist, as you pleased to terme him.

Politically the Calvinistic triumph over the Arminians was followed by the startling result of the trial of John of Barnevellt, the head of the State-rights party, who was marked for destruction and whose execution took place at The Hague on May 23.

1 An English translation appeared in London in 1620. 


\section{CHAPTER VIII}

THE YEAR OF THE DEPARTURE - 1620

WE now have reached 1620 , the famous year when their undertaking was suceessfully executed. Few records, however, throw light upon their last months in Leyden. There was one wedding. On Jan. 10 Leonard Dunster, a say-weaver, and Mary Brown, a daughter of Mary (Mrs. James) Sunderland, apparently from Colchester, were betrothed, with her mother and step-father as witnesses, and they were married on Jan. 25.

Isaac Allerton, then living in the Pieterskerkhof, buried a child in St. Peter's on Feb. 5. On Apr. 1 Thomas Rogers ${ }^{1}$ sold his house, on the Barbarasteeg, for 300 gilders to Mordecai Cohen. On June 10 Fuller, Winslow, Bradford and Isaac Allerton wrote ${ }^{2}$ to Carver and Cushman, the active agents in England, Brewster evidently being in hiding, in which Thomas Nash is mentioned as recently arrived in Leyden. Presumably be had been there before and had gone to England on their behalf. Evidently he brought back the pilot who took the emigrants to England in the Speedwell in August, and Nash probably went as far as Plymouth, Eng. He became conspicuous among those who remained in Leyden, and appears now and then in the records until 1640 .

Early in the year another project $^{3}$ for colonization came up. According to Winslow, the Dutch offered the Pilgrims free passage to the Hudson river and to furnish every family with cattle if they would "go under them." Who made this offer is unknown. It may have come from the directors of the Amsterdam company which for several years had controlled most of the trade to New Amsterdam, now New York, and who, on

1 Prot. Op. w w, 46.

2 Bradford, Hist. 49. The absence of Brewster's signature may be an additional indication that he had remained in England.

8 Ibid. $43, \mathrm{n}$. 
Feb. 12, petitioned ${ }^{1}$ the Stadtholder for protection to Robinson's company if they should emigrate thither. In English the significant passage is this :-

Now it happens that there is residing at Leyden a certain English preacher, versed in the Dutch language, who is well inclined to proceed thither to live, assuring the petitioners that he has the means of inducing over four hundred families to accompany him thither, both ont of this country and England, provided they would be guarded and preserved from all violence on the part of other potentates, by the authority and under the protection of your Princely Excellency and the High and Mighty Lords States-General, in the propagation of the true, pure Christian religion, in the instruction of the Indians in that country in true learning, and in converting them to the Christian faith, and thus, through the mercy of the Lord, to the greater glory of this country's government, to plant there a new Commonwealth, all under the order and command of your Princely Excellency and the High and Mighty Lords States-General.

A request was added for two ships of war to guard the territory, and this item was a sufficient reason for its negative answer.

Further negotiations were abandoned by the advice of Thomas Weston, a London merchant, who, as Bradford ${ }^{2}$ says : came to Leyden aboute $\mathrm{y}^{\mathrm{e}}$ same time, . . . haveing much conferance $\mathrm{w}^{\text {th }} \mathrm{MI}^{\mathrm{r} \cdot}$ Robinson \& other of $\mathrm{y}^{\mathrm{e}}$ cheefe of them, perswaded them to goe on (as it seems) \& not to medle with $y^{e}$ Dutch, or too much to depend on $y^{\mathrm{e}}$ Virginia Company; for if that failed, if they came to resolution, he and such marchants as were his freinds (togeather with their owne means) would sett them forth.

He must have told them also that his friends controlled a patent from the Virginia Company, on Feb. 2, to John Peirce and others. They accepted his proposals, articles of agreement were approved by him, for the Merchant Adventurers of London, and by them, and Cushman and Carver were sent again to England to complete arrangements. Preparations for emigration then were hastened at Leyden. In Bradford's words : -

Those that weare to goe, prepared them selves with all speed, and sould of $[\mathrm{f}]$ their estats and (such as were able) put in their moneys

1 Docs. Relat. to Col. Hist. of N. Y. i : 22-24.

2 Hist. 42-5s. Arber shows (300) that Weston's visit must have been between Feb. 2 and Apr. 1. 
into $\mathrm{y}^{\mathrm{e}}$ commone stock, which was disposed by those appointed, for $\mathrm{y}^{\mathrm{e}}$ making of generall provisions.

Winslow explains that it was decided that only the younger and stronger members should go at the first, and, as a small majority elected to remain, Robinson was desired to stay, Brewster, ${ }^{1}$ the Elder, accompanying the emigrants. Bradford says : -

They concluded botl what number and what persons should prepare themselves to goe with $\mathrm{y}^{\mathrm{e}}$ first; for all $\mathrm{y}^{\mathrm{t}}$ were willing to have gone conld not gett ready for their other affairs in so shorte a time; neither if all could have been ready, had ther been means to have trāsported them alltogeather;

and adds :- -

It was allso promised to those $y^{t}$ wente first, by $y^{e}$ body of $y^{e}$ rest, that if $y^{e}$ Lord gave them life, \& meäs, \& opportunitie, they would come to them as soone as they could.

This implies that practically the whole company, including those originally reluctant, had decided to go ultimately. But it is more probable that some did not intend to go at all. Bradford adds, confirming Winslow :-

Those that staied being $y^{e}$ greater number required $y^{e}$ pastor to stay with them; and indeede for other reasons he could not then well goe, . . . The other then desired $\mathrm{y}^{\mathrm{e}}$ elder, $\mathrm{MI}^{\mathrm{r} \cdot}$ Brewster, to goe with them, which also was condescended unto.

And, in regard to their church organization, he continues :-

It was also agreed . . . that those that went should be an absolute church of them selves, as well as those $\mathrm{y}^{\mathrm{t}}$ staid . . . yet with this proviso, that as any of $y^{e}$ rest came over to them, or of $y^{e}$ other returned upon occasion, they should be reputed as members without any further dismission or testimoniall.

Various hindrances, however, chiefly in England, befell them. Bradford adds : -

Some of those $y^{t}$ should have gone in England, fell of \& would not goe; other marchants \& freinds $y^{t}$ had offered to adventure their

1 This does not necessarily imply that Brewster had returned to Leyden; nor do Winslow's words (Hyp. Unm. 90) : "The minor part, with Master Brewster their Elder, resolved to enter upon this great work," although each utterance rather suggests that he had. On the whole it is more probable that he was in England. 
moneys withdrew, and pretended many excuses. Some disliking [that] they wente not to Guiana; others againe would adventure nothing excepte they wente to Virginia. Some againe (and those that were most relied on) fell in utter dislike with Virginia, and would doe nothing if they wente thither. In $y^{e}$ midds of these distractions, they of Leyden, who had put of their estats, and laid out their moneys, were brought into a greate streight, fearing what issue these things would come too; but at length $\mathbf{y}^{\mathrm{e}}$ generalitie was swaid to this latter opinion [i. e., to go to Virginia].

Moreover, Weston, then in London, insisted upon altering the accepted conditions, to their disadvantage, and Cushman, ${ }^{1}$ unauthorized, conceded his demands.

Bradford preserves a letter from Robinson to Carver, probably of June 4, which depicts pathetically their lack of funds and their disappointment in Weston and Cushman, and criticises the changes made in the agreement. Then follow the letter of June 10, from Fuller, Bradford, Winslow and Allerton to Cushman and Carver, consisting mainly of remonstrances to Cushman and messages to Weston; and two replies by Cushman, one undated, defending himself, and the other of June 11, mentioning having secured the refusal of the Mayflower. Still another letter is in Bradford, written by Cushman, June 10, to Carver at Southampton. There had been some prospect that certain emigrants from Amsterdam, presumably English exiles, would join them, and Cushman says :-

As for them of Amsterdam I had thought they would as soone have gone to Rome as with us; for our libertie is to them as ratts bane, and their riggour as bad to us as $\mathrm{y}^{\mathrm{e}}$ Spanish inquisition.

Probably it was fortunate for the Plymouth Colony that they did not venture. Meanwhile the Speedwell, a vessel of about sixty tons, to be used in America, had been bought and equipped in Holland, whence she was to bear them to England, where the Mayflower, of three times her capacity, was to join in transporting them.

When at last ready to sail, they kept a day of fasting and prayer, and Robinson preached from Ezra viii: 21, the last sermon which the colonists were to hear from him. The occa-

1 Carver was acting for them at Southampton and Cushman at London. 
sion must have been affecting. Their peculiar ties were about to be severed, and even some families were to be divided. Their future was unknown and dark. They could foresee only that trials and perils, perhaps surpassing any in their whole sad experience, must be encountered. But they made brave efforts to maintain courage and cheerfulness. Winslow tells us that after their worship

they that stayed at Leyden feasted us that were to goe at our Pastors house being large, where we refreshed our selves after our teares, with singing of Psalmes, making joyful melody in our hearts, as well as with the voice.

It was during these services that Robinson uttered those famous exhortations which Winslow has paraphrased in saying :-

Hee used these expressions, or to the same purpose; We are now ere long to part asunder, and the Lord knoweth whether ever he should live to see our faces again: but whether the Lord had appointed it or not, he charged us before God and his blessed Angels, to follow him no further then he followed Christ. And if God should reveal anything to us by any other instrument of his, to be as ready to receive it, as ever we were to receive any truth by his Ministery: For he was very confident the Lord had more truth and light yet to breake forth out of his holy Word.

This advice, so much discussed, must be interpreted by the context, in which Lutherans and Calvinists are instanced as fettered by the beliefs of their original leaders, a conservatism which Robinson condemns.

Probably it was on Friday, July 31, that the emigrants left Leyden for Delfshaven, the port of Delft, on the Maas. The canal route remains much as it was then. They doubtless left Leyden by the Vliet, which stretches south for a mile and then turns to the southwest. A few villages diversify the green expanse and near Ryswick the canal bends almost southeast to Delft. Passing through this picturesque city, it continues to Delfshaven. The distance is perhaps twenty-five miles and the journey must have occupied six or eight hours. They found the Speedwell ready, and, in addition to their Leyden friends, others had come even from Amsterdam to take leave. They sailed on the next day, Aug. 1, and no picture of the intervening 
hours and of their parting can surpass that furnished by Bradford's touching words : -

That night was spent with litle sleepe by $\mathrm{y}^{\mathrm{e}}$ most, but with freindly entertaimment \& Christian discourse and other reall expressions of true christian love. The next day, the wind being faire, they went aborde, and their freinds with them, where truly dolfull was $y^{\mathrm{e}}$ sight of that sade and mournfull parting; to see what sighs and sobbs and praiers did sound amongst them, what tears did gush from every eye, \& pitly speeches peirst each harte; that sundry of $y^{\mathrm{e}}$ Dutch strangers $\mathrm{y}^{\mathrm{t}}$ stood on $\mathrm{y}^{\mathrm{e}}$ key as spectators, could not refraine from tears. Tet comfortable $\&$ sweete it was to see shuch lively and true expressions of dear \& unfained love. But $\mathrm{y}^{\mathrm{e}}$ tide (which stays for no man) caling them away $\mathrm{y}^{\mathrm{t}}$ were thus loath to departe, their Reṽe $\bar{e}^{\mathrm{d}}$ : pastor falling downe on his knees, (and they all with him,) with watrie cheeks coñended them with most fervente praiers to the Lord and his blessing. And then with mutuall imbrases and many tears, they tooke their leaves one of an other; which proved to be $\mathrm{y}^{\mathrm{e}}$ last leave to many of them.

Winslow's reference to these scenes suggests that Robinson's final prayer was offered on the quay, but probably, as Bradford says, it was on shipboard. The claim that they held service in a Delfshaven church is neitler demonstrable nor probable.

A long and tender parting letter of advice by their pastor, written four days earlier, is transcribed by Bradford. Whether it were given them or sent later is uncertain. Bradford also has one of the same date from Robinson to Carver personally.

The Speedwell made a quick passage to Southampton, where they found the Mayflower, which had brought other colonists from London. They also found Carver and Cushman, and drew up on Thursday, Aug. 3-13, a letter to the London merchants about the revised conditions. These are named by Bradford. Their chief features are that the partnership was to continue seven years, when an equal division of all capital and profits, including "honses, lands, goods and chatles," was to be made. The original conditions had provided that then the honses and improved lands shonld remain the private property of the colonists, and that during the term of partnership each colonist should have two days a week for his personal affairs. Weston's alterations, accepted by Cushman, had injured their 
prospects gravely. But they were comparatively helpless. Yet they sailed without modifying their position, althongh it cost them dearly. They even were obliged to sell some supplies in order to pay their debts, and found themselves in "great extremities, scarce haveing any butter, no oyle, not a sole to mend a shoe, nor every man a sword to his side, wanting many muskets, much armoure, \&c." After about a year, however, when Cushman visited the colony, they were in such straits that they conceded the demands of the Adventurers rather than allow them to abandon the enterprise.

According to Bradford, the two vessels set sail on Aug. 5-15 from Southampton. But they made slow progress and, after covering about 150 miles, the Speedwell was reported leaky and they both put into Dartmouth, apparently on Sunday, Aug. 13-23. While there, Cushman, on Thursday, Aug. 17-27, wrote to Edward Sonthworth, formerly of Leyden but then of London, a letter, transeribed by Bradford, showing that Cushman had lost all heart for the voyage. Once more they sailed, on Wednesday Aug. 23-Sept. 2, ${ }^{1}$ but, when some distance at sea, fresh complaints of the Speedivell's condition ${ }^{2}$ arose, and they put back again to Plymouth. There it was decided to reduce the expedition to one shipload, and the Speedwell with some twenty passengers, including Cushman and his family, returned to London.

The final departure was from Plymonth on Wednesday, Sept. 6-16. The passengers numbered 102. Of the ship's officers it is known only that the captain's name was Jones; ${ }^{3}$ but there is evidence that Giles Heale ${ }^{4}$ probably was its doctor,

1 Capt. John Smith, N. Eng's Trials, 1622, 16.

2 She had been oversparred purposely so as to cause her to strain and leak, but in proper trin was perfectly sound. Her captain wished to evade his agreement to serve the colony for a year.

3 Neill claims to have identified him with Thos. Jones, captain of the Lion in 1617 (N. E. Hist. \& Gen. Reg. xxviii : 314-316), but the eridence is not convincing, and a Christopher Jones appears at Plymouth, as witness to the nuncupative will of William Mullins, on or before Feb. 21, 1621 (Ibid. xlii : 68). It is reasonably certain that he was an officer of the Mayflower.

4 Another witness of Wm. Mullins's will. A copy of Ainsworth's Psalms was sold in London a few years ago with the inscription on the fly-leaf, "Given unto Mr. Giles Heale, chirurgeon, by Isaacke Allerton, tailor, in Virginia, the $\mathrm{x}$ of February, 1620." 
and that "Master Williamson," I concerned in the earliest encounters with Indians at Plymouth, was another officer, perhaps the agent of the Merchant Adventurers. The ancient causeway where they embarked at Plymouth has disappeared, but in 1891 a memorial tablet was placed in the pavement of the adjoining Barbican pier.

1 One of Mullins's executors. 


\section{CHAPTER IX}

\section{CONCLUDING WORDS}

The remaining incidents in Robinson's life deserve record. On Feb. 7, 1621, he buried a child in St. Peter's, and another on Mar. 27, 1623. Durie, if meant, probably would have been termed "the Scotch preacher," but the record says " the English preacher" in each case, and the former entry gives his residence as the Pieterskerkhof and the latter as "by the bell house," i. e., the tower opposite to Robinson's door. On June 1,1621 , he received a power of attorney enabling him to sell his brother-in-law's, Randall Thickins's, rights in the Robinson house. The census of Oct. 15, 1622, records him in the Zevenhuysen with his wife, Bridget, their children, John, ${ }^{1}$ Bridget, Isaac, Mercy, ${ }^{2}$ Fear and James, and their servant, Mary Hardy.

In 1624 he published, probably in London, his " A Defence of the Doctrine propornded by the Synode at Dort; " and also "An Appeal on Truths behalfe." In 1625, one of his last labors, he saw through the press at Leyden his "Observations Divine and Morall."

He died on Mar. 1, 1625, after an illness of eight days, painless but incurable. It was not the plague, then raging, but some disease which Roger White, in a letter ${ }^{3}$ of Apr. 28 to Bradford and Brewster, calls " a continuall inwarde agne, but free from infection, so $\mathrm{y}^{\mathrm{t}}$ all his freinds came freely to him." White touchingly adds, "And if either prayers, tears, or means, would have saved his life, he had not gone hence." He was buried in St. Peter's on Mar. 4, many university professors and other eminent citizens being present. The church

1 Either he or James probably was the son intended for the ministry. (See letter by Walaeus, p. 592.) He is more likely to have been the one, as the oldest son.

2 Probably the child buried May 27, 1623.

3 Bradford, Hist. 205. 
register shows that nine florins were paid for opening the grave. This sum was customary, - only six had been paid in the case of Arminius, - the few instances of a larger payment being those of burials at some other than the usual time, then between 12 M. and 1.30 P. M. The place of his grave is unknown, but a tradition, possibly well-founded, locates it in the bay or alcove ${ }^{1}$ which projects from the cathedral at the point nearest to his house.

His widow is recorded as in Leyden as late as April 6, 1640, and Hoornbeeck states that she and their children, with others of his friends, joined the Dutch Church.

In 1872 Dr. Dexter found in the archives of the English Reformed Church at Amsterdam a document of which this is a translation :-

I, the undersigned, hereby certify that $\mathrm{D}[$ omine]. Rubbensonus, pastor of the English church here which is called the Brownists', has at divers times conversed with me concerning the separation between their congregation and the other English congregations in this country, and that he has at divers times testified that he was disposed to do his utnost to remove this schism; that he was also averse to educating his son for the work of the ministry in such congregations, but much preferred to have him exercise his ministry in the Dutch churches; that to this end, by the help of Domine Teellinck and myself, he had also begun to move some good people in Middelburg to provide some decent support for his son's studies for a few years ; that he, moreover, at divers times assured me that he found in his congregation so many difficulties in connection with this, that he with a good part of his congregation was resolved to remove to the West Indies where he doubted not he should be able to accomplish his desires.

This has passed between us at divers times.

Given at Leyden, 25. May, 1628.

Antonius Walaens,

Professor of theology in the university.

1 The accompanying photograph represents the memorial tablet to Robinson erected in 1891 by the National Council of Congregational Churches of the United States. It is on the outside wall of St. Peter's, just across the Kloksteeg from the site of his house. It was unveiled, with public ceremonies, by a committee of the Conucil on July 24, 1891. Addresses were delivered in the cathedral by Rev. C. R. Palmer, D. D., chairman of the committee, and by representatives of the city, the university, ete. A man still living recalls having seen Robinson's uame in the alcove pavement on a stone now removed. 


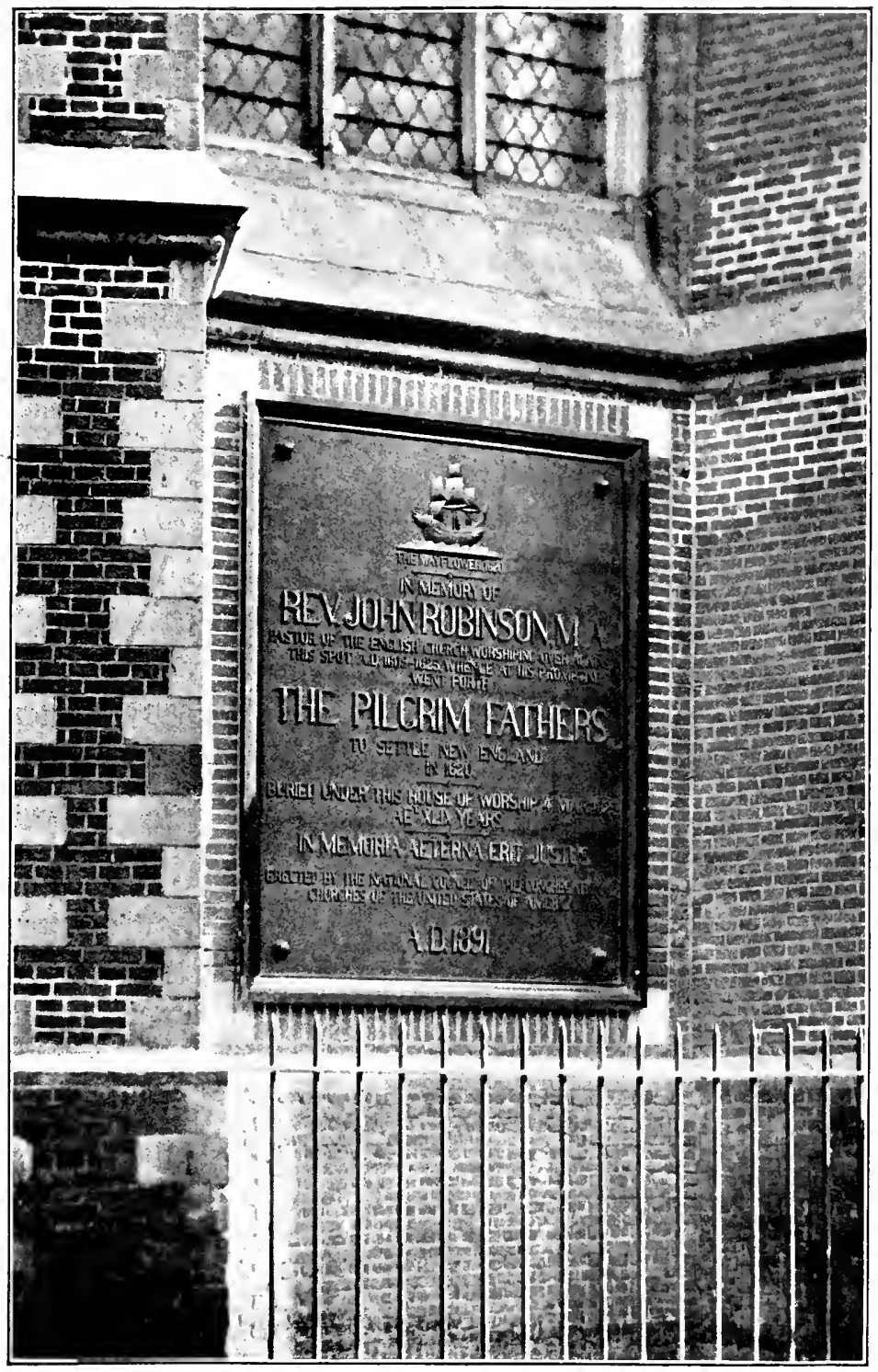

ROBINSON TABLET ON THE PIETERSKERK 

That which is above testified concerning the union of the English churches in this country, I, the undersigned, likewise certify that I have divers times heard from the late $\mathrm{D}$ [omine]. Robinson.

At Leyden, 26. May, 1628.

Festus Hommins, Rector of the Theological College.

The history of this document is unknown. Perhaps it was written to aid the transfer of members of Robinson's church to the Dutch Church. It suggests that Robinson, always catholic for his time, came to regard the position of the Reformed churches as, on the whole, the wisest. It may indicate the explanation of his willingness to subscribe to the articles drawn up for submission to the Council in 1617.1 The same revision of opinions also is intimated by a manuscript found in Robinson's study and published in 1634, "A Treatise of the Lawfulnes of Hearing of the Ministers in the church of England." 2 Here he exhibits increasing mildness towards the Anglican Church, and Hoornbeeck states, in a highly laudatory notice, ${ }^{3}$ that, under the influence of Ames and Parker, he began to consider returning to that church. That he grew increasingly liberal in mind with advancing years is easy to be believed. It is a common experience with good men. But Hoornbeeck's assertion cannot be accepted without more evidence than seems to exist. Moreover, Robinson probably did not contemplate going to the West Indies. Doubtless Walaeus had the Plymouth Colony in mind. Another little book from Robinson's pen is "A Briefe Catechism concerning Church Government." Although no edition earlier than that of 1642 is now known, it probably was printed at Leyden

1 See p. 568 .

2 The introduction. by the printers, shows (xi) that the Lerden church still existed, although it had dwindled to about one fifth of its former size. Moreover, the following extract from the Acts of the Church Council of St. Peter's, June 17, 1639 , to which Mr. L. G. LePoole has called my attention. proves that the church still lingered at that date: "John Meester and his wife, also Steven Butterfield, English, from the congregation of the sainted Robinson, complaining since his death of a lack of appropriate exercises, so that they cannot be edified as if they were members of some other church provided with a pastor, request that they may be allowed to become members of our church, which is granted by the brethren." And John Cotton says (Way of Cong. Churches Cleared, 14) that as Robinson's church began before him, so "it continued after him, and still doth," which statement apparently was written in 1647 .

¿ Sum. Controv. Relig. Lib. x. 
before his death. Evidently it was prepared for his own use in instructing his congregation.

Like Browne, the re-discoverer of substantial Congregationalism, Robinson - who, although not precisely a modern Congregationalist, did more than any one else, excepting Browne, to prepare the way for its later development - seems to have failed to find in its workings, as he knew them, something which he expected. The time was not ripe for it. The best conditions with which he had to deal were unfavorable. In order to get rid of the traditions and beliefs which hindered its growth into a self-consistent and efficient form of church life, as in the early years of the Christian era, experiment with it in the free atmosphere of a new country and an unformed political State had become necessary. Neither Browne nor Robinson was able to share in making that experiment, but each contributed much which helped the experiment, when made, to succeed.

In the Plymouth Colony and, later, in that of Massachusetts Bay, the free church system flourished. It had a large part in shaping the thought and life of the colonists. It tinctured their political ideas and aided powerfully in preparing the way for American independence, and ever since their day it has continued a potent factor for good in our national life. In the mother country also, although hampered by many hostile conditions and not wholly free, even yet, to do its best work, it has become conspicuous and effective, and during the nineteenth century it accomplished much of what it could not bring to pass in the seventeenth.

During the intervening generations Episcopacy and Presbyterianisin, too, have freed themselves from most of their former unlovely and discreditable characteristics, and now they exhibit on each side of the Atlantic a purer and nobler spirit than ever in the past. Each of the three forms of church organization and government has been benefited by the example of the others. Each also has learned already, in larger measure than conld have seemed possible to the devoutest minds of the seventeenth century, that Christianity, as taught and illustrated by Christ him. self, is spiritual rather than dogmatic or ecclesiastical.

It would be a mistake, however, to regard the Pilgrim Colony 
in America, the outgrowth of the conditions and struggles which these pages have narrated, as merely ecclesiastical in origin or development. Primarily it was this, but also it was more than this. It was one of the earliest manifestations of that resistless impulse of expansion and conquest which asserted itself in the England of that period, and even earlier in Spain, and which changed the whole face of the globe. It opened a fresh and vitally important era in human history. It was practically the beginning ${ }^{1}$ of the civilized, permanent settlement of an almost unknown continent. It prepared the way for the birth of a new and mighty nation. The world's debt to the Pilgrims is not limited by any denominational lines. It is universal. The adherents of the free-church systems fairly may claim to possess special justifications for pride in the Pilgrim history, but nobody can monopolize it. All lovers of intelligence, progress, and civil, as well as religious, liberty have the right to share in it.

Vale, et sine gratia, sine odio, lege, judica.

Episcopius, Op. ii, Pt. 2 : 108.

1 "Virginia in it's infancy was struggling for life, and what it's fate would have been if the fathers of it in England had not seen the rise and growth of other colonies near it, is uncertain." - Hutchinson, Hist. Col. Mass. Bay, i : 3. 

APPENDIX 



\section{APPENDIX}

Dr. Dexter caused investigations of the Amsterdam and Leyden archives to be made, in order to learn everything relating to the individual Pilgrims during the whole, or any part, of their residence in Holland. He also made such researches himself. But the results were incomplete and sometimes inexact, as he did not live to perfect them. I have supplemented his efforts by more than seven months of personal examination of the records, and the following pages contain the fruits of this labor. The chief sources of information have been mentioned already. ${ }^{1}$ Some advantage also has been taken of knowledge gained elsewhere.

Some members of the Pilgrim company in Leyden are known positively, e. g., William Bradford, William Brewster and John Robinson. The records show who were associated with them in all sorts of transactions, and thus indicate their fellow-members. When they had need of witnesses or guarantors they sometimes called in their Dutch or Walloon friends, but ordinarily they depended upon each other for such aservices. There also were English residents who did not belong to their body, yet even somewhat remote links of connection may not be disregarded because the Pilgrins numbered more than those who can possibly be identified now. ${ }^{2}$ The first names of those who certainly, or presumbly, belonged to their company are italicized. as are the last names, in parenthesis, of married women who were Pilgrins before marriage.

As the Dutch recorders wrote down an English name merely from the sound, seldom, if ever, inquiring how it was spelled, it often is difficult, and occasionally is impossible, to be certain what English name is represented. Sometimes this can be determined by external evidence. For example, the name of Brewer is established by the letters of his countryman, Ambassador Carleton, although the Dutch records give it as Brower, Bronwer and Braeber ; and Pontus, written at Leyden as Pantus and Pantes, is settled by the Plymouth Colony records. But in such a case as that of Rose Singer's last name,

1 Pp. 502, 503.

2 In the Proceedings of the Mass. Hist. Society, II, Ser. XVII : 167-194 for April, 1903 , is a paper by me, briefly summarizing the following notes as to the membership of the company in Leyden. Since that article was written I have discovered some additional facts, and in a few instances my opinion has been amended. 
recorded as Chinheur, one is left in doubt. Prolonged stndy, remembering the peculiarities of the Dutch pronunciation, and consultation with English-speaking Dutch scholars have led to the conclusions which are set down. It is by no means certain that they are correct in every instance, but at any rate they are probable. A few persons, evidently holding relations with the English, are included, although no English equivalents of their names are known, because they, too, may have been English whose names the Dutch clerks have managed to disguise; e. g., Peter Boey and George Materscé.

When it is possible that the deceased first husband, or wife, of one of the company may have been in Leyden for a time, such a person is included ; e. g., Samuel Fuller's first wife, Alice (Glascock). When the only known parent (or both parents) was in Leyden until July, 1620 , it is assumed, if there is no indication to the contrasy, that the children also were there; e. g., the Allerton children. Each case, however, needs to be considered by itself, and occasionally in very similar conditions different conclusions have seemed probable. Undoubtedly some other persons, not now to be idlentified, were members of the company, which from first to last - i. e., from the spring or early summer of 1609 to about the end of July, 1620 - must have included at least from 400 to 500 individuals. The examination of the records has been continued down to the end of the seventeenth century. by which time the members of the company had died; had left Holland, or had become absorbed in the Dutch population.

In connection with their residences in Leyden it should be noted that several names are those of districts, much like the wards of a modern city and each including a number of streets. Such are the Noordende, Nieuvestadt, Zevenhuysen, etc. At least a hundred and fifty of the company lived within the shadow of the Pieterskerk or within five minutes' walk of that spot. Apparently the Pieterskerkinof was similar in appearance to the "hofs" in a modern Dutch town and evidently was the little colony of houses built upon the grounds of the Robinson estate. Sometimes, also, it is called the Groenepoort, and in other instances somewhat dissimilar names evidently mean one place; e.g., Coepoortsteeg and Coepoortsgracht, Middleberg and Middlegracht.

It las not been thought worth while to print the hundreds of references to the Dutch archives which substantiate the successive items mentioned, many of which, indeed, have been given already, but they all are in my possession. In the following lists m. against a name means that its owner came over in 1620 in the Mayflower ; $F$. in 1621 in the Fortune; and A. L. J. in 1623 in the Anne or the Little James.

M. D. 


\section{THE PILGRIM COMPANY IN LEYDEN.}

Ainsworth, John. Tobacco-worker. Betrothed to Eliz. Keble Dec. 5, 1636, with witnesses Thos. Naslı and her moth., Eliz. Keble. Married Dec. 24. Guaranteed as citizen by Thos. Johnson and Sam. Lee Nov. 4, 1639. With bro.-in-law, Wm. Back, and wives sold house to Steph. Butterfield May 3, 1646. Witnessed betrothal of Sam. Lee Oct. 18, 1648. Lived on Pieterskerksteeg. Elizabeth (Keble). Wife of John. With moth. and sist., Mercy, mortgaged house on Dwarsheerensteeg for 300 gilders Sept. 13, 1638. With sist., Mercy, and husbands sold house on St. Michelsteeg for $1500 \mathrm{~g}$. to Steph. Butterfield May 3, 1646. Sold mortgaged house for 1700g. to Dirckson van Assel Dec. 13, 1646. Wit. bet. of Gid. Bartlett Feb. 10, 1651. Lived on Chursteeg. Wit. bet. of Joln Price June 8, 1651. Do. Jas. Jennings May 21,1654 .

Allerton, Isaac. м. From London. Tailor. Bet. to Mary Norris Oct. 7, 1611, with wits. Rich. Masterson, Ed. Southworth, Dille (Priscilla) Carpenter and Anna (Susanna) Fuller. Mar. Nov. 4. Guar. by Rog. Wilson and Hen. Wood Feb. 7, 1614. Guar. bro.in-law, Deg. Priest, Nov. 16,1615. Wit. bet. of Ed. Winslow Apr. 27, 1618. Do. Rog. Wilkins Sept. 16, 1619. Buried child ${ }^{1}$ in St. Peter's Feb. 5, 1620. Then lived in Pieterskerlikof. With Bradford, Fuller and Winslow wrote letter from Leyd. to Carver and Cushman in Eng. June 10, 1620.

Mary (Norris). M. From Newbury, Berks. Wife of Is. Wit. bet. of John Reynolds July 28, 1617. Do. Ed. Winslow Apr. 27, 1618. Do. Dan. Fairfield July 14, 1618.

- Child of Is. and Mary. Died Feb., 1620.

Burtholomew. M. Son of Is. and Mary.

Remember. м. Dau. of Is. and Mary.

Mary. M. Dau. of Is. and Mary.

John. м. Bur. child in St. Pet., May 21, 1616. Then lived in Pieterskerkhof.

- Child of John. Died 1616.

Robert. From Scotland. John Brown and Rob. Robertson deposed, Aug. 21, 1619, that he had lived in Leyd. 12 years.

Arnold, Elias. Watch-naker. Bet. to Sincere Pickering Feb. 22, 1636, with wits. his bro., Nath. Arnold, of Amst., and her moth., Mary Pickering. Mar. Mar. 18. Wit. bet. of John Jennings, Jr., Aug. 21, 1648. Lived on Rapenburg.

1 Not necessarily young. Of any age under twenty-one. 
Arnold, Sincere (Pickering). Wife of Elias.

- Sylvanus. From London. Hat-maker. Bet. to Hest. Butterfield, July 16,1632, with wits. her bro., Steph. Butterfield, and Sar. Lee. Mar. July 31. Lived on Groenensteeg.

Hester (Butterfield). Wife of Sylv.

Back, William. Son of Hen. Shoemaker. Bet. to Mercy Keble Apr. 7, 1640, with wits. Corn. Symons and her moth., Eliz. Keble. Mar. Apr. 30. Lived on Langebmuge, With bro--in-law, John Ainsworth, and wives sold house to Steph. Butterfield May 3, 1646.

Mercy (Keble). Wife of Wm. With moth. and sist., Eliz., mortgaged house on Dwarsheerensteeg for 300g. Sept. 13, 1638. With sist., Eliz., and husbs. sold house on St. Michelsteeg for 1500g. to Steph. Butterfield May 3,1646. Sold mortgaged house for $1700 \mathrm{~g}$. to Dirckson van Assel Dec. 13, 1646.

Bailey, Daniel. Wit. bet. of Sus. Bailey to Is. Chilton May 6, 1615 . Prob. her bro.-in-law.

Susanna (de la Cluse). From Norwich, Norf. See Sus. Chilton. Barker, Elizabeth. M. From "Chatsum." ' See Eliz. Winslow.

Barlow, Thomas. Bur. wife in St. Pet. July 1, 1621. Then lived on Langebrugge. Wit. bet. of dan., Abig., to John Dunham Oct. 7, 1622. Do. dau., Anna, to Nath. Walker May 28, 1624. Do. dau., Mary, to Steph. Foster, of Rotterdam, June 4, 1639.

$-(-)$. Wife of Thos. Died 1621. Abigail. Dau. of Thos. See Abig. Dunham.

Anna. Dau. of Thos. Wit. bet. of sist., Abig., to John Dunham, Oct. 7, 1622. See Anna Walker.

- Mary. Dau. of Thos. Bet. to Steph. Foster, printer's man, of Rotterdam, June 4, 1639, with wits. her fath., Thos. Barlow, and Bridg. Robinson. Mar. July 23.

Barrow, ${ }^{2}$ Zechariah. Wool-carder. Widower of Ellen. Bet. to Joan Barrow June 16, 1616, with wits. John Crackstone, MIos. Fletcher and Wyb. Pontus. Mar. July 2. Lived on Vliet. Wit. bet. of dau., Marg., to Rog. Wilkins, Sept. 16, 1619. At census of Oct. 15,1622 , lived with wife in Zevenhuysen. Bur. in St. Pancras May 22, 1624. Then lived on Ramsteeg.

Ellen (-). 1st wife of Zech.

- Joan (Barrow). 2d wife of Zech.

- Margaret. Dau. of Zech. and Ellen. See Marg. Wilkins.

Bartlett, Gideon. Tobacco-pipe-maker. Bet. to Anna Stuart, Feb. 10, 1651, with wits. John Price and Eliz. Ainsworth. Mar. Mar. 4.
1 Doubtless Chattisham, Suff.
${ }^{2}$ Possibly Barry. 
Bartlett, Anna (Stuart). Wife of Gid.

Bassett, William. F. From Sandwich, Kent. Master-mason. Widr. of Cicely. Bet. to Mary Butler, Mar. 19, 1611, with wits. Wm. Brewster, Rog. Wilson, Anna (Susanna) Fuller and Rose Lisle. She died before marriage. Bet. to Marg. Oldham, July 29, 1611, with wits. El. Southworth, Rog. Wilson, Eliz. Neal and Wyb. Pontus. Mar. Aug. 13. Mar. 3d wife, Eliz. —, before coming to N. E. in 1621.

Cicely (Light). 1st wife of Wm.

Margaret (Oldham). 2d wife of Wm.

Elizabeth (-). F. 3d wife of Wm.

Beere, Elizabeth (Sharp). See Eliz. Coit.

Belden, Mareus. Guar. John Spooner Sept. 18, 1623.

Benuett, Anthony. Cloth-maker. Widr. of Eliz. Bet. to Mercy Peck Apr. 6, 1644, with wits. Pet. Powell and Eliz. Williams. Mar. Apr. 23. Lived on Langegracht.

Elizabeth (Whittington). 1st wife of Anth.

Mercy (Peck). 2d wife of Anth.

Bishop, Elizabeth (-). From Canterbury, Kent. Wit. bet. of dau., Mary, to Pet. Wood, Jr., July 8, 1643.

- Mary. Dau. of Eliz. See Mary Wood. - Mary (Another). See Mary Johnson.

Blossom, Thomas. From Cambridge. Geo. Rogers, student, when matric. in Leyd. Univ., Oct. 27,1609, lived with him. Gave power of atty. to wife, Amn, Mar. 12, 1610, to sell houses in Cambridge, Eng. Bur. child in St. Pet. Apr. 12, 1617. Then lived in Pieterskerkhof. With Fras. Jessop, Rich. Masterson, Thos. Nash and Rog. White wrote to Wm. Bradford at Plym., N. E., Nov. 30, 1625. Wrote to same Dec. $15,1625 .^{1}$ Came to N. E. with wife and two sons in 1629 .

- Ann (-). Wife of Thos. Inherited by will of moth's. fath. certain houses in Cambridge, Eng., and received power of atty. from husb. to sell them, especially two in St. Giles Parish, Mar. 12,1610 .

- Child of Thos. and Ann. Died 1617.

Thomas. Son of Thos. and Ann.

Peter. Son of Thos. and Ann.

Boey, Peter. Guar. Rog.Wilson Dec. 7, 1609. Do. John Turner Sept. 27, 1610.

Bowman, Margaret. Bet. to Edm. Elias White Ang. 14, 1629. Banns forbidden. See E. E. White.

1 Bradford. Letter Bk. Mass. Hist. Soc. Colls. I. iii : 41, 44. 
Bradford, William. M. From Austerfield, Yorks. Fustian-weaver. Guar. by Wm. Lisle and Rog. Wilson Mar. 30, 1612. Wit. bet. of Dor. Pettinger Nov. 1, 1613. Bet. to Dor. May at Amst. Nov. 9,1613 , he being 23 and she 16, with wit. her fath., Hen. May; and at Leyd. Nov. 15 unaccompanied and by "attestation upon their own behalf." Mar. at Amst. Dec. 10. The Leyd. records have an entry of the marriage with the note "No certificate left." Wit. bet. of Mos. Fletcher Nov. 30, 1613. Guar. Sam. Lee Oct. 19, 1615. Borrowed $400 \mathrm{~g}$. from Jan van Griecken on house in Achtergracht June 12, 1617. Sold this house for $1120 \mathrm{~g}$. to Jan des Obrys Apr. 19, 1619. Guar. Wm. Ring June 7, 1619. With Is. Allerton, Fuller and Winslow wrote letter ${ }^{1}$ from Leyd. to Carver and Cushman in Eng. June 10, 1620.

— Dorothy (May). M. From Wisbech, Cambs. Dau. of Hen. ${ }^{2}$ Wife of Wm. Wit. bet. of Hen. Wilson, May 13, 1616.

John. Son of Wm. and Dor. Came to Plym. in 1627 or soon after.

Brewer, Thomas. Printer. Matric. in Letters at Leyd. Univ. Feb. 17, 1615, aged 35. Bought Groenehuis, next but one to John Robinson's, for $3200 \mathrm{~g}$. from Johann de Lalaing, June 17, 1617. Bur. child in St. Pet. Aug. 30, 1618. Bur. son there Oct. 3, 1618. Bur. 1st wife there Oct. 20, 1618. Assoc. with Wm. Brewster in printing business. Exam. by univ. authorities Sept. 21-23, 1619, and had printing materials seized upon demand of Eng. ambassador. Imprisoned. Exam. further Oct. 21, 1619. Sent to Eng., accomp. by — Jenkins and Wm. Lisle Nov. 12, 1619. Ordered detained in Leyd. May 9, 1620. Bur. young dau. in St. Pet. Aug. 27, 1620. Lived in Zevenhuysen, ${ }^{3}$ Oct. 15, 1622, with wife, six children, and Thos. and Hest. Willis (not servants and possibly the Willets). As one of Merch. Advents. signed at London Apr. 7, 1624, and Oct. - 1626, letters to Plym. Col. and made new terms through Is. Allerton, Sold house in Leyd. July 15, 1630. E. Arber cites document ${ }^{4}$ to the effect that Brewer lived in Kent about 1626.

$-\longrightarrow$ (—). 1st wife of Thos. Died 1618.

1 IIist. 49.

2 Rog. White in letter of Dec. 1, 1625 (Mass. Hist. Soc. Colls. I. iii : 42), to Bradford speaks of "your father-in-law, Mr. May."

3 The record describes him as "Engelsch Edelman," i. e., English nobleman. Apparently he was understood to be of high descent.

4 Story, 246. James Martin's Detection of Brownists in Kent.

"The said BrEwER . . . being a man of good estate, is the general patron of the Kentish Brownists; who, by his means, daily and dangerously increase." 
Brewer, - Child of Thos. and 1st wife. Died Aug., 1618.

—. Son of Thos. and 1st wife. Died Oct., 1618.

Stephen. Son of Thos. and 1st wife.

Trintye. Son of Thos. and 1st wife.

Margaret (-). 2d wife of Thos. Must have mar. him soon after 1st wife's death, as she apparently had four children before Oct. $15,1622 .^{1}$

Daniel. Son of Thos. and Marg.

Rebecea. Dau. of Thos. and Marg.

John. Son of Thos. and Marg.

- Daniel. (A second) son of Thos. and Marg.

Brewster, William. M. From Scrooby, Notts. Teacher and masterprinter. Guardian of Ann Peck on June 12, ${ }^{2} 1609$. Bur. child in St. Pan. June 20,1609. Then lived on Stinksteeg. Made affidavit June 25, 1609, with wife and son, Jon., of receipt of bale of cloth from Bern. Ross. Then about 42 and lived on St. Ursulasteeg. Wit. bet. of Wm. Pontus Nov. 13, 1610. Do. Wm. Bassett Mar. 19, 1611. Do. Rand. Thickins Apr. 1, 1611. Do. Wm. Buckram Nov. 30, 1611. Sent to Eng. with Rob. Cushman in 1617 to treat with Virg. Co. With Robinson received at Leyd. letter of Nov. 12-22, 1617, from Sir E. Sandys. With Robinson replied Dec. 15, 1617. With Robinson sent to Sir Joln Wolstenlolme letter of Jan. 17, 1617, and two declarations of belief of church for submission to Council. Cushman's letter of May 8-18, 1619, from London seems to prove that Brewster then was in England again. Whether he ever returned to Leyd. is uncertain. The following works were printed by Brewer and himself : -

1. An Abridgement of that Book which the Ministers of Lincoln Diocess delivered to his Majestie upon the first of December last, being the first part of an Apologye for themselues and their brethren that refuse the subscription and conformitie which is required. [Reprint.] 1617.

2. Commentarii Succincti \& Dilucidi in Proverbia Salomonis. Quibus adhibita est Prafatio Iohannis Polyandri. By T. Cartwright. 4to. 1616 or 1617 .

3. A Full and plaine Declaration of Ecclesiastical Discipline. By W. Travers (?), 1616 or 1617 .

1 Possibly she was a widow already having children. This supposition would account for their number. But the records do not suggest it. All the children have Brewer as the last name or the contrary names would be stated. That two contemporary children should have the same first name was the fact occasionally later in the Plym. Col., but no other instance at Leyden has been noted.

2 Recorded twice, and one entry says June 10. 
4. Guil. Amesii ad Responsum Nic. Grevinchovii Rescriptio contracta. By W. Ames. 1617.

5. A Trve, Modest, and Ivst Defence of the Petition for Reformation, exhibited [in 1603] to the Kings most excellent Maiestie, containing an Answere to the Confutation published under the names of some of the Vniversitie of Oxford. 16mo. 1618.

6. Certain Reasons of a Private Christian against Conformitie to kneeling in the very act of receiving the Lords Supper. By T. Dighton. 16mo. 1618.

7. A Little Treatise vpon the first verse of the 122. Psalme. [Reprint.] By R. Harrison. 16mo. 1618.

8. A Godly Sermon upon the 3. 4.5.6.7. and 8. verses of the 12. chapter of the Epistle of $S$. Paule to the Romanes. By L. Chaderton (?). 16 mo. 1618.

9. The Peoples Plea for the Exercise of Prophesie, against $M^{r}$. Iohn Yates, his Monopolie. By J. Robiuson. 16mo. 1618.

10. A Confitation of the Rhemists Translation, Glosses and Annotations on the New Testament. By T. Cartwright. fol. 1618.

11. De vera et genuina Jesu Christi Domini et Salvatoris nostri Religione. 16 mo. 1618.

12. Hieronymi Philadelphi de Regimine Ecclesiae Scoticanae Brevis Relatio. By David Calderwood. 1618.

13. Apologia Ivsta et Necessaria Qvorvndam Christianorum, aque contumeliose ac communiter dictorum Brownistarum sive Barowistarum. By John Robinson. 16mo. 1619.

14. Perth Assembly. Containing the Proceedings thereof. Anon. [But by David Calderwood.] 4to. 1619.

15. The Second Part of a Plain Discovrse of an Vnlettered Christian, wherein by Way of demonstration hee shevveth vvhat the reasons bee vvhich hee doth ground upon, in refusing conformity to kneeling in the act of receiving the Lords Supper. By Tho. Dighton, Gent. 16mo. 1619.

16. An Ansvver to the Ten Covnter Demands, propvnded by T. Drakes, Preacher of the Word at H. and D. in the County of Sussex. By Wil. Euring. 16mo. 1619.

Brewster, Mary. M. From Scrooby. Wife of Wm. Made affid. with husb. and son, Jon., June 25, 1609. 'Then about 40. Wit. bet. of John Reynolds July 28, 1617.

\section{—- Child of Wm. and Mary. Died 1609.}

Jonathan. F. From Scrooby. Son of Wm. and Mary. Born Aug. 12, 1693.' Ribbon-maker. Made affid. with parents June 25, 1609. Then about 16. Bur. child in St. Pet. Nov. 27, 1610. Guar. by Is. de Syde and Sebastianson van Hout June 30, 1617. Wit. bet. of John Reynolds July 28, 1617. Do. Ed. Winslow Apr. 27, 1618. Bur. wife in St. Pet. May 10, 1619. Lived in Pieterskerkhof.

1 Brewster Bk. See Mayflower Descendant, i: 7. 
Brewster, - (- Wife of Jon. Died 1619.

- Child of Jon. Died 1610.

Patience. A. L. J. Dau. of Wm. and Mary. Wit. bet. of Thos. Smith Dec. 12, 1618. Mar. T. Prince in 1624, at Plym.

- Fear. A. L. J. Dau. of Wm. and Mary. Mar. Is. Allerton in 1626 at Plym.

- Love. y. Son of $\mathrm{Wm}$. and Mary.

- Wrestling. M. Son of Wm. and Mary.

Bridgman, William. Joined with Brewsters in affid. June 25, 1609.

Then about 26. Bur. child in St. Pet. July 20, 1612. Guar. John

Lee July 9, 1629. Then kept inn.

——. Child of $\mathrm{Wm}$. Died 1612.

Brook, Hubert. From Leicester. Watch-maker. Guar. by Sam. Lee and Jac. van de Wan Nov. 1, 1630. Wit. bet. of John Masterson Sept. 16, 1633.

Brown, John. Wool-comber. Deposed with Rob. Robertson about Rob. Allerton Aug. 21, 1619.

Mary. From Colchester, Essex. See Mary Dunster.

Buckram, William. From Ipswich, Suff. Block-maker. Widr. of Judith. Bet. to Eliz. Neal Nov. 30, 1611, with wits. Wm. Brewster, Abr. Gray, Bridg. Robinson and Jane Thickins. Mar. Dec. 17.

- Judith (—). 1st wife of Wm. Elizabeth (Neal). 2d wife of Wm.

Butler, Mary. From Norwich. Bet. to Wm. Bassett Mar. 19, 1611. Died before marriage. Bur. in St. Pet. Apr. 9, 1611. Lived on Pieterskerkgracht.

- (Another). Wit. bet. of Wm. Pontus Nov. 13, 1610. Bur. in St. Pet. July 16, 1616. Lived near Vrouwekerk.

Samuel. From Yarmouth, Norf. ${ }^{1}$ Merchant. Bet. to Sar. Porter Aug. 7, 1615, with wits. Sam. Fuller, Wm. Jepson, Rosam. Jepson and Sar. Minter. Mar. Aug. 25.

Sarah (Porter). Wife of Sam.

Butterfield, Hester. From Diss, Norf. Sist. of Steph. See Hest. Arnold.

Stephen. From Norwich. Bro. of Hest. Say-weaver. Bet. to Rose Singer Oct. 13, 1617, with wits. Abr. Gray and Sar. Minter. Mar. Oct. 30. Lived on Nieuwesteeg. Wit. bet. of sist., Hest., to Sylv. Arnold July 16, 1632. Then lived near Kraan. Guar. by Chris. Ellis and John Jennings Nov. 20, 1637. Then book-

1 Much more probably that from which several Pilgrims had come than the other Yarmouth, that in the Isle of Wight. 
seller. Bonght house on St. Josephsteeg for $1050 \mathrm{~g}$. from Hen. Jepson June 6,1642. Bought house on St. Michelsteeg for $1500 \mathrm{~g}$. from Eliz. Ainsworth and Mercy Keble May 3,1646. Bur. in St. Pet. Dec. 24, 1652. Then lived by Doelens.

Butterfiell, Rose (Singer). Wife of Steph. Wit. bet. of Rog. Wilkins Sept. 17, 1619.

— John. Son of Steph. Sold to Pet. Godefroy for 1175g. Feb. 27, 1669, house bought by Steph. in 1642. Mortgaged house for $500 \mathrm{~g}$. Mar. 11, 1670. Bought for $3790 \mathrm{~g}$. from est. of Fear Jennings house near Coepoort May 31, 1670. A guard. of her childrell. Sold mortgaged house for $842 \mathrm{~g}$. to Mich. Verschoore June 4,1672 .

Carey, Sarah. A. L. J. From "Moncksoon." 1 Wit. bet. of Rog. Wilkins Mar. 28, 1614. See Sar. Jenny.

Carlisle, James. From Hull, Yorks. Silver-smith. Bro. of Anna and Ellen. 1st husb. of Eliz.

- Anna. From Hull. Sist. of Jas. and Ellen. See Anna Ross. Ellen. From Hull. Sist. of Jas. and Anna See Ellen Kingsland.

Elizabeth (-). Wife of Jas. See Eliz. Smith.

Carpenter, Alexander. From Wrington, Somers. Wit. bet. of dau., Jul., to Geo. Morton July 6,1612. Do. dau., Agnes, to Sam. Fuller Mar. 15, 1613.

Agnes (or Anna). Dau. of Alex. Wit. bet. of Ed. Pickering Nov. 24, 1612. See Agnes Fuller.

Alice. A. L. J. Dau. of Alex. Wit. bet. of sist., Jul., to Geo. Morton July 6, 1612. Do. Ed. Pickering Nov. 24, 1612. Do. sist., Agnes, to Sam. Fuller Mar. 15, 1613. See Alice Southworth.

Juliana. A. x. J. Dau. of Alex. See Jul. Morton.

Priscilla (or Dille). Dall. of Alex. Wit. bet. of Is. Allerton Oct. 7, 1611. Came to Plym., N. E. "soon after 1627." 2 There mar. Wm. Wright.

John. Say-weaver. Guar. Bart. Smith Apr. 5, 1611.

Carver, John. M. Apparently bur. child in St. Pan. July 10, 1609. Then lived on Middleberg. Wit. bet. of Hen. Wilson May 13,

1 Probably Monk Soham, Suff. Possibly Monkton, Hants.

${ }^{2}$ Goodwin, 462. He also says that there was another daughter, Mary, who buried her aged mother at Wrington in 1644 and then came over to Plymouth, where she died in 1687 , aged about 90 . As no mention of the mother or of this daughter occurs at Leyden, possibly they never went to Holland but remained at Wrington. She seems to have been poor in 1644 . 
1616. Do. John Jennings Mar. 3, 1617. Apparently ${ }^{1}$ bur. anoth. child in St. Pan. Nov. 11, 1617. Then lived on Middlegracht. Wit. bet. of Rog. Simmons July 14, 1618. Acted more or less with Brewster and Cushman as agent of Pilgrims in England $1617-20$.

Carver, Catharine (-). M. Wife of John. Wit. bet. of Rog. Chandler May 22, 1615. Do. Rob. Cushman May 19, 1617.

- Prob. child of John and Cath. Died 1609.

__ Prob. child of John and Cath. Died 1617.

Chandler, Edmond. Say-weaver. Guar. by Rog. Wilson and Hen. Wood Nov. 11, 1613. Guar. Jolm Keble Apr. 27, 1615. Bur. child in St. Pet. Mar. 26, 1619. Then lived in Nieuwestadt. Guar. Rog. White May 5, 1623. Then draper. Guar. Ed. Coolidge Apr. 17, 1626. Then pipe-maker.

— Child of Edm. Died 1619.

- Roger. From Colchester. Say-weaver. Bet. to Isab. Chilton May 22, 1615, with wits. Rog. Wilson, Cath. Carver and Sar. Minter. Mar. July 21. Lived in Zevenhuysen with wife and two children Oct. 15, 1622.

Isabella (Chilton). Wife of Rog. Wit. bet. of Hen. Collet May $19,1617$.

Samuel. Son of Rog. and Isab.

Sarah. Dau. of Rog. and Isab.

Charles, Mildred. See Mild. Terry.

Chilton, Angelina. See Ang. Nelson.

Isaac. From France. Looking-glass-maker. Bet. to Sus. Bailey May 6, 1615, with wits. Dan. Bailey, prob. her bro--in-law, her parents, Jean and Cath. de la Cluse, ${ }^{2}$ and Anna van Tyburgen. No rec. of wedding. Prob. it was at Amst. ${ }^{8}$

1 In the first case the name in the record seems to be Carceer, and in the second Taver. Without much donbt each stands for Carver.

2 They lived in Amsterdam, but apparently had lived earlier in Norwich and London, Eng. He was an elder (Cong. in Lit. 339. But J. Howells - Epis. Ho. Elian. 10- says a deacon) in Ainsworth's church in 1612. The Leyden records give "Cathlyne" plainly. But as the Amsterdam records state that when Jean married Alice (Lewis), widow of Thos. Dickens, Aug. 7, 1604, he was widower of Cath., the Leyden clerk must have set down Susanna's mother's name, which naturally might have been mentioned, as that of her step-mother who evidently was present. This step-mother must have been Jacqueline (May) de la Clnse, from Wisbech, Cambs., whom Jean had married May 14, 1609, sister of Dor. (May) Bradford.

3 The absence of any entry of a marriage following a betrothal may have been accidental in some cases, but is more likely to mean that the wedding took place elsewhere and was recorded where it occurred. 
Chilton, Susanna (de la Cluse, Bailey). Wid. of —_. Wife of Is. - Isabella. From Canterbury. See Isab. Chandler.

Clark, Susanna (Cleary). Wid. of Thos. John Lee and Thos. Mitchell testified to her good standing Aug. 15, 1622.

Claverly, Nicholas. Tobacco-pipe-maker. Sam. Lee and Deg. Priest deposed, Apr. - 1616, that he had lived in Leyd. 4 years. For some reason this record is crossed out, but the deposition evidently was made.

Clement, Anthony. Bombazine-weaver. Wit. bet. of Steph. Tracy Dec. 18, 1620. Guar. Rog. White May 5, 1623. Widr. of Jane. Bet. to Clara Jones Mar. 5, 1627, with wits. Quiryn Johnson and Mary Jones. Mar. Mar. 20. Lived on Marendorp.

Jane (Jones). 1st wife of Anth.

- Clara (Rogers, Jones). Wid. of John. Lived on Haarlemstraat. $2 d$ wife of Anth.

Coit, John. Bro. of Thos. Wit. his bet. Apr. 14, 1623.

Thos. Say-weaver. Bet. to Eliz. Beere Apr. 14, 1623, with wits. his bro., John Coit, John Fowle, and her moth., Jane Sharp. Mar. Apr. 29. Bet. to Pris. Phillips Mar. 17, 1626, with wits. Wm. de Corninck and Justina Jones. Mar. Apr. 4.

— Elizabeth (Sharp, Beere). Dau. of Jane. Wid. of ——. 1st wife of Thos.

— Priscilla (Fletcher, Phillips). Wid. of —. 2d wife of Thos. See Pris. Terry.

Collet, Henry. Twine-maker. Bought house on Dwarsheerensteeg from Thos. van Oudermarck Mar. 21, 1612. Guar. by Abr. Gray and Rich. Masterson Mar. 30, 1612. Sold same house to John Keble Mar. 28, 1614. Widr. of Anna. Bet. to Alice Howarth May 19, 1617, with wits. John Crackstone, Thos. Harris and Isab. Chandler. Mar. June 3. Lived on Korte Heerensteeg.

- Anna (Harris). 1st wife of Hen.

- Alice (Thomas, Howarth). Wid. of John. 2d wife of Hen.

Coolidge, Edward. Tailor. Guar. by Edm. Chandler and John Spooner Apr. 17, 1626.

Cox, Valentine. 1st husb. of Anna.

Anna (Hamden). ${ }^{1}$ Wid. of Val. See Anna Hatfield.

Crackstone, John. M. From Colchester. Wit. bet. of Zech. Barrow June 16, 1616. Do. Hen. Collet May 19, 1617. Do. dau., Anna, to Thos. Smith Dec. 12, 1618.

- (Anna). Dau. of Jolın. See Anna Smith.

- John. M. Son of Jolin.

1 Hentem in entry. 
Crips, Joseph. From Chichester, Sussex. Card-maker. Guar. by Joost Lambrechts and Thos. Sunitl June 3, 1616. Lived in Zevenhuysen Oct. 15, 1622.

- Christina. Wife of Jos.

- Anna. Dau. of Jos. and Clurist.

Jeremiah. Son of Jos. and Christ.

Crook, Authony. Advocate. Husb. of Eliz.

- Elizabetl (Ellis). Evidently related to Chris., etc. Mortgaged ten houses in Groenepoort to minor child of Jochem Rous Oct. 5, 1667. Sold louse for $300 \mathrm{~g}$. to Aernout Conerniet Jan. 7, 1668. Sold anoth. for $750 \mathrm{~g}$. to Pet. La Broij Mar. 10, 1668. Sold anoth. for $420 \mathrm{~g}$. to Pet. Piadt June 30,1668 . Sold anoth. for $625 \mathrm{~g}$. to Nich. Schinkels Nov. 15, 1668. Sold anoth. for $900 \mathrm{~g}$. to John Poock Dec. 8, 1668. Her children, Rich. and Hest., wife of Lenfer Ramp, sold the ten mortgaged houses to Mary Maartens Mar. 2, 1678.

Hester. Dau. of Anth. and Eliz. Mar. Lenfer Ramp.

Richard. Son of Antli. and Eliz.

Cushman, Robert. From Canterbury. Wool-comber. Bought house from Corn. Gliysberts van Groenendael Nov. 4, 1611. Bonght anoth. from same Apr. 19, 1612. Bur. child in St. Pet. Mar. 11, 1616. Then lived on Nomnensteeg. Bur. wife, Sar., in St. Pet. Oct. 11, 1616. Then lived on Boisstraat. Bur. anotl. child in St. Pet. Oct. 24.1616. Then lived on Hontmarclit. Bet. to Mary Singleton May 19,1617, with wits. Joln Keble and Cath. Carver. Mar. June 5. Sold first named house to John de Later Sept. 19, 1619. With Brewster and Carver acted as agent of Pilgrims in England 1617-20. Went as far as Plym., Eng., with Pilg. emigrants but returned. Letters ${ }^{1}$ from him at Lond. to company at Leyd. and to Carver, at Dartmouth to Southworth, and, apparently from Lond., to Plym. Col. preserved by Bradford. Visited, Plym. Col. in 1621.

- Sarah (-). 1st wife of Rob. Died 1616.

—. Child of Rob. and Sar. Died Mar. 1616.

- Child of Rob. and Sar. Died Oct. 1616.

Thomas. F. Son of Rob. and Sar. Born 1607.2

- Mary (Singleton). Wid. of Thos. 2d wife of Rob.

Cuthbertson, Cuthbert. A. L. J. Hat-maker. Bet. to Eliz. Kendall

1 Hist. $36,51,54,56,122.143,159$. Also one from Jas. Sherley and others to the Col. "wrote with Mr. Cushman's hand ; and it is likely was penned by him at the other's request." Letter Bk. Mass. Hist. Soc. Colls. I. iii : 29.

214 in 1621. Goodwin, 190. Mayflower Descendant, iv : 37-38. 
May 12, 1617, with wits. her bro. and moth., Ed. and Eliz. Kendall, and Eliz. Keble. Mar. May 27. Bet. to Sar. Priest Oct. 25, 1621, with wits. Joln Josephson, Wm. White and Sar. Talbot. Mar. Nov. 13.

Cuthbertson, Elizabeth (Kendall). 1st wife of Cuth.

— Sarah (Allerton, Vincent, Priest). A. L. J. Sist. of Is. Wid. of John. Wid. of Deg. 2d wife of Cuth.

- Samuel. A. L. J. Son of Cuth.

Denby, William. 1st husb. of Sar.

— Sarah. Wid. of Wm. See Sar. Fletcher.

Dennis, Herbert. Guar. Rob. Robertson and John Warnes May 20, 1622.

De Soete, John. 1st husb. of Anna.

— Anna (Kendall). Dau. of Aar. Wid. of John. See Anna Dunster.

Dunham (or Denham), John. Widr. of Sus. Bet. to Abig. Barlow Oct. 7, 1622, with wits. her fath. and sist., 'Thos. and Anna Barlow. Mar. Oct. 22. Lived in Zevenhuysen Oct. 15, 1622, with three children by 1st wife.

- Susanna (Kenney). 1st wife of John.

- John. Son of John and Sus.

—- Humility. Dau. of John and Sus.

- Thomas. Son of John and Sus.

Abigail (Barlow). 2d wife of John. Wit. bet. of sist., Anna, to Nath. Walker May 28, 1624.

Dunster, John. Bro. of Sim. Wit. his bet. Sept. 22, 1623.

— Leonard. Say-weaver. Bet. to Mary Brown Jan. 10, 1620, with wits. her moth. and step-fatl., Mary (Brown) and Jas. Sunderland. Mar. Jan. 25. Wit. bet. of Jas. Milbrook Nov. 17, 1622.

— Mary (Brown). Dau. of Mary (Brown) Sunderland. Wife of Leon.

Simon. Bro. of John. Say-weaver. Bet. to Anna de Soete Sept. 22, 1623, with wits. John Dunster and Anna Martins. Mar. Oct. 8.

_- Anna (Kendall, de Soete). Wid. of Jolnn. Wife of Sim.

Ellis, John. Wool-comber. Deposed to knowledge of bro.-in-law, Rich. Masterson, Mar. 20, 1619. Then about 50. Wit. bet. of Rich. Masterson Nov. 8, 1619. Apparently had been married twice with one child by each wife. Having removed to Eng. and being about to marry again, gave house on Barbarasteeg to son, Chris., June 18, 1629. Gave nothing to dau., Mary, she having had much more from her mother's estate. 
Ellis, - (Masterson). Prob. 2d wife of John.

\section{- Mary. Dau. of John.}

Christopher.' Son of John. Cabinet-maker. Guar. by Fred. Jones and Quiryn Mees Dec. 2, 1619. Bet. to Hest. Leonard Nov. 12, 1621, with wit. Pet. van Zyl. Mar. Dec. 3. Received house on Barbarasteeg from fath. June 18, 1629. Bought two houses from Martha Jepson, by her guards., John Jennings and John van Leewen, Jan. 11, 1636. Sold house on Sonnerveltsteeg for 1100g. to Ancl. Parkins Aug. 4, 1636. Sold house in Pieterskerkhof for $1100 \mathrm{~g}$. to And. Williams June 18, 1637. Bought several houses in Groenepoort from Martl. Jepson, by same guards., June 25, 1637. Guar. Steph. Butterfield Nov. 20, 1637. With And. Johnson, guard. of children of Jasper Eelhont, and Ivar Powells sold house on Langeschoolsteeg to Sierick van Tritsum Dec. 3, 1637. Sold house for $1200 \mathrm{~g}$. May 10, 1638. Sold house on Papengracht for 645g. to Dud. Rochester Nov. 8, 1638. Sold house for $400 \mathrm{~g}$. to Corn. van Warmont Mar. 17, 1639. Sold him anoth. for $600 \mathrm{~g}$. May 16, 1639. Sold mortgage for 1438g. to Benj. de Wannemaker May 17, 1639. Bought from Pet. Gerritson part of house in Groенероort formerly owned by Thos. Brewer May 4, 1640. Sold house for 3248g. to Jac. Lauwyck Apr. 29, 1641. Sold house for $4590 \mathrm{~g}$. to And. de Moieys May 31, 1641. Sold house on Bouwenlouwensteeg for 534g. to Charel Volmans June 25, 1641. Sold house for 2183g. to Hillis van Heussen Oct. 10, 1641. Sold half house on Langegracht for $850 \mathrm{~g}$. to Pet. de Norm Oct. 16, 1641. Sold house for $680 \mathrm{~g}$. to Rich. Thonisson Apr. 16, 1642. As guard. of children of Josse Maria van Houtons sold house for $750 \mathrm{~g}$. to Joachim Lemme May 27, 1642. Sold house for 455g. to Hen. Melchiors July 4, 1642. Rented house valued at $300 \mathrm{~g}$. for $15 \mathrm{~g}$. a year to Tobias Moyaert Jan. 16, 1643. On same day also sold him house for $2310 \mathrm{~g}$. Sold house for $1480 \mathrm{~g}$. to Cath. van de Wyngaert May 6, 1643. Sold house for 1182g. to Carl Toinison June 3, 1643. Sold house for $602 \mathrm{~g}$. to Jost Clementia, wid. of Prof. Reynerus Bontius, June 22, 1643. With And. Parkins sold house for 712g. to Christ. Heneman Ang. 6, 1643. Sold house on Langebrugge for 1640g. to Alb. Henricks van Diggerhorst July 15, 1645. Joined niglit watch, or city guard, in place of Hen. Peterson, sent to hospital, June 26, 1646. Sold vacant lot for $160 \mathrm{~g}$. to Hillis Janson May 28, 1647. Sold house for $770 \mathrm{~g}$. to Hendrick van Stoffeert May 7 ,

1 Generally recorded as Stoffel Janson, i. e., Christopher, son of John. Now and then, however, his name is written Stoffel Janson Ellis, thus identifying him. 
1648. Sold house for 567g. to Jolnn van de Stoffe Dec. 10, 1648. Sold house for $900 \mathrm{~g}$. to Machtel, wid. of Gerrit Adriens, and oths. June 18, 1650. Excused from service in night watch, being 60 years old, Aug. 22, 1651. With John Price became guard of Sam. Parkins July 31, 1653. Will dated Sept. 23, 1656. Died before Aug. 11, 1668.

Ellis, Hester (Leonard). Wife of Chris. Wit. bet. of John Jones, Sept. $29,1634$.

Abraham. Son of Chris. and Hest. Cabinet-maker. Eleven houses in Groenepoort ${ }^{1}$ transferred to him Feb. 29, 1664. Applied to magistrates Jan. 21, 1666, for leave to mortgage one house in order to raise money to repair oths. By fath's. will had income from them but could not mortgage or sell without special permission. Living in Leyd. in 1681.

Jacob. Son of Chris. and Hest.

Anna. Dau. of Chris. and Hest. Living unmarried in Leyd. in 1681.

England, ${ }^{2}$ Thomas. M. Wit. bet. of Jac. McConkey May 31, 1613.

Fairfield, Daniel. From Colchester. Son of Jac. Say-weaver. Wit. bet. of Rog. Simmons July 14, 1618. Bet. to Rebec. Willet same day with wits. Rog. Simmons and Mary Allerton. Mar. Aug. 4. Lived in Zevenhuysen Oct. 15, 1622, with wife and three children. Wit. bet. of sist.-in-law, Hest. Willet, to Pet. Wood Oct. 19, 1623.

- Rebecca (Willet). Wife of Dan. Wit. bet. of sist., Hest., to Pet. Wood Oct. 19, 1623. See Rebec. Jepson.

- Daniel. Son of Dan. and Rebec.

— Rebecca. Dau. of Dan. and Rebec.

- Joln. Son of Dan. and Rebec.

Fassett, Roger. Glove-maker. Guar. by Geo. Ferguson and Pet. Wright Sept. 8, 1623.

Ferguson, George. From Scotland. Shoe-maker. Deposed in 1616 that he was 36. Guar. Rog. Fassett Sept. 8, 1623. Do. Wm. Smith Feb. 16, 1626. Do. Humph. Howell Dec. 4, 1626.

Ferris, John. Bro.-in-law of Rob. Lamkin. Wit. his bet. Mar. 18, 1616.

Finch, Mary. Wit. bet. of Rich. Masterson Nov. 8, 1619.

Fletcher, Moses. M. Smith. Widr. of Maria. Bet. to Sar. Denby Nov. 30, 1613. with wits. Wm. Bradford, Wm. Lisle, Sar. Priest and Marg. Savory. Mar. Dec. 21. Wit. bet. of Zech. Barrow June 16,1616 .

1 Here this evidently is the same as the Pieterskerkhof.

2 Undoubtedly the Thos. English of the Mayflower. 
Fletcher, Maria (Evans). 1st wife of Mos. Sarah (-, Denby). Wid. of Wm. 2d wife of Mos.

Fowle, John. Wit. bet. of 'Thos. Coit Apr. 14, 1623. Do. Mart. West Dec. 27, 1625 .

Freeman, Joseph. Vouched for by affids. of Anth. Fretwell and Thos. Smith June 13, 1613.

Fretwell, Anthony. From Norwich. Tailor. Made affid. in behalf of Jos. Freeman June 13, 1613. Then 36. Guar. Pet. Wright May 6,1622 .

Fuller, Samuel. Mr. From London. Say-weaver. Said to have been born at Wrington, Somers., and bred a butcher. ${ }^{1}$ Wit. bet. of Deg. Priest Oct. 7, 1611. Do. Wm. White Jan. 27, 1612. Willr. of Alice. Bet. to Agnes Carpenter Mar. 15, 1613, with wits. her fath., Alex. Carpenter, Ed. Southworth, Wm. White, Rog. Wilson, her sist., Alice Carpenter, and his sist., Auna (Susanna) White. Mar. Apr. 24. Wit. bet. of sist.-in-law, Alice Carpenter, to Ed. Southworth May 7, 1613. Do. Sam. Terry May 16, 1614. Bur. child in St. Pet. June 29, 1615. Bur. wife there July 3, 1615. Then lived in Pieterskerlihof. Wit. bet. of Sam. Butler Aug. 7, 1615. Do. Edm. Jessop Sept. 16, 1615. Bet. to Bridg. Lee May 12, 1617, with wits. her moth. and bro., Josephine and Sam. Lee. Mar. May 27. Then lived near Marepoort. Wit. bet. of John Goodman Sept. 16, 1619. With Is. Allerton, Bradford and Winslow wrote letter from Leyd. to Carver and Cushman in Eng. June 10, 1620.

Alice (Glascock). 1st wife of Sam.

Agnes (Carpenter). 2d wife of Sam. Bur. in St. Pet. July 3, 1615 .

- Child of Sam. Died 1615.

Bridget (Lee). A. L. J. 3d wife of Sam. Wit. bet. of bro., Sam. Lee, Mar. 26, 1621.

Susanna. M. Sist. of Sam. Wit. bet. of Wm. Pontus Nov. 13, 1610. Do. Wm. Bassett Mar. 19, 1611. Do. Is. Allerton Oct. 7, 1611. See Sus. White.

Golding, Elizabeth. From Diss. See Eliz. Jolunson and Eliz. Price.

Goodale, Mary. From Leiston, Suff. See Mary Masterson.

Goodman, John. Mr. Linen-weaver. Widr. of Mary. Bet. to Sar. Hooper Sept. 16, 1619, with wits. Sam. Fuller, Rose Jepson and Anna (Susamna) White. Mar. Oct. 10.

Mary (Backus). 1st wife of John.

Sarah (Hooper). 2d wife of John.

1 Morton's New Eng. Canaan, 152. 
Gray, Abraham. From London. Cobbler. Guar. by Wm. Lisle and Rog. Wilson June 25, 1610. Guar. Hen. Wood Dec. 10, 1610. Wit. bet. of Wm. Buckram Nov. 30, 1611. Guar. Hen. Collet Mar. 30, 1612. Do. Wm. Minter May 3, 1613. Do. Thos. Tinker Jan. 6, 1617. Wit. bet. of Steph. Butterfield Oct. 13, 1617.

Greenwood, John. From London. Matriculated at Leyd. Univ. in Philos. July 9, 1625, aged 20. Then lived with John Keble. Bet. to Bridg. Robinson May 10, 1629, with wits. Sam. Lee, Thos. Nash, Eliz. Keble and Bridg. Robinson, the bride's moth. Mar. May 26. Matric. in Theol. May 22, 1634, aged 28. Still lived with John Keble.

Bridget (Robinson). Lived on Beestemarckt. Wife of Jolın. Mar. Wm. Lee, of Amst., from Eccleston, ${ }^{1}$ July 25, 1637.

Grindon, Prudence. From London. See Prud. Reynolds.

Hallett, Anna (—, Harding). Wit. bet. of dau., Anna Harding, to Rog. Wilkins Mar. 28, 1614.

Hammond, Dorothy. Memb. of Smyth's church at Amst. in Mar., 1609. ${ }^{2}$ Wit. bet. of Rob. Peck Oct. 1, 1609.

Hanson, Wybra. See Wyb. Pontus.

Harding. Anna. Dau. of Anna Hallett. See Anna Wilkins.

Hardy, Michael. From Sudbury. ${ }^{3}$ Baize-weaver. Lived on Scheistraat. Bet. to Mary Hardy Sept. 11, 1626, with wits. François Le Leu and Ann Spooner. Mar. Sept. 26.

— Mary. From Colchester. Servant in Robinson's family Oct. 15, 1622. Wife of Mich.

Harris, Thomas. 1st husb. of Jane. Wit. bet. of Hen. Collet May 19, 1617. Prob. bro. of Anna (Harris) Collet.

-Jane. Wid. of Thos. See Jane Milbrook.

Hatfield, Thomas. Wool-comber. Bet. to Anna Cox Apr. 16, 1621. with wits. John Hawley and Jane Lee. Mar. May 1. Wit. bet. of Rob. Warriner Mar. 1, 1624.

Anna (Hamden, Cox). Wid. of Val. Wife of Thos.

Hawley, John. Wit. bet. of Thos. Hatfield Apr. 16, 1621.

Nicholas. Guar. Wm. Lisle June 21, 1610.

Hazel, ${ }^{4}$ Jane. Niece of Eliz. Barker. Wit. her bet. to Ed. Winslow Apr. 27, 1618.

Hillebrant, Margaret. Wit. bet. of Jac. McConkey May 31, 1613.

1 Probably Eggleston, Dur.

2 Evans. Early Eng. Bapts. i: 252.

3 Whether that in Derby., Mid., or Suff. is unknown.

${ }^{4}$ Spelled Phesel in the entry, but with the $\mathrm{P}$ crossed out. 
Hooper, Sarah. See Sar. Goodman.

Horsfield, Edward. Prob. fatl. or bro. of Rosam. Lived with Wm. Jepson Oct. 15, 1622.

- Rosamond. From Worksop, Notts. See Rosam. Jepson.

Horswell, Mary. See Mary Parsons.

Howarth (or Houth), John. 1st husb. of Alice.

Alice (Thomas). Wid. of John. See Alice Collet.,

Howell, Humphrey. Tailor. Guar. by Geo. Ferguson and John

Spooner Dec. 4, 1626.

Hunt, Abigail. From Guernsey. See Abig. Jessop.

Hurst, Jacob. Linen-weaver. Wit. bet. of Rob. Peck Oct. 1, 1609.

Lived in Zevenhuysen Oct. 15, 1622, with wife, three children and maid. "Too poor to be taxed."

Margaret. Wife of Jac.

- Isaac. Son of Jac. and Marg.

— Mary. Dau. of Jac. and Marg.

- Silvester. Son of Jac. and Marg.

Jackson, William. Stocking-seller. Made affid. ${ }^{1}$ Feb. 26, 1619. Then

40. Guar. by John Keble and Rog. White May 26, 1631.

Jacobson, William. Wit. bet. of Geo. Materscé Apr. 6, 1640.

Jenkins, ${ }^{2}$ - With $\mathrm{Wm}$. Lisle accomp. Thos. Brewer to Eng. in Nov.-Dec., 1619.

Jennings, John. From near Colchester. Fustian-weaver. Wit. bet. of Rob. Peck Oct. 1, 1609. Bet. to Eliz. Pettinger Dec. 17, 1610, with wits. Ed. Southworth, Rog. Wilson, Jane Peck and Anna Ross. Mar. Dec. 31. Bet. ${ }^{3}$ to Rose Lisle Mar. 3, 1617, with wits. John Carver and Rose Jepson. Mar. Mar. 23. Then merchant. Guar. by Hen. Jepson and John Keble Nov. 25, 1627. Then lived on Coepoortsgracht and stocking-merchant. Wit. bet. of John Masterson Sept. 16, 1633. With John van Leewen, as guards. of Marth. Jepson, sold houses Jan. 11 and Dec. 5, 1636,

1 Its purport was that, when he recently was in Amsterdam, one Rob. Starre was eharged with some offence and was in hiding, and that Starre's wife had begged him, when he shonld have returned to Leyden, to warn Benj. Engells and Geo. Hillers to go away lest they be arrested and forced to testify against her husband. Without their evidence she thought that the action against Starre would be dropped.

2 Letter from Sir W. Zouche to Sir D. Carleton, Nov. 26-Dec. 6, 1619. Quoted by Arber. Story, 226-227.

3 This entry affords one of the most striking illustrations of the strange transformations of English names in the Dntch records. Jennings is called here Jan "Gielles," but is described as " widower of Eliz. Pettinger," which identifies him. 
and June 25, 1637. Guar. Steph. Butterfield Nov. 20, 1637. Then tobacco-dealer. Made will May 18, 1639. Buught house in Coepoortsteeg in 1642.

Jennings, Elizabeth (Pettinger). 1st wife of John. Wit. bet. of Ed. Southworth May 7, 1613. Do. sist., Dor., to Hen. Collins Nov. 1, 1613.

Rose (Lisle). $2 \mathrm{~d}$ wife of John. Wit. bet. of Steph. Tracy Dec. 18, 1620. Do. Mart. West Dec. 27, 1625. Lived on Coepoortsgracht. Wit. bet. of And. Parkins Jan. 4, 1630. Do. John Masterson Sept. 16, 1633. Made will May 18, 1639. Wit. bet. of dau., or step-dau., Mercy, to Sim. Stuart Mar. 17, 1640. Then lived on Delftsche Vliet. Bought house from Balten van Vliet May 16, 1641. Bought anoth. on Coepoortsgracht, for 2400g. from heirs of wid. of Hen. Hendricks Nov. 21, 1642. Wit. bet. of son, or step-son, John Jennings, Jr., Aug. 21, 1648. Bought anoth. house Oct. 29, 1648. Made codicil to will Oct. 11,1666. Bur. in St. Pet. between Feb. 11 and 18 (prob. 11 or 12), 1668. Then lived on Coepoortsgracht. Inventory of property dated Mar. 18, 1668. Elizabeth. Dau. of John. See Eliz. Vliers.

John. Son of John. Wool-comber. Lived on Coepoortsgracht. Bet. to Fear Robinson Aug. 21, 1648, with wits. Elias Arnold and Rose Jennings, his moth. or step-moth. Mar. Sept. 8. Made will Dec. 1, 1664. Bur. in St. Pet. Dec. 7, 1664. Then lived on Molesteeg.

Fear (Robinson). Lived on Kloksteeg. Wife of John, Jr. Chose Is. de Meij and Thos. Jones guards. of three minor children, Mar. 12, 1668. Received Apr. 18, 1668, as share of husb.'s estate house on Coepoortsgracht, valued at about $1950 \mathrm{~g}$., which his fath. had bought in 1642. Made will ${ }^{1}$ Mar. 20, 1669. Made codicil Jan. 27, 1670. Died, leaving three minor children, before May 31,1670. House of hers near Coepoort, prob. the above, sold to John Butterfield on that date for $3790 \mathrm{~g}$. by guards. of her children.

Mercy. Dau. of John. See Mercy Stuart.

Joseph. From London. Cloth-filler. Bet. to Sar. Lee May 21, 1654, with wits. John de Bort, — Jennings, his bro., and $\mathrm{E}^{*}$

Ainsworth. Mar. June 14.

Sarah (—, Lee). Wife of Jos.

1 One record (Burg. Dag. Bk. B. fol. 272) says plainly, "Will of Joln Jennings, widower of Fear Robinson, of date Mar. 20, 1669." But the recorder transposed the names. John had died in 1664, and the record should read, "of Fear Robinson Jennings, widow of John." 
Jenny, John. A. L. J. From Norwich. Brewer's man. Bet. to Sar. Carey Sept. 5, 1614, with wits. Rog. Wilson and Jane Lee. Mar. Nov. 1. Bur. child in St. Pet. June 16, 1618. Then lived on Veldestraat.

Sarah (Carey). A. L. J. Wife of John.

——. Chill of John and Sar. Died 1618.

Saral. A. L. J. Dau. of John and Sar.

Samuel. A. L. J. Son of John and Sar.

Abigail. A. L. J. Dau. of John and Sar.

Jepson, Anna. Moth. of Jolnn. Wit. his bet. Apr. 18, 1637.

- John. From Yarmouth. Cooper. Bet. to Hel. Smith Apr. 18, 1637, with wits. And. Parkins, John Price, Anna Jepson, his noth., and Dor. Parkins. Mar. May 9.

Helena (Snith). Wife of John.

Henry. From Worksop. Bro. of Wm. Say-weaver. Bet. to Jane Powell Dec. 8, 1617, with wits. Hen. Wood and Jane Lee. Mar. Dec. $23^{1}$ or soon after. Guar. by Wm. Jepson and John Keble May 17, 1621. Guar. Jos. Spalding June 11, 1621. With bro., Wm., bought house on St. Josephsteeg July 21, 1621. Received power of atty. from Hen. Wood to sell property Feb. 2, 1622. Guar. John Jeunings Nov. 25, 1627. Sold property for Hen. Wood Dec. 13, 1629. Wit. bet. of bro.-in-law, Pet. Powell, June 13, 1631. Bought right of bro. Wm.'s heir, Marth. Jepson, in house in St. Josephsteey owned jointly Dec. 5, 1636. 'Then merchant. Sold this house for $1050 \mathrm{~g}$. to Steph. Butterfield June 6, 1642 .

Jane (Powell). Wife of Hen. Wit. bet. of bro., Pet. Powell, June 13, 1631. Then lived in Vrowencamp. Wit. bet. of Wm. Waldron Ang. 25, 1634.

Thomas. Leather-worker. Widr. of Christina. Bet. to Rebec. Fairfield Sept. 18, 1626, with wits. Pet. Wood and Hest. Thomas. ${ }^{2}$ Mar. Oct. 3.

Christina (Wood). 1st wife of Thos.

Relecca (Willet, Fairfield). 2d wife of Thos.

William. From Worksop. Bro. of Hen. Carpenter, afterwards merchant. Bet., at Amst., to Rosam. Horsfield Apr. 11, 1609, he being 26 and she 25. Mar. Apr. 28. With John Robinson, Hen. Wood and Jane White bargained for house in Kloksteeg, Jan. 27, 1611. Completed purchase May 5,1611 . Wit. bet. of Wm. White

1 The date of the third, and last, publication of the banns, usually followed immediately by the wedding.

${ }^{2}$ Hest. (Willet) Wood, dan. of Thos. Willet. 
Jan. 27, 1612. Sold house on Groenhasegracht for $971 \mathrm{~g} .^{1}$ to Wm. Minter Sept. 10,1614. Wit. bet. of Sam. Butler Aug. 7, 1615. Do. Edm. Jessop Sept. 16, 1615. Do. Hen. Wilson May 13, 1616. Guar. by John Keble and Wm. Minter Dec. 16, 1616. Then said to be from Hull. Guar. Thos. Rogers June 25, 1618. Do. bro., Hen. Jepson, May 17, 1621. With bro., Hen., bought house on St. Josephsteeg July 21, 1621. Lived in Zevenhuysen Oct. 15, 1622, with wife, two daus. and Ed. Horsfield. Bought out oth. owners of Robinson estate Dec. 13, 1629. Believed to have died of plague in 1635 , aged about 52 .

Jepson, Rosamond (Horsfield). Wife of Wnı. Wit. bet. of Rand. Thickins Apr. 1,1611. Do. Deg. Priest Oct. 7, 1611. Do. Wm. White Jan. 27, 1612. Do. Sam. Butler Aug. 7, 1615. Do. Edm. Jessop Sept. 16, 1615. Do. John Jennings Mar. 3, 1617. Do. John Goodman Sept. 16,1619. Do. Wm. Officier July 27, 1624. Died before Jan. 11, 1636.

Abigail. Dau. of Wm. and Rosam. Died before Jan. 11, 1636.

Martha. Dau. of Wm. and Rosan. As sole surviving heir sold, by guards., John Jennings and John van Leewen, two houses to Chris. Ellis, Jan. 11, 1636. Sold her half of house in St. Josephsteeg to oth. owner, her uncle, Hen. Jepson, Dec. 5, 1636. Sold little houses in Robinson estate, the Groenepoort, to Chris. Ellis, June 25, 1637.

— Elizabeth. Perhaps dau. of Hen. See Eliz. Loder and Eliz. Materscé.

Jessop, Edmond. From Ackworth, Yorks. Bombazine-weaver. Bur. wife, Ellen, in St. Pet. June 15,1615. Then lived on Styensteeg. Bet. to Abig. Hunt Sept.16, 1615, with wits. Sam. Fuller, Wm. and Rosam. Jepson and Mary Wood. Mar. Oct. 3. Bur. child in St. Pet. July 24, 1618. Then lived in Pieterskerkhof. Auth. of "A Discovery of the Errors of the English Anabaptists" in 1623. Ellen (Underwood). From Ackworth. 1st wife of Edm. Died 1615.

_- Abigail (Hunt). 2d wife of Edm. - Child of Edm. Died 1618.

Francis. From Rotherham and Sheffield, Yorks. Son of Rich. Had mar. Frances White, at Worksop, Jan. 24, 1605. Guar. by John Keble and Rog. White May 5, 1625. Then shop-keeper. With Blossom, Rich. Masterson, Thos. Nash and Rog. White

1 Another record says $850 \mathrm{~g}$. 
wrote letter from Leyd. to Bradford and Wm. Brewster Nov. 30, 1625. Returned to Eng., to Beccles, Suff. Mar. again in 1637.

Jessop, Frances (White). From Worksop. Apparently sist. of Rog. White, Bridg. Robinson and Jane Thickins. Wife of Francis. Wit. bet. of Thos. Nash Oct. 27, 1628. Died in Eng. in 1636.

Johnson, Jacob. 1st husb. of Eliz. —- Guar. Wm. Smith Feb. 16, 1626.

Elizabeth (-). Dau. of Wm. Wid. of Jac. Lived in Vrowencamp. See Eliz. Peck.

Quiryn. Wit. bet. of Anth. Clement Mar. 5, 1627.

Thomas. Wool-comber. Guar. Wm. Kibbett and Walt. Tucker

Dec. 6, 1638. Do. John Ainsworth Nov. 4, 1639. Widr. of Mary.

Bet. to Eliz. Golding Mar. 2, 1640, with wits. Sam. Lee and Anna Spooner. 'Mar. Mar. 20. Then lived on Oude Vest.

- Mary (Bishop). 1st wife of 'Thos.

Elizabeth (Golding). 2d wife of 'Thos. Lived on Oostdwerststeeg. See Eliz. Price.

Jones, Clara (Rogers). See Clara Clement.

- Dorothea. Wit. bet. of Jas. Milbrook Nov. 17, 1622.

Elizabeth. Wit. bet. of Sam. Lee June 15, 1618.

— Frederick. Guar. Chris. Ellis Dec. 2, 1619.

Jane. See Jane Clement.

John. Widr. of Pris. Bet. to Eliz. Thomas Sept. 29, 1634, with wits. Pet. van der Bosch and Hest. Leonard. ${ }^{2}$ Mar. Oct. 15. Lived on Vrowensteeg.

Priscilla (Jennings). 1st wife of John.

- Elizabeth (Seymour, Thomas). Wid. of Sam. 2d wife of John. Justina. Wit. bet. of Thos. Coit Mar. 17, 1626.

- Mary (Van Vredenburg). Moth. of Anna Van Vredenburg. Wit. bet. of dau., Anna, to Sim. Moses Nov. 4, 1616. Do. Anth. Clement Mar. 5, 1627.

Thomas. From Dorchester, Dorset. Say-weaver. Bet. to Anna Swift Nov. 8, 1619, with wits. Rob. Robertson and Marg. Savory. Mar. Nov. 23.

Anna (Swift). Wife of Thos.

Thomas (Another). From "Beere," ${ }^{8}$ Kent. Say-weaver. Bet. to Jane Peters June 13, 1637, with wits. Rob. Lamkin and her moth., Mary de Croo. Mar. July 19. Lived on Haarlemstraat. Guar. Raph. Lovell Sept. 23, 1639. Guard., with Is. de Meij, of

1 Ann (Peck-Spooner) Powell.

2 Hest. (Leonard) Ellis.

${ }^{3}$ Unknown. If in Kent, it must have been some small place. The Beer in Devon and that in Dorset are unlikely. 
Fear Jemnings's children Mar. 12, 1668. As such sold house on Coepoortsgracht for $3790 \mathrm{~g}$. to John Butterfield, May 31, 1670. Jones, Jane (de Croo, Peters). Dau. of Mary. Wid. of Abr. Wife of Thos.

Josephson, John. Wit. bet. of Cuth. Cuthbertson Oct. 25, 1621. Joy, Robert. Wit. bet. of Jas. Kingsland Nov. 27, 1615.

Keble, John. From Canterbury. Wool-comber and say-draper. Wit. bet. of Rog. Wilkins Mar. 28, 1614. Bought house on Dwarsheerensteey from Hen. Collet same day. Bur. child in St. Pet. July 23, 1614. Then lived on Coepergracht. Guar. by Edm. Chandler and Hen. Wood Apr. 27, 1615. Guar. Wm. Jepson Dec. 16, 1616. Do. Thos. 'Tinker Jan. 6, 1617. Wit. bet. of Rob. Cushman May 19, 1617. Guar. Hen. Jepson May 17, 1621. Do. Fras. Jessop May 5, 1625. Had John Greenwood in family July 9, 1625, and (doubtless with wife, Bridg.) May 22, 1634. Guar. John Jemnings Nov. 25, 1627. Wit. bet. of Thos. Naslı Oct. 27, 1628. Do. And. Parkins Jan. 4, 1630. Guar. Wm. Jackson May 26, 1631. Then tobacco-merchant. Wit. bet. of Wm. Waldron Aug. 25, 1634. Bur. in St. Pet. Oct. 19, 1635. Then lived in Camp.

— Elizabeth (Acres). Wife of John. Wit. bet. of Cuth. Cuthbertson May 12,1617. Do. Rich. Masterson Nov. 8, 1619. Do. John Greenwood May 10, 1629. Bur. dau. in St. Pan. May 2, 1635. Bur. husb. in St. Pet. Oct. 19, 1635. Then lived in Camp. Wit. bet. of dau., Eliz., to John Ainsworth Dec. 5, 1636. With daus., Eliz. and Mercy, mortgaged for $300 \mathrm{~g}$. Sept. 13, 1638, house on Dwarsheerensteeg bought by her husb. in 1614. Wit. bet. of dau., Mercy, to Wm. Back Apr. 7, 1640. Then lived on Vischbrugge. Bur. in St. Pet. May 2, 1645. Then lived in Marendorp.

Elizabeth. Dan. of John and Eliz. See Eliz. Ainsworth.

Mercy. Dau. of John and Eliz. See Mercy Back.

—_. Child of John and Eliz. Died 1614.

Kendall, Aaron. Husb. of Eliz.

- Elizabeth (-). Wife, or wid., of Aar. Wit. bet. of dau., Eliz., to Cuth. Cuthbertson May 12, 1617.

- Elizabeth. Dau. of Aar. and Eliz. See Eliz. Cuthbertson.

— Edward. Son of Aar. and Eliz. Wit. bet. of sist., Eliz., to Cuth. Cuthbertson May 12, 1617.

- Anna. Dau. of an Aar., perhaps the same. See Anna de Soete. Kibbett (or Cubitt), William. From Norwich. Tobacco-merchant. Guar. by Thos. Johnson and Sam. Lee Dee. 6, 1638. Guar. Mich. Knollys May 14, 1640. 
Kingsland, James. Clothier. Bet. to Ellen Carlisle Nov. 27, 1615, with wits. Rob. Joy, Bart. and Doreas Smith and Anna Ross. Mar. Dec. 12.

Ellen (Carlisle). Wife of Jas.

Knollys, Michael. From London. Guar, by Wur. Kibbett and Sam. Lee May 14, 1640.

Lamkin, Robert. Say-weaver. Bet. to Jacq. de Graef Mar. 18, 1616, with wits. John Ferris and her moth., Jacubnyne de Graef. Mar. Apr. 16. Wit. bet. of Thos. Phillips Aug. 9, 1630. Do. Thos. Jones June 13, 1637. Do. Wm. Parsons, his apprentice, Mar. 13, 1638. Lived on Haarlemstraat.

Jacqueline (de Graef). Wife of Rob. Wit. bet. of Wm. Parsons Mar. 13, 1638.

Le, ${ }^{1}$ Tryphosa. A. L. J. See Try. Tracy.

Lee, Bridget. A. L. J. Dau. of Josephine. Sist. of Sam. See Bridg. Fuller.

- Jane. ${ }^{2}$ Wit. bet. of John Jenny Sept. 5, 1614. Do. Hen. Jepson Dec. 8, 1617. Do. Thos Hatfield Apr. 16, 1621.

John. Made affid. with Thos. Mitchell about Sus. Clark Aug. 15, 1622. 'Then 44. Guar. by $\mathrm{W}_{\mathrm{m}}$. Bridgman and Rich. Monek July 9, 1629. Then tobacco-merchant.

Josephine. Moth. of Sam. and Bridg. Wit. bet. of dau., Bridg. to Sam. Fuller May 12, 1617.

Stmuel. Hat-maker. Guar. by Wm. Bradford and Rog. Wilson Oct. 19, 1615. Wit. bet. of John Spooner Nov. 9, 1616. Do. sist., Bridg., to Sam. Fuller May 12, 1617. Bet. to Maria Nash June 15, 1618, with wits. Isr. Nash and Eliz. Jones. Mar. June 30. Guar. Hen. Stafford Nov. 26, 1618. Bur. child in St. Pet. Feb. 18, 1619. Then lived in Nieuuestadt. Deposed with Deg. Priest to knowledge of Nich. Claverly Apr. -, 1619. Then 30. (Entry crossed out.) Bet. to Sar. Talbot Mar. 26, 1621, with wits. Is. Marcus and his own sister, Bridg. Fuller. Mar. Apr. 10. Guar. Jas. Spalding June 11, 1621. Do. Rob. Robertson and Joln Warnes May 20, 1622. Wit. bet. of bro.-in-law, Sam. Thomas, Jan. 31, 1623. Do. John Greenwood May 10, 1629. Guar. Hub. Brook Nov. 1, 1630. Wit. bet. of And. Parkins Jan. 12, 1636. Then lived near St. Pancras. Guar. Wm. Kibbett and Walt. 'Tucker Dec. 6,1638. Then tobacco-merchant. Bought house for 1000g. Feb. 15, 1639. Guar. Raph. Lovell Sept. 23, 1639. Do.

1 This usually has been taken as Le-, but is quite as likely to be Lee. Sam. Lee's name is recorded so at least once.

2 Seems to be recorded once or twice as Joanna Lyons. 
John Ainsworth Nov. 4, 1639. Wit. bet. of Thos. Johnson Mar. 2, 1640. Guar. Mich. Knollys May 14, 1640. Sold house on Houck van Hoogelandsche Voorsteeg for $2532 \mathrm{~g}$. to Jehens Anthony June 5, 1640 . Sold mortgage of $548 \mathrm{~g}$. to Benj. de Wannemaker Sept. 8, 1642. Guar. Thos. Otley Sept. 26, 1642. Bet. to Sar. - Oct. 18, 1648, with wits. Jolın Ainsworth and her moth., Deb. - Mar. Oct. 27. Then lived on Pieterskerkchunsteeg. Bur. in St. Pan. Sept. 16,1652. Then lived in Kerk. hof. Had become bankrupt. House sold June 13, 1653.

Lee, Maria (Nash). 1st wife of Sam.

——. Child of Sam. and Mar. Died 1619.

Sarah (Thomas, Talbot). Sist. of Sam. Wid. of Wm. 2d wife of Sam. Wit. bet. of Cuth. Cuthbertson Oct. 25, 1621. Do. Sylv. Arnold July 16, 1632.

— Sarah (—). Dau. of Mich. and Deb. 3d wife of Sam. See Sar. Jennings.

Leonard, Hester. See Hest. Ellis.

Lisle (or Lesley), William. From Yarmouth. Guar. by Nich. Hawley and Rog. Wilson June 21, 1610. Guar. Abr. Gray June 25, 1610. Do. John Turner Sept. 27,1610. Wit. bet. of Deg. Priest Oet. 7, 1611. Guar. Wm. Bradford Mar. 30, 1612. Wit. bet. of Mos. Fletcher Nov. 30, 1613. With — Jenkins accomp. Thos. Brewer to Eng. in Nov.-Dec., 1619.

Rose. Dau. of Wm. Wit. bet. of Wm. Bassett. Mar. 19, 1611. See Rose Jennings.

Mary. Dau. of Wm. See Mary West.

Catharine. Dau. of Wm. See Cath. Masterson.

Loder, William. 1st husb. of Eliz.

Elizabeth (Jepson). Wife of Wm. See Eliz. Materscé.

Lovell, Raphael. Cloth-draper. Guar. by Thos. Jones and Sam. Lee Sept. 23, 1639. Guar. Thos. Otley Sept. 26, 1642.

Lyons, Joanna. Apparently same person as Jane Lee.

Marcus, Isaac. Wit. bet. of Sam. Lee, Mar. 26, 1621. Do. Thos. Nash Oct. 27, 1628.

Marshall, Henry. Wit. bet. of Ed. Pickering Nov. 24, 1612.

Martins, Anna. Wit. bet. of Sim. Dunster Sept. 22, 1623.

Masterson, John. From Henley. ${ }^{1}$ Say-weaver. Lived in Coepoortsgracht. Bet. to Cath. Lisle Sept. 16, 1633, with wits. Hub. Brook and Joln and Rose Jennings. No record of wedding.

- Catharine (Lisle). Wife of John.

Richard. From Sandwich. Wool-carder. Wit. bet. of Is. Aller-

I Whether that in Oxford., Suff. or Sussex is unknown. 
ton Oct. 7 , 1611. Guar. Hen. Collet Mar. 30, 1612. Surety for Rob. Cushman in buying house Apr. 19, 1612. Bought house on Uiterstegracht for $800 \mathrm{~g}$. from Rog. Wilson Jan. 2, 1614. Subj. of depos. of John Ellis and Rog. Wilson Mar. 20, 1619. Bet. to Mary Goodale Nov. 8, 1619, with wits. John Ellis, Wm. Talbot, Mary Finch and Eliz. Keble. Mar. Nov. 23. With Blossom, Fras. Jessop, Thos. Nash and Rog. White wrote letter to Bradford and Wm. Brewster, Nov. 30, 1625. Came with wife to Plym., N. E., in 1630 .

Masterson, Mary (Goodale). Wife of Rich.

Materscé, George. Son of Hen. Linen-weaver. Bet. to Eliz. Loder Apr. 6, 1640, with wits. Wm. Jacobson and Bridg. Robinson. ${ }^{1}$ Mar. Apr. 21. Lived in Vrowencamp.

Elizabeth (Jepson, Loder). Wid. of Wm. Lived in Pieterskerkhof. Wife of Geo.

McConkey, Jacob. From Scotland. Glove-maker. Bet. to Bletgen Peters May 31, 1613, with wits. Thos. England and Marg. Hillebrant. Mar. June 22.

Bletgen (Peters). Wife of Jac.

Merritt, Jane. See Jane Peck.

Milbrook, James. Say-weaver. Bet. to Jane Harris Nov. 17, 1622, with wits. Leon. Dunster and Dor. Jones. Mar. Dec. 4.

Jane (Harris). Wid. of Thos. Wife of Jas.

Minter, William. ${ }^{2}$ From Norwich. 1st husb. of Sar (Willet). Guar. by Abr. Gray and Rog. Wilson May 3, 1613. Bought house on Groenhasegracht for $850 \mathrm{~g} \cdot{ }^{8}$ from Wm. Jepson Sept. 10, 1614. Guar. Wm. Jepson Dec. 16, 1616.

Sarah (Willet). Dau. of Thos. Wife of Wm. Wit. bet. of Rog. Chandler May 22, 1615. Do. Sam. Butler Ang. 7, 1615. Do. Hen. Wilson May 13, 1616. Do. Steph. Butterfield Oct. 13, 1617. See Sar. Simmons.

Mitchell, Thomas. Made affid. with John Lee about Sus. Clark Aug. 15, 1622. Then 56. Thought to have been fath. of Experience Mitchell, who came to Plym., N. E., in 1623, and, possibly, the Thos. Mitchell, from Cambridge, who belonged to Fras. Johnson's

1 Wid. of John. Her danghter, Bridget, had become Bridget Lee and was living in Amst.

2 A John Minter is recorded as having had Arthur Aston living with him when the latter was matricnlated in Leyd. Univ. as a student in Letters June 8, 1611. Nothing but the name, Minter, connects either with the Pilgrims, yet John is likely to have been related to $\mathrm{Wm}$.

3 Another record says $971 \mathrm{~g}$. 
church at Ams. in 1597-98, a turner, widr. of Maria, bet. to Marg., wid. of Chris., Uochin (or Digehin) in Amst. Apr. 15, 1606, and mar. May 9.

Monck, Richard. Tobacco-merchant. Guar. John Lee July 9, 1629.

Morton, George. A. L. J. From York. Bro. of Tlios. Prob. born at Harworth, Notts. Merchant. Bet. to Jul. Carpenter July 6,1612, with wits. Thos. Morton, Rog. Wilson, her fath. and sist., Alex. and Alice Carpenter, and Anna Robinson. Mar. July 23. Wit. bet. of Ed. Pickering Nov. 24, 1612.

- Juliana ${ }^{1}$ (Carpenter). A. L. J. Wife of Geo.

- Nuthaniel. A. L. J. Son of Geo. and Jul. Born 1613.

- Patience. A. L. J. Dau. of Geo. and Jul. Born 1615.

_ John. A. L. J. Son of Geo. and Jul. Born 1616.

— Sarah. A. L. J. Dau. of Geo. and Jul. Born 1618.

- Thomas. F. Bro. of Geo. Wit. his bet. July 6, 1612.

Thomas. A. L. J. Son of Thos.

Moses, John. From Sandwich. Bet. to Josine Sacharias Dec. 5, 1619.

Wit. bet. of Help. Terry May 9, 1637. Lived on Oude Singel.

Josine (Sacharias). From Gouda. Wife of John.

Simon. Lock-maker. Bet. to Anna Van Vredenburgh Nov. 4, 1616, with wits. his guard., Pet. Wall, and her moth., Mary Jones. No record of wedding.

Anna (Van Vredenburgh). Wife of Sim.

Myers, Dorothy. From Yarmouth. See Dor. Parkins.

Nash, Israel. Wit. bet. of Sam. Lee June 15, 1618.

- Maria. Possibly sist. of Isr. See Mar. Lee.

Thomas. Mentioned in letter of Is. Allerton, Bradford, Fuller and Winslow from Leyd. to Carver and Cushman in Eng., June 10, 1620, as recently arrived from Eng. with their pilot. Prob. went with Pilg. emigrants as far as Plym., Eng. With Blossom, Fras. Jessop, Rich. Masterson and Rog. White wrote to Bradford and $\mathrm{Wm}$. Brewster from Leyd. letter of Nov. 30, 1625. Widr. of Marg. (Porter). Bet. to Marg. Stuart Oct.27, 1628, with wits. John Keble, Is. Marcus, Frances Jessop and Eliz. White, the bride's aunt. Mar. Nov. 11. Lived in Rijnsburgerpoort. Wit. bet. of John Greenwood May 10, 1629. Do. And. Parkins Jan. 4, 1630. Then lived in Noordende. Wit. bet. of John Ainsworth Dec. 5, 1636. Do. Sim. Stuart, his step-son, Mar. 17, 1640. Margaret (Porter). 1st wife of Thos.

$2 d$ wife of Thos.

1 Here set down as from "Baert" (Bath ?) in Eng. 
Neal, Elizabeth. From Scrooby. Wit. bet. of Wm. Bassett July 29, 1611. See Eliz. Buckram.

Nelson, Robert. Baize-weaver. Bet. to Ang. Chilton Aug. 6, 1622, with wits. Rog. and Marg. Wilkins. Mar. Aug. 27.

Angelina (Chilton). Wife of Rob.

Nicholas, Elizabeth. From Yarmouth. See Eliz. Wilson.

Norris, Mary. See Mary Allerton.

Officier, William. Bet. to Rose Prince July 27, 1624, with wits. Rog. White and Rosam. Jepson. Mar. Aug. 17.

- Rose (Prince). ${ }^{1}$ Wife of Wm.

Oldham, Mlargaret. See Marg. Bassett.

Otley, Thomas. From London. Cloth-weaver. Guar. by Sam. Lee and Raph. Lovell Sept. 26, 1642.

Parkins, Andrew. From Yarmouth. Brewer's man. Widr. of Mar. Bet. to Marg. Woodcock Jan. 4, 1630, with wits. John Keble, Thos. Nash, Rose Jennings and Ann Spooner. Mar. Jan. 19. Then lived near Rijnsijlpoort. Bet. to Dor. Myers Jan. 12, 1636, with wits. Sam. Lee and Pet. and Anna Powell. Mar. Feb. 2. Then merchant. Lived in Noordende. Bought house on Sonnerveltsteeg for $1100 \mathrm{~g}$. from Chris. Ellis Aug. 4, 1636. Wit. bet. of John Jepson Apr. 18, 1637. With Chris. Ellis sold house for' 712g. to Christian Heneman Aug. 6, 1643. Died before July $31,1653$.

Maria (-). Dau. of Wm. 1st wife of And.

- Margaret (Woodcock). Lived in Vrowencamp. 2d wife of And.

Dorothy (Myers). 3d wife of And. Wit. bet. of John Jepson Apr. 18, 1637.

Samuel. Son of And. and Dor. Had Chris. Ellis and John Price as guards. July 31, 1653. Mar. Anna van Ackern. Nom. for postal service Oct. 2, 1669. Involved in debt by wife. Both died in 1679.

Parsons, William. From Newbury. ${ }^{2}$ Clothing-dealer. Apprentice of Rob. Lamkin. Bet. to Mary Horswell Mar. 13, 1638, with wits. Rob. and Jacq. Lamkin. Mar. Apr. 3.

- Mary (Horswell). Wife of Wm.

Peck, Ann. From Lownd. ${ }^{3}$ Sist. of Rob. Ward of Wm. Brewster. Gave power of atty. June (10 or) 12, 1609, to Thos. Simkinson, of Hull, Eng., to receive $£ 7$ left by her with Mr. Watkinson,

1 "brine" in entrr.

2 Prob. Berks. The records say Yorks., but that in Berks seems the only one.

3 Whether that in Line., Notts. or Suff. is unknown. Prob. Notts. 
minister of Clarborough, Notts. See Ann Spooner and Ann Powell.

Peck, Robert. Bro. of Ann. Fustian-weaver. Bet. to Jane Merritt Oct. 1, 1609, with wits. Jac. Hurst, John Jennings and Dor. Hammond. Mar. Nov. 21. Lived at Blue Lark on Hoogewoerd. Lived in Marendorp in 1610. Bur. child in St. Pet. Sept. 12, 1619. Then lived in Kerkhof. Wit. bet. of Pet. Powell June 13, 1631. Then lived on Molesteeg and later on Kolfmakersteeg. Bur. wife in St. Pet. Nov. 2, 1631. Then lived on Kollembersteeg. Bet. to Eliz. Johnson Feb. 26, 1633, with wit. Pet. Powell. Mar. Mar. 19. Jane (Merritt). 1st wife of Rob. Wit. bet. of John Jennings Dec. 17, 1610. Died 1631.

—_ Child of Rob. and Jane. Died 1619.

— Elizabeth (—, Johnson). Wid. of Jac. 2d wife of Rob.

- Mercy. Perhaps dau. of Rob. and Jane. Lived in St. Pancraskerkhof in 1644. See Mercy Bemnett.

Peters, Bletgen. See Blet. McConkey.

—_ Jane (de Croo). See Jane Jones.

Pettinger, Dorothy. From "Moortel." 1 Sist. of Eliz. Bet. to Hen. Collins, of Amst., widr. of Marg. (Grimsdike), Nov. 1, 1613, with wits. Wm. Bradford, Ed. Sonthworth, her sist., Eliz. Jennings, and Anna Ross. Mar. Nov. 20.

Elizabeth. From "Moortel." Lived at Douver's in Marendorp. Sist. of Dor. See Eliz. Jennings.

Phillips, Priscilla (Fletcher). From Sandwich. Wid. of - See Pris. Coit and Pris. Terry.

Thomas. From Norwich. Lived at Vrydom, near Leyd. Sayweaver. Bet. to Sus. Sears Aug. 9, 1630, with wits. Rob. Lamkin and her moth., Eliz. Sears. Mar. Aug. 25.

_ Susanna (Sears). Wife of Thos.

Pickering, Edward. From London. Mercliant. Bet. to Mary Stubbs Nov. 24, 1612, with wits. Hen. Marshall, Geo. Morton, Rand. Thickins, Rog. Wilson and Alice and Anna (Agnes) Carpenter. Mar. Dec. 15. One of Merch. Advents. in London 1620-22. Apparently reluctant to invest in scheme for colony. ${ }^{2}$

- Mary (Stubbs). Wife of Ed.

${ }^{3}$ Mary. Lived on Papengracht. Wit. bet. of dau., Sincere, to Elias Arnold Feb. 22, 1636.

1 Prob. either Moortown, Leic., or one of the seven Mortons, presumably that in Linc. or Notts.

2 Bradford, Hist. 47, 49, 117.

3 Plainly written Thickins. But the daughter's is Pickering, which probably 
Pickering, Sincere. Dau. of Mary. See Sinc. Arnold.

Pontus, William. Fustian-weaver. Lived at Douver's in Marendorp. Bet. to Wyb. Hanson Nov. 13, 1610, with wits. Wm. Brewster, Ed. Southworth, Rog. Wilson, Mary Butler, Anna (Susanna) Fuller and Jane White. Mar. Dec. 4. Lived in Zevenhuysen with wife and dau. Oct. 15, 1622. Then wool-carder and "too poor to be taxed." Came to Plym., N. E., by 1633.

Wybra (Hanson). Wife of Wm. Wit. bet. of Wm. Bassett July 29, 1611. Do. Zech. Barrow June 16, 1616.

Mary. Dau. of Wm. and Wyb.

Porter, Margaret. See Marg. Nash.

Sarah. From "Mindelton." 1 See Sar. Butler.

Powell, Jane. From Maldon, Essex. Sist. of Pet. See Jane Jepson. Peter. From Essex. Glove-maker. Lived in Vrowencamp. Bet. to Ann Spooner June 13, 1631, with wits. his bro.-in-law, Hen. Jepson, her bro., Rob. Peck, his sist., Jane Jepson, and Hest. Wood. Nar. June 28. Wit. bet. of Rob. Peck Feb.26,1633. Do. And. Parkins Jan. 12, 1636. Do. Anth. Bennett Apr. 6, 1644.

— Ann (Peck, Spooner). Wid. of John. Lived in Noordende. Wife of Pet. Wit. bet. of And. Parkins Jan. 12, 1636. Do. Thos. Johnson Mar. 2, 1640. Then lived on Papengracht.

Price, Alexander. Camlet-merchant. Guar. by Rog. Wilson and Hen. Wood May 18, 1615. Guar. And. Sharp Aug. 24, 1618. Do. Wm. Ring June 7, 1619. Lived in Zevenhuysen Oct. 15, 1622, with wife and three children. Bought house on Nonnensteeg for 175g. from Hen. Richard Dec. 13, 1627. Then say-draper.

Jane (-). Wife of Alex.

John. Son of Alex. and Jane. Prob. wit. bet. of John Jepson Apr. 18, 1637.

Joseph. Son of Alex. and Jane. Only survivor of fath. Left orph. children whose guard. sold, June 2,1671 , house bought by Alex. in 1627 for same sum paid for it, $175 \mathrm{~g}$.

Isaac. Son of Alex. and Jane.

John. From Kingston. ${ }^{2}$ Student in Leyd. Univ. Wit. bet of Gid. Bartlett Feb. 10,1651. Bet. to Eliz. Johnson June 8, 1651, with wits. his bro., Jos. Price, and Eliz. Ainsworth. Mar., at Oudekerk,

is right. No Mary Thickins is known. Yet, as Ed. Pickering had gone back to England by 1622 , this Mary presumably is another than his wife, although she may have remained in Holland or returned there.

1 Presumably one of the twelve Middletons and probably that in Norf. or Yorks. Bnt possibly one of the ten Miltons.

2 There are twelve. Probably he came from that in Norf. or Cambs. 
near Amst., June 25. With Chris. Ellis was guard. of Sam. Parkins July 31, 1653.

Price, Elizabeth (Golding, Jolnson). Wid. of Thos. Wife of John. Joseph. Bro. of John (stud.). Wit. his bet. June 8, 1651.

Priest, Degory. M. From London. Hat-maker. Bet. to Sar. Vincent Oct. 7, 1611, with wits. Sam. Fuller, Wm. Lisle, Rosam. Jepson and Jane Thickins. Mar. Nov. 4. Guar. Nov. 16, 1615, by bro,in-law, Is. Allerton, and Rog. Wilson. Deposed with Sam. Lee to knowledge of Nich. Claverly Apr. - , 1619. Then 40. (Entry crossed out.)

— Sarah (Allerton, Vincent). A. L. J. Sist. of Is. Wife of Deg. Wit. bet. of Wm. White Jan. 27, 1612. Do. Mos. Fletcher Nov. 30, 1613. See Sar. Cuthbertson.

- Mary. A. L. J. Dau. of Deg. and Sar.

- Sarah. A. L. J. Dau. of Deg. and Sar.

Prince, Rose. See Rose Officier.

Reynolds, John. From Lonclon. Printer. Employed by Brewer and Wm. Brewster. Bet. to Prud. Grindon July 28, 1617, with wits. Jon. Brewster, Mary Allerton and Mary Brewster. Mar. Aug. 18. Later removed to Amst. and there mar. Persis Bailey Apr. 24, 1621.

Prudence (Grindon). 1st wife of John.

Ring, Mary. Prob. wife of Wm. Wit. bet. of Sam. Terry, May 16, 1614. Very likely the widow Ring who, with children, ${ }^{1}$ came to Plym., N. E., about 1629.

William. Say-weaver. Guar. by Wm. Bradford and Alex. Price, June 7, 1619. Accomp. Pilg. emigrants as far as Plym., Eng., but returned.

Robertson, Robert. From Colchester. Polisher. Deposed with John Brown about Rob. Allerton Aug. 21, 1619. Then about 38. Wit. bet. of Thos. Jones Nov. 8, 1619. Guar. by Herb. Dennis and Sam. Lee May 20, 1622.

William. Leather-dresser. Guar. by Bern. Ross and Rog. Wilson Dec. 3, 1610. Was 37 in 1611. Owned house on Groenhasegracht next to Wm. Jepson's Sept. 10, 1614, and same house Sept. 20, 1619.

1 She was at PIymonth in 1630 and had at least three children, Andrew, Elizabeth and Susanna, who were grown up. If she were the same woman, probably these children were with her in Leyd., although they do not appear in the records there.

${ }^{2}$ Cushman's letter to Southworth. Bradford, Hist. 71. The name is misprinted King in the Hist. It is plainly Ring in Bradford's manuscript. 
Robinson, Anna. ${ }^{1}$ Perhaps dau. of John and Bridg. Wit. bet. of Geo. Morton July 6, 1612.

John. From Gainsborough, Linc. Pastor of Pilg. church. With Wm. Jepson, Hen. Wood, and Jane White, his sist.-in-law, bargained for Groenepoort, a house with land on Kloksteeg, for $8000 \mathrm{~g}$. Jan. 27, 1611. Wit. bet. of Jane White to Rand. Thickins Apr. 1, 1611. Completed purchase of house May 5, 1611. Gained possession May 1, 1612. Granted leave to join univ. Aug. 5, 1615. Enrolled Sept. 5, 1615, aged 38. Prob. bur. child in St. Pet. May 15, 1618. ${ }^{2}$ Bur. anoth. child there Feb. 7, 1621. Atty. for bro.-in-law, Rand. Thickins, to sell latter's rights in their estate June 1, 1621. Lived in this house in Zevenhuysen Oct. 15, 1622, with wife, six children and Mary Hardy, a servant. Bur. child in St. Pet. Mar. 27, 1623. Wrote these works :-

An Answer to a Censorious Epistle. 1608 or 1609.

A Ivstification of Separation from the Church of England. Against Mr. Richard Bernard, his invective Intitvled; The Separatist's Schisme, etc. 4to. 1610.

Of Religious Communion Private, \& Publique. With the silencing of the clamoure raysed by $\mathrm{Mr}$. Thomas Helwisse agaynst our reteyning the Baptism receaved in Engl: \& administering of Bapt: vnto Infants. As also, $A$ Survey of the confession of fayth published in certain conclusions by the remaynders of $M^{r}$. Smythes company. 1614.

A Manumission to a Manvdvction, or Answer to a Letter inferring Publique communion in the parrish assemblies upon private with godly persons there. 1615.

The Peoples Plea for the Exercise of Prophesie, against Mr. Iohn Yates, his Monopolie, etc. 1618.

A pologia Ivsta et Necessaria Quorvndam Christianorum, aeque contumeliose ac communiter dictorum Brownistarum, sive Barowistarum, etc. 1619. Reprinted in English in 1625.

A Defence of the Doctrine propounded by the Synode at Dort: Against Iohn Mvrton and his Associates, in a Treatise intituled: A Description

1 The name Robinson occasionally occurs in the archives as Roberts, and an Anna Roberts, widow of Jan Sclietter, of Utrecht, is recorded in Leyden, Aug. 22, 1625 (Hypothek Bk.S. 345), as paying to her unmarried sister, Bridget Roberts, from Assenroij, an annual rent of over $1 \mathrm{gg}$. The identity of names is noticeable, and something may have led Bridget Robinson, the daughter and unmarried in 1625 , to live away from Leyden for a time. At her marriage, in 1629 , although in Leyden, she did not live with her family on the Kloksteeg, but in the Cattle Market. Jan Schetter may have been some Englishman whose name the Dutch clerk misunderstood, or Anna may have married a Hollander. But the probability is strong that this Anna and Bridget did not belong to the John Robinson family.

2 The entry is "A child of John Robert of the Pieterkerkhof." 
what God, etc. With the refutation of their Answer to a Writing touching Baptism. 1624.

An Appeal on Truths behalfe (concerninge some differences in the Church at Amsterdam). 1624.

Observations Divine and Morall. For the Furthering of knowledg and virtue, 4to. 1625 .

A Treatise of the Lawfulnes of Hearing of the Ministers in the Church of England. . . Together with a Letter written by the same Authore, and approued by his Church: which followeth after this Treatise. Published 1634, nine years after his death.

A Briefe Catechisme concerning Church Government. Pub. 1642.

Bur. in St. Pet. Mar. 4, 1625. For oth. facts of pers. hist. ete., see body of this book (pp. 560, 591).

Robinson, Bridget (White). Prob. orig. from Worksop, Notts., or Beverley, Yorks. Sist. of Rog. White, Jane Thickins, and, apparently, Frances Jessop. Wife of John. Wit. bet. of sist., Jane White, to Rand. Thickins Apr, 1, 1611. Do. Wm. Buckram Nov. 30, 1611. Agreed, as John's wid., to pay int. on her share of part, $2000 \mathrm{~g}$., of purchase money still due for estate on Kloksteeg Jan. 15, 1626. Wit. bet. of dau., Bridg., to John Greenwood May 10, 1629. With otl. owners sold her share, and, as his atty., Rand. Thickins's share of house to Wm. Jepson Dec. 13, 1629. Still lived in Pieterskerkhof in 1635. Wit. bet. of Mary Barlow June 4, 1639. Do. of Geo. Materscé Apr. 6, 1640.

- John. Son of John and Bridg.

_ Bridget. Dau. of John and Bridg. See Bridg. Greenwood.

- Isaac. Son of John and Bridg. Came to Plym., N. E., in 1631.

- Mercy. Dau. of John and Bridg.

- Fear. Dau. of John and Bridg. See Fear Jennings.

James. ${ }^{1}$ Son of John and Bridg. Bur. in St. Pet. May 26. 1638.

Then lived in Engelschepoort.

\section{—_- Child of John and Bridg. Died 1618. \\ —_ Child of John and Bridg. Died 1621. \\ - Child of John and Bridg. Died 1623.}

Rogers, George. Student in Leyd. Univ. Lived with Thos. Blossom wlien matric., in Med., Oct. 27, 1609. Then 25.

Thomas. M. Camlet-merchant. Guar. by Wm. Jepson and Rog. Wilson June 25, 1618. Sold house on Barbarasteeg for $300 \mathrm{~g}$. to Mordecai Cohen Apr. 1, 1620.

- Joseph. ${ }^{2}$ r. Son of Thos.

1 Or Jacob. Entered as Jacobus.

2 Bradford says (Hist. 453) that Thos. Rogers had other children and that they came over, but they do not appear in Ieyden. 
Ross, Bernard. While living in Amst. sent cloth to Wm. Brewster before June 25,1609. Guar., in Leyd., by Mahieu van der Mersche and Rog. Wilson Apr. 2, 1610. Guar. Wm. Robertson Dec. 3, 1610. Prob. the Bern. Ross who made depos. Apr. 11, 1616, abont difficulty with Jos. Lewis. Wit. bet. of Bart. Smith July 4, 1618.

- Anna (Carlisle). Evidently wife of Bern. Wit. bet. of John Jennings Dec. 17, 1610. Do. Ed. Southworth May 7, 1613. Do. Dor. Pettinger Nov. 1, 1613. Do. sist., Ellen, to Jas. Kingsland Nov. 27, 1615. Do. sist.-in-law, Eliz., to Bart. Smith July 4, 1618.

Savory, Margaret. Wit. bet. of Mos. Fletcher Nov. 30, 1613. Do. Thos. Jones Nov. 8, 1619.

Sears, Elizabeth. From Sandwich. Moth. of Sus. Wit. her bet. to Thos. Phillips Aug. 9, 1630.

- Susanna. See Sus. Phillips.

Seymour, Elizabeth. Sist. of Jane. See Eliz. Thomas and Eliz. Jones. _ Jane. Sist. of Eliz. Wit. her bet. to Sam. Thomas Jan. 31, 1623.

Sharp, Andrew. Cloth-worker. Guar. by Alex. Price and Rog. Wilson Aug. 24, 1618.

Jane (-), Moth. of Eliz. (Sharp) Beere. Wit. her bet. to Thos. Coit Apr. 14, 1623.

Silloway, Margaret. See Marg. Warriner.

Simmons, Roger. From Sarum, Wilts. Mason. Bet. to Sar. Minter July 14, 1618, with wits. John Carver, Dan. Fairfield and her parents, Thos. and Alice Willet. Mar. Aug. 18. Then lived at Amst., but apparently removed soon to Leyd. Wit. bet. of Dan. Fairfield July 14, 1618. Sold for 746g. Sept. 20, 1619, house on Groenhasegracht bought by Wm. Minter in 1614 .

Sarah (Willet, Minter). Wid. of Wm. Wife of Rog. Bur. in St. Pet. Mar. 6, 1629.

Singer, Rose. From Yarmouth. See Rose Butterfield.

Singleton, Mary. From Sandwich. See Mary Cushman.

Smith, Bartholomew. From London. Merchant. Guar. by Joln Carpenter and Jac. Stevens Apr. 5, 1611. Wit. bet. of sist.-in-law, Ellen Carlisle, to Jas. Kingsland Nov. 27, 1615. Evidently husb. of Dorcas Smith and the Bart. Smith (from Lond., tobacco-pipemaker and widr. of Dorcas) bet. to Eliz. Carlisle July 4, 1618, with wits. Bern. and Anna Ross, her bro.-in-law and sist.

Dorcas (-). 1st wife of Bart. Wit. bet. of Jas. Kingsland Nov. 27, 1615 . Elizabeth (Carlisle). Wid. of Jas. 2d wife of Bart. 
Smith, Helena. From Yarmouth. Lived on Sonnerveltsteeg. See Hei. Jepson.

— Thomas. From "Berry." Wool-comber. Bet. to Anna Crackstone Dec. 12, 1618, with wits. her fath., John Crackstone, and Patience Brewster. Mar. Dec. 22.

- Anna (Crackstone). Wife of Thos.

- Thomas (Another). From Colchester. Cloth-merchant. Ex-deacon of Eng. Church in Amst. Deposed to knowledge of Jos. Freeman June 13,1613. Then 46. Guar. by Jan Questroy Peters and François van der Becke June 29, 1615. Guar. Jos. Crips June 3, 1616.

William. Engraver. Guar. by Geo. Ferguson and Jac. Jolnnson Feb. 16, 1626.

Southworth, Edward. Bro. of Thos. Say-weaver. Wit. bet. of Wm. Pontus Nov. 13, 1610. Do. John Jennings Dec. 17, 1610. Do. Wm. Bassett July 29, 1611. Do. Is. Allerton Oct. 7, 1611. Do. Sam. Fuller Mar. 15, 1613. Bet. to Alice Carpenter May 7, 1613, with wits. Sam. Fuller, Thos. Southworth, Rog. Wilson, Eliz. Jennings and Anna Ross. Mar. May 28. Wit. bet. of Dor. Pettinger Nov. 1, 1613. Lived in Lond. in Aug., 1620. Died before summer of 1623 .

Alice (Carpenter). A. I. x. Wife of Ed.

Constant. Son of Ed. and Alice. Came to Plym., N. E., in 1628, aged "about 14."

— Thomas. Son of Ed. and Alice. Born 1616. Came over soon after Constant. ${ }^{2}$

Thomas. Bro. of Ed. Wit. his bet. May 7, 1613.

Spaiding, Elizabeth. Possibly wife or sist. of Jos. Wit. bet. of Rog. Wilson Mar. 11, 1616. Do. John Spooner Nov. 9, 1616.

— Joseph. Tailor. Guar. by Hen. Jepson and Sam. Lee June 11, 1621. Lived with John Spooner on Ketelboersteeg in Wolhuis, Oct. 15,1622 .

Spooner, John. Ribbon-maker. Bur. 1st wife, Sus., in St. Pet. Mar. 28, 1616. Then lived on Bogertsteeg. Bet. to Ann Peck Nov.9, 1616, with wits. Sam. Lee and Eliz. Spalding. Mar. Dec. 24. Lived with wife and three children on Ketelboersteeg in Woltuis Oct. 15, 1622. Had Jos. Spalding in family. Guar. by Marcus Belden and Jacques Duvaechijs, Jr., Sept. 18, 1623. Then factor. Guar. Ed. Coolidge Apr. 17, 1626. Do. Humph. Howell

1 Probably either Bury St. Edmunds, Suff., often shortened into Bury, or one of the three Burys in Hunts., Lanc. and Sussex.

2 Goodwin, 322, 462, 249, 460-461. 
Dec. 4, 1626. Bur'. in St. Pet. July 6, 1628. Then lived in Noordende.

Spooner, Susanna (Bennett). 1st wife of John. Died 1616.

- Ann (Peck). Sist. of Rob. 2d wife of John. Wit bet. of Mich. Hardy Sept. 11, 1626. Do. And. Parkins Jan. 4, 1630. Then lived near Wittepoort. See Aun Powell.

- Sarah. Dau. of John.

John. Son of John.

Rebecca. Dau. of John.

Staftord, Henry. Son of Jolın. Tallow-chandler. Guar. by Geo. de Paau and Sam. Lee Nov. 26, 1618.

Stevens, Jacob. Guar. Bart. Smith Apr. 5, 1611.

Stuart, Anna. From Yarmouth. Prob. sist. of Sim. Lived in Noordende. See Anna Bartlett.

Simeon. 1st husb. of Marg.

Margaret (—). Niece of Eliz. (Wales) White. Wid. of Simeon. See Marg. Nash.

Simon. From Yarmouth. Sou of Simeon and Marg. Tobaccopipe-Inaker. Bet. to Mercy Jennings Mar. 17, 1640, with wits. Thos. Nash and her moth., Rose Jennings. Mar. Apr. 17. Lived in Noordende.

- Mercy (Jennings). Lived on Delfsche Vliet. Wife of Simon. Apparently died without children before settlement of her parents' estate in 1668.

Stubbs, Mary. From "Stromse." I See Mary Pickering.

Sunderland, James. Step-fath. of Mary Brown. Wit. her bet. to Leon. Dunster Jan. 10, 1620.

- Mary (- Brown). Wife of Jas. Moth. of Mary Brown. Wit. her bet. to Leon. Dunster Jan. 10, 1620.

Swift, Anna. From Yarmouth. See Anna Jones.

Symons. Cornelius. Wit. bet. of Wm. Back Apr. 7, 1640.

Talbot. William. 1st husb. of Sar. Wit. bet. of Rich. Masterson Nov. 8, 1619.

— Surah (Thomas). Sist. of Sam. Wife of Wm. See Sar. Lee.

Terry, Help. Bunting-maker. Lived on Sprachsteeg. Bet. to Pris. Coit May 9, 1637, with wits. John Moses and Eliz. - (dau. of Mich. and living on Oude Vredesgracht). Mar. June 1.

— Priscilla (Fletcher, Phillips, Coit). Wid. of —_. Wid. of Thos. Lived on Korte Sandstraat. Wife of Help.

Samuel. From Caen, Normandy. Say-weaver. Bet. to Mild. Charles May 16, 1614, with wits. Sam. Fuller, Rog. Wilson,

1 Probably either Strumpshaw, Norf., or Romsey, Hants. 
Mary Ring and Jane Thickins. Mar. May 31. Admitted to Pilg. church in Leyd. from French church. ${ }^{1}$

Terry, Mildred (Charles). Wife of Sam.

Thickins, Randall. From London. Looking-glass-maker. Bet. to Jane White Apr. 1, 1611, with wits. Wm. Brewster, John Robinson, Rosam. Jepson and the bride's sist., Bridg. Robinson. Mar. Apr. 21. Representing wife completed purchase of Robinson's house with Wm. Jepson, Robinson and Hen. Wood May 5, 1611. Wit. bet. of Is. Allerton Oct. 7, 1611. Do. Ed. Pickering Nov. 24, 1612. Bur. child in St. Pet. Jall. 25, 1615. Then lived on Nieuwesteeg. Appointed John Robinson atty. to sell his share of estate June 1, 1621, having removed to Amst. and being about to return to Eng. Sold this property by Bridg. Robinson, atty., to Wm. Jepson Dec. 13, 1629.

Jane (White). Wife of Rand. Wit. bet. of Deg. Priest Oct. 7, 1611. Do. Wm. Buckram Nov. 30, 1611. Do. Sam. Terry May 16,1614 .

— Child of Rand. and Jane. Died 1615.

Thomas, Samuel. Bro. of Sar. Bet. to Eliz. Seymour Jan. 31, 1623, with wits. Sam. Lee and her sist., Jane Seymour. Mar. Feb. 18.

— Elizabeth (Seymour). Wife of Sam. See Eliz. Jones. Sarah. Sist. of Sam. See Sar. Talbot and Sar. Lee.

Tinker, Thomas. M. Wood-sawyer. Guar. by Abr. Gray and John Keble Jan. 6, 1617.

$-(-)$. M. Wife of Thos.

- M. Son of Thos.

Tracy, John. Ribbon-weaver. Guar. by John Natalis and Rog. White Sept. 6, 1624.

Stephen. A. L. J. Say-weaver. Bet. to Tryphosa Le Dec. 18, 1620, with wits. Anth. Clement and Rose Jennings. Mar. Jan. 6, 1621. Lived with wife in Zevenhuysen Oct. 15, 1622.

_ Tryphosa (Le). A. L. J. Wife of Steph.

-_ Saral. A. L. J. Dau. of Steph. and Try.

Tucker, Walter. From Newport. ${ }^{2}$ Guar. by Thos. Johnson and Sam. Lee Dec. 6, 1638.

Turner, John. M. Merchant. Guar. by Pet. Boey and Wm. Lisle Sept. 27, 1610.

——. M. Son of Joln.

- M. M. San of John.

Van Vredenburg, Anna. See Anna Moses.

1 E. Winslow. Hyp. Vnm. 96. Date not stated.

2 Which of the six is not stated. Probably that in Yorks. 
Vincent, John. 1st husb. of Sar. Priest.

- Sarah (Allerton). A. x. J. IVid. of John. See Sar. Priest and Sar. Cuthbertson.

Vliers, Burchard. Husb. of Eliz.

Elizabeth (Jennings). Wife of Burch. Received as share of parents' estate house on Lange Ramsteeg Mar. 28, 1668. Made will June 2, 1668 .

- Samuel. Son of Burch. and Eliz. As only surviving child sold house on Lange Ramsteeg, inherited from moth., Feb. 4, 1671.

Waldron, William. From "Clackfort." I Bombazine-weaver. Widr. of Ruth Walker. ${ }^{2}$ Bet. to Anna Wood Aug. 25, 1634, with wits. John Keble and Jane Jepson. Mar. Sept. 16.

- Anna (Wood). 2d wife of Wm.

Wales, Elizabeth. Aunt of Marg. (Stuart) Nash. See Eliz. White.

Walker, Nathaniel. Say-weaver. Widr. of Jane. Bet. to Anna Bar-

low May 28, 1624, with wits. her fath. and sist., Thos. Barlow and Abig. Dunham. Mar. June 15.

- Jane (-). 1st wife of Nath. Auna (Barlow). 2d wife of Nath.

Wall, Peter. Son of Hen. Guard. of Sim. Mloses. Wit. his bet. Nov. $4,1616$.

Warnes, John. From Wymondham (or Windhan), Norf. Cobbler. Guar. by Herb. Denuis and Sam. Lee May 20, 1622.

Warriner, Robert. Wool-carder. Bet. to Marg. Silloway Mar. 1. 1624, with wits. Thos. Hatfield and Sar. Wiseman. Mar. Mar. 17.

- Margaret (Silloway). Wife of Rob.

West, Martin. Candle-maker. Widr. of Joanna. Bet. to Mary Lisle Dec. 27, 1625, with wits. John Fowle and her sist., Rose Jennings. Mar. Jan. 24, 1626.

$\longrightarrow$ Joanna (-). 1st wife of Mart.

Mary (Lisle). 2d wife of Mart.

White, Jane. From "Bebel." 3 Sist. of Rog. White and Bridg. Robinson and, apparently, of Frances Jessop. Wit. bet. of Wm. Pontus Nov. 13, 1610. With Wm. Jepson, John Robinson and Hen. Wood and assisted by Nich. White, bargained for Robinson's house, Jan. 27, 1611. See Jane Thickins.

Joseph. Wit. bet. of Cuth. Cuthbertson Oct. 25, 1621.

1 Undiscoverable. Possibly Clacton, Essex.

2 Had married her, and had lived in Amst. Whether he continued to live there or in Leyd. does not appear.

3 Probably Beverley, Yorks. 
White, Nicholas. ${ }^{1}$ Jeweller. "Assisted " Jane White in business about Robinson's house Jan. 27, 1611, she then being unmarried.

Roger. Bro. of Bridg. Robinson and Jane Thickins and, apparently, of Frances Jessop. Grocer. Bet., at Amst. and aged 32, to Eliz. Wales, aged 22, Feb. 20, 1621. Mar., at Leyd. Mar. 13. Guar. by Edm. Chandler and Anth. Clement May 5,1623. Wit. bet. of Wm. Officier July 27, 1624. Guar. John Tracy Sept. 6, 1624. Sent news of death of bro.-in-law, John Robinson, to Plym. Col. in letter to Bradford and Brewster Apr. 28, 1625. ${ }^{2}$ Guar. Fras. Jessop May 5, 1625. With Blossom, Fras. Jessop, Rich. Masterson and Thos. Nash wrote to Bradford and Brewster Nov. 30, 1625. Wrote to Bradford Dec. 1, 1625. ${ }^{3}$ Guar. Wm. Jackson May 26, 1631.

Elizabeth (Wales). Wife of Rog. Aunt of Marg. (Stuart) Nash. Wit. bet. of Thos. Nash Oct. 27, 1628.

William. M. Wool-carder. Bet. to Sus. Fuller Jan. 27, 1612, with wits. her bro., Sam. Fuller, Wm. and Rosam. Jepson and Sar. Priest. Mar. Feb. 11. Wit. bet. of bro.-in-law, Sam. Fuller, Mar. 15, 1613. Bur. child in St. Pan. June 18, 1615. Then lived on Groenesteeg. Bur. anoth. child there Dec. 21, 1616. Then lived on Uiterstegracht.

Susanna (Fuller). M. Wife of Wm. Wit. bet. of bro., Sam. Fuller, Mar. 15, 1613. Do. John Goodman Sept. 16, 1619.

- - Child of Wm. and Sus. Died 1615.

- _. Child of $\mathrm{Wm}$. and Sus. Died 1616.

Resolved. м. Son of $\mathrm{Wm}$. and Sus.

William. Tobacco-merchant. Bur. wife in St. Pet. Jan. 27, 1618.

Then lived in Pieterskerkhof. Wit. bet. of Cuth. Cuthbertson Oct. 25, 1621. Guar. by Corn. van Quackenbos and Corn. van Voosboom Dec. 8, 1628.

(—). Wife of Wm. Died 1618.

Edmund Elias. Son of Wm. (Apparently the tobacco-merch.) Lived near Sijlpoort. Bet. to Marg. Bowman Aug. 14, 1629, with wits. Geo. Bosoy and Anna Borfaeu. But, through burgomaster of Leyd., Geo. Winter, of Amst., to whom she had engaged herself already, forbade banns, after they had been published twice, and marriage with White was broken off.

Whittington, Elizabeth. See Eliz. Bennett.

1 Tritten de Witte, one of the Dutch forms of White. Possibly brother, or other relation, of Jane and the others. No other mention of him occurs.

2 Bradford, Hist. 20.5.

${ }^{3}$ Bradford. Letter Bk. Mass. Hist. Soc. Colls. I. iii : 42. 
Wilkins, Roger. Wool-carder. Bet. to Anna Harding Mar. 28, 1614, with wits. John Keble, Rog. Wilson, Sar. Carey and the bride's moth., Anna Hallett. Mar. Apr. 12. Bet. to Marg. Barrow Sept. 16, 1619, with wits. Is. Allerton, her fath., Zech. Barrow, and Rose Butterfield. Mar. Oct. 5. Wit. bet. of Rob. Nelson Aug. 6, 1622. Lived with wife and dan. in Zevenhuysen Oct. 15, 1622. "Too poor to be taxed."

Anna (Harding). 1st wife of Rog.

Margaret (Barrow). 2d wife of Rog. Wit. bet. of Rob. Nelson Aug. 6, 1622.

Sarah. Dau. of Rog.

Willet. Thomas. From Norwich. Bur. child in St. Pet. July 10, 1615. Then lived on Jacobsgracht. Wit. bet. of dau., Sar. Minter, to Rog. Simmons July 14, 1618. Lived witl dau., Hest., in Zevenhuysen Oct. 15, 1622.

Alice. Wife of Thos. Wit. bet. of dau., Sar. Minter, to Rog. Simmons July 14, 1618.

Sarah. Dau. of Thos. and Alice. Had mar. Wm. Minter before going to Leyd. See Sar. Minter and Sar. Simmons.

Rebecca. Dau. of Thos. and Alice. See Rebec. Fairfield and Rebec. Jepson.

Hester. Dau. of Thos. and Alice. See Hest. Wood.

Thomas. Son of Thos. and Alice. Born 1610-11. Came to Plym., N. E., by 1631.

- Child of Thos. and Alice. Died 1615.

Williams, Elizabefh. From Yarmouth. Sist. of Thos. See Eliz. Wilson. Elizabeth (Prob. anoth.). Lived on Papengracht. Wit. vet. of Antl. Bennett Apr. 6, 1644.

Thomas. M. Bro. of Eliz. Wit. her bet. to Rog. Wilson Mar.11, 1616.

Wilson, Henry. From Yarmouth. Pump-maker. Bet. to Eliz. Nicholas May 13, 1616, with wits. John Carver, Wm. Jepson, Dor. Bradford and Sar. Minter. Mar. May 28.

Eliaabeth (Nicholas). Wife of Hen.

Roger. From Sandwich. Bapt. in St. Clement's in 1584. Guar. by Pet. Boey and Matys Janson Dec. 7, 1609. Guar. Bern. Ross Apr. 2, 1610. Do. Wm. Lisle June 21, 1610. Do. Abr. Gray June 25, 1610. Wit. bet. of Wm. Pontus Nov. 13, 1610. Guar. Wm. Robertson Dec. 3, 1610. Do. Hen. Wood Dec. 10, 1610. Wit. bet. of John Jennings Dec. 17, 1610. Do. Wm. Bassett

1 Thos. Brewer then had in his household Thos. and Hest. Willis. Whether these were the Willets or not cannot be determined. 
Mar. 19 and July 29, 1611. Guar. Wm. Bradford Mar. 30, 1612. Wit. bet. of Geo. Morton July 6, 1612. Do. Ed. Pickering Nov. 24, 1612. Do. Sam. Fuller Mar. 15, 1613. Guar. Wm. Minter May 3, 1613. Wit. bet. of Ed. Southworth May 7, 1613. Guar. Ed. Chandler Nov. 11, 1613. Sold house on Uiterstegracht for $800 \mathrm{~g}$. to Rich. Masterson Jan. 2, 1614. Guar. Is. Allerton Feb. 7, 1614. Wit. bet. of Rog. Wilkins Mar. 28, 1614. Do. Sam. Terry May 16, 1614. Do. John Jenny Sept. 5, 1614. Guar. Alex. Price May 18, 1615. Then say-weaver. Wit. bet. of Rog. Chandler May 22, 1615. Guar. Sam. Lee Oct. 19, 1615. Do. Deg. Priest Nov. 16,1615. Bet. to Eliz. Williams Mar. 11, 1616, with wits. her bro., Thos. Williams, and Eliz. Spalding. Mar. Mar. 26. Guar. 'Thos. Rogers June 25, 1618. Do. And. Sharp Aug. 24, 1618. Deposed to knowledge of Rich. Masterson Mar. 20, 1619. Then camlet-merch. and about 34 .

Wilson, Elizabeth (Williams). Wife of Rog.

Winslow, Edward. M. From London. Son of Ed. Born at Droitwich, Worc., Oct. -, 1595. Printer. Bet. to Eliz. Barker Apr. 27, 1618, with wits. Is. Allerton, Jon. Brewster, Mary Allerton and Jane Hazel, the bride's niece. Mar. May 6 or soon after. With Is. Allerton, Bradford and Fuller wrote letter from Leyd. to Carver and Cushman in Eng. June 10, 1620.

- Elizabeth (Barker). M. Wife of Ed.

Wiseman, Sarah. Wit. bet. of Rob. Warriner Mar. 1, 1624.

Wood, Anna. From Yarmouth. Lived in Vrowencamp. See Anna Waldron.

- Christina. Perhaps sist. of Pet. See Christ. Jepson.

Henry. Draper. Guar. by Abr. Gray and Rog. Wilson Dec. 10, 1610. With Wm. Jepson, John Robinson and Rand. and Jane Thickins bargained for and bought Robinson's house Jan. 27 and May 5, 1611. Guar. Edm. Chandler Nov. 11, 1613. Do. Is. Allerton Feb. 7, 1614. Do. John Keble Apr. 27, 1615. Do. Alex. Price May 18, 1615. Wit. bet. of Hen. Jepson Dec. 8, 1617. Made Hen. Jepson his atty. to sell his share of Robinson's house Feb. 2, 1622. Marle sale by Jepson Dec. 13, 1629.

Mary (-). Perhaps wife of Hen. Wit. bet. of Edm. Jessop Sept. 16, 1615.

Peter. From Staindrop, Dur. Say-weaver. Bet. to Hest. Willet Oct. 19, 1623, with wits. her bro.-in-law and sist., Dan. and Rebec. Fairfield. Mar. Nov. 4. Wit. bet. of sist.-in-law, Rebec. Fairfield, to Thos. Jepson Sept. 18, 1626. Do. son, Pet., July 8, 1643. Then lived in Vrowencamp. 
Wood, Hester (Willet). Wife of Pet. Wit. bet of sist., Rebec. Fairfield, to Thos. Jepson Sept. 18, 1626. Do. Pet. Powell June 13, 1631. Do. son, Pet., July 8, 1643.

Peter. Son of Pet. and Hest. Say-weaver. Lived in Vrowencamp. ${ }^{1}$ Bet. to Mary Bishop July 8, 1643, with wits. his parents, Pet. and Hest. Wood, and her moth., Eliz. Bishop. Mar. July 25. Left Leyd. about 1645. Estate divided Aug. 8, 1680, he not having been heard from for 20 years.

Mary (Bishop). Lived on Rhine. Wife of Pet., Jr.

Thomas. Son of Pet. and Mary.

Abigail. Dau. of Pet. and Mary. Mar. Matt. Siericx before Aug. 8, 1680.

Maria. Dau. of Pet. and Mary. Mar. Is. Day before Aug. 8, 1680 .

Elizabeth. Dau. of Pet. and Mary. Mar. Jac. Plateel and died before Aug. 8, 1680.

- Henry (Another). Perhaps son of Hen. Came to Plym., N. E., by 1643 .

Woodcock, Margaret. See Margaret Parkins.

Wright, Peter. From Norwich. Say-weaver. Guar. by Anth. Fretwell and Malliaect Cloet May 6, 1622. Guar. Rog. Fassett Sept. 8,1623 .

\section{OTHER ENGLISH PEOPLE IN LEYDEN.?}

Acton, Anna. Moth. of Elean. Wit. her bet. to Thos. Hackney Jan. 7,1611 .

Eleanor. Dau. of Anna. See Elean. Hackney.

William. Prob. fath. or bro. of Elean. Wit. her bet.

Ainsworth, John. Mason. Guar. Sam. Curtis Dec. 3, 1610.

Aston, Arthur. Matric. at Leyd. Univ. in Letters June 8, 1611, aged

15. Lived with John Minter.

1 In a letter of Oct. 30, 1863, from Baron Elzevir, then Archivist of Leyd., to Dr. Dexter the writer says :-

"In 1644 a congregation of Brownisten existed in the Vrouwekamp at Leyden proved by a gathering in their church or house in behalf of the poor protestant Irishmen, persecuted by the Catholics or papists."

He adds, in another communication, his opinion that one of John Keble's two houses in this locality was used by the company for religious meetings after Robinson's death in 1625. But no evidence of this appears beyond the holding of this single meeting.

2 This list is not absolutely complete, but it includes all who seem at all likely to have had any relations with the members of the Pilgrim Company. 
Augustine, Jane. Wit. bet. of Nich. Haskins May 16, 1618.

- Thomas. Wit. bet. of Nich. Haskins May 16, 1618.

Bailey, John. Lived in Pieterskerkhof. Bur. in St. Pet. Sept. 23, 1616.

Barker (or Baker), Dorothy. Moth. of Mercy. Wit. her bet.

- Mercy. Dau. of Dor. See Mercy Buckingham.

Barrett, John. From Sandwich. Fustian-weaver. Widr. of Abig. van der Welde. Bet. to Hel. Hendricks Oct. 28, 1616, with wits. her cousin, John Ganne, and her sist., Anna Myers. Mar. same day.

- Helen (Myers, Hendricks). Wid. of Dan. Wife of John.

Brown, Josephine. Wid. of Wm. Lived in Zevenhuysen Oct. 15, 1622, with children and four servants.

William. Son of Josephine.

- Percy. Son of Josephine.

- Barbara. Dau. of Josephine.

- Mary. Dau. of Josephine.

— Mary (Another). Lived on Cortemaeren. Bur. in St. Pet. Jan. $15,1628$.

Buckingham, Samuel. From Crediton, Devon. Bet. to Mercy Barker, of Amst., Feb. 12, 1639, with wits. her moth., Dor. Barker, and Pet. Stalpaerts. Mar. Mar. 12.

- Mercy (Barker). Wife of Sam.

Butterfield, Abraham. Lived in Nieuwestadt. Bur. in St. Pan. Sept. 15,1635 .

- Stephen. Lived near Vischbrugge. Bur. in St. Pet. Sept. 23, 1635. Perhaps son of Steph. of Pilg. Comp.

Campbell, William. From Scotland. Guar. by Geo. Drummond and Jacques van de Burge May 20, 1611.

Carpenter, D. Had Lawrence Wright, student, living with him Aug. 22,1612 .

- "The wife of Master." Bur. in St. Pet. Oct. 4, 1620.

Cox, George. From Coventry. Glove-maker. Bet. to Marg. Manuel Oct. 1, 1627, with wits. Rog. Pachet and Eliz. Davids. Mar. Oct. 17. - Marguerite (Manuel). From Guise, France. Wife of Geo.

Crichton, William. Guar. by Simon Cuypen and And. May Oct. 12, 1618. Made affid. with Wm. Dennis Jan. 1, 1620. Then 48.

Crickett, Daniel. From Sandwich. Bet. to Françoise Le Mahieu Apr. 23, 1611. Lawrence Lancey a wit. Mar. June 10.

- Françoise (Le Mahieu). Wife of Dan. Bur. in St. Pet. Mar. 18, 1616. They then lived in Noordende.

Cruger, Robert. Tobacco-merchant. Deposed with Sim. Higgins about Rob. Day Mar. 24, 1621. Then 42. 
Crutz, Robert. Guar. Anth. Hatfield May 27, 1611.

Curtis, Samuel. From Scotland. Wool-comber. Guar. by John Ainsworth and Anth. Hendrickson Dec. 3, 1610. Was 33 in 1612.

Cushman, Peter. Lived in Oostnieuwelant Oct. 15, 1622.

Cuypen, Sanuel. Son of Thos. Guar. Wm. Crichton Oct. 12, 1618.

Davids, ${ }^{1}$ Elizabeth. Wit. bet. of Geo. Cox Oct. 1, 1627. See Eliz. Halinek.

William. Cloth-maker. Bet. to Marg. Reyers Apr. 15, 1625, with wits. Jochim Jochimson and Jacquemyntge Michielson. Mar. May 3 or soon after.

- Margaret (Reyers). Wife of Wm.

Davidson, Thomas. Widr. of Cath. Bet. to Sar. Neal Apr. 25, 1637, with wits. Geo. Salomon and Anna Juwelen. Mar. May 18. Catharine (Dorne). 1st wife of Thos. Sarah (Thomas, Neal). Wid. of Jos. 2d wife of Thos.

Dawson, Andrew. From Scotland. Deposed with Jas. Moore about Henley Johnson Apr. 13, 1611. Then 35.

Day, Robert. Cloth-draper. Subj. of depos. of Rob. Cruger and Sim. Higgins Mar. 24, 1621.

Dennis, William. Made affid. with Wm. Crichton Jan. 1, 1620.

Dorne, Catharine. See Cath. Davidson.

Dow, Samuel. Say-draper. Guar. by Nath. Drew and Abr. Woods Aug. 26, 1622.

Drew, Nathan. Guar. Sam. Dow Aug. 26, 1622.

Drummond, George. Guar. Wm. Campbell May 20, 1611.

Edmands, Nathaniel. Wit. bet. of Abel Jones Jan. 10, 1614.

Edwards, Phineas. Stocking-weaver. Bought house on Nonnensteeg for 390g. Aug. 4, 1610. Sold it to Hen. Richard June 5, 1614.

Tobias. From Colchester. Baize-weaver. Lived on East Rapenburg. Bet. to Mary de Bonnet Mar. 18, 1616. Mar. Apr. 5.

— Mary (de Bonnet). Wife of 'Tob.

Fones, Lydia. Wit. bet. of Thos. Hackney Jan. 7, 1611.

Ganne, John. Wit. bet. of cousin, John Barrett, Oct. 28, 1616.

Garretson, Albert. Student in Leyd. Univ. Lived in Zevenhuysen Oct. 15, 1622, with wife, children and sist.

Susanna (Peters). Wife of Alb.

- Anna. Dau. of Alb. and Sus.

— Susanna. Dau. of Alb. and Sus.

— Mary. Dau. of Alb. and Sus.

— Daniel. Son of Alb. and Sus.

1 Eliz. (Davids, Joosten) Halinck. 
Garretson, Peter. Son of Alb. and Sus.

- Margaret. Sist. of Alb.

George, - - See Morris.

Gerritson, Peter. Guar. Anth. Hatfield May 27, 1611. Sold part of Thos. Brewer's former house in Groenepoort to Chris. Ellis May 4,1640 .

Greenwood, William. From Norwich. Bet. to Rach. Pettes Nov. 24, 1617, with wits. Sam. Singleton and Rob. and Marg. Hopkins. No record of wedding.

- Rachel (Pettes). Wife of Wm.

Hackney, Thomas. Wool-comber. Bet. to Elean. Acton Jan. 7, 1611, with wits. her prob. fath., or bro., Wm. Acton, Rob. Knights, her moth., Anna Acton and Lyd. Fones. Mar. May 27.

- Eleanor (Acton). Wife of Thos.

Halinck, Elizabeth (Davids, Joosten). From London. Wid. of Maljaert. Wife of Corn. Wit. bet. of Geo. Cox Oct. 1, 1627.

Halton, Susanna. Wid. of Clem. Lived in Zevenhuysen Oct. 15, 1622 , with two children.

— C C Child of Clem. and Sus.

John. Son of Clem. and Sus.

Haskins, Nicholas. From Norwich. Baize-weaver. Widr. of Mary. Bet. to — Wright May 16, 1618, with wits. Thos. and Jane Augustine, John Chyschen (Haskins?) and Ursula Peters. No record of wedding.

- Mary (-). 1st wife of Nich.

- (Johnson, Wright). Wid. of Pet. 2d wife of Nich.

Hatfield, Anthony. Guar. by Rob. Crutz and Pet. Gerritson-May 27, 1611.

Hendricks, Daniel. 1st husb. of Hel.

- Helen (Myers). Wid. of Dan. See Hel. Barrett.

——. See Jones.

Hendrickson, Anthony. Guar. Sam. Curtis Dec. 3, 1610.

Higgins, Simon. Hat-maker. Deposed with Rob. Cruger about Rob. Day Mar. 24, 1621. Then about 28.

Hopkins (or Atkins), Margaret. Wit. bet. of Wm. Greenwood Nov. $24,1617$.

— Robert. Wit. bet. of Wm. Greenwood Nov. 24, 1617.

Hunt, Jacob. From Wales. Baize-weaver. Lived in Leyd. in 1612.

Johnson, Andrew. As guard. of children of Jasp. Eelhont with Chris. Ellis and Ivar Powells sold house Dec. 3, 1637.

- Cornelius. Looking-glass-maker. Guar. John Robertson June 15,1612 . 
Johnson, Henley. Subj. of affid. of And. Dawson and Jas. Moore Apr. $13,1611$.

Jones, Abel. From London. Stocking-weaver. Bet. to - Hendricks Jan. 10, 1614, with wits. Nath. Edmands and -Ysbrants. Mar. Jan. 25. Guar. Aar. Lovett May 28, 1638. Then tailor. (Hendricks). Wife of Abel.

John. Wit. bet. of Rich. Richardson Feb. 19, 1622.

Susanua. See Sus. Richardson. Perhaps dau. or sist. of Joln.

Juwelen, Anna. Wit. bet. of Thos. Davidson Apr. 25, 1637.

Kendall, Elizabeth. Dau. of Aar. and Anna (Cornelis). Bet. to Mos. Paijens Mar. 21, 1618, with wit. her moth.

Knights, Alice. From Yarmouth. See Alice Smith.

Robert. Wit. bet. of Thos. Hackney, Jan. 7, 1611.

Lancey, Lawrence. Wit. bet. of Dan. Crickett Apr. 23, 1611.

Leighton, John. Lived on Achtergracht. Bur. in St. Pet. Mar. 14, 1613.

Lewis, Joseph. Referred to in depos. of Bern. Ross Apr. 11, 1616.

Lewison, Jacob. Guar. John Robertson June 15, 1612.

Lovett, Aaron. From Sandwich. Baize-merchant. Guar. by Dan. Severijn and Abel Jones May 28, 1638.

May, Andrew. Guar. Wm. Crichton Oct. 12, 1618.

Minter, John. Had Arth. Aston, stud., living with him June 8, 1611.

Moore, James. From Scotland. Deposed with And. Dawson to knowledge of Henley Johnson Apr. 13, 1611. Then 30.

Morris (or Morse), Elizabeth. Wit. bet. of Wm., July 28, 1617. Prob. moth. or sist.

- John. Wit. bet. of Wm. Prob. fath. or bro.

William. Hat-maker. Bet. to — George July 28, 1617, with wits. his fath., or bro., Jolm Morris, his cousin, John Sterling, Ed. Williams, Eliz. Morris and Magd. Peters. Mar. Aug. 12. Then lived with Ed. Williams.

George). Wid. of Rob. Wife of Wm.

Fanny. Wit. bet. of Rich. Richardson Feb. 19, 1622.

Moses, Jane. Bet. to Wm. Poor Nov. 27, 1615.

Myers, Anna. Sist. of Hel. Wit. her bet. to John Barrett Oct. 28, 1616. Prob. same as Mary Anna Myers, who wit. bet. of Jos. Parsons July 8, 1621.

- Helen. From Sandwich. Sist. of Anna. See Hel. Hendricks and Hel. Barrett.

John. Perhaps fath. or bro. of Anna and Hel. Wit. bet. of Jos. Parsons July 8, 1621. 
Neal, Edward. From Warrenton, ${ }^{1}$ Lanc. Bet. to Mary van Rokigen Nov. 25, 1616, with wits. his bro., John Neal, and Jane Scudder. No record of wedding.

Mary (Buffkin, van Rokigen). Wid. of Louis. Wife of Ed.

- John. Bro. of Ed. Wit. his bet. Nov. 25, 1616.

— Joseph. 1st husb. of Sar.

Sarah (Thomas). Wid. of Jos. See Sar. Davidson.

Parsous, Joseph. From Colchester. Say-weaver. Bet. to Mar. Smith July 8, 1621, with wits. John Myers, her fath., Rob. Smith, and Mary Anna Myers. Mar. July 29 or soon after.

Maria (Smith). Wife of Jos.

Peck, Nicholas. Matric. at Leyd. Univ. in Med. Dec. 7, 1611, aged 30. Peters, Magdalene. Wit. bet. of Wm. Morris July 28, 1617.

Ursula. Wit. bet. of Nich. Haskins May 16, 1618.

Pettes, Edward. From London. Wool-carder. Widr. of Anna. Bet. to Eliz. Potters Dec. 30, 1609, with wits. Raph. and Marth. Rowlands. No record of wedding.

- Anna (Johnson). 1st wife of Ed.

- Elizabeth (Brants, Potters). Wid. of John. 2d wife of Ed. Rachel. From London. See Rach. Greenwood.

Poor, William. Bet. to Jane Moses Nov. 27, 1615. No record of wits. or wedding.

Potters, John. 1st husb. of Eliz.

— Elizabeth (Brants). From Waltham. ${ }^{2}$ Wife of John. See Eliz. Pettes.

Randall, George. Made depos. Feb. 26, 1619.

Reyers, Margaret. See Marg. Davids.

Richard, Henry. From Sandwich. Bought house on Nonnensteeg from Phin. Edwards June 5, 1614. Sold it for 175g. to Alex. Price Dec. 13, 1627.

Richardson, Richard. Wool-carder. Bet. to Sus. Jones Feb. 19, 1622, with wits. John Jones and Fanny Morris. Mar. Mar. 12. Susanna (Jones). Wife of Rich.

Robertson, John. From Norwich. Guar. by Corn. Johnson and Jac. Lewison June 15, 1612. Perhaps the John Robertson, living on the Sonnerveltsteeg, licensed Nov. 9, 1613, to sell beer.

Rochester, Dudley. Bought house on Papengracht for $645 \mathrm{~g}$. from Chris. Ellis Nov. 8, 1638.

Root, Roger. Wit. bet. of John Wiseman May 16, 1625.

Rowlands, Mary. Wit. bet. of John Tessens Jan. 26, 1613.

1 Warrington.

2 Whether in Linc., Lanc., or Kent is unknown. 
Rowlands, Martha. Wit. bet. of Ed. Pettes Dec. 30, 1609. Raphael. Wit. bet. of Ed. Pettes Dec. 30, 1609.

Salomon, George. Wit. bet. of Thos. Davidson Apr. 25, 1637.

Scudder, Jane. Wit. bet. of Ed. Neal Nov. 25, 1616.

Simmons, Auna. Bet. to Wm. Bradford, soldier at Nymegen, June 2, 1622.

— Jane. Wit. bet. of Joln Wiseman May 16, 1625.

Singleton, Samuel. Hod-carrier. Wit. bet. of Wm. Greenwood Nov. 24, 1617. Lived on Mirakelsteeg. Belonged to night watch, or city guard, Apr. 30, 1620. Bur. in St. Pan. June 14, 1620.

— Mary (Williams). Wid. of Sam. Deposed Aug. 7, 1620, that he had been dead two months.

Smitl, Johı. From Yarmouth. Say-weaver. Widr. of Fanny. Bet. to Alice Knights Oct. 20, 1618, with wits. John and Anna Lepelaer. Mar. Nov. 11. Lived in Zevenhuysen Oct. 15, 1622.

Fanny (Wrangham). 1st wife of John. Alice (Knights). 2d wife of John.

Maria. From Colchester. Dau. of Rob. See Mar. Parsons.

Robert. Father of Mar. Wit. her bet. to Jos. Parsons July 8, 1621.

- Roger. Wool-comber. Was 34 in 1611.

Spooner, Mrs. Bur. child in St. Pet. May 18, 1630. Bur. anoth. June 3, 1630. Bur. anoth. June 20, 1630.

Stalpaerts, Peter. Wit. bet. of Sam. Buckingham Feb. 12, 1639.

Sterling, Joln. Wit. bet. of cousin, Wm. Morris, July 28, 1617.

Stuart, Robert. Lived in Leyd. in 1612.

Watts, Thomas. 1st husb. of Eva.

Eva (-). Wid. of Thos. See Eva Wiseman.

White, Rosamond. Wit. bet. of John Wiseman May 16, 1625. Possibly wife of Thos. White of Amst., who pub. "A Discoverie of Brownism" in 1605.

Wiggins, Susanna. Wit. bet. of Malieu Casier Dec. 18, 1627.

Williams, Andrew. Bought house in Pieterskerkhof for $1100 \mathrm{~g}$. from Chris. Ellis June 18, 1637.

- Edward. Had Wm. Morris living with him when Morris was bet., July 28, 1617. Wit. his bet.

Wilson, Thomas. From Cambridge. Say-weaver. Date uncertain.

Wiseman, John. Tailor. Bet. to Eva Watts May 16, 1625, with wits.

Rog. Root, Jane Simmons and Rosam. White. Mar. May 31.

Eva (Watts). Wid. of Thos. Wife of John.

Woods, Abralıam. Say-weaver. Guar. Jac. Woods Mar. 29, 1613.

Do. Sam. Dow Aug. 26, 1622. 
Woods, Isaac. Guar. Jac. Woods Mar. 29, 1613.

- Jacob. Say-weaver. Lived in Hoofdkerken. Guar. by Abr. and Is. Woods Mar. 29, 1613.

Wright, —. Wid. of Pet. See —— Haskins.

- Lawrence. Student in Leyd. Univ. Matric. in Med. Aug. 22, 1612, aged 22. Lived with D. Carpenter.

From the two foregoing lists an estimate of numbers may be made, as follows. It is as nearly exact as is possible in the existing conditions.

Known, or fairly presumable, members of the Pilgrim Company in Leyden until July, 1620,

Others associated more or less closely with them until that time, or with the remaining members later,

Deduct those named more than once,

The whole Pilgrim colony,

The other English in Leyden, 1609-81, of whom perhaps some belonged to the colony,

Deduct those named more than once,

Total English colony likely to have been associated with the Pilgrims in any degree

There were others, however, who do not appear to have been so associated.

\section{CITIZENSHIP LIST.}

The following sixty-five menbers of the Pilgrim Company became citizens of Leyden. Before the emigration in July, 1620, these thirty-three:-

1609. Pet. Boey and Rog. Wilson.

1610. Abr. Gray, Nich. Hawley,* Wm. Lisle, Wm. Robertson, Bern. Ross, John Turner and Hen. Wood.

1611. John Carpenter,* Bart. Smith and Jac. Stevens.*

* A star over a name means that the date at which its owner became a citizen is not recorded but that in the course of this year he guaranteed some one else, thus demonstrating his own previous citizenship. 
1612. Wm. Bradford, Hen. Collet and Rich. Masterson.*

1613. Edm. Chandler and Wm. Minter.

1614. Is. Allerton.

1615. John Keble, Sam. Lee, Alex. Price, Deg. Priest and Thos. Smith.

1616. Jos. Crips and Wm. Jepson.

1617. Jon. Brewster and Thos. Tinker.

1618. Thos. Rogers, And. Sharp and Hen. Stafford.

1619. Chris. Ellis, Fred. Jones * and Wm. Ring.

After the departure of the emigrants these thirty-two:-

1621. Hen. Jepson and Jos. Spalding.

1622. Herb. Dennis,* Anth. Fretwell,* John Warnes and Pet. Wright.

1623. Marcus Belden,* Anth. Clement,* Rog. Fassett, Geo. Ferguson,* John Spooner and Rog. White.

1624. John Tracy.

1625. Fras. Jessop.

1626. Ed. Coolidge, Humph. Howell, Jac. Jolnnson * and Wm. Smith.

1627. Joln Jennings.

1628. Wns. White.

1629. Wm. Bridgman.*

1630. Hub. Brook.

1631. Wm. Jackson.

1637. Steph. Butterfield.

1638. Thos. Johnson,* Wm. Kibbett and Walt. Tucker.

1639. John Ainsworth, Thos. Jones* and Raph. Lovell.

1640. Mich. Koollys.

1642. Thos. Otley.

\section{ENGLISH SOURCES OF THE PILGRIM EMIGRA'TION.}

The English homes of the Pilgrims, when known, have been stated in connection with individuals. As to many no record exists. In most cases it is uncertain whether the place recorded is that of birth or of residence just before leaving for Holland, and in some a doubt remains which of two or more places of the same name is meant. Yet there is a certain interest in noting from what parts of England they went, and, so far as the various hindrances permit, this has been attempted, as follows :- 
From the North of Eng. Dur. (1) - with Scot. (3) - 4- 4 From the East of Eng. Yorks. (East.) . . . 5

Norf. . . . . . 32

Suff. . . . . . . 3

Essex . . . . . . 11

Kent . . . . . . $17-68$

From the Middle of Eng. Yorks. (remainder) . . 6

Linc. . . . . . . 2

Notts. . . . . . 9

Cambs. . . . . . 3

Leic. . . . . . 1

Berks. . . . . 2

Wilts. . . . . . $1-24$

From the South of Eng. Somers. . . . . . 5

Dorset. . . . . . 1

Sussex . . . . 3

Hants. . . . . . $1-10$

From London . . . . . . . . . . . . 17-17-123

Uncertain - prob. . . Notts., Norf., Suff., or

Kent - . . . 14-14-137

This classification, although necessarily very imperfect, affords some suggestion as to the comparative prevalence of Nonconformity at the period. But it is more than probable that those who fled to Holland from the Scrooby region alone - in So. Yorks., Notts. and Linc. numbered several scores of persons, although only some twelve or fifteen can be traced to that region from the Dutch records.

\section{PLYMOUTH COLONISTS FROM LEYDEN.}

Children who were in Leyden witl parents who became colonists are included. The following thirty-five ${ }^{1}$ persons came over in 1620 in the Mayflower :-

Allerton, Isaac. Mary.
Allerton, Bartholomew. Remember.

1 The John and Bridget Tilley of the Mayflower probably came from Shipton, Shrops, and were not the John Telly and Bridget (van der Welde) who were betrothed in Leyden Feb. 13, 1615, with his fath., Paul Telly, as wit. and married Mar. 3. Bradford says three times distinctly that Eliz. Tilley was John's daughter (Hist. 450, 453). And she had married John Howland long enongh before the division of cattle in the colony, June 1,1627 , to have two children then and must have married him as early as 1624-25, when she could have been only nine or ten years old if she were the daughter of the John married - and for the first time in Leyden in 1615. Edward Tilley, of the Mayflower, apparently was from Shipton, and the records of that place show that there also were John Tilleys there. 

Allerton, Mary. John.
Priest, Degory.
Rogers, Thomas.
Bradford, William.
Joseph.
- Dorothy.
Brewster, William.
Tinker, Thomas.
Mary.
Love.
Carver, John.
Wrestling
Catharine.
_ Thomas, Mrs.
—. Son.
Turner, John.
—. Son.
‥ Son.
White, William.
Crackstone, John.
- John, Jr.
Winslow, Edward.
- Susanna.
English (England), Thomas.
Fletcher, Moses.
Fuller, Samuel.
- Resolved.
Williams, Thomas. Elizabeth.
Goodman, Jolnn.

No student of the Leyden records is likely to doubt the identity of Thos. English and Thos. England. Another passenger, Desire Minter, has been supposed to have come from Leyden, but there is no evidence of her ever having been there. Bradford says ${ }^{1}$ that she "returned to her freinds . . . and dyed in England," which suggests that she may have joined the company at Southampton.

The following four came over in 1621 in the Fortune :-

Bassett, William. ${ }^{2}$

Brewster, Jonathan.
Cushman, Thomas.

Morton, 'Thomas.

The following twenty-four came over in 1623 in the Anne or the Little James : -

Brewster, Fear.

- Patience.

Cuthbertson, Cuthbert.

- Sarah.

- Samuel.

Fuller, Bridget.

Jenny, John.
Jenny, Sarah.

- Saral.

- Samuel.

- Abigail.

Morton, George.

- Juliana.

- Nathaniel.

1 Hist. 450. Francis Cook also may have been the man of that name who was married to Hester Mahieu in Leyden on June 9, 1603, but no allusion to him occurs later.

2 Bassett's third wife, Elizabeth, apparently was from Leyden, but there is no proof of her presence there, or any record of their marriage. 
Morton, Patience.

- John.

- Sarah.

— Thomas, Jr.

Priest, Mary.
Priest, Sarah.

Southworth, Alice.

Tracy, Stephen.

- Tryphosa. Sarah.

The following eighteen came over later at different times :-

Blossom, Thomas. 1629.

Ann. 1629.

Thomas, Jr. 1629.

Peter. 1629.

Bradford, John. 1627 or soon after.

Chandler, Edmond. 1633 or earlier. Roger. 1633 or earlier. Masterson, Richard. 1630. Mary. 1630.
Pontus, William. 1630. Mary. 1630.

Ring, Mary. 1630.

- Andrew. 1630. Elizabeth. 1630. Susanna. 1630.

Robinson, Isaac. 1631.

Southworth, Constant. 1628.

Thomas. 1628 or soon after.

Eighty-one in all. It is not absolutely certain that Edmond and Roger Chandler and the Rings are the same who were in the company at Leyden, but there can be little doubt in the matter. Robert Cushman also made a short visit to the colony in 1621 . 


\section{INDEXES}





\section{INDEX OF PUBLICATIONS}

This index is intended to serve merely as a guide and only indicates titles. In order to prevent it from being largely a duplicate of the General Index, which follows it, authors whose uames occur solely in connection witl the titles of their works ordinarily are mentioned in this index only. A reference here to a work by any other author is in each ease to that mention of the work which gives its title most fully, and all other references to it are in the General Index under the author's name.

Aвridg. Bk. Deliv. to Maj., 357, 566.

Abr.'s Faith, J. Nichols, 332.

Abstr. Acts Parl., Stoughton, 141.

Acet., Evelyn, 10.

Act-bk., York, 253, 323, 391, 392, 401.

Act Suprem., 65 .

Act Uniform., 73, 80, 91, 93, 105, 107, 114.

Acts and Mons., Foxe, 38.

Acts Ch. Coun. St. Pet., Leyd., 593.

Add. MSS. Brit. Mus., 257.

Admon. Parl., Cartwright, 126.

Admon. Peop. Eng., Cooper, 181.

Ad Respons. N. Grev., Ames, 566.

Ad Tract. de Minis. Grad., Beza, 16.5.

Adv., Clyfton, 429.

Adv. conc. Bk. Lately Pub., 464.

Adv. Corrup., Broughton, 437.

Adv. or Admon., Helwys, 538.

Adv. Pap-hatehet, R. Harvey, 181.

Advice to Son, Shaw, 424, 458 .

Advs., 94, 97, 105.

Agric. and Prices, J. E. T. Rogers, 22.

Ainsworth, Axon, 423.

Almond for Parrot, Nash, 181.

Ambass., Noailles, 85.

Amer. Biog., 286.

Amer. Jour. Edue., 22.

Amesii, Gul. (Op.), 520.

Anat. Abuses, Stubbes, 13.

Anat. Armin., P. du Monlin, 582.

Anat. Melau., R. Burton, 15.

Anc. Eceles. Pract. Confirm., Hakewill, 551.

Anc. Truth Rev., 458.

Angl. Schism, Sanders, 92.

Animad., Ainsworth, 466 .

Annals, Anderson, 376, 539.

Annals, C. H. Cooper, 257, 258, 278.

Annals, Holmes, 500 .

Annals, Prince, 500.
Aunals, Scot., Balfour, 47.

Annals, J. Stow, 43, 107.

Annals, Strype, S, 63, 87, 101, 119, 124, $139,143,289,305$.

Annots., H. Ainsworth, 428.

Ans. for Time, 116 .

Aus. of Vice-chanc., 335, 387, 438.

Ans. to Cartwright, Browne, 194.

Ans. to Cens. Epis., Robinson, 451.

Ans. to Cert. Calum. Let., Suteliffe, 153.

Ans. to Cert. Libel, Whitgift, 105.

Ans. to Cert. Libel Supplic., Suteliffe, 164.

Ans. to G. Gifford, Greenwood, 207.

Ans. to Jacob, F. Johnson, 437.

Ans. to Ten Demands, Furing, 578.

Ans. to Treat. Cross Bapt., Bradshaw, 359.

Ans. to Two Treats., Cosin, 141.

Antimartinus, 181.

Antiq. Annals Stamford, Peck, 282.

Antiquary, 30.

Apol., Johnson-Ainsworth, 465.

Apol. against Brownists, J. Hall, 393.

Apol., Cathol., T. Morton, 348.

A pol., Eceles. Angl., Jewell, 165.

A pol. for Sundry Proceeds., Cosin, 169.

A pol. or Defence, 489.

Appeal to Parl., or Slon's Plea, Leighton, 45.

Arch. Hist. Camb., Willis-Clark, 264, 265.

Arg., N. Fuller, 364.

Args., Sprint, 358.

Armill. Op., 512.

Arrow, Paget, 524 .

Arts., Eleven, 93, 105.

Arts. Enquiry, 106, 109, 111.

Arts. Faith Nat. Ch., Hommius, 574.

Arts., Forty-two, 77-80, 98, 94. 
Arts., Injuncts. and Canons, Sparrow, Caesura Lit., 181. 70 .

Arts., Lambeth, 261, 396.

Arts., Seven (Pilg.), 568.

Arts.. Six, 66, 70, 76 .

Arts., Ten, 66, 75 .

Arts., Thirty-nine, 94, 105, 106.

Arts. Visitation, 84 .

Asin. Onust., 181.

Assert. for Ch. Policy, Stoughton, 345.

Assert. Sept. Sacram., Hen.VIII, 58.

Astrol. Disc., R. Harvey, 32.

Ath. Cant., 124, 126, 160, 257, 429.

Ath. Ox., 273.

Attest. of Learn. Divines, Jacob, 550.

Audit-bk., Peterhonse, 275.

Austerf. Par. Rees., 379, 389.

Author. Ch. in Making Canons, Mason, 365.

Bannatyne Pubs., 302.

Barrow, H., Powicke, 182, 380.

Basil. Dor., Jas. I, 369.

Beschr. Stad Leyd., Orlers, 475, 482, 497,498 .

Bible, Bishops', 258.

Bible, Clyfton, 387.

Bible, Gutenberg, 55.

Bible, Mazarin, 55.

Bible. Revised, 375.

Bib. Repos., 512.

Birch Add. MSS., 377.

Blessings, Gerizim, Sutcliffe, 348.

Bloody Ten., Williams, 423.

Blow at Mod. Sadducism, Glanvil, 39.

Blyth, Raine, 217, 218, 236, 380.

Bodleian Jurid., 311, 316.

Book Psalms, Ainsworth, 543, 589.

Book Wh. Sheweth, Browne, 193.

Brev. Rom., 72.

Breviary Health, Boorde, 31.

Brief Ans. to Objects. against Descens. Christ into Hell, 351.

Brief Ans. to Cert. Reasons, Covell, 362.

Brief Censure Pur. Pamph., 331.

Brief Discourse against Outward Apparel, 114.

Brief Disconrse Cert. Points of Relig., Gifford, 146.

Brief Discourse Troubles Frankfort, 135.

Brief Discov. False Ch., Barrowe, 17.

Brief Diseov. Untruths, Penry, 170.

Brief Exam. for Time, 115 .

Brief, Plain Declar., Fnlke, 153.

Brief Treat. Declaring Ch., 113.

Brief Treat. Oaths, Morice, 169.

Britan. Depict., Owen, 9.

Broth. Persuas. to Unity, Sparks, 339.

Brownism Turned Inside Out., Lawne, 546.

Caius Coll. MSS., 316.

Calvin, Henry, 184.

Calvin Letters, Bonnet, 185.

Camb. Un. Matric. Regs., 256.

Camb. Un. Trans., 337.

Campion, Simpson, 302.

Carleton's Letters, 562.

Cartwright, Brook, 138.

Cases Consc. conc. Witeheraft, I. Mather, 39.

Cassander Angl., Sprint, 576.

Cath. Supplic., Powel, 347, 440.

Cav. for Cursetors, Harman, 6.

Cert. Args. to Persuade Parl., 358.

Cert. Arts or Reasons, 330.

Cert. Arts out of Admon. to Parl., 133.

Cert. Consids. from Canons Last Syn., 361.

Cert. Consids. touching Pacif., Bacon, 363.

Cert. Demands, 356 .

Cert. Letters, $428,434,436$.

Cert. Letters and Confers., 201.

Cert. Miner. and Metaph. Sch. Points, Marprelate, 180.

Cert. Questions, H. Ainsworth, 437.

Cert. Reasons, F. Johnson, 149.

Cert. Reasons against Conform., Dighton, 574 .

Cert. Sermons, 70.

Cert. Slanderous Arts., Barrowe, 202.

Chapters Relig. Hist. Spain, Lea, 52.

Charlestown Recs., Wyman, 425 .

Char. of Beast, Smyth, 453.

Chief of Pilgs., Steele, 255, 283, 286, 295.

Christ. Adverts., Bernard, 459.

Christ. Letter, 173, 174.

Christ., Mod. Offer, Jacob, 369.

Chronol. of Med., Richards, 32.

Chrons., Holinshed, 97, 107.

Chrons. of Pilgs., Young, 52. (See W. Bradford.)

Close Roll, Kg. John, 216.

Colet's Lects., Romans, 56.

Collectanea, Leland, 218.

Collects. conc. Founders N. Plym., Hunter, 228.

Comfort. Epis., Wyburne, 122.

Comment., A pos. Creed, Jackson, 551.

Comment., Blackstone, $S$.

Comment., Cartwright, 566 .

Comment. Pent., H. Ainsworth, 424.

Com. A pol., J. Hall, 398.

Commul. Saints, Steuart, 428.

Cone. New Ch. Discip., G. Cranmer, 172.

Concil. Mag. Brit. et Hibern., D. Wilkins, $328,354$.

Coneise Deserip. Endow. Gram. Sehs., Carlvle, 24, 25. 
Confessio Fid., 210, 492, 444, 46.5.

Confession and Protest., Jacob, 563.

Confessions, Knollys Soc., 538.

Confirm. and Discov. Witeheraft, Stearne, 39.

Confut. Cert. Arts., Wilkinson, 178.

Confut. Heresies H. N., Kuewstubs, 17 .

Confut. Rluem. Trans., Cartwright, 574.

Congm. in Lit., H. M. Dexter, 182, 199, $200,262,371,422,442,557$.

Consid. Cert. Posits., Bradshaw, 359.

Consid. Deprived Ministers' Args., Powel, 358.

Consids, touching Difference, Sprint, 358.

Consolat. for Gram. Schs., Brinsley, 26.

Cornwall, R. Carew, 16.

Coron. ad Coll. Hag., Ames, 575.

Corp. Jur. Can., Greg. XIII, 37.

Costumes in Eng., F. W. Fairholt, 12.

Cotton MSS., 263, 292, 296, 307, 309, 344.

Counterblast, Jas. I, 15.

Countercuff, Nash, 181.

Counterpoison, H. Ainsworth, 149.

Counterpoison, D. Fenner, 142.

Court and Country, 15.

Cranmer, Strype, 65, 74.

Credulity in Deny. Witches, Casaubon, 39.

Creed, First Cong'l, 201.

Creeds, 66.

Creeds Christendom, Schaff, 396.

Crudities, Coryatt, 15.

Daemonology, Jas. I, 35.

Dang. Proceeds. and Posits., Bancroft, 170.

Davison, Campbell, 298.

De Bello Belg., Strada, 415.

De Brownisten, Scheffer, 386.

De Divers. Min. Evang. Grad., Saravia, 16 ).

De Fasein. et Incant., Tandlerus, 39.

De Orig. ac Prog. Schism. Angl., 87.

De Perpet. Eccles. Gubern., Bilson, 538.

De Polit. Eccles., Parker, 5:0.

De Prestig. et Incant., Wierus, 38.

De Reg. Eccles. Scot., 580.

De Vera et Gen. Relig., 574.

Declar. and Plain. Open., Jacob, 520.

Declar. Faith Eng. Peop., 443, 520.

Declar. Practices Earl Essex, F. Bacon, 261.

Defence Arts. Prot. Relig., Barlow, 330.

Defence Chhs. and Mins. Eug., 438.

Defence Eccles. Discip., D. Fenner, 158.

Defence Godly Mins., D. Fenner, 158.

Defence Govt. Ch. Eng., Bridges, 157.

Defence Holy Scrips., H. Ainsworth, 460 .
Defence Mins. Reasons, Hieron, 358.

Defence Reas. Counterpois., 143.

Defence R. Some's Last Treat., Some, 161.

Defence That Written, Penry, 159.

Defense Ans. Admon., Whitgift, 134.

Defense Eccles. Reg., 133.

Defens. 'Tract., Saravia, 166.

Delices de Leide, 491.

Demonstr. Discip., 14.̆.

Demonstr. 'Truth Diseip., Udall, 154.

Deserip. Brit., IV. Harrison, 4.

Descrip. Ch. Christ, 457.

Deserip. Fam. Love, Snow, 178.

Descrip. N. Eng., J. Snith, 563.

Deserip. Oxon. Acad., Fitzherbert, 256.

Descrip., What God Predestin., Murton, $386^{\circ}$.

Desid. Curiosa, 276 .

Despatches Veuet. Ambas., 58.

Detection E. Glover, Bredwell, 205.

Devil an Ass, Jonson, 15.

D'Ewe's Journ., 307.

Dial. Ceremonies, Gardiner, 355.

Dial. Light Daneing, Fetherstone, 17.

Dial. Pap. and Prot., Gifford, 146.

Dial. Strife of Ch., 144.

Dial. Tyran. Dealings, 146.

Dial. Witehes, Gifford, 39.

Dialect. Lib. Duo, Ramus, 27.

Diary, Evelyn, 10, 22, 23, 32-84, 42, 4649.

Diary, Pepys, 24, 32, 34, 42, 46-18, 314.

Dict. Dates, Haydn, 14, 34 .

Dict. Nat. Biog., 79, 149, 169, 189, 193 , $257,273,80.2,355,520,538$.

Differences Chhs., Smrth, 460.

Directory Ch. Govt., Cartwright, 185.

Directs, to Know True Ch., G. Carleton, 558 .

Discourse Abuses, Whetenhall, 365.

Disconrse Damned Art Witeheraft, Perkins, 39.

Discourse Impostures, Brinley, 39.

Discourse, Proving Witehes, 89.

Discourse, Reform., Ed. VI, 69.

Discourse, Some Troubles, G. Johnson, 210.

Discov. Brownism, T. White, 441.

Discov. Errors Eng. Anabapts., Jessop, 392.

Discov. Impostures, Brinley, 39.

Discov. Witcheraft, Scot, i5.

Display. Supposed Witcheraft, Webster, $3 \overline{7}, 40$.

Disquis. cone. Eccles. Coun., I. Mather, 359.

Dissent in Relat. to Ch. Eng., Curteis. 100.

Disserts. and Discuss, Hamilton, 497. 
Dissuasions from Separatists, Bernard, 517.

Dissuasive from Errors of Time, R. Baillie, 524.

Doctr. et Polit. Eccles. Angl., Mocket, 563.

Docum. Annals, E. Cardwell, 84, 90, 93, $94,107,109,110,179,352,354,376$.

Docums. Relat. Col. Hist. N. Y., 584.

Docums. Relat. Univ. Camb., 24, 265.

Doomsday Bk., 216.

Dress, Habits Eng. Peop., J. Strutt, 13.

Dutel Drawn to Life, 419.

Dutch Way of Tolerat., Baron, 410.

Early Eng. Bapts., Evans, 448, 616.

Eboracum, Drake, 11, 12, 49, 229.

Eccles. Biogs., Wordsworth, 173, 222.

Eecles. Discip., Travers, 138.

Eccles. Memors., Strype, 65, 74, 90, 229.

Een Nieu Liedeken, $10 \%$.

Egerton, Paps., 113, 183, 200, 257, 315.

Ene. Amer., 321.

Enc. Brit., 6, 15, 20, 21, 35, 62, 193, 257, 320,487 .

Enchirid., Erasmus, 57.

Eng. Creed, T. Rogers, 374.

Eng. Puritanism, Bradshaw, 359.

Eng. Sehoolmaster, Coote, 22.

Eng. Seen by Foreigners, Rye, 9, 42, 45 .

Epis. Anglis Frankfort, Calvin, 104.

Epis. Mag. Benedict., Erasmus, 183.

Epis., Marprelate, 180.

Epis. Tigurin., 74-76, 81, 83, 84 .

Epis. to Distracted, Clapham, 360.

Epis. unto Daus. Warwick, Refut. by Ainsworth, 178.

Epists., Erasmus, 31.

Epit., Marprelate, 180.

Error on Left, Clapham, 457.

Error on Right, Clapham, 201.

Europ. Specul., E. Sandys, 374.

Evang. Reg., Niclaes, 178.

Exam. and Chron., 446.

Exam. and Confut. Scurril. Treat., Suteliffe, 348.

Exam. Barrowe, Greenwood, Penry, 199.

Exam. Cartwright's Late Apol., Suteliffe's, 164.

Exam. Whitgift's Censures, 137.

Exhort. to Govs. and Peop. Wales, Penry, 159.

Explic. $\kappa a \tau \hat{\eta} \lambda \theta \in \nu$, Bronghton, 351.

Expos. Catech., Bastingius, 498.

Faith, Doctr. and Relig. in Eng., T. Rogers, 374.

Famil. Colloq. Form., Erasnuns, 183.

Famil. Letters, Howells, 42, 609.

Fast. Ebor., Dixon - Raine, 217, 221, 222.
Fast. Eecles. Angl., J. Le Neve, 233.

First and Sec. Diar. Eng. Coll. Douay, T. F. Knox, 513.

Foedera, 'T. Rymer, 345.

Friendly Admon. to Marprel., L. Wright, 181.

Fruitful Serm., Chaderton, 149.

Full, Plain Declar., Travers, 138.

Genesis U. S., A. Brown, 573.

Gen. Martyrol., Clarke, 472.

Giustinian at $\mathrm{Ct}$. Hen. VIII, 222.

Godly Serm., Chaderton, 574 .

Godly Treat., Some, 161.

Godly Treat. Confut. Execrable Fancies, Some, 161.

Gravesend, Cruden, 20.

Grenville, Collect. Proclams., 113, 199.

Grindal, Strype, 96, 108.

Grt. Schs. of Eng., Staunton, 25.

Guide to Grand Jury Men, Bernard, 39.

Gull's Horn Bk., Dekker, 15.

Hague Archives, 309.

Hallamshire, Hunter, 7, 34.

Hamp. Ct. Serms., Barlow, etc., 363.

Handbk. Lond., Cunningham, 262.

Harl. Misc., 44.

Harl. MSS., 23, 149, 178, 179, 183, 204, $285,288,297,316,386,394,397,421$, 448.

Harmony Pent., Calvin, 37.

Hay Work for Cooper, Marprelate, 180.

Herbal, Gerard, 262.

Heresiog., Pagitt, $17 \mathrm{~S}$.

Het Bloed. Toon., Van Braght, 107.

Hidden Ch., Waddington, 199.

Hieron. Phil., Calderwood, 574.

High Commis., Burn, 169.

Hist. and Stands., West. Assemb., Mitehell, 95 .

Hist. Arts. Relig., Hardwick, 65.

Hist. Christ. Ch. during Ref., Hardwick, 100.

Hist., Ch., of Brit., T. Fuller, 99.

Hist. Ch. of Eng., Perry, 100.

Hist. Chhs. in Eng., Staveley, 22.

Hist. Col. Mass. Bay, Hutchinson, 595.

Hist., Cong'l., J. Waddington, 188, 199.

Hist. Const. of Eng., Hallam, 8.

Hist. Corp. Christ. Coll., Masters, 284, $393,897,398$.

Hist. Early Purs., J. B. Marsden, 92.

Hist. Eccles. Govt. Brit., Collier, 99.

Hist., Eliz. Relig., H. Soames, 90.

Hist. Eng., Froude, 67.

Hist. Eng., Gardiner, 328.

Hist. Eng., Herbert, Ld., etc., 304.

Hist. Eng., Hnme, 52.

Hist. Eng., Knight, 3.

Hist. Eng., Lingard, 93. 
Hist. Eng., I. von Ranke, 72, 85, 303.

Hist. Eng. Bapts., Crosby, 538.

Hist. Eng. Bapts., Iviney, 458.

Hist. Eng. Ch., Dodd, 92.

Hist. Eng. Gen. Bapts., Taylor, 458.

Hist. Eng. Peop., Green, 9.

Hist. Eton Coll., Lyte, 25,256 .

Hist., Gen., Bapt. Denom., Benedict, 458.

Hist. Hamp. Ct. Pal., Law, 220, 340.

Hist. Holl. and Dutch, Davies, 417, 477.

Hist. Inquis., Lea, 35.

Hist. Mar. Arch., Charnock, 20.

Hist. Marprel. Controv., Maskell, 181.

Hist. Neths., A. Young, 417, 4S2.

Hist. Nottingham, Thoroton, 227.

Hist. Pays Bas, Van Meteren, 416.

Hist. Plym. Plant., Bradford, 260.

Hist. Presbs., Heylin, 99.

Hist. Prot. Nonconform., T. Price, 185.

Hist. Purs., Neal, 386, 428.

Hist. Ref. Ch. of Eng., Burnet, 59, 61, $66,69,72$.

Hist. Reform. Low Countries, Brandt, 416.

Hist. Roche Abbey, Aveling, 217, 218.

Hist. Salem, Upham, 35.

Hist. Scotch Ch., Rotterdam, Steven, 422,444 .

Hist. Scotland, Tytler, 303.

Hist. Vit. et Mort., F. Bacon, 32.

Hist. World, Raleigh, 555 .

Histor. Collects., J. Pushworth, 46.

Histor. Paps., Waddington, 1S8, 199.

Histor. Paps. and Lets. from North. Regs., 217.

Holy State, T. Fuller, 260.

Hooker. Hanburs, 17:?.

Hooper, Early Writings, 73.

Hooper, Later Writings, 86.

Humble Motion, 160.

Humble Motives for Assoc., Digges, 390.

Humble Petit. Commonalty, 151.

Humble Petit. Ministers, 334.

Humble Supplic., 440.

Hypoc. Unmask., Winslow, 3S7, 636.

Iconess, Holland, 260.

Injunctions, 105, 107.

Inner Life Relig. Socs. Commonwealth, Barelay, 177, 442, 455 .

Inq. and Ans., Johnson, 212.

Instit. of Christ. Man, Wolman, 394.

Institutes, Calvin, 37.

Itin., Hentzner, 15.

Itin., Leland, 224.

Itin., Morsson, 571 .

Just Censure Martin, Jr., Marprelate, 181.
Just, Necess. Apol., Robinson, 578.

Just, Temp. Defence Ilooker, Covell, 175.

Justif. Separ., Robinson, 516.

Knox and Cl. Eng., Lorimer, 75.

Korte Besgryving, Van Leewen, 475.

Lambeth MSS., 143.

Lament. Complaint Commonalty, 151.

Lans. MSS., 2:, 133, 183, 306, 394-396, $422,428$.

Laws Eceles. Polit., Hooker, 166.

Leets. Witcheraft, Upham, 35.

Leicester Corresp., 290, 29:3, 296.

Letter against Brownism, Cartwright, 206.

Letter conc. Separ., J. Hall, 450.

Letter from Keu. Castle, Laneham, 42.

Letters, Mrs. Adams, 500.

Leyd. Rees., $501,502,506$.

Leyd. 300 Jaren, Plexte, 488.

Leyd's. Wee, Hofdijk, $417,479,480,481$.

Lib. de Nup. Con., Augustine, 161.

Life Colet, Erasmus, 57.

Life Smith, Strype, 91.

Life Washington. Marshall, 500.

Lit. Hist. Eur., Hallam, 28.

Little Treat. Ps. 122: 1, R. Harrison, 205.

Liturg. Sac., 72.

Liturgs. Ed. VI, 75.

Liturgs. Two, 75 .

Lives Archbs. Cant., W. F. Hook, 99.

Lives Ch. Justs., Campbell, 38.

Lives Purs., Brook, 124.

Lives Thirty-two Eng. Divs., Clarke, 183.

Logos pros tous Geneb., Broughton, 351.

Lollard Stats., 71, 85, 91.

Lond. Mag., Sharpe, 32.

Lud. Lit., Brinsley, 25.

Magnalia, C. Mather, $3 \& 8$.

Mag. Rot. Pip., Rich. I, 216.

Manuduct., Ames, 555 .

Mauumiss. to Manuduct., Robinson, 399.

Mar-Martine, 181.

Marre-Martin, 181

Martin's Month's Mind, 181.

Mary, Scots, Leader, 11.

Mary, Scots, Letters, 315.

Mary, Scots, MSS., 302.

Maryland, Bozman, 500.

Mass. Bay Rees., 19.

Mass. Hist. Soc. Colls., 500, 557 .

Mayflow. Descend., 611.

Med. Econ. Mid. Ages, Fort, 42.

Memoirs, Melvill, 285.

Memorials, Winwood, 526 .

Memorials N. Eng., N. Morton, 391. 
Memorials Stuarts, R. Vaughan, 357.

Memorials West. Abbey, Stanley, 80.

Middlesex Co. Recs., ㄴ․

Mild, Just Defence, Bradshaw, 358.

Miles Christ., T. Rogers, 171.

Milton, Masson, 27.

Mind of Bucer, 119.

Minis. Ch. Eng., F. Jolınson, 325.

Nirror Martinists, Turswell, 181.

Modest, Reason. Exam., Covell, 334.

Mod. Relat. conc. Witches, Hale, 39.

Mor. Eneom., Erasmus, 183.

More Work for Dean, T. Wall, 201.

Most Hum. Supplic., Murton, 385.

Myst. Witeheraft, T. Cooper, 39.

Nederl. Archief., Kist, 467.

Nederl. Oorlogen, Bor, 481, 486.

N. Eng. Canaan, T. Morton, 548, 615.

N. Eng. Hist. and Geneal. Reg., 20, 253, 589.

N. Eng. Trialls, J. Smith, 589.

News from Spain and Holl., 331.

Note Things Called in Quest., 537.

Notes and Quer., 199.

Nov. Test., Erasmus, 57.

Nug. Antiq., 342.

N. Y. Hist. Soc. Colls., 568.

Obed. or Eccles. Un., Wilkes, 362.

Objections Ansd., Murton, 385.

Observations Bills Mortal., Graunt, 6 .

Of Ch., R. Field. 348.

of Cross, T. Parker, 367.

Of Profic. and Advance. Learning, $\mathrm{F}$. Bacon, 819 .

Of Relig. Commun., Robinson, 553.

Of Suprem. in Relig., Hayward, 350.

Old, New Lond., 43.

Order, Enquiry, 106.

Orig. Lets., H. Ellis, 71, 72, 224.

Osnaburg Chron., 42.

Overall's Convoc. Bk., 366, 386.

Oxford Ref., Seebohm, 5t, 56.

Oyer's Reports, Notes, 43.

Pammachius, Kirchmayer, 27?.

Pandaemon., Bovet, 39.

Papiers d'Etat, Ecosse, 302.

Pappe with hatch., Lily, 181.

Parall., Smyth, 459.

Paraphras., Erasmus, 70.

Parker Corresp., 91, 96, 99, 101, 103.

Parker, Strype, 273, 274.

Part of Reg., WValdegrave, 122, 139, 142, $143,151,158,175,188$.

Pattern True Pray., Smyth, 380.

Pedig. Eng. Gall., Bulwer, 13.

Pedig. F. Gorges, Brown, 304.

Penry, J., Pilg. Martyr, Waddington,
People's Plea, Robinson, 574.

Perf. Discov. Witches, Ady, 39.

Perpet. Govt. of Ch., Bilson, 167.

Persuas. to Eng. Recus., Dove, 346.

Perth Assemb., Calderwood, 578, 579.

Peterbor. Reg., 200.

Petit. Assoc. Relig., Digges, 330.

Phenix, 339.

Phil. II, Prescott, 415, 417.

Pict. Pap., Ormerod, 350.

Pict. Purit., Ormerod, 335, 350.

Pilg. Faths., J. Brown, 188.

Pilg. Repub., Goodwin, 533, 611, 634.

Placards, 416.

Plain Confut., Alison, 207.

Plain Deelar., Gifford, 207.

Plain Evid., Bernard, 517.

Plain Percevall, R. Harvey, 181.

Plain Refut. Gifford, Barrowe-Greenwood, 442.

Platform, Barrowe, 539.

Plea Infants, Clyfton, 460.

Plea Innoc., J. Nichols, 332.

Pleas. Dial., Gilby, 119.

Pleas, Treat. Witches, 39.

Plym. Col. Recs., 259.

Politic Plot, Hitcheock, 6.

Praest. ac Erud. Vir Epis., Taffinus-Arminius, $427,434,435$.

Praise Folly, Erasmus, 57.

Pr. Bk. 1549, 71-74, \$0, 90, 91, 105, 128, 352-354.

Pr. Ek. 1552, 74.

Pr. Bk., Bullinger on, 73.

Pr. Bk., First, Ed. VI, 72.

Pr. Bk., Hist., Lathbury, 100.

Pr., Bk. of Com., 71.

Pr., Bk. of Com., Hist., Procter, 71, 72.

Pr., Book of Com., New Hist., Frere, 33.

Pr. Bk., Rev.. 74.

Prin. Epists. H. N., Niclaes, 178.

Prins, and Infers., Smyth, 381.

Proceeds. Priv. Coun., Nicolas, 228.

Prof. Schism, Lawne, 545.

Progs. Jas. I, Nichols, 220, 238, 280.

Proph. Spir. Love, Niclaes, 178.

Propos. conc. Kneeling, Bradshaw, 359.

Protest. King's Suprem., Bradshaw, 359.

Protest. M. Marp., Marprelate, 180.

Prot's. Apol. Rom. Ch., Brerely, 348.

Public Wants, Wales, Penry, 159.

Pur., or Widow, W. Smith, 366.

Quest. Witcheraft, Wagstaffe, 40.

Rat. Theol., Christ. Phil., Tulloch, 52.

Razing Fonnds. Brownism, Bredwell, 206.

Reasons by way of Apol., Burgess, 362.

Reasons for Refus. Subscrip., T. Hutton, 358. Also 2d Pt. 
Reasons Taken Out God's Word, Jacob, $36 s$.

Recant. Brownist, Fairlambe, 442.

Recolls., Lenox, 55.

Reconcil. Pastors, Marten, 163.

Rees. Eng. Prov. S. J., 513.

Reformat., Fisher, 418.

Reformers and Theol., Prin. Cunningham, $76,77,80$.

Reg. Admis. Gon.-Caius Coll., Venn, 423.

Reg. Leases, York, 225, 229-231, 235.

Reg. Priv. Coun., 426.

Rejoind. to Mild Def., Powell, 358.

Relation State Relig., E. Sandys, 373.

Relig. Commun., Robinson, 553.

Relig. Med., Browne, 410.

Relig. Thought, Eng., Hunt, 177.

Relig's. Peace, Busher, 550.

Reminisc. Ct. Holl., 544.

Remonstr., Sutcliffe, 162.

Removal of Imput., 358.

Reply to Ans. Whitgift, Cartwright, 125.

Reply to Hooker, Ridley, 362.

Reply, Second, Cartwright, 125. Rest of Reply, 137.

Reply, Short, Gifford, 207.

Report of Disc. conc. Sup. Power in Relig.. 349.

Report of Roy. Com. Hist. MSS., 570.

Resol. to Countryman, Perkins, 40.

Retract., Smyth, 455.

Return of Pasquill, 181.

Revel. Dei, Niclaes, 178.

Revel. St. John, Brightman, 562.

Rise Dutch Repub., Motley, 480.

Robinson, O. S. Davis, 252.

Roll Roy. Coll. Phys., 32.

Roy. Exchange, Payne, 428.

Sabbat. Errors, Sov. Antid., 373.

Sabbath and Ld's. Day, Dow, 373.

Sabbath Day, Defence, Brabourne, 373.

Sabbath Day, Discourse, Brabourne, 373.

Sabbath Day, Treat., F. White, 373.

Sabbath, Doctr., Byfield, 373.

Sabbath, Doctr., Prideaux, 373.

Sabbath, Doctr., Walker, 373.

Sabbath, Doctr., Widley, 372.

Sabbath, Hist., Herlin, 373.

Sabbath, Learn. Treat., Brerewood, 373.

(Sabbath) Three Quests., Broad, 373.

Sabbathi Vindic., Abbot. 373.

Sabbathum Vet. et Nov. Test., N. Bownd, 371.

Sabbato, Tract. de, Abbot, 373.

Sabbatum Redeviv., Cawdry, 373.

Sadducis. Triumph., Glanvil, 39.
Salomon, T. Morton, 171.

Satan's Invis. World Discov., Sinclair, 39.

Schol. Acad., Wordsworth, 27, 269, 276, 280.

Scholast. Disc., T. Parker, 519.

Sealed Fount. Opened, Wilkinson, 385.

Seasou. Treat., Woolsey, 437.

Second Admon. to Parl., Cartwright, 126.

Second Mannduct., Ames, 398.

Second Pt. Plain Disc., Dighton, 578.

Select Cases Conse. cone. Witches, Gavle, 39.

Sermon, Bancroft, 166.

Sermon, Copcot, 143 .

Sermon, Lever, 81.

Sermon, T. Rogers, 150.

Sermons, Howson, $17 \%$.

Sermons, Revel., Gifford, 176.

Shakespeare's Eng., Thornbury, 10, 12, 17.

Sbakespeare's Time, Goadby, 32.

Sheffield, Hnnter, 220.

Shield of Def., Fowler, 545.

Short Catech., Mosse, 171.

Short Dial., Hieron, 354.

Short, Plain Proof, Helwys, 538.

Short Reply, Gifford, 422 .

Short Treat. against Donatists, Gifford, 207.

Short Treat. conc. Tell Ch., F. Johnson, 464.

Simancas MSS., 99.

Sloane MSS., 397.

Society Eliz. Age, H. Hall, 320 .

Soc. Life Eng. Univs., Wordsworth, 26, $257,274,275,394$.

Sophronistes, 148.

Spectator, 38 .

Spir. of Laws, Montesquieu, 38.

Standard, Chicago, $446,454,458$.

Star Chamber, Burn, 316.

State Ch. Eng., Udall, 322.

State of Poor, Eden, 3, 7.

State Papers, Dom., 11, 64, 87, 89, 188, $230,234,237,238,240,241,255,288$, $297,304,307,309,318,322-324,338$, $35 \%, 370,377,580$.

State Papers, Dom. Add., 288, 304, 320.

State Papers, Dom. Jas. I. 357.

State Papers, Dom. Proc. Bk., 4.

State Papers For., 230.

State Papers Holl. and Fland., 290, 292.

State Papers Mary, Scots, 307.

State Papers Scot., 88, 280, 315.

Statut. Acad. Cant., 273, 274, 276, 278.

Statut. Reconcil., 84.

Stirp. Hist. Pempt., Dodoens, 262.

Story Pilg. Faths., Arber, 214.

Sum and Subst., Barlow, 339. 
Sum. Controv. Relig., Hoornbeeck, 447. Sun Theo, 346.

Supplic. of Mass Priests, Radford, 347. Supplic. to King, 347.

Surtees Soc. Pubs., 218, 237, 328.

Survey Christ's Sufferings, Bilson, 351.

Survey New Relig., Kellison, 347.

Survey Pretend. Holy Discip., Bancroft, 170.

Survey Spir. Antichrist, Rutherford, 178.

Table, Bk. about, Jeaffreson, 15.

Terra Pacis, Niclaes, 178.

'Th' Appellation, Penry, 159.

Theol. Axioms, Clapham, 427.

Theses Martin., Marprelate, 181.

To Div. Begin. of Ch., Jacob, 519.

To Mr. Smith and Mr. Rob., J. Hall, 420.

To my Loving Breth., Gilby, 119.

Touchstone for Present, Hake, 137.

Tower, Her Maj's. WV. II. Dixon, 33.

Town Life, Mrs. J. R. Green, 15.

Tract. de Deo, Vorstius, 535.

Tract. de Eccles., De Mornay, 176.

Treat. cone. 1Sth Matt., F. Johnson, 521.

Treat. conc. Witches, Ady, 39.

Treat. contain. Equity Hum. Supplic., Penry, 159.

Treat. of Ch., Darrell, 571.

Treat. of Ch., De Loque, 161.

Treat. of Div. Worsh., Bradshaw, 359 .

Treat. of Eccles. Discip., Sutcliffe, 164.

Treat. of Justif., Bradshaw, 558.

Treat. of Minis. Ch. Eng., HilderslıamF. Johnson, 175 .

Treat. of Nat. and Use Things Indiff., Bradshaw, 359 .

Treat. of Reform. without Tarrying, Browne, 193.

Treat. of Suf. and Vict. of Christ, Jacob, 351.

Treat. of Witcheraft, Roberts, 39 .

Treat., Short, of Cross in Bapt., Bradshaw, 359 .

Treat. Tend. to Mitig. towards Cath. Subjs., Persons, 348.
Treat. upon 23 Matt., Browne, 194.

Treat. Wherein Proved, Penry, 160.

Trial Witcheraft, Cotta, 39.

Troubles, R. Gawton, 139.

True Confess., 20S-210.

True Deserip. Vis. Ch., 201, 203, 421.

True Difference, Bilson, 169.

True Marks Christ's Ch., 188

True, Modest, Just Def. of Petit., 334, 574.

True, Short Declar., Browne, 194.

True, Sincere, Modest Def. of Eng. Caths., Allen, 169.

True Story J. Smyth, H. M. Dexter, 378.

Trying Out Truth, H. Ainsworth, 513.

'Tuba Acad., I. F., 352.

Tumult. Anabapt., Hortensius, 78.

Twelve Gen. Args., Bradshaw, 359.

Univ. Camb., Mullinger, 27.

Unlaw, of Read. Pray., Maunsell, 364.

Unlaw. of Read. Pray., Staresmore, 582.

Un. Neths., Motley, 3.

Unreason. of Separ., Bradshaw, 555.

Utop., T. More, 57.

Val. Eccles., 224.

Voyages Eng. Nat., Hakluyt, 427.

Voyages, Wks., J. Davis, 20.

Warn-word to Hastinge's Wast-word, Persons, 346.

Watehman, 458.

Way of Chhs. Cleared, Cotton, 593.

Wheth. Sin to Transgress Civ. Laws, 119.

Whip for Ape, 181.

Whitgift, Strype, 110, 126, 169, 334, $338-340,438$.

Wolsey, Cavendish, 220, 222, 224.

Works, Jas. I, 370.

Works, Jewel, 165.

Works, Robinson, 451.

Worthies, T. Fuller, 257, 258.

Wurtemberg, Confess., 94. 


\section{GENERAL INDEX}

As the Appendix is arranged alphabetically, names occurring there are not included here without special reason.

Аввот, G., 373.

Abbot, R., 402, 573 .

Abel, 114.

Achurch-cum-Thorp, 189, 200, 325.

Adams, Mrs. J., 500.

Addison, 38.

Ady, T., 39.

Ainsworth, Anna, 423.

Ainsworth, H., 149. 178, 204, 205, 381, $398,423,424,429,432,433,437,440$, $441,444-448,451,452,454,457,459$, $460,465,466,513,517,521-524,543$, $550,558,562$.

Ainsworth, J., 513, 558.

Ainsworth, T., 428 .

Alesius, A., 73 .

Alison, R., 201, 207.

Allen, Card., 140, 169.

Alley, W., 89, 93 .

Alva, 417, 418.

Ames, W., 359, 398-400, 519, 520, 535, $545,553,557,562,575,582,593$.

Anabaptism, 78, 83, 419 .

Anderton, J., 348.

Andrews, 339.

Anjou, 98, 140, 263.

Anne, Q., 33.

Antwerp, 18, 70, 291, 411-413, 415.

Appleby, Marj., 432.

Arber, E., 81, 180, 181, 214, 274, 387, $405,562,578,581,584$.

Argyropulos, 54 .

Armada, Span., 321.

Arminianism, 396, 512 .

Arminius, J., 80, 427, 434, 435, 461, $462,510-513,592$.

Arthington, H., 171.

Arthur, Prince, 58, 299.

Ascham, R., 25, 27, 28.

Ashton, R., 398, 451.

Aston, A., 625.

Aukley, 389.

Aurispa, J., 54.

Austerfield, 243, 332, 333, 330, 387-390.

Aylmer, 95.

Babington Conspir., 302, 305.

Babworth, 377, 379, 387.

Bacon, A., 28t, 288.
Bacon, Anne, 28, 165.

Bacon, F., 29, 32, 261, 273, 278, 284, $285,288,363,558$.

Bacon, N., 107, 394 .

Baillie, 524.

Bainbridge, C., 395.

Baker, J., 228.

Ballard, 316.

Balsham, H., 256, 265, 271.

Balthasar, Wid., 170.

Bancroft, G., 568, 569.

Bancroft, R., 49, 125, 126, 166, 170, 185, $198,200,322,3 \pm 5,341,344,348,349$, $354,360,366,376,386,424$.

Baptists, Early, 212.

Barbar, T., 126.

Barbary, 428.

Barker, 91.

Barkers, 376.

Barlow, 93.

Barlow, W., 330, 339-343, 371.

Barneveldt, J., 468, 5๋4, 570, 574, 582.

Baro, P., 260, 396.

Baron, W., 410.

Barrowe, H., 17, 182, 199-211, 325, 421, $422,428,441,539$.

Barrowism, 201-203, 208, 211.

Barthelot, J., 103.

Bartlett, IV. F., 500.

Bawtry, 223, 237, 242, 243, 254,389, 390 .

Baynes, P., 399.

Beale, R., 308, 312.

Bedford, 118.

Belknap, J., 286.

Bellarmine, Card., 351, 370.

Bellingham, 93.

Benedict, 458 .

Benet (C. Christ.) Coll., 189, 393.

Bentham, 93.

Berkeley, 22.

Berkeley, 33.

Berkeley, 93.

Bernard, R., 39, 40, 375, 350, 351, 384, $452,455,457-459,516-519$.

Bernher, T., 428.

Best, 93 .

Bevercotes, S., 324.

Beza, T., 104, 128, 129, 150, 157, 165, $183,185,461$. 
Bill, W., 89-91.

Billet, A., 201.

Bilson, T., 167, 169, 351, 376, 538.

Bishop, T., 446.

Blackstone, \&, 23, 38, 336.

Blackwell, F., 573.

Blake, 344 .

Blanchard, W., 392, 393, 401.

Blyth, 217, 218, 223, 238.

Boissot, 451.

Boleyn, Anne, 63, 64, 88 .

Boleyn, T., 60.

Bolton, J., 188.

Bonham, W., 125.

Bonner, E., S1, S4, 224.

Books chained, 30, 269.

Bossy, R. J., 43.

Bowes, R., 285.

Bowman, C., 149, 204, 421, 427, 446.

Bownd, N., 269, 371-373.

Bownd, R., 268.

Boys, Mrs., 425, 426, 429.

Bozman, 500.

Bradford, Alice, 389.

Bradford, Alice H., 388, 389.

Bradford, Alice W., 380.

Bradford, Eliz., 3\$9, 390.

Bradford, Marg., 389.

Bradford, Marg., 389.

Bradford, Marg., 389, 390.

Bradford, Mary, 389, 390 .

Bradford, R., 388, 389.

Bradford, R., 389, 390.

Bradford, T., 388 .

Bradford, W., 388.

Bradford, IV., 388.

Bradford, W., 253, 255, 260, 276, 283, $284,287,295,326,327,332,377-380$, $384-391,400,402-407,431,442,443$, $445,446,449,450,453,463,464,490$, 491 , э04, 506, 519, 541, 560, 561, 567, 58:-586, 591, 630, 632, 638.

Bradshaw, W., 252, 330, 358-360, 558.

Braithwait, M., 446.

Brandt, G., 416, 418, 419, 434-436, 478, $484,485,507,509-511,513,550$.

Branthwayte, W., 395.

Braybrooke, 47.

Bredwell, S., 198, 205, 206, 212.

Brewer, J. S., 60, 61.

Brewer, T., 579-581.

Brewster, Fear, 326.

Brewster, H., 254, 256, 325.

Brewster, Jas., 254, 255, 325, 325, 379.

Brewster, Jon., 326, 505, 514 .

Brewster, Mary, 326, 505.

Brewster, Patience, 326.

Brewster, Prudence, 253, 323, 326.

Brewster, WV. Sr., 232, 236-23s, 253256, $320,323$.

Brewster, W., 138, 149, 175, 205, 240,
252-298, 304, 308, 313, 316, 317-329, $346,368,377,386,401,403,406,466$, $467,505-507,523,550,568,573,574$, 579-581, 585 .

Brewster Tablet, 250.

Brewster's Fellow-students, 259-263.

Brewsters, 255.

Bridges, J., 157-159, 179.

Briggs, R., 390.

Brightman, T., 259, 395, 562.

Brill, 290-292.

Brinley, J., 39.

Brinsley, J., 25, 26.

Bristow, D., 425, 446.

Bromhead, Anna, 384, 448.

Bromhead, H., 384, 448, 520.

Bromley, T., 311.

Brook, B., 124, 126, 138, 149, 339, 354, $369,395,428,437,442$.

Broughton, H., 351, 437.

Brown, A., 573.

Brown, J., 188.

Browne, P., 190.

Browne, R., 189-208, 211, 262, 325, 360, $382,383,421,422$.

Browne, T., 29, 410.

Brownism, 198-198, 202, 211, 381, 382.

Brute, W., 3S.

Bryne, J., 225, 229-231, 236.

Bucer, M., 72, 73, 77, 86, 115, 117, 257.

Buck, D., 204, 386.

Buckhurst, 308, 313.

Builli, J. de, 388.

Bullinger, H., 77, 90, 96, 118, 119, 129, 150.

Bulward, R., 536.

Burckhardt, 65.

Burgess, J., 361.

Burghley, 128, 133, 140, 285, 289, 290, $301,305,309,312,313,394,395,397$.

Bury St. Edmunds, 38, 255, 256, 262.

Busher, L., 550.

Butler, W., 32.

Butterfield, S., 593.

Caius, 265.

Calais, 18, 93.

Calderwood, D., 574, 578.

Calvin, J., 37, 71, 72, 76, 77, 88, 104, $123,150,157,170,184,185,189,211$, $365,421,461$.

Cambray, 64 .

Cambridge, 62, 72, 76, 1S9-191, 282, $337,398,397,399,424$.

Cambridge Colleges, 259, 394.

Camden Soc., 183.

Camden, W., 304, 305, 307, 315.

Campeggio, 60, 61 .

Camperell, 170.

Canopus, N., 14.

Canterbury, 70, 166. 
Carey, R., 314, 328.

Carleton, G., 558.

Carleton, D., 562, 574, 579-581.

Carlisle, 43.

Carpinters, 297.

Cartwright, T., 29, 95, 110, 125, 126, 128-138, 162, 173, 183, 185-187, 189, $193,200,203,206,210,211,273,346$, 359,421 .

Carver, J., 568, 570, 584, 588.

Casalis, G., 64.

Cathari, 10.5 .

Cathie, Catì., 86.

Cavendish, H., 220, 222, 224.

Cavendish, T., 19, 394.

Cecil, Lady, 28.

Cecil, R., 28S.

Cecil, T., 28s, 292.

Chaderton, L., 149, 343, 361, 376, 399.

Chalcondyles, 54 .

Ch., Amst., Ainsworth's, 522, 524, 545, 554.

Ch., Amst., Ane., Johnson's, 188, 386, $423,427,429,432-436,441,442,445$, $449,521-524,536,545,554$.

Ch., Amst., Clapham's, 427, 442.

Ch., Amst., Eng. (Seot.) Presb., 427, $443,444$.

Ch., Amst., Robinson's, 449, 450.

Ch., Amst., Smyth's, 442, 446, 454-457, 460,555 .

Ch., Amst., White's, 441, 442.

Ch., Lond., First Cong'l., 563, 573.

Ch., Norwich, 191, 196, 198, 212, 437.

Ch., Pilg., Serooby, 239, 384, 386, 393.

Charke, W., 125.

Charles, Prince, 45.

Charles I, 169.

Charles II, 39, 46, 47.

Charles V, 60, 415-417.

Chartley, 300, 301, 304, 305.

Chartre, de la, 527.

Chasteauneuf, 308, 309.

Chattisham, 212, 602.

Cheney, 93.

Chichester, A. M., 508.

Christopherson, 90.

Christ's Coll., Camb., 378, 422.

Chrysolaras, E., 54 .

Chrysostom, 172.

Churchson, J., 113.

Clapham, H., 201, 360, 427, 442, 457.

Clark, J., 426.

Clark, R., 377.

Clark, Ursula, 432.

Clayton, R., 396.

Clem. VII, 60.

Clergy, Benefit of, 23.

Clerke, W., 204.

Clink Prison, 199, 423, 425, 438.

Cluse, de la, J., 482, 537.
Clyfton, Anne, $387,550$.

Clyfton, E., 387.

Clyfton, R., 239, 377, 387, 400, 406, 407, $446,447,449,450,454,457,459,460$, $520,521,541,546,550,561,562$.

Clyfton, 'T., 387.

Cole, R., 96.

Colet, J., 56, 57.

Collier, 99, 135, 170, 334, 357.

Collins, 424.

Collins, H., 469.

Commis., High, 93, 105, 110, 160, 234, 336.

Commis., High Ct., 380, 391, 392, 401.

Commun., Order, 71, 74, 75 .

Confess., Angs., 65, 66, 94.

Confess., Wurtem., 94.

Cong'l Lib., Boston, 248, 249.

Constantinople, 54 .

Contarini, 'T., 412 .

Convocation, $62,63,65,66,72,91,353$, $354,366$.

Cook, A., 28, 89, 97.

Cook, F., 651 .

Cook, G. W., 241.

Coolhaes, C., 483, 485.

Cooper. 165.

Coote, E., 22, 25, 262.

Copcot, J., 143, 260, 394.

Coppin, 209.

Coppinger, E., 171.

Cordallion, 309.

Cornelison, P., 484 .

Cornelius, A., 511.

Corp. Christ. (Benet) Coll., Camb., 189, 393.

Correr, M. A., 45.

Coryat, T., 15 .

Cosin, R., 141-143, 169, 345.

Cotta, J., 39.

Cotton, J., 196, 273, 524, 593.

Covell, W., 173, 175, 333, 362.

Coverdale, M., 71, 101, 118, 123.

Cox, 91, 93, 273.

Crane, N., 125.

Crane, N. (anoth.), 421.

Cranmer, G., 172, 273, 2S8, 297, 298, 326.

Cranmer, T., 62, 64-67, 69-71, 73, 74, $76-78,85,90$.

Cranmer, T., Friends, 76-77.

Cranmer, T. (neph.), 297.

Crashaw, 398, 452 .

Creichton, 87 .

Crewe, 242.

Crofts, 316.

Cromwell, 46, 284.

Crosby, T., 458.

Cumberland, 316.

Cunaeus, P., 534.

Curle, 304.

Curteis, 100. 
Curzon, J., 220.

Cushman, R., 568-570, 579, 584, 580, $588,589$.

Darnley, H., 299.

Darrell, J., 261, 571.

Davenport, J., 273.

Davies, 93.

Davis, J., 20.

Davis, O. S., 252.

Davis, W. T., 286.

Davison, W., 283-298, 304, 305, 307$314,316-319,401$.

Dawson, W., 233, 253.

Day, G. E., 531.

De Poenitent., Order, 256.

Deane, C., 399.

Deane, N., 263.

Delfshaven, 587, 588.

Denis, W., 209.

Deventer, 310.

D'Ewes, S., 277, 307.

Dexter, Collect., 138, 175, 255, 459, 508, $521,533,543$.

Dexter, H. M., 136, 170, 178, 182, 189, $201,241,248,253,254,326,378,387$, $388,431,463,501,531,592$.

Deyman, P. A., 529.

Dickens, Alice, 432.

Digges, T., 330 .

Dirksz, F., 456.

Dodd, C., 92, 97, 339, 348, 513.

Dodonaeus, R., 491.

Dodsworth, M., 402.

Does, van der, J., 479, 482, 483.

Dolman, N., 347 .

Donatists, 156.

Donteklok, R., 511.

Dort (Dord recht), 200, 205, 422.

Dort, Syn., 463, 575, 581, 582.

Douglas, J., 443.

Downes, A., 261, 277.

Downes, W., 390.

Downham, 93.

Drake, F., 15, 20, 319 .

Drury, D., 311.

Ducket, 263.

Durie, J., 560, 591.

Durie, R., 557, 560 .

Du Trappes, 309.

Eden, F., 3, 7.

Edmunds, T., 126.

Ed. VI, 69, 70, 80-83, 256.

Egerton, S., 126.

Egmont, 418.

Eiles, IV., 429.

Eliz., Princess, 5 $46,551$.

Eliz., Q., 3, 11, 12, 28, 41, 85, 88, 92-99, $103,107,111,233-235,289-291,294-$ 297, 299-30:3, 305ั-317, 328.

Ely, R., 268.

Elzevir, J. C. R., 501, 641.

Emden, 550, 571.

Engelbrechtszen, C., 492.

Epine, de l', Cath., 432.

Episcopius, S., 80, 525, 544, 550, 560, $561,582,595$.

Erasmus, 31, 57, 183.

Essex, 260, 278, 305, 317.

Evans, 458, 521.

Everton, 228.

F. I.. 352.

Fabricins, 482.

Fagius, P., 77, 86, 90, 257.

Fairlanıe, P., 149, 442.

Falstaff, J., 12, 13.

Fénelon, La M., 285.

Fenner, A., 47.

Fenner, D., 142, 143, 158.

Feria, 96, 97.

Fetherstone, C., 17.

Field, J., 105, 125, 126, 128, 130, 185.

Field, R., 348, 349.

Fisher, 61 .

Flanders, 415, 416.

Fleet Prison, 86, 183, 422, 425.

Fleming, A., 262.

Fletcher, H., 389.

Fletcher, R., 394.

Floyd, 45.

Flushing, 290-292.

Forshall, J., 56.

Fotheringay Castle, 306, 308, 311.

Fowler, 516.

Fowler, J., 536.

Foxe, 421.

Foxe, J., 38, 74, 90, 93, 347.

Francis, Dauph. Fr., 299.

Fred., Elect. Pal., 546, 551.

Fred., Hen., 526.

French, Peddlers, 6.

Frobisher, M., 19.

Froude, J. A., 67, 83, 86, 93, 97, 99, 295, $311,316$.

Fruytiers, 480 .

Fulke, W., 153, 179.

Fuller, N., 364.

Fuller, T., 29, 99, 126, 135, 169, 170, $189,256-258,260,334,339,345$.

Fytz, R., 188.

G., R., 434.

Gainsborough, 228, 378-380, 384-386, 393,399 .

Galloway, P., 340.

Gardiner, 81 .

Gardiner, R., 126.

Gardiner, S., 355 .

Gardiner, S. R., 328, 334, 338, 344, 357, 370,551 . 
Gawton, R., 139.

Gayton, 255 .

Gellisbrand, 185.

Geneva, $88,89,113,166,184,185,188$, 416.

Gerrits, L., 448, 453, 457.

Gifford, 32 .

Gifford, G., 39, 147, 176, 207, 422.

Gilbert, H., 20.

Gilby, A., 119, 124, 144.

Glastonbury, 76 .

Glastonbury Service Bk., 72.

Goadb5, E., 11, 12, 19, 20, 32, 49.

Goch, von, J., 54.

Gomar, F., 461, 462, 486, 510, 513.

Gorges, T., 304.

Goulart, S., 558.

Gowrie, 286.

Graevius, 497.

Gravesend, 295.

Green, J. R., 9, 301, 536.

Green, J. R., Mrs., 20, 22, 31.

Greenham, R.. 183, 190.

Greenwich, 61, 298, 310.

Greenwood, J., 183, 199, 203, 204, 207$209,259,262,325,421,422,425,442$.

Greg. Great, 362.

Greg. XIII, 302.

Gresham, Marg., 388.

Grey, Jane, 28, 83.

Grimbrye, Rose, 441.

Grimsby, 404, 405.

Grimsdike, Marg., 469.

Grindal, 91, 93, 96, 99, 100, 103, 109, $110,118,189,281$.

Grotius, H., 417, 552, 555, 574 .

Gualter, 92, 97, 118, 128, 129.

Guest, E., 89, 93.

Gueux, Les, 417, 418.

Guiana, 568, 586.

Guicciardini, 415 .

Gutenberg, J., 55.

Hackett, W., 171.

Hague, The, 290, 293, 374.

Hale, M., 38, 39.

Hales, de, A., 351.

Hales, J., 575.

Hall, F., 401.

Hall, J., 393, 398, 420, 450, 451, 453, 457.

Hallam, H., 8, 28, 45, 276, 278.

Halletus, N., 498 .

Hamilton Pal., 300.

Hamilton, W., 497.

Hammond, M., 140.

Hamp. Ct., 220, 240.

Hamp. Ct. Conf., 338-344, 352, 371, $375,386$.

Hamp. Ct. Preachers, 363.

Hanbury, 173, 175, 201, 326.
Handborough, 432.

Handson, 2.55.

Hanson, Alice, 388.

Hanson, J., 388, 505.

Hanson, Marg. G., 388.

Hanson, Wybra, 514 .

Harcourt, R., 568.

Hard wiek, 65, 78, 80, 84, 94, 100.

Harper, J., 220.

Harrington, J., 342.

Harris, Ann, 432.

Harrison, 4, 6-10, 12, 14, 15, 20, 24.

Harrison, R., 191, 205, 262.

Harsnet, S., 240.

Harvey, G., 181.

Harvey, R., 32, 41, 181, 261.

Harworth, 223, 254, 379.

Hastings, F., 346, 357.

Hatfield, 216, 219, 228.

Hatton, C., 309, 312, 313, 316.

Hawkins, J., 19.

Hawkins, WV., 19.

Heale, G., 589.

Heath, N., 81, 226, 229, 231.

Helen's, St., 388.

Helwys, Joan, 385.

Helwys, T., 385, 454, 456, 458, 520, 521, 588.

Helwys, W., 385.

Hen. III (Eng.), 216, 282.

Hen. III (Fr.), 290, 291.

Hen. IV (Fr.), 468, 527, 536.

Hen. VII (Eng.), 218, 299.

Hen. VIII (Eng.), 57-70, 82, 85, 228, $256,299$.

Hen., Prince, 340.

Hentzner, P., 15, 42, 257.

Herbert, 64 .

Herbert, G., 29, 277.

Hereford, 12.

Herman, Prince Arch., 72.

Hertford, 69.

Hesse, Phil., 65.

Heurnius, J., 491.

Heylin, P., 99, 185, 373.

Hieron, S., 354, 358.

Hildersham, A., 175.

Hodgkin, Jane, 385, 432.

Holgate, 229, 241.

Holgate, Barbara, 229.

Holland, Countess, 42.

Hommius, F., 525, 551, 560, 575, 593.

Hooft, 419.

Hook, 66, 69, 72, 99, 334.

Hooker, R., 126, 166, 167, 172-175, 297, $325,326,349,547$.

Hoole, C., 25.

Hooper. J., 73, 74, 81, 83, 85, 86, 194.

Hoornbeeck, 423, 424, 447, 545, 592, 593.

Hoorne, 418. 
Hopton, O., 314.

Horne, C., 263 .

Horne, R., 89, 90, 93, 95, 100, 118.

Horsfield, Rosam., 469.

Hortensius, L., 78.

Houghton, 242, 248.

Hout, van, J., $468,498$.

Howard, 309-311.

Howson, J., 172.

Hudson Propos., 583.

Hull, 404, 405.

Humber, 215, 405.

Hume, 52.

Humphrey, L., 90, 98, 101, 102, 118, $124,12 \overline{0}$.

Hunt, 212.

Hunt (anoth.), 487.

Hunt, J., 177, 371, 538.

Hunter, J., 7, 34, 220, 228, 233, 241, $242,252,254,255,320,322,325,326$, $328,332,388-393,398,401$.

Huss, J., 54.

Hutton, L., 359 .

Hutton, M., 49, 239.

Hutton, Thos., $35 \mathrm{~S}$.

Hutton, Tim., 328.

Idle, 215.

Inquisition, 54, 93, 170, 416, 417.

Ireland, 212, 424.

Isabella, Q., 58 .

Islington, 204, 421.

Iviney, J., 458.

Jackler. 364.

Jackson, Rich., 391, 401.

Jackson, Rob., 429.

Jackson, T., $5 \overline{0} 1$.

Jacob, H., 335, 351, 368, 386, 437, 438, $519,520,546,563$.

Jacobs, 14 .

James I (Eng. VI, Scot.), 15, 35. 39, 47, 237-239, 280, 308, 314, 315, 317, 330, $384,336,344,370,376,386,527,536$, $546,551,562$.

James IV (Scot.), 218, 299.

James V (Scot.), 299.

Jegon, J., 394, 396, 398.

Jenkins, 581.

Jennings, J., 506, 507, 618.

Jenny, J., 506.

Jepson, W., 469.

Jerome, 115 .

Jessop, E., 392, 457.

Jessop, F., 392.

Jessop, Frances W., 392.

Jewell, J., 93, 97, 99, 115, 165.

John (Wesel), כ4.

Johnson, Eliz., 432.

Johnson, F., 149, 175, 204, 205, 207, 208, $212,325,395,396,421-423,425-429$,
$437-439,441,442,451,464,465,517$, 521-524, 536, 537, 550, 570, 576.

Johnson, G., 204, 208, 210, 212, 259, $421-423,425-429,433,435,437$.

Johnson, Jac., 429, 537.

Johnson, John, 422, 429.

Johnson, Persev., 425.

Jones, C., 589.

Jones, T.. 589.

Jonson, B., 15, 24, 29.

Jowett, B., 2.

Jugge, R., 115.

Jülich, 526, 527 .

Julius II, 59, 62 .

Junius, 158, 428, 434-436.

Kampen, 204, 427.

Kanter, D., 526.

Kath. (Aragon), 58-64.

Kath. (Valois), 47.

Kellison, M., 348.

Kendal, 14.

Kent, 312.

Kent (Co.), 87.

Killigrew, Cath., 28.

Killigrew, H., 285, 288.

Kiln Ferry, 405.

King, 573 .

Kingsmill, A., 124.

Kingston, 405.

Kist, N. C., 467.

Kitchin, 93.

Knewstubs, J., 178. 341, 343.

Knollys. H. Soc., 385, 386.

Knox, J., 70, 75, 88, 170, 299.

Knox, T. F., 563.

Knyveton, G., 204, 421, 446.

Koornhert, R., 511.

L., A., 181.

Lad, T., 364.

Lamb, 397, 398.

Lambeth, 48, 189, 201.

Lascaris, C., 54.

Lascaris, J. A., 54.

Latham, IV., 432.

Lathibury, 100.

Latimer, H., 70, 85, 90.

Land, 241.

Lawne, C., 204, 520, 524, 535-537, 545, $546,550,553$.

Lea, H. C., 35, 37, 52, 54, 170.

Lee, N., 204, 421.

Legate, B., 546.

Legatine Ct., 60, 61 .

Legge, T., 424.

Leicester, 98, 285, 292-297, 310, 319.

Leicester Revolt, 485, 486.

Leighton, A., 45, 46.

Leland, 218, 224-228, 237.

Le Neve, 233. 
Le Poole, 599.

Leo X, 54, 58 .

Lever, 'T., 81, 91, 124, 274.

Leyden, Professors, etc., 483, 493-498, $550,553,582$.

Leyden, Records, 502, 503.

Leyden, Residences of Pilgs., 490.

Leyden, Siege, 478-481.

Lincoln, 3, 14, 378, 380 .

Lingard, J., 93.

Lisle, W., 581.

Listers, 242.

Liverpool, 19.

Lochleven, 300, 306.

Lollardy, 56 .

Lombard, P., 56.

London, 3, 11, 90, 188, 212, 295, 308, $320,323,415$.

Loque, de, B., 161.

Lorimer, P., 75, 186.

Love, Fam. of, 177-179.

Lumley, 316.

Luther, MI., 56-5S, 65, 66, 177.

Lyly, W., 256.

Lyons, Sec. Coun., 256.

Madden, F., 56.

Marg., Princess, 218-221, 299.

Marlowe, C., 261, 394.

Marprelate, M., 179-184, 258, 423.

Marsden, 92, 100.

Marshall, 500.

Marshall, W., 231, 235.

Marten, A., 163.

Martin (Morton), 389, 390.

Martin's, St., 70.

Martyr, P., 73, 74, 77, 84, 90, 95, 115, 117.

Mary, Bloody, 59, 60, 81, 83-88, 188.

Mary, Duch. of Holl., 477.

Mary Lorraine, 299.

Mary Magd. Hosp., 254, $32 \mathrm{~s}$.

Mary, Scots, 11, 2S9, 299-313, 315.

Maskell, WV., 181.

Mason, F., 365 .

Mass. Bay, 19.

Masson, D., 27, 256-258, 272, 275, 277, $279,284$.

Mather, C., 382, 367, 380, 388, 391.

Mather, I., 39, 359.

Mattersey, 216, 223.

Maunsell, R., 364, 582 .

Maurice, Prince, 292, 468, 526, 527, 570.

May, H., 604.

May, Jacq., 432.

May, W., \$9, 91.

Mayflower, 5\&6, 58s, 589.

MeIllraith, J., 444.

Medici, de, C., 54 .

Meester, J., 593.

Melancthon, 65, 72, 76, 77, 461.
Mercer, S., 429, 446.

Merick, 9:3.

Merlin, 282.

Mersius, $476,479,482$.

Michael's, St., 22.

Middleberg, 129, 189, 198, 290, 292, $422,428$.

Middlesex, 28, 87.

Millenary Petit., 334-336, 386, 438, 440.

Milner, G., 390.

Milnes, R. P., 242.

Minter, J., 625 .

Misson, 223.

Mitchell, A. F., 95

Mocket, P., 562.

Montagu, J., 340, 563.

Montesquieu, 38.

Moody, 309.

Morden, J., 263.

More, 'T., 57.

Morgan, T., 302.

Morice, J., 169.

Morley, 397.

Mornay, de, P., 176.

Morton, G., $379,389$.

Morton, N., 380, 386, 391, 445.

Morton, T., 171, 348, 395.

Moryson, F., 7, 11, 12, 14, 33, 263, 323, 412,571 .

Mosse, M., 171.

Motley, J. L., 3, 289, 293, 295, 412, $413,417,418,478,480-482$.

Muller, F., 444, 537.

Mullinger, J. B., 27, 76, 256-258, 264, $273,275,276,278,279,282,394,398$, $424,497$.

Mullins, WV., 589, 590.

Mundham, 398.

Mlïnster Insurrect., 78.

Munter, J., 44, 587.

Mïnzer, T., 78 .

Murphy, H. C., 501.

Murray, 300.

Murton, J., 385, 386, 432, 455, 458, 520, 521,538 .

Mus., Brit., 189, 201, 206, 319.

Mylls, 324 .

Naarden, 204, 427.

Nan, 304.

Naunton, R., 579.

Neal, Eliz., 393.

Neille, 241.

Nestorius, 351.

Nethenus, M., 520 .

Newark, 283.

Newcastle, 18, 302.

Newstead Abbey, 215, 223.

Neville, G., 392.

Nichols, J., 331, 332. 
Niclaes, H., 177-179.

Nicolas, 228, 314 .

Noailles, 85.

Norfolk, 189, 312.

Northampton, 344.

Northumberland, 83.

Norton, J., 273.

Norwich, 3, 189, 191, 398.

Nowell, 99.

Nun's Creek, 405.

Nuremberg, 72, 76.

Oglethorpe, 88 .

Olave's, St., 199, 263.

Orange, Prince, 581.

Ormerod, O., 3:5, 350.

Ostorod, C., 436.

Oxford, $14,56,62,76,86,278,337,338$.

Paget, J., 443, 450, 524, 545, 562, 576.

Pagitt, E., 178, 458.

Palmer, 3:3.

Parker, M., 89, 92-96, 99-101, 103, 105107, 119, 258, 273, 274, 351, 394.

Parker, R., 367, 519, 562.

Parkhurst, 93, 118.

Parma, Prince, 295, 302.

Parvise, 22.

Pattison, M., 483.

Paul, St., 362.

Paulet, A., 300, 302, 304, 305, 311-313, 316.

Peacham, E., 558.

Peasants' War, 78.

Peck, I.., 507.

Peeters, J., 107.

Peirce, J., 584.

Pembroke, 19.

Penn, W., 47, 48.

Penredd, T., 43.

Penry, Deliv., 432.

Penry, J., 159, 160, 162, 170, 182, 188, $209,212,263,322,325,422,432$.

Pepys, Mrs., 47.

Percy, C., 328.

Perkins, W., 39, 40, 260, 395, 399.

Perne, A., 257, 258, 263, 268.

Perry, 100, 165.

Perse, 423.

Persons, R. (N. Dolman), 346, 348.

Peterhouse, 256-258, 262, 265-271, 279.

Phil. II, 19, 84, 93, 289, 290, 295, 300, $302,414,417,418$.

Phillips, 302.

Pigott. T., 520, 546.

Pigott, W., 521.

Pike, L. O., 2, 3, 23, 43, 44.

Pilkington, J., 90, 91, 93.

Piscis, N., 4:.

Pleyte, W., 532.

Plym. (Col.), 19.
Plym. (Eng.), 589, 590.

Pole, Card., 87.

Polyander, J., 498, 534, 544, 560.

Pontanns, 65, 414.

Powel, G., 347, 358.

Powell, T., 441.

"Precisians," 105, 313.

Presbyterianism, 203, 210, 211.

Presb. Tercent., 186.

Preston, J., 280.

Preston, T., 395.

Prince, T., 326, 380, 386, 391, 500.

Printing, Secret, 112, 123, 183.

Protestantism, Span., 417 .

Purchas, 20.

"Puritans," 105.

Quignon, 72 .

Radford, J., 347.

Rainea, 426.

Rainolds, J., 339-343, 345, 371, 375, 376.

Raleigh, W., 10, 15, 19, 28, 29, 33, 261, $555,568,571$.

Ramus, P., 27, 262.

Randolph, T., 323, 324.

Ravenna, Clergy, 115.

Reculvers, 295.

Reform. Contin., $416,418$.

Reform. Eng., 55, 57, 92.

Rich, N., 570 .

Richardson, 43.

Richardson (anoth.), 389, 390.

Ricobaldi, 42.

Ridley, 85, 90, 115, 362 .

Ries, de, H., 448, 453.

Ripon, 240, 377.

Rishton, E., 87, 92.

Road, Great North., 282, 320.

Roberts, A., 39.

Robinson, J., 40, 149, 239, 252, 260, 346, $385,386,393-400,406,407,410,429$, $443,449-454,456,457,466,467,487$, $495,500,501,504,517,520,523,529$, $531,583,535,541,544,550,553,555$, $557,560,561,568,573,574,578,585-$ 588, 591-594.

Robinson, R., 398.

Roche Abbey, 217.

Rochester, R., 391, 401.

Rogers, T., 150, 171, 374.

Ross, B., 505.

Rowland, T., 188.

Rowlett, Marg., 28.

Rufford Abbey, 223.

Rughford, 237.

Russell, Eliz., 28.

Ryton, 215, 225, 237, 238, 246.

Sabbat, 36.

Sackville, R., 27. 
Sadler, 28.

Sadlington, M., 263.

Sampson, T., 90, 98, 101, 102, 118, 124.

Sancroft, 366.

Sanetuary, Right of, 28.

Sauders, C., $5: 36$.

Sands, 185.

Sandys, 89, 91, 93, 97, 99, 101, 233, 239, $241,242,305,316,424$.

Sandys, E., 297, 298, 373, 570, 573, 579.

Sandys, F., 242.

Sandys, G., 29, 322.

Sandys, MI., 263.

Sandys, Penel., 242.

Sand ys, S., 225, 236, 241, 242.

Saravia, H., 165, 166, 485.

Savage, T., 219, $221,222$.

Savonarola, 54.

Saxony, Elect., 65.

Sayer, R., 263.

Seambler, E., 93, 171.

Scheffer, J. G. de H., 279, 385, 386, 423, $431,453,455,456,521,538$.

Seory, J., 90, 93.

Scot, R., 35, 39.

Scotus, D., 56.

Scriverius, P., 499.

Serooby, $: 320,379$.

Scrooby Manor, 221, 222-242, 245-250, 380.

Scrope, Lady, 328.

Seamer, T., 521.

Seebohm, 54, 56, 57.

Separatists, Early, 203, 212, 421.

Settle, T., 259, 421, 426.

Seymour, 82.

Sheffield, 7, 34 .

Sheldon, 48 .

Sherley, J., 611.

Sherwood Forest, 70, 215, 219, 238.

Shrewsbury, 219, 237, 312.

Sidney, P., 285, 292, 296, 308, 310, 319.

Silva, de, 99.

Silvester, T., $389,390$.

Simons, M., 521.

Skitterhaven, E. Halton, 405.

Slade, M., 434, 576.

Slafter, E. F, 20.

Smith, J., 18s.

Smith, J. (Capt.), $563,589$.

Smith, M., 376.

Smith, T., 91, 579.

Smith, W., 366.

Smith, W.' (anoth.), 438.

Smith, Went., 366 .

Smyth, J., 279, 377, 378, 380-386, 392, $399,400,436,442-444,446-448,440-$ $451,453-460,517,520,521,537,538$, 545 .

Snel (Turwert), H., 107.
Snellius, R., 511, 550 .

Snowden, R., 402.

Some. R., 161.

Somerset, Duke, 82, 185.

Somerset, Earl, 563.

Somerset, T., 328.

Somersetshire, 8.

Southampton, 588.

Southwell, 222, 223, 233, 234, 238, 239, 242,402 .

Sparks, T., 361.

Speedwell, 586-589.

Spelman, F., 285.

Spelman, Kath., 285.

Spencer, G., 24.

Sprint, J., 358, 452, 576.

Stafford, $308,309$.

Stallingborough, 405.

Stamford, 282.

Standen, N., 125.

Stanhope, J., :318, 324.

Stanley, W., 310.

Stapletons, 242

Star Chamber, 46.

Staresmore, S., 573, 582.

Starre, R., 617.

States-Gen., 290, 415.

Staveley, T., 22.

Stepney, 317, 401.

Stevens, H., 539.

Stokes, R., 200, 262.

Stoughton, W., 141, 142, 345.

Strangeways, 44.

Strutt, 13.

Stuart, MI, 512.

Stubbe, J., 140.

Stubbes, Mrs., 206.

Stubbes, P., 13, 16 .

Studley, D., 204, 421, 426, 429, 432, 446, 521.

Stuffen, Anne, 387.

Sturbridge Fair, 17, 275, 277, 396.

Suffolk, 61 .

Sumner, G., 500, 501, 507.

Sundav Games, 106.

Sutcliffe, M., 153, 162, 164, 348.

Sutton, 216, 241, 254, 379.

Swale, 424.

Swanenbnrgius, C., 557.

Swannenburch, I., 530.

Taffinus, $427,434,435$.

Talbot, H., 918.

Tandlerus, T., 39 .

Taylor, A., 458.

Tarlor. J., 29, 49 .

Tetrode, C., 525.

Thacker, E., 209.

Thickins, R., 533.

Thomason, 185.

Thoresby, de, J., 222. 
Thoroton, 227, 242.

Thorp, G., 516, 543 .

Tickhill, 891.

Tilley, Bridget, 650 .

Tilley, E., 650 .

Tilley, J., 650.

Tilley, P., 650.

Toller, T., 377.

Topliffe, R., 237.

Tortus, M., 370.

Tower, 84, 313, 314.

'Tracy, W., 63.

Traheron, 72.

Trappes, J., 587.

Travers, W., 110, 125, 138, 153, 162, 166, $185,210,272,547,566$.

Treby, 43.

Trelcatius, L., 486.

Tremellius, J. E., 76, 158.

Trent, $215,405$.

Trent, Coun., 76.

Triglandus, 510.

Tuke, B., 320.

'Tulloch, 52.

Tunstall, C., 81, 228, 277.

Turner, Mrs., 48.

Turswell, T., 181, 184.

Turwert (Snel), H., 107.

Tuxford, 218, 219, 282, 329.

Tyburn, 124, 200, 422 .

Tyndal, 396.

Udall, J., 145, 146, 154, 157, 162, 259, 322 .

Uitenbogart, 461, 510, 551.

Underhill, S. B., 458.

Use, Bangor, 71.

Use, Hereford, 71.

Use, Lincoln, 72.

Use, Salisbury, 71.

Use, York, 71.

Utrecht, $418,526$.

Valentia, de, Greg., 351.

Van der Does, J., 479, 482.

Van der Velde, E., 499.

Van der Venne, A., 499.

Van der Werff, 480, 485.

Van der WVerff, A. P., 506.

Van Hogeveen, A., 529.

Van Leewen, 475.

Van Leyden, L, 492.

Van Mieris, $482,493$.

Van Rijn, R., 499.

Van Vesanevelt, A. J., 506.

Vaucanson, de, J., 487.

Venator, A., 462.

Venn, 423.

Villiers, G., 563.

Virginia, ¿\$6.

Virginia Co., 573, 579, 584 .
Voidovius, A., 436.

Vorstius, C., $520,535,536,544,551$.

Wade, Sir WV., 304.

Waddington, J., 188, 199, 422.

Wagenaar, 4:35, 444.

Waigestaff, Alice, 389.

Walaeus, A., 592.

Waldegrave, R., 142, 175.

Wall, 201 .

Walsingham, F., 289, 296, 301-304, 307, 308-311, 574.

Walton, I., 29, 297.

Warham, 59.

Watering, St. T., 124, 263.

Ventworth, T., 230, 233, 253.

Wessel, J., 54.

Weston, T., 584, 586, 588.

Whetenhall, T., 365.

Whitaker, S., 432 .

Whitaker, WV., 396, 421.

White, Bridg., 392.

White, Frances, 392.

White, Jane, 392.

White, R., 93.

White, Rog., 392, 591.

White, T., 204, 212, 423, 427, 435, 441, 442.

Whitehead, 91.

Whitgift, J., 49, 105, 109-111, 126, 129, 131, 134-137, 165, 166, 273, 278, 316, 338, 343-345, 352.

Whittingham, 110.

Whittington Coll., 124.

Wickham, 384, 455 .

Widley, G., 372.

Wierus, J., 38.

Wightman, R., 241.

Wileox, T., 105, 125, 126, 128, 130 , 161.

Wilfred's, St., 217, 241, 327, 377.

Wilkes, W., 362.

Willet, A., 173.

William, Orange, 289, 418, 479, 482, 527.

Williams, R., 423.

Williamson, 590 .

Wilson, R., 508.

Wincob, J., 579 .

Wingfield, 312 .

Winslow, E., 380, 541, 543, 567, 573, $585,587$.

Winwood, R., 468, 526, 536, 551.

Withers, G., 103.

Wolley, J., 316.

Wolman, R., 394.

Wolsey, Card., 60, 62, 222-224.

Wood, 212, 539.

Woolsey, 437.

Worcester, 323.

Worcester (town), 316. 
Worksop, 219, 237, 238, 378, 392, 432. | Wyburne, P., 122.

Wostenholme, J., 573.

Wyclif, J., 54, 56.

Wotton, A., 395.

Wraye, C., :\$16.

Yarmouth, 393.

Wren, MI., 2\$ن.

Yates, J., 574.

Wrentham, 255.

Wright, L., 181.

Wright, W. A., 424.

York, $3,11,18,224,234,320$.

York, R., 310.

Young, T., 90, 93, 231.

Writers, Eliz., 29.

Wroth, $4: 38$.

Wroth, T., 89.

Younge, J., 218.

Zutphen, 310. 
Che triberside pregly

Electrotyped and printed by $H . O$. Houghton \& Co.

Cambridge, Mass., U.S. A. 


$$
\text { - }
$$




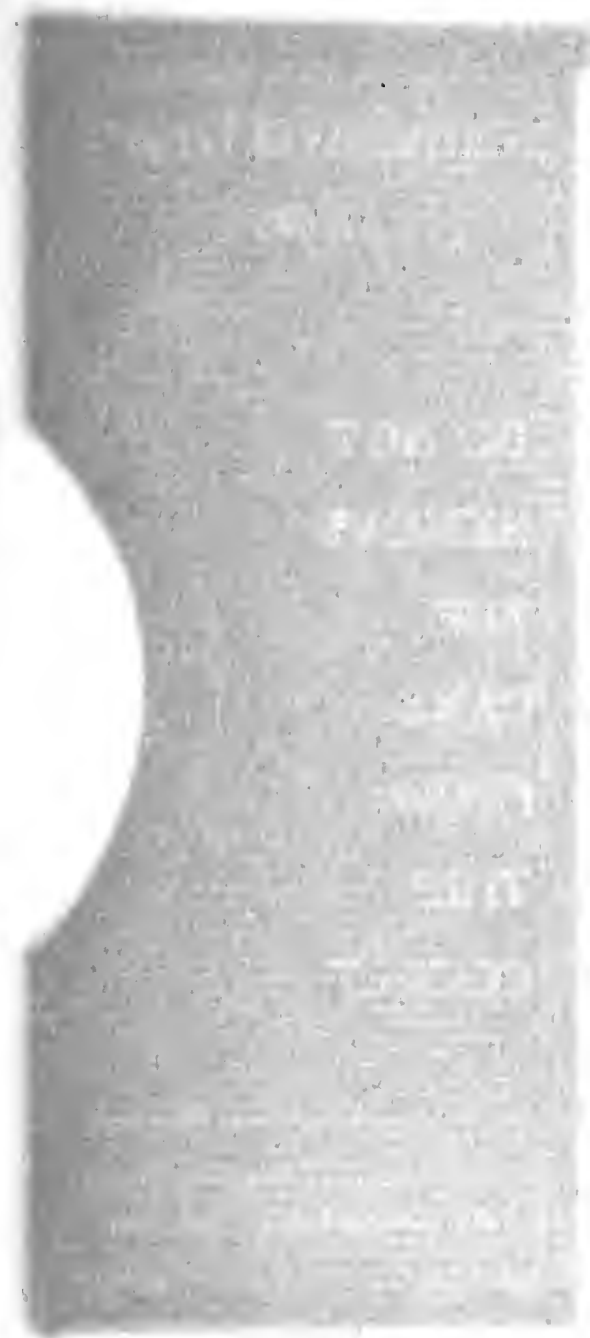




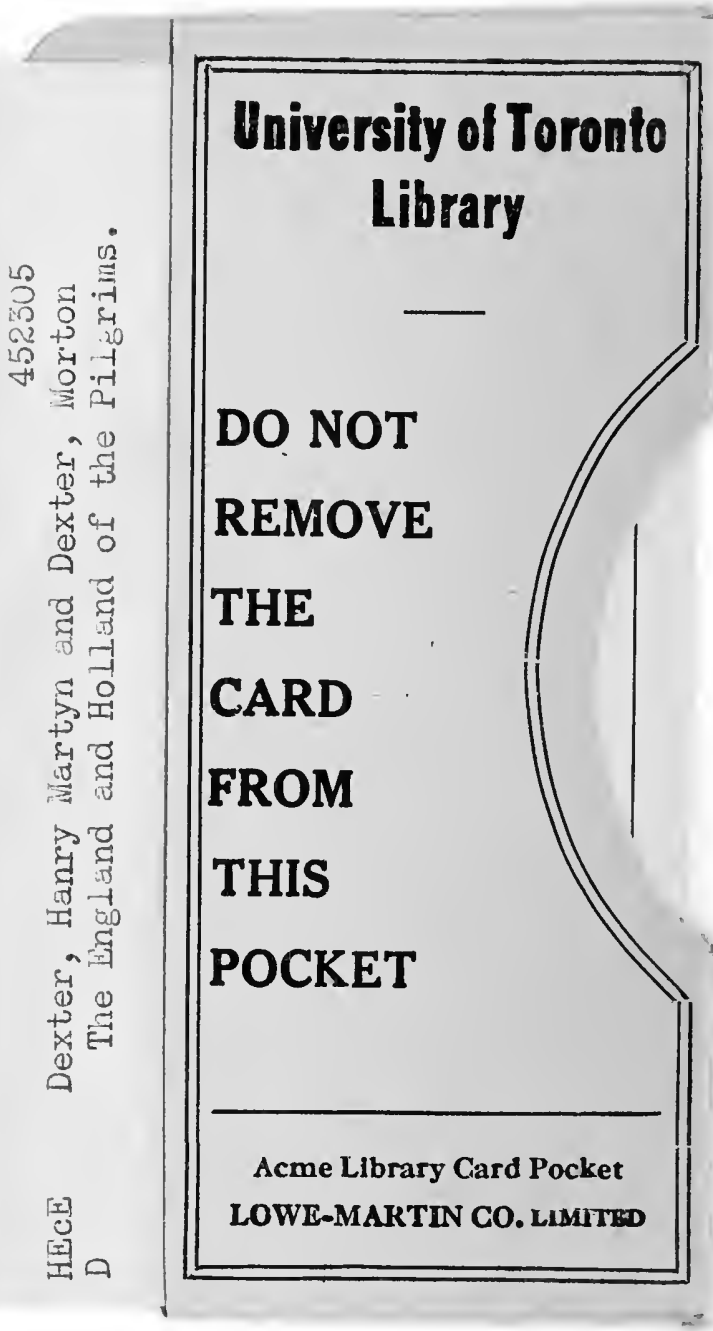


